
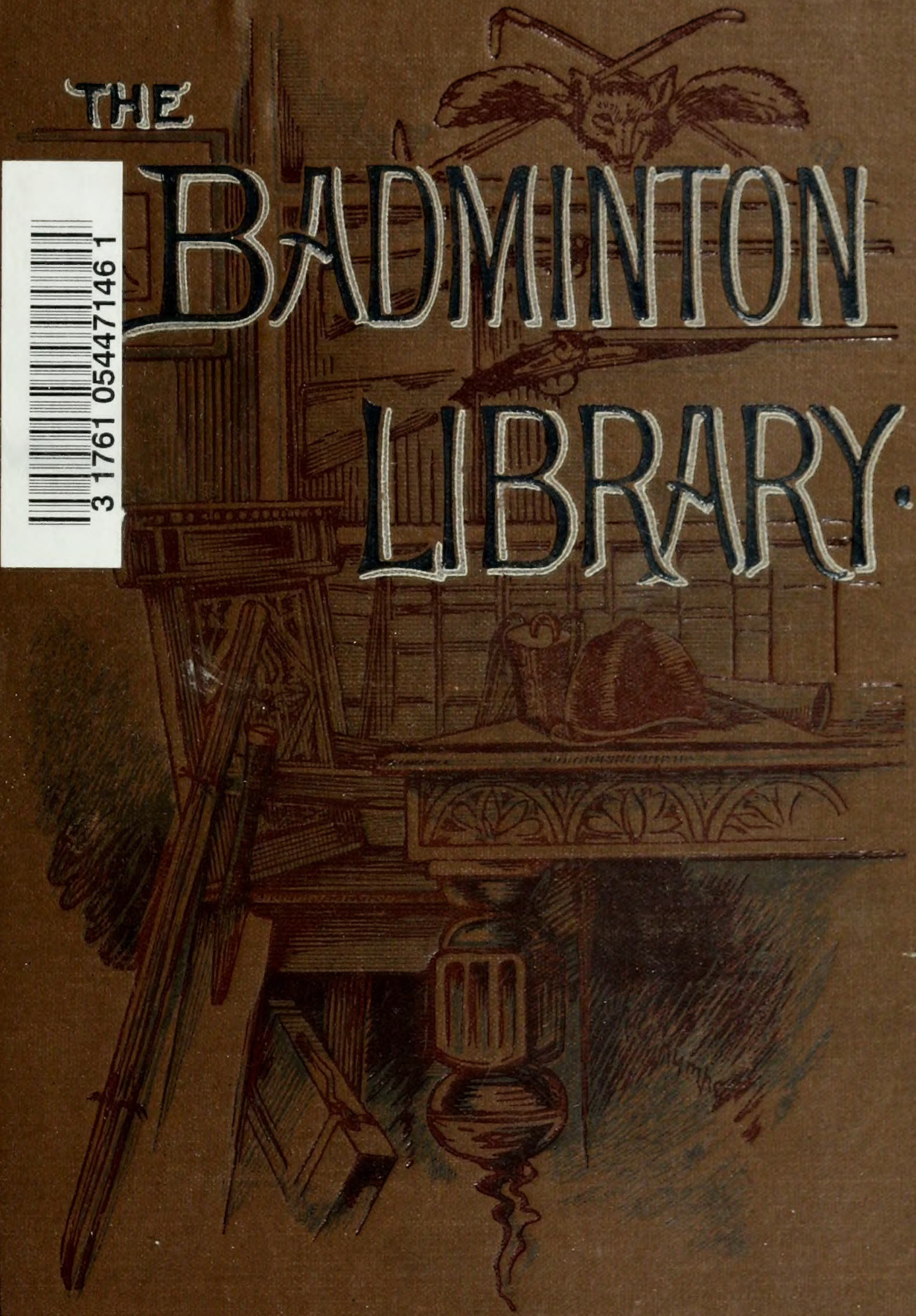
17248
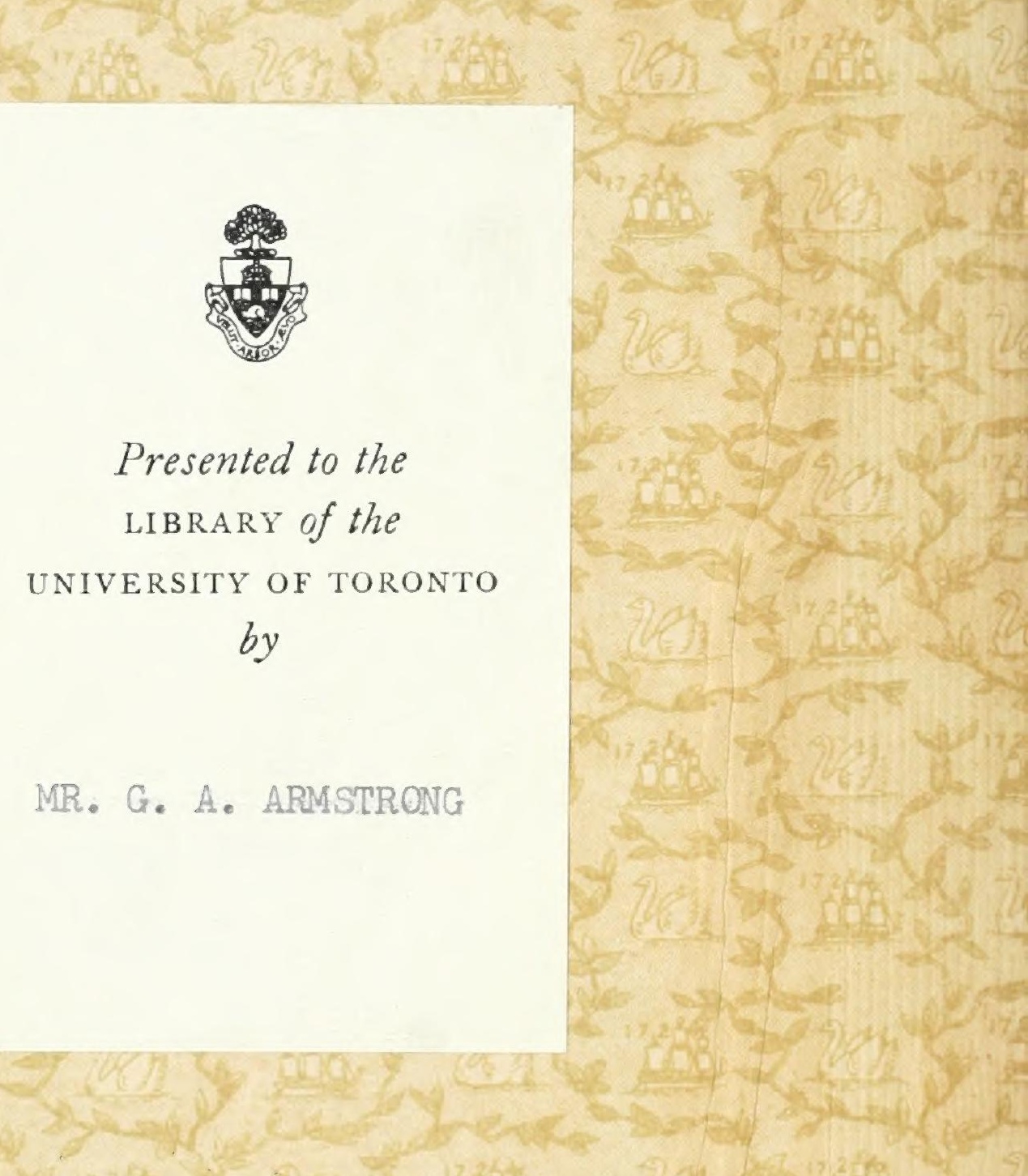

MR. G. A. ARMSTRONG 

$w^{n}$ 



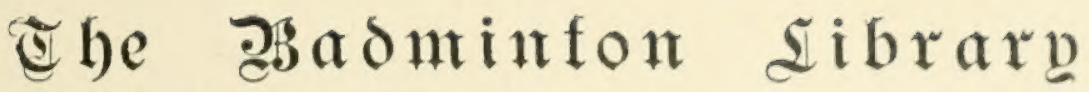 OF
}

\section{SPORTS AND PASTIMES}

\author{
EDITED BY
}

HIS GRACE THE (EIGHTH) DUKE OF BEAUFORT, K.G. ASSISTED BY ALFRED E. T. WATSON 

a 


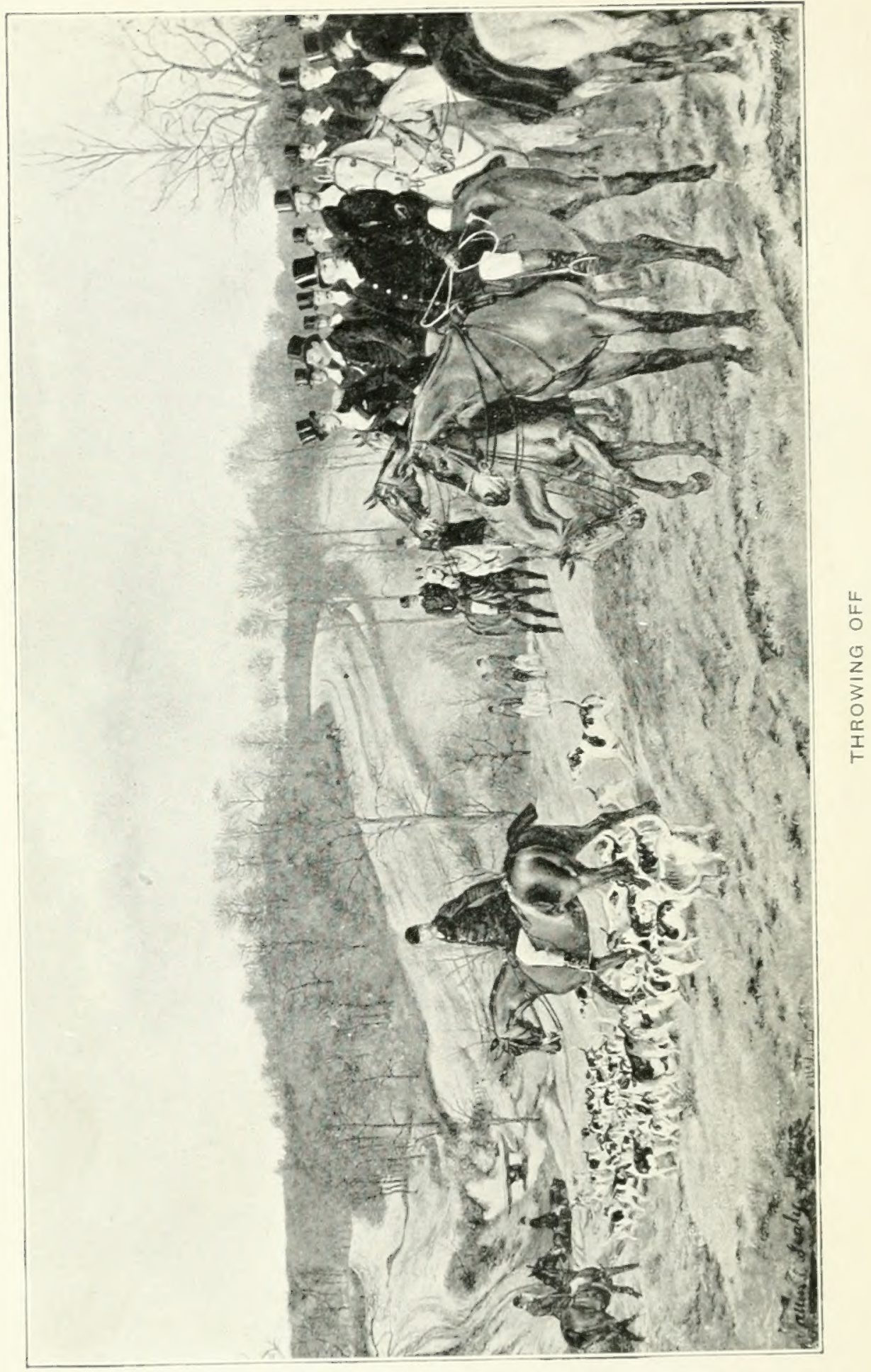




\section{HUN T I NG}

BY HIS GRACL

THE (KIGITH) DUKE OF BENULURT, K.G.

$$
\text { A } v \text { (I) }
$$

MOWBRAY MORRIS

WITH CONTRIBUTIONS BY THE VARL OF SUFFOLK AYI JERKSIIRE REV. W. W. I. DAVIES, DIGIYY COLLINS, ALIRLD E. T. WAISON

SIR IARIEINI: LI,OYD, BART., GEORGF II. I.ONGMAN, AND J.S. GIBBONS

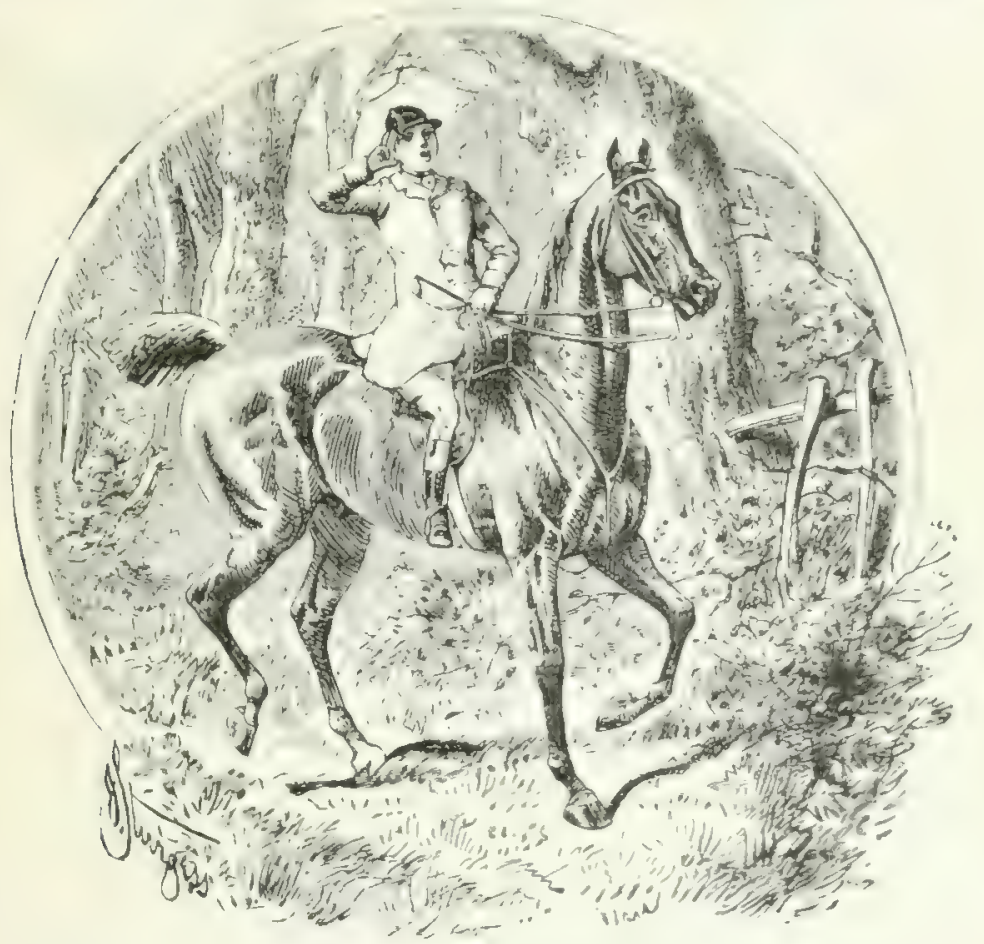

WITH ILLUSTRATIONS BY J. STLRGESS, J. CHARLTON

G. D. GILES, A.VI A. C. SEALI

iscur bition

LONGMANS. GREEN. A ND CO.

39 TATERNOSTER ROWI, IONTON

AND 13() .113 .11 


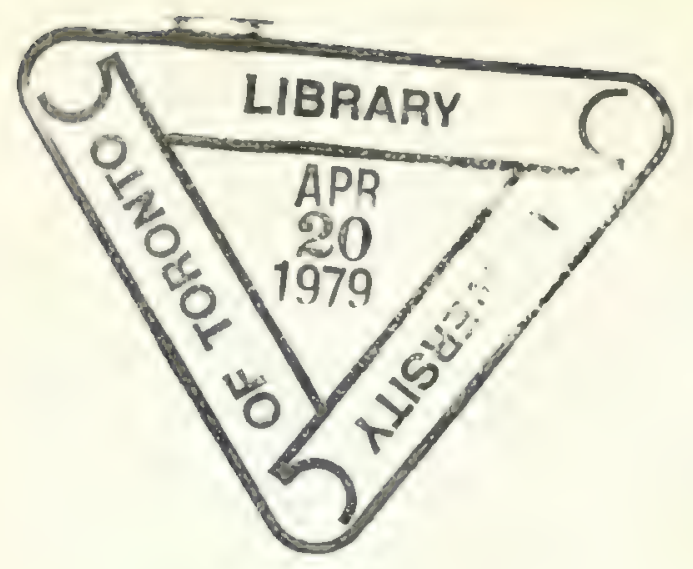

BIBLIOGRAIHICAL NOTE.

First Etition, September 1885 ; Reprinted Decomber I885, November i886, December I887, August I889, March I891. Revised, with additional matter and additional Illustrations, March 1894.

Cheaper K'cissue, July I901. Reprinted September. I901. Newo Edition, July I 906. 


\section{DEDICATION}

TO

\section{H.R.H. THE PRINCE OF WALES.}

\section{BADMinton: October I885.}

HAVING received permission to dedicate these volumes, the BADMINTON L,IBRARY of SPORTS and PASTIMES, to His Royal Higiness tie Prince of Wales, I do so fceling that I am dedicating them to one of the best and kecnest sportsmen of our time. I can say, from personal observation, that there is no man who can extricate himself from a bustling and pushing crowd of horsemen, when a fox breaks covert, more dexterously and quickly than His Royal Highness; and that when hounds run hard over a big country, no man can take a line of his own and live with them better. Also, when the wind has been blowing hard, often have I seen His Royal Highness knocling over driven grouse and partridges and high-rocketing pheasants in first-rate 
workmanlike style. He is held to be a good yachtsman, and as Commodore of the Royal Yacht Squadron is looked up to by those who love that pleasant and exhilarating pastime. His encourasement of racing is well known, and his attendance at the University, Public School, and other important Matches testifies to his being, like most English gentlemen, fond of all manly sports. I consider it a great privilege to be allowed to dedicate these volumes to so eminent a sportsman as His Royal Highness the Prince of Wales, and I do so with sincere feelings of respect and estcem and loyal devotion.

BEAUFOR'T. 


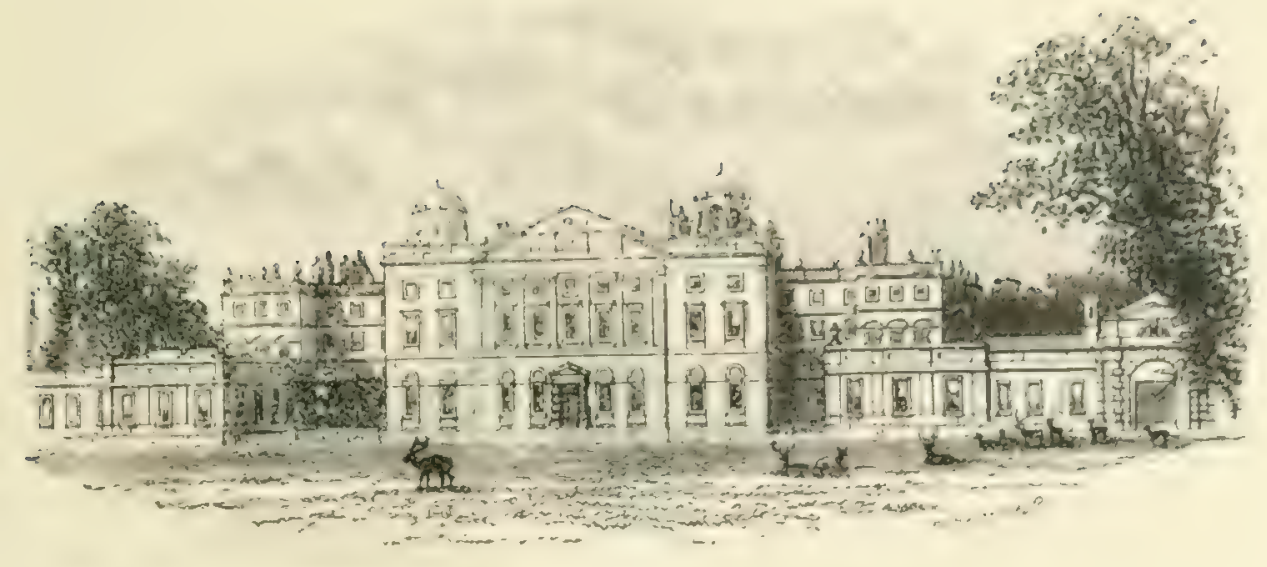

BADMINTON.

\section{PREFACE}

A FEW LINES only are necessary to explain the object with which these volumes are put forth. At the time when the Badminton Library was started no modern encyclopxdia existed to which the inexperienced man, who sought guidance in the practice of the various British Sports and Pastimes, could turn for information. Some books there were on Hunting, some on Racing, some on Lawn Tennis, some on Fishing, and so on ; but one Library, or succession of volumes, which treated of the Sports and Pastimes indulgeded in by Englishmenand women-was wanting. The Badminton Library was produced to supply the want. Of the imperfections 
which inust be found in the execution of such a design we are conscious. Experts often differ. But this we may say, that those who are sceking for knowledge on any of the subjects dealt with will find the results of many years' experience written by men who are in every case allepts at the Sport or l'astime of which they wite. It is to point the way to success to those who are innorant of the sciences they aspire to master, and who have no friend to help or coach them, that these volumes are written.

To those who have worked hard to place simply and clearly before the reader that wich he will find within, the best thanks of the Editor are due. That it has been no slight labour to supervise all that has been written he must acknowledge; but it has been a labour of lore, and very much lightenced by the courtesy of the Publisher, by the unfinching, indefatigable assistance of the SubEditor, and by the intelligent and able arrangement of each subject by the various writers, who are so thoroughly masters of the subjects of which they treat. The reward we all hrupe to reap is that our work may prove useful to this and future generations. 


\section{CONTENTS.}

CHAPTER

I'AGS

I. THE History AND Literature of Hunting . I

II. BeAsts of the Chase . . . . 36

THE STAG . . . . . . 36

THE FOX AND HIS HABITS . . . . 62

HARRIERS AND THE HARE . . . . 74

BEAGLES . . . . . . . 83

1II. THE STABLE. . . . . . , 99

IV. THE KENNEL . . . . . . . . II9

V. HUNT SERVANTS. . . . . . . : 145

THE DUTIES OF A HUNTSMAN IN THF FIELD. 145

THE DUTIES OF A WHIPPER-IN . . . . I5I

THE DUTIES OF A KENNEL HUNTSMAN . . 158

THE DUTIES OF AN EARTH-STOPPER . . . I6I

COMPENSATION FOR DAMAGES DONE BY HORSE-

IEN AND BY FOXES . . . . . 163

ARTIFICIAL FOX EARTHS . . . . . I66

V1. THE HORSE . . . . . . . 169

VII. THE RIDER . . . . , . . . . 196

VIII. THE SHIRES - . . . . . . 226 
CHAFTER PAGR

IX. ThE PROVINCES . . . . . 253

X. HUNTING FROM LONDON . . . . . 276

XI. THE OTTER AND HIS WAYS . . . . . 296

APPENDICES.

A. List of MASTERS OF HOUNDS, AND SERVANTS . 33I

B. NaMes of Hounds . . . . 3 $3^{f} 2$

C. HUNTING TERMS . . j6S

D. BIBLIOGRAPHY . . . . . . 372

INDEX . . . . . . . . 3S'I 


\title{
IL.LUSTRATIONS.
}

\author{
PLATES.
}

TO $\mathrm{PACH}$

ARTIST PACIE

Throwing OFF - • . . . Allen C. Sealy' Front.

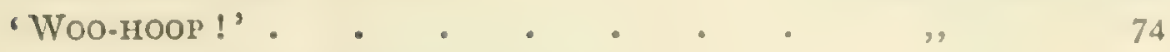

'As they Croivd on to the Line' . . G. D. Giles 89

Fult CRY . . . . . . . Allen C. Sealy 221

Gone Aivay . . . . . . . . . 299

\section{ILLUSTRATIONS IN TEXT.}

\section{- $\Lambda$ View HolloA' (Vignette on Title Fage) • J. Sturgess}

IN THE OLDEN TIME - . . . , , . I

Chased the Fox as vigorously as he did
THE French
.

PAGE

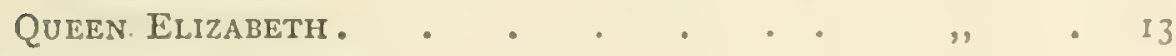

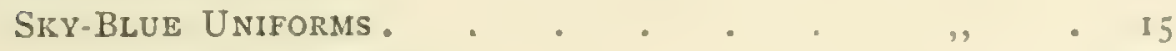

LARIING BACK TO MELTON • . . . . , , . 26

AS WE KNOW IT NOW . . . . . . , . 34

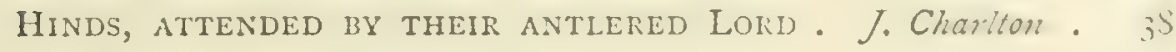

Head DOIN, AND TONGUE OUT . . . , . 60

IN Search of a SUPPER . . . . . . " .

StEAling AWAY . . . . . . . . . . 65

HOUNDS WHIMPERING IN FRONT . . . . J. Sutrgess . 77

The Field NOT to PRESS ON THE PACK . . , . SI

The Pleasure of IT . . . . . G. D. Giles . $\$_{5}$

The PAIN OF IT . . . . . . , . 87

'WILLJNG' • • • • . . . . . • . 91

A GOOD DEAL TOO HOT . . . . . J. Sturgess . 100 
THE BADYISTON STABLES, ELEVATIOY- ARTIST PAGK

", ", GROUND PLAN . . . 105

A Natural Position . . . . J. Simgess . . 106

THE QUORN KENIELS . . . . . . . . I24

THE BADMATON KENiElos . . . . . . . . I 26

A Converted Keñel . . . . . . . . 129

PUPpiEs. . . . . J.CKarlion . . I33

Badinton PuPPy Houses, Elebation . . . . . 135

Bringing Hounds into Feedixg Room • J. Charlion . I36

HOUNDS FEEDING . . . . . , . . I3S

HOUNDS AFTER IAAVING BEEN FED . . . . . I39

EXERCISING HOUNDS ON TIE ROAD. . . . I40

A GOOD HOUND (from a picture) . . . . . . . I42

A BAD Hound . . . . . . J. Charlton . . I4.3

The Huntsman . . . . . Agnes M. Biddulph 148

THE IVHIPPER-IN . . . . , , , . I5I

THE KENNEL HUNTSMAY . . . . , , , . I59

THE EARTH-STOPPER. . . . . , , , . I62

ChOOSE BY IIS HEAD . . . . J. Sturgess . . I8I

A Collection of Bad Points. . . . . I,$S_{4}$

RAPPED IT LIKE THUNDER . . . . , , . 192

A BAD MAN ON A GOOD HORSE . . ", . IgS

NEVEr IPART COMPANY . . . . . , . 209

GIVE YOUR PILOT PLENTY OF ROOM , •, • . 22 I

GET OFF AND WALK . . . . . . . . 225

A Gallop over Tivyford Vale . . . . 236

TiIE Niagara-like Rusil . . . . , , . 249

A libiral supply of Gates . • . , , 251

ROUGH AND VARIOUS GROUND . . . , . 253

TO CREEP WIERE HE MUST NOT FLY " " . 255

SOMETHING TO TIINK ABOUT NEXT DAY • ", . . 263

' WhERE JACK The IVhrp iN AMBUSh LAY'。 , . 266

SONS OF MACADAMI . . . . . . . 279

WITH YOU BY TRAR. . . . . . . 2Sz

Thr. Escape of the OtTer. . . J. Charllon . . 30z

O'TERS AT I'LAY . . . . . . . 315

FUIL CRY . . . . . . . . . . 323 


\section{CHAPTER I.}

DF THE HISTORY AND IITERATURE OF HUNTING.

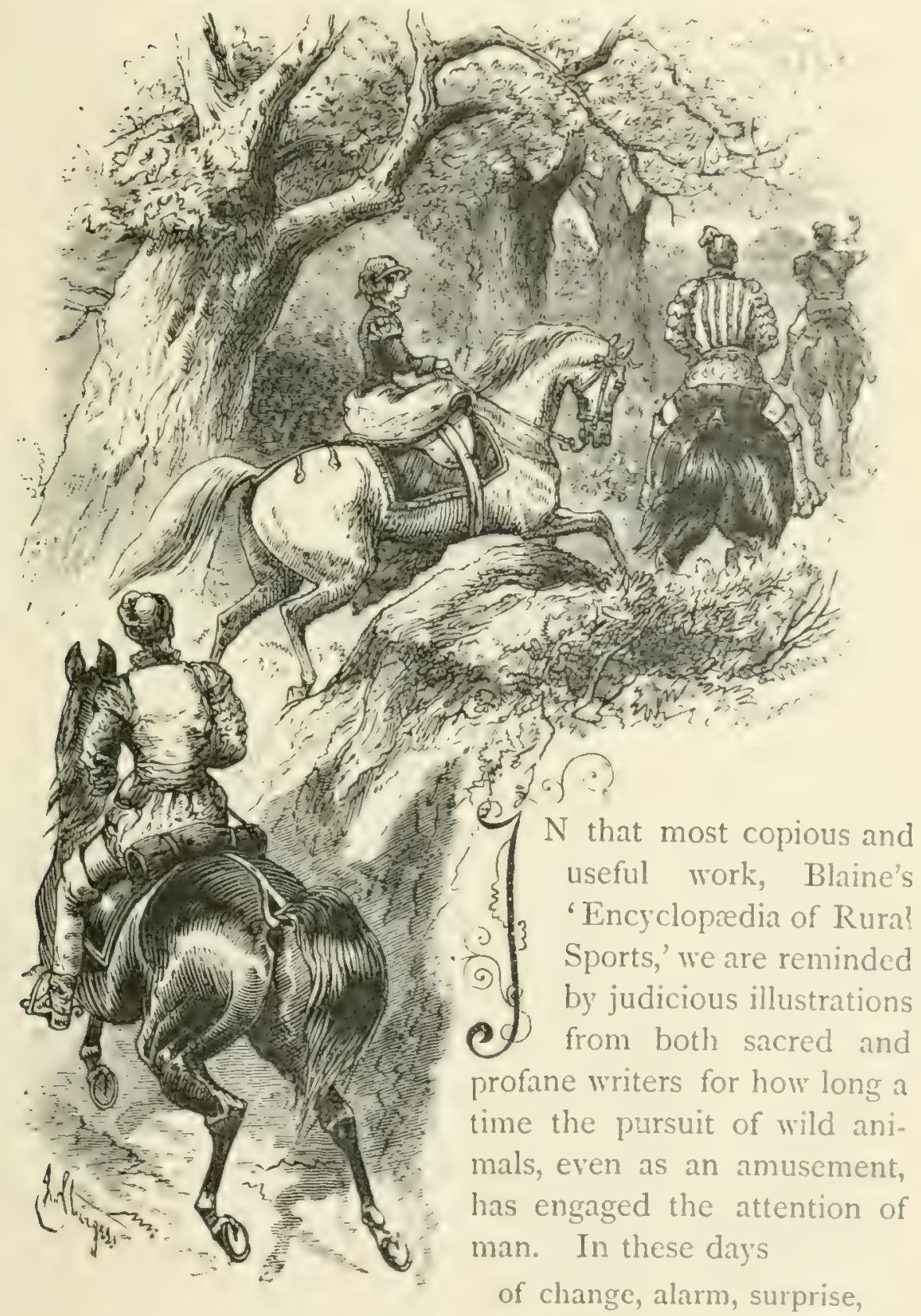


when the brutality of field-sports is being denounced with so much eloyuence and energy that one cannot but wonder how the world has remained unconvinced through so many years, it is, perhajs, idle to speculate how much longer our attention will be suffered to employ itself on a pastime which so many wise men have agreed to brand as wanton and debasing. A sort of melancholy pleasure, therefore, has attended the re. searches into which our studies have led us. "Still distant the day,' about a quarter of a century agro sang Egerton Warburton, that Homer of the hunting-field,

Still distant the day, yet in ages to come,

When the gorse is uprooted, the foxhound is dumb.

When that race of 'hamless vegetarians,' for whom Mr. Froude anticipates the mastery of the world, shall have come into their kingdom, then Nimrod will no doubt be dead as Pan, and the sports of the field as much an old-world story as the 'bloody laws' of the Roman circus. Those days, however, are not yet. This pious crusade against sport is, after all, no new thing. Even in this small matter we are not really refining on the morals and manners of our fathers.

The man who plants cabbages imitates, too!

That member for County Waterford, who, as he himself has cold us from his place in I'arliament, once and only once joined in the cruel game, and then on the side not of the hunters but the hunted--does not he find his prototype in Master Harry Sandford, whose valorous defiance of a whole field of brutal huntsmen brought a horsewhip across his shoulders, and tears into our ingenuous eyes? Nay, we may go firther back still; we may go back to the eleventh century, and to Ansclm, Archbishop of Canterbury, of whom we read in Mr. Cireen's 'History of the English People,' that when once a hunted hare took refuge under his horse, 'his gentle voice grow loud as he forbade the huntsmen to stir in the chase while the creature darted off again to the woods.'

As to speak of hunting, then, in the future may seem but 
a vain thing, so the more excuse may there be for gathering up into one convenient compass the scattered records of its ancient and honourable past. That we shall find anything new to say of it either historically or, if the word may scrve, scichtifically, we may hardly hope. 'Though it is certainly true, as Gervase Markham observed on a somewhat similar occasion, that "Time (which is the mother of experience) doth in our labours show us more new and more nearer ways to our ends than at the first we concerve,' still, since he discoursed on the arts of hunting and of 'riding great horses,' so many men have followed in his steps, that it would be a bold spirit indecd who should sit down now to such a theme with the assurance that he had anything fresh to offer either to the knowledge of the veteran or the curiosity of the tyro. A 'Country Cientleman,' writing little more than a century ago, found himself constrained to admit, 'there hath alrearly (by many well-experienced men) been so much written of this subject that I know not well what to write, except I should in some sort repeat another man's tale.' Nevertheless the literature of hunting is of many kinds. To present in a convenient shape the best, to use the fashionable phrase of criticism, of all that has been thought and said on the subject, is the prime purpose of our book. If so far we shall be held in some sort to have succeeded, we shall trust to be excused for having added one more to the many volumes that have been written on a sport which one of its most honourable chroniclers has declared to be 'most royal for the stateliness thereof, most artificial for the wislom and cunning thereof, and most manly and warlike for the use and endurance thereof.'

We do not propose to begin, as children love to have the-ir stories told them, at the very beginning. Writers of all sorts and conditions, from the gravest, have not disdained to recurd the pleasures of the chase, and to expound its mysteries. From Xenophon to Major Whyte-Melville, from Oppian to MIr. Bromley-Davenport, from Dame Juliana Berners to the curious individual known to men and columns as 'Ouida,' the list is 
incleed a loner and varied nne. To exhaust it would involves demand upon spare and time scarce less, if less at all, than that which would have been required by Mr. Caxton's 'History of IIuman Error,' hat that immortal though unwitten work feen ever released from the brain of its illustrious projector. Attractive, therefore, as $1 \mathrm{t}$ might be to turn the eyes of the imagimation backward rier the 'alyss of time' to Xenophon putting his precents into practice anung the hares he loved so well to follow in his quict Fluan home; or side by side with Synesius, the squire-bishop of Cyrene, to chase the ostrich or the antelope through the heavy African sands; we propose to resist the attrartion, and to confine ourstives to the history of the chase as followed and recorded within our own islands; starting from the time when it began to be regarded rather as a recreation than as a means for suplying what Mr. Mathew Amold has chofuently styled the 'gruat first needs of our poor mortalitylodging, food, and rament.' It is prossible that our readers may be inclined not to regret our self-denial.

Incliford, in the introductory chapter to his "Thoughts on rlunting,' observes that Somerville is the only man, so far as he knows, "who has written on this subject so as to be understood; ' an obserwation supported by the preface to the edition of $\mathrm{r} \$ 20$, in which it is stated with amazing effontery or ignorance, that 'till Mr. lieckforl's book appeared no work on the subject of huntings had been published, except an anonymous publication in I 7.33 , entitied "An Essay on Hunting." 'This is a cruel slur on some most worthy men and amusing writers. Indeed, the early masters of the 'Noble Art of V'enerie,' as they mostly delight to style their farourite pastime, are in their way as fluaint and cnturtaining companions as a man not too stcadily serious, to use Johnson's phrase, need wish to pass an idle hour with. Their style is, no doubt, not exactly Adcii. sonian; their spelling is somewhat arbitrary; the cntertain. ment they pmovide is apt on occasion to take a form of expres. sion comtram io the modern rook of grood manners. I.et it be 
granted, too, that one would hardly ges to them now for motrue: tion, though as a matter of fact the lirst primejules of the crath have changed but little since their day; we naty teach dir. ferentiy, but we teach pretty much the salne ductine. Still, they were quite as kech about their business ats Somenille, and, allowing for the inevitable change of years, knew quite as much about it. And, certainly, they are very mulh more amusing than Somerville, if not quite so classical as is that erudite squire.

'The earliest manuscript on hunting I have net with,'siy's Strutt, in his 'S Sports and P'astimes of the l'erple of Iingliand, 'is one in the Cotton Library at the British Muscum, written at the commencement of the fourtecnth century:' 'The manu. script Strutt saw was an English version of a Ifrench treatise, according to a note in Wirton's 'History of English l'vetry' at that time in the possession of a Mr. Farmor, of 'Musmor in Oxfordshire. Its full title was as follows: "Art de Tencrie le quel Maistre Guillaume 'Twici venour le Roy d'Alighterre list en son temps per Aprandre autres.' This Master William 'Twici was huntsman to Edward II. The King, as became a ruyal sportsman, had another 'Maister of the Game,' an Englisluman, one John Gyfford, and he it was who made the translition of the Frenchman's treatise that Strutt saw. A secund translittion, or rather a rescript of the first with additions, was made later by Henry IV.'s huntsman, for the special edilication of that 'imp of fame,' Harry of Mommouth, Prince of Wiales. 'This may be jdentical with the 'Maister of the (rame;' to be nentioned later, but neither Strutt nor 'Cecil' (who, in his 'Records of the Chase,' quotes largely from it) makes this clear. Irom the extracts the latter gives, it is, however, evident that the writer, whether the Duke of York or another, haxl carcfully studied his predecessor's work.

Next we come to the treatise popularly ascribul to I wune Juliana Berners, of pious and immortal, if somewhat ajocryphal memory, and included in the famous 'Buke of St. Allans,' so called from having been printed at that town in 1456 . A clutd 
of mystery hung for a long while over the lady and her work, nor indeed has it ever been wholly cleared away. Her name has been variously printed as Barnes, Bernes and Berners. Even her sex was for a time doubtful, for Baker, in his Chronicles, supposing Julyan (as her Christian name was originally printed) must needs be a man's name, describes the worthy prioress as 'a gentleman of excellent gifts, who wrote certain treatises of Hawking and Hunting.' Nor is her share in 'The Boke' known for certain. By carlier authorities she was held to have been responsible for ail three divisions of the volume, Hawking, Hunting, and Heraldry; by the latest, Mr. William Blades (in the preface to his edition of 'The Buke' published in IS8I), she is dismissed with sad contempt as having 'probably lived at the beginning of the fifteenth century, and possibly compiled from existing MSS. some rhymes on hunting.' Yct, as a matter of fact, this is all that a strictly conscientious historian can permit himself to say about her Down to a late period she was popularly supposed to have presided over Sopwell Nunnery in Hertfordshire, a house founded about I 40 under the rule of St. Benedict, and subject to the Abbot of St. Albans; subject indeed in late years after a fashion not contemplated, let us hope, by its original founders. This conjecture, one would have thought, might have rendered her authorship of a book on field sports, to say the least, somewhat problematical. But the obstacle was satisfactorily removed by the further supposition that our dame's youth was passed at Court, where she would naturally have joined in all fashion. able amusements. Unfortunately for the history-makers, Mr. Blades has pointed out that in the lists of the Prioresses of Sopwell for the fifteenth century no such name as Barnes or Berners is to be found. He also mentions another curious fact on the authority of Mr. Halliwell-Phillips, which may possibly help to cxplain the mystery, though he does not precisely venture to say so. It seems that men called Bemers were employed by the sportsmen of that century to wait upon them with relays of horses-second horsemen, in fact-and also to feed the hounds 
Somewhere between these two comes "The Maister of the Game,' not mentioned by Strutt, but a copy of which 'Cecil' says he had seen in the possession of a Mr. Richard I)ansey, of Herefordshire. He supposes it to have been written by Edmund de Langley, Duke of York, son of Edward III., whos was noted among his contemporaries for his delight and skill in hunting and hawking, and was made by his father, as I Iardin: tells us in his Chronicle,

Maister of the mewhouse, and of hawles feire,

Of his Venerie, and maister of his game.

From the extracts quoted by 'Cecil' it seems to be superior in point of style to Twici's work, and also more exhaustive and practical, but to those extracts our knowledge is confined.

In the following century our bibliograj,hy apjears to have been enriched by only two writers, George Turberville, and Sir Thomas Cockaine. Of the latter history is silent, but Turberville, or Tuberville, was a personage of some note, a poet and diplomatist, as well as a sportsman. He was educated at Winchester, and at New College, of which he was a Fellow. He went to Russia as secretary to Randolph, Elizabeth's famous ambassador, and published a poetical description of that country, besides other volumes of verse, songs, sonnets, and translations. Anthony Wood in his 'Athenæ Oxonienses' describes him as a most accomplished gentleman, and 'much admired for his excellencies in the art of poetry.'

As far as we have got hitherto, there is certainly some coluur for Beckford's contemptuous dismissal of all writers bufure Somerville. It is certainly not easy to gather from these books any very precise idea of the way our forefathers took their pleasure in the field. Turberville's and Cockaine's - the latter but a small pamphlet-are worth looking at chiefly for the quaintness of the woodcuts, and also of their language. Twici busies himself chiefly with the different notes to be sounded on the horn, according to the game being hunted and the state of the chase; but he also gives the names of the variuus beasts 
that are legitimate objects of siort, and some directions for blooding the hounds and breaking up the game, the huntsman being particularly warned against giving any part of the fox to the hounds, 'fur it is not good for them.' Dame Juliana, or whoever is to be credited with the book that goes under her name, has practically done little more than put into doggre? rhyme the precepts of 'Twici and his English translator, though the rhymester quotes the legendary authority of Sir Tristram, who seems to have been regarded in those days as the par. ticular patron of huntsmen; we find Cockaine, for example, gravely asserting that 'it hath been long received for a truth that Sir 'Tristram, one of King Arthure's knights, was the first writer and as it were founder of the honourable and delightful sport of hunting.' They have their own interest, all these works, but the interest is one which appeals rather to the antiquarian than the sportsman. They tell the latter little, and it is hard to inagine that they can have told their own contem. poraries very much.

Our knowledge of what we may call the dark ages of hunting is derived mainly from the indefatigable Strutt, who has, if we may employ a sporting metaphor, drawn all sorts of coverts which up to that time had been undisturbed, and but for him had very likely remained so to this day. It is true that what he has contrived to unearth is not verv much, but it is something; it gives us some idea of the estimation in which hunting was held by our remote ancestors, if not very much of the way in which it was pursued. He found, for example, that Alfred the Great, that pious and learned king, was a 'most expert and active huliter, and excelled in all the branches of that most noble art, to which he applied with incessant labour and amazing success.' While the Danes ruled in England the sport began to be fenced about with certain restrictions tending to confme it to the uplecr classes, though ('anute, who also prohibited all hunting and hawking on the Sabbath, while rigorously forbidding all tresjass on the royal hunting grounds, allowed each man to disport himself at will on his own. Any violation of these restric. 
tions was severely punished, in certain case's with death. These game-laws were in existence at any rate down to the time of John, and lost, we may be sure, none of their rigour under the Norman rule. Iunting was then pre-eminently a royal pastime. Even Edward the Confessor, who abhorred all secular amusements, made an exception in favour of the chase both with hound and hawk. He took the greatest delight, says Strutt, quoting William of Malmesbury, "to follow a pack of swift hounds in pursuit of game, and to cheer them with his voice.' Everyone knows the cruel measures taken by the Conqueror to make and stock the royal hunting-grounds, an example followed, though in a less brutal degree, by his son Henry, who made the great park at Woodstock, and walled it round with seven miles of stone; wherein after him his grandson, the first of our Plantagenet kings, kept, if history spexik truth, other game than stag and boar. Gradually the great nobles followed suit. Henry, Earl of Warwick, made a park at Wedgenoke, and others began to inclose ground in various parts of the country, without much regard to the rights of the commons. A contemporary writer, John of Salisbury, gives a gloomy picture of the height to which the ruling passion had grown, and of the hardships to which the lower classes were subject for their rulers' pleasure. 'In our time,' he says, 'hunting and hawking are esteemed the most honourable employments and most excellent virtues by our nobility, ard they think it the height of worldly fulicity to spend the whole of their time in these diversions; accordingly they prepare for trism with more solicitude, expense, and parade, than they do for war; and pursue the wild beasts with greater fury than they do the enemies of their country. By constantly following this way of life they lose much of their humanity, and become as savage nearly as the very beasts they hunt. Husbandmen, with their harmless herds and flocks, are driven from their well-cultivated fields, their meadows and their pastures, that wild beasts may range in them without interruption.' And he then gives the following piece of advice to all whom it may concern: "If one 
of these great and nereilens hunters shall pass by your habitadion, bring forth hastily all the refresinent you have in your house, or that you can readily buy or borrow from your neigh bours: that you may not be involved in ruin, or even accused of treason.' 'This refreshing pratetice is, happly, still much in rosuc, thoush not from the same interested motives. Perhaps the worthy chronicler dici not disclain a little to overcolour his picture, after the fashion of sundry good souls of our own day. Histury, at any rate, hardly bears out the com-

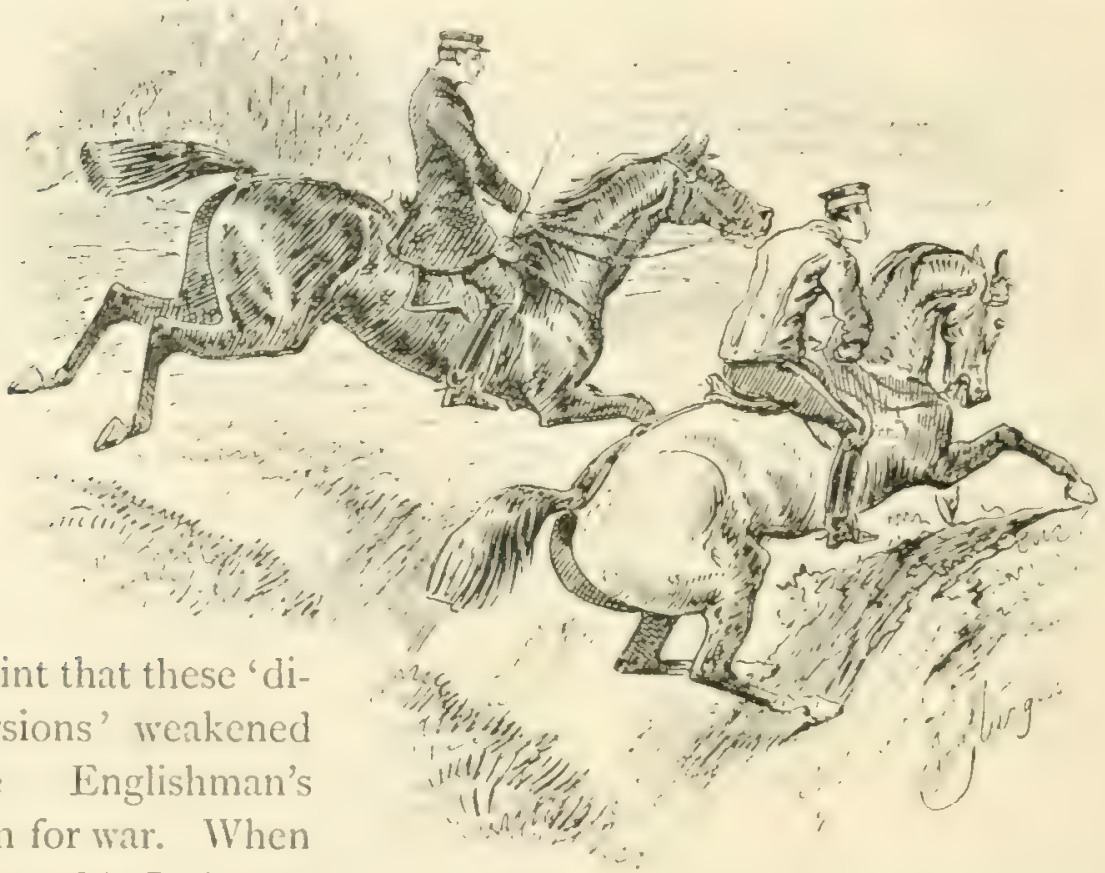

plaint that these 'diversions' weakened the Englishman's arm for war. When Edward III., for example, was engaged

'Chased the for as vigorously as he did the French.' in his lineneth wats, he had always with him in the field sixty comple of starghounds and as many hamiers, with which he diverted himself when not more stemly engaged-a practice

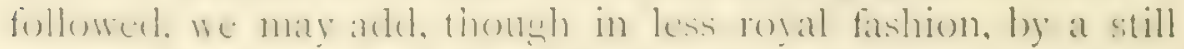

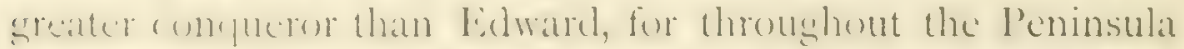
campainn ildelingtom always kepte a park of hounds at head-

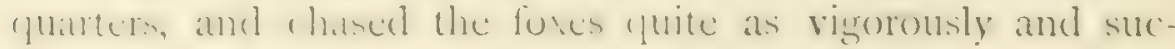
restully as he dist the linemh. But there is no doubt that 
nuntung, as then cnjoyed by the upper classes, entailed munh suffering and oppression on the lower. 'The clergy wese fatrticular offenders. By a charter of Henry 111. archlishops and bishops were allowed, when travelling through the royal foresti, on the King's service, to kill two deer under certain conditions. In time their permission came to be construed more largety; and the priest grew as mighty a hunter as the baron. Chaurer has many a hit at this unclerical practice. In the Prologue to his 'Canterbury Tales' the monk is described as-

A fayre for the maistrie,

An outrider that loved renerie;

A manly man to bell an abbot able.

Full many a deinte hors hadde he in stable.

Therefore he was a prickasoure a right:

Grcihoundes he hadde as swift as foul of flight:

Of pricking and of hunting for the hare

Was all his lust, for no cost wolde he spare.

Again, in the 'Ploughman's 'Tale,' if that be truly Chaucer's, which is specially directed against the luxury and loose living of the clergy, it is laid among the monk's malpractices that he wu

ride on courses as a knight

With hawkis and with houndis eke,

and that,

He mote go liunte with dogge and bich

And blowen his horne and cryin Hey.

Of a certain Walter, bishop of Rochester in the thirteenth century, Strutt tells us that 'he was an excellent hunter, and so fond of the sport that at the age of fourscore he mate hunting his sole employment, to the total neglect of the dutics of his office.' Another occupant of the episcopal tench, Reginald Brian, bishop of Worcester, we find writing. in the following century, to his brother, bishop of St. Davds. to remind him of a promised gift of some hounds. Ilis heart languishes, he says, for their arrisal: "let them come then, oh! 
reverend father ! without delaty; iet my woods re-echo with the music of their cry and the cheerful nutes of the horn, and let the walls of my jalare be decorated with the trophies of the chase!' Again, William de Clowne, Abbut of St. Mary's in Leicestershire, was so fimous a hunter and so renowned for his breed of hounds, that he was granted, ly royal charter, the privilese of holding an annual fair or market for their sale. From the carliest times, indeed, it secms Churchmen were wont to be particular sinners in this respect, for Mr. Froude tells us that Wulsig and Walnoth, Abbots of the great monastery of St. Albans in the ninth century, were notorious for neglecting their duties for the society of hound and hawk, as well as for other socicty even less convenient for an abloot. Henry II. and Richard II. both in their times tried to put a stop to such scandals, lut probably more with a view to thwart the power and ambition of the priesthood than from any strictly moral motive. At any rate neither they nor their successors seem to have been able to effect much. In the reign of Henry VI. the clersy are particularly warned against 'hawkynge, huntynge, and dawnsynge;' and at the time of the English Reformation the see of Norwich alone owned thirteen parks well stocked with game of every kind!

The presence of ladies in the hunting-ficld dates from very early times. At first probably they were content to be spectators only, watching the sport from wooden stands crected for the purpose, bencath which the grme was driven. But they evidently soon aspired to a more active part. From an illus trated manuscript of the fourteenth century, some cuts from which are given by Strutt, we learn that ladies took the field on horsetsack, and bestrode their horses, moreover, after the fashion of men! IIow they disposed of the garments proper to their sex, which they aplatently still retained, does not scem very claur. The costume now in vogrue among Amazons did not apparently come into use till three centuries later, and then only partially. Strutt guotes a writer of that time to the effect that the ladies of bury in Suffolk, "that used hawhing and hunting 
were once in a great value of wearing hmerhes, whence arese, he says, many severe and luelicrous samasms. It wals ureferl,

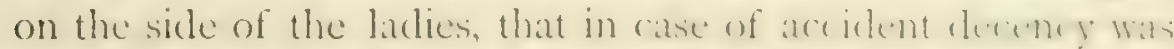
thus better preserved; but to this the answer was, "that suth

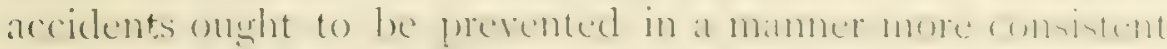
with the dedicacy of the sex, that is, he refraining from sul h dangerous recreations and possibly, ats (ioldsmithis commotis. sedur observed of a different matter, there is morh to be anil

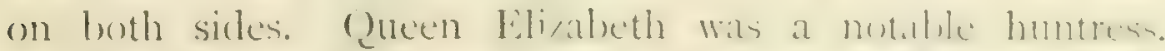

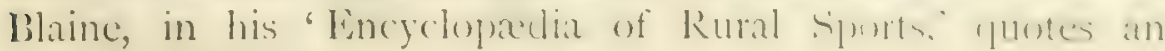

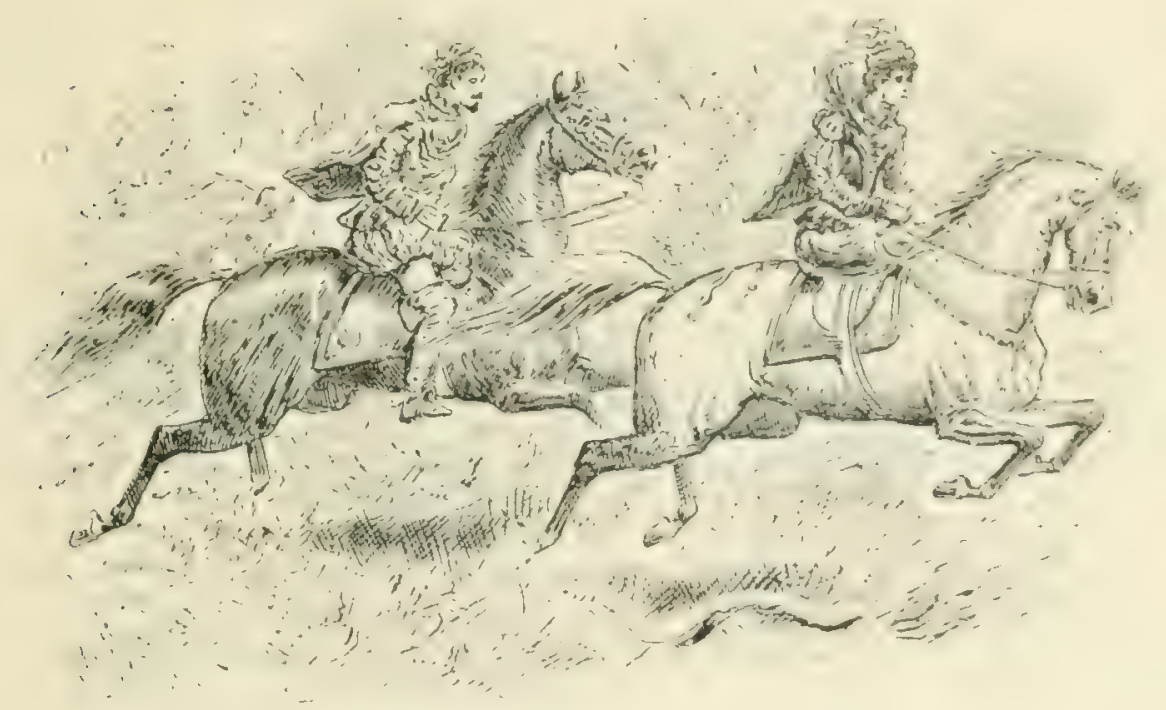

'Queen Elizabeth was a notable huntress.

account from an eye-witness of her Majesty fordesen at Kenilworth during her manificent entertainment he I ciesster in 1575 ; and towards the end of her long life, when at Oatlands, she is described in a contemporary letter as still

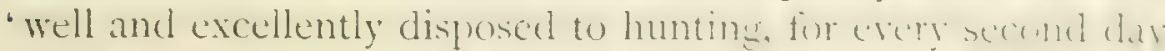
she is on horseback and continues the sport lone.' 'Iheush I ord Tennyson has called her the "man minded offepring" of her father, it does not appear that she was sufficiently man- 11 line to adopt the seat in vogue amones her sex in the founteconth century. According to blaine that fashion was gut ont we court 
in England by Anne of Bohemia, wife of Richard II., who was the first to ride in the modern manner; though in Portugal, if Sir Nathaniel Wraxall may be trusted, the earlier style still prevailed in the latter half of the last century. If this were so, we must suppose that the 'Inury ladies' aped the sterner sex only in their garl and not in their seat; that, in fact, they draped themselves much as the Dianas of our own time, save that they did not consult decorum to the extent of a skirt. From a passage in Pope's correspondence we learn that in his time hunting was high in fashion among the Court ladies, though in one instance, at any rate, it seems to have been a fashion followed, like so many other fashions, less from inclination than etiquette. 'I met the Prince,' he writes to some anonymous fair, 'with all his ladies on horseback coming from hunting. Mrs. B- and Mrs. L_ took me into protec. tion (contrary to the laws against harbouring Papists), and gave me a dinner with something I liked better, an opportunity of conversation with Mrs. H_- We all agreed that the life of a Maid of Honour was of all things the most miserable; and wished that every woman who envied it had a specimen of it. To eat Westphalia ham in a morning, ride over hedges and ditches on borrowed hacks, come home in the heat of the day with a fever and (what is worse a hundred times) with a red mark in the forehead from an uneasy hat; all this may qualify them to make excellent wres for fox hunters, and bear abun. dance of ruddy-complexioned children.' The most renowned I)iana of that century seems to have been Lady. Salisbury, who kept a pack of dwarf foxhuunds at Hatfield, and went a-hunting in great state, her servants magnificent in sky-blue uniforms, black collars, lappels, and jockey-caps. In the 'Sporting Magazine' for March 1795 , there is an account of her triumplis in a graat run of two hours and a half: 'Out of a field of fourscore,' says her enthusiastic chronicler, 'her ladyship soon gave honest Daniel the go-by; pressed Mr. Hale neck-andnuk, soon bluwed the whipper-in, and continued, indeed, thromghout the whole of the chase to be acarest the brush' 
A worthy mateh to here womld have lecen that stout old livemeh lady of whom Mr. Vyner tells us in his ' Notitid Vindile a: Tame Marie Cécile ( harlotte de Jauretam, Barnnne de l)r.u cle.

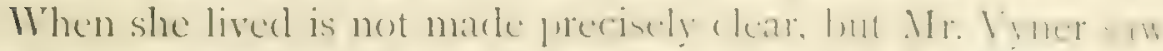
her picture in 1839 when he risited the oht reste in whe he he used to hold her state, about sisteen miles from (ialdis. Sire was painted on her farourite arey horse, dresed in a steren coat, with a gold waist-belt. Her hatr wats powrlerel and

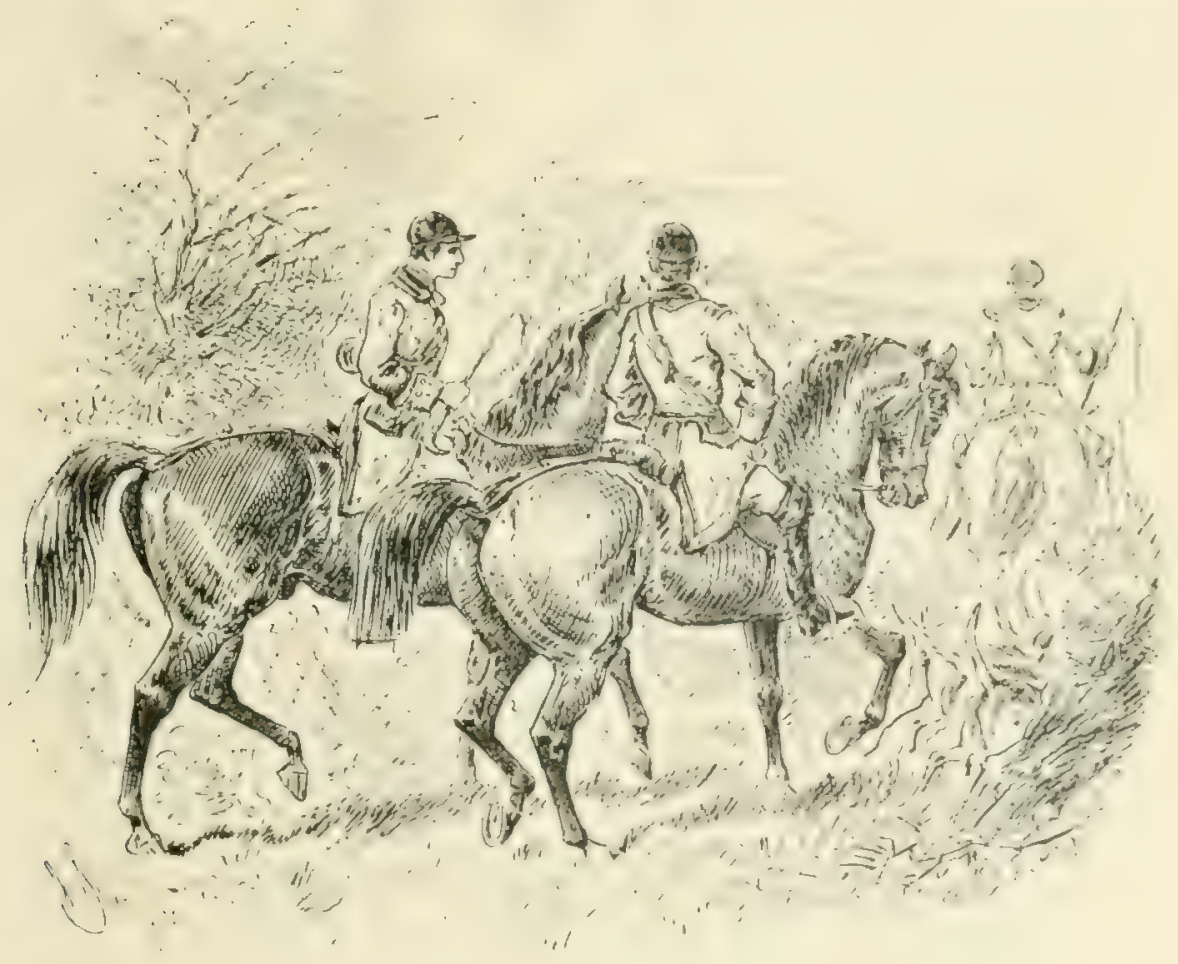

'Magnificent in sky-blue uniforms.

arranged in large curls, and her hat was high crommed with a gold band. Her nether woman was clat in bouts and levther breeches, and she rode as men do. kight hunters were in her stable, and in her bedroom she kept her farourite ams and saddles. She hunted three dass a reek. and had a dinne: party on every hunting day. More than $6-0$ wolves are sibl wh lawe fallen by her hand : and when sterner same was not to be hat 
she did not disdain the badiger or the fox. She died of apoplexy in her own house at seventy-five years of age. There was a certain Miss Draper also, appropriately christened Diana, the daughter of a famous old Yorkshire squire, who won great praise in her time. She was wont to assist her father in the field, 'cheering the hounds with her voice.' It is also ncted of her that she 'died at York in a good old age, and, what was more wonderful to many sportsmen who dared not follow her, she died with whole bones in her bed.' Her father was quite 'a character,' and as he must be the earliest of the old fox-hunters of whom we have any note, if it be true, as the 'Druid' says, in 'Scott and Sebright,' that he commenced operation in 1726 , the following account of him, from 'The Hunting Directory,' may be interesting:

In the old, but now ruinous, mansion of Berwick Hall, in the East Riding of Yorkshire, once lived the well-known Wrilliam Draper, Esq., who bred, fed, and hunted the staunchest pack of foxhounds in Europe. Upon an income of only jool. he brought up creciitably eleven sons and daughters; kept a stable of excellent foxhounds, besides a carriage with horses suitable for the convenience of my lady and her daughters. He lived in the old honest style of his ccuntry, killing every month a good ox of his own feeding, and priding himself on maintaining a substantial table, but with no foreirn kickshaws. His general apparel was a long, dark dirab hunting-coat, a belt round his waist, and a strong relvet cap on his head. In his humour he was very facetious, always having some pleasant story, both in the field and in the hall, so that his company was much sought after by persons of good condition, and which was of great use to him in the advancement of his children. His stables and kennels were kept in such order, that sportsmen observed them as schools for huntsmen and grooms, who were glad to come there without wages merely to learn their business. When they had obtained proper instruction he then recommended them to other gentlemen, who wished for no better character than Squire Draper's recommendation. He was always up during the hunting scason at four in the morning, mounted on one of his mars at five, himself bringing forth his hounds, who linew every note of their old master's volce. In the field he rode with judgment, avoiding what was unnecessary, and helping his 
hounds when they were at fault. After the fatigues of the day, which were generally crowned with the brushes of a brace of foxes, he entertained those who would return with him, and which was sometimes thirty miles' distance, with old Engrlish hospitality. Cood old Oitolier was the liquor drunk; and his first fox-hunting toast was All the brushe's in Christentum. At the age of cighty years this gentleman died as he chiefly lived, for he died on horseback. As he was going to give some instructions to a friend who was rearing up a pack of foxhounds, he was seized with a fit, and dropping from his old favourite pony, he expired! There was no man, rich or poor, in his neighbourhood but lamerted his death, and the foxes were the only things that had occasion to be glid Squire Draper was no more.

Though hunting was, as we have seen, in its carly diys the exclusive amusement of the noble classes, an exception was always made in favour of the citizens of London from almost immemorial times. Strutt quotes a charter granted to them by Henry I. which contains the following clause: "The citizen, of London may have chases, and hunt as well, and as fully; as their ancestors have had; that is to say, in the Chilure, in Middlesex and Surrey.' According to 'Cecil,' the Lord Mayor himself kept hounds from a time vaguely specified as 'many' centuries ago;' and Lincoln's Inn Fields, St. James's, and May Fair were the favourite places of meeting. The privileges granted by Henry were confirmed by all succeeding kings. In the reign of George I. we find 'riding on horseback and hunting with my Lord Mayor's hounds when the common-hunt goes out,' reckoned by Strype among the favourite amusements of Londoners. This 'conmon-hunt' was, no doubt, the origin of that 'Epling Hunt' which has been the butt of so many wits from the time of I'Lriey' down to our own. In the 'Sporting Magazine' for I 795 there is an account of a run with the Lord Mayor's hounds, designed to show how unfounded were the jests cut at the grood citizens' expense, and that the sport was a scrious and a legitimate business. A stag is turned ont, and it is particularly noted that his antlers had been sawn off, a practice which has 
long been common in the Royal Hunt, but was then an innovation. 'This gallant beast was taken in 'Burleigh's Pond,' as we see in an accompanying engraving, but reserved for a future occasion. So far all may have been well enough, but the chronicler, unfortunately for his cause, is a little too minute in his details. Not only were booths for refreshment erected at the place of meeting, but, after the proper sport of the day was over, a 'genteel marquee' was pitched, appropriately enough near an inn known as 'The Bald-Faced Stag,' wherein a lady', 'elegantly dressed' in a riding-habit, and with 'a bewitching face and fascinating address,' presided over sundry E.O. tables.

To turn again to our bibliography, in the seventeenth century we find a great improvement. Gervase Markham's 'Country Contentments,' and Richard Blome's 'Gentleman's Recreation,' are not only intelligible enough for any reader, but also cxtremely useful and practical ; so that Beckford's saying is itself intelligible only on the supposition that he was unaware of their existence. Markham was the son of a Nottinghamshire squire, and a man of many pursuits and accomplishments. He was a soldier, a poet, and a playwright, as well as a sportsman and farmer. It was in his latter capacities, however, that he won most fame. His treatises on horsemanship and sport were once highly esteemed, but it appears that he soon 'wrote himself out,' and his method of producing quasi new books was to repeat what he had said in his old ones, the consequence being that he was finally forced to sign an undertaking to write no more. Of Blome, or Bloome, we know less. 'There is a man of that name very roughly handled in the 'Athene Oxonienses' for pirating an edition of Bareham's 'I isplay of Iteraldry.' He is described by Wood as 'a kind of arms painter (originally a ruler of paper, and now a scribhler of books), who hath since practised for divers years prosging tricks in employing necessitous persons to write in sereral arts, and to get contributions of noblemen to promote the work.' Blome's book was certainly published by subscription, one of the editions containing the coats-of-atrms of the varions subseribers. It also includes a treatise on heraldry, 
as well as a disquisition on the arts and sciences, so that we may reasonably conclude that more than one hand went to its composition Still, despite Wood's objurgations, the bouk is really both a curious and valuable one, in the department of field-sports at any rate, whatever may have been 13lome's precise share in it. It contains, moreover, a number of plates, which are not only good specimens of the engraving of the day; but useful as showing the costume in which our fathers trok the field. On the whole it may be said of all our carly works on sport to be the one which gives the fullest and nost practical information on the subject. Markham is practical, tco, but he occupies himself more with the breeding, training, and management of horses and hounds, than with the actual pursuit of the game, though he does not altogether neglect that. Blome is naturally, moreover, less archaic in his language and style than the elder writer, about whom still hangs that flavour of quaintness which belonged to English prose down to the age of Dryden. Hunting, for example, he defines as 'a curious search or conquest of one beast over another, pursued by a naturall instinct of enmitie, and accomplished by the diversities and distinctions of smells onelie, wherein nature equallie deviding her cunning giveth both to the offender and offended strange knowledge both of offence and safety.' He writes of 'highway dogges,' hounds, that is to say, which will carry the scunt along a high road; of 'dogges of nimble composure,' meaning quick and well-made; and of certain others being 'the most principall best to compose your kennell off.' In Blome's book of course we get much less of this style of writing, though he, too, can amuse as well as instruct us; by warning, for example, those who go forth to hunt the hare, that it is 'a very' melancholy beast,' and therefore 'very fearful and crafty.'

First in the next century comes that anonymous author of that 'Essay on Hunting' which Beckford's editor declares, as we have seen, to have been the only book written on the sulject prior to the famous letters. It was published in 1773 and is said by the same authority to be fill of 'good sense and 
prartical knowledge.' Whether this statement is more in accorlance with fact than the other we cannot say, as we must confess to have never met with a copy. Our only knowledere of it is derived from the 'Druid,' who was more fortunate than we. 'The author, as he tells us in 'Silk and Scarlet,' 'presumes on parrlon from the lopuacious world, if among so many treatises, vinclications, replies, joumals, craftsmen, hyp-ductors, and lay preachers, the press be borrowed a day or two for a plain eisay on the innocent recreation of us country squires.' The hunting of the hare was clearly the recreation nearest the heart of this particular squire. In the 'Druid's' words, 'a fox, it is truce, is cunled up at the end of the cssay ; but he runs hare throughout.' Still more candid is the next writer, a Mr. Garliner, author of 'The Art and the Pleasures of Hare Hunting, in six letters to a I'erson of Quality,' who evilently thinks the 'triumph of the timid hare' is the only triumph worthy of a true sportuman. Three years later we gret inte a wider field with 'The Country Centleman's Companion,' compiled by 'a Country Gentleman from his own Experiences;' a sensible little book, owing a great deal, of course, to its predecessors, despite the author's prefatory disclaimer, nor always acknowledging its debts, but yet with a good deal to say for itself, especially on the breeding and management of hounds, and the general economy' of the kennel. IBetween the anonymous 'Essay on Hunting' and these wo works comes Somcrville's 'Chase,' which most people interested in the subject have probably read once at least in their lives; if they have nerer studied the original, they must at any rate hare grot a very fair idea of it from leckford's hook, in which from first to last the most important part of the prem is prartically reprinted. Fectiford himself of course marks an era not only in the literature hut in the history of hunting. Whatever maly have been the real value of the writers before lim, it is certain that to all who have come after him he has been a 'guide, philosiphler, and friend.' It is scarcely too muh to siy that since his. 'Thoughts upon I Iunting' were furst printed in sist there has lecen no writer who has gone at all 
seriously into the science and ecumbug of the suhjert whro hat mot more or less made une of their alausing pagect. For the anc as amusing as semsible. Fven those who regard the subjent itself with indifference or dislike coulel not but allow on trial that Beckford is at least never tedious or dull, for all his own modet declatration that 'fox-hunting, howerer lively and animating it may be in the field, is but a dull dry subject to write up,on.' He has generally some witty story or shrewd salying at hand to point his moral, and his style is culite a model for surh a work. No man ever so happily illustrated Johmson's sayng of the importance of being able to write trifles with dignity. Al the same time he is never pompous or pechantic, any mote than he is slowenly or vulgar. beckford was in fact a remarlialily well. read and cultivated man, one of the very best specintens of the English country squire the last century aflords us-a striking antithesis, indeed, to that other fox-hunting sefure whom Ficlding drew, more typical of the breed, pertiaps, than Iteckford. Cousin to that famous I.ord Mayor, John Willes's champinn, patron that was to have been of poor Chatterton, and father to the great lord of Fonthill, our author inherited from his huther a comfortable estate in Dorsetshire which enalsled him to indulge his tastes both for letters and sport. His ' I'amiliar I cetters from Italy to a Friend in Lingland,' the record of a continental tour made just before the outbreak of the lirench Revolution, are most agreeable reading, the work of a man well rersed in ancient and modern literature, and of good taste and perce puim. A contemporary writer has thus pithily summed lim up): 'Never had fox or hare the honour of being chased to dcath by so accomplished a huntsman; never was huntsmin's dinner gracel by such urbanity and wit. He would bay a for in (incels, find a hare in Latin, inspect his kennels in Italian, and dircit the economy of his stables in exquisite French.'

With Beckford's book our retrospect of the literiture of hunting may fitly close. He clearly marks the end of the old

1 We are indebted to the courtey of Mr. Rotert Itarrisun, Libnatin of the London Library, for these particulius of Bechford's accomplishment: 
school and the berimning of the new. With the works of the latter, both serious and fictitious, from Delmi Radcliffe and 'Nimrod,' down to 'Scrutator' and 'Cecil,' Surtees, John Mills and Whyte-Melville, we may suppose our readers to be well enough acquainted; and as we shall ourselves have many occasions to consult them in the course of the following parges, it would be superfuous to spend further time over them here.

When hunting began to be regarded as an organised pastime with laws and arts of its own, a list was drawn up of the beasts a true sportsman might legitimately occupy himself in chasing. It was, of course, a pretty' large one, and was divided by 'Twici into three classes. The first contains four, distinguished as 'beasts for hunting,' the hare, the hart, the wolf, and the wild boar; the second five, known as 'beasts for the chase,' the buck, the doe, the fox, the martin, and the roe; in the third come the grey or badger, the wild cat, and the otter, mentioned as affording 'greate dysporte' to the huntsman, but evidently regarded as legitimate game only in default of something better. By later writers the 'beasts of the chase' were subdivided into two further classes. In the first were the buck, the doe, the bear, the rein-deer, the elk and spytard, a hart of one hundred years old; in the second, which obviously includes also the original third class, the fulimart, the fitchat or fitch, the cat, the badger, the fox, the weasel, the martin, the squirrel, the white rat, the otter, the stoat, and the pole-cat. The first division was known as beasts 'of sweet Right,' to distinguish it from the others who were classed as beasts of 'stinking flight;' a distinction which Strutt interprets as referring to the scent the latter give when chased; but inasmuch as the former must certainly have supplied a smilar mears of pursuit, it most probably was designed to distinguish the estimation in which the two classes of game were held. It is at any rate clear that our ancestors, when they went a-hunting, were pretty much of a mind with the accommodating witness provided for one of Mr. Jaggers's clients, and were prepared 'in a general way for anythink.' 
As our business, however, lies with the gitue of to-lily, we need not stay to consider in what manner the cayture of whe weasel or the pole-cat was encompissed, or even of the wolf or the boar. As the forest gradually disappeared, and lancl cance more and more under cultivation, the greater part of these buasts either vanished altogether or became so infrecuent as to drop' out of the sportsman's list and take their place on the roll of vermin. Even 'Twici practically confines himself to the star, the fox, and the hare, and we may be well content to follow Twici's example.

Of these, the stag of course held the first place, frum his size, swiftness, and courage, as well as from the uses to which he could be put after death in supplying both the inner and the outer necessities of man. 'Of the Stagge,' says Markham, 'which is the most princelie and roiel Chase of all Chase's, and for whom indeed this Art of Hunting was first found out and invented, he is of all beasts the goodliest, statelyest, and most manly.' But though the supreme qualities of the stag were thus duly acknowledged, the triumph over the hare seems from very arly times to have been considered the prime test of a huntsman's quality. 'We will begin with the hare,' says 'Twici. "Why, sir, will you begin with the hare, rather than with any other beast?' 'I will tell you. Because she is the most marvellous beast which is on this earth.' The study of natural history was then but in its infancy, and some of the properties which struck King Edward's 'Master of the Game' with such astonishment will hardly surprise us very much to-day. Among other marvels we are told that 'at one time it is male, and at another time it is female,' but whether this diversity of sex is supposed to belong to the individual hare, or to be a general characteristic of the species, is not clear. Markham thought hare-hunting the 'freest, readiest and most enduring pastime;' and Iilome follows suit, styling it an art 'full of subtlety and craft, and possessed of divers delights and varieties, which other chases do not afford,' though he adds, 'whosoever hath hunted one and the same hare twice, and doth not kill her the third time, 
deserves not the name of a huntsman, for gencrally they use the same sleights, doublings and crossings.' In Shatespeare's immortal stanzas, of the three beasts which the love-sick groddess advises her flinty-hearted boy to 'uncouple at :'

the timorous flying hare,

Or at the fox which lives by subtlety,

Or at the roe which no encounter dare,

the first is evidently the chase the poet knew best, though from his compassionate epithets he seems, like a later bard, to have thought it but a 'poor triumph.' Thomson, as we know, held this opinion, and urged the 'sylvan youth' of IBritain, since such noble prey as 'the roused-up lion,' or the 'grim wolf,' or the 'blincied loar,' are not for them, to direct their energies against the fox.

Your sportive fury, pitiless, to pour

Loose on the nightly robber of the fold:

Him, from his craggy winding haunts unearth'd,

Let all the thunder of the chase pursue.

'Throw the broad ditch behind you; o'er the hedge

High bound, resistless; nor the deep morass

Refuse, but through the shaking wilderness

Pick your nice way; into the perilous flood

Bear fearless, of the raging instinct full ;

And as you ride the torrent, to the banks

Your triumph sound sonorous, running round,

From rock to rock, in circling echoes toss'd;

Then scale the mountains to their woody tops;

Rush down the dangerous steep; and o'er the lawn

In fancy swallowing up the space between,

Pour all your speed into the rapid game;

For happy he who tops the wheeling chase ;

Has every maze evolved, and every guile

Disclosed; who knows the merits of the pack ;

Who saw the villain seized, and dying hard,

Without complaint, though by a hundred mouths

Relentless torn: O glorious he, beyond

His daring peers! 
Beckfurd, too, was evidently of the same mind with Thomson. 'By inclination,' he say's, 'I was never a harehunter. I followed this diversion more for air and exercise than for amusement; and if I could have persuaded myself to ride on the turnpike-road to the three-mile stone, and back again, I should have thought I had no need of a pack of harriers.' He adds, however, with his wonted respect for every legitimate form of hunting, that he speaks only of the country where he lives, where "the hare-hunting is so bad, that, did you know it, your wonder would be how I could have jersevered in it so long, not that I should forsake it now.' On the other hand, John Smallman Gardiner, Gent, whose letters have been already mentioned, has scarce words enough to express his admiration of the hare as an object of chase, and his contemptt for the fox. He allows, indeed, that it 'would be imprudent to declaim against other people's diversions to enhance the satisfaction found in mine;' yet he does declaim, and pretty vigorously, though his objections scem to be much of a nature with those which a certain Etonian of a past generation found against football, that it was too rough and violent to take rank as a 'gentlemanly' game! This is what he says: 'A lover of hunting almost every man is, or would be thought ; but twenty in the field after an hare find more delight and sincere enjoyment than one in twenty in a fox-chase, the former consisting of an endless variety of accidental delights, the latter little more than hard riding, the pleasure of clearing some dangerous leap, the pride of bestriding the best nag, and showing somewhat of the bold horseman ; and (equal to anything) of being first in at the death, after a chase frequently from county to county, and perhaps above half the way out of sight or hearing of the hounds. So that, but for the name of foxhunting, a man might as well mount at his stable-door, and determine to gallop twenty miles an end into another county.' This is a view of fox-hunting that has been accepted since Mr. Gardiner's day by many less inclined to go along with him in his objections to the hard riding part of it, if there be any truth in the saying 


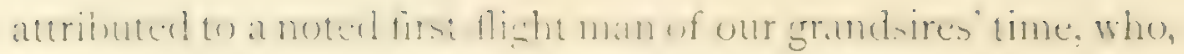

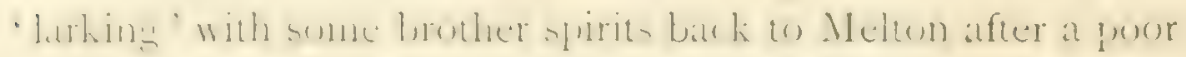
day's sport, exclaimed in a burst of rapture, "What fun w'e might hav'e, if it ausn't for these d-d hounds!"

It is clear that till about the middle of the last century fo:humbing he means helel the prite of plate amonest sportsmen

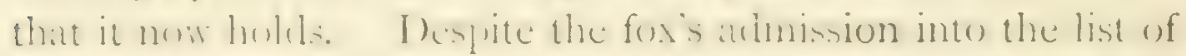
beatsts of chasc, there can be no doubt that then and for long

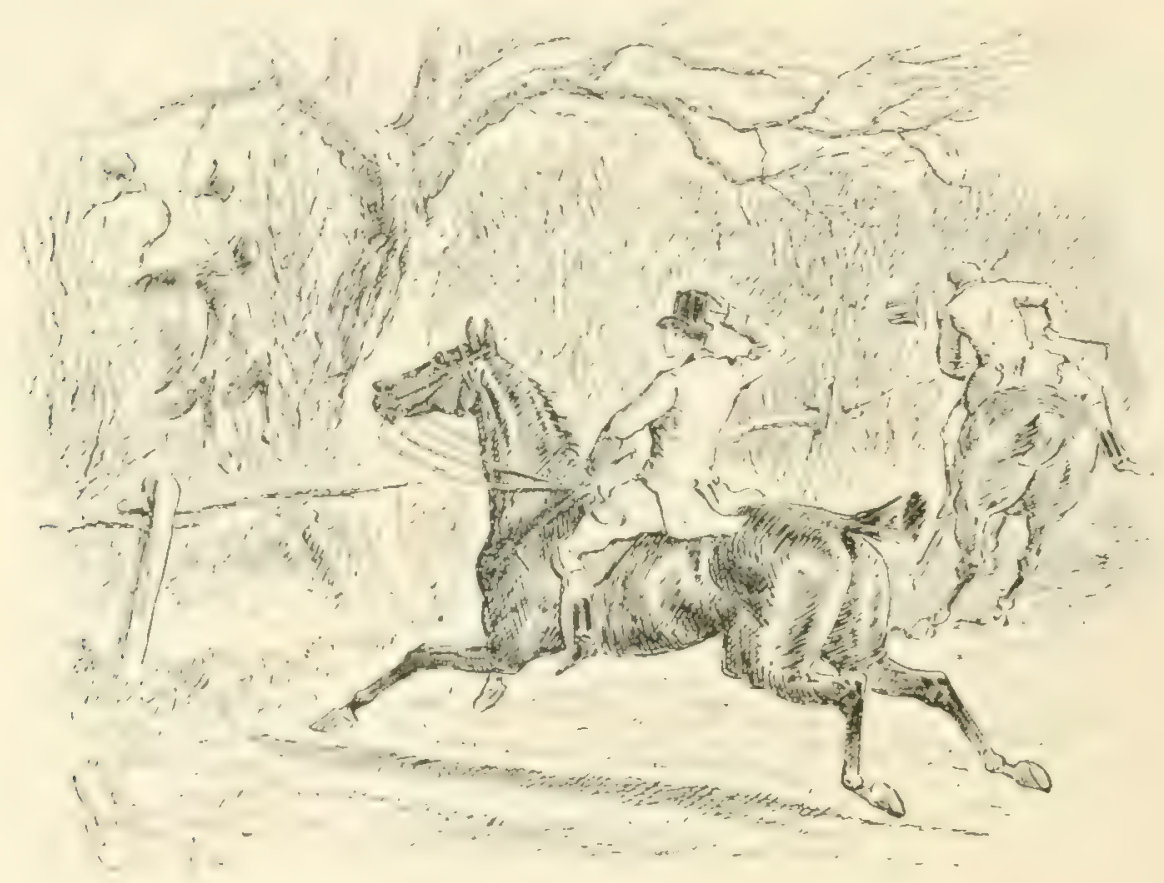

' Larling with some brother spirits back to Melton.'

after he wats holicel on as a mataucler, whose death was w be encouraged by any means, fair or foul. The well-known passige in ('haucer's 'Nun's 'Take' revealing the treacherous

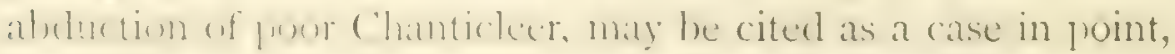
where, by the way, the fox is called 'I)an Russet' from his red

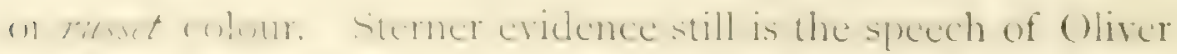

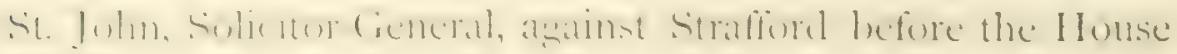
of Lords in 16.1. 'It is true,' he said, as reported by 
Clarendon, "that we give law to hares and deer leccause they are Beasts of Chase; but it was never accounted either cruelty, or foul play, to knock foxes and wolves on the head as they can be found, because they are beasts of prey.' W'alter scott, too, it will be remembered, puts the same sentiment in the mouth of Roderick Dhu;

-but, though the beast of game

The privelege of chase may claim,

Though space and law the stag we lend

Ere hound we slip, or bow we bend,

Who ever reck'd where, how, or when,

The prowling fox was trapp'd or slain!

It is true, Twici gives directions for hunting him 'above ground,' which shows that he was then beginning to lex regarded as something better, at least, than a badgrer ; but muct. later writers than 'Twici evidently regard his chase, though in default of a better it may yield sport enough, as not com. parable to that of the stag or the hare. Markham, for example, who, by the way, does class poor Reynard with the badger, says of both that they 'are chases of a great deal lesse use or cunning than anie of the former,' though his reasons 'be. cause they are of much hotter scent, and indeed very few dugrges but will hunt them with all egernesse,' may strike us as not very cogent. Blome considers the cliase of the fox 'not so full of diversity as the hare,' and the 'Country Gentlem:an' agrees both with Blome and Markham. He is always mentioned as 'the craftiest beast that is,' trusting less in his 'strength of body or swiftness of legs' than in his cunning. Turberville, indeed, gives some very remarkable instances of his shifts to escape from his pursuers, which the verbal decorum of our age will not allow us here to reproduce. But perhaps the most striking illustration of our ancestors' ideas on the subject of fox-hunting is to be found in Cockaine, who tells us that 'every huntsman his part is to hew him, or backe him into the covert again wher, he offereth to breake the same.' This murderous piece of advice may perhaps be partly condoned by the fact that in those 
dais the fox seems generally to have been hunted on font; even in Bicme's time it appears from the illustrations to his book that the huntsman proper did not put his trust in the legs of a horse.

A former Lord Wilton in his 'Sports and Pursuits of the English,' says it was not till I 750 that hounds were entered solely to fox. But in his famous 'Quarterly' article on 'The Chase,' 'Nimrod' (puotes a letter written to him by Lord Arundel, from which it appears that one of his lordship's ancestors kejt a park at the close of the previous century. They hunted besth in Wiltshire and Hampshire, and remained in the fanily till I $7 S_{2}$, when they' were sold to 'the great $M I r$. Neynell,' the real father of the modern English chase. 'There must, however, have been another park at least coeval with this, for some few years aso there was in the 'Field' an engraving of a hunting-hom in the possession of the then master of the Cheshire hounds, on which was the following inscription: "Thomas Boothby, Esq., 'Tooley Park, Leicester. With this horn he hunted the first pack of fox-hounds then in England 55 years: born 1677 , died I 752.' Another authority gives 1730 for the year when Thomas Fownes, of Stepleton in Dorsetshire, kept a resular pack of fox-hounds, which were afterwards sold to Mr. Bowes, of Yorkshire. It is, however, very possible that Lord Wilton's date may be the correct one, for there is nothing to show that these packs were not occasionally stooped to other game than fox; a practice which even leckford, that staunch legitimist, though he does not recommend 1t, writes of as a possibility when foxes are unusually scarce. According to a memoir of the Belvoir hounds, the present pack can prove an uninterrupted descent from the year griven by Iord Wilton. Seven years earlier the records of the Jadminton kenncls could show only one couple of fox-hounds, the rest heing ciecr-hounds and harriers. According to 'Cecil,' it was not till 17 fo that this famous hunt tumed itself solely to the chase of the fox. In that year the fifh Duke, then still a minor, white prissing silk Wood on his way home after a poor 
day's sport, threw his hounds into covert: 'a fox was found which gallantly faced the open, a capital run was the result, which so delighted the young sportsman, that the hounds were forthwith steadied from deer, and encouraged to fox.' Ithen the last Iord Berkeley kejut hounds his country stretehed from Bristol to Wormwool Scrubs, a distance, that is, of some I 20 miles, necessitating four separate suts of liemnels! Ilis son, Grantley Berkelcy, has told us he had often heard from their old huntsman how he had killed a fox where the flowers now blossom in Kensington Ciardens. Nor was this lord the first of his name who found his sport so near I,orion; an earlier Lord Berkeley used to kennel his hounds at Charing Cruss, and hunt in Gray's Inn lields, and round about Islington. 'The tawny liveries still worn by the Old Berkeley Hunt are a relic of those days.

Before 1750 , and in many parts of the kingdom for long after, every country squire no doubt kept a few couple of hounds, and on occasions he and his neighbours would unite their force and so form a respectable pack. 'These were known as 'trencher hounds,' from thair running loose about the place, and picking up their food as they best might, and 'Nimrod' supposes them to have been much of a piece with the large broken-haired Welsh harriers. A day's hunting was then in all probability very like that described in 'Guy Mannering,' though the sportsmen were stirring at even an carlier hour than Dandie Jinmont and his guest. For a'most the only point on which we can really afford to be certain was the desperately early hour at which our fathers commenced cperation, 'so soon as they could distinguish a stile from a gate,' says 'Nimrod.' A famous old sportsman, Mr. Lockley, a contemporary of Meynell's, used, says 'Cecil,' always to begin the account of a certain wonderful day's sport with, 'We breakfasted at twelve o'clock at night.' Men in those days did not hunt to ride, and their greatest pleasure was to watch their favourites drawing up to their game on a cold scent. We know, too, that the for was hunted then as the stag is now A couple or two of steady old hounds were 
thrown in when the drag had led the pack up to the covert where he lay, taking his rest after his midnight rambles, and it was not till he was fairly on foot and away that the body of the park was laid on. Foth hounds and horses were slow then as compared with now, and the riders we may guess to have been much like Squire Draper, 'avoiding what was unnecessary and riding with judgment.' The whole affair was eminently slow no doulst, according to our modern notions, but still, one fancies the sfort, as distinct from the ridin's, may not have been much the worse. In the 'Sporting Magazine' for July 1827 , there is a description of a pack of hounds kept by an old Essex squire who at the close of last century hunted the country between Colchester and the sea on the Maldon side. The hounds were known as harriess, 'because they used to hunt the hares,' but, 'the deep-toned blue-mottled, the dwarf fox-hound, the truebred harrier, the diminutive beagle, all joined in the cry, and helped to supply the pot.' The general economy of the establishment was peculiar. The hounds were kept anyhow, ' having a butcher for one master, a baker for another, a farmer for a third, spreading pretty well through the village.' Whippers-in seem to have been numerous, the butcher, the baker, \&c., each probably playing that part to his favourite hound. The huntsman seems to have been of a piece with the rest, and to have been at least as famous for his feats at table as in the field. Yet 'he was a capital sportsman, and could almost hunt a hare himself.' 'This picture might probably serve for most of the provincial packs at that time hunting in England whether fox or hare.

The chase of the stag was pursued in much more orthodox fashion, and with far more pomp and ceremony, both from the nature of the animal and the fact of the sport being so much older and more fashionable. From a very early date the royal buckhounds were quartered in their present neighbourhood. In Henry VIII.'s reien the kennels were in Swinley, probably on the spot where the deer-paddocks now stand. 'There, too, in the old days lived the masters of the royal pack, and kept 
high revels according to the 'I)ruid' in a houre which has long since disappeared, but whose site he marked under the shadow of some noble limes hard by that where Cotterill, the juesent keeper of the paddocks, lives, as his fanily liverl for many generations before hmm. There is a record of a wonderful run in the time of the second Charles from that place to Lord Petre's in Essex, a distance of serenty miles, the Duke of York being one of the few who saw the decr pulled down. The indefatigable 'I)ruid' has unearthed too another big afiair, from Aldermaston to Reading in the days of "Good King George.' On this occasion both his Majesty's horses were dene 'to a turn,' and their rider had to make his way back to Windsor in a butcher's cart, chatting affably to the driver on crops, stock, and other such congenial topics. The present fashion of stag-hunting seems to have been furst practised in this reign, and to suit King (seorge's sober pace the custom of stopping the hounds seems also to have been inaugurated. According to Blaine the meet was then a much more imposing affair than it now is. The King himself was almost always present, attended by his master of the horse and the equerries-in-waiting. The servants of the hunt wore the familiar scarlet and gold-laced liveries then as now, but the master's coat was light blue, with collars and cuffs of black velvet, the costume also of his Majesty, who, moreover, if a story told by the 'Druid' on the authority of the late Bill Lcan, of hard riding and facetious memory, be true, never took the field without a star on his breast.' 'There was always a great show of carriages and foot-people, and apparently rather more blowing of horns than would chime with modern notions. The Fourth George patronised the stag but rarely, either as prince or king, though he kept up the hunt in great splendour, and penned with his own hand a most courtly note to Charles I)avis on his appointment as huntsman, hoping that he would get the hounds

1 The late Prince Consort (Alhert) always wore the ribbon under his waistcoat out shooting. The Editor has often shot with him, and invarially serd! it on him. 
so fast that they would 'run away from everybody', which was pretty well what that excellent sportsman and rider did do. The Prince had been entered to fox in his father's lifetime, and fir a few seasons hunted the ITambledon country from Moor Critchell, solacing himself on by days with a park of rablitbeagles, seven couples of which could rirle to the meet in a couple of panniers. But, despite the 'Druid's' loyalty, one can hardly supjose him ever to have been very keen about hounds. 'The turf suited him better than the chase; and Carlton IIouse and Brighton better, probably, than either.

No pack of hounds in England could show a cleaner or more direct pedigree than could the staghounds of North Devonshire up to the year 1825 . Exmoor was a royal hunting. ground in the time of the Conqueror, and from that day down into the present century there has always, we believe, been a Ranger of Exmoor holding office under the Crown. The history of the Devonsinire hounds can be traced in a straight line back to the year 159\$, when Hugh Pullard, Elizabeth's kanser, kept a pack at Simonsbath. From that time down to 1825 the spurt flourished exceedingly under a goodly roll of masters, particularly under Sir Thomas Acland, the second of the name, and the late Lord Fortescue, who kept the hounds at Castle IIill in 1802 and again from ISI2 to ISI8. "Those were glorious days,' sighs the historian of the latter's mastership: "When a grood stag had been killed, the custom was for Iames Tout, the huntsman, to enter the dining-room at Castle Hill after dinner in full costume with his horn in his hand, and after he had sounded a mort, "Success to stay-hunting" was solemnly drunk by the assembled company in port wine.' I In I $\$ 25$ the gark was sold, but two years later another was formed, and, with one or two short intervals, the North Devon starhounds have continued to show what is in many ways the finest and most genuine sport in England.

The twelfth Earl of Derby, great-grandfather to the present, also kejut a lark of some note in his day, with which he

' See Collyns's Notes on the Chase of the IVild Red Deer. 
nunted from The Oaks, his place near Eysom from which the tamous race takes its name. The deer were all hed at linowsley, and occasionally crossed with the Yorkshire breed of I ord Fitzwilliam; they were noted for their specd and stontuess, and the hounds were a good match for them in buth rualities. Pace was becoming the fashion then everywhere, and there is at story told of Lord I) urby's huntsman summing up the pratises (f a favourite bitch by vowing that she could run four miles in less time than a groyhound! 'The late Thomas Noreton Fitzhardinge Berkelcy (born in 1794 , died in August I S82, legally Earl of Berkeley, but who, out of respect to his mother's memory, neicer would assume the title) and his brother Grantley when young men also hunted stag with a pack kept at Cranford, the family' seat. The brothers were the officers of the hunt, together with Mr. Henry IVombwell, all wearing the orange tawny livery of the tamily. The pack was given up about i $S_{30}$, when Mr. Grantley Berkeley went to hunt the Oakley. A smart little pack was also kept some years ago near Leamington, and the Surrey Starhounds are of very ancient fame. But save in the West Country the wild stag has not been hunted in England (excepting occasionally in Windsor Forest in George III.'s time), certainly within this century, though in Ireland the sport has been, we believe, occasionally followed within more recent times, but not as we understand 'hunting.' It consists in driving the woods of Killarney and forcing the stags into the Lake, where they are shot or caught with ropes by the horns. Wild deer exist nowhere else in Ireland.

Fox hunting, as we know it now, with its pace and its hard riding, its sumptuousness and refinement, may be said to hare come in with this century. Mr. Childe of Kinlet, says "The Druid,' first began hard riding in Leicestershire to MIr. Meynell's great disgust, and on a half-bred Arabian, too! When Lords Forester and Jersey came with the reckless style of riding, the good old sportsman declared that he 'had not had a day's happiness ;' as he has been described as a 'regular little dumpling' in the saddle. probably the new style of going was 
not much (o) his tante. Mereover, one of his first laws was never to cast his hounds so long as they would hunt; and the obscration of this law was cicurly not compatible with hard ridine. Whether the sport is now what it was in the days whoce rories - linmod has written of and Alken painted, it would he as unecencerous to ask as dificult to answer. If the stories uncarthed by the untiring industry of 'The Druid'

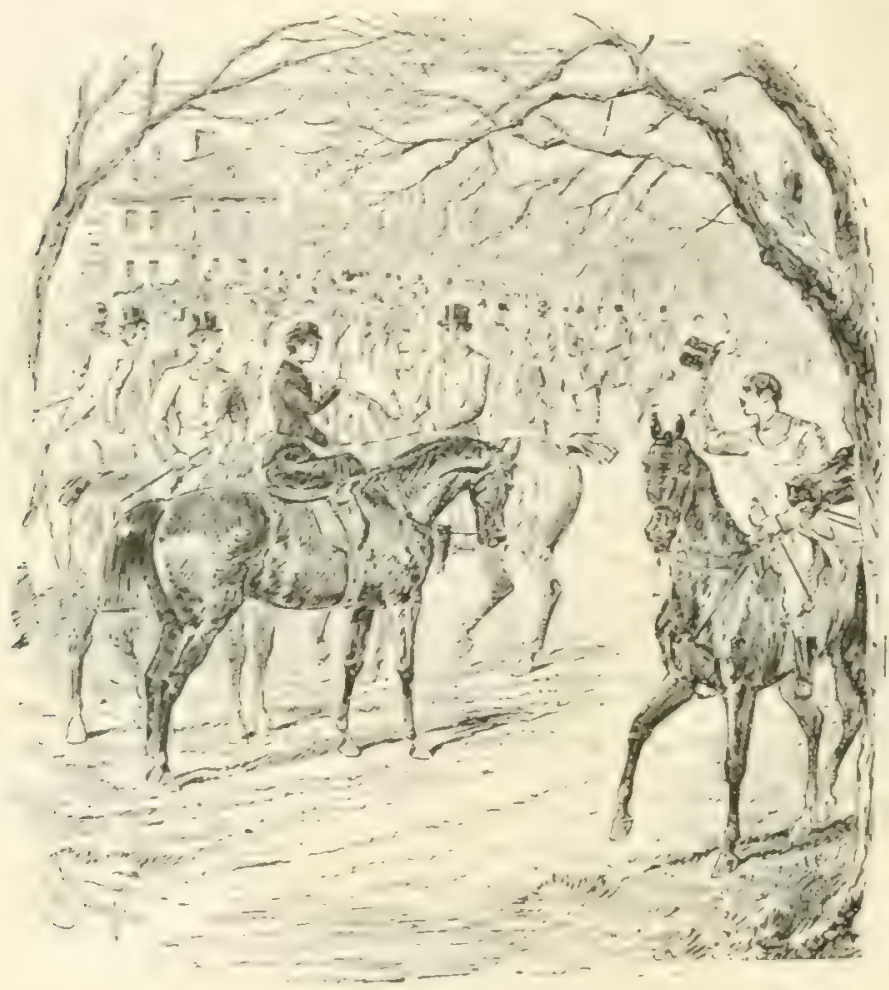

'As we know it now.'

may ail be relied on, there must have been siants indeced in these dits : hounds, horses, riders, and, we may adel foxes. must all hate been marvels of their kind. "The peaches are not so big now as they were in our dass.' wrote Haydon to Nordswerh. when they two were the sole relics of a slorious hand.' let 'ceril rowed that 'where there was one sood herseman thirty years ance (that is, in the first quarter of the (entury) there are twenty now.' 'The younger men of his day 
(they are the 'old men' of ours !) rode, he thought, with better judgment and science than their fathers, and with guite as much pluck. Comparisons, however, are always odious where there exists no sound ground for making them. Those who may feel a desire to try and puzzle out one for themselves cannot do better than turn to the pages of 'Nimrod' and 'The Druid,' where, if the question may be solved, they will find ample means for solving it. That Iords Jersey, Forester, and Delamere, Messrs. Assheton Smith and (Mhaleleston, and others of that period were splendid riders, is undoubted. That fences were fewer, as is sometimes asserted, is not the case, for man: have been thrown down. Ox fences or rits were more numerous, and bullfinches also; but they did not cut and plaish the fences then, and they knew not the binciers that turn horses over. They used to fly the oxers or crash through the bullfinch. That neither hounds nor horses went so fast then, is undoubted. As fewer men hunted, it was easier to gret good horses. There was more room, not so much hurry and crowding; and more pleasure. There were fine horsemen and good riders across country, there have also been the same since, and there are happily many now. For our part we have tried to bring the history of hunting down to the period when it had reached the plase familiar to us. Having done that, the real business of our book begins, and to the great deeds and the great men who did them we shall from time to time find other occasions to refer. 


\section{CHAPTER II. \\ BEASTS OF THE CHASE.}

THE STAG.

The chase of the stiug was considered, as we have already read, the most 'princely' and royal chase of all chases,' and the animal itself of ali beasts 'the goodliest, stateliest, and most manly.' Among modern sportsmen the fox now holus the pride of place, if not in personal qualities, at any rate in the diversion those qualities afford. Your true Devonshire stag hunter certainly will not allow this, and even the staunchest follower of the fox has been known at times to confess that for thorough genuine sport there are few things to compare with a Eallop) after a 'warrantable' stag at the stern of the North Devon hounds, and not many things harder than to keep in that place! The field sport that has stood the test of public criticism through a period of from three to five hundred years may surely asscrt its clain to the title of a national pastime.

Stag hunting, as evcryone knows, has existed from time immemorial; but whether it was conducted in precisely the same manner as it is at present, until the reign of Queen Elizabeth, is very doubtful. Historical records prove conclusively that there was, kennelled at Simonsbath, in this reign, a pack of staghounds, which hunted the red deer on the Fimeors on a system similar to that now in vogue. It is not, perhaps, too much to hope, that while English noblemen, Echtemen, yeomen, and famers retain their profound love of fichl sumts, there will be, at some convenient centre on the moorland range, a pack of staghounds as efficient in every 
respect as that now under the descrvedly popular heir of the House of lortescue, whose history furnishes a long list of ardent supporters of the sport. 'That the ardour of the stag hunter is incapable of being quenched by the devotion of a lifetime will be readily admitted by those who have shared the pleasures, excitements, and dangers of the chase with the many veteran local sportsmen over whose shoulders nearly fourscore years have passed harmlessly.

Nothing, perhaps, strikes the stranger, on his first visit to this historic hunting ground more than the enthusiasm for the sport displayed by men of all ages and all classes of the community. If he should be indiscreet enough to comprare the merits of stag hunting with those of fox hunting, his remarks will invariably meet with unveiled disapproval, coupled with an oppressive load of commiseration.

It is possible that stag hunting on the Exmoors and Quantocks derives some of its fascination from their unique wilchess and picturesqueness. On emerging from the fertile Sonicrsetshire valleys and sheltered Devonshire 'coombes' and reaching the Exmoors, the vast expanse of heather-clad moorland, with its richly wooded ravines, stretching far away to the Bristol Channel, is, as if by magic, brought within one's vier; and as the sportsman canters briskly towards the far-famed Dunkery Beacon, the romantic beauty of the surroundings, together with the influence of the crisp mountain air, enables him readily to understand the native stag hunter's enthusiasm. As he winds his way to Cloutsham, and views, at about a mile distant, four or five hinds, attended by their antlered lord, cantering up a steep hillside, with their nostrils expanded and elevated, expelling their heated breath, like curls of smoke from cottage chimneys, he is fain to admit that no nobler quarry could be found.

In no other district of the British Isles can the sport of hunting the wild Red Deer be enjoyed in the same perfection as it is on the Exmoor. Therefore, we shall offer no apolcrey for referring to the methods practised in this district. 
In the aree of stag hunting, as in that of every other sport, it is alowe all thines neressary that they who undertake the manacement of a prok of homols should have a semeral linowledge of the nature and habits of the animal to be hunted.

Without this knowledge the most vigorous and sustained cfforts will surely end in failure and vexation, because it would be imposible to out maneure the many stratagems that the Red leer will invariably adopt for outwitting his pursuers. It is a vexed question, but a wholly unimportant one to all persons everpt naturalists, whether the Red leer is a native of the British Islands. Lut that he is a tolerably old

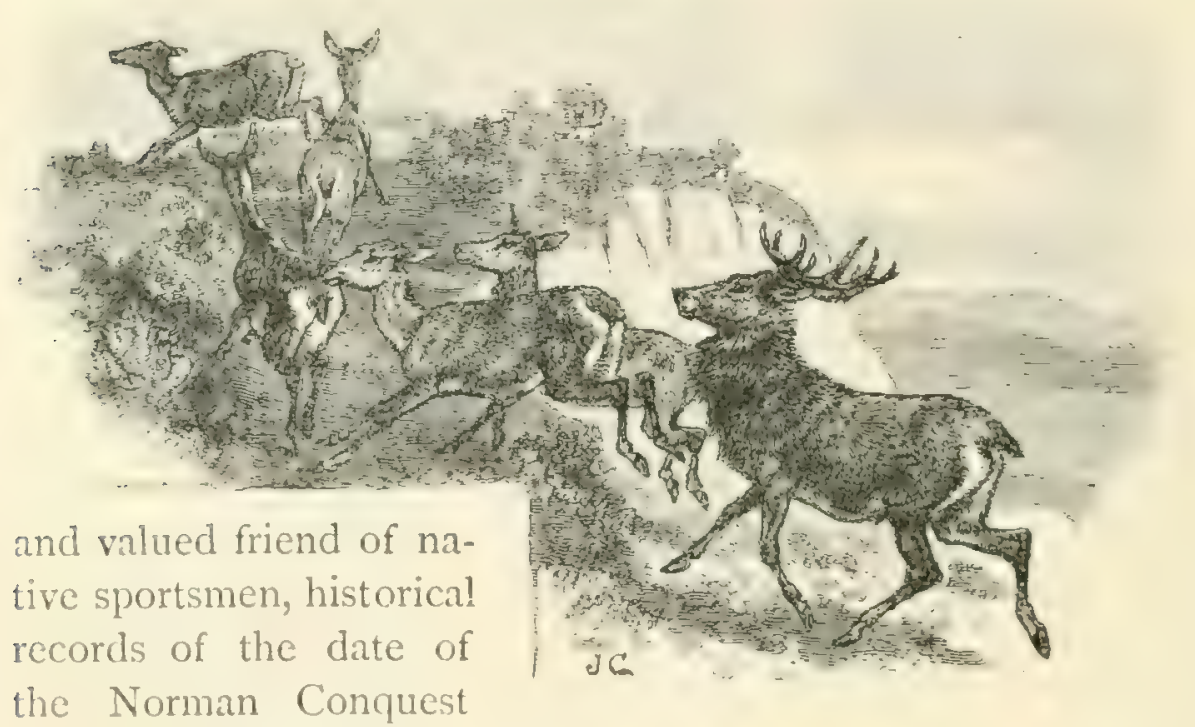

clearly establish. More- 'Four or five hinds, attended by their antlered over, these leave us in lord, cantering up a hillside.'

no doubt about the

peition of supremary arcorded hom by kings. lawmakers. and historians, as well as sportsmen, over all other beasts of the

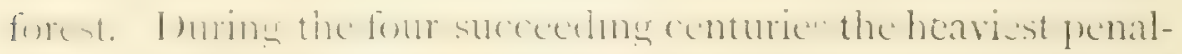
ties were intlie ted ulum persons who killed or in any way injured

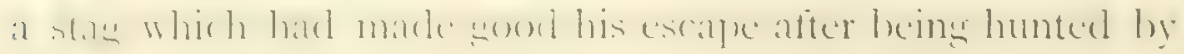
the king or queen. On such an incident occurring, a royal proclamation was posted in all the adjoining hamlets and 
villages warning all persons against killing or injuring him; and he was placed under the surveillance of the harbourer, whose special business it was to safeguard the exhausted animal until its return to the forest was effected. It would be well if the same chivalrous spirit towards animals that have ministered to our cravings for sport prevailed more generally in the present unsentimental age.

The colour of the Red Deer is for the most part a reddish brown; while from the tail, or, as it is technically termed, "the single,' underneath the body the colour becomes much lighter. Strangely enough, the calves, up to their fifth or sixth month, bear a very close resemblance in colour to the Fallow Deer.

The Red Deer has ever been known by his horns, which differ very materially from those of all other kinds of deer. The horns, or, to use the technical term, 'the head,' consists of a beam, from which points or processes project. The number of these points or antlers determine his age. The yearling deer has no horns, but at two years old a short spire is thrown out. This lengthens, and from its base, at the completion of his third year, projects horizontally towards the front, the 'brow antler.' At four years old the horns increase to nearly eighteen inches in length, and another process, termed the bay antler, is formed. At five years the tray antler is thrown out, and two points appear on the top of one horn. At six years old there are two points on each horn. At seven years, one horn has three points and the other two. At eight years, the stag will have three points on each horn. When hunting, the expression 'two on top' and 'three on top ' will be used to signify that the stag is seven and eight years old, as the case may be. After the latter age, the changes of the head are slight, though naturally, as the age increases, it becomes wider in its spread.

It is customary to speak of a stag by the total number of his 'rights'-brow, bay, and tray antlers, and by that of his 'points.' Thus, at six years old, he will be 'a stag of ten ;' that is to say, he will have two brow antlers, two bay antlers, two tray antlers, 
and two proinis of carh horn; while at eight years old he will be 'a stag of twelve.'

I)r. Pall: Collyns, in his excellent work on 'Stag Hunting on the Lxmoors,' states that he has seen as many as seven points on the i(o) of a very old stirg s horn; and that an old stag, long known as the Birdgeworthy Deer, had seven on the top of one hom, and siy on the other, when killed on September S, I 786 . Ile womll lie called a stary of nineteen points. This intelligent obrerrer grives as his opinion that after a stag has passed his frinte, the homs decrease in size and form until the horn (ieteriomes, and nothing but an upright or single spire, like that appearing in the three-year-old deer, is visible.

Before leaving the subject of the horns, it may be well to make a passing allusion to the marvellous and almost incredible powers of reproduction of horn with which deer are enduwed. 'They shed their horns annually in the spring-seldom after May. When the period of shedding approaches, they leave the open, and remain in the covers until the formation of new horn besins. In about sixteen weeks the magnificent pair of homs (weighing about fourteen pounds) will be replaced.

As may be readily imagined, during the growth of the horn cxcesive pain, accompanicl by hleeding, would be caused by a blow from a branch of a tree, or other hard substance; and coisciucntly deer will, at this time, aroid coppice and thicket and conline thenselies to woods or plantations which present ferer ebjects of danger. That this period is one of pain and sufiering to the stay is very evident, for in adclition to the orrational litwi: he can hardly avoid, fles licep him in a state of continual torment.

The funcus lor. Bell thus describes the process of renewing the horn :

"The grom the of the horn is an astonishing instance of the rapility of frubution of bone under particular circumstances, and umparalleled in its evtent in so short a period. During its furnth the hranches of the external carotid arteries, which lend their a. istance in the fomation, are considerably enlarged 
for the purpose of carrying the great flow of blood regumer for the production of the bone. It extends by means of the velvet (a plexus of blood-vessels) all over the external parts of the horn; it is quite soft and highly vascular, so that the slightest injury causes blood to flow freely, and the horn, when this occurs, to be imperfectly developed.'

The hind is mated in her second year, and seldom gives birth to more than one calf at a time. The rutting seisom begins in October; and, as the period of gestation is nine months, the calves will be dropped in June.

It is clear, therefore, that stag hunting should be discontinued before the rutting season commences; and that, to avoid the commission of unsportsmanlike conduct, the scason for hunting stags should not be carried beyond the first week of October.

A period of three or four weeks ought then to be allowed to elapse before hunting the hinds, that they may be left free to enjoy the society of their lords. The practice on the Exmoors is to begin stag hunting in the second week of August, and to bring it to a close in the first week of October; to begin hind hunting at the end of October, and to carry on the sport, weather pernitting, until April. Perhaps the most important office in connection with a stag-hunting establishment is that of the harbourer, for on the industry, care, and experience which he brings to bear upon the discharge of his duties, the sjort will very largely depend. Nothing can be more vexatious to a huntsman, master, and field than to receive false information with regard to the 'harbour' of a deer, and to be driven in consequence to the necessity of drawing at a renture for hours before a 'warrantable' deer is roused. Such an unworkmanlike pursuit of sport is a sad trial to the patience of huntsman, hounds, and field, and ought not to be often repeated.

The harbourer ought to be a man of active habits, keen sight and observation, and possessed of a thorough knowledge of the habits of the deer. We will suppose that it is desired to harbour a stag in any particular cover. The harbourer 
should take up a convenient position at least an hour before daybreak. The choice of position is most important, and should be detemined by the circumstances of the case. If the cover should have, on its outskirts, a field of turnips, a field of cats, a mendow, or other tempting feeding ground, the position taken up ought to command as much of it as possible. Sume harbourers prefer climbing a tree, while others incline to secreting themselves in a ditch for the purpose of making observations.

We will suppose that the harbourer is desirous of harbour. ing a deer for the next morning in a wood of 100 acres covering a ravine, whose two slopes, running north and south are separated by a rapid stream, and whose ridges are bounded by a vast expanse of moorland. On the south side, about half a mile down stream, there is feeding yround, consisting of a field of turnips; a small inclosure partly covered with onts and partly by old grass and rushes.

This will prove difficult ground to survey. But the harbourer must do his best. He groes to bed early that he may not ofersleer himself; but he cannot sleep for thinking of to-morrow's work. 'The wind apneared unstendy over-night, and his plan of approach may have to be altered. He must nut go down wind, for he may, by coughing or tripping over a stone, and ejaculating compliments to nature, arouse the alarm of the ever vigilant stag, whose exquisite scentins powers would confirm them. The harbourer goes men. tally orer the sround, agrain and again; surveys every path, every litte ridge, every tree, every point of vantage; and having exhausted each altermative that gives promise of an unchlsurved approach, he falls asleep for an hour or two, and then walies with a start, inpressed with a sense of fear that daylicht will be upon him before he can take up his gerition. Tery fow minutes are deroted to his toilette. He groes humbedly drwn-talus, throws open the cupboard, cuts off a crust of brail, which he stuffs into his pocket, and goes straight to the sherl, in which is an old pony, quite a local 
celebrity, who knows what he will te recpuired to do, and is prepared to do it.

'The pony; saddled and brilled, is guided, at a shossgings trot, to a point about two miles north of the ravine, for there is a sharp breeze blowing from the south-west. A well-known ford is crossed, and the pony is strugsting up the precipitnus sheep-walk under his rider, rendered heavier by the weight of care, which has made him unmindful of the place in which he ought to sit on the saddle.

The summit of the ravine reached, a wide cletour is marle. The pony is eased of his burden, and is turned into a small moorland inclosure, about half a mile from the south-eastern corner of the wood. The harbourer walks briskly to within two hundred yards of the wood, then pruses. The wind is blowing straight in his face-so far well. But the ground is exposed between the wood and the feeding ground-only small clumps of firs here and there breaking the view. No risk must be run. So he beats a retreat, in a south-ensterly direction, until level with a clump of firs, from which he knows he can command the feeding ground. He wallis as noiselessly as possible, straight up wind. His heart sinks! There are nothing but fir trees and he cannot climb them. Happily a few paces off in the open is a stunted oak. This will do. He at once throws himself on his face and wriggles on his chest to the oak tree, not attempting to raise his head until he has swung round, and the trunk of the tree hides the ravine frum his view.

Now he can rise with safety, for he knows that the deer can ncither see nor wind him. He climbs the tree with the stealth of a panther, taking care not to put his fect on any doubtful branch that might break and scare the decr. Haring reached a convenient fork from which can be obtained a full riew of the southern entrance to the ravine, and the intermediate space covered with brushwood, leading up to the feeding ground, the period of unbroken watching begirs.

A drenching shower shortly succeeds the break of day. But it will not do to descend for shelter. Where he is, there 
he must remain whatcuer may hapjen; and there he does stay, till he is soaked to the skin. A keen wind rises, and eents a chill through his weather-beaten frame. What shall he do? He certainly can cat his crust of bread. He will. One bice is all he can take. Two maspies and a jay are fitting abnut over the centre of the western slope of the ravine. His heart throls until he fears that the deer will hear its pulsations, for he knows that something is moving.

The livels ny from tree to tree southwards, chattering to one another.

There is a pause: the sound of the birds ceases. He strains his eyes in all directions, but can see nothing. The crust of breid is agim prociuced, now well sodden and coat stained, yet his palate is not insulted by its condition and miscullaneous fitvour. He is evidently superior to the ordinary triuls of lite. ITis patience is incxhanstible, but he has fears that he will not 'harbour' a stag this morning.

Presently, he observes that the magpies are once more on We alert, this time flitting straight up the ravine. What can this mean? 'There is no feeding ground that way. He feels sure that if the deer are on foot, they will come back.

lint they dont, and the birds take wing up the western slope of the ravine, unt lost to riew. This scems to denote that the decr will take the ojen, and come by a circuitous route to the feeding ground. And surcly enough, there they come orer the moorland, but sinking behind a ridge are in a moment completely hiblen. The hariourer sees no more of them. Ireicntly he hats a human roice coming from the direction of the feeding around. It is the voice of a boy diving a horac. If the tree on which our friend is sitting were struck by lightning, Ine could not have been more bewildered.

"What hings he here this time o' the morning, 1 wonder?' falls inwinturily from his lips. lit he knows better than to dewend from tis perch for the purpose of inquiring.

He is keppirg his eyes fived upon the point where he last 
viewed the deer. l'resently he observes then, only for a second, cantering back in the same direction from whence they came, but he cannot distinguish them. Nothing daunted, he will not leave his post until half-past nine o'clock. Crumpd, cold, and not a little disappointed, he climbs down and walkes briskly off to the feeding ground. He dows not enter it at once, but examines the fences and their approaches with scrupulous care. Fiverything is arainst him; the gromel has been so hard for the past month that no mark of a slot can be detceted. But he has other resources at his command.

He first enters the oat and grass inclosure, but no decr have been there. He then explores the turnip field, and this reveals to him the cause of the boy's visit. A lond of turnips has beer carted away from the part next the gate. No sign of damage done by the deer is discernible here. However, he strolls on hopefully, examining every turnip, until his eyes rest on a patch of ground strewed with turnips lying with their roots uppermost.

A glow of triumph lights up his face, for he knows that a stag did this. Yes; there are his marks! Every turnip bitten once, and once only. No hind has worked such purposeless havoc.

The rain will have rendered the ground soft enough to make the stag's slot sufficiently clear to a vision as acute as his. So he hurries off to the inclosure, where he left the pony some five hours ago, and, having mounted, jogs off to the ford, which he crossed in the early morning.

There a circuit of the western slope of the ravine is made. Every path and piece of turf is minutely examined, without revealing the much wished-for confirmation of the evidence in the turnip field until the point where he had riewed the deer is reached.

Here the slots are distinct; but further search has to be made before the slot of a stag is cliscovered. 'There it is, broad at the licels and blunt at the toes! It is quite fresh and deeper than the slots of his companions. 'He is a big, heary 
varnint, or he would not push his feet that fur into the land!" is the only remark. 'The slot, however, is deciphered with case to the south-west corner of the ravine. Off goes the harbourer to his cottage, detemined to come again on the following morning, and to pursue the same tactics as he did to-day. Tomorrow's dawn finds him on his perch once more, and before 5 A.M. he sees the stag with all his rigits and 'four on top' emerge from the same point of the ravine, attended by half a dozun companions of various ages, and renew his depredations in the turnip ficld. Not content with this, he waits patiently until he has safuly harboured the stag in the western slope as before.

'The harbourer returns home quite confident that, if the woor is not disturbed, the stag with his 'rights and four on tol,' will be roused when the tufters are put in by Arthur on the next day.

This description of the harbourer's work may seem somewhat trite, as in truth it is; but, like many other undertakings that are easier of description than execution, it will tax to the utmost the patience and skill of the shrewdest expert.

We have frequently heard persons, whose knowledge of the sport is very limited, express the opinion that any gamekeeper has sufficient knowledge and powers of observation to harbour a stag. Our experiences of the ability of the majority of gamekec] ers to discharge the duties of a harbourer certainly do not confimm this opinion. A case in point, still fresh in our menory, occurred some years ago. A grmekeeper asserted that 'he had harboured a stag with three on top' in a plantation, and that 'he saw him most days.' True enough he had seen the stan enter the plantation on several occasions after feceling, and had marked the spot exactly. The tufters were thrown in, and drew the cover, while everyone was in a state of breathless excitement, in the expectation of hearing 'Romues' sprak to him. Not a bit of it! 'The keeper was interrogated, and stoutly maintaincel that 'the stag must be there, for he had never seen him come out.' 
The huntsman soon explained the matter. The stitg harl gone into the cover, but had gone out on the oppurite side; and, indeed, as it was afterwards proved, had never harbeured there at all, but some tour miles off! Such a blunder, due to a mixture of ignorance and carelessness, would never have occurred had an expert been employed. But the great difficulty in these days lies not in finding a stag, but in killing him. 'The class of hound best fitted for hunting deer on the lixmoors is very difficult to procure.

We are of opinion that it would be well nigh impossible to breed, in any establishment, a pack of hounds of sufficient size and speed, though the most matured judgment should be brought to bear on the undertaking. The desired height is twenty-five inches, and is, therefore, probably one and a half inches above that of the ordinary foxhound. Consequenily it is better not to attempt to breed a pack of hounds, but to depend on drafts of oversized hounds from the best foxhound kennels in the country. Even with such a prolific source to draw upon it is very difficult to maintain the strength of the pack.

The reason why hounds of twenty-fire inches are required is apparent to anyone who has seen a pack on the Exmoors, where the length of the heather sorely hinders the work of hounds that do not stand well over it. Nor is it enough that the hound should have height; he must be well put together, more particularly as to his feet and shoulders. Heavy-shouldered hounds very soon become crippled, however good their legs and feet may be, by racing down the precipitous hills and ravines that abound on the Exmoors. It will not do to take hounds that have been entered at any other quarry, consequently young drafts must be obtained.

Much trouble is occasioned in breaking the pack from riot. Many persons who have hunted in this district durmy the greater part of their lives maintain that the tendency of the pack to kill sheep is in a measure due to the scent of the moorland sheep being similar to that of the deer. Withcut being a 
beluer in this theory, we are convinced that the scent of the moorland slicep, differs considerably from that of the ordinary sleep kept in the inclu-ed comntry. Then the temptations in the case of the moorland sieep are far greater; for hounds, when they are quite out of the reach and observation of the huntsman, frequently come upon a single sheep, in the middle of a wood, at the exact sput passed by the hunted deer. Conscquently all entrics, as soon after their arrival at the kennels as lussible, must be thoroughly brolien from sheep, and entered and blooded at deer. The best method of breaking puppies from sheep is to take them out, compled to old hounds, and exercise thum on pirts of the mour where sheep are kept in large numburs. If, during exercise, any of the puppies should make an atternyt to run at a sheep, he should be approached stealthily and hit sharply with the whip, after which he should be ruted sererely. If this practice be continued until July, when the pupjoies should be entered at deer and blooded, they will not give much trouble.

The wcar and tear to a pack of hounds hunting on the Iixmoors are very great. Not only have the hounds to go long distances to and from the meets, and to endure the strain of prolonged runs over very hard ground, but they have also to leave their licunels for some days at a time in order that they may hunt a distant fart of the country: When kennelled in a barn or otiur suitable building, biscuits must take the place of oatmeal, since it is next to impossible to take the necessary appliances for making judding. The result of this change of diet is rery prejudicial to the condition of the hounds, who return to tleir kennels with their muscles wasted and their coats dry. In all resperts the kennel management of staglounds is the same as that in rogue in the best foxhound kimmels. The hour of feeding hounds on the day prurious to huntire has long leun a vexed question. But the weight of erireme is deriderlly in farour of cight o'clock in the mornings, the hour at which the Exford pack is fed.

Thure is also considerable diffurence of opinion in relation 
to the number of hounds which should he brought into the ficld. We do not think that any hard and fist rule cion be lidid down on this point, because the numerical strength of the park must be determined by the nature of the country to be hunterl. It is, howerer, safe to take the mean of eighteen and twentyfour couples. There can be no question that of all the animals hunted in this country, the stag leaves behind lim the most lasting scent. We have not unfreduently noticed the pack carrying a grood head at a raring pace, for a mile or two, quite a gunshot wide of the line taken by the stas. Indeed so marvellous was the diffusion of scent that on several occasions we were induced to believe that there must be a double line; and it was only after a minute examination of the exact line run by the hounds that we were convinced that no deer had taken it.

It must not be inferred from this that it was a matter of no difficulty to run down a deer; for such is his cumning and stratagem that he will, very frequently; though handi. capped by a burning scent, out-manceuvre and elude the most experienced huntsmen and the closest hunting pack of hounds.

As all deer will take the water, or 'soil,' as it is technically termed, as often as opportunity occurs, the hounds must be able to hunt on a cold scent. It is also absolutely necessary that they should be under perfect command, for the many incidents of a run, to be dealt with effectively, require great steadiness. IVhen a stag 'takes soil,' the pack must be divided and cast up or down, as the case may be, both banks of the river or stream.

When the hunted stag 'runs to herd,' pushes up another deer, and lies close, it is all-important that the hounds be brought back immediately.

This operation is often a matter of extreme difficulty, for the stratagem, in nine cases out of ten, is practised in a large woodland, where the working of the hounds is continually hidden from the observation of the huntsman. An old trusted 
hound, standing still and declining to join the others, is a sign that the pack have changed to a fresh deer.

Moreover, it frequently happens that the deer that has been pushed up goes away in view of the hounds, which, at such a period of a run, are particularly eager for blood and intolerant of restraint.

The choice of tufters is important; for, upon their fitness for the work of rousing and separating the stag from the herd, the sport of the season depends. Of course old and trusty hounds must be selected. But tufters must be possessed of unusual quickness, handiness, and patience, or delays fatal to sport will be occasioned. When the wrong animal-either a calf, hind, or 'broket'- has been roused, and has been driven hard by the tufters for perhaps half an hour or more before the sex or age of the quarry is discovered, it is a creat trial to the temper of hounds to be whipped off, and required to begin their work $d c^{\prime} n 0^{\prime} \theta$. If, therefore, there should be any suspicion of sulkiness or want of perseverance in a hound he should not be used as a tufter.

As to the number of tufters to be used, no precise directions can be griven, because the number must be determined by the size of the cover or the area of open ground that the tufters will be required to draw. If the cover be of moderate size, that is to say, under fifty acres, four tufters would be sufficient. but in the case of a large cover, or vast cxpanse of moorland, two couples would be wholly insufficient, for they might draw all day without rousing a deer, though they might approach within fifty yards of his lair. Probably the number of tufters should not in any case be less than four nor more than twelve. In the event of the latter number being used, the huntsman and whip) should be especially vigilant; and if the services of one or two amatcur aides-de-camp can be obtained, the chances of hounds separating, and hunting three or four lines, will be materially lessened.

It is not often that an old stag hunter, if he should hare but one horse out, will discount his prospects of taking a forward 
place in the run proper, by getting to the bottom of his horse through keeping the tufters together, so that special arransements should be made by the master to provide the necessary additional aid to the huntsman.

Considerable judgment is required in selecting headquarters for the pack. A barn or some convenient part of a farm homestead generally affords all the accommodation recuuired. But such homesteads as are accessible only at one or two points are unfit for the purpose; since, if the tufters should run their deer into the open on the side of the farm buildings to which there is not a ready access, a serious waste of time must be occasioned in bringing the pack to the point where the tufters were stopped.

When once deer take the open their habit is to move on, whether pursued closely or not, until they take soil, or run to herd in a cover. It is perfectly evident, therefore, that nothing can compensate for a want of smartness in bringing the pack to the huntsman. If the pack should be, as it ought to be when the tufters are at work, left under the direction of the master, his second horseman should be told off to keep the huntsman in view, so as to be ready to gallop back to his master immediately the tufters are stopped, or when the huntsman signals for the pack. It is surprising with what dash staghounds when liberated will race to meet the huntsman. The reason of their liberation is very soon grasped by every hound in the pack, so that the services of the whipper-in are not much needed. It cannot be pointed out too frequently that unless the huntsman is a man of experience, dash, nerve, and is thoroughly acquainted with the habits of deer, he will fail to show good sport on the Exmoors whatever his merits may be in the kennel and saddle. Staghounds cannot be hunted on the "let alone'principle, which would mean 'a rest-and-be-thankful' existence for the deer. When the pack reaches the huntsman, he should clap them on the line and drive them, so long as they are on the line, as fast as his horse can carry him. By this method he may succeed in driving them till they get on good 
terms with their cuamy. To attempt to crawl down a stag, unless he be very fat and heavy, is to attempt an impossibility. Staghounds at fault ought not to be lifted to a distant halloo unless the huntsman has good reason for depending upon it; for if a mistakie should be made, and hounds laid on a fresh line, neither deer will be accounted for. Such blunders will surcly promote an incurable slackness, for the very best hounds will not bar being deceived frequently. If they cannot own the line, little or mo hrm can arise from their being lifted as far as the huntsman may think fit for the purpose of recovering it. When the stagr is brought to bay, old hounds will not attack him. They appear to know perfectly well that the coup de grite will be delivered by human hands, and that when they have run him to bay their work is done.

The intelligence of the stagliound is proportionate to his scenting powers. It is difficult to believe that in the excitement of the chase he is able to distinguish by his nose between a hind and a stag, and between an old deer and a young one. Nivertheless, during a single season he frequently demonstrates his ability to do so.

As the climate of the Exmoor is very severe during the winter and spring, and as the habit of the deer to 'take soil' at all seasons of the year is universal, and cntails upon the hounds frequent immersion, the temperature of the kennel lodging-room may be raised by artificial means, which the stove in the boiling-house will economicaly supply.1 That huntsmen, like poets, 'are born and not made,' is a maxim that fow sportsmen will have the temerity to dispute. A good training will undoubtedly give a man a knowledge of the most aproved system of handling a pack of hounds; but it will never take the phace of that venatic instinct with which some nen are endowed.

1 Scone authorities think that this system produces rhematism in hounds, and is thercfore to be avoided-to souse them well in warm water when they

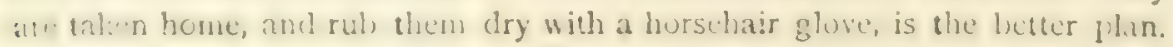
Artificial heat is only necessary if they have. been swimming about in cold weathur. 
The grood fortune that has attended the packs of stayhounds kept on the Exmoors during the last thirty years in resard tu the ability of their huntsmen is very remarkable. Most of us are inclined to compare things of the present unfarouralily with those of the past; and this inclination is almost universal when questions connected with hunting are under discussion It is, however, very doubtful if a veteran stag hunter could be found in Devon or Somerset who conld be induced 10 assert that a more able cxponent of the art of stag hunting than the present huntsman, Arthur Heal, ever carried the horn on the Exmoors. If anyone is desirous of observing a practical demonstration of the Dest methods of surmounting the many difficulties and emergencies with which a huntsman has to deal, he should pay a visit to Exford as soon as may be after the middle of August. That Heal has succeeded in making his hounds very handy under all circumstances without laving subjected them to that sererity of treatment considered by some huntsmen to be essential, entitles his system in the kennel and the field to the approval of all lovers of sport and of the hounds that furnish it.

Being a light weight, a good horseman, and having a thorough knowledge of the country, he scarcely ever loses touch of his hounds. Conseguently, they can seldom divide or run riot without his knowledgre. He rarely loses any of his hounds for more than three or four days at a time, owing to the excellent practice of exercising the pack on the moors, with every road to and from which they become well acquainted; so that, if separated from the pack through lameness or other accidental causes, they are able to find their way to the kennels.

All the local supporters of the Hunt are exhorted not to 'harbour' any lost hound that may honour them with a visit, but to expel him from their doors with as much force as may' be necessary. This system averts an infinite amount of trouble, anxiety, and expense, and renders that loitering and loating propensity, so strong in some hounds, utterly unprofitable. 
The main cause of alsence of hounds from 'the roll call' after hunting is that they have roused a calf, run into it, and remaled themselves on its carcase. If this is of tolemble size it will last the truants three or four dars; and until the last morsel has bein deroured they are not to be tempted, eren by visions of Arthur's apletising pudding, to return to their liennels.

The habit of stashounds under these circumstances is peculiar. After satisfying their hunger to the full on the carcase they do not, as one would suppose, lie close to it and guard it agrinst plunderers; but they ' lie up)' gencrally as much as two or three gunshots away from it. Probably this habit had its origin in a desire to aroid detection; for, when hounds are surprised during the periol of feasting they are particularly shy, and averse to the approach of any human being.

It will be reudily apprehended after what has been said that it would be as fatal to the good conduct of the pack as to sport to bring out more than four or five couples of young hounds at a time, since it would be impossible to keep a larger number with the pack.

The duties of the whipper-in are very different from those of a whipper-in to foxhounds. The latter has principally to confine himself to the work of preventing riot, assisting the huntsman, verifying halloos, \&c., while the former must frequently be sejarated a mile or two from the huntsman. He must take u!) positions from whence he can see whether the right or the wrong animal is hunted; and he must frequently maintain communications with the huntsman by means of signals.

If hounds cross one of the many precipitous ravines to be found in the comntry he must not cross till he has viewed them away on the other sille, for if the deer should soil in the luttem of the ravine, as will probably be the case, or lireak cover on the opposite side and head back again, he would most probahly come bark in the teeth of the whipler-in, who wabl le in a position to ascertain his exact condition, ll e probable duration of the run, and the point for which he 
was making. Moreover, the whipper-in could go on with the bounds in the event of their having outpaced the huntsman. The office of a whipper-in is a very important one, and if he is really fond of the sport, his opportunities of observation ought to cnable him to act the part of huntsman with success.

It is quite necessary that the huntsman and whipper-in to a pack of staghounds should have two horses out, for it is irnpossible that any man can do his work efficiently on a day of average sport with one horse, however stout the animal may be. Speed, as has been before asserted, is an essential attribute of the staghound. It is no less so of the hunter. If hounds are fast, horses must be fast. But, on the Exmoors, this maxim is so universally accepted that there need be no fear of a grood local sportsman, like Lord Ebrington, mounting his men on horses that are deficient in speed or stoutness. In fact, one wcek's experience on the moors would be sufficient to convince anyone capable of forming a reasonable judgment that horses of high quality are indispensable factors in a stag-hunting establishment. Much care ought to be exercised in the selection of horses with long clean shoulders, short backs, and very hard and sound feet; for if they are not properly constructed in these points they cannot go up and down hill, and over rough, rocky ground, at the necessary speed.

We must now break off, and make the best of our way to the meet at Cloutsham, or we shall not be able to give an account of the doings of the redoubtable Arthur and his pack on this second day of October. The second horsemen, aware that no time is to be lost, are jogging over Exford Bridge, having a vivid recollection of the long and steep hill that has to be climbed before the moorland ridge is reached, so we shall follow them until the hounds overtake us. Every promise of sport is present. A soft and somewhat damp breeze is coming from the east, but there is yet no sign of fog or rain. The heather is at its best. It is true that the bloom has partly fallen, but the delicate colouring of what remains lends a rare attractiveness to the scene. Coming from all quarters 
wremen in hunting costume, menuted on wiry, tough-looking litte horses, that seem hardly up to their riders' weights, which, it must bu armitted, testify to the sood fare provided for their lords by the Devon and Somerset housewives.

sis far all the arly arrivals are worthy representatives of the clasis of yeumen and tenant furiners; classes that, we trust, will crer be represented at the cover side, where their ruddy cheery faces and frank and independent manners contrast agrecably with the blanched skin and reserved demenour of the visitors who have arrived in their tens to put the finish on their sponting elucation, to restore their physical vigour squandered in the metrupolis, and to work themselves into condition for six ding a week in the shires during the following month. It must be almitted that Arthur has a very critical assembly, lut we have conficlence that the but horsemar in the field, if there he a rum, will have to play the wame of follow my leader ; the lover of precision and dash will he compelled to applaud, and the worshiper of close hunting will have nothing to complain of.

I3ut where are the hounds? 'They are in the farm buildings, which are in the occupation of a keen lover of the sport. We wish him goorl moming, hope that there is a stag at home, and that he will give us 'the run of the season.'

"There te a vine stag down along in the lottom; and if he don't give '(e) a vince run, he's cat my outs to no purpose,' is the reply.

liut his lordship has come, so we feel that the business of the day is drawing near.

Arthur, his lorelhip, and the harbourer bave a brief confercnce, and then retire to the other side of the farmyard. We follow the trio and soon learn that the tufters are to be brought out. The whipper-in is at the door of the barn, and in acerelines with Arthur's instructions calls out fire and a half (w) bite w stady workmanlike-looking hounds, whose appear ance lenotes comart with anything but a bed of roses.

Howewer, ihey hear their honourable scars with dignity, and 
leave their confrères to endure their disappointment as best they may. A move is made. The visitors jull up their girths, test the length of their stirrups, and prepare for a burst over the moors. They little know what is in store for them, though they express to one another some surprise at the indifference to the proceedings displayed by the local sportsmen. IIJwever, they leave the provincials tc take care of themselves and trot down the hills after Arthur and the tufters, prepared to lave the day's sport to themselves. There is no dwelling on the part of Arthur, and while the visitors have been engaged in conversation, they discover that they have been left in the lurch and must gallop along the hard road at the bottom, that they may' ascertain which direction he has taken.

They cannot see him, for he has turned up the hill into the cover, about two hundred yards forward. They have, however the satisfaction of hearing his voice, and the stones rolling under his horse's feet. Very soon a hound opens. 'Hush! is that right?' comes from half a dozen voices. Arthur's cheer settles the doubt. Then another hound challenges. 'Where's Arthur? What are the hounds doing? Good Hearens, why Arthur is going out at the top! How the deuce did he get there?' Happily a local sportsman with an expression of calm satisfaction comes to the rescue with 'All right, gentlemen, get you back to the meet as quickly as you can, or the hounds will go without 'ee.'

We turn our horses' heads, beat a retreat up the slippery; narrow lane, find three-fourths of the field standing by their horses, and chatting-as cool as cucumbers. "We have done something foolish, but what it is I can't explain,' says a cynical sportsman, who has just arrived from the bottom, his horse's flanks heaving as though the labours of the day have already been more than he cares for.

Presently, a smart groom arrives on a quick blond-like little horse, and loses no time in communicating to his lordship that Arthur has stopped the hounds just olitside the cover on the round hill. All then is bustle and excitement. The barn 
dowr; are thrown open, his lordship gives a shrill blast from his hom, and the whole pack rush down the stecp bill after him at a pace that is particululy unfleasant to all but the native si citimen and their hortes. "That's the best way, my lurd right up the road! 'says a farmer on a pony. The hint is taken, and the summit of the wood is ganed in less than five minutes from the start. 'lhere is Arthur, impatient as the hounds. He gives one cheer, rlaps them on the line before a third of the lield has reakhed the open, and kcejs driving the pack on at their best face. The ground is meven and rugeged, but the pace is good, and the hounds are crawing away from the horses. On yonker hill Arthur views the quarry running westwards to the inclosed country, where he is lost to sight. The local sportsmen make the best of their way to the point where he was last vicwed, while the veteran huntsman and the hard riciers drive their horses along in pursuit of the pack.

On the crest of the hill they throw up, but Arthur will not let them rest. Sticking his spurs into his horse, and giving a couple of twangs with his horn, he gallops at their head to the inclosed country. There the hounds hit off the scent, and race pamillel with the moor rond for a couple of miles, when a turn at right ansles down to the bottom fills the minds of the timil horicmen with amazment. 'Tis no use going there,' is protamed far and wide. Tet the hounds go, and they who wish to see the end must follow suit.

At the bottom is a bog, from whence fluws a small stram. The hounds are at fault again. Iagrer eyes are straining to di-rern the 'slot.' None is perceptible. 'He's gone right on,' chime in those who are well mounted. "What has Arthur grone lark for?' He has seen the slot fifty yards back pointing harliwards. A shout soon proclaims that the stag is seen in the pros] rown the stream. The ho'mds interpret the meaning of that hout correctly, and race off. But hefore they can rearh him, he rises from the pool, or 'breaks soil' in the fullness of his strength and majesty, and with the drops of water trickling from his neck and helly; he races back to the moors, 
apparently as fresh as though he had only just heen rousci. The cumning sportsmen are seen galloping bark to nocet us. The day is theirs. They will have it all to themselves yet. 'Ah! it ain't over yet!' says a farmer on a little sancly-lonking grass-fed horse that was galloping more casily than we lil.ed. 'The hounds show now how they can race when they are on good terms with their yuarry. 'A horse down.' 'Ies, there he is, to the right.' 'What brought him down?' 'Ile is pumped out, like many others.' Still, Arthur on his chestnut seems tied to his hounds, and we follow him as nearly a. we can to the edge of a large cover, and down a steep path, until we see him pause. Here come the hounds straight to us, with the stag not twenty yards ahead of them.

He crosses the path at a bound. Like lightnmg Arthur presses his horse to the point, and shouts, 'Tally-ho, back!' 'What's that about?' "Why, the hunted stag is lying close, and has turned out another.'

About two minutes elapse before the hounds speak, then there is a chorus of voices, and a crash rown to the bottom. All is silent again. We view him running down strenm at a sharp trot. But no hounds are after him? Yes, they are; running in cover parallel to him.

'Forrard!' shouts the whipper-in from the opposite side of the wood, and we gallop in line down a dry watercourse, full of boulders and roots, until we reach a turn in the valley. I Iounds are off the line. We all conclude he has gone down in deep' water. But 'Tally-ho!' from the whipper-in assures us that he has once more broken cover.

After struggling up the hill in line, and sceing Arthur galloping away on his second horse, which has apparently dropped from the clouds, we find that the time for nursing our horses has arrived. Happily we are riding inside the circle, and can see every yard of the run. Twenty munutes in the open brings us to a long rocky ravine corered with lisushwood, and glad enough we are to see Arthur casting his hounds along the slope nearest to us. The hounds cannot 


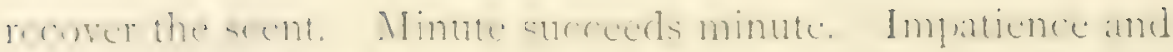

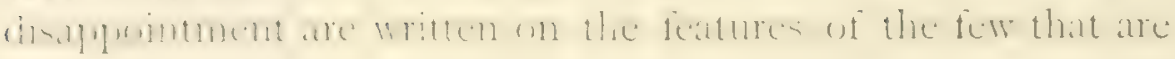
with us. Arthur will not give it up. He takes the hounds to the river, and casts them on both banks down the stream. 'llien he brings them back, and casts them up the stream.

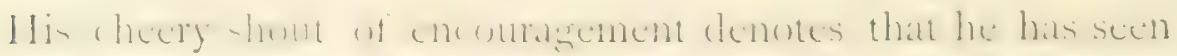
somethins. What is it? Ilis guich rision has dederted that the larec boukler in miel stream has lecen splashed, and is still

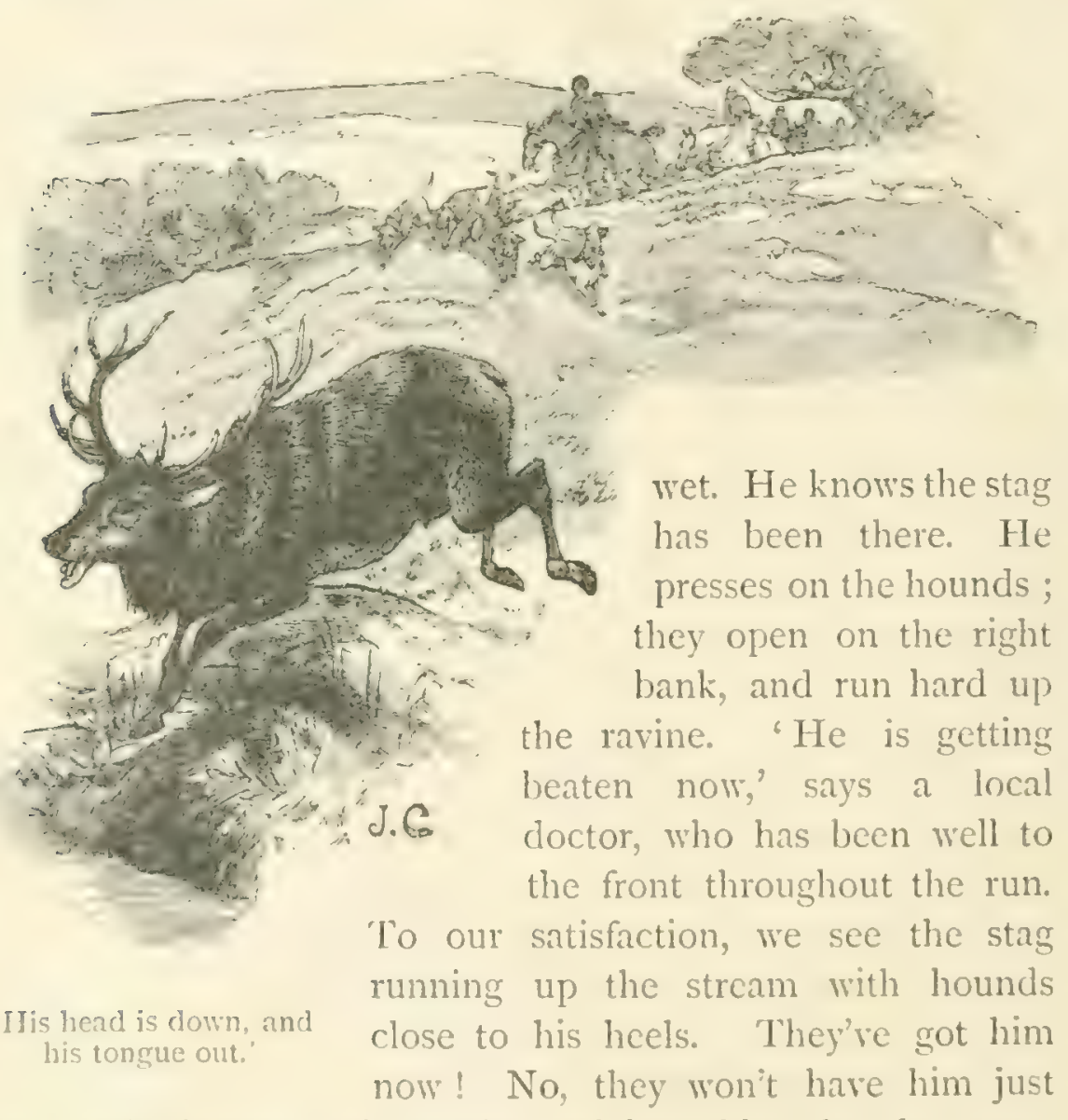

yet. He's 'broken soil' again, and is making for the open.

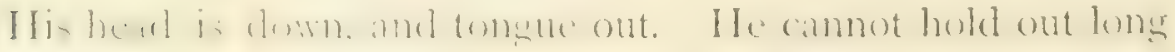
at this pace. 'The hounds know he is sinking, and race after him with a dash that we have not scen them show before. He turns in our tecth, runs down the slope again, crosses the 
road, and plunges once more into the river with the lusmels all around him. 'The whipper-in and a fimer jump off their horses, scramble from stone to stone until they get on cither side of him. He does not apparently notice their approach, his attention is confined to the hounds in front of him.

In an instant his horns are seised, and his lead bent down and back; while the ever-present Arthur approatches him in front and delivers the couf de sritce with the roolness and adroitness of a Liston. 'Whoo whoop)!' proclimes that life is extinct, and his carcase is dragred by half a dozen of the ficld to the bank. The slots are cut off, and srracufully presented to two visitors by his lordship. The head is removed, the carcase cleaned for the purpose of blouding the hounds, and directions given for the distribution of the venison. A splendid head it is, with 'four on top,' to add to the fine collection at Castle Hill.

After running for two hours and twenty minutes, brokin by but few brief intervals for relaxing the strain uysun the respiratory organs of our horses, we willingly swell the number of the first detachment bound for home; and as we joy along the moorland road we feel, as we have often done bufore, that the ride homeward with sympathetic companions is by no means the least enjoyable part of a day's hunting.

The conversation naturally turns on the ability of Arthur and the high character of the jack; and when we karn that by their joint efforts over one hundred deer have been run duwn in a single season, we are not surprised at the homage paid to the Exford establishment.

The fact that the country is so well stocked with deer speaks volumes for the tact and liberality displayed by Lord Elrington and his popular predecessor, Mr. Fenwick Bisset, and curtilics to the existence of an excellent understinding between all classes of the community.

The destructive propensity of the deer must be experienced to be believed. The majority of the farmers on the borders of the moors suffer considerable and vexatious losses. Thuse 
huyply are fully and comrteously recosnised, the presents of venison being in propertion to the damase sustained. At one time many magnificent deer fell by the bullet of the poacher, who maimed and mutilated more than he killed; but these atrocities were perpetrated during that period of demoralisation when the country was not regularly and systematically hunted. Such an unhaply state of affairs will, we trust, never recur. We scarcely think it is likely to do so until existing Acts of Parliament for the preservation of game and deer have been repraled, and replaced by special $\mathrm{Acts}$ for the encouragement and protection of the poacher.

\section{THE FOX AND HIS HABITS.}

We shall not be very wide of the mark if we describe the fox as the 'spoilt darling of the nineteenth century,' and at the same time as the most irreconcilable to civilisation of our fauna.

No one, so far as we know, has ever given the stoat or the weasel, the baliger or the otter, a fair chance of proving whether by care and kindness and a regular diet they can be so far domesticated as to refrain from destroying at all times and seatsons and out of sheer cussidness, what they may consider their leritimate and lawful frey in the shape of flesh, fowl, or fish. With the fox, on the contrary, the experiment has been repartedly tried - that he can be tamed to a certain extent, as regards contact with human beings, is undoubied. He may, if taken as a cub, be handled, played with, and perhaps, though he is not exactly larender water at the best of times, may be tallint habits of cleanliness, sufficient to secure his admission moler protest to the house. Nay, more, he may be brought to live on terms of amity with his natural enemy the des or his rery neutral ally the cat, but one instinct of the savage state will alwalys rematin so thoroughly ingramed as to be incralicable. With poultry or rabbits he can never be trusted, or, to speak more correctly, he ann thoroughly be trusted to posme on and kill them. It is the old Adam, the nature which 
you cannot expel even with the handle of a pitehfork; the prongs, as used by an irascible hemwite, maty in individual instances prove efficacious, whthout at all upsetting our therry.

That in his wild state he is the most petted of anmali, the only felon the condonation of whose felony finds fivene with a law-abiding public, is beyond contradiction. Hunted he must be ; if he is to exist all all in Fingland it is his rasom ditri, and if consulted on the suljecet he would probably not wish it otherwise. IIe thoroughly understands the sport in all its branches. Pursuit by a terrier is looked upon as a friendly game of rompes ;

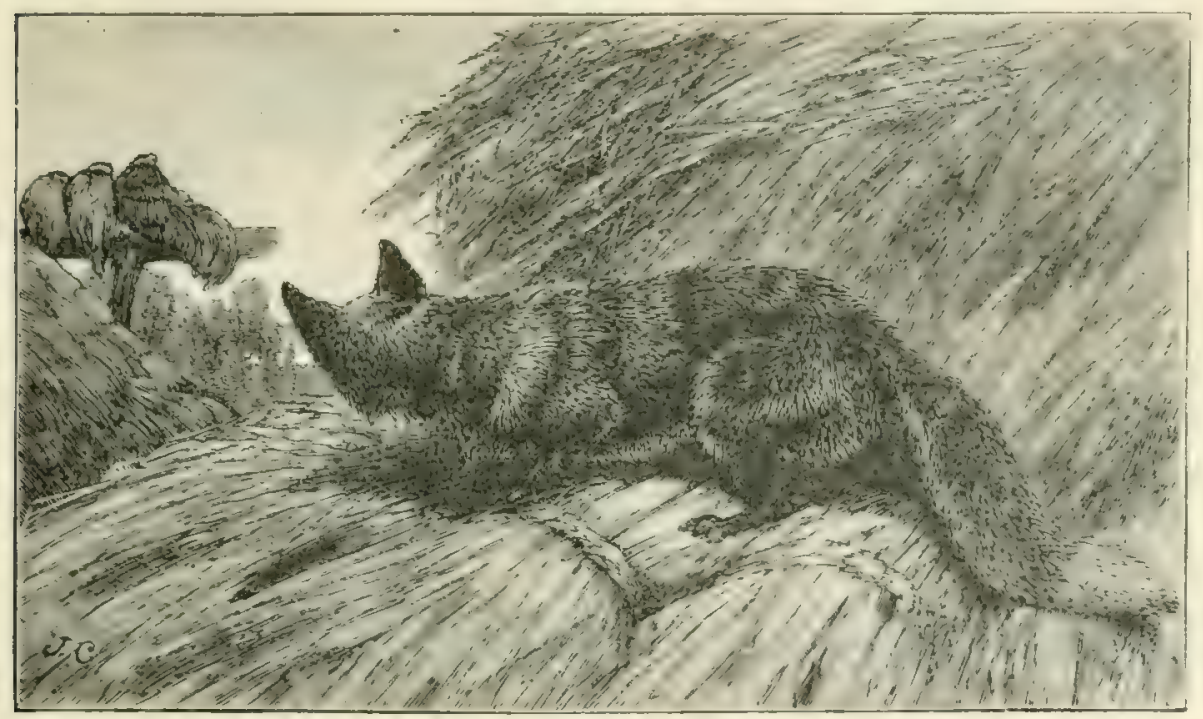

'In search of a supper.'

a merry-go-round with a pack of harricrs (not too his) is re. garded in much the same light, and it is omly the pack of adrertised foxhounds (he is particular on the score of adrertisement) whom he considers really worthy of the steel of his cmming and staunchness.

Of course he has (o) contend with incidental anmerance, such as that of being coursed by a brace of ereyhounds-these are soon settled by a stiff bullfinch-of being shot at ly a shortsighted or over-enthusiastic gunner-- a much more serinds 
Inutter; or of finding himself fast in a nerglected rabbit trap), the most serious case of all, reruiring instant amputation by his own tecth of the imprisoned limb; but these accidents lie Eenerally delyits in his life's ledger as the drawbachs inseparable from a nobly selfish carcer, so long as he is free, as in ali well-regulated countrics he is free, from fear of poison or other malicious conspiracy against his existence.

For the rest, who is there in these troublous times that conjuys such complete inmunity from the universal depression, as the 'thici o' the world,' the chartered freebooter of our fielis and forests? A certain amount of deprivation he may indeed have suffered from the Ilares and Rabbits Bill, when it first came into ojeration, but he soon learned to recoup himself by increased raids upon pheasant preserves, or poultry yards, learing the M.F.H. and the hunt fund on the one part, the heep,ers and the farmurs on the uther, to adjust their differences as best they could.

Broadly speaking, his hand is against every man and no man's hand is, without due notice, agrainst him. Hunting days excepted, he parcels out the twenty-four hours after the manner of most predatory animals, eren after the fashion of the man about town; the nights he derotes to refreshment, plunder, and love, the days to the luxury of rest and sleep, being extrunely fastidious as to the warmth and dryness of his bedroom. Of course it is annoying after a hard and perhaps unsuccessul night's poaching to find the main earth 'put to,' but is not this barring ont a sufficient hint to his acute intellect that he may look out for squalls on the following day? And he letakes himself with grim complacency to a hole under a haystack, the top of an ivy-covered wall, a grassy bank, the shelter of a thick grorse or thom covert, or scme other well-known coign of vantage, where experience, or the excellent advice of his rixen mother has taught him that he can see without being seen.

Here, when a decp sleep) comes upon him, he may be occasionally taken unawares, but the due and lawiul warning 


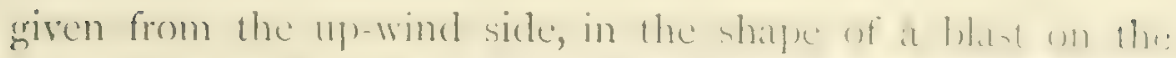

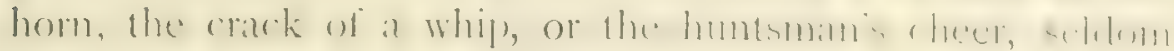
fails to arouse him to timely wakefulness.

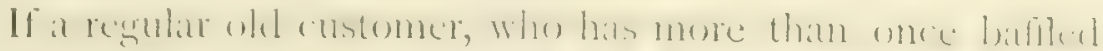
his kech pursucts, the tramp of the horse-houfs heard from afar will often suffice to put him on his less, and caube him to steal away before the smartest of whips ran 'iset round' for a view. 'Threading his invisible way as he well knows how,

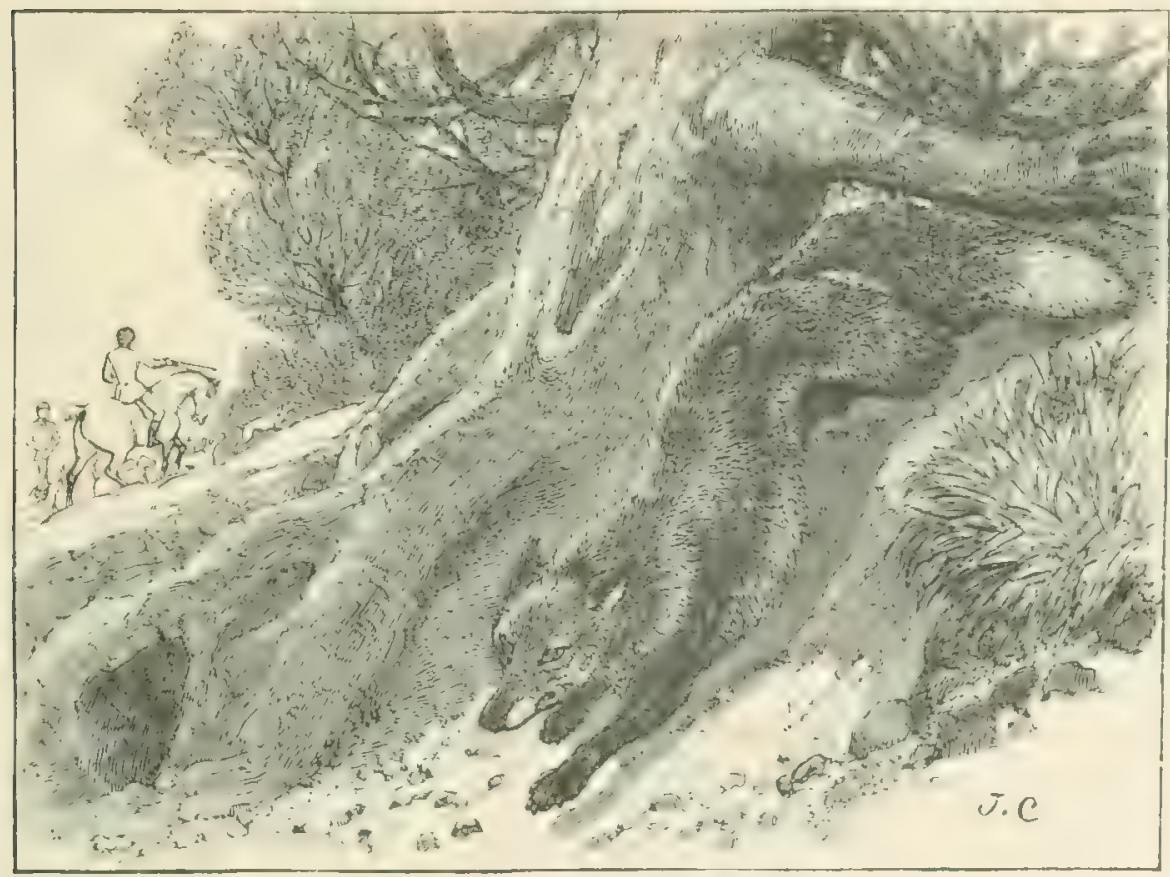

'Stenling away.'

under bank or hedge, he leares no sign or trace sare the mysterious inexplicable clue which men call scent.

And by no better name could it be called. The french, from whom we have borrowed many of our terms of vencery, say la idvic or le fiste, expressions which to English cars, at least, fail to convey the idea of the "ravishing pertume: I on

1 Vide the adaptation of the Bloomer editress in Mr. Sponge's immortal tour. 
which the sport of fox hunting depends, and about which such various and contradictory theories have been upheld.

For scont it uniuestionally is which enables the hound to follow the line of the fox, but from what portion of the frame it emanates, whether it sometimes lies on the ground, cr rises a few inches above it, and what are the atmospheric conditions most favourable to its develoment, scem to be rexed questions as far from accurate solution as are those of the squaring of the circle, or the precise date of the Greek kalends. This much is certain-that hounds will, on really good scenting days, carry as good a head, and run as unerringly fifty yards down wind of the Jine, as they can when following in the actual track, showing that scent can be difused over a very considerable space of ground; and instances there are, rare but well authenticated, whure hounds have been laid on to a spot where the fox has been sim to pass, and have failed to show even an indication of feathering, yet on being brought back to the same place after an interval of five or ten minutes, have taken up the line and gone away at score, though it was absolutely impos. sible that a fresh taint could have been left; thus making it apjear that scent may be held in shipense, or rise for a short period above the reach of hounds' olfactories, and then settle down again. Our own experience leads us to believe that scent in a great measure depenris upon the individual animal, but, as we cannot sustain our conviction by scientific joroof, we refrain from arguing upon it.

On these, as on many other interesting points, the fox could give us trustworthy information. He and he alone knows the secret of his scent, and by his knowledge he doubtless regulates his movements; he is not, however, of a confiding nature, and for the sake of his own security, and for other obvious reasons, he remains-dumb.

So manifold are the devices of the fox for eluding his pursuers, that volumes might be filled with the stories of his cumning, and of the skill and presence of mind with which he extricates himself from apparently hopeless dificulties; what. 
ever he may feel he never looks flurricd, and whether swinging with his long easy strile over the first ficld, in the full vigutur of freshness, or crawling along with his back up as the part breaks from scent to view, he presents ever the same rusulute appearance of knowing exactly what he means to do nextthough, in the latter case, his meaning is limited to a grim determination to make his teeth meet in the first hound that lays hold of him, and to quit life and grip together. But all runs do not terminate with a tragedy, and considering the craft and resources of the hunted animal, we can only mirvel at the perseverance and science which bring so many foxes fairly to hand during the course of a season.

Gifted with speed, for a few furlongs, at least, in excess of that of the fleetest foxhound, our hero, save in exceptionally open countries, is not long in bringing the pack to their noses; to get out of sight is his first care, and, even on the downs, his instinct at once shows him how to avail himself of pay's accidenté in order to break the view; of ploumhen and shepherds he takes his chance-he sees them long before they see him, and, if cliased by the dogs of the latter-a liberty which is seldom carried to close quarters - he comforts himself with the reflection that more foxes have been lost than killed through the interference of an over-zealous cur.

Strongly inclosed or wooded countries naturally afford the fullest opportunities for the exercise of his wiles and dodges; with the carte du pay's at the tips of his pads, he knows every dry ditch, watercourse, meuse, or run where he can slip easily along, but where the hounds must file or force their way, and if he takes to water, which he can do like an otter, we may feel pretty sure that he has no struggle on getting out, though the honeycombed ledge which gave him foot-hold crumbles away at the first touch of his heavier-footed pursuers.

With a sidelong climb he can surmount most park walls, and he can run up a tree like a cat, if the bark be rough and the incline slightly in his favour, but this is a trick which he does well not to try too often, for if a fox takes to perching, he 
is sure to be 'tree'd' at last, and a drop of fifteen or twenty feet, land he never so lightly, is neither bracin's at the commencement, nor restorative towards the end, of a run.

One bred in the neighbnumborl of a country town, soon makes hincif acianted with the ins and outs of every pigstye and hovel alrout the place; he can thread a suburb like a rate collector. Wearying to the hounds and exasperating to the huntsman, such an animal is appreciated only by the publicans, who on occasion of a town hunt, glean a goodly harvest from the drinking division, which always furnishes a considerable contingent in every field of horsemen. Adrenturous wanderer though he is, and much as we admire his courace, it is impsible to ignore the fact that the fux is somewhat too apt to seck ignoble refuge beneath the surface of the soil, and, however diligent the earth stoppers, however carefully grated the old store drains, some underground lurking place always seems to have escaped man's obscrvation, though duly noted by the retentive rulpine memory as open and good at need.

Gone to ground! Who-whoop! It is neither one thing nor the other, and the spirit of the chase is chilled. Then follows the question, What shall we do with him? If the sanctuary is a short drain, or culvert, with two ends to it, and the terriers are handy, a bolt may be speedily effected; a squib, a charge of powder from a gun, or hychaulic pressure, where there is a slight stream of water which can be dammed and suddenly sluiced down upon the refugee, will equally serve the jurposes of what we may call legitimate eriction; but against frolonged disinterment by a gang of labourers, ending with a worry over the mouth of a yawning chasm, we at lenst would fain enter chergetic protest. The stock argunents in farour of a dis are ahmost too well linown to need repetition, but have we subicieritly consillered them from the fox's point of view?

If the act of sefultus de se occurs early in the run, there arises at once a chorus of "Wretched brute! Cowardly devil! Not worth saving: Incerves his fate!' de. How do ai' know? May 
not a brave fox have headache, or toothache, or dysuef esia, or some ailment which he feels for the time incapacitates him from doing justice to himself, and to the pack whose prowess he has learnt rightly to esteem? May he not laudably' wish to reserve himself for some future day, when, in the full rigour os matured strength and perfect health, he will be ready to try conclusions over that ten-mile point which is recorded in the annals of his county hunt to have been safely traversed by his predecessors?

Who can tell? And why should we condemn him unheard? If, on the other hand, he just saves his brush at the end of a good thing by going to ground a few yards in front of the leading hound, we are told 'The hounds deserve him; he was dead beat ; sure to die in the night,' \&r. All this may be true, but he is a hardy, good-constitutioned brute, used to roughing it, and will, no doubt, gladly take his chance of recovery from over-exertion; and as for the hounds, they get plenty of blood in the course of the season, let them for once go without these deserts ; they are perfectly aware that, though baffled, they have not been beaten; so why not spare him? What he has done once, he may, and probably will, do again; and next time, perchance, the euthanasia in the open shall reflect the more credit upon all parties concerned.

Nevertheless, we are aware that it is good for foxes to understand that subterranean fortresses are not absolutely impregnable. We know also that farmers may grumble if the cherished marauder is permitted too often to laugh at the beard of the huntsman. 'Circumstances alter cases,' was a favourite maxim with the late Lord Beaconsfield-though we forbear giving his favourite illustration thereof.

When all is said and done, the decision to dig or not to dig must, and should be, left to the judgment of the master. He can hardly be expected to summon a jury of his fellow-sportsmen on the spot, still less to take a verdict from the down or upturned thumbs of the whole field; on him and on him alone rests the ultimate responsibility, let us hope that he may usualiy 
incline to mercy, and that at any rate 'grive him a chance,' may be the final and percmptory order to the hunt-servants. We may here mention that one of the most remarlialle hiding phaces we have ever seen resorted to by a fox was the large wheel of a mill.

N.B.-The mill was not going at the time.

Iike other wild animals, the fox is supposed to be, and probably is incapable of recognising his parents or offipring after he has ceased to be dependent on them, or they on him. If this is not so he displays at times an almost human intelligence in subrordinating family feeling to sulf-interest, for one of his chosen methods of esrape consists in diverting pursuit into another channel, and to this end he hesitates not to push his son or mother out of his or her lair, and to ensconce himself therein till the cry has rolled far away on the track of the improvised scapegoat, when chuckling over the success of his ruse he retires discreetly in the opjusite direction. His knowledge of numurals being elementary, his thuughts are mainly concentrated on No. I, except perhaps cluring the breeding season, say from March to June-for though hazy in his ideas on the subject of monogamy he does to a certain extent recognis his duty as a hustiand and a father-i.e. he will do some of the foraging, and act must fiercely in the defence of his household; such matters are indeed distinctly within the sphere of his sporting and fighting instincts. The drawing the earth, and other preparations for the accouchement he is supjosed to leave entirely to the vixer, thin whom no more deroted mother exists up to the tine when, having taught them all she knows, the family party is lorwen uis, and the litter dispersed in the rarly mornings of cub-hunting. This 'teaching them all she knows' is of farmount importance in the interests of sport, and if they are not to show sport why joreserve foxes?

Erlurateil hy a wathelul but not too indulgent grarent in the herelitary cumning and tralitions of their ancient race, the cubs suon leirn how to take care of themselies in every sense of the word; but if while yoling they are deprived of their 
mother they may become as useless for hunting purpuses as tame cats.

It is not an uncommon trick with keepers, who, whatever they may say to the contrary, all hate foxes, to kill the old ones a few weeks after laying down, and to hand rear the cubs on rabbits, rooks, offal, or even milk where it can be charged to the game account.

'Thus artificially raised, young master fox grows up an cmasculate and almost innocuous animal. He would probably kill the chickens if he grot into the poultry yard, which he is not allowed to do, but never having felt the pangs of hunger, he has for the must part neither the wish nor the ability to destroy grame. When the hounds come, a splendid show of foxes and pheasants dazzles the uninitiated. The huntsman of course soon sees through the trick, and having blooded his pack easily and liburally, goes away laughing in his sleeve, and gives his master a hint that this is a good place on a bad-scenting day. During the remainder of the season the field will occasionally express surprise that the foxes in Mr. So-and-So's coverts hardly scem to know their way from one quarter to another of the wood in which they were littered; but beyond this, scant notice is taken, and the furce may be successfully played for many years, and will be the only run likely to be witnessed.

But our theme is the wild fox, and to him we willingly return, though before doing so we would fain guard ourselves against a possible charge of injustice.

We have said that all keepers hate foxes, and we believe it; Dut there are unquestionably hundreds of honest servants who loyally obey their master's instructions to 'preserve foxes at any cost.'

It is difficult to say what a fox will not eat; rabbits and game probably form the highest, beetles, mice, and even fross: the lowest scale in his dietary. $\mathrm{He}$ is said to be partial to water hens and water rats, and he is certainly fond of frequenting withy beds, river banks, or low-lying grounds where the amphibii do mostly congregate; though he does not succeed 
in waking any appreciable diminution in their numbers, he will kill common rats for sport like a terricr, and may in times of famine eat them. But it is not a food after which he hankers.

Raw horsefish is about the most deleterious article he can take into his larder, though often put in his way to save game. It is apt to produce mange, the only malady from which, as far as is known, foxes frequently and seriously suffer. 'This dire complaint may, and no doubt dues arise, from other canses, such as orcr-exertion followed by privation and exposure to wet, but however he may contract the disease a fox once really mangy is a micery to himself and a source of contagion to others; he had better be destroyed at once, though the precedent of a sentence of death by shooting is at all times a risky one to establish.

'There is no rule without an exception, and this may be made in favour of a heary but mangy vixen-she does not necessarily infect her young, though she herself remains incurable.

Habitual criminal as he is-a felon of the deepest dye-the fox, like the devil, is not quite so black as he is painted, and sins are laid to his charge, of which he is wholly guiltless;was it Mr. Jorrocks or another of Surtees's sporting celebritics who received a bill with request for immediate payment for a 'young bull and ten acres of vetches,' said to have been consumed by rarenous Reynard? Such items as these are, perhaps, not often delited to his account, but the accusation of lamb slaughter, false as it is frequent, has been brought against him in every county in England. That he will eat a dead lamb or shecp) which has been thrown out of the fold, just as he will devour any other carrion is undeniable; that he even attacks them when alive we bulicre to be a convenient fiction of careless servants. I.ct the consigne to the shepherd be: "Tie up your own doy att night, and talie care that no other curs come near the plice, and it may safely be asserted that the flock will be free from death by violence.

It is true that foxes hang about ewe-pens at night for the 
sake of the cleanings and offal which they delisht in, and mangy or dying ones creep into the folds for wamth, and these facts have given a show of plausibility to the tales of the slanderer. In the hatching season, the fox commits much havoc amongst the sitting birds, and though there is a previling belief that the hen partridge or pheasant can while on her nest retain her scent, so as to give no indication of her presence, game preservers would do well not to trust to this oft-exploded fallacy, but to give orders to surround such nests as are known with paper or tow, steeped in a mixture of tar and assafretida, a preparation which does to some extent fend off the foxes. Nevertheless it not unfrequently happens that a wholly unprotected hen pheasant rears and takes away her brood from close proximity to a breeding earth, and farmers have been known to declare that they like having a litter hard by the yards, as the fox prefers foraging at a distance from home.

We give this theory 'quantum valeat,' oursclves believing that it has been founded on a few fortunate accidents. It should be noted that fur seems to be almost essential to a healthy condition of the fox's digestive organs; it has at least been proved to be so where necessity has arisen for hand rearing cubs, and the excreta of the wild animal will be found, on analysis, to contain a large proportion of this ingredient.

We have endearoured in this admittedly imperfect sketch, to give the leading characteristics of the fox; and take him ' all in,' if any of the carnizora are to be preserved for the sake of sport, no other animal in the British Isles could answer the purpose so well, or at all.

Owing to his strength and ferocity the wolf is out of the question, even if he were not, as he is, happily extinct; the otter cannot be pursued on horseback, and the badger is a slow bad traveller. We beg pardon of the two last-named worthies, for classing them amongst the real carnirora. So to the fox we are restricted, for hunting on a great scale, and small reason have we to grumble at the restriction.

Fleet, and staunch, and cumnirg, ne can test the mettle of 
the best men, horses, and hounde, in the world. Me spreils the rich with injunity, and leaves them to jay the costs when he rols the poor. Long may he flourish. It will he an evil day, when, the land being siven over to 'Chamberlain and wantonness,' the gun, instcad of the horn, shall sound the death-knell of the fox.

\section{IIARRIEIS AND THE HARE.}

What is the harricr? Well, the Encyclopredia tells us that it is 'the English name for the hound used in hunting the hare, and it would be difficult to give a more defmite description, for he would be a bold man who would undertake to say that there is now-a-dilys a distinct bried of this nature in the United Kingrlom, nor is it worth while to inquire whether there cver was such a breed. It may be taken for granted that all harriers have a very strong dash of foxhound blood in them, derived either from immediate or more remote ancestry, and that the packs composed of what are called true-bred harriers are those whose owners have not wittingly purchased drafts from foxhound kennels, or renovated their blood by a cross therefrom.

On the other hand, many packs consist entirely of dwarf foxhounds, that being the simplest, most expeditious, and probably' the cheapest method of getting and keeping together a 'cry' of hare dugs.' 'That there is no difficulty in persuading them to run hare, any M.F.H. who has attended to the entering of his puppies during the cub-hunting scason will bear witness, but the drawbacks to the system are these: First, as to size. Dwarf foxhounds, dwarf though they be, are apt to be too big, it being difficult to obtain them under 2 I or 20 inches (they often top 22), whereas harriers that are restricted to their legitimate quary, and it is of these only that we are writing, should never cxecel 19 inclus, 17 or is being perhaps a better standat, otherwise in cutuntes where the negular sport is carried on they may become an unmitigated nuisance.

All harricrs, except perhaps ihe wariest veterans, will pursue 


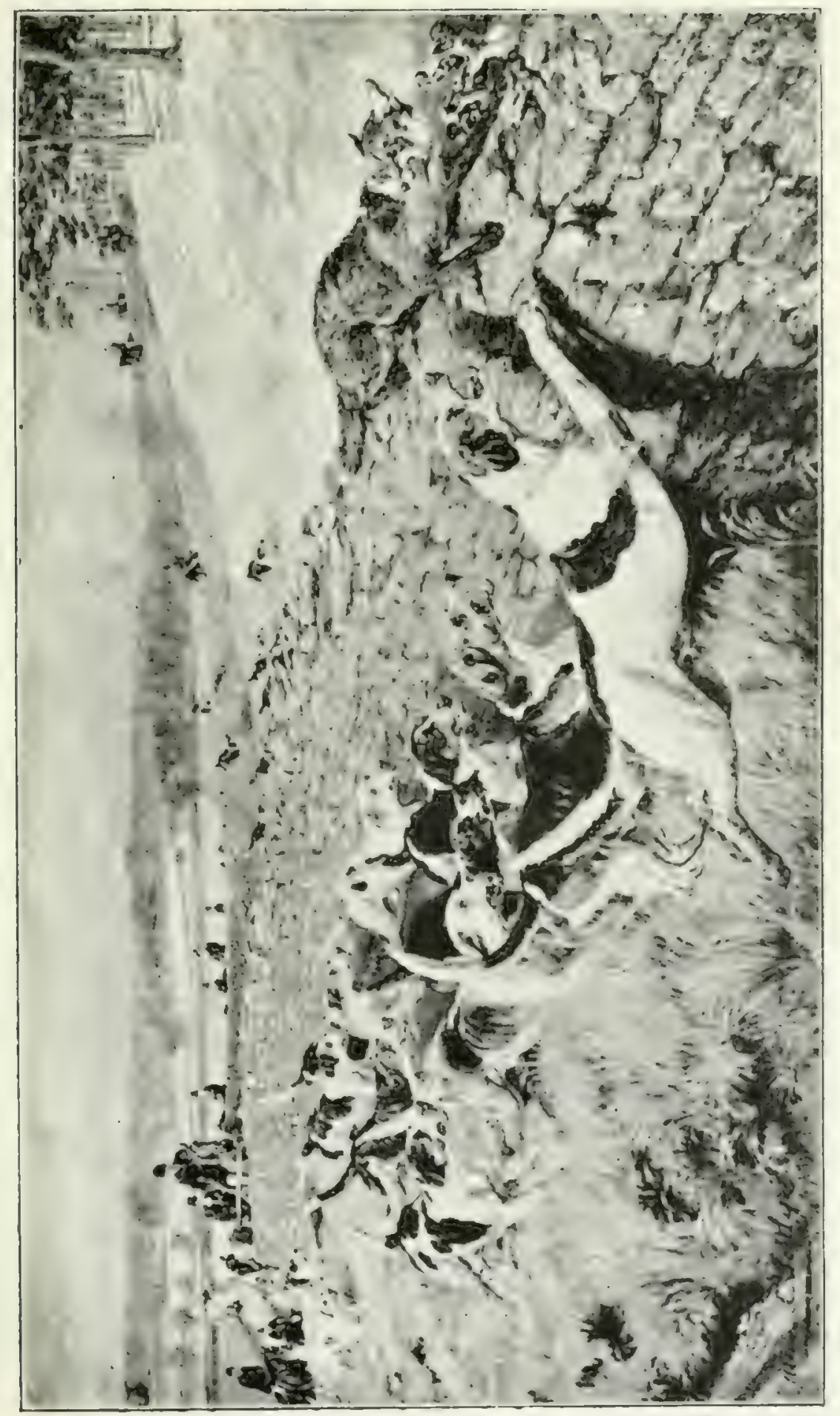



fox as eagerly as hare, and though in districts where outlyers are frequent, an occasional dart after a brush is incvitable, there rarely results much mischicf or a tragic funish; when the hounds are really small, they can usually be stopjed before a holding covert is reached, and on the whole do more good than harm by moving the 'thief of the world' out of the odd holes and corners he is so fond of frequenting, and where he is seldom discovered by his natural enemies. Ijut let a pack of $2 \mathrm{I}$-inch pure bred foxhounds get a fair start on a good scentung day at a fox out of a hedgerow; they are as likely as not-and why not?-to rip him up in five-and-twenty minutes, let the green-coated master and his retainers ride never so valiantly; then when the first flush of triumplh is over, there is shame and remorse, and when the story gets wind the M.F.H. is indignant, the owners of coverts are annoyed, and the subscribers wax hot in their wrath, while all unite in cursing the currant-jelly dogs. We wonder if any of our readers ever heard the late George Payne give an account of how with his harriers (for that Ulysses of sport had in his time kept harriers) he once found a fox in a remote Pytchley withy bed, and 'killed him on the top of the inain earth at Arthingworth.'

Shame and remorse we may be sure he felt none, but even in the paroxysms of laughter occasioned by his inimitable description of how he 'cut him into collops with a penlinife, to tempt the confounded hounds who wouldn't eat him,' we remember thinking that no one but G. P. 'aurait su se tirer de l'embarras.'

Secondly, dwarf foxhounds have too much dash, and when the hare begins to double, and execute her manifold manouvres, they keep over-running the scent, and casting themselves forward, instead of trying back, which seems to be the natural instinct of hounds descended from some generations of harehunting forefathers.

The best plan, therefore, for a berinner is to purchase a draft of old dogs and bitches, from one or more established harricr kennels - if he has any friends in the line so much the 
better -and start breeding at once on his own account. He is pretty sure to buy some curious specimens of the maimed, the halt, and even the blind-people don't sell their best houndsbut of one thing he may feel tolerably certain, that being so many season hunters, they must have ben good, or they would not hare been lient so long. IIe will get them as little related to cach other as my be, and in hunting he must at first take his chance. Of all perplexing sciences commend us to harrier breeding. I'ut a straight dog and a straight bitch together and the litter is as likely as not to exhilhit every shade of canine deformity, whereas the progeny of a slack-loined dog and a bandy-lessed bitch may be as neat little fellows as ever walked the flags. Then, again, when the foxhound cross is remote, wire-cuats become very common, not that this is altogether a disadvantage, as it is a hardy, keen-scented sort, but the wiry ones rather destroy the general smariness and uniformity of the pack, and where the master is afraid of criticism he may object to overhearing remarks about terriers and otter hounds at the meet. But after all the main object is to show sport, and to this end the most important thing is breeding for nose. Always use a hound that can be depended upon on roads, especially when roads are dry. He is a treasure, cherish him, and try to reproduce him as often as possible, for in road work harricrs are apt to lose their heads, hurry each other, and act in a manner entircly contrary to their usual nature; it is wonderful how far a hare will travel the highway if she be not headed, sometimes for a mile or so at a time, nueanwhile if there be no 'Macadamite Mientor' in the pack, the master sufiers tortires as he sees one hound after another whimpering in front ; he mistrusts their jealousy, dares not stop them just yit, hut has grave misgiving; that l'uss has tumed off right or left some hundreds of yards back.

If on the other hand he has an old (or young) 'smellwell' absolutely trustwortly' over the stoncs and dust, he can trot gaily along, fecling sure that so long as he hears that well-known tongrle his guarry has not diverged from the beaten track. 
Colour is unimportant unless the M.II. hat a crotehet that way; and, thanks to bloolhound crosies; some romatrathle:

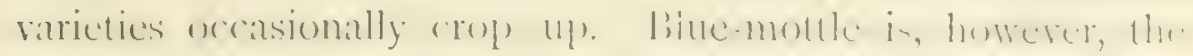
traditional harriur hue; it is now enmparatively srare, and we are bound to say we never remember seeing a biel hound in a blue-mottled skin.

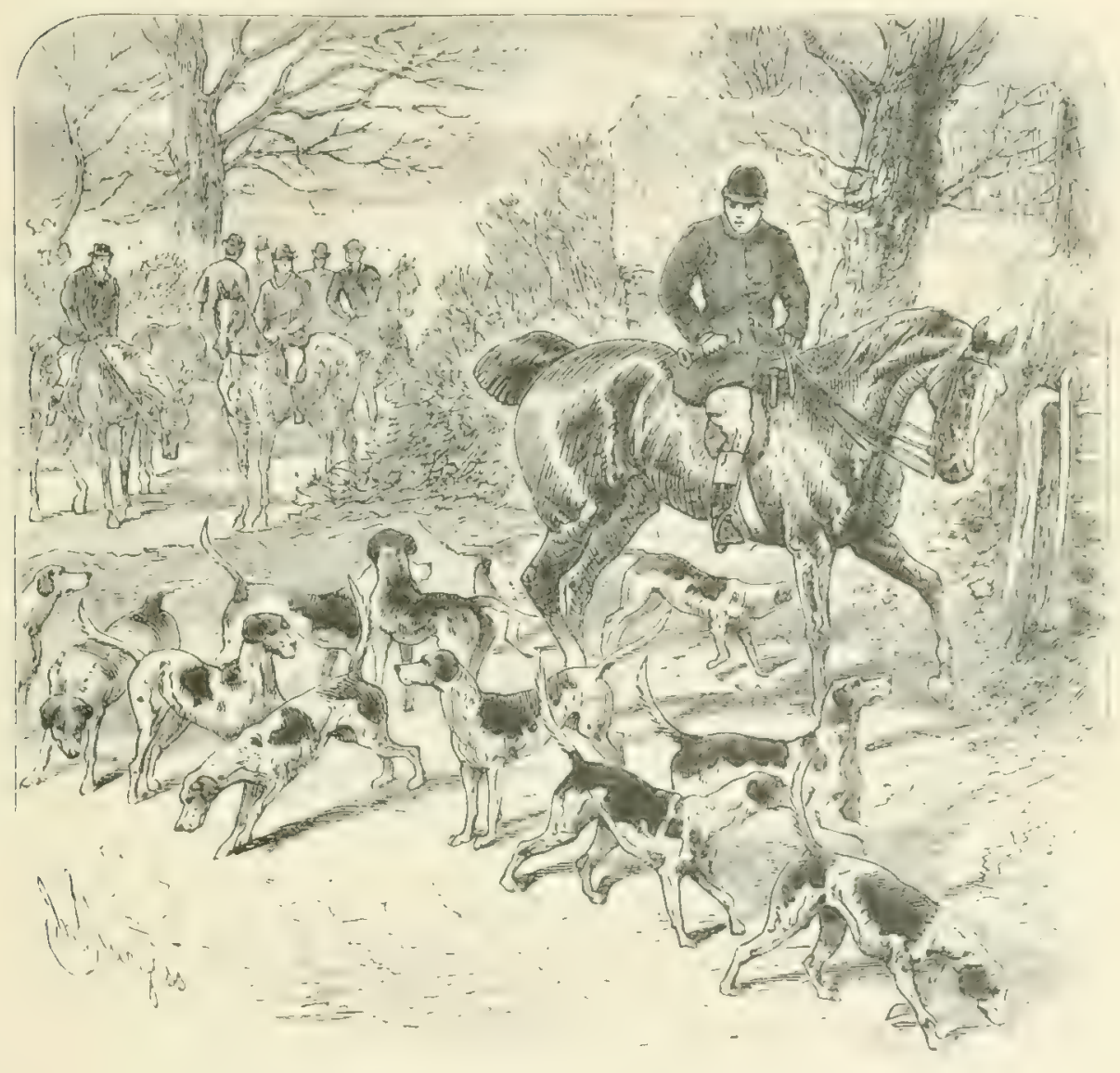

- One hound after another whimpering in front.

The puppies should be sent out to walk about the end of September; when they come in depends a sood deal unon the forbearance of the famers' wives. As many are sent loome in February it is not a bad plan to take such as are strong tnough out hunting for a short time in March; they get more than an 
inkling of their business, and enter without further trouble at the begınning of the following season.

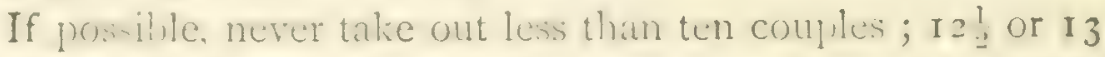
is perhalys the best number, and nuwer more than is coupies, anything in excess of that complement lovks ridiculuus, and when unravelling an entangled skein of work, a lot of hounds only tumble over one another and gut in each other's way.

It is well, however, to keep I5 or Io couples of working hounds; bitches have an inconvenicht knack of going to heat at the same time, accidents occur in the freld, and deadly fights are not uncommon in the kennels. No more quarelsome fiend exists than your harrier in private life, and there is often a Mephistopheles in the pack, who, having started a wrangle, sneaks quietly out of the fray, and with grim contentment watches his brethren rolling over in a compact mass, and worrying to the death. To aroit this internecine strife, the hounds should, where there is accommodation for the purpose, be separated into small batches, especially at night, except after hunting, when they will sleep torgether quictly enough and lie warmer. Feeding is conducted on much the same lines as with foxhounds; the dict consisting of flesh and meal, and the kitchen refuse is often thus utilised. In kennels where economy is studied, Indian me:ul, though not so nutritious, may safuly be sulstituted for natmeal. IIarriers do not generally travel such long distances to covert, or make such long days as the fox-hunting packs, and can therefore do with less stimulating food. In sone few establishments Spratt's biscuits are exclusively used, steeped for twenty-four hours in cold water, but the mess should be wamed before it groes into the troughs. Slaughtering and all the rugular lirty work is of course avoided by this system, which nercrtheless is not popular amongst kennel huntsmen. Lones and hides, where allowed, are valuable perquisites.

The staff necl not necesitrily consist of more than two serrants ; one man can easily double the parts of kennel and freld huntsman, or he can whipoin if the master, as he usuatly 
does, hunts the hounds himself ; but it is adv:sable that there should be some one in authority whose attention is not entirely devoted to the pack, as he may and should, by example and precept, prevent much damage being done to vetches, turnips, sceds, beans, and wheat, though in the case of the last-named the mischief is far more apparent than real; still it must ever be borne in mind that farmers who allow their land to be hunted over by harriers make a far grenter concession to sport than is required for foxhounds, as a field may be crossed not once or twice, but ten or twelve times in the course of the day's diversions. Harriers should always be taken to covert and brought home ly two persons, otherwise they loiter and forage, and not unfrequently pick up a scent, with the result perchance of a sharp spin before the work begins, or in the dark after it should have terminated.

In drawing, the hounds should be permitted to scatter themselves pretty frecly; it may look smarter to have them kept within a short radius of the huntsman's horse, but the draw is thus often unduly prolonged. They will strive quickly enough to cry when the game is afoot, or when a line is touched fresh enough to be spoken to, for though they may appear indifferent they are in reality keenly observant of each other's actions: witness the way they will gather as if by telegraphic signal the moment a trusted comrade shows even the faintest indication of feeling a scent ; witness also their utter disregard of the vnice of a babbler, if such a one has, through misplaced kindncss, escaped his well-merited doom for two or three weeks. In inclosed countries the services of the pedestrians may be most useful in beating the banks and hedges; few harriers will thread a hedgerow properly without the stimulus of a scent, nor is it quite desirable that they should do so, as they are thus liable to become rabbit hunters. We have never seen the experiment tried, but have always been of opinion that a small hardy terrier would be a valuable coadjutor for hedge work; he would of course, be often outpaced, but if interested in the business he wonld be sure to turn up whenever he was wanted. As to the 
habilut of hares at various seasons, there are numernus theories, hut the famers and their shepherd; if they will part with their information, are the best guides. In uccasional half (m,inn (1) the latter is money really well laid out.

- Tom lin - The old poacher who knows where 'a hare do mostly bide,' is by no means to be encouragred in his researches, if he does know he do mostly transfer that hare to his own pocket, and if he stumbles upon one by accident he considers himself entitled to a pension for life.

'The game once started and hounds farly in pursuit, the maxim 'leave 'em alone' can hardly be too rigidly observed, when they come to a check either from over-running, from a bit of cold scenting ground, from cattle foil, or from whatever cause, let them swing and cast; sit still and give them every chance of rectifying their own error, or of puzzling through the difficulty in their own way; only when they are utterly nonflussed should the huntsman go to their assistance. View holloas may be, and often are, of material aid, but they are always open to suspicion, especially when there is reason to suppose that the hare is getting tired. Few men can discriminate between a fresh and a beaten animal, but everyone is alsulutely certain that the hare he has seen is the hunted one. In cases of doubt it is best to send the whip quietly forward to interview the owner of the 'voice crying', and to elicit as far as possible from what direction the hare was coming when last seen, which way was her head, and where the hounds were when she was viewed. The remarkable answers usually given to these apparently simple questions would drive a public-school examince into a lunatic asylum. Above all things, never try to lift harriers when they are really running. In the attempt to cut off a comer and hasten the desired catastrophe, many a hare has been lost which would otherwise have succumbed in the course of a few minutes. If harriers get their heads fairly up, they take far longer to put them down again than do foxhounds, who will storp almost as soon as their huntsman ceases cheering and galloping. The field should never be allowed to 


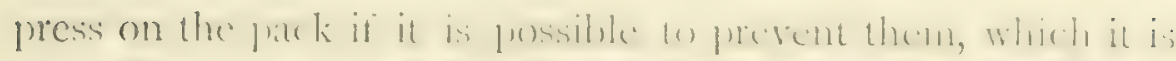
not. Harriers hate being eroweled hy horses, and if met ly them will often appear (o) check on perpose, and try bat k on in any direction but the one in which they were rumning. Then the huntsman should catch hold of them at onee, set the crast clear, and calst beyond the sene of opprosition. illos on hat scenting days, when hounds lang and potter and are inclined to run hack and rejolio over spots which have been favoured

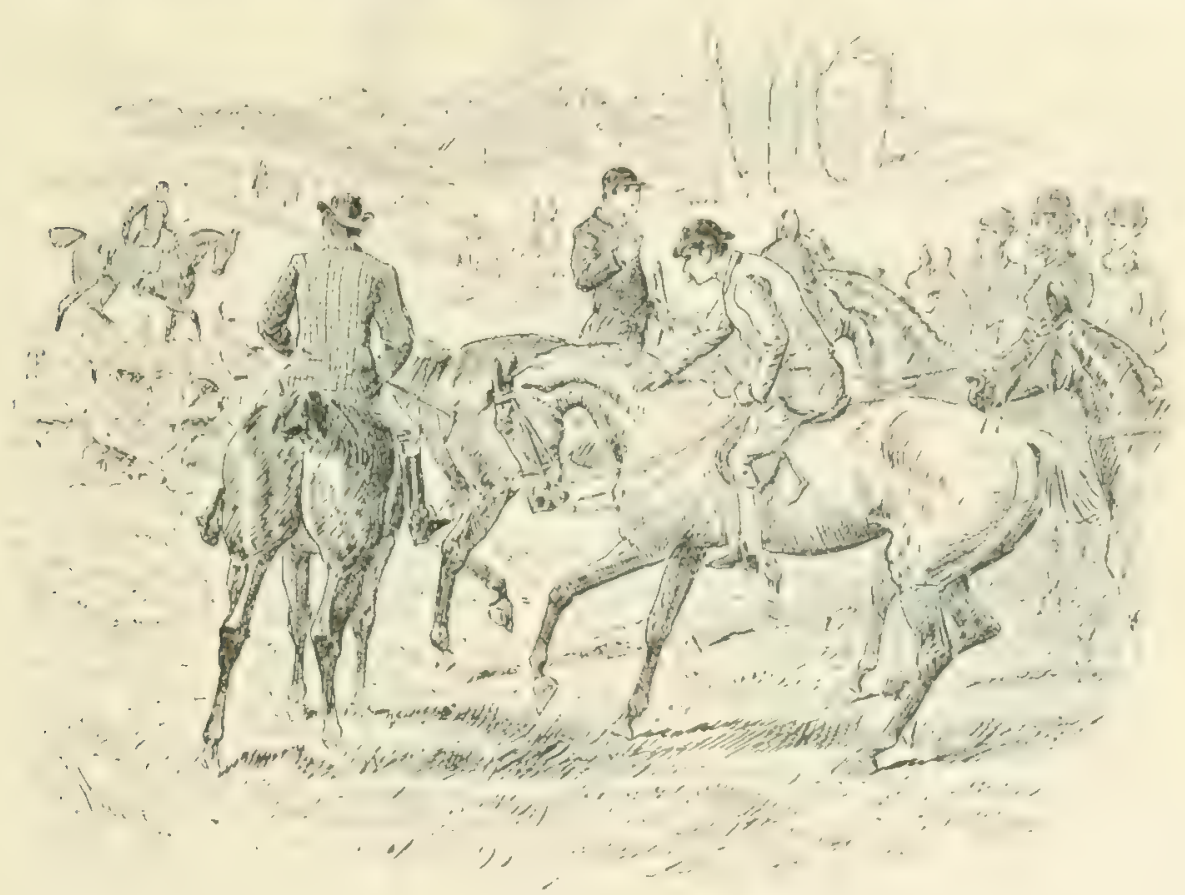

"The field should never be allowed to press on the pack."

with special marks of the hare's attention, the huntsman or master will do well to ride at a walk reght on to them and keep) gently pressing them forward, but this must be done with great caution and observance of the older houncls. Mysterious are the ways of Puss and marvellous her workings. She may les sepuatting within a dozen yards, having run her foil two or three times before throwing herself to nne side and down: and squatting she appears to be, as far as harriers are concerned, scentless and invisible; they will walk over her, jump over her: 
and even step upon her, but so long as she remains motionless they take no more heed of her than of the turnip or clod under which she is crouching.

The interference of the amateur or volunteer huntsman with his uncouth noises and grotesque gestures must at all times be sternly repressed. Was there ever a happier rebuke than the one administered by the late Sir Riclard Sutton to a stranger, whom he found gesticulating with outstretched fingers to the puzzled pack? "When you have quite done feeding your chickens, sir, perhaps you will allow me to cast my' hounds.'

Hares are weaker, and come to hand far more readily before Christmas than later on in the season; January, February, and March, being the months when the best sport may be looked for. Though running in rings of more or less circumference is the rule, there are occasions when a hare of exceptional stamina, usually an old Jack, will travel a four or five mile point in a style which would do credit to a fox; these are of course the red-letter days which can only be expected to occur at most three times during the year, though a series of lucky changes may sometimes give the same result as to distance, and appear the same thing to the majority of the field.

The 'amari aliquid' inseparable from all sport 'surgit' in the one of which we are writing, at the death of the hunted animal. There is no more pitiful, more helpless object than a thoroughly tired-out hare, hopping the last fifty yards of her career, in front of the pack. Contrast this spectacle with that of a fox beaten to a stand-still in the middle of a field, and the learling hound junt running into him. We know at least which of this pair looks the most afraid.

Yet hares, if they are to be hunted at all, must sometimes be lilled ; they have at any rate a better chance with harriers than before a brace of greyhounch, or a shot-gun, and it is not wise for the pursuer ton elosely to amalyse the feclings of the pursued.

In performing the last rites, the paunch is a sufficient reward and encoungement to the hounds. The corpse should be given to the farmer on whose land the raw material was found, and the ear: are the lue truphy to retain, and nat up in the kemnel. 
To sum up-Enthusiasm for hare hunting will be felt only by those who are thoroughly interested in the patient working of hounds; seldom encumbered with a large field of horsemen, they can be watched without riding in the huntsman's porket, or otherwise interfering with his preceedings, while to the ardent youth who is fond of jumping the facilities for breaking his neck, or his horse's back, over a cramped country after a pack of harriers are simply unequalled; and the more cautious rider who prefers cantering from gate to gap will, in cight days out of ten, receive ocular demonstration of the truth of the French proverb, Tout vient à qui sait attendre.

We will conclude by quoting a remark of an eminent sportsman-MIr. George Lane Fox, whom we once heard asked his opinion of hare hunting. He replied with his most courtly sneer: 'I have always understood it to be a most scientific amusement.' There is many a true word spoke sarcastic

\section{BEAGLES.}

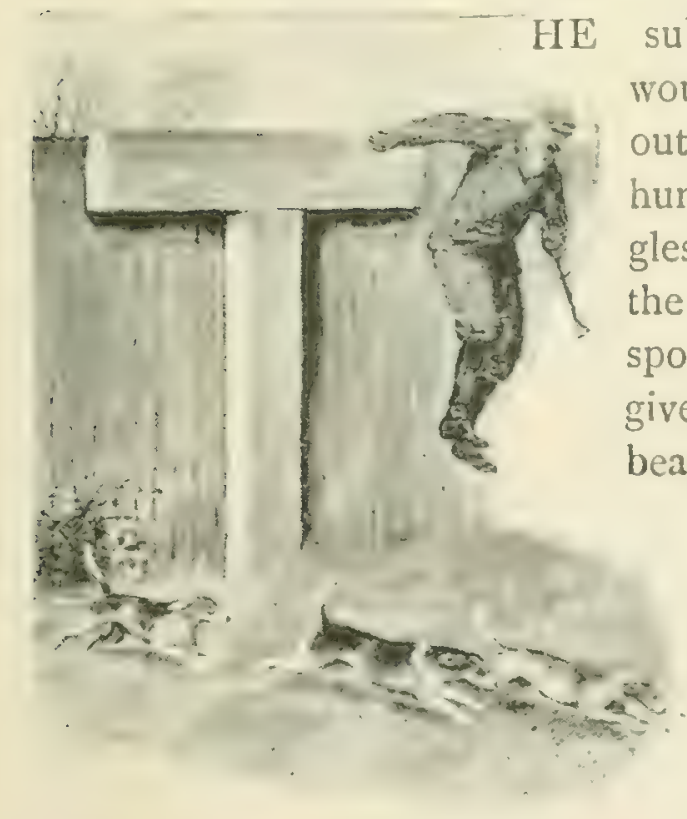

sube hunting would be incomplete without some few remarks upon hunting the hare with beagles, especially now, when the growing popularity of the sport renders it necessary to give a little more attention to beagling than was the case when this volume first made its appearance. It is a pretty sight to see a pack of these merry little fellows at work, and those who are not familiar with beagles would be surprised at the amount of sport which they can 
show, when the chase is properly conducted. It may be useful to enumerate some of the most essential points to be observed in hunting a pack of these diminutive hounds.

First of all comes the question of what stamp of hound is best suited to the diversion. 'This will necessarily vary somewhat with the country orer which it is proposed to hunt, but the chicf points to look to are steadiness, handiness, and endurance, and these points are of importance in any country. Steadiness can only be ascertained by experience; for until you see a hound at work, you cannot say whether he is steady or riotous. To obtain handiness you must do everything in your power to gain the affection of your hounds. Deckford says: "Hounds should love and fear their huntsman; they should fear him much, but love him more;' and it is perfectly certain that the presence of this love is an essential feature of any pack of hounds that is really handy. With regard to endurance there are a few points which may be incidentally noted. Weedy hounds are always very objectionable for two reasons. They are likely to be ton fast in the first burst, and will almost invariably tire. The hounds then must have good bone without any lumber, be stoutly bred-i.c. possess staying powers and a good heart, and for the rest, with the exception of the head, which is typical, their points should resemble as nearly as possible those of a foxhound. It must, however, be observed that nothing but careful breeding will produce a really level and uniform pack. You may, with judgment and some luck, get together a lot that will show sport cren in your first scason; but they will not possess that level uniformity which breeding will alone accomplish.

Experience has shown that no pack under fourteen inches will show real sport and account for their hares in any country, while in very strongly fenced lands, over heather, and in a fen country, the standard should be raised to fifteen or sixteen inches, as in such districts as these the pack will not go so fast on account of the fences or height of the heather, and more stanima is necessary than in a lecs inclosed country. Sixtecn 
inches is certainly quite the maximum height, and the wording of the standard fixed by the Harrier and Beagle Association is 'No beagle to be over sixteen inches.' In very' large and slightly fenced fields or over the open downs the standard may be fourteen inches, as in countries of this sort a pack of beagles up to fifteen or sixteen inches would run away from people on foot. It must, however, be borne in mind that no pack which cannot go faster than men can run

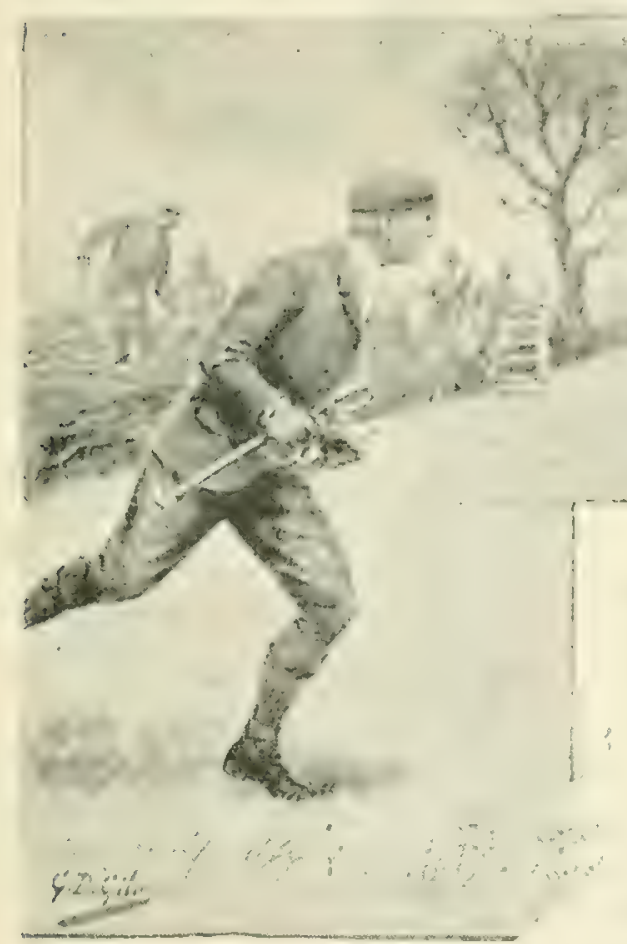

-The pleasure of it.

will show sport and kill their hares, while for the comfort of faint-hearted sportsmen it may be recollected that 'poor puss' comparatively seldom runs straight, and that a good deal of the fun may be generally seen from a neighbouring hill. If the standards adopted are less, according to the country to be hunted, than those above mentioned, a strong hare will soon run the pack 'out of scent,' the hounds will tire before half the day is over, and in cold windy weather will be perished if they have to cross water.

These remarks upon the pace of the pack suggest one precaution which should if possible be taken, wherever the 'merry beaglers' enjoy their diversion : one man on horseback should be in attendance; but it is essential that this person 
should not be the huntsman, and that he should on no pretence whatever, except at the request of the master or huntsman, interfere with ihe pack, unless the hare has cntered a fox covert, same preserve, or any tract of country forbidien to the hunt. 'This horseman should have strict injunctions not to ride to the hounds, but to hover on the outrkirts of the line of chase, always leanng to that side which is newest to the furbiden country, and his duties should be, in the frrst place, to coldervour to head the hare away from that direction, and if he fail in that, to stop the hounds before they enter such country.

If this precaution is carefully carricd out, much of the foxhunter's jualousy of beagling will disappear, and it is certain that any landowner or farmer who has forbidden the little jelly-doss to cross his land will be far sooner reconciled by sceing his reto respected than by any apology offered after the trespass (for such it is) has been committed.

The huntsman of a foot-pack should never be mounted, for a mounted huntsman will always, in some degree, spoil the sport for those on foot.

In the first place, hounds will generally get away more quickly and go fister with a horse behind or aloneside of them, and this is a little hard on the runners. The case is harder still at a chect. A man may have toiled bravely after the pack for some twenty minules or so, and is congratulating himself on their having checked at last. Irancy the feclings of this poor fellow if the hombls are at once cast at a hand cinter, and hit off the line before he has had a moment to recover his wind: Worst of all is it if, the cast having been unsuccessful, a holloa is hearu at the distance of some half-mile or mure, and jerhaps uphill all the way. Off gallups the huntsman, and if he be excited may add insult to injury by shouting to the brave rumer to 'put 'en to him' when he has hardly got enuigh stcam left in him 10 crawl after the fast disappearing puck. 'This is grierous incleed, and shows the advisability of the huntsman sharing the toil with his fellow-sportsmen. 
It maly here be of some assistance to make a few remarks upon the best method of hunting a pack of beatgles in pursuit of a hare.

It must, of course, be borne in mind that the following hints only apply to hounds perfectly to be trusted, and are especially inapplicable to a pack which contains any babblers or mute

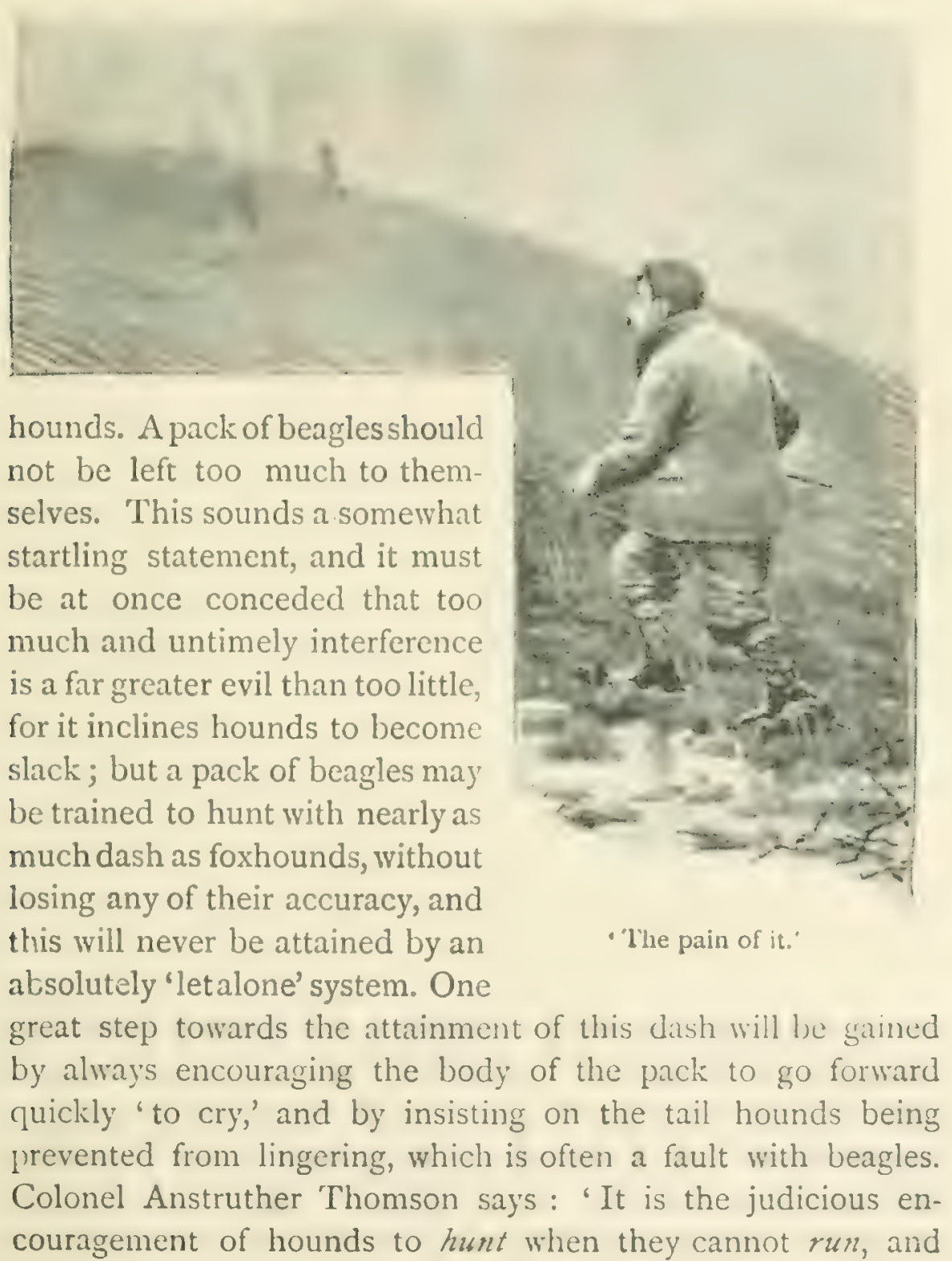


the preventing them from losing time by liunting when they mi, ht run, which distinguishes a good huntsman from a bad one.' When the hounds check, a good pack will generally spread and try all ways, so do not be in too great a hurry to assist them unless you have certain information of the line the hare has taken; and cren then sometimes a smart frack will swing on to the line and get to the point where the hare was viewed more quickly than you could get them there by lifting them, though this is not, of course, always the case. If, then, you have no information, always allow your hounds to make their own cast before you malie yours, and watch proceedings closely: for they will uften cast themselves in the right direction, but not far enough to recover the line. In (asting, do not be afraid to cast forward in the first instance. If your hare is forward, time is of conside rably more importance than if she has doubled, and a pack of bengles will generally be found to have a far greater tendency, if left too much to themsulves, to swing back when the line is forward than to swing forward when the line is back. When once settled to the line beagles will seldom go many yards forward without a scent, but it is ly no means so certain that they will always take the line as far forward as the hare has gone. This is particularly to be borne in mind on bad scenting days.

Bufure leaving the subject of casting, the advice giren on p. I57 is most importint, for it grives the huntsman the benefit of a doulshe cast, and it is therefore repeaced here. It is as follows: "When the huntsman is making his cast, some one ur even two or three couple of hounds with funer noses than the others stop and try to puzzle out the scent. The whipper-in should not then interfere with them; he should leare them, and, putting the others on to the huntsman, watch them. If he finds them feathering on the line he should (quietly') cncourage them, and call the huntsman's attention to them.' 'This may be the saving of much precious time at a critical moment. lior the rest, if you have a good pack, always helievetheir lomgues rather than any other source of information 



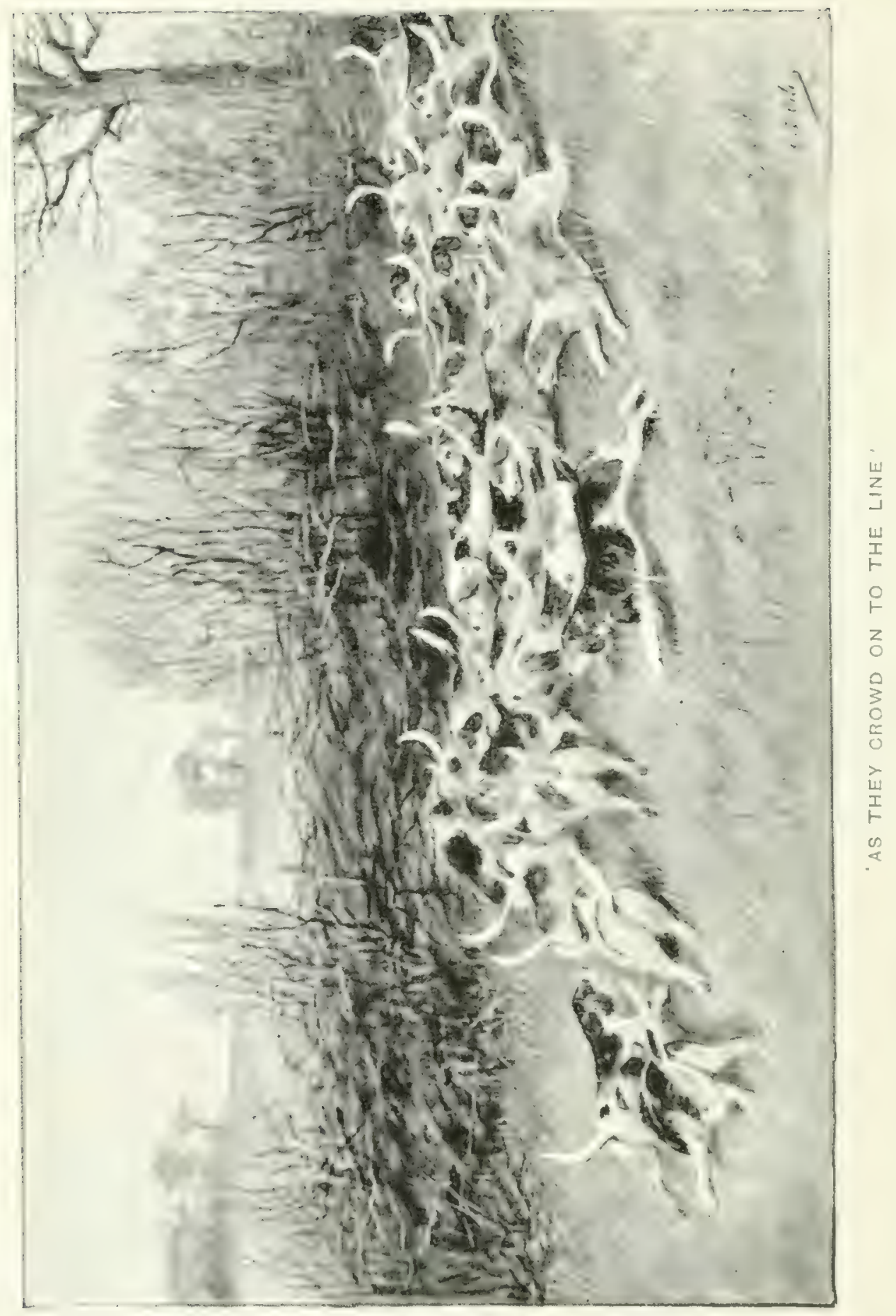


with regard to the line the hare has taken, leave them as much alone as you can, so that you do not suffer them to jutter, and if you should take them in hand, do it as quickly as possible when you are at it. Running after beagles is no child's play, if you would be near cnough to the little follows as they crowl on to the line of their hare to note those niceties of the chase which may perhaps be seen to as great advantage with heagles as with any other hounds. To accomplish this a man must be blessed with a good pair of legs, good wind, should be able to tell by the use of his cars which way hounds are runninis, and, above all, he must have that determination to be with them which the genuine love of the sight of a pack of any hounds m full cry will alone give him.
Of all delights that earth doth yield, Give me a pack of hounds in field, Whose echo shall throughout the sky Make Jove admire our harmony, And wish that he a mortal were To view the pastime we have here.

Sir Marteine Lloyd, an authority of the highest rank, has kindly consented to give some results of his experience, and his contribution follows.

I have been asked to add a short contribution to the Beagle section of this chapter, and to make a few observations on the Harrier and Beagle Association which was formed in March i $S_{9}$ I, so far as it relates to the latter hound.

As I have hunted beagles myself for the last twenty-six years, and previously to that hunted with my father's pack ever since I was eight years old, I am very pleased to have the opportunity of adding my quota of remarks on a subject which is of great interest to myself. If, in addition, they should be of use to anyone forming a pack, I shall not have written in vain.

The beagle has been much neglected for years. Until lateiy there was apparentiy no regulation about him, and small 
harriers were drafted into beugle packs resardless of rule or standard; beagles were, in fact, of all sorts, sizes, and conditions. Some years ago I appealed to the Petorborough Committee, through the medium of the 'Field' newspaper, asking them to form a show, and give prizes for harriers and beagles, on the same principle as that on which the Foxhound Show was based.

The Committee, with much courtesy, consented to give the scheme a trial, and appointed the day after the Foxhound Show as the most convenient time. The first show touk place in IS\$9, under the presidency of the Miayor of Peterhorough. It was a success, and in the following year another was held under the same conditions. I)uring the show in I890, at the suggestion of Major Roburtion-Aikman, M.H., a meeting of masters of harriers took place to decide what hounds should be shown as harriers in future. After much discussion, this meeting was adjourned until the following spring, when Sir John 'Thursby most kindly placed his house in London at the disposal of masters of harriers and beagles, he himself issuing circulars inviting them to attend.

At this meeting it was proposed by Mr. J. S. Gibbons, Master of the Poddington Harriers, that a Harrier and Beagle Association should be started, and this motion was carried unanimously. One of the chicf ofjects of the association was to start a stud-book for harricrs and a stud-book for beagles respectively, and this book was at once organised and armanged under the able auspices of the Ilonorary Secretary, Mr. L. E. Rickards, to whom much praise and thanks are due for his untiring and successful efforts.

Since starting these annual shows at P'eterborough and the formation of the stud-book, a marvellous change for the better has taken place in both the harrier and the bengle, but in the present instance, of course, my remarks must be confined to the latter.

No luagle can now be cntered in the stud-bnok with a diect harrier cross nearer than two generations back. Under 
the association, classes are armoned at the ammual show for beagles not over sixteen inches which are entered in or are eligible for admission into the stud-book, and during the year I $S_{9} 3$ there was a very strong entry of these hounds.

Leavirg the association, I will endetwour to describe the best kind of beagle for hunting the hare, and I may remark that the little beagle of about twelve or thirteen inches, very

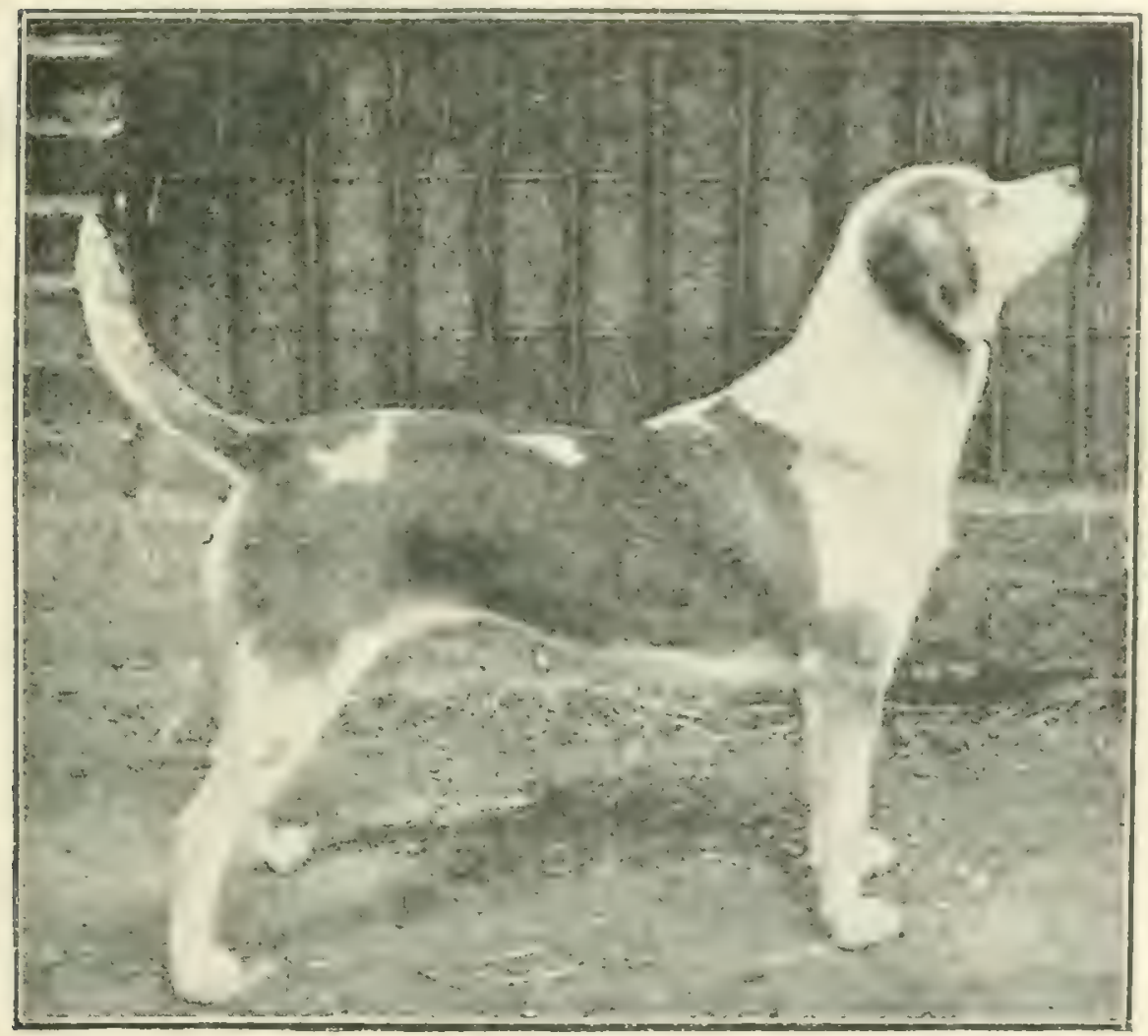

'Willing '

pretty, and uscful for rabbit hunting, is absolutely of no use whatever.

The writer of the preceding section observes that no hound is of any use for hare hunting under fourteen inches; they cannot stand work or weather, however flat the country may be, and in hilly or bank and ditch districts the toy beagle is worthless. 
To my mind the Worcester I'ark 'Bertram' and 'TVilling' are as nearly as possitile the perfertion of what beargles should be. 'Dertram' is ten years old, and has lost a little muscle over the loins, but he is wonderful considering his age, and has all the points of a true beagle. 'Willing' is a really wellmale bitch, with the lust of legs and feet, has a good head, straight back, with rure loins and shoulders, and is all over the sort of hound to hunt the hare in any kind of country.

Some people, I know, consider that the beagle should be of the same make and shape as the foxhound. 'There are, of course, some points which should be the same in all hounds, but the beigle has a typ of it. own, which should be most certainly Ireserved. In all hounds the straighter they are in front the letter, but I think one may be too particular as to this in a leagle. I have seen and have bred hounds almost straight, but they are rare. Posibly, now that a stud-book is started, and these littic hounds will be nore carefully bred, they may gradually improve in their feet and legs.

I have a great objection to beagles being long in their larks, as they are invariably weak over the loins, which is the srreatest fault, except bad shoulders, a hound can possibly baye.

I am also arerse to the heary, cobby hound, much preferring the active sort that can drive a hare when there is a scent good cnough to cnable them to do so. As to colour in beagles, like other hounds, it matters little; an old huntsman once told me 'a good hommi was never a bad colour.' What I like best is a lilack and rich clark tan with a little white, or a blue mottle.

And now as to the points of these little hounds. 'The head and neck of the beagle are quite typical, and as compared with the foxhound the differences appear to be as follows :-

The muzzle should be shorter, the jaws lighter, the skull should show more rise from the mumle betwen the cyes, the dence of the head should be linger and broatler, the neck should we shorter and thicker, with possibly a very slight tendency to 
throatiness. To this fulness of the throat may probuhly lu: attributed the fuller and more musical voice of the beagle, as compared with that of the foxhound and modem harrier. The eyes should be larger, fuller, and softer than those of the frowhound. 'The ears should be hung on lower down, and be nearly long enough to reach to the end of the nose. It is a mistake for beagles to have ears of any greater length, as they gret them so terribly torn in a rough gorsy country and when they have to rmm through corerts and thorn funces. I hear judges of bearles at dog shows make a point of the longest ears possible, but these animals are bred for the show-bench and not for work, and my sincere hope is that the beagle will be bred for hunting and not for show purposes. What we want to encourage at our annual show at Peterborough is the breeding of beagle:i as perfect as possible in make and shape for work : with neck as above described; with shoulders well sloped and not heavyfor no hounds are of any use if defective in this respect, and will soon show their weak point when hounds are running hard, as they cannot run up; with back quite straight to the stern; with good loins, well ribbed up and not flat-sided; with stern the same shape as that of a foxhound, and not coarse or very much feathered. The legs in front should be as straight as you can get them, but do not draft a beagle if he is not quite straight and a bit back in the knees, because here is the difficulty of this point as a standard-very few bengles are quite straight, and their feet are hardly ever cat-shaped; the hind legs should be long from the hip to the hock, and short from the hock to the foot.

In the previous section of this chapter the hunting of a pack of beagles has been so fully discussed that I can add nothing, but advise the beginner to carry those instructions in his mind when he first takes his pack out. If he will try to understand. what his hounds are doing themselves, and leare them alone, he will after a little experience learn more from obserration than books can teach him. IIuntsmen who have hunted hounds all their lives learn something fresh day after day. 
I do not advice taking a very large number of homeds ont humting, as they are very apt to get in one another's way.

Secnt is a question which 'passes the wit of man." It is governed greatly by climate and the different soils run orer, some places holding a scent, some not; but of one thing I am quite certian-riz. that some hares have much better scent than others. A hare in kindle, at the end of Feloruary or March, has hardly any scent, while at the same period a straight-running jack, if the weather is not too dry, has a burning scent. Hares run roads very much in some countries, and nothing saves the life of juss more often than a road; scent on roads differs very much, some carrying a very good scent at times, others never. Hounds will flash up and duwn a road, particularly if the scent is catchy and the field are too close after them, and it is necessary to have at least a couple of road hounds, to put the rest of the pack right when they are casting each side, and to teach others to put their noses down on a road. Until hounds are five or six seasons old they seldom take to it, but there are of course exceptions.

A hare, if she has time to do so, will run her foil on the same highway for some distance so as to baftle her pursuers. It is most importunt not to press hounds under these circumstances. It is a well-known fact that the scent of a sinking hare dies with it, and this alone renclers the killing of a hare difficult.

Before I close, some of my reiders may like to hear my experience of feeding these small hounds, as they are so often delicate catcrs. It may surprise not a few when they hear the advice, '(lon't sire ontmeat, but instead plain ship) biscuit with horiclesh (always hoiled) in moderation, and always fresh.' For a time I followert the old system of feeding on oatmeal, lut gave it up as it was too stimulating and too heating for litte hounds. 'They do nut cat it nearly as well as they do biscuit, and it is apt to give them a turked-up appearance. A burliet of kitrhen scraps malies a nice change at any

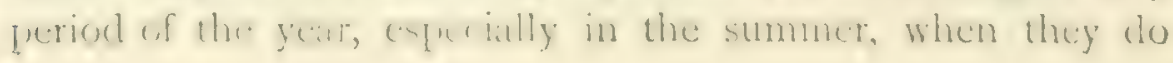


not reguire flesh at all. I give biscuit all the year round (soaked in water for twelve hours previously), and there is no better or cheaper food. In the winter flesh or scraps may be advantageously mixed with the biscuit, and during the summer scraps and boiled green food, young nettles and calsbages form a wholesome addition. Give powdered brimstone once a weck cxternally and intemally (mixed in the food), with a dose of salts occasionally. If the kennels are free from that curse kennel-lameness, this treatment, with regular daily exercise, will keep a pack in perfect health.

Since the publication of the first edition of this volume a movement has taken place amongst those interested in the breeding of harriers which deserves notice. In I 859 a show of harriers was held at Peterborough on the day following the well-known Foxhound Show; there was a considerable diversity of type in the hounds shown, and much public correspondence followed, with the result that in March ISg I a large meeting of masters of harriers and beagles was held, proba!bly the first really representative meeting of the sort which has ever taken place. The outcome of this meeting was that an Association of Masters of Harriers and Beagles was formed, which undertook the work of founding stud-books for harricr.s and beagles respectivuly, and of drawing up rules under which future shows at Peterborough should be held. The Harrier Stud-book was started on the broadest possible lines, taking in every existing pack which chose to enter, add the show at Peterborough has since been carried on under the rules drawn up by this association. All this has naturally caused a stir and movement in harrier breeding which has never before been known; masters of harriers hate been bitten by the spirit of emulation, and alrcady the show of harriers at Peterborough is a very different affair from what it was the first year or two. licsides the abne-mentioned facts, the spirit of the age appears 
to lee working in the direction of making harriers rather different animals from many of those with which our forefathers ued to pursue the hare. Everyone wants to go fast nowadays, and the master of harriers, as well as the M.F.H., finds that if he is to plase the majority of his supporters, he must have a quick pack of hounds which can get out of the way of horses and show a gallop when they have a scent to do it with; so that, between the modern demands of the hunting-field and the influence of the Peterborough show ring, the harrier bids fair to become very like the foxhound in make and shape; and providing that his size is kept down to something like twenty inches for the largest hounds, this is certainly the highest canine ideal, so far as bodily formation groes, that can be arrived at. 'The old-fashioned harrier was often sadly deficient in his understandings; loins and quarters he often had of the best, but legs and feet left much to be desired, and shoulders were often not satisfactory; his nose was good, it is true, but of what avail is the best nose if the animal's physical powers are so deficient that he camnot do a real good day's hard work with comfort to himself and those who have to rille home with him? There certainly seems to be no rason why the fine scenting powers and hereditary instinct of the harrier should not be preserved, and a more shapely animal produced than has often been the case in the past. We now appear to be on the high road to such a consummation, and the next few years will probably prove eventful in the histury of harrier breeding.

some people talk as if it were a heresy and a poisonous thing to introduce foxhound blood into harrier breeding, but let us for a moment consider what sort of hound it is that we want to pursue the hare with. Delicacy of nose, and that hereditary instinct which leads him to cast sideways and back at a check instcal of flinging forward, are necessary qualifications of the first importance; so that the pure-bred foxhound, not possessing the litter of these, is not, as has been before stated in this work, the exact article we repuire, although, if he were liept for several generations to the pursuit of the hare, I 
believe he would soon acpuire this particulat instinet. The size of the hatricr is to a large extent a maller of taste; in many instances a hound of eighteen inches or thereathumts will do his work and kill hares cvery whit as well as a lareer one, and can go quite fast cnough to male horses gallop; hut where much heavy clay ploughed land has to be crossed, where high walls have to be surmounted, or where long distances have to be travelled to and from the scene of operations, a larger hound will be found more satisfactory, and one approaching twenty inches, or, in some cases, even a little more, will do his work with greater ease and comfort both to himself and his master. Now, having secured our wished-for qualities of nose and harehunting instinct, the important question of make and shape comes to be considered. A sloping shoulder will last longer than a straight one, and a round, compact foot will wear out one which is spread open and 'down at heel'; (lepth of back ribs and plenty of bone show a good constitution and staying power, and let us have legs as straight as we can get them; all these points have been secured in the foxhound by careful breeding for gencrations, and we cannot do bettur than imitate an example which has produced such a beautiful animal as the modern foxhound undoubtedly is. To obtain this desired improvement in the appearance, which, after all, simply means the working powers, of the harrier, we need not now have recourse to foxhound kennels; for, owing to the large infusion of foxhound blood in the Harrier Stud-bonk, we can make use of hounds which, although closely alliced to pure foxhound blool, are yet descended from hare-hunting parents, and so are on the high road to acquiring that hereditary hare-hunting instinct which is so valuable. Finally, let the master of harriers jealously preserve his old hare-hunting blood; but let him also bear in nnind that shapely necks and shoulders, straight lers and goud fect will carry a good nose faster and farther than a clumsy con. figuration, that to the joys of the actual pursuit in the field 
there cun be added the calmer though not less interesting delighis of showing his hounds to appreciative friends in the kennel, or competing in friendly rivalry in the show-ring, and so may his pack be 'a thine of leauty and a joy' not on'y in the winter, but all the year round. 


\section{CHAPTER III.}

\section{SIABLES.}

PrUdence, no less than humanity, should induce every man who owns horses to do his best for them. If they are fit and well they will do their work with comfort and satisfaction alil:e to themselves and their master. By common care a score of ills which afflict horscflesh may be avoided; but common care is an uncommon thing in many establishments. Horses get 'out of sorts' as men do, except that in the latter case the fault is usually with the sufferer, whereas in the case of the horse it is with a careless, ignorant master, or a servant who develops his master's qualities. The horse owner who knows nothing of horses is in a false position, especially when he depends upon a servant who knows little more, or who has prejudices and absurd traditions which do as much mischief as sheer ignorance. A horse may often look well in himself when he is really not well able to do his work. A large inajority of stables, for instance, are a great deal too hot. Grooms like to keep them so because when living in such an atmosphere the horses' coats look beautifully smooth and glossy, and layers of fat which the uneducated eye mistakes for muscle are perceptible. The groom is pleased, the ignorant owner delighted ; but in spite of appearance the horses are constantly going wrong. They catch cold; they do not clean out their mangers, and are knocked up when an effort is demanded. They stop in the middle of a run while other horses with rougher coats go steadily on, and their owners zre sorely puzzled.

The truth is that they pass their days and their nights in an 
atmosphere the breathing and rebreathing of which must necds be deleterious. When a visitor enters the stable his nose and ejes are effually pained, for the latter sensitive oreans are fricted by exhalations from the foul atmosphere. let this is the air which the horse breathes not only all day when in the stable, but all night as well; for he has no change of apartment. Iresh air is as necessary to him as to his master, but so little does the sroom beliere this that he will sometimes eren bleck up the means of rentilation. A stable should be ats sweet and

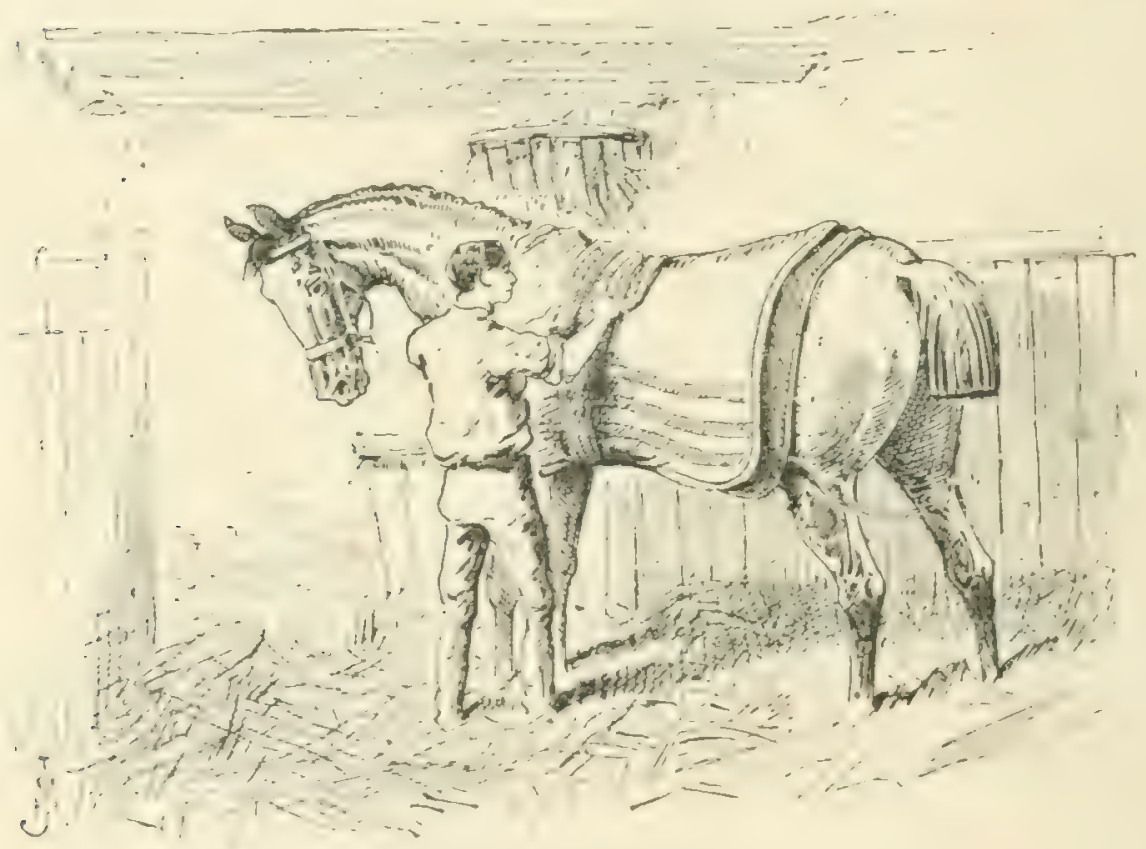

'A good deal too hot.'

clean as a hemes. Of course some animals are less susceptible (1) the cifects of foul air than others: just as some men thrive in slums which would be fatal to those who have been more arcfully mortured. As at gencral principle it may lue lad clown that if a horse is to be healthy he must live in a healthy place ; dranghts are to be aroided, but rentilation and light, together with excre ixe of a proper description, are lirst esinentials, no less minertant to him than sound food and wholesome water.

That no effort should be spared fo find trustworthy servants 
for the stable need scarcely be pointed out. Their shortcomings here are less directly obvious than the shortcomings of servants in the house under the master's eye. It frequently happens that grooms have theories of their own as to the management of horses. The animals suffer, or even sometimes die, under these systems ; they are often not fit to come out of their stables, still less to do their work; but nothing will persuade the groom that the fault is not with the horse, but with him; such an idea never in fact occurs to him. That his master can really know anything about horses he cannot be brought to believe, and too often the master does, in fact, leave everything to his groom, who, he vaguely supposes, being a groom, must know what is best. Very frequently the groom is a slave of bad old customs and really knows nothing about any horse, still less is able to understand the various constitutions and peculiaritics of the different animals in his charge. Perhaps it may be said without injustice that the majority of grooms possess that little learning which is a dangerous thing. As an example of this, one winter four or five horses belonging to the late Lord Henry Bentinck died so mysteriously that post-mortem examinations were made. Symptoms of poison were detected, and it presently appeared that the groom had continually given them small doses of arsenic to make their coats shine. It is most necessary, therefore, that the horse owner should acquaint himself with the best principles of stable management. He will not do well to trust too implicitly to hastily acquired knowledge, but great advantages are likely to arise if his servantssupposing them to be servants of the average sort, and not those treasures of servants which are so rare, men who know their business thoroughly and do it conscientiously-perceive that their master understands what he is about. An old proverb says that 'It is the master's eye that makes the horse fat.' Fat horses are not wanted in the hunting field, but the idea applies none the less to the man who owns a stud of hunters.

The annexed plans of the Badminton Stables will convey an idea of the accommodation afforded in this establishment. For 
these stables this at luast may be claimed, that horses thrive in them, though the Badminton horses most certainly do a great deal of work. Days and distances are long in this country, and it must be remembered that the sewvants of a hunt tax their horses severely. That horses should keep well and come out fit in their turn is a strong argument in firvour of their residence and treatment. Here the stud is necessarily large. A pack which hunts five days a week makes heavy demands on horseflesh; but the rules which are found serviceable here will be equally suitable for smaller stables.

All the hunters at Badminton are provided with loose boxes, the dimensions of which will be seen in the drawings. The fitteen feet of height to the ceiling line insures by the aid of ventilation the needful supply of fresh air. A ventilator is fixed in the ceiling line over every box, and air bricks a few inches from the ground are let into the walls behind the boxes. Windows are built on the division line of every other box, and there are windows also on the opposite walls, the positions of which are indicated. A free and abundant current of air is thus provided. The weather is rarely so bad that these windows may not be opened at least for some part of the day: if the horses appear to be cold, additional clothing is put upon them. It was formerly the custom to completely darken many stables during severa! hours of every day, the plea being that horses could then rest better. The system is totally unnatural and therefore totally wrong. Horses are creatures of custom, and will rest perfectly well in the daylight. A dark stable almost inevitably becomes a hot stable, and the absolute necessity of air to keep a horse in health cannot be too strenuously insisted on.

That a horse should stand day after day with his fore legs on a higher level than his hind must surely be detrimental to him. Ilis back sinews and fetlock joints will be more or less strained. This again is unnatural, and it may be broadly said that whatever is unnatural is mischievous. The floors of the Badminton loose boxes are therefore laid perfectly level, and 
paved with large flat flagstones, much after the fashion of the I ondon foot parement. There are no drains of any sort in the stables, and, as a consequence, none of those noxinus cxhalations which are practically inseparable from the best system of drainage. A plentiful supply of clean straw is of course spreacl in every box, and replared as necessity demands; but it has been found that no inore straw is used now than was used formerly when the stahles were drained. The freedom which boxes permit seems to have a very beneficial effect on their occupants. Boxes cannot of course be always provided ; but stalls should be as nearly as possible on the same principles.

By the side of the manger in every box is a slate receptacle for water, which is kept always supplied. If the horse can take water whenever he wants it he will drink very much less than when it is brought round to him in a bucket at stated times; the difference in quantity is, indeed, surprising. To come to figures, a horse will drink about eight gallons daily if watered twice a day, and about five gallons if water is always in the box at his disposal. The receptacles are water-tight, having no outlet or plug of any description; consequently there is no clrip to make the box damp. They are cleaned every day, a sponge being used to soak up any water which remains wien the groom attends to his charge. The manger and rack are made of wellseasoned oak, and along the top of the piece of wood which forms the front of the manger an iron bar standing up about an inch from the wood is fastened. The object of this is to prevent crib-biting, a bad trick the frequency of which is a source of astonishment to the horse owner. The animal doubtless takes to crib-biting for want of occupation, it grows into a confirmed habit and often ends in ruining his wind, which crib-biting always has a tendency to affect. This iron bar to a certain extent prevents the trick, but it cannot be said that even this is wholly effectual, nor can any method of curing the horse be discovered. He is very much less likely to learn the trick, however, if this precaution be taken. Manser and riack are placed at such a height that the horse can stand in a natural 


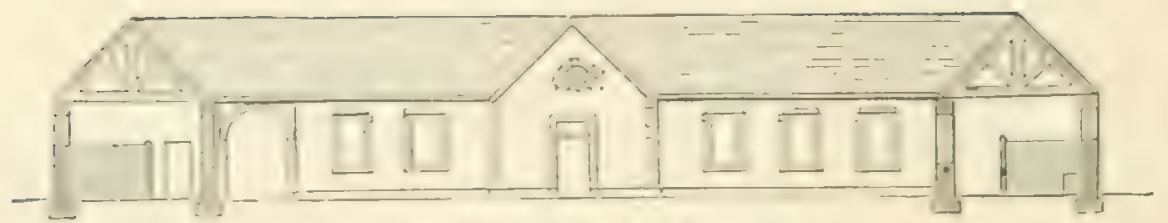

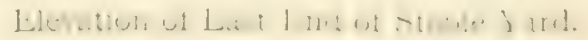

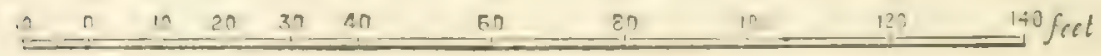

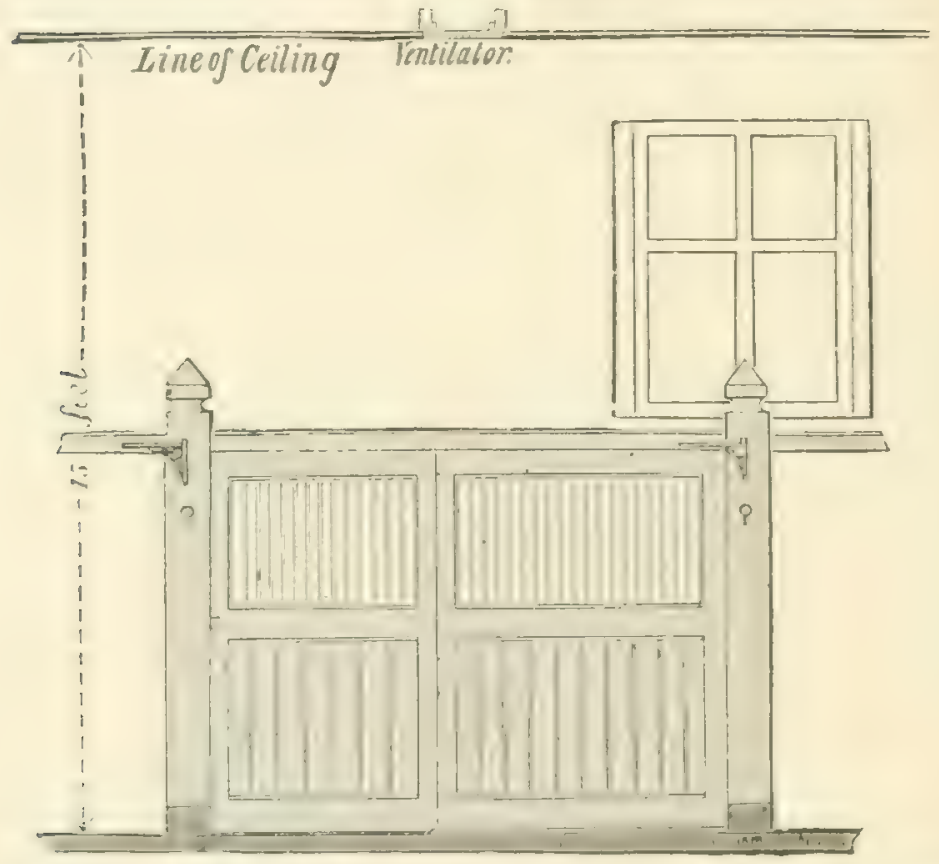

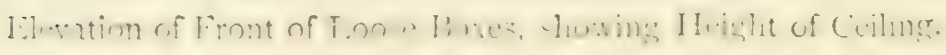

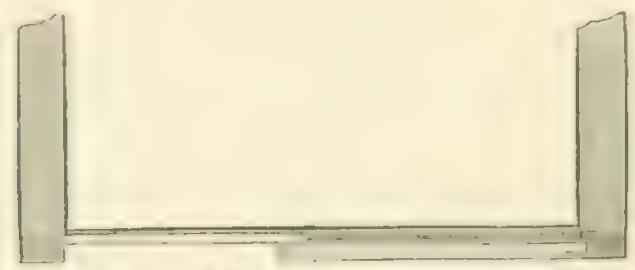

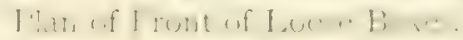




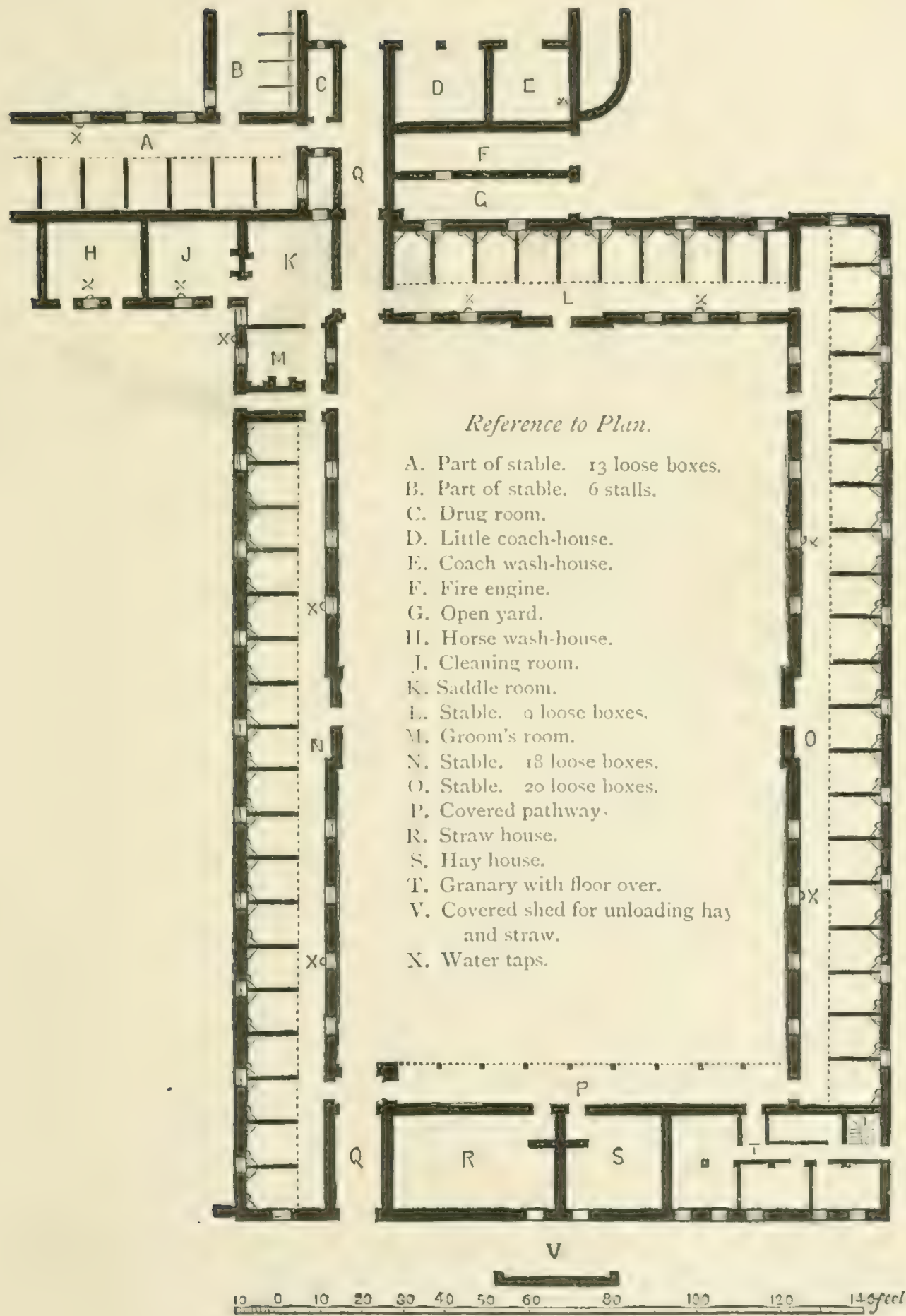


position to eat his fond. It is dificult to understand why rackis were fomerly put high up above the horse's head so that he had to stretch for his hay, while secels full into his eyes and cars: but se it was. The water taps will be sech marked in the flan. Hay, com, and traw are tation into the stables along a cosered way and there is a cosered shed for unhalines prosvender. In the saddle room is a very simple and useful invention for cirying siuldles. This is in the shape of a larege

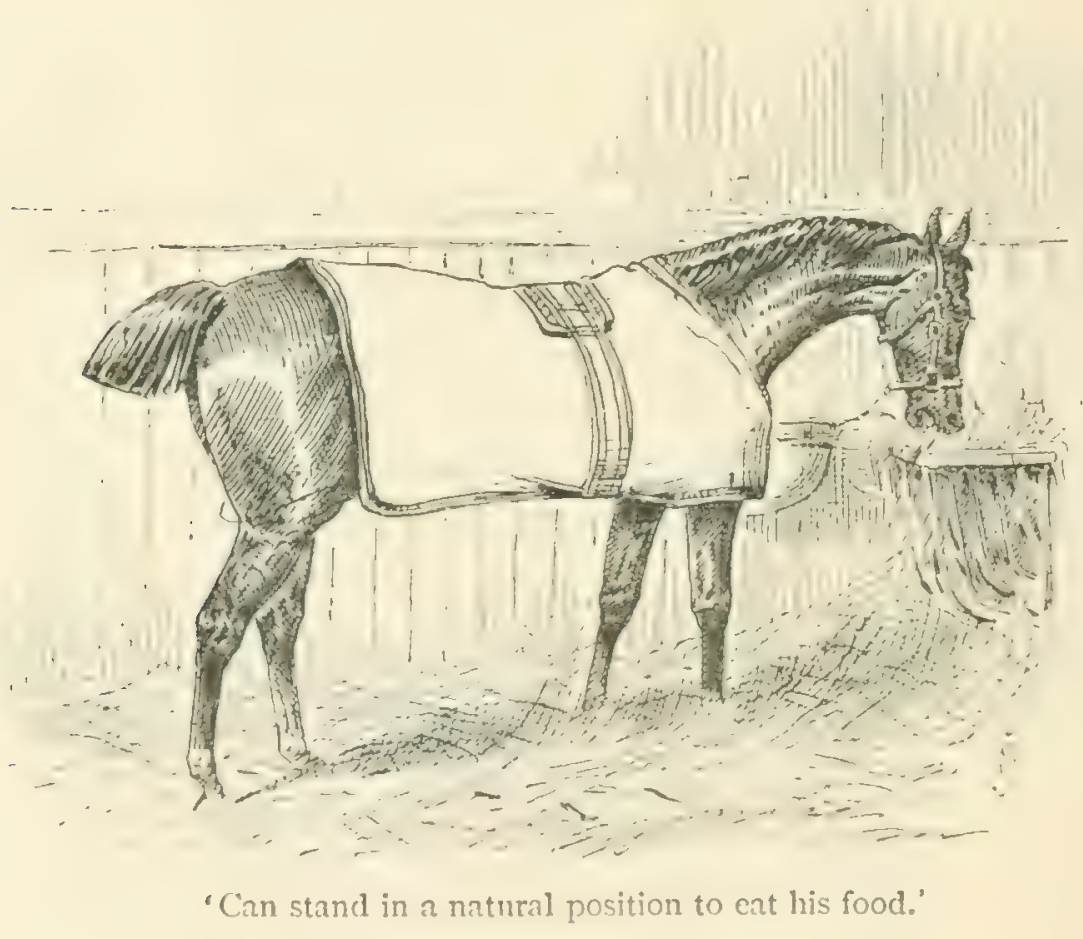

towel-horse, with jrom bars set bark some comple of inches, rumning behind and half-way between each rail. The rails are just sufficiently far apart to contain a sublle. Fome fifteen or twenty sadkles (an he so arranged on the sadelle-horse and placed before the fire to dry at the sume time. Other cyplanations will be found fully set forth in the plan.

It should be observed that these stables are modern. The

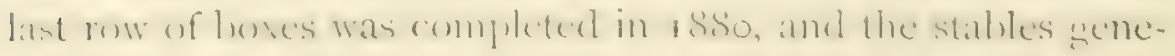


rally, as a matter of course, are carefully designed and fitted with a view to providing everything that long experience of a hunting establishment shows to be necessary for the horse's comfort and well-being.

The question of summering the hunter has provoked much discussion. Some authorities are all for turning him out, others for keeping him in his box, and in the multitude of counsellors there is confusion. The old fashion was to turn the hunter out for his summer's run, and of this fashion Beckford was an advocate. 'After a long and tircsome winter,' says the accomplished thinker of 'Thoughts upon Hunting,' 'surely the horse deserves some repose. Let him then enjoy' his short-lived liberty; and as his feet are the part that suffer most, turn him out into a soft pasture. . . Can standing in a hot stable do any good? Is it not soft ground and long rest that will best refresh his limbs? I have often remarked that, thus treated, they catch fewer colds, have the use of their limbs more freely, and are less liable to lameness than other horses.' Lawrence, too, the author of an excellent work, is here in sympathy with Beckford. He would have every hunter turned out 'to enjoy that best of all coolers and alterants, the spring grass, the purifying elastic external air and the dew of heaven. 'The holiday of a month or two out of the twelve is a kindness we owe to the horse which so dearly earns it.'

This is exceedingly plausible. No man would deny the good hunter that deserved repose and dearly earned holiday for which these writers plead; but the question is whether the horse benefits, whether it is best for him, and as a necessary consequence, best for his master, that he should be thus treated. Beckford, it will be observed, pleads for the soft pasture and condemns the hot stables. As already set forth, we would have no stable hot; and with regard to soft pasture, where can it always be found during a hot dry summer? The picture of the faithful horse peacefully cropping the grass in some pleasant meadow, his feet covered by cool dewy vegetation, is a very pleasing one. But as a matter of fact what usually 
happens? The gnats and fies are an unfailing pest, the meadow is too often parched and sun-baked. On this surface the horse is tormented till, after much stamping, he gallops about on the hard ground and ton probably lames himselt. Ile gets sadly out of condition, as a matter of course, and requires extra care and a reat deal of time to make him fit, when at last he is taken up. There are many objections to turning horses out.

After a very hard season such treatment may at times be advisable. As a rule the animal's box is the best place for him. His shoes must be taken off, and abundance of good litter is required, tan, sawdust, or some other material. If the horse be left in his box, with his shoes remored, his food wil! not, of course, be the same as that which he has in the hunting season. Three times a day he may have green meat; and 5 lbs. of oats, in two feeds, will be sufficient. When August comes, and his period of service is approaching, the green meat must be discontinued. A dose of physic may first be given, in the shape of a ball containing 4 drachms of aloes, or, in the case of an animal of an exceptionally strong constitution, 5 drachms may be needed. Of oats io lbs. a day may then be given, with a liberal allowance of hay cut into chaff. Long hay is bad for the horse's wind, though all grooms are fond of giving it, partly from ignorance of the fact, and partly, no doubt, to save themselves trouble. Every day the horse should have an hour and a half of walking exercise. In September-we are assuming that the horse is not wanted for cub hunting, for if he is he must be taken up and conditioned sconer - he should be walked and trotted for three hours a day, and his allowance of onts increased to 12 lbs. A handful of beans will be an agreeable addition. A little meal may also occasionally be griven. In the Badminton stables a compound called I.ong's Reading Feeding Meal, the manufacture of Mr. I.oner, a son of the huntsman who was for so considerable a time connected with these hounds, has been used with good results. If a horse be a delicate feeder a little of this meal sprinkled on his corn will 
induce him to cat. 'The corn may just be damped by nipping a little water over it, and four or five ounces of the meal then added.

'The hard rider can scarcely expect to be carried satisfactorily more than three days a fortnight, though a sound horse in grood condition may be brought out twice a week if not over-taxed; much, of course, depending upon the distance he has to go to the meets. The treatment of the horse when he comes in from lunting is a matter of the highest importance, for at this time, if not properly cared for, harm of a more or less serious character can very soon be done in several ways. A little oatmeal grue] should first of all be given, but it is a mistake to provide this too liberally. A large pailful of this gruel will distend the animal and take away his healthy appetite. A gallon is quite enough, and then, while he is being dressed, a little hay will keep him occupied and be welcome. In most stables a horse's legs are washed when he comes in; but though this may often do no harm, and in many cases does none, it is very much better not to wash the legs at all. They should be thoroughly brushed and rubbed, and may then judiciously be wrapped in flannel bandages. Twenty-five years ago every horse at Badminton was washed with warm water when he came in from hunting, and mud fever all over the animals' legs, bellies, and backs was hardly ever absent from the stables. A remedy, or rather a means of prevention, was sought; dry brooms, wisps, and hand rubbing were tried; and since the adoption of this system, even in the wettest seasons, there has been no case of the fever. The experience of solong a period, and complete freedom from what was previously a standing plague, must be held to prove the efficacy of the plan. Equally beneficial results are reported from very numerous quarters where the practice of washing has been abandoned.

It is difficult to make white legs look quite clean without using water, but if they must be washed the job should be left till next morning, when they are cool-the legs having, of course, been treated as already described when the horse 
comes home. The dry flannel bandages mentioned above are for horses that return to their stables with no symptoms of heat about them. If the legs are hut, bandages should be put on wetted with vinesar and water in equal parts. The value of the cold water bandage is increased by the admixture of vinegar, which has at once a cooling and hardening effect.

Anything in the nature of a cut or over-reach should be carefully looked for and promptly treated. The wound of an over-reach may be made by the toe, or the inner edge of the hind shoe, which latter is often very sharp, and the injury, a combination of cut, tear, and bruise, will speedily produce inflammatory symptoms if neglected. The wound should in the first place be carefully washed out with warm water, and a linseed poultice then applied. When it is healing a little tincture of myrrh may be used. It must by no means be assumed, however, that the above treatment is suitable for all wounds to the lers, such as broken knees. For such cases, and in every case where a joint is injured, threatened, or affected, poulticing is the worst course that could possibly be followed, and almost surcly productive of serious evils. It is not our purpose to write a book on veterinary science. Injliries to joints, or particularly deep wounds, are beyond the stableman's province. Veterinary aid should be sought, and the owner should be exceedingly careful whose services he employs. Not a few stable practitioners are, or until lately were, accustomed to fall into the very error agrainst which we are now cautioning readers. They poulticed and fomented injuries to a joint, the result being to destroy its vitality and insure permanent weakness or lameness. Modern treatment of such cases is purely antiseptic. The nature of a hunter's work renders it very probable that he will be occasionally junctured by thorns, such punctures being a frequent cause of lameness and swellings. The extraction of the thorn is of course the first thing to be done, and if it cannot be found, though it is known to be there, veterinary aid should be procured. If the thorn be in the forearm there may be danger of its working to the knee. Blisters may be necessary; 
but unless there are men of long expericnce about the stable, such cases had better be confided to the veterinary surgeon. It is not easy to be too careful.

That some horses have a predisposition to various discases is almost too much a matter of course to be mentioned, but it is equally true that disease usually arises from neglect or mistaken treatment. It is a not unfrequent boast with many men that they have not had a veterinary surgeon in their stable for long periods. They do not always say, and doubtless do not alway's recognise the fact, that their horses would often have been cured of ailments more surely and speedily if the best medical advice had been obtained. Most grooms think that they can perform a number of operations which they are tutally incompetent to perform, partly from want of practice and partly from ignorance of the horse's anatomy and of the real objects and effects of the treatment they endeavour to follow. In serious cases, or cases which threaten to become serious, it is best to obtain skilled advice; but at the same time there are many simple cures which any experienced stableman can accomplish, especially if he really understands the cause of the illness or injury. With many diseases of the feet-as a rule the consequences of bad shocing-the groom can deal. We cannot do better than summarise the very clear and effective remedies prescribed by Mr. Digby Collins in his work, "The Horse Trainer's Guide,' for those comparatively simple diseases for which veterinary aid need not be sought. There is usually one right method and many wrong methods of trcatment for every ailment, and these are perhaps nowhere more tersely and lucidly summed up than in the book named.

Corns are the result of pressure on the sole of the foot, whereby the blood-vessels are ruptured, giving rise to a morbid secretion, which, if allowed to continue, will render the corn well-nigh incurable. The treatment will consist in removing the pressure and stimulating the sole to secrete a healthy deposit of horn, by means of the application of oil of turpentine and spirits of wine-equal parts of each, after having cut out the corn with the buttress.

This dressing should be applied for three consecutive days, 
when the horse should be shod with a leathern sole of the strongest hide, and the hoof should be stuffed with tow, saturated with the above dressing. This will enable the horse to resume moderate work without injury to the corn. Corns most frequently arise from shoes being left on too lons, whereby the inner heel of the shoe works in and presses on the sole between the crust and the bars.

Sandcrack consists in a separation of the fibres of the hoof, owing to a want of gelatinous secretion. The treatment should consist in cutting the edges of the cracks with a knife until the crust is thimned so as to be flexible; a poultice should then be applied for two days; after which the whole crust must be dressed with some stimulating application, which should be continued for some months. The best ointment consists of equal portions of grease and oil of turpentine for the first month, after which the turpentine should be considerably diminished. The horse should have his shoes removed entirely, and be put to stand on a deep bed of tan, fresh from the tanner's yard. Tan can be procured anywhere, and is the only proper material for litter when the hoof is thus diseased.

Thrush proceeds from various causes, but inflammation of the frog is the immediate cause. Some horses have very soft frogs, which will become diseased by the application of cow dung as a stopping, and contact with straw saturated with urine, which causes 1rritation to the sensitive frog, and this contracts a diseased secretion which exudes through the cleft of the frog. If allowed to go on this will assume an ulcerative form, which will most probably terminate in canker. This kind of thrush is best treated by carefully avoiding the exciting cause, by strict attention to providing dry litter, as well as by applying a lotion consisting of 2 scruples of chloride of zinc to the half-pint of water, three times daily. When thrush results from plethora, cooling cliet and alteratives should be given, and the frog dressed with common tar; and if the secretion does not abate, the chloride of zinc lotion should be tried.

When either fever in the fect or navicular discase gives rise to thrush, the cleft of the frog must be left free, and the exciting causes treated as recommended hereafter. $\Lambda$ horse with a thrush should not be ridien without knce-caps; for if he bruise the frog, he will generally fall and cut his knees severely.

Quittor consists in an internal abscess of the foot, forming in sinuses. The parts surrounding the os corona are generally enlarged and puffy, and hot and cender to the touch, followed, unless relieved, by a bursting of one of the alsscesses at the superior border 
of the hoof, from which an oficonsive and rather thin discharge exudes. The treatment should consist in liberal but not leating food; but on the whole, as this disease maly reyuire delicite operations, it should be professionally treated.

Navicular disease, and nearly every kind of foot lameness laid to the charge of this discase, consists in: first, inflammation of the synovial capsule of the navicular joint, resulting from inflammation of the perforans tendon, which passes under the navicular, and is attached to the pedal bone. It is met with in the very best and strongest-looking feet, and the decrree of lameness occasioned by it is very variable. When ulceration occurs the synovial capsule is absorbed, and the tenclon comes into contact with the bone. The horse will usually rest the affected foot when standing at his case. Ile will be much more lame on leaving than on retuming to the stable, the friction of the parts giving rise to a temporary secretion of synovia. When the disease is at all advanced; all treatment will be hopeless; but, in the carly stages of the cliscase, bleeding at the toe, followed by emollient poultices, will be found beneficial, when combined with rest in a roomy and cool box, well littered with fresh tan. This discase is casily distinguished from laminitis by the horse 'culking' perfectly sound. A hunter or steeplechaser affected with this disease need not be despaired of, as such horses will go over soft ground perfectly well and soundly. Only they should be ridden to and from cover at a pace not exceeding a walk. Indeed, on a road, no horse affected with navicular disease should be ridden at a greater speed than a walk, since more or less pain will be occasioned by the concussion.

Founder, fever in the feet, or laminitis consists in inflammation of the laminie and the adjacent parts of the foot. It is caused by continued exertion on hard ground, straining the crust beyond its powers; but the most frequent cause is an injury to the linee or shoulder of the horse, on account of which he is fearful of lying down, and thus the continuance of an upright position causes too severe a strain of the sensitive lamine. In this case a lengthened rest after the cause has subsided, on puddled clay during the daytime, with a plentiful litter at night, will be absolutely necessary to effect a permanent cure. Where the horse has to continue his work, his feet should be placed in two buclets of cool water after coming in from exercise, and allowed to remain there so long as the horse feels disposed to maintain the same position. Mr. Collins states that he has more than once seen horses neigh for the buckets 
and put their fect hurrichly into them of their own accord imme. dintely they were placed before them. The suftening of the hoof by water, ildeby causing increascel pliability of the crust, diminishes the atin occasioned by the want of roum for the expansion of the bloort-resels ccnseruent on inflammation. The symptoms wili be marked by the horse standin's with his hind legs in a much more forward position than usual, for the purpose of relieving his fore fect of their proper proportion of weight. If the foot be felt it will be discovered to have an unusual degree of heat, and if pressed or squeceed by a pair of pincers an unusual jliniting will le perceptible. On ruming him out, the weight will be thrown principally on the heels-a marked contrast to the symptoms of naviulat disease, in which the toes are almost the only parts of the feet placed on the ground when the horse trots. Bleeding is certainly not advisable where the inflammation is not very acute; since it weikens the foot so much that it will be unfit for hard worl: for miny weeks afterwards. The food should consist of bran mashes and a litte hay; and, although a violent purge should be aroided, when the intiammation runs very high, laxatives should be freely administered; the best dose beingr 2 drachms of emetic tartar and half an ounce of nitre, given every day for a week.

A very common source of trouble arises from cracked hecls, due generally to overwork in an unfit condition. Glycerine or vaseline should be carefully applied to the seat of this very painful disease; this, with liberal diet and abstinence from work, will in time effect a cure.

Swelled legs, another evii from which many horses suffer, usually arises from over-work and under-feeding or from working animals when they are unfit. 'The remedy is the removal of the exciting causes.

Colic is of virious kinds, and due to various causes, the precise nature of which it is most essential to discover. A homely lut often effective remedy is a cuart of warm ale conlaining a glass of spirits and a tablespoonful of powdered gingur. A duse of aloes may be tricd if relief is not obtained; and should the illness still be obstinate, 2 ounces of tincture of opjum in a pint of water may be administered. If this does not lring about a cure it will be well to consuit the surgeon, 
for the animal nay be suffering from obstruction, twisted bowel, hernia, enteritis or some grave disease.

For every reason the question of sadding is of the very fir.t mportance; that is to say, a well-fitting, well-kipt saddle is a first essential to the comfort of the horse and his rider. In connection with horsemanship we hear much, and most properly, of 'hands.' A moment's reflection will show that hands are mainly dependent on seat, and seat is greatly influenced by saddle. Can there be any doubt of this? A man firmly, ensily, and comfortably seated in a chair, can pen the most delicate line with great precision. l'ut him in a jolting carriage, or on some insecure and unsteady seat, and he cammot direct his hand with accuracy. The same rule applies to seat in the saddle: unless it be firm, easy, and comfortable, the nicety of touch on the bridle which will 'humour it like a silken thread' cannot be acquired. A firm seat, totally independent of bridle, and to a great extent independent of stirups, is the foundation of all good horsemanship. By a well-fitting saddle, it should be added, a saddle that fits both horse and rider is meant.

The choice between plain and padded flaps must be left to the discretion of the rider. At Badminton plain flaps are the invariable rule. They, no doubt, make the horse's forchand look b.tter, and give a freedom to the rider's leg which the padded flap does not permit. Men who are accustomed to the older fashion usually feel more comfortable, however, with this support for the knee. Great care must at all times be taken to see that the stuffing is thoroughly dried and free from lump. The perspiration which is absorbed into the receptive stuffing makes it most necessary that the saddle should be beaten and brushed, as well as dried. Nerlected saddles are a constant source of warbles, sitfasts, and sore backs in general, evils which are also rery frequently induced by the fact of the saddle being too short for the rider, thus bringing undue pressure on the cantle. Cold water will generally effect a cure, if the sure be taken in time. If it be bad, poulticing will relieve and cure the injury, absolute rest being 
of course incispensable; and in all cases where inflamma. tory symptoms show themselves laxative food, green-meat, gruel, and bran mashes must replace the allowance of corn. It may be added that the fit of a saddle depends upon the suitability of the shape of the tree to the back of the horse. Excessive stuffing is bad. A man should be as near to his horse as possible.

Into the question of bits we cannot possibly here enter at length. It may be briefly remarked, however, that if a bit does not secm to be sufficiently severe to stop a horse, one that is less severe may wisely be tried. The ordinary double bridle is, as a rule, the best for hunting. The sportsman will look to his gear before he mounts. Comfort to his horse will mean comfort to himself, and he will therefore sce that the snaffle lies lightly on the bars of the horse's mouth, and that the curb is neither inconveniently tight nor too loose to be effectual if wanted. There is no lack of severe bits of all descriptions, but the use of them generally implies bad horsemanship or bad breaking. Severe bits should be the last resource, to be used with the utmost caution, and then only by the best riders.

It was remarked on a former page that whatever is unratural is mischievous, but allowance must be made for the circumstance that a horse's life is not such as that which he would lead in a state of nature. He would not have to bear weight on his back, nor to travel for so many miles at a stretch, nor to gro on the hard road. Horses, mureover, are not indigenous to this climate, and must be shod in order to fulfil the duties of modern life. At bachinton the material for the shoes is cut from bars of patent iron, which is sold in lengths groved for the reception of nails. The smith cuts off the length he requires from the bar and fashions it into.the shoe. 'l'he recliless use of the knife is to be condemned : the excedingly and beautifully delicate structure of the hoof forbids it. The farrier must take care that the frog comes well down to the ground, so as to relieve pressure on the other bearing surfaces of the foot, and where a horse has contracted heels, every 
encouragement to expansion must be left. Patent shoes of different sorts have been tried at different times, and in peculiar cases some of them have perhaps peculiar advantages. For hunters and coach horses alike, however, nothing has been found to answer better than shoes of this patent iron, carefully fitted and fixed. It is desirable that the day before the horses go out hunting their shoes should be examined. As a rule a set of shoes last rather more than a month, but constant attention must be paid to the feet, as corns almost always arise from the shoe being left on too long. No competent smith need be cautioned to use only the best nails. A prick caused by a nail which has divided, part going into the horn of the hoof and part into the sensitive portion of the foot, may lead to worse than temporary lameness.

In a large hunting establishment it may be roughly calculated that one man can look after three horses. When the animals come home from lzunting everyone whose services are available will lend a hand to dress them down; three or four men may be uscfully employed on each horse. It is scarcely necessary to remark that grooming must at all times be thorough. Nore than the appearance of a horse's coat depends on this. Unless the animal is diligently curry-combed and brushed, scurf will form, close the pores of the skin, and affect the horse's health. A bright coat, always supposing that it be properly obtained, means a bright eye. It is easy to see, by moving a little of the hair back and looking at the roots, whether the horse has been thoroughly dressed. On first coming home after a hard day particular attention should be paid to the horse's ears. IVell cleaning them seems to afford special relief, and as regards the legs, friction has long been recognised as both a cure and a preventive of disease.

In a chapter which is not intended to instruct the stableman in the rudiments of his business, but rather to express a preference between disputed systems, the questions of clipping and singeing need not be discussed at length. It is highly desirable that horses should be clipped, for if they were not 
perspiration would accumulate and dry in the long coat, and chills, together with other illnesses, would be invited. Many years ago a barbarous custom of cropping a hunter's ears was in vogue. The objectless cruelty was practised because cropped ears were thought to give a game look to a horse, no consideration being paid to the poor creature's sufferings; and at that period the horse's dock was a matter of very few inches. Happily these savage ideas have passed away, and though many bad and stupid fashions are revived, it need not be feared that these will be among the number. When ear-cropping was common it was usual to bleed the hunter before summering him, but this absurdity, which must have cost our forefathers dearly, since many horses did not survive the practice, is happily unknown at the present day. There is, and there always will be, something new to be learnt about the horse, as about the man. Veterinary science, however, has made such great progress that it must be an altogrether exceptional case for which adequate treatment cannot be found, while accurate general knowledge is always extending. Horses are no longer bled as they used to be at times when their vital forces required to be sustained instead of diminished, and a hundred other ridiculous customs have vanished. The most invaluable medicines for horses are sweet stables, an abundance of sound, wholesome food, sufficient exercise, and kind treatment. The horse is not entirely the scrvant but also the friend of his owner, and friendly consideration is his just due. A man who gives less fails to discharge a debt of honour. 


\section{CHAPTER IV。}

THE KENNEI.

IN a certain romance which most of us, probably, have read at some period of our existence, if it has a little passed out of memory now-in the late Lord Lytton's 'Last of the Barons'-the old philosopher, Adam Warner, being suddenly called upon to apply some simple surgical remedy, of which his only knowledge is derived from the book in his hand, exclaims in great perplexity, "But the book telleth me not how the lancet should be applied : it is casy to say do this, or do that, but to do it once it should have been done before.' He who addresses himself to the practical business of the Chase, which includes, let it be remembered, a great dcal more than the mere getting across a country and encompassing the death of his game-he, we say, who addresses himself to this business after having first mastered the written experience of others and gained from them such wisdom as he can, will, no doubt, buy his own experience cheaper than he who has neglected or been unable so to train and prepare himsilf. But he must not think to grow to a Meynell, or an Assheton Smith, or an Anstruther Thompson, by books alone. 'Hunting's a science, and riding an art.' All arts and sciences hare their own laws, which those who would practise them must learn or abide by the consequences. WTe must not, therefore, be understood to depreciate the value of books, which would, indeed, be a most unwarrantable defiling of our nest. Neither do we wish to feel our withers wrung by that sly hit of Beckford's: "All who have written on the subject of hunting, 
$5 e c m$ to agree in this, at least-to speak indifferently of one another.' We wish only to guard ourselves against misconception, and our readers against disappointment. And so to our business.

As no man would think of buying a pack of hounds who was not sure of a place to keep them in, we will begin with the kennel. In building a kennel, as has been very pertinently observed, there are two capital points to be remembered ; firstly, the means of the builder ; sccondly, the extent of his hunting establishment. The kennels at Goodwood, for eximple, cost several thousand pounds; those at Woburn have, or had, a frontage of 455 feet. On the other hand, kennels sulficient for all practical purposes may be built on a much more modest and frugal plan from the outhouses and barns that gencrally form part of the equipment of every country gentleman's estate. Beckford, indeed, sneers at their cconomy, though he is by no means wont to recommend useless expenditure. 'It is true,' he says, 'hounds may' be kept in barns and stal)les; but those who keep them in such places can bust inform you whether their hounds are capable of answering the purposes for which they are kept.' And he goes on to say that, as all our hopes of sport depend on the delicacy of our hounds' noses, 'I cannot but suppose every stench is hurtful to it.' This is very true. If a pack of the best bred and best trained hounds in the world were turned to pig together as best they might into some dirty outhouse or discased barn, it is probable they would not long be worth much. Tut on the basis of such buildings kennels may be fashoned sufficient to kecp hounds in health and comfort, which will practically answer all the purposes of Woburn and Goodwood, and cost very much less than those princely establishments. Still, it is no doubt better, where adequate means and space are forthcoming, that the kennel should be a building of and by itself.

But on whatever scale, or after whatever plan it be built, there are three essentials to be observed. It must be dry, airy, and warm. Sweetness and light are as vital to the proper well. 
being of the hound as we are so often reminded they are to his master. Nay, it may be said that, in proportion, they are even more so ; for, while some men do certainly in this world contrive to get on without them, we are very sure no hound can. It must never be forgotten that both the horses and the hounds used for the chase are a very different sort of animals from what they are in their natural state. Their state is one not of nature but of art : a highly artificial state. They differ as much after their kind from the nag who picks up his living off a common, or from the village cur, as their masters differ from the Digger Indians, or the aboriginals of the Australian bush. The man of civilisation who lives in a damp, ill-drained, ill-ventilated house will never be able to do his work properly, even if he can get through life at all. And it is the same with horse and hound. But extravagance is not an essential to hound or horse any more than to man. He who hunts five or six days in the week will naturally require a much larger and costlier establishment than he who hunts two or three. The conditions under which hunting is, one might perhaps say must be, now carred on in the Shires will entail a larger outlay than will be found necessary in those less fashionable parts of hunting Britain known as the Provinces-where, however, the sport, if less splendid, is not seldom quite as good. But even in the former case economy can be and should be practised. Superfluities should be avoided as well as shortcomings, and ostentation is in its way as distasteful and as injurious to sport as parsimony. Hunting is certainly not an amusement to be enjoyed for nothing, or even for very little, whether it be enjoyed in the state of a master of hounds, or in the more simple capacity of a private individual; but it may be enjoyed for very much less money than is perhaps popularly supposed, and certainly is very often expended on it. Not every man can go to Corinth; but it is quite possible for a wise man to get a good deal of pleasure less far afield.

The situation of the kennel is of first-rate importance. It should be built, says Somerville, 
Upon some little eminence erect, And fronting to the ruddy dawn; its courts On either hand wide opening to receive The sun's all-cheering beams.

And he is right. It should stand on open and rising ground; not in a bleak exposed situation, so that the winds of heaven visit it too roughly ; but on the other hand, not in a hollow, or on low-lying ground, or too much shut in and overshadowed by trees. The Ascot Kennels, which have much such a situation, and are built moreover on sand with a substratum of bog, long suffered from that mortal scourge which among men is known as rheumatisin, and among hounds as kennel lameness; nor was it till Charles Davis had a false flooring put so as to admit a free current of air, that the evil really disappeared. It may be here remarked, however, that in very many cases kennel lameness is another name for kennel idleness, i.e. want of exercise in summer and putting hounds to hard work unprepared by horse exercise.

The material of which the kennel should be built, and the style of the architecture must be determined, of course, by the taste and the purse of the owner. But there is a good deal of sense in Beckford's suggestion that it should have 'a neatness without, as well as cleanliness within, the more to tempt you to it.' For the same reason, he advises it should be as near the house as possible. A chorus from a restless pack is, no doubt, not an agrecable lullaby, nor is the smell of the boiling house the swectest of perfumes; but there is a mean in all thingrs, and such a measure of distance between the homes of the master and his hounds may be contrwed as to avoid all unpleasantness to the former, while keeping the latter under his supervision. Good servants are, probably, more plentiful now than they were in Beckford's time, when the demand for them is so much greater, and their rewards so much higher. Nevertheless, a master who leaves everything to his servants, whether in house, kennel, or stable, is not likely to be so well served as he who makes it understood that he knows how things 
should be done, and is determined to sec that they are so done.

When the late Lord Suffield undertook to hunt the Quorn country in ${ }_{1} \delta_{3} S$, his first act was to remove the hounds from Thrussington, where Sir Harry Goodricke had quartered them a few years previously, to their present kennels at Billesdon. He consulted Mr. Smith (not Assheton, though also a "Tom" Smith), who was then showing good sport in the Craven country, as he afterwards did in the Pytchley, on the economy both of his kennels and stables, and in Mr. Smith's admirable little book, 'Extracts from the Diary of a Huntsman,' which every fox hunter ought to have by him, the results of the consultation may be learned. The precise cost of the work is not stated, but we are told it was 'less than half of a previous plan designed by a first-rate architect,' which would, however, as Mr. Smith candidly adds, have been 'a splendid building.' The affairs of such a pack as the Quorn are of course conducted on a larger and more liberal scale than every master of hounds will either find possible or necessary. But for the interior economy of a kennel, Mr. Smith's plan may well serve as a model, those who use it of course making such modifications as their wants and means will suggest. As the book has for some years now been out of print, and copies, as we happen to know, not very easy to get, we make bold to lay this plan before them. 


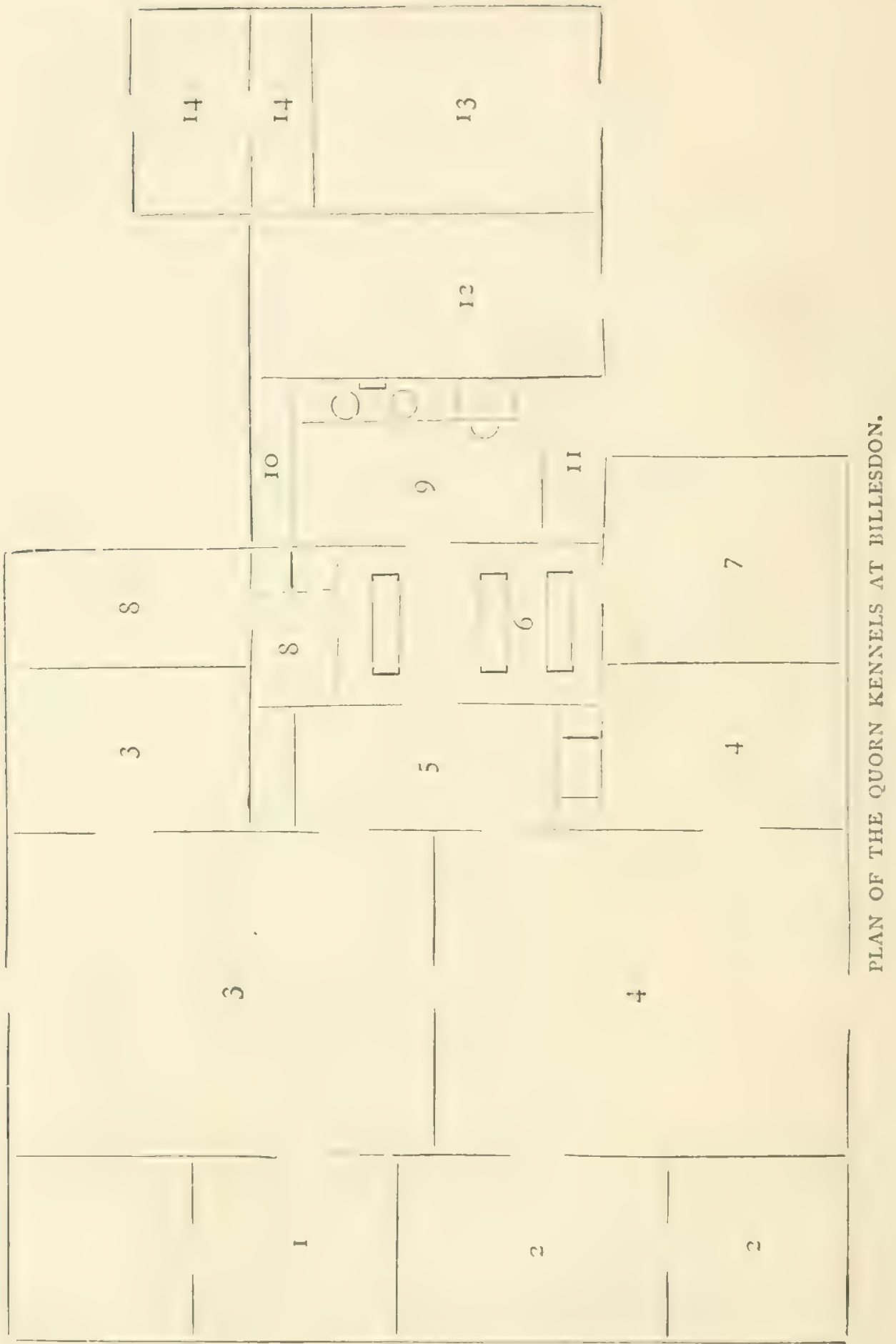

Grass court, enclosed. 


\section{Explanations.}

1. Young hounds' lodging room, if feet by 20 feet; yaved court, is fect by 20 feet; also a door opening into an inclosed grass yard.

2. Hunting pack lodging room, 16 feet by 20 feet; paved court, 18 feet by 26 feet. 34 feet.

3. Principal lodging room, 16 feet by 20 feet; paved court, 30 feet by

4. Principal lodging room, 16 feet by 20 feet; paved court, 30 feet by 34 feet.

5. Covered court before feeding, 14 feet by 20 feet; at one end a cistern to supply the kennel with water; at the other, a flight of stairs to the feeder's sleeping room above.

6. Feeding room, 16 feet by 19 feet.

7. Straw court after feeding, 22 feet by 24 feet.

8. Hospital for sick hounds, to be near so as to be fed often; three lodging rooms-two, 6 feet by 6 feet; the other, 12 feet by 12 feet-and court, 20 feet by 12 feet.

9. Boiling house, 15 feet by 20 feet.

10. Cooler, 3 feet wide.

I1. Coals, 6 feet by 10 feet.

12. Store roum for meal, 15 feet by 27 feet.

13. Straw house, 15 feet by 21 feet.

14. Bitch house, 6 feet by 15 feet ; court, 9 feet by 15 feet.

To this plan MIr. Smith adds the following remarks, which are well worth reprintıng:

All the doors, except those on the outside of the kennel, are in two parts, which open separately, which gives the opportunity of first looking at the hounds, and of seeing that no hound is injured on the feet by the door when opened against it. And the feeder can see better which hounds require to be fed first, on opening the top door.

The granary for oatmeal is placed for convenience, and to be dry, being at the back of the chimney to the boiling house.

The straw court, after feeding, is so placed, in order that the feeder may turn out every hound separately, if desirable, until the whole have been fed (this door should be in two, to enable him to look them over, and see if any want to be fed again), where they remain till he has time to walk them into the adjoining field. This is a most desirable acquisition to every kennel, as it keeps the field cleaner: and the droppings from the hounds make the straw 
indathic to farmers, which is talien from the lodging rooms, and is otherwise uncless. It is these considerations which male a famer think it worth his while to supply straw for the manure.

It is also desirable that the hospital for sick hounds should be near the fecling room, or they are not attended to as they should be, but be liept out of sight. Here the man has only to open the top part of the door, and look in, and if a hound is in want he has him in at once. This lodging room is divided into three parts in case of any doubtful hound, by putting which aside in time, the whole pack may often be saved from illness, or, a worse evil still, from madness.

The door out of the young hounds' kennel into the grass yard is intended to be open all day long, as it is most desirable that they should have room to exercise themselves, when first brought home from their walks, before they are under command, while by constantly taking them to be fed they soon come to. The time they are brought home is generally during the season when the men have not time to talie them out, even if under command, which makes it so necessury for them to have a grass plot, inclosed, to run over: and often prevents distemper going through the whole lot, as is often the case when they are confined close torrether.

There are pipes to convey water to every kennel, with a tap in each.

Artificial heat of any sort is to be entirely condemned. The system of warming kennels by hot-water pipes is wholly mischievous and wrong. Plenty of straw or fern should be spread on the benches, and the warmth of the hounds' bodies as they lie huddled together close to each other will give out sufficient heat. At no time should the top half of the kennel door be quite closed.

It will be found very useful to have the benches made with hinges, as beckford advises, and hooks in the wall, that they may be folded up while cleaning is going on. The necessity for the most scrupulous cleamess in every part cannot be too often or too strongly insisted on. 'This cannot be really preserved without two lodging rooms. It is bad for the hounds to stand shivering outside in the cold, while their one room is being swept and washed; and worse still for them to be kept in the room which is being washed. 


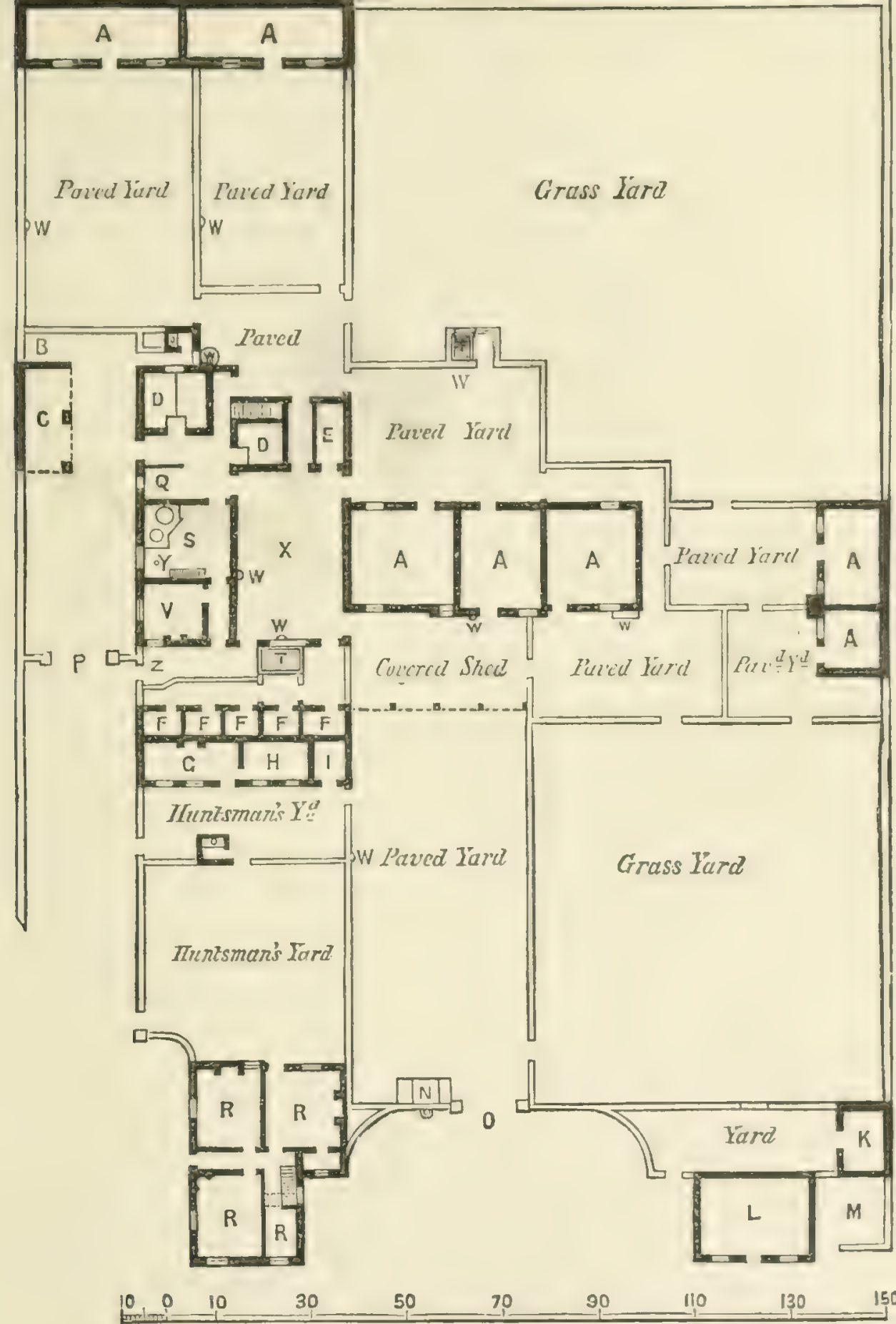

PLAN OF KENNELS, BADMINTON.

A. Iodging Houses. B. Bones Store, C. Larder. D. Meal Houses. E. Store Closet.

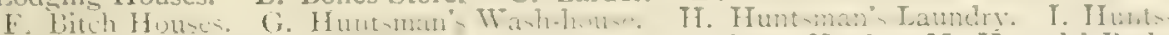
man's Cellar. K. Spare House. L. Stable. M. Dung Yard. N. Hounds' Bath.

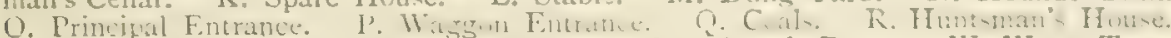
S. Boiling House, T. Water Cisterns, V. Kennelmen's Room. IV. Water Taps. X. Feeding House, Y. Pump. Z. General Entrance. 
The annexed plan of the Badminton kennels will show the residence of a five-days-a-week pack. There is probably nothing in this which, by the aid of its reference, will not be readily understood. 'T'he hounds' bath is, it will be seen, placed at the entrance to the kennels. It slopes down one side and up the other, and through this every hound is driven when he comes home from hunting, or from taking his walks in the park, which he does two or three times daily. Some authorities have filled their baths full of pot liquor instead of water, and Long, who formerly hunted the Badminton hounds, used to set one of his men to splash pot liquor over the hounds as they ran through, the object being to make the animals lick each other, for the heal. ing properties of the tongue are considerable, and slight wounds caused during the day's work are thus benefited. Without this, nowever, hounds will always lick as they lie on their benches, the food which they sprinkle over their bodies while at the troughs helping to induce the habit.

We may also here give a sketch plan and explanation of one of these converted kennels which Beckford seems to condemn altogether, and which, in his time, no doubt deserved to be condemned. Had he seen the one here described he would have written differently. The work was dene cheaply, without plans or specifications, by local men.

The original building was a long potato house, a granary, and a wall, besides a yard. The building was tiled, but the tiles were removed and the roof thatched, thatch being warm in winter and cool in summer; the floor was levelled with rough stones, broken brickbats, \&c., the whole concreted and made smooth on the surface, with a good slope from back of lodging room right through to outside fence of yard; a surface grip in concrete along outside fence of yard running through all the yards to a drain outside the yard at end, then conveyed through glazed pipes to the river. The height of fence outside and round the yards is about 8 feet, 6 feet closely boarded, 2 feet paled, and the same round grass yards. The alley outside 4 feet broad with an outside railing 4 feet 6 inches high. The alley is very useful as hounds can be taken from top yard to fecding room without groing through the other yard, especially for 
YU: KINNHI.

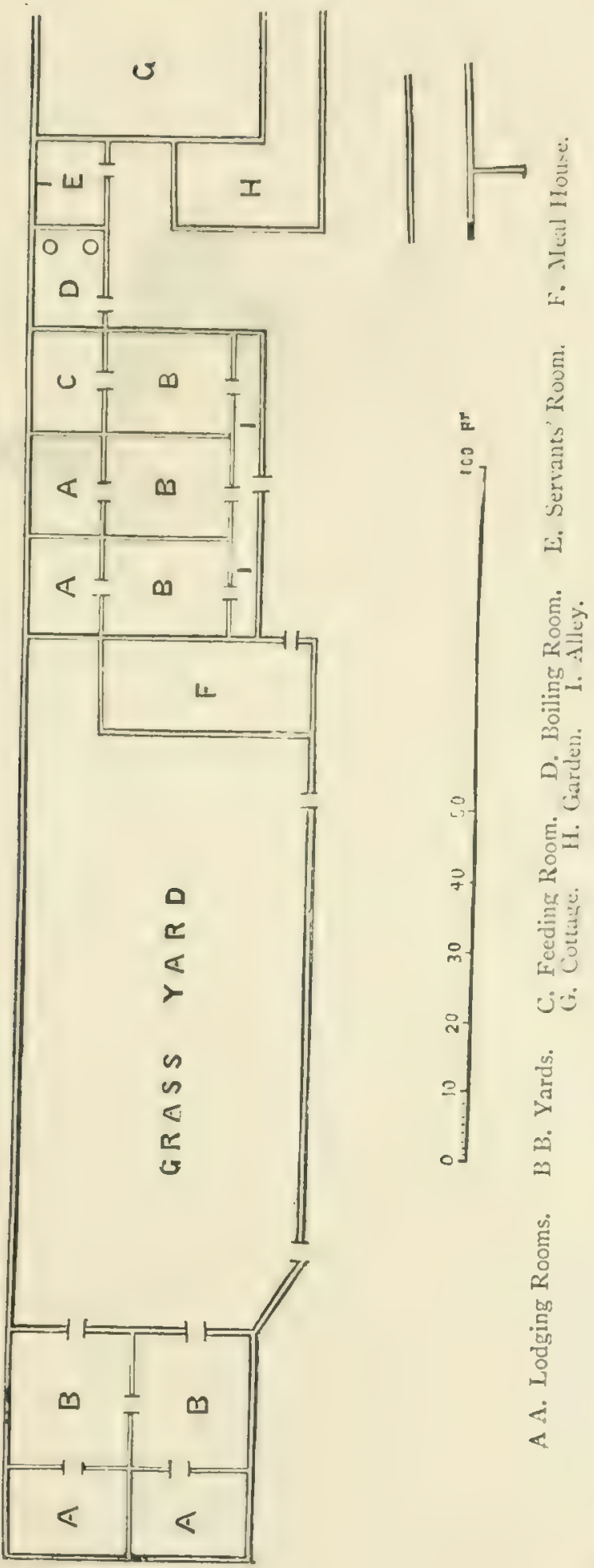


young hounds if they bolt out of yard they are stopped by alley fence. The beds for hounds are made of deal, two in each lodging house, $7 \frac{1}{2}$ feet long by 5 feet wide, made to fit with length of kennel. They work on hinges, so that they can be chained up to back wall when cleaning out. The floor of lodging room is a wooden latticed flooring of deal to prevent hounds lying on damp or cold floor, a fruitful source of rheumatism. Two coppers, one for flesh and one for meal pudding, are shown in plan, tosether with coolers, feeding troughs, Sc. There is a loophole at the end of whole range of building so as to let a top current of air right through. The top kennels are quite new and a little larger. The grass yard is half gravel and half grass. At the top of the old wall on the north side a paling to heighten it has been erected. The kennels face South, top kennels about South-East by East. The young hounds are generally kept in the top new kennels; the old ones in the lower, dogs and bitches being divided. The granary floor and walls half-way up were boarcled to keep the meal from getting damp-doorways are 2 feet 10 inches wide all through. The cottage at end was there when the kennels were made, and now kennelman and two whips live in it. The water supply is from a cistern which is filled by horse-power from the river and laid on into all piaces. In each yard is a trough of cast iron raised on two or three bricks. The other part of the original ofthand farm consisted of a barn, a long shed and outbuildings now converted into the following: Two small kennels, one for sick hounds, one for bitches which it may be desirable to separate from the pack, and coal house. The barn was converted into a capital stable with a floor made of cement as in kennels, but ribbed for water ro run off into surface drains. A lons row of buildings of the same height as kennels were made into a forge, a place to shoc horses, a lhay and straw room, a corn room, a sleeping and mess room for stable helpers, a harness room, a washing room with coppers for hot water. As to the cost, both included :

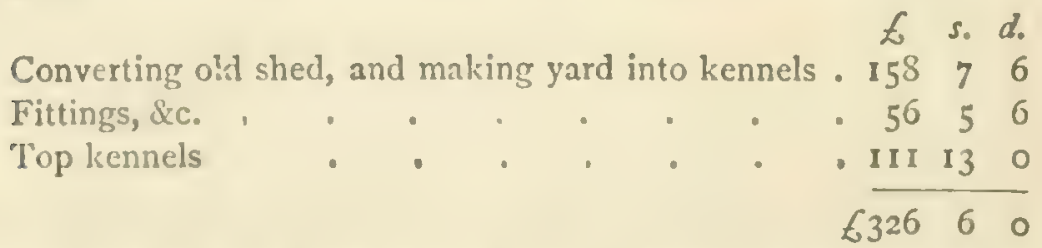

The stables \&.c \&. cost about 7ool. Two nice houses for hunts. men and stud groom cost about $600 /$. the pair. It is necessary to have a meat house for dead horses well ventilated. A new one was 
put up just outside the range of buildings at a small rect. Every. thing in these cases naturally depends upon the convenience to he utilised, but the above will at least convey an idea. 'The only' fault of the arrangement is the meal house, F, being so far from the bniling house, D.'

The kennels having been so far considered, we turn to the question of their occupants. A hound's life, for working jurposes, is short. He berins to hunt as a puppy of some eighteen months; if all goes well with him he is perhays in the plenitude of his power at the age of four, that is, in his third season; he may last two or three seasons longer. Hounds have been known to run at the head of the pack even in their seventh season; the judgment of their breeders in such a case is amply proved. After their fourth or fifth season hounds usually begin to fail. They do not tire, if of a good sort, but the pace bothers then ; they are not so forward as of yore, though they still keep with the pack and trot home with their sterns up. Every pack must, therefore, be recruited annually; in proportion, as nearly as circumstances admit, to the strength of the establishment. About six and a half couples are sufficient for one pack, but ten or twelve couples should be put forward and drafted down to six and a half of the best after cub hunting. How then should hounds be bred so as to maintain the needful supply of puppies from which to replenish the pack?

The breeding of hounds, perhaps even more than the breeding of horses, is a lottery. This is partly so because more varied qualities are necessary in a hound than in a horse. The latter-we are now speaking of thorough-bred horses, to which in this consideration hounds can only be comparedfulfils the chief object of his being if he can gallop and is sound; but the hound must possess nose, stoutness, specd, courage, and a number of valuable qualities which may be briefly summed up under the head of intelligence. If a hound

1 We are indebted for this information to the courtesy of Mr. Archibn'd Ruggles-Brise, lately master of the East Essex hounds, the establishment here described. With the one single exception noted, nothing could be more serviceable and convenient than these kennels and stables, and very cheap. 
be handsome so much the better, of course; but the best hound is the one that works best, nut the handsomest. 'There is somcthing particularly pleasing to the eye in the sight of a level, symmetrical pack. To breed a pack of hounds, perfect alike in appearance and in work, is, however, the labour of a lifetime. Nose and stoutness are the two things which the breeder of hounds should first of all seek to obtain, and experience shows that no two attributes are more distinctly hereditary. The beginner, therefore, especially in a small kennel, should disregard all ideas of pleasing his eyes and breed exclusively from the best nosed and stoutest hounds of both sexes, irrespective of size and appearance.

The generative powers of the dog are retained in their full strength longer than those of the bitch. A promising log may begin his duties as a sire in his first season, he is usually at his best in his third. The bitch cannot be hopefully trusted to produce a serviceable progeny after she is six years old. That the parents should be in perfect health is before all things essential. If the bitch suffers from any ailment during the period of her pregnancy her produce is likely to be affected. The state of the weather when the whelps are born and during the first three or four months of their lives has an immense influence on their future stoutness, usefulness, and soundness. Under the most favourable conditions the litter will consist of seren or eightnearly twice as many have been known, but this is a misfortune. A young bitch will bring up about four puppies comfortably to herself and with benefit to them. If she is three or four years old she may bring up five, but much depends upon whether she is a good milker and a good mother. How the breeder is to nake his choice which to leare with her and which to take is a matter that must be left to his discretion, but if the puppies are from specially good parents on both sides it is desirable to get a sheep dog or spaniel wet-nurse to bring up three or four of the puppies beyond those which the mother is capable of suckling.

Masters usually have prejudices about colour, preferring generally dark hounds to ught. 'The mother's prejudices are 
not safe guides, as she may derote herelt elicily a the

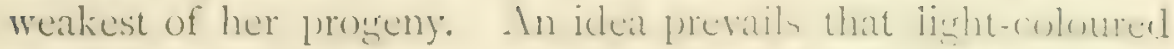
hounds halve weak ronstitutions, and some suppene then to lxe worse tempered than their darker hrethren : but this is a batec less theory, for some of the stoutest and best hounds cher secon have been light-colourel. 'The pentes of a whelp (an, hewerer, be but fantly discernud if they can be percived att all, so that on the whole colour must be the guide.

The mother should suckle her whely for six or scrent wecks according as her milk latsts. When weaned their fourl should

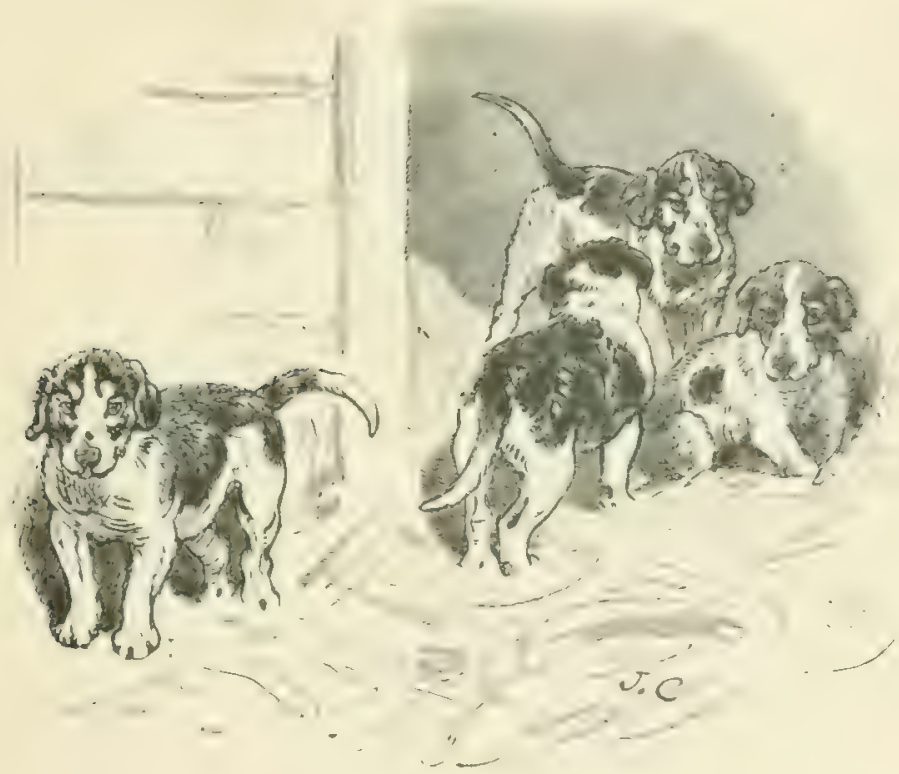

Puppies.

be the best oatmeal (neither barley nor wheat should erer be griven to hounds), and dog biscuit, mised in cows or gronts milk, with just enough soup-horsellesh soup-to make it warm. 'This should be griven them twice a day, and in addition, for the first few days after they ceise to suckle. abunt half a pound of parboiled horsefesh (hopped up inte mince. When wo months old this meat may be siven them raw. It is desirable that the puppies should be born in liebruary. The 
young things thrive in the carly spring as they do at no other unc of ycar, and experience shows that puppies so born grow into the best hounds.

When the mother is about to whelp, she is taken at Badmin. Ion to the bitch and puppy houses, of which drawings are given. The kennel at the back of each little run closes with a door divided into two parts, over the bottom half of which the mother can easily pass to and from her puppies. Gates, as will be scen in the eleration, shut in each run, so that the little creatures cannot stray, and the roof comes right over so as to afford shelter. The divisions between the half-dozen little yards are movable, and thus the puppies can have a fair-sized run if the divisions are taken away. The mother, it will be observed, can be shut in if necessary, ventilation being provided over every door. That a good bed and an abundant supply of food must be given to the mother is too obvious to need explanation.

About May, when three or four months old-the period must be judged by the growth and condition of the animalspuppies are ready to be sent to their walks, where they remain to be tended at the discretion of their temporary masters till the following spring. Those that find quarters at a dairy farm are well placed, but during this year of their lives the puppies are usually well cared for. Often, indeed, they return to their kennels as fat as pigs going to market, and this is bad; a few are perhaps on the other hand thin and poor, owing to the innorance or carelessness of those with whom they have been living, and such puppies are generally very shy and wild.

Their childhood is now over, and the serious business of life berins. They must be brought by degrees to be as other hounds are; lut as diffurent puppies have been differently treated during the past year at their various homes, some are much longer than others before they accept the food and discipline of the kennel. I'uppies often take to kennel food at once, others are some days, orcasionally some weeks, before they eat with relish. The food supplice to them is much the same as that 


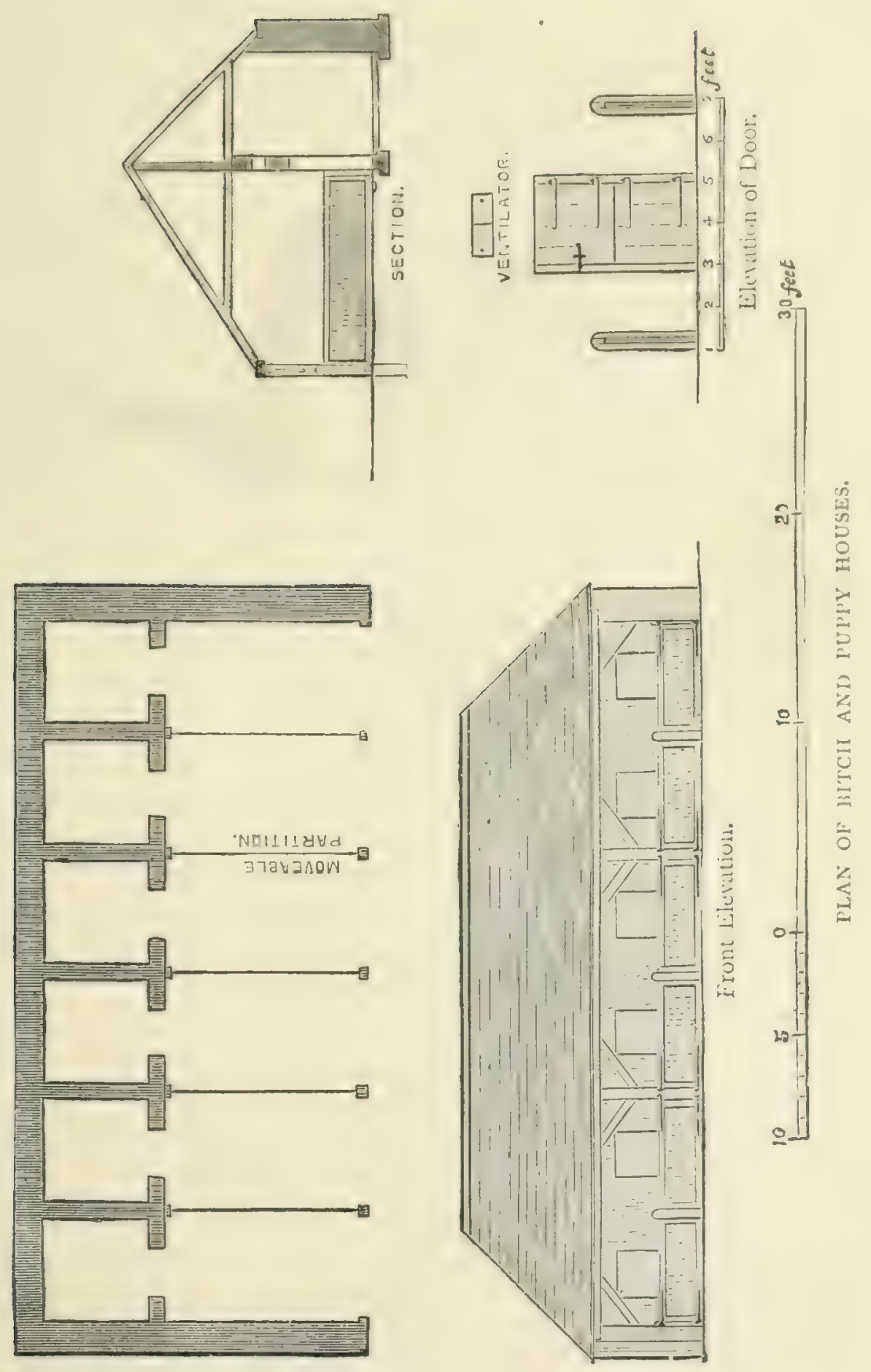


which they had when they were first weanerl. P'uttung milk on the top of the food in the trough will often induce those who do not take kindly to their new table of dictary to lap, it up.

They are to be fud twice a day at first, once a day afterwards when they display good appetite, the delicate feeders being drawn in for a few mouthfuls a second time. It is very neces-

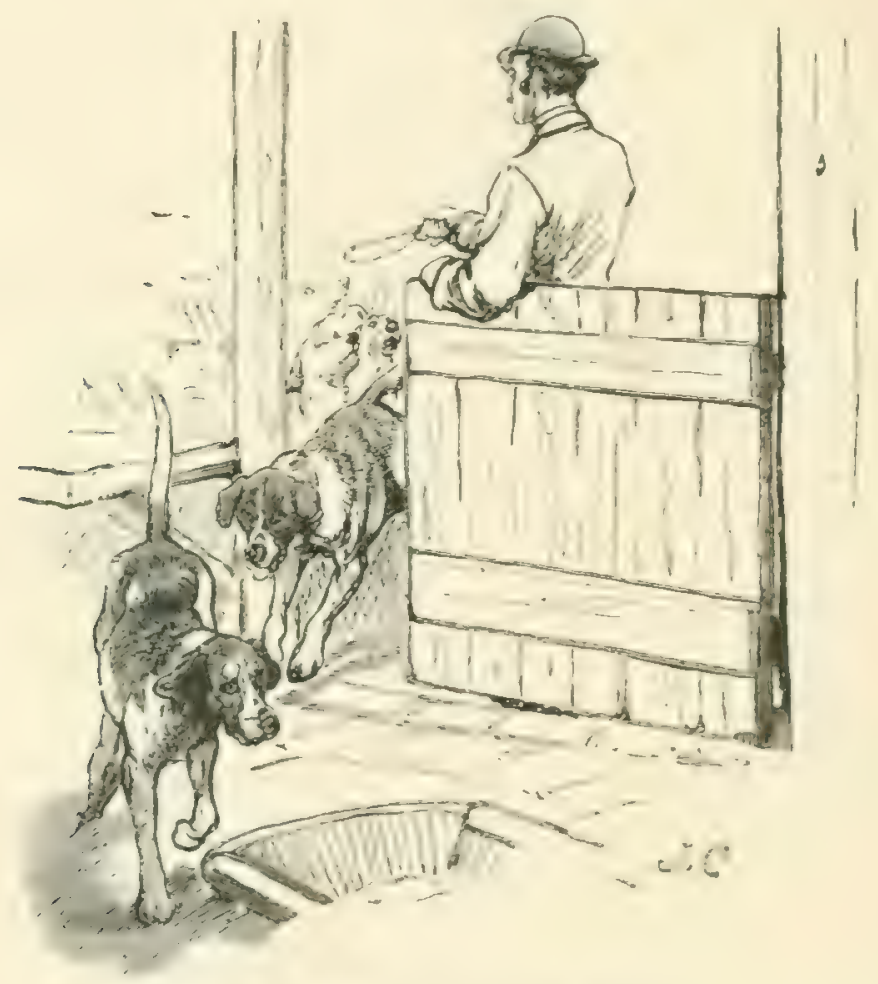

Bringing Hounds into Feeding Room.

sary to comsider these delicate feeders, which are to be found in all establishments. Even when they have bezun to work they will digest their food better, and conseptuently be better, if they are fed twice a day. Coarse oatmeal some twetre months old is the only proper grain for hounds.

One sreat reason for keeping the pupplies temperate in the matter of diet and for giving them due exere ine on their 
return to the kenncl, is that distemper, the curse of all kennels, is likcly soon to attack them. It is far better that they should have it now than some months hence. In all probability if they escape for the time being, the disease will take them in the following February when they are in good work, and then they have it, as a rule, much more severely. If they do not die the master loses their work for the rest of the season, and they are thrown back, so that it is more convenient to get it over. The severity and even the nature of distemper varies so much fiom year to year, that it is impossible to suggest any specific cure. One year it attacks the lungs, and is then very fatal, particularly if the yellows (jaundice) is a symptom. Another year it goes to the head, when blindness, violent bleedings at the nose, discharge of matter, and other troubles ensue. Often the hound looks as if he were dead, being utterly unable to stand. Distemper occasionally affects the limbs with fearful twitchings, from which in some cases the hounds never recover, that is to say, these symptoms never wholly disappear. Hounds thus affected have scemed so well in other respects that a few years ago in the Badminton kennels it was determined to see whether they would stand a day's work, and it was found that some of those which never lost this result of the disease could run up with the best and stand the longest and hardest days. Distemper appears to be especially fatal to the fincst, strongest, and best young hounds. Sucking puppies if attacked are hardly ever known to survive. The master is powerless to avert the disease. Many people vaccinate their hounds as a preventative, but though few sane men doubt the efficacy of vaccination as a safeguard against small-pox, it can have no effect against distemper in a hound, a disease of a totally different character. Mr. F. Gillard, huntsman to the Duke of Rutland at Belvoir, has compounded a medicine which is perhaps as good as any that can be used, but it will be found much more efficacious in some seasons than in others on account of the various methods in which hounds are affected in different years. Much also depends on the weather, a lung spell of 
biter catnt wind in March or April is tre be dreaded by the master whose hounds are down with distemper.

Life in the kinnels may be best describud by a brief account of a day s pocedines during the hunting scason. l)eviralsle as it is to cexcrise the pupplies when they rome in, it is almost impossible when the hunting is groing on, except perhaps in a two-days-a-week country; but if the kimnel staff is stroner enuugh, one man can lead out for an hour or more three

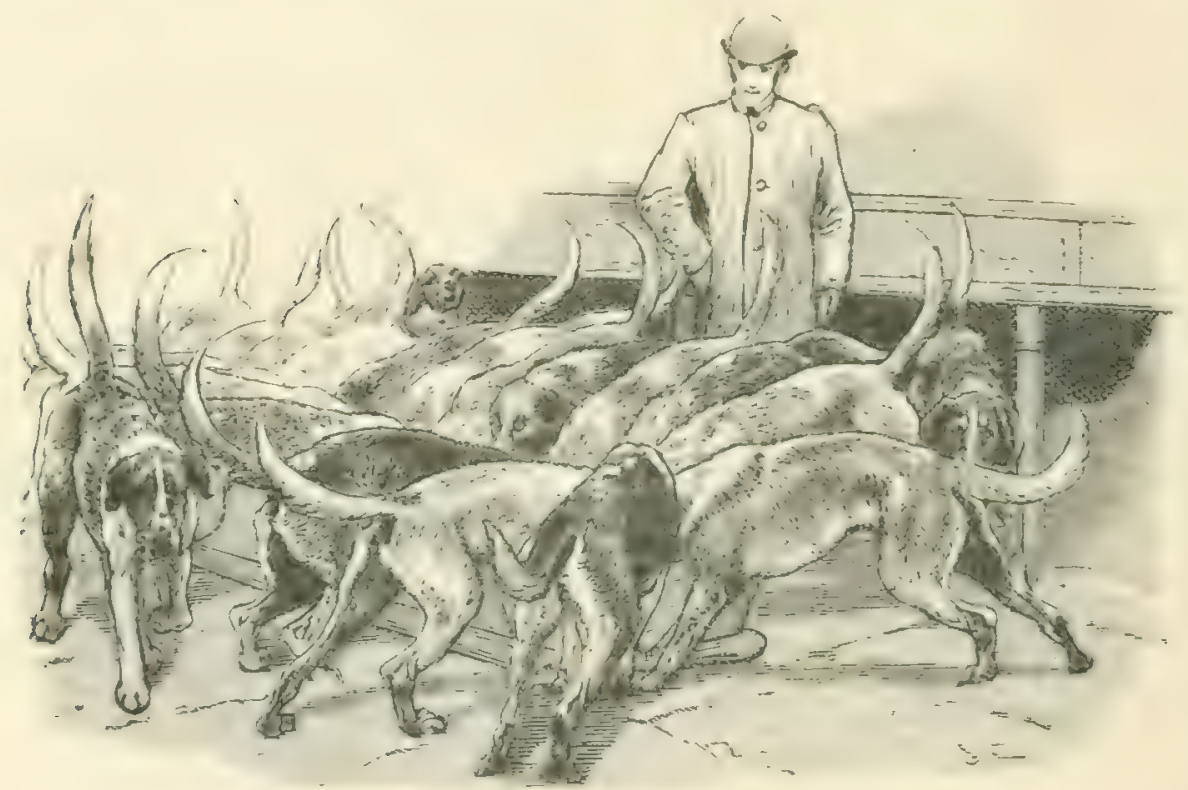

Hounds feeding.

couples at the tinne. with three conds or straps, ore to each couple.

'The hounds' day passes as follows :

As soon as it is light, in winter and summer, the kennel huntsman opens the liennel dours and takes his chatress out for a walk for a quarter of an hour or so, and in their absence the room is clumed and fresh bedding supplied. 'The tromghs have meantine lecen libled: and if it is the hunting

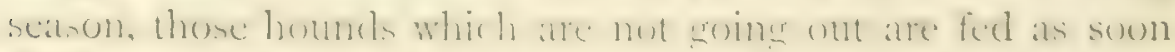

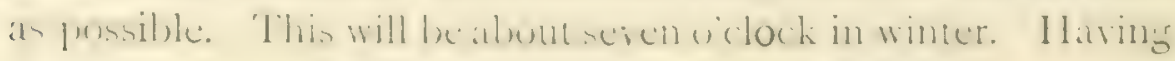


eaten their dialy meal, they are asain tumed out, and then left to themselves till about ten o'denk, when they hate and der run, and again about four, at which time a few delicate feclers, if there be any in the pack, as is alnost invariably the catice, are allowed a little more food. The pack which is going to hunt is of course not fed till it comes home. Then after rumning through the bath three or four times, as described, they are called to the troughs. The huntsman will of course look cure-

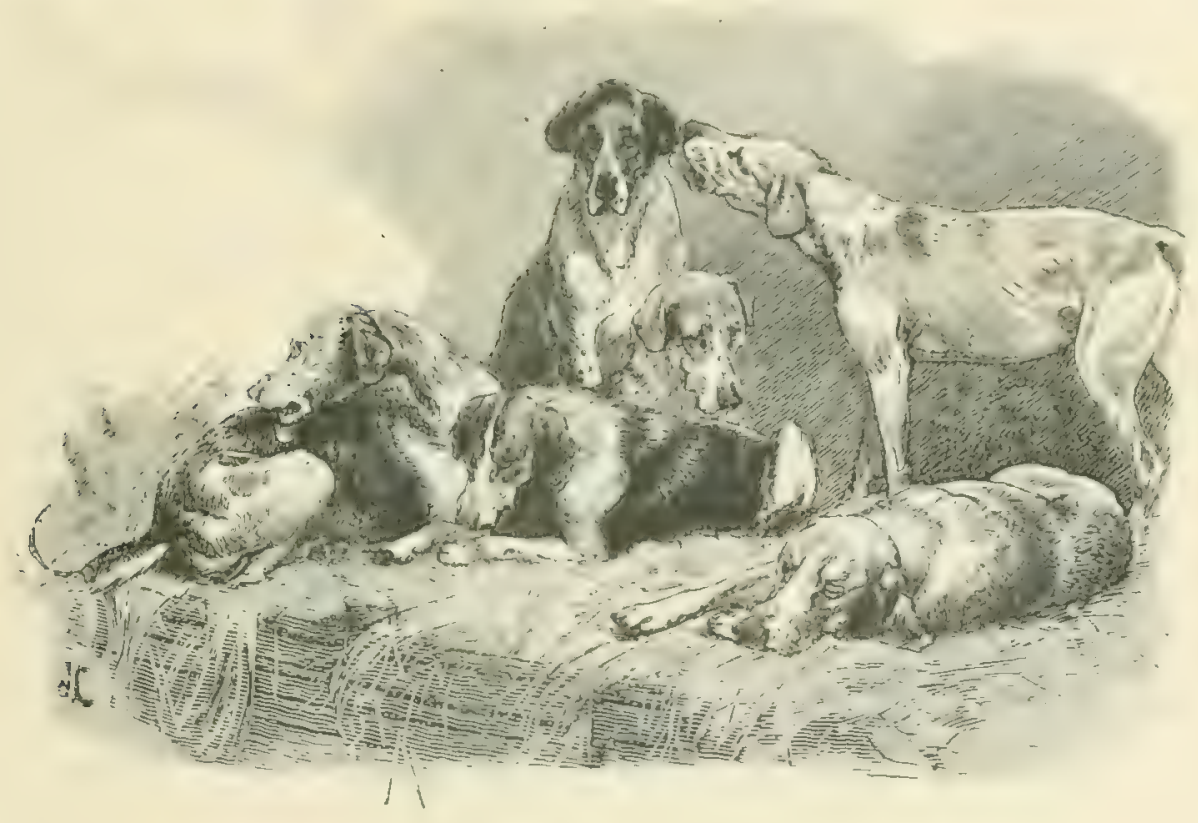

Hounds after having been fed.

fully to note any signs of lameness or injury. Thorns in the hounds' legs and feet are naturally frequent, scratches and tears are also common, and these are treated, when the thoms have been extricated, with a little tincture of myrrh, which may also usefully be applied to hot bruised feet.

In the summer-time hounds should be taken out four times a day, and permitted to play and lic about moler the trees. They will scratch intes the wround for jig nuts, and eat not only grass but earth. The huntsman should put on a pair of 
rough horshar ghom, whin which to rub their backs as they (c) nuar him, a joxceding which is obriously pleasant to the hounds. In summer they will need a litte water, which they (1) not want in winter, exrept indecel wilen they are hot after bunting, and then they must nut have it ; the moisture of their food suffices.

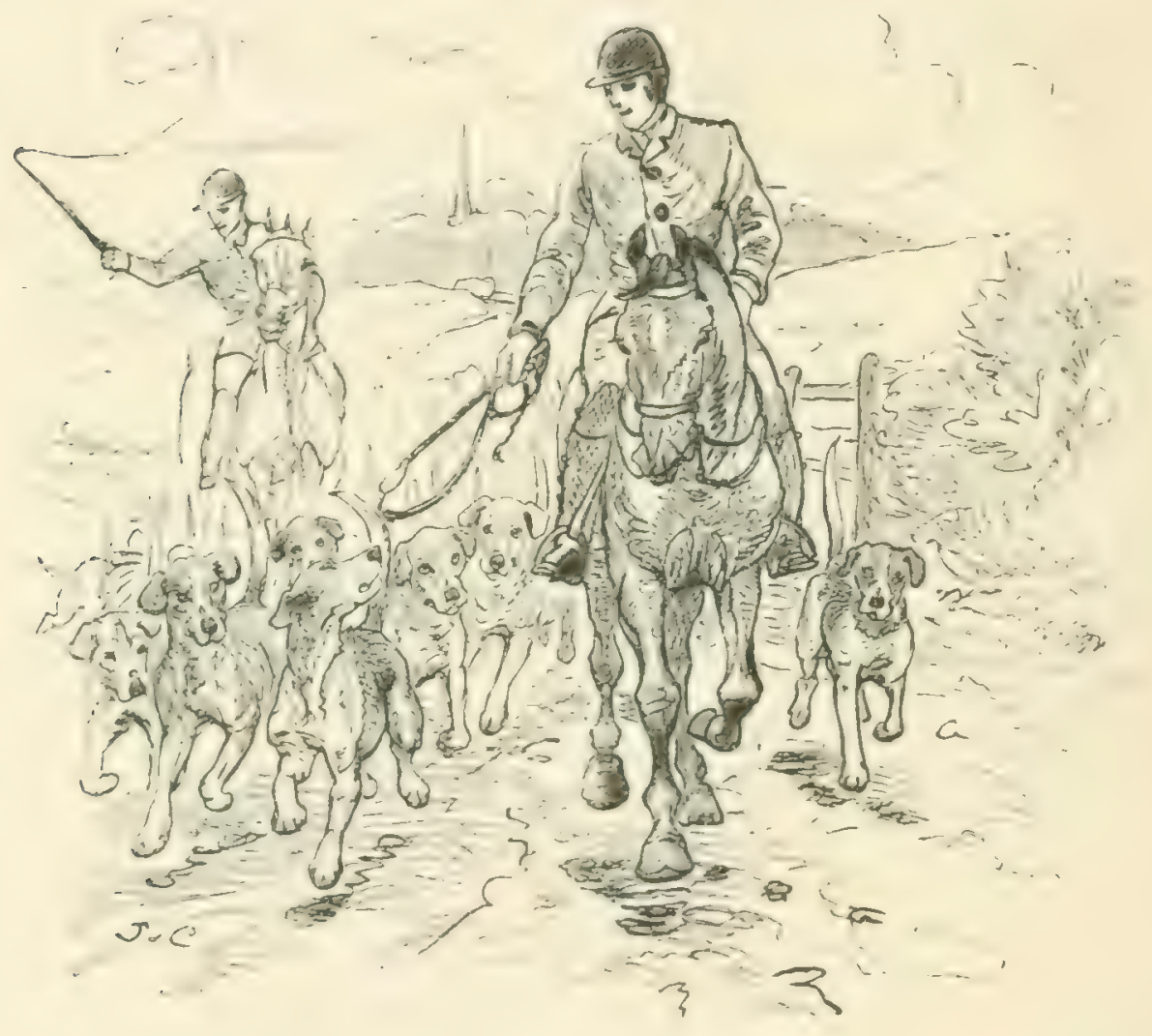

Exercising Hounds on the Road.

As the hunting season ajproache hounds, like horses, must He renditioned. The huntsman anel whipes now mosmt and trot the packs about, six or cight miles at first, and longer distances as they become more fit to were. A groud deal of the werl: womlel be done on the roals, forthe purpese of hardening the hounds' feet. 
Of late years one or two liasters have abondoned the custom of rounding the puppies' ears. Must of the operations which are performed on animals are ecpually stupid and cruct. There was a time when even a hunter's ears were cropped, thus giving the flies and gnats special facilities for tormenting him. But rounding puppies is desirable, for the reason that their long drooping ears would be continually torn and wounded by thorns and briars in the thick undergrowth, into which the foxhound has to force his way, as well as in the hedges, through which he must also scramble. Many huntsmen are of opinion that rounding has a good effect in certain cases of distemper, though Beckford lays it down that 'dogs must not be rounded all the time they have the distemper upon them; the loss of blood would weaken them too much.'

At Badminton the young hounds are taken out in their couples among the deer in the park, and soon learn to take no notice of them. Obedience is before all things necessary in the kennel, and it is not only possible, but in the highest degree desirable, to secure this by the voice. The whip should be rather a symbol of authority than a weapon of punishment.

Of the perfect hound it is not easy to better Somerville's description :

See there, with countenance blythe, And with a courtly grin, the fawning hound Salutes them cow'ring; his wide op'ning nose Upwards he curls, and his large sloe-black eyes Melt in soft blandishments and humble joy: His glossy skin, or yellow pied, or blue, In lights or shades, by Nature's pencil drawn, Reflects the various tints: his ears and legs Fleckt here and there in gay enamel'd pride, Rival the speckled pard; his rush-grown tail O'er his broad back, bends in an ample arch, On shoulders clean upright and firm he stands: His round cat feet, straight hams, and widespread thighs And his low drooping chest, confess his speed, His strength, his wind, or on the steepy hill 
Or far extended plain; on every part

So well proportioned, that the nicer skill

Of I'hidias himself can't blame thy chorce.

Of such compose thy pack.

The poet's demand, that he shall stand 'upright and form' is wise. Ite must he straight on his legs; "the widespread thighs imply a powcrtul back and loins, that, in fact, the hound

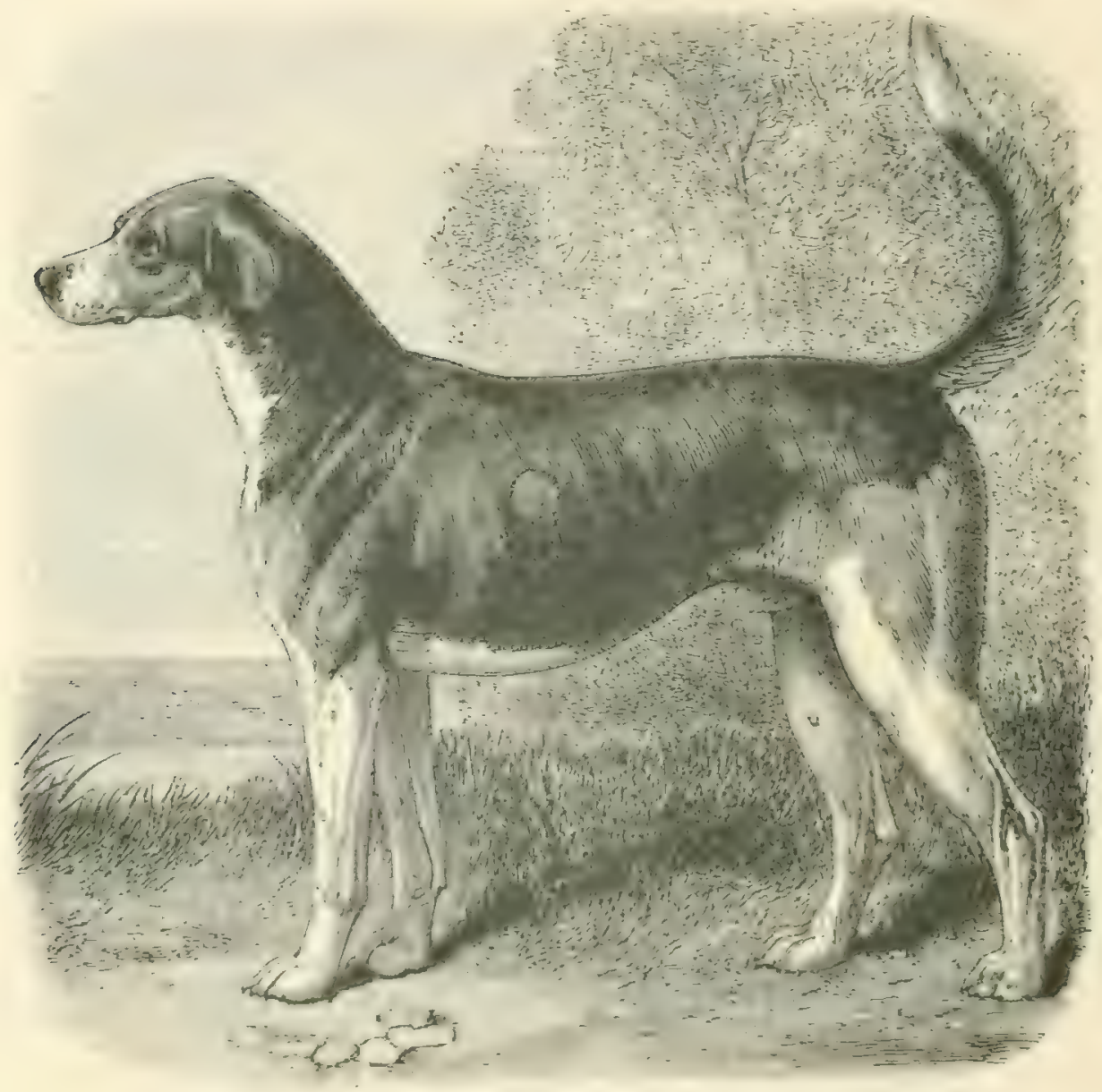

A good hound (from a picture in the possession of His Grace the Duke of Beaufort, K.G.)

in 'egene? to follew.' 'The shouklers, besicks being 'clean,' must

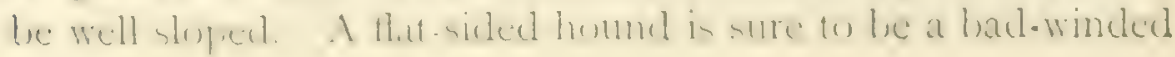


one. Speed and strength alike call for great length from hip to hock, and as little as posible from hork to foot. Is for the siec of the hound's head, that is the best size which is oftenest well to the fore on the line of the fox.

The animal chosen as an cxample of what a hound should be is the Badminton Potentate, a dog which, born in is 8 o, did notable service in the hunting field for cleven seasons, and has transmitted his wn sterling qualities to successive generations. He is one which the man in search of a hound

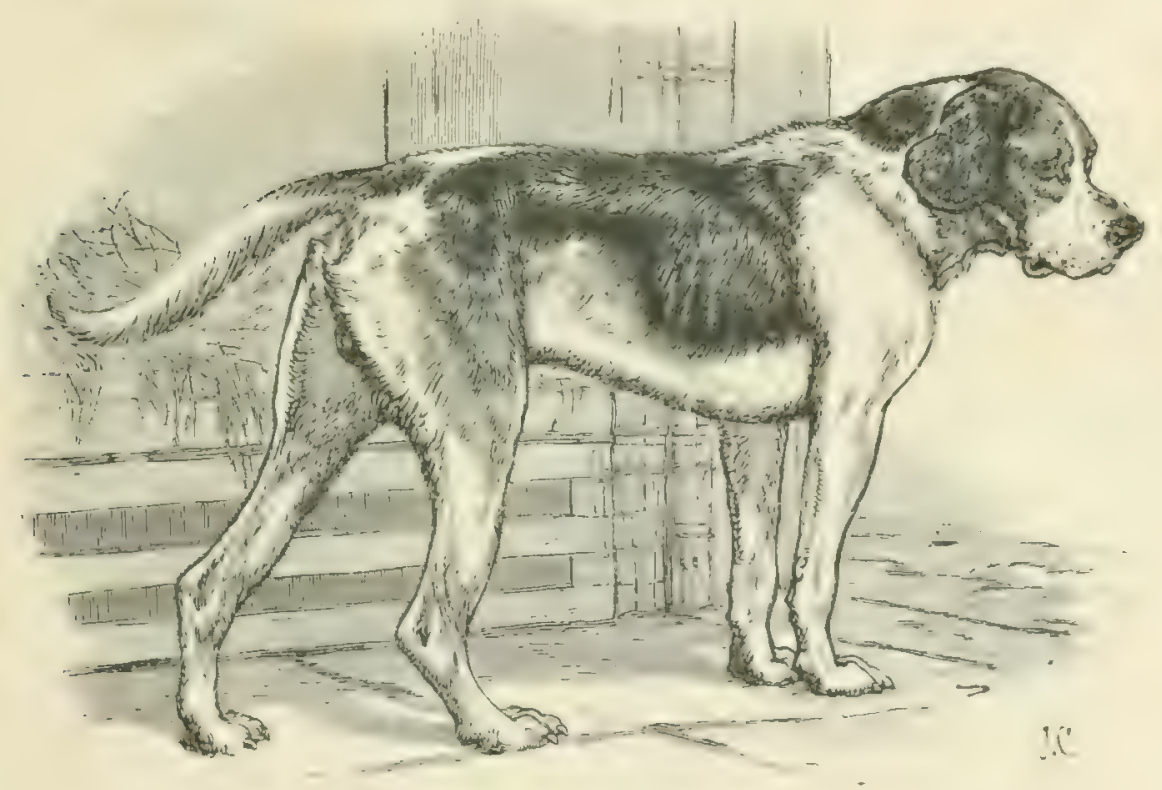

A bad hound.

will do well to carry in his eye. He died in $185 \mathrm{I}$. As a contrast to him the picture of a bad hound is giren, his defects being purposely emphasised in order that they may at once strike the observer. Such a nightimare of a hound is not to be discovered in any hunting field, but by a course of injudicious breeding he might conceivably be produced. From head to stern he is all that a hound should not be. His shapeless head is joined by a thick neck to a shockingly clumsy pair of shoulelers, which hase no liberty of action about them. Iis 
less are weak and crooked; he has the reverse of those 'round cat feet' which Somerville properly desires. He is flat-sided and slack in the loins; his stern is hadly put on in the wrong place, and there is a total lack of muscle in his lean and longdrawn thighs.

The expenses of a pack of hounds naturally depend upon the number of days per week that the master hunts, and the number of hounds that it is therefore necessary to keep. In the Bachininton kennels there are, as a rule, about 75 couples, and this provides $\mathrm{I} S \frac{1}{2}$ or 20 couples five days a week. For a pack which hunts four days a week, 52 couples will suffice. The two-days-a-week man will be well found with $2 S$ couples, or, if he does not breed, 23 couples will be enough.

The annual consumption of 75 couples includes about 40 tons of oatmeal, 3 tons of dog biscuit, and 50 horses. Great care should be taken in selecting the meal. It should be bought before the new oats are harvested. Once placed in the meal room, it must not be moved or it will ferment. If it be possible to obtain damaged nary biscuits nothing is better. Some makers are grossly careless, and their manufacture has a deleterious effect on the hounds. A two-days-a-week pack will consume about $\mathrm{r}_{3}$ tons of oatmeal, I ton of dog biscuits, and 50 horses. Prices vary. Oatmeal ranges from $10 l$. to $18 \%$. per ton; biscuit is about $13 l$. per ton, and horses may generally be had from Il. to 5 s. and less. They are difficult to get about harvest time, and the supply seems scanty near the large towns when sausages are in season!

The servants immediately connected with the kennels include the kennel huntsman, a feeder, who unites the office of butcher and cook, and a couple of lads. Of the duties of hunt servants, however, we shall proceed to speak in the next chapter. 


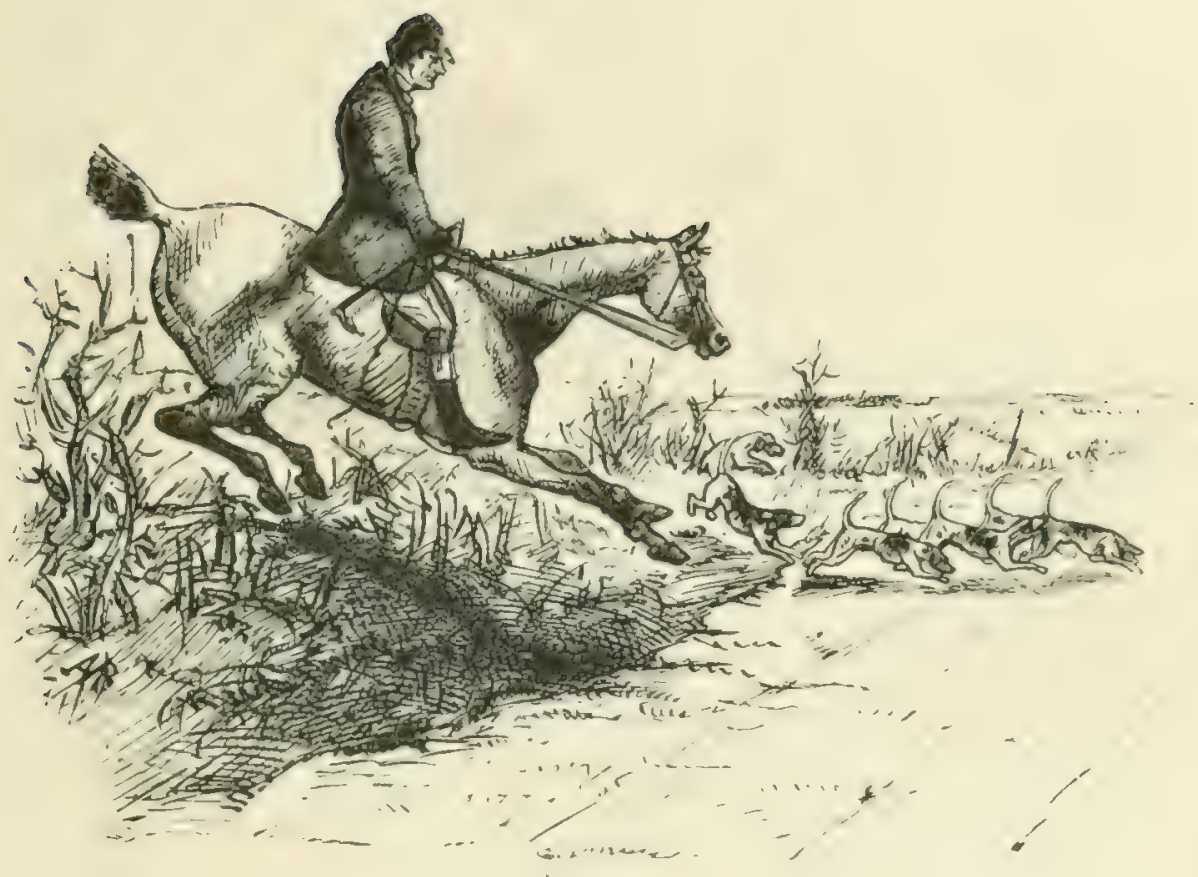

\section{CHAP'TER V.}

HUNT SERVANTS.

THE DUTIES OF A HUNTSMAN IN THE FIELD.

THis is a subject most difficult to treat on paper. 'The natural answer that would be given to an inquirer, by anyone of long experience in the hunting field, would be, "If you would learn the business of a huntsman go and hunt with one of good repute, and exercise all your intelligence and common sense in explaining to yourself the why and the wherefore of the various things you observe him do.'

Our Library being intended for the use of beginners in various sports and pastimes, we must, howerer imperfectly, try 
to give to such a one, if he seeks it, sufficient information to enable him to commence his career as a huntsman, and leave it to his natural aptitude to perfect him after experience in the profession.

A resident in our colonies or in a foreign country, where no hounds are kept, would be naturally dependent on books for instruction, and to him, therefore, are these lines specially addressed. An aspirant to fame as huntsman resident in the United Kingdom or Ireland may be recommended to follow the advice already suggested.

The huntsman having made himself well acquainted with his hounds, and they having got to know him, sallies forth from his kennel, his object being to find a fox. Should he be drawing an open country, he should draw directly up the wind or with a good cheek wind. The pace at which he draws should be regulated by the thickness of the stuff through which hounds have to go, whether it is gorse, heather, bracken, fern, or the rushy materials and myrtle that grow on bogs. And here let me remark that there is no place in an open country where a fox is so likely to be found as a bog. Water rats, moor hens, ducks, and mice, all favourite articles of food, are there in abundance; there are generally high dry tussocks of strong rough grass, and on these he makes a warm dry bed. Often a fox is found a hundred to a hundred and fifty yards away from the bog, he having made his bed in a thick patch of short gorse within easy reach of his larder. One of the prettiest sights to a lover of hunting is to nute this up-wind or cheek-wind draw. You will observe some hounds quietly pass on, drawing and sniffing at the bushes by which a fox has passed during the night, and you will suddenly see one hound to whom a whiff has come put his nose up into the air, sniff, and going first right then left, finally make his mind up whence comes this scent. He will follow it patiently as it gets stronger and stronger, leave the bog and go a hundred or a hundred and fifty yards to a thick bed of grorse or bramble. He will go all round it, losing the scent when he gets the up-wind side 
of the thicket. Returning down wind he catches it again, and after sniffing and poking about some little time will suldenly throw his tongue loudly and dash into the lreal; ; and out will go the fox. I quote this that the aspiring huntsman may understand the necessity of giving his hounds time when drawing. I have several times $m$ my life seen this occur just as I have described it.

In an open country to draw down wind means to get a bad start with your fox, for even those that have never been hunted will be very apt to move and be off, and one that knows what hounds are is sure to take the hint very quickly. Should the country be an inclosed one and the corerts large, the same rule as to drawing up wind applies. Here the huntsman should be very particular about regulating the pace of his horse by the pace at which the hounds can travel whilst drawing for their fox. Should the covert be hollow a good brisk trot is necessary, but if it is a real fine thick covert the huntsman cannot go too slowly. It is an advantage, and makes hounds draw better, if some of them are ahead of the huntsman. I have often known a huntsman put hounds in and trot away, speaking to them all the tume. After a bit, as the huntsman's voice gets fainter and fainter the hounds stop, listen, and instead of going on drawng come out into the ride and trot up it after the huntsman; and in this way often miss a fox. In a woodland a huntsman should be rather noisy than quiet, make good use of his voice, and occasionally blow a single note on his horn. It is a judicious course, and makes hounds much livelier, if the huntsman only uses a single note when no fox is on foot, but 'doubles his horn' when a fox is found; the difference in the way hounds move to it is extraordinary. The horn may be advantageously used in case of hounds running riot (hunting a hare or any wrong game), or taking the scent heelways of a fox. A screech or, as perhaps it may be called, discord blown on the horn will stop them more quickly than the cry of 'ware heel!' The ear of a hound or dog is very sensitive, and he dislikes the discord. The screech may also be used in covert 
by the huntsman if he comes upon hounds eating carrion, or funds a litter of cuhs in a hollow tree or stool, and wants his whipper-in to as int him and chive the homnds away. It should be understood that when he is sitting still and blowing discords, the whipper-in or some of the field should go to him.

In large woodlands the humtsman should draw everything, and closely, as otherwise he may leave a fox in some unlikely corner. When the coverts are small they should be drawn down wind, to aroid the chance of chopping a tox. A few cracks of a hunting whip or a gentle touch or two on the horn should put a fox on his legs, and the down-wind side being kept clear of horse and footmen he should have a chance of going away. One of the most annoying things in hunting is the cholping of foxes. If small coverts are near together and they have to be drawn down wind, some quick-eyed servant of the hunt, or some keen and observant sportsman who can be trusted, should be sent on down wind. He must conceal himself so as not to head the fox, and yet be able to command a grood view of the country. In the event of his seeing a fox away he should gallop back and hold his cap or hat up or otherwise attract the huntsman's attention. It is no use sitting and halloaing down wind with the result of making the fox hurry himself whilst the huntsman and field do not hear the halloa.

-Now as to the huntsman's duties when the fox is afoot. Having made sufficient roise with voice and horn to get the hounds together and keep them togrether whilst in the woods, and also, I often think, to frighten the fox into seeking the open country, the huntsman should then subside and be as quiet as possilule. As to telling a man what he should do when hounds come to a check aftur ruming hard - say, twenty minutes-it is injossible; but the first thing to do, if happily no horsemen were near them when they checked, is to leave them alone and let the hounds swing and cast forward, back and round ; then the huntsman must exercise his keenest sense of observation and his natural intelligence. Of course, if there is a plough team or an old woman sitting on a stile right in front, the pro- 
babilities are that the fox has been turned, and after the hounds have tried their best and failed to recover the scent, the huntsman must try his hand, but he must always allow the hounds to have a good try first. In a strange country, and where there is nothing to indicate whether the fox has most likely turned right or left or straight back, a short cast up the wind and a longer one down the wind is not a bad mode of solving the difficulty.

There is one check that beats hounds and the bust of huntsmen, and that is when the fox not having been turned hounds check on his line. That very mysterious and little understood thing, scent, brings this about at times. It seems to float up in the air above the hounds' heads, and when the huntsman returns, after ten minutes' vain endeavour to hit off his fox, away go the hounds straight on from the very place at which they checked. Another thing that constantly baffles a huntsman is when, the fox being ten minutes before the hounds, the object that frightened and turned him has passer out of sight before the arrival of hounds and huntsmen. The great thing for a huntsman to remember is that the hounds are more likely to recover the scent than the huntsman if they only have sufficient time given them, and the longer in reason he lets them alone the better; but when once he thinks they have had sufficient time the sooner he makes his cast the better. Old Goosey, the late Duke of Rutland's celebrated huntsman, used to say, 'I take leave to say that a fox is a toddling animal, and never stops, and if you are not quick after him you will very soon lose him.' On open downs, where there is always a great draught, hounds are constantly blown off the line and want their heads just turning up the wind, and then away they go again.

A huntsinan should keep as near his hounds as he can without inconveniencing them, and never be straight behind them, otherwise he will drive them when they wish to turn and bring them to check. Whilst hounds are running the huntsman's eyes should always be well forward. If he has good quick eyes 
he will often see the fox, and will at other times see some olject that has turned his fox from the joint he is running to. A sheep or cur dog who has coursed him perhaps. Sometimes a shepherd or man with a dog, more truthful than his neighbours, will say, 'I'm sorry my dorg has run your fox up to such a joint,' but as a rule eren when you have seen the dog coursing the fox, the dog's master will swear he did not run him. Ex. perience has taught me never to ask the man, but to ask the dor. If you find him with his mouth shut, you may be satisfied he has not run him; if the dor's tongue is out and he is panting, you will know he has run the for, and then you can ask the master how far the dog did run.

It is a very extraordinary but well-known fact that in nine cases out of ten if a fox is coursed by a dogr during a run all scent ceases afterwards, even when you get your hounds to the line of the fox beyond where the dog has been. Scent is one of the things 'no fellow can understand,' and this is one of the most remarkable phenomena relating to it. Except practice and experience and what a huntsman will learn from it, I know nothing more that I can say to assist a beginner in his work. One remark I may make, and that is, that though to get to know the hounds and make them know their huntsman is is as well to feed them at first, after you have killed one fox with them it is unnecessary, as they will always leave the man who feeds for the man who hunts them. Also I strongly advise hounds being allowed to eat thesr fox when they catch him; they should not be knocked about and beaten when the fox is taken away to be cut up by the whipper-in.

Should any beginner try to get a hint from these pages, I shall be pleased if these few remarks (which for convenience, having so much personal observation to make, I am putting in the frist person sin:rular) prove of any assistance to him. 


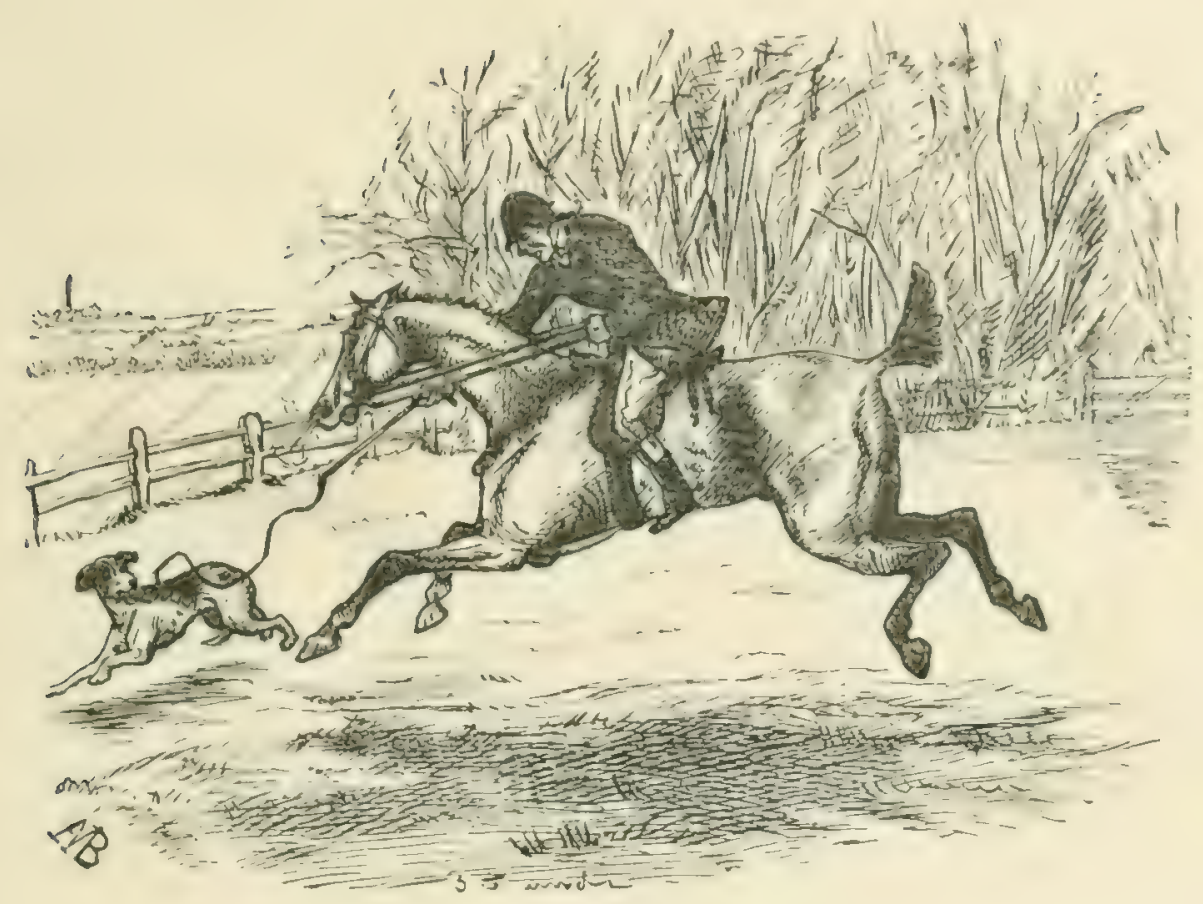

THE DUTIES OF A IVHIPPER-IN.

Various and diverse are the ideas of Masters of Hounds and Huntsmen as to these duties. The system mostly in vogue now I abominate and detest, for which I will presently give my reasons. 'That system is that when there are two whippers-in, on whichever side of the covert each may happen to be, when the fox and hounds gro away the first whipper-in is to make the best of his way to hounds whilst the second is to hang about and halloa and bring on any' left behind. If he is in time to 'tell' them and sees all are there, of course he comes on, but if he either finds that a hound or a couple or more are short, or if he has no chance of 'telling' them, he must hang about in case they should be left behind. I was brought up under old bill I.ong a man of singular intelligence, one who reasoned and turned orer carefully in his mind all things connected with hunting. He 
used tu say to me, 'Ilounds are like children, they du not like to be left behind, and if they know you will not wait for them they bustle to get after you; but if they know you will wait, they don't hurry themselves, but they will stop just inside the fence peeping at the huntsman and pack waiting, and will not come out till they see them moving off (this, of course, when there is no fox on foot); or if hounds are away with a fox will try and do a bit of hunting for themselves, in some independent way; and why? because they know that some one will come back and fetch them.' Bill Long was nineteen years a whipper-in and twenty-seven years a huntsman, and first class in both capacities. Some years later Tom Clark (who began in Devonshire and Hampshire, whipping-in to Captain Howarth who hunted his own hounds, and then was in the Shires and eventually hunted the Old Berkshire, when kept by the late James Morrell) came to me as huntsman, beginning the cub hunting in the scason I $857-1858$. He was excellent in the kennel, conditioning the hounds well, and giving them real good long summer horse exercise, and he could kill a fox in the open or in the woodlands when once found as well as any huntsman I ever saw, so that it was a pleasure to hunt with him. He was wonderfully cheery and fond of a gallop. I learnt many wrinkles from him, enjoyed many a good day's sport, and saw him kill many a good for that would have beaten a less expert huntsman than 'Sagacious Thomas.' I think he spoilt my hounds by his anxiety to get away for a gallop. He would stop them off the fox they were running, and lay them on to another that had gone away, so that they lost that excellent quality of not changing from one fox to another, which in Bill Long's day they had. After a long run if they got to a covert with fresh foxes in it they would not change, but stick to and kill their uwn fox. Clark's system of gralloping lost them that, and they have never recovered it. He was, however, inferior in intellect to, and less observant than, bill Long, would often draw over a fox, was proverbially a bad finder of foxes, and his system with the whippers-in was bad. In the first place, it was as 
regards going away that which I have above written as the prevailing system now. Further, when hounds had run five or six miles, if he found a hound away he would send his second whipper-in back--where do you think to ? Why, to the covert the fox had come from. Now, any sportsman of average intelligence who thinks of this, will, I dare say, come to the conclusion that an hour after hounds have left a covert any hounds left, if they were hunting a fox, will have rattled him out of covert and no longer be there, or if they were not hunting will have set off on the line of the pack, or trotted off home; the last place such hounds are to be found in is the covert you have quitted. To this, however, Clark used to send. I positively forbad the practice, but it was done when I was not out, and sometimes when I was; but if I saw the whip going I always stopped him. I remember on one occasion we had run from Great Wood through a very large strong covert of the V.W.H. called Webb's Wood. The ground being deep, and the pace very severe, the hounds beat us, so it was impossible 'to tell them' away from Webb's Wood through which the fox had gone very straight, and we did not discover till we had killed the fox, some five miles beyond, that three couple of hounds were away. As we were returning into our country to find another fox I saw the second whipper-in turn away. 'Where are you going ?' I asked. 'To Webb's Wood.' 'Certainly not,' I said ; 'come on with the hounds.' Clark was very cross, till I told him that I should contract with him to find the second whipper-in's horses and then perhaps he would be less fond of sending them miles round to flounder through the rides of one of the deepest, stickiest clay woods in England. I said, 'Keep touching your horn as you go.' After we had got back into our country and within a mile of the covert we were going to, some three or four miles from Webb's Wood, as we were trotting down the towing path of the canal, which was our shortest route, there on the path were the three couple of absent hounds. How they got there, why they were all together, whether they had hunted their fox to near there, lost him, or run him to ground, or whether they 
were on their way home and heard the horn and came, I know not, and never was able to make out from the country people; but there they were.

Now Bill I.ong's system I hold to be correct. Whichever whipper-in happened to be on the side the hounds broke away had to gro with the hounds, and the other one coming round or through the covert, making use of his voice and holloaing 'Forward,' Sc., was to make the best of his way after them, being sure to turn round with his face to the covert before setting off, and holloaing 'Away,' at the top of his voice, so as to insure any stragsling hound hearing him; and then he used to come on. Of course, in the event of hounds dividing, it would be the duty of whicherer whipper-in harpens to be nearest the smaller lot to do his best to stop them, and make them join the budy of the jack. I am confident that, besides the injury to horseflesh caused by sending back for hounds, it tends more to make hounds helpless and slack than anything else in the world. All hounds diclike being left behind, and all hounds when let alone will find their way home. Often have I secn Tom Clark sitting under a covert blowing his horn. 'What are you doing there?' 'Two couple of hounds away.' 'Well, if you sit there for a week they won't come. Shog on !' and before he had gone three fields I have seen them coming at a good pace.

Whilst hounds are drawing a whipper-in cannot be too quict. If hounds riot and he can get to them to stop them, let him do so without making a noise; if he cannot, then he must rate them; but the more quietly the letter. If they take a scent heel-ways, the puieter and lower he says 'Ware heel!' the better. If he is in a hig covert watching a straight ride let him never turn his head or lake his eye off the ride, for at that instant a fox will surely cross ; and most particularly if he sees him cross, even if he holluas immediately, let him nut talie his eye off the ride for a minute or two, as the result of holloaing immediately a fox has crossed a ride often is to make him po! lack again over the ride, and if he does that 
without being seen it is more than proluable he will be lost. Certainly it will bring hounds to a long check, and the holloa will have done more harm than good. Whippers-in when sent on down wind, or to the far end of a covert, are very fond of situng at the exact point of the angle of a corert. Now this is a great mistake, for if a fox does not actually break there, I believe he generally will g(r) there before breaking to look if he can, if there is anyone to olserve him, and most certainly to listen to what is gomg on. Some few foxes are bold and do not care who sees them, but these are rare, and I fancy are strangers out visiting, who, hearing a noise, and, if they have been previously hunted, recosnising the voice and the horn of the huntsman, think it time to be off home.

Foxes know the huntsman's roice as well as hounds do after they have heard it a few times, and the generality of foxes are shy at breaking corert, and hate to be seen. One small child will keep a fox from going, while a regiment of cavalry can't prevent his going back again. I say, therefore, let the whipper-in hide himself as well as he may, where he can command both sides of the angle if possible: if not on the most likely side, but never at the angle. If anyone follows him, let there be no convelsation. If two or three gentlemen come down, let him (the whipper-in) beg them either to go away or not to talk or smoke. If he is fortunate enough to have hit upon the right spot and to sce the fox break away, let him not move or speak till the fox has got through at least two, and much better, three fences; and if he even then gires him another field no harm is done. In the first place, the fox will not turn back into covert; in the second he will be more likely to go straight, which all sportsmen know is better for hounds and pleasanter for those who ride to them. A fox with a guod five minutes' start of hounds is much more likely to give a good fine straight run of from six to ten mile points than one on whose very back hounds get away.

Just one word on the voice, and its use. To a huntsman a fine, voice is of the greatest benefit; it exercises a marrellous 
influence over his hounds, and is a pleasure to all who hunt with him. Old Carter, who died in the autumn of 1884 , having survived his ninetieth birthday, had a lovely wice. Even when he was over serenty years of age it was a treat to hear him draw a big woodland. William Long also had a most musical roice. To a whipper-in such a voice is a misfurtune, and he should nourish and cherish it till such time as he becomes a huntsman and carrics a horn. I fully agree with the late Earl Fitzhardinge, who was one of the best sportsmen that erer lived, whose knowledse of hunting and ail apjertaining thereto was inferior to no man's. He used to say, 'I hate a whipper-in with a fineloud voice. If anything goes wrong, if hounds riot or get hold of carrion, he is satisfied to sit a mile off and rate them.' That may do very well once, and hounds may fear the consequence of not aroiding whaterer their misdeed is; but when they find nobody comes, the next time they will take no notice of it. The whipper-in when he finds wrong-doing should say nothing but get quickly to the hounds; when he is right on top of them, a quick rate with the roice and a smack of the whip will probably jut matters to rights; should it not, then a smart stroke with a not too heary whip may be necessary. The last thing it strikes me to remark about the voice is that in coming away from a corert clrawn blank the huntsman's roice and horn should be suficicnt to bring hounds away; the whipper-in's roice should not be heard. I hear constantiy whippers-in making as much noise as though six foxes had gone away. This is wrong, and makes hounds slack and slow in coming when a fox has grone. You cannot make more than a certain noise, and if you make all you can when no fox is grone how are hounds to know the difference of being simply drawn out of a blank covert or being wanted to get quickly away afier a fox? This is lartictiluly objectionable when drawing a succesion of small coverts, which you are probably doing down wind, and it moves a fox that is a mile or even two miles off. I have known several whipuers-in-good men in their way- I should have liked to talic out with muzzles on. 
I ought to say a word on the subject of horses as regards whippers-in. I have often in my life hearl a MI.F.II. say of a brute that can neither jump nor gallop, 'Oh, he will do to carry a whipper-in.' Now this is a very great mistake. Leave your whipper-in at home sooner than mount him badly. 'To be of any use he should be able to get to hounds and to stop hounds if wanted. If you are too stingy or too badly off to buy good horses for him, buy none, and begin your economy at the right place. It is just as expensive to feed, and keep helpers to attend to, a bad horse as a good one, and your whipper-in badly mounted is useless. I would impress on whippers-in that horses are not steam engines that will go as long as you choose to keep the steam on, and that even if they were they have no tender with water and coal to feed them with. I know some who never take care of their horses, always tire them, gallop in the deepest and worst, instead of the firmest and best, ground, and ride them over the biggest place instead of the easiest in the fence, when there is no necessity for it. To these men I would say, 'Nurse your horse; the run may be severe, the day may be long, and to get to the end of either you must ride with care and judgment.' A good horse deserves to be well treated, and a whipper-in who ill-uses and knocks his horses about deserves the fate with which I always threatened Dick Christian, who was a butcher on a horse-namely, that I would buy blind fly horses in Bath or Cheltenham and give him nothing else to ride.

A huntsman, whether he be a gentleman or a professional, should impress on his whippers-in certain things that they should or should not do. This is better done by quietly talking to them in the kennels or elsewhere than by blowing them up or swearing at them in the hunting field, though it is at times necessary to speak out there. I have observed that nine out of ten interfere with hounds when they ought not to do so. For instance : having got a long way behind his fox, and the hounds being at check, the huntsman is making his cast. Some one, or perhaps even two or three, couple of hounds, with finer 
noses than the others, stop and try to puzzle out the scent. The whipper-in should not then interfere with them. He should leave them, and putting the others on to the huntsman, wate them. If he finds they are feathering on the line, he should encourage them and call the huntsinat's attention to them. As a rule directly a whipur-in sees hounds doing this he rides at, rates, or hits them, any way drives them on. It never seems to strike a whilper-in that hounds come out to use their noses, and to hunt a fox! In countries where foxes lie out much in hedgerows or in trees, in trotting from one covert to another you may move a fox without anyone seeing him. Should you cross his line, directly hounds put their noses down and begin to speak to it, or to quicken their pace, without even looking or considering whether it is a hound given to rioting or a staunch foxhound that will hunt nothing else, hang goes the whipper-in at them, with voice and whip to stopthem. My experience is that with very few exceptions nine days out of ten that a whipper-in goes out hunting he does more harm than grood.

I persistently call these men 'whippers-in,' agreeing with the late Earl Fitzhardinge that it is the proler name for that species of kennel servant, that a whip is a thing you carry in your hand, and not a man on horseback.

I dare say I have omitted many things I ousht to have noticed, but at the present time the only other hint I should gire is that whips in the kemnel cannot be too short or tou light, as many hounds have been seriously injured across the bark by the use of the usual heavy whips served out.

\section{THE DUTIES OF A KENNEL HUNTSMAN.}

In the urdinary case of a professional huntsman being engaged, he must have moler him either a man of experience whom he can trust to fied the hounds fropurly when he is away from home flumgh generally that can be done before he starts for his day's duty), and to look after lame and sick hounds, or he must have an intellicent young man who will wey orkers and carry out the instructions grven to him. This 
functionary would be called the licmet feeder, and it would be his duty amongst other things to walk ont all the homels left at home three or four times a diy for fiftech or tenenty

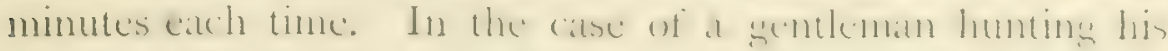
own hounds, or the substiption park of which he in mateter, it is necessiry to have a kemmel huntsman. There are three

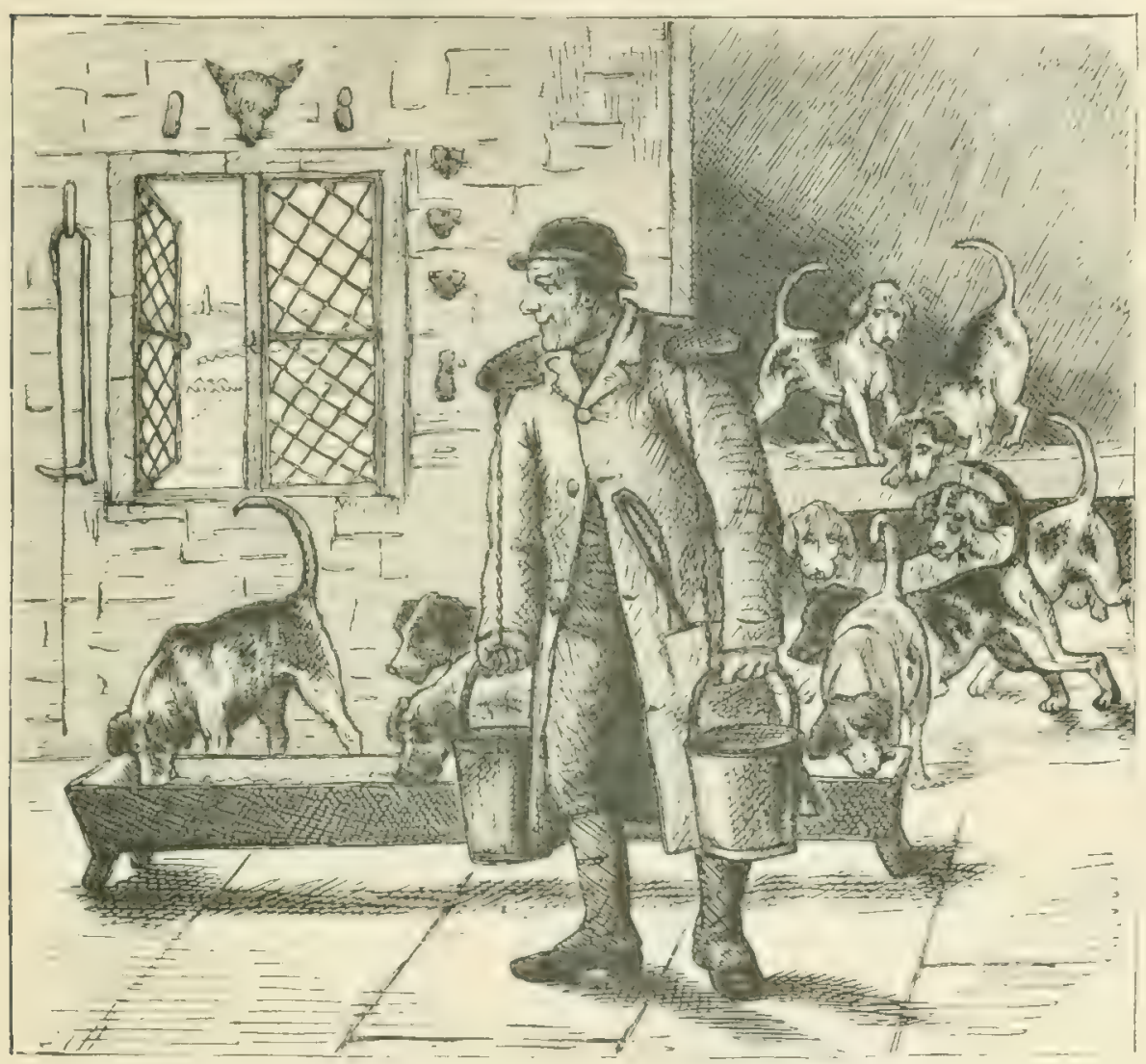

sorts : one who is old and does not ride, except to exercise the hounds in summer, and whose sole oreupation is to feed and look after them and doctor them during the hunting season; another, a man capable of hunting them should illness or business oblige the master to absent himself from the field. There are great adrantages in this secomel sort, because it is not firir to ask a whipger-in to hunt hounds, nor to ask hounc? 
to recognise the whipper-in in his new capacity. It stands to reason that the n.an who has been for weeks or months driving hounds from him wilanot find them come to him very freely when he wants them to do so. Shen the kennel huntsman comes in. It is a great adrantage to a man who has to feed hounds to see them in the field, and he should always have two or three horses at his disposal, to be able to hunt at times, twice or thrice a weck say. He then sees how his conditioning answers, and whether some want rather more, others rather less, food. The third sort is, I think, objectionable. It is the kennel huntsman to whom the hounds look for protection in the kennel, who whips-in to his master, and is obliged to drive and rate, and perhaps strike a hound in the field. A good man as kennel huntsman is a very valuable addition to a kennel establishment. If he has studied veterinary books a little and knows the proper. ties and effects of different medicines, it is a great advantage. Kennel servants are often terribly ignorant on this point, and might as wull give known poisons as the medicines they administer in certain circumstances.

I am very fond of listening to hounds singing in kennel. It is delightful to hear as it rices and falls, and seems as if each hound had studied his notes; it is also a beautiful sight to see them sitting up with heads in air enjoying their chorus. At Badminton, ever since I can recollect it has been the practice not to interfere with them and to let them have their song out. Charles Hamblin has a theory that they are apt to fight; but that is all nonsense; they are much more apt to fight if they are stopped. I never knew a case of their fighting after singing. They seem satisfied and quiet. They sing much more in the summer time and when they are fresh than during the hunting season; still they will do it at all times, but more or less according to how fresh they are, and with regard to the state of the weather. Fine weather induces them to sing. I am sure it is much better for them to enjoy their music. To my mind a huntsman will do well to allow this without any interference, and to aroid a much more likely source of fights, 
and that is keeping terriers, by day and by night, in the hound;' lodging houses. Those are the little fellows that gret into mischief ar.d first begin a row and a fight; they are briter in separate lodging houses.

\section{THE DUTIES OF AN EARTH-STOPPER.}

One of the most vexatious and constantly recurring annoyances that befall those who pursue the fox is his getting to ground. To begin at the beginning, we will say that the sarthstopper's duty is, after the fox has gone out on his nightly prowl, and before he comes home to his rest in the morning, to stop out all the main earths, and such drains as he knows the foxes use at night. The hour must depend on the setting and rising of the sun at the various periods of the hunting scason. Here let us pause to say that the term 'stopping out' means doing it during the night, and the term 'putting to' means stopping the earths or drains later in the morning, just in sufficient time to prevent the fox getting to ground after he is found. That part of the country in which the hounds are likely to draw for a fox should be 'stopped out,' and that part to which they are likely to run should be 'put to.' It is a good plan and saves time to have packs of post cards with the names and addresses of the stoppers printed on the back. You have then only to write 'Stop out 'Tuesday night,' or 'Put to Wednesday,' and date and post it. In most countries, if a man's stop is not too large to enable him to do so, it is advisable for him to visit the main or largest earths again in the morning, to see that no one has pulled out the stones or faggots; in those in which there are badgers this is absolutely necessary. A small terrier dog is a very useful adjunct to an earth-stopper. In the first place, if he wants to stop a drain permanently it is necessary, on the commonest principles of humanity, to run a dog through so as not to starve to death some wretched fox, rabbit, or cat that may happen to be in it. This saves a great deal of trouble, and the omission of it is a fruitful source of running to ground, for either some mischievous fellow moves the 
stones or the water washes a way through, or a rabbit, a fox, or a badger has scratched a way in, and a good run may be spoilt by the fox going to ground there. If the drain is srited it should be constantly looked at. 'The better way is (1) set the slatting in masonry about a yard in (1) aroid its beings stolen, but that makes it more difficult to sece if the water has scowered sufficiently under it to make room for a fox after a little drawing by a rabbit. In the

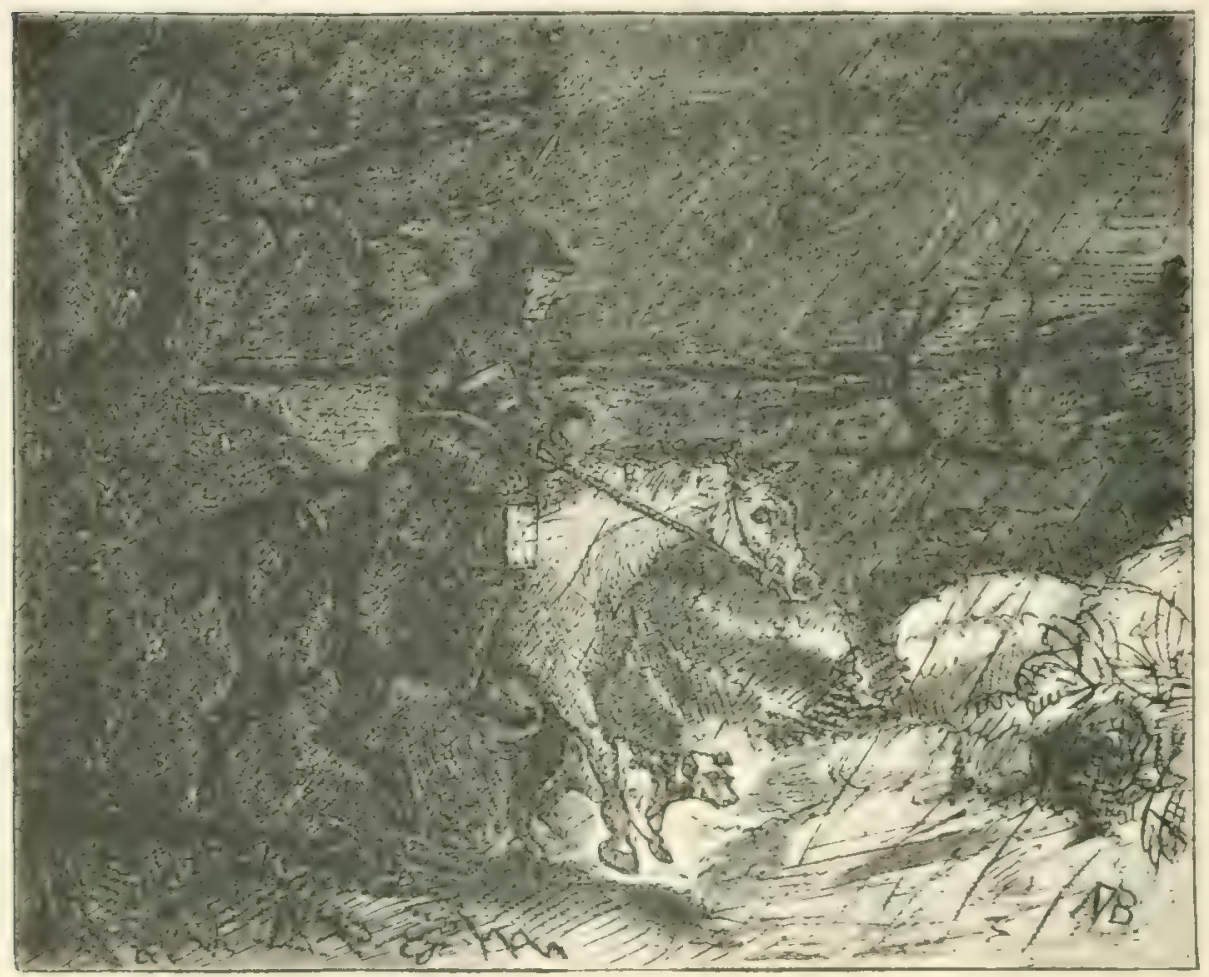

spring of the year it is better not to 'stop out,' so as to let vixens get to anume. When there are cubs about, the 'putting to' should not be too late, say about $S$ A.M., for vixens when their cubs pet strongs on in and suckle the little mes, hat often conce out again and take up a position near, whence they can watch the carth, hecause the culs scratch and worry the mother; and if the earth is 'put to' too late the viven wh ts steped ont insteat of being stopled in. Killiner 
a heavy vixen is annoying, but killing one that has laid up cubs is still more so. If you do not find them the poor things are starved to death; if you find them and get a cat to bring them up, you do not often raise them. If the cubs are three or four months old, the $\operatorname{dog}$ fox will sometimes provide them with food and bring them up. A great deal of the success and sport of a season's hunting depends on efficient and careful earthstoppers. In spite of the greatest pans and troulsle a M.F.II. will find himself constantly running to ground in the same earth or drain. If he does get a really good man in whose stop he rarely or never gets to ground, he should treasure and encourage him in every way.

\section{COMPENSATION FOR DAMAGES DONE BY HORSEMEN AND BY FOXES.}

This is a most difficult subject to treat of. As a rule, during the hunting season, horsemen do but little damage beyond making gaps in the fences, and occisionally hurting a field of vetches or young clover seeds or winter beans. The bulk of farmers are so sporting and so good-natured that they do not mind. You may come across one every now and then who says, 'I won't have my bounds broken,' or 'You sha'n't ride over my wheat.' But that is rare, and practically very trifling damage is done. Sometimes in a wet spring, after grass has been bush-harrowed, it is otherwise. Wheat is a very hardy plant, and it takes a great deal to hurt it. I have seen fields three times in my life that I thought utterly ruined by horses' hoofs, and I arranged with the occupiers of the land to send, before harvest, a good agriculturist to look over and report on their state, with a view to compensation; and on each occasion I received a letter saying it was quite unnecessary, that there had never been a better crop on those particular lands. But all the same, the feelings of the farmer must be taken into consideration, and he should be treated with gentleness and civility at all times, and compensated at the proper time if neces- 
sary; though it will senerally be found that not much damage has heen done. A hunting famer of my accuaintance once told me he never went over any part of his farm across which the hounds had run for at least ten days after their visit, and that then, beyond gaps in his fences, he found hardly any marks. Every man has a right to object to his land being ridden over, and when he does so, must be treated as a man who is within his rights. To those who do noi hunt themselves, and yet welcome the hounds, all hunting men are deeply indebted; they are indeed generons and unselfish specimens of humanity. To those who hunt we are also indebted, but as they partici. pate in the sport, and ride over other people's lands, it is in a less degree. I remember a tenant of Iady Holland's at Foxley, in North Wilts, a gentleman of the name of Baker, once opening the gate of one of his own ficlds-forty acres of wheatin the month of Felbruary, when we were going to draw his gorse covert, which he had asked us to make on his farm, and saying, 'This is the best way!' There were three hundred horsemen at least, and I remonstrated and suggested going a field farther on - 'Iiless you, it will do it good!' he said; and rode first into it. There are many such, I am haply to say, but when it is otherwise, it is grod policy to keep them friendly, to listen to their complaints, and recompense them if they want it. As regards foxes killing lambs, there is a great deal of nonsense talked and of misconception about it. That a fox will uncoubtedly kill one, if it is very weak, or sometimes, when a ewe has two, will nip) up one whilst she is defending the other, is a fact; but it is only when they are very small. The ewe is quite capable of defending her lamb. One man declared to me that the foxes came in troops and attacked his fold, which of course is ridiculous, as foxes seck their prey 'single-handed,' and do not hunt in troops like wolves. He said he could prove it, and laid a dead lamb down. When it stank, of course foxes passing winded it, and he found three foxes fishting orer it. In almost every case where a fox is found eating a lamb, it has been killed hy a clog, and gencrally by a sheep dog; more often 
than nut by the lamb's own shepherd's dug. Foolishly, when lambs die, the shepherds give them to their dogs. When the larder is empty, doggry, being sagacious, forages for himself. One certain way in which you can tell if a fox has killed a lamb and berun eating it, is that he will do so by maling a hole in the side of the chest under one or other fore legr, and getting at the heart. If a doy begins to eat it, he does so by gnawing off the head or making a hole in the throat in endeavouring to do so. I do not say that foxes never kill lambs, but I say that such an occurrence is very rare. When it can be proved, the lamb should be paid for ; but it reçuires good proof first.

Three cases have come to my knowledge, within the last four or five years, in which farmers' belief in the harm done by foxes has been eradicated. On two of these occasiuns the men who had declared war against foxes made a party of three or four with guns, and in both instances they slew the culprit. There was a who-hoop! and a rush at the animal they had bowled over; in one instance it was the farmer's own sheep dog, in the other it was his neighbour's. In the other case the farmer, if not actually convinced, was effectually cured of his wish to destroy foxes. He sat up in a tree for two or three nights waiting for his enemy. On the last night he went to sleep, fell out of the tree, broke several of his ribs, and vorved that for the future he would never try to shoot a fox. As regards the claims for loss of poultry, they increase and multiply to a degree that threatens to make it one of the heaviest items in the expense of keeping hounds. My hunting country is a very large one. I should say, if the boundaries were measured right round, it would be at least 160 miles. We have divided it as well as we can into districts, and in each of these some gentleman has kindly undertaken the very difficult task of adjudicating as to whether the claim shall be jaid or not. We make a rule that no poultry shall be paid for that are not shut up at night. If a fox burglariously enters a hen roost and takes and destroys, they must be paid for. The worst of a fox is that he likes killing better than eating. He is the prototype of the 
Englishman looked at from the foreigner's point of view : 'God dam it is fine to-day! What shall we kill?' If he would only take the little that satisfies his appetite he would not be grudged his food. I'ut if there are twenty or thirty or more fowls that he can get at, he will kill them all. He may take away three or four and bury them and one to eat presently, but the rest he leaves. Ioultry taken in broad daylight near the owner's farm or residence are paid for also. But we must have some proof, such as the feathers strewn about, and like a paper chase dropped on the line he has gone, for a fox makes a rare mess when he kills poultry. In a country full of foxes, and where such claims are paid, directly a fowl is missed, without inquiry or demur, its loss is set down to the foxes; and consequently the two-legred foxes, in whose pots they might be often found, get off with impunity. It is therefore very necessary to have these claims inquired into and made out to be genuine. I have had claims for calves and cows killed by foxes, but they are too ridiculous to require any remarks from me. Bulls and cart horses as yet have not been claimed for.

\section{ARTIFICIAL FOX EARTHS.}

In describing the various methods of making artificial fox earths, or drains as they are called in some countries, it is of course impossible to lay down any hard and fast rules, as their construction must depend in every case upon local considerations. A few of the principal points to be aimed at may be noted, however, and the constructor must then use his judgment in putting them in force according to circumstances.

Artificial earths are primarily meant for breeding establishments, and among the chief points to be borne in mind are the Aspert, Position, Soil, I)rainage, Construction, Materials, and Form of earth. 
With regard to $A$ spect, i.e. the aspect of the entrances or mouths, it is first of all necessary to look at the habits of the young cub. It will be found that he does not come out of the bowels of the earth till he is about four or five weeks old, generally at first only for an hour or two morning and erening, after sunrise and before sunset; and as it is a well-known fact that the sun has a great power in making young animals healthy, it is evident that the mouths of the earth should be situated where they will catch the most sun ; but at the same time it must be in such a place that it is sheltered from the prevailing winds, and especially from the north. It will be also noticed of young cubs that for some wecks after coming out of the earth they keep close to the mouth of the hole, sambolling and playing in a circle of a few yards. Care should be taken, therefore, that the ground round the mouth of the earth is of as dry a nature as possible, as the little animals often play till they get hot and lie down, and if the ground is at all swampy or wet they are very liable to get what is commonly called 'yellows,' a canine form of jaundice; therefore let the aspect be as sunny as possible, sheltered from the winds with dry ground round the mouth of the hole.

With regard to the Position of the earth there are also many points to be considered. Some people place their artificial earths in a gorse, but this I hold to be a mistake; as if the earth is put as it should be, away from a ride or path, the carthstopper when the gorse is grown up will have great difficulty in finding the earth in the dead of night unless he has a mark to guide him. The result of this will be that he will always go the same way, and eventually make a conspicuous path right up' to the earth. Besides this, a grorse covert is a covert where foxes are expected to lie above ground, and the keeper groing to stop the earth at night disturbs the covert for the next day's draw. Moreover, in regard to the question of breeding, very little sun would reach the mouth of the earth. To some extent these objections apply to the making of earths in large coverts. The best artificial carth is probably one that is built in a small spinney close by a large stronghold with a dell in it, the earth 
being placed on the north side of the dell, half-way up the bank, so that the sun may get at it in the afternoon and evening. The Soil of the place should be a matter of careful selection. The great object to be aimed at is that the vixen may have a dry place to lic on and drop her cubs, and it is also an advan. tage that she should be alle to scratch or draw out a snug corner in the lodging room to litter her offspring. It is the instinctive nature of the vixen some few weeks before her confinement to scratch out and make for herself a bed on what may be called fresh soil in order that she may here lay up her cubs; and by giving her the opportunity of following her instincts there is a greater chance of her taking to her artificial home. Chalk we all know is the driest and best soil for this purpose, and it is at the same time a soil that is easily moved by the burrowing animal; also, it is not so likely as gravel or sand to fall in. Endeavour then to get jour earth made where you have a subsoil of chalk. If no chalk site is obtainable, the nearest possible approach to a soil of this nature is the best.

Drainage is also a matter of consequence, but one upon which it is impossible to offer any very definite suggestions. Everything depends on the situation, but this can be said: always make the lodging room considerably higher than the mouth of the hole. 'This will assist the drainage considerably, also drain the ground outside the mouth if damp.

As for Construction and Matcrials, it is not advisable to construct these earths in a smart or neat way. They should be made as roughly as possible, and with as rough materials. 'The outside cuts of trees, old bricks or flints-anything, in fact, which is sufficient to kecp the ground from falling in.

Two matters ought to be taken into consideration. First, that the first few feet of the entrance must not be large enough to allow a terrier or cur dog to get in. Secondly, that there should be more than one entrance to the lodging room, so that in case of an enemy getting in the fox is able to slip round and get out. 


\section{CHAPTER VI.}

THE HORSE.

Many stories are told of that facetious nobleman, lord Barrymore, the 'Cripplegate' of those three brothers whose eccentricities secm to have so largely' delighted the old historians of the turf. Not all of these are particularly interesting to us, or creditable to his lordship's memory, but in the following, rclated by 'The Druid,' there is a little grain of salt that has sufficed to keep it still sweet enough for our purpose. He walked one fine morning out on to the pavement in front of his stables at Newmarket, and roared at the top of his voice, 'O yes! O yes! O yes! who wants to buy a horse that can walk five miles an hour, trot eighteen, and gallop twenty?' Of course a crowd was round my lord in a moment, and on his repeating the flattering tale, there was no lack of aspirants to the possession of this remarkable animal; but they were forced to content themselves with the assurance that "When I see such a horse I will be sure to let you know.' 'There is no recorded reason for believing that such a wonder has yet been found; perhaps the ncarest approach to it was that famous stecd of whom the enthusiastic dealer assured a doubting purchaser, "The shadow of him on the wall is worth all the money I axes; he can pick up his feet, and go, and catch a bird.' But the desire for a good horse is as keen now as in Lord Barrymore's time, and if the prices do not as a rule run quite so high now as they did in the days I)ick Christian has waxed so eloquent over, nobody with a good animal to sell need ever look long for a buyer. 
Mr. Sidney, in that vast equine encyclopxedia of his, ${ }^{1}$ has printed a 'table of contents' of the stables of Algernon Percy, fifth Earl of Northumberland, in I5 I2, which gives one a very fair notion of the sort of stud a great nobleman of those days thought it necessary for his comfort and dignity to maintain :

This is the ordre of the chequir roule of the nombre of all the horsys of my lorde's and iny lady's that are appointed to be in the charge of the hous yerely, as to say, gentell hors, palfreys, inobys: naggis, clothsell hors, male hors.

First, gentell hors, to stand in my lorde's stable, six.

Item.-I'alfris for my ladis: to wit, oone for my lady, two for her gentlewomen, and one for her chamberer.

Four hobys and nag; for my lorde's oune saddell, viz. one for my lorde to ride, one led for my lorde, and one to stay at home for my lorde.

Item.-Chariot hors to stand in my lorde's stable yearly; seven great trottynge hors to draw in the chariot, and a nag for the chariot man to ride-eight. Arain, hors for Lord I'ercy, his lordship's son and heir; a great double trotting hors, called a curtal, for his lordship to ride out of townes; a frefier amblynge little nag, when he gocthe hunting and hawhing; a great amblynge gelding or trotting gelding, to carry his male.

A single hunter, it will be seen, was then thought sufficient for a 'lord of high destree, and though distinguished from the rest, as kept for hunting and hawking only, he is somewhat contemptuously dismissed as an 'amblynge little nas', though 'proper.'

But a century later things have advanced. Then we get into the days of our friend Gervase Markham, a time which, as Mr. Sidney rightly says, 'may be taken as a standpoint for summing up the condition of the English horse before the production of the thorough-bred racuhorse, which was not effected till nearly a hundred years later.' In James the First's reign the English horse had berome a notable beast. He was of foreign blood of course, as were the English men themselves, of lureign bluod mixed and mixed again with the native stock

1 The Book of the Horse, and ed. ch. ii. 
There were horses in Britain when Ciesar landed with his Romans ; ponies in the hilly wooded districts, others of larger and stronger build on the rich pastures of the lowlands. "The Normans imported those solemn ponderous beasts one sees in the Bayeux tapestry, and later, the Crusaders brought back with them from their wild pilgrimage some Eastern strains, 'genets' as they were then called, and still are called in Spuin. From the earliest days our kings had made horseflesh their care. Before the Norman rule, Athelstan had forbidden English horses to be sent out of the country except as presents, and one of the few good acts recorded of John is his importation of a hundred Flemish stallions. Edward III. tricd to make the breed lighter and speedier by the infusion of a Spanish strain; but it does not seem as though all this care had been very efficacious, for in his French campaigns that king found such difficulty in mounting his cavalry that he had to send for large drafts from Hainault. Nevertheless of some kind or other horseflesh was growing in our islands, in quantity if not in quality, and to such an extent that Richard II. compelled the dealers to fix their prices at a minimum value. In Henry VII.'s reign the practice of gelding first came into use in consequence of the vast herds of horses that were kept at grass together. The eighth Henry took the matter in hand with his usual vigour. He passed an Act of Parliament for the improvement of the breed of horses, the preamble to which ran to this effect :

Forasmuch as the generation and breed of good and strong horses within this realm extendeth not only to a great help and defence of the same, but also is a great commodity and profit to the inhabitants thereof, which is now much decayed and diminished by reason that in forests, chaces, moors, and waste ground within this realm, little stoned horses, and nass of small stature and of little value, be not only suffered to pasture thereupon, but also to cover mares feeding there, whereof cometh in manner no profit or commodity.

'This Act made it law that no entire horse above the age of 
two years and under fifteen hands high shrould be "put in any forest, chace, moor, heath, common, or waste within the shires of Norfolk, Suftolk, Cambridge, Buckingham, Huntingdon, Essex, Kent, Scuth Hants, Berks, North Wilts, Oxford, Worcester, Gluacester, Sumerset, Wales, Bedford, Warwick, Nottingham, Iancaster, Silop, Iceicester, or Lincoln, nor under fourteen hands in any other county.' It ordained also that 'all commons and other places shall, within fifteen days after Michaelmas, be driven by the owners and keepers, and if there be found in any of the said drifts any mare not able to bear foals of reasonable stature, or to do profitable labour, in the discretion of the majurity of the drivers, they may kill and bury them.' 'The Archbishops and Dukes were each to keep seren entire trotting horses, no one of which was to be under fourteen hands high; and every clergyman whose living was worth a hundred pounds yearly; or whose wife could afford a bonnet of velvet, was to keep one such horse. By a subsequent Act all owners of inclosed grounds to the extent of one mile were ordered to heep) two mares thirteen hands high (handfulls was the old expression) for breeding purposes; where the grounds were fourmiles in extent, four such mares were to be keft. The counties of Westmoreland, Cumberland, and Northumberland, and the bishopric of Durham, were exempted from these laws, all violations or newlect of which were strictly punished; or, at any rate, ought to have been if the officers did their duty. IIenry is also said to have imported fresh blood from Turkey, Naples, and Spain, all famous for their breed of horses in those days. Nevertheless the result does not seem for all his care to have been worth very much. In $15 S S$, when England was looking out from her cliffs for the coming of the great Armada, only three thousand cavalry could be mustered, though Catholic and I'rutestant alilie forgot their quarrels as they rallied to their (zueen's call. And these horses were, according to a contemIorary, "very indifferent, strung, heary, slow draught-horses, or light and weak.'

Markham was writing only a quarter of a century later, 
yet, unless he or Blundeville (the aforesaid contemporary) has largely exaggerated, a vast change must have taken place in our horseflesh within those years. James was the first king to import an Eastern sire for the express purpose. Ijut 'the Arabian horse,' called 'Narkham' after the merchant from whom he was bough! for I $54 l$, did not set foot in England till 16 r6, the date of Gervase Narkham's book. The improvement, therefore, cannot have been due to the Arabian, who was, moreover, a notorious failure. At any rate, Narkham (the man, not the horse) is very plain-spoken in his approval of the English horse of his day, and as he had travelled and knew well what he was writing about, his praise cannot be set down to mere 'provincialism.' He says :

I do daily find in mine experience, that the virtue, goodncss, boldness, swiftness, and endurance of our true-bred English horses is equal with any race of horses whatsocver. Some former writers, whether out of want of experience, or to flatter novelties, have concluded that the English horse is a great strong jade, cleep-ribbed, sid-bellied, with strong legs and good hoofs, yet fitter for the cart than either saddle or any working employment. How false this is all English horsemen know. The true English horse, him I mean that is bred under a good clime, on firm ground, in a pure temperature, is of tall stature and large proportions; his head, though not so fine as either the Barbary's or the Turk's, yet is lean, long, and wellfashioned; his crest is high, only subject to thickness if he be stoned, but if he be gelded then it is firm and strong; his chine is straight and broad; and all his limbs large, lean, flat, and excellently jointed. For their endurance I have seen them suffer and execute as much and more than ever I noted of any foreign creation. I have heard it reported that at the massacre of Paris (St. Bartholomew) Montgomerie, taking an English mare in the night, first swam over the river Seine, and after ran her so many leagues as I fear to nominate, lest misconstruction might tax me of too lavish a report. Again, for swiftness, what nation has brought forth that horse which hath exceeded the English-when the best Barbarys that ever were. in their prime, I saw them overrun by a black hobby at Salisbury; yet that hobby was more overrun by a horse called Valentine, which Valentine neither in hunting or running was ever equalled, yet was a plain-bred English horse both by sire and dam? Agrain, for 
infinite labour and long endurance, which is to be desired in our hunting matches, I have not seen any horse to compare with the English. He is of tolerable shape, strong, valiant, and durable.

1 contemporary, Michael Barratt, ${ }^{1}$ writes pretty much in the same strain, though 'for all gencral uses, for service (that is, war), swiftness, and proud going, as well as for pleasure pace as a gallant trot,' he thinks, 'the Barbary and the Turkey stallions are the best.' But for 'toughness' he holds by the English horse, a cross between one of the foreigners and an English mare.

Markham was the first to really distinguish the hunter from other horses, to explain his points and qualities, and call attention to the particular circumstances necessary for his proper breeding, training, and keeping. His remarks are worth considering; entertaining of course, as all his writing, but also very sensible (as, too, he generally is), and not very much perhaps to be improved on by modern experts.

Although some men hold an opinion that every horse which can gallop may be made a hunting horse, and albeit we daily see that many horses, which indeed can do no more but gallop (and that not long together neither) are ordinarily used in this exercise of hunting, yet I am of that mind, that if a horse has not some virtue more than ordinary, as either in his swiftness, toughness, wind or courage, that he is not worthy the name of a hunting horse, and neither doth deserve the labour, cost, and good food which he must eat, nor the grace to be employed in such an honourable pastime.

Now therefore to save ill-cmployed cost, and the repentance which follows hours that are in vain wasted, you shall (being admitted to pursue this pleasure) be excecding careful in the choice of that horse which you intend for hunting. For as before I told you in the breeding of horses, some are grood for service in the wars, some for running, some for coach, some for cart, and some for the hamper, now all these in their kind good, yet very few excellent in Eeneral for all these uses whatsoever, and those few which are so well compounded, both of mind and body, that they are fit for any purpose, they only and none else are most excellent for hunting, as having the strength of the war horse, the toughness of the hunting 
horse, the good pace of the traveller, the swiftness of the runner, a good breast for the coach, a strong joint for the cart, and a back like a beam for the hamper.

But forasmuch as there be three especial characters or faces by which a man shall choose a good hunting horse, to wit his breed, his colour, and the shape of his lineaments, I will by them show you what observations you shall regard when you make choice for this purpose.

And first for his breed, if he be either bastard Jennet or bastard Polander, his breed is not amiss; for I have known of all these sorts of bastards excellent humting horses. Now if you demand what I mean by this word bastard, it is when a horse is begotten by any of these country horses upon a fair English mare, or by a fair bred English horse upon any of these country mares; but neither to flatter other countries, nor to take from our own that which is due unto it, the world doth not afford in all points (both for toughness and swiftness being joined together) a better horse than the true-bred English horse for hunting: which assertion should I maintain by the best proof, which is example, and could repeat so many instances as were sufficient to fill up the rest of this volume, but I will not at this instant be so troublesome.

Through all the many gradations of colour we need not lollow Markham. In his day the colour of a horse was a very particular point, and considered an infallible indication of his temper and qualities. The saying we go by now that 'a good horse cannot be of a bad colour'-a saying, by the way, clearly susceptible of more readings than one-would not have been allowed by him for a moment. 'As a horse is coloured, so is he for the most part complexioned: and according to his complexion, so is his disposition of good or evil quality.' Such was our forefathers' opinion, and very ingeniously did they go about to explain it. We will satisfy ourselves, however, for the present by noting that brown bays, dapple greys, black 'with silver hairs,' 'well mixed ' roans, the 'ashy' grey, and 'the white liard, which hath his outward parts, as the tips of his ears, mane, tail, feet, and suchlike, black,' were all in tavour. A black horse with no relief of white whatever, is much to be avoided, for 'he is furious, doged, full of mischief and misfortunes.' A bay or chestnut: 
on the other hand, without such relief might be made something of, 'only in his pare and natural motions he will be fantastical, forgetful, and uncertain.' 'Then, for the shape:

His head should be somewhat long, lean, and large, with a spacious wide chaule, both thin and open; his ear if it be short and sharp, it is best, but if it be long and upright, it is a sign of speed and good metile. His forehead long and rising in the midst, the feather thereof standing above the top of his eye ; his eyes full and round; his nostrils wide and without rawness; his mouth large and hairy; his thropple within his chaule as much as a man can grip and by no means fleshly or so closed with fatness, that a man can hardly find it (as many fine-shaped horses are), the setting on of his head to his necle would be strong, but thin, so as a man may put his hand l,ctwixt his neck and his chaule, and not bull-cras-like, thick and full, that one cannot easily diocern where his chap licth: his crest strong and well-risen; his neck straight, frrm, and as it were of one piece with his body and not (as my countrymen say) withy-crasered, which is loose and pliant. The thropple or nether part of the neck, which goes from the underchaps to the breast, should, when the horse reineth, be straight and even, not bending like a bow, which is called cock-throttled and is the greatest sign of an ill-wind. If the nether-chaps, and that nether part of the neck also be full of long hair, and bearded down to the setting on of the brcast, it is a sign of much swiftness : a broad strong breast, a short chin, an out rib, a well-hidden belly, short and weil-knit joints, that legs excecding short, straight and upright pasterns, which is a member alove all others to be noted; his hoofs both black and strong, yet loner and narrow; and for his mane and tail, the thinner the more spirit, the thicker the greater sign of clulness; to be (as some term it; sickle-houghed behind, that is somewhat crooled in the grambrel joint, as hares and greyhounds are, is not amiss, though it be a little eyesore. And for my own part I have seen many good which have borne that proportion.

Of course the hunter of those days, and of days very nfuch later, was an altogether different sort of animal from that in rogue with us. The hunter as we know him now may be said to have come in with the century, just as the siyle of hunting now practised came in. 'Nimrod,' who had some knowledge of the rid ordur as well as the new, writes thus of the changes the 
latter has made necessary in the composition and circumstances of the English hunter :

The half-bred louse of the early part of the last century was when highly broken to his work, a delightful animal to ride, in many respects more accomplished as a hunter than the generality of those of the present day. When in his best form he was a truly shaped and powerful animal, possessing prodigious strength, with a fine commanding frame, considerable length of neck, a slight curve in his chest, which was always high and firm, and the head beautifully put on. l'ossessing these advantages, in addition to very great pains taken with his mouth in the bitting, and ar excellent education in the school or at the bar, he was what is termed a complete snaffle-bridle horse, and a standing as well as a flying leaper. Held well in hand--his rider standing up in the stirrups, holding him fast by the head, making the best of, and being able to pick or choose his ground-such a horse would continue a chase of some hours' duration at the pace he was called upon to go, taking his fences well and safely to the last; and he would frequently command the then large sum of Ioo guineas. But all these accomplishments would never have enabled a horse of this description to carry the modern sportsman, who rides well up to modern foxhounds, on a good scenting day, over one of our best hunting countries. His wind would be spent and his strength exhausted before he had gone twenty minutes by the increased pace at which he must be called upon to travel, but to which his breeding would be quite unequal; and his true symmetry, his perfect fencing, his fine mouth, and all his other points, would prove of very little avail. If ridden close to the hounds, he would be powerless and dangerous before he had gone across half a dozen Leicestershire inclosures. The increased pace of hounds, and that of the horses that follow them, have an intimate connection with each other, if not with the march of intellect. Were not the hounds of our day to go so fast as they do, they would not be able to keep clear of the crowd of riders who are now mounted on horses nearly equal to the racing pace. On the other hand, as the speed of hounds has so much increased, unless their followers ride speedly', and, for the most part, thorough-bred horses, they cannot see out a run of any continuance, if the scent lies well. True it is, that at the present time, every Leicestershire hunter is not thorough-bred; but what is termed the cocktail, or half-bred horse of this day is a very different animal from that of a hundred years back. In those 
days, a cross between the thorough-bred, or perhaps not quite thorough-bred, horse and the common draught mare, was con sidered grood enough to produce hunters equal to the speed of the hounds then used. There was not such an abundance of what may be termed the intermediate variety of the horse in the country'pretty well bred on each side of the head'-which has of late years been in demand for the fast coaches of England, in which low-bred horses have no chance to live. Nares of this variety, put to thorough-bred stallions, and their produce crossed with pure blood, create the sort of animal that comes now under the denomination of the half-bred English hunter, or cocktail.'

This question of blood has always been a rexed one among hunting men. Dick Christian has decided pithily as usual in their favour. 'Give me 'em lengthy, short-legged for Leistershire; I wouldn't have 'em no bigrger than fifteen-three : great rump, hips, and hocks; fore-legs well afore them, and good shoulders; thorongrh-lired if you can get them, but none of your high short horses. Thorousth-bred horses make the best hunters. I neier heard of a great thing yet but it i'as done by a thorough. bred horse.' 2 Whyte-Melville, too, held by the same creed. ${ }^{3}$ 'In all the qualities of a hunter,' he says, 'the thorough bred horse is, I think, superior to the rest of his kind.' He adds, however, 'though undoubtedly the best, I cannot affirm that they are always the pliasantest mounts. The horse he had in his eye is not one bred expressly for hunting but a cast-off from a racing stable, one found not fast enough to be worth training, or rather one whose 'distance is found to be just short of half a mile,' one who 'fails under the strain on wind and frame, of galloping at its very best, eight hundred and seventy yards, and fades into nothing in the next ten.' This failure in his opinion is a question more of speed than stamina: "There is a want of reach or leverage somewhere, that makes its rapid action too laborious to be lasting, but there is no reason why the animal that comes short of five furlongs on the trial ground, should not hold its own in front, for five miles of a steeplechase, or fifteen of a run

1 Quarterly Review, March 1832. 2 Silk and Scarlet, ch.i

3 l'iding Recollections, ch. $\mathbf{x}$. 
with hounds.' IIis commendation of the steeplechaser as hunter is one we fancy not generally shared, but, as usual, he gives reasons for his taste worth considering:

A good steeplechaser, properly sobered and brought into his bridle, is one of the pleasantest hunters a man can ride, particularly in a flying country. He is sure to be able to make haste in all sorts of ground, while the smooth easy stride that wins between the flags is invaluable through dirt. He does not lose his head and turn foolish, as do many good useful hunters when bustled along for a mile or two at something like racing pace. Very quick over his fences, his style of jumping is no less conducive to safety than despatch, while his courage is sure to be undeniable, because the slightest tendency to refuse would have disqualified him for success in his late profession, wherein also he must necessarily have learnt to be a free and brilliant water jumper.

Such a nag as this would certainly be a pleasant one to ride ; and no doubt a horse good enough to win the Liverpool under eleven stone or more would be both a brilliant and a safe mount across Leicestershire. But all steeplechasers are not good enough to win that race under such a weight; indeed, they seem to get scarcer every year; and all hounds do not run across Leicestershire. Much as we respect Whyte-Melville's opinion on all matters connected with horseflesh, we have to doubt whether a man would be wise to look for a hunter in a steeplechasing stable now-a-days. He might get hold of a pearl of course, but the chances are, to say the least, zery doubtful. Even with a horse taken out of a racing stable Whyte-Melville owns immense pains must be taken to make him really fit for hounds. He warns you 'not to feel disappointed that he seems to require more time and tuition than his lower-born cousins.' 'It is not that he has less valour but more discretion! In the monotonous progress of training he has acquired, with other tiresome tricks, the habit of doing as little as he can, in the different paces, walk, canter, and gallop, of which he has become so weary.' And he tells a story of the difficulty that famous horseman, Sir Charles 
Knightley, had in persuading his scarce less famous hurter, Sir Marinel, even to luxk at a fence when first taken out of training. let this horse, with Benvolio, also a thorough-bred one, were far and away the best Sir Charles ever rode.

Colonel Cook is as thorough an adrocate for blood as Whyte-Melville, but he rather shakes his head at the training stable. 'Many fox hunters,' he says, 'prefer thorough-bred horses, others cocktails; I always gave the preference to the former, if it was prossible to get them. It is the general opinior that thorough-bred horses cannot leap so well as cocktails : I think otherwise; and if you will try the experiment, by taking ten young herses of the furmer and ten of the latter sort, I am convinced you will find the thorough-bred ones to have the advantage, and naturally to clear their fences with more ease to themselves. Horses that have been in training for years cannot be expected to make hunters; but, nevertheless, what superiority has a thorough-bred one in every respect-above all, in speed, bottom, and wind! It often happens when a cocktail is at the height of his speed, a thorough-lored is only at threequarters, and the latter will always go through dirt (as the term is) best.'

"The Druid' 'gives us the word of an old hunter breeder, that he could never get exactly the animal his heart was set on, till he put his short-lescred cart mare to a thorough-bred horse, ${ }^{2}$ and crussed her first filly foal ("laid up in lavender till she was rising fire') with a thorough-bred. 'The Druid's' own idea is that the size should be on the side of the dam, and the breeding on that of the sire; 'a large roomy mare should be put to a small compact blood horse ;' and he calls Sir Harry Goodricke (no mean authority) in evidence. Another friend of his, vaguely described as 'one of the finest horsemen and judges of the day,' gave him this standard for a grood hunter, as good a piece

1 Observations on Fox Hunting.

a My ow a experience is that unles; the mare is well bred the produce lacks speed. I prefer both Sire and I)am to be well bred, but a weli-bred mare and an under-bred hore will produce a fister animal than a thorough-bred horse and an under-bred mare.-EDITOR. 
of advice for an intending purchatser to carry in his monel at.; any we know of:

Ilacl I to choose a hunter by seeing one point only, it should be his heat ; for I never linew one with a small, cleam, intelligent fate and prominent eyes to be bate. I like his neck atso to be mus ular, but not heary; shoulelers well back, with lons arms; short from! the knee to the fetlock; proterns lather long lout not upright : his feet camnot well be described on paper, but they should be latre and perfect, or all the rest is as 'leather and pruncllat. Ilis bate

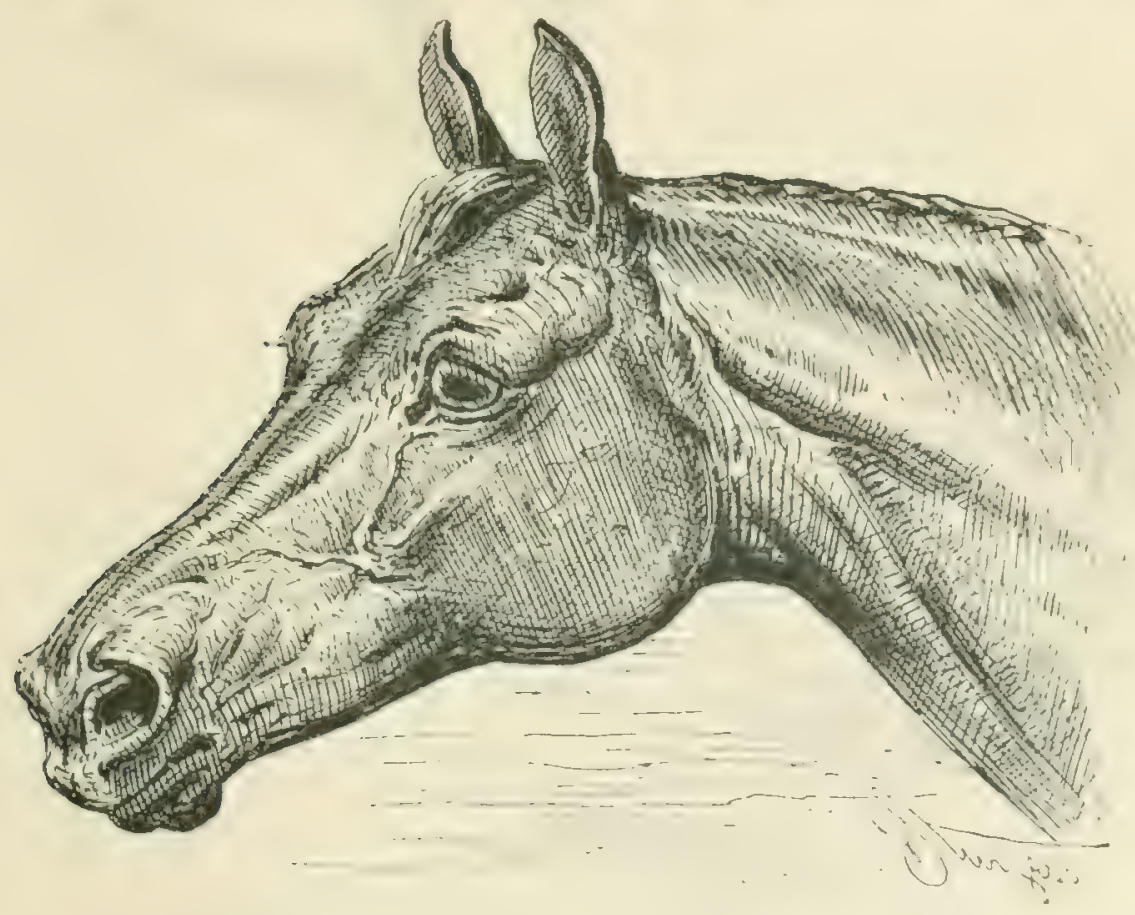

'Had I to choose by one point, it should be his head.'

shoudd not be too short, and he should have stout loins and wide hips, and good length from the latter to his hocks, which should be rather tumed inwards. Arded to this he should be larere round the sirth, but whether in depth or width does not much sisnify; and the higher he is bred the greater his intelligence, and the speedien his recovery from the effects of a hard day. ${ }^{1}$

The objections to thorough-bred hunters come nustly from heavy men. No doubt the system of handicapping has pro- 
duced an inordinate number of 'weeds' among our racing stock, and it may also be said that the majority of our steeplechasers would not carry heavy men, either fast or far, to hounds. But size, it nust be remembered, does not necessarily mean stringth; it has been well said, it is action that carries aveight. A thorough-bred horse is always bigrer than he looks, and stronger. Nevertheless, it would be unwise to expect that these aliay's make the best hunters. It may be, as Dick Christian said, that the greatest things have always been done by the thorough-b:eds ; 'blood,' as the old adage goes, ' will tell,' and no doubt in difficulties the blood horse will show the most courage, will struggle the longest, and often get himself and his rider out of scrapes which his lowlier-bred cousin will accept as incvitable. Still, in the heavy cramped countries the plebeian will often prove as useful as the aristocrat; and possibly, from his more phlegmatic temperament, a safer conveyance. Where it is rather necessary for a horse to be as nimble as a cat, as thick-skinned as a badger, and as patient as an ass, than to gallop fast and leap big, a three-quarter, or even half-bred horse is as useful a beast as a man need wish. There is also rather a sense of these high-couraged, high-bred animals being wasted in such countries, to say nothing of their high prices. I'erhaps, after all is said on either side, the safest verdict to fall back upon is this, that, whercas a half-bred horse cannot be made of use in the reat grass countries, a thorough-bred horse can be made of use anywhere.

The saying, a good horse cannot be of a bad colour, is, as we hare seen, susceptible of a double interpretation; so is that other saying, a grood horse cannot be of a bad shape. A horse - may be perfect to a hair's breadth in every proportion, yet thoroughly worthless as a hunter ; on the other hand, many first-rate hunters have been very' queerly shaped, 'rum 'uns to look at, but devils to so,' as the old song says. Mr. Sidney gives in his book a portrait of a famous hunter, Lnknown, who had camried the thirteen stone of his master, Mr. John Bennett, for many seasuns with the Quom and Pytchley without a fall, and was 
declared by Sir Richard Sutton, then hunting the furmer pack, to be one of the best animals he ever saw cross l ceicestershire. If the portrat tell truth, no man certainly would have bought Unknown for his shape, to say nothing of the fact that he was under fifteen hands high. One of the first points a buyer looks at in a horse recuired to carry weight is the back. When the nature of the horse's anatomy is considered, and the position of the saddle, it will be clear that a back disproportionately long is, to say the least, not the one thing needful. Yet Whyte-Melville tells us that the best hunter owned by each of the three heaviest men he ever saw ride perfectly straight to hounds had that fault. These were Sober Robin, owned by Mr. Richard Gurney, who rode twenty stone; a bay horse belonging to Mr. Wood, of Brixworth Hall, who was no lighter, and used to vow his horse 'had as many vertebre as a crocodile ;' and a black mare, belonging to Colonel Wyndham, at least three inches too long behind the saddle. 'I remember also,' he adds, 'sceing the late Lord Mayo ride fairly away from a l'ytchley field, no easy task between Iilbourne and Cold Ashby, on a horse that, except for its enormous depth of girth arguing unfailing wind, seemed to have no good points whatever to catch the eye. It was tall, narrow, plain-headed, with very bad shoulders and very long legs, all this to carry at least eighteen stone; but it was nearly, if not quite, thorough-bred.' Certainly no good horse, no horse at all one might say, could well have a more extensive collection of bad points than this. The bad shoulders, for instance; what man, unless he 'knew something,' would buy a horse to ride, let alone to ride to hounds, with bad shoulders, the very first qualification, as is universally agreed, for carrying a saddle with comfort and safety to its occupant? Emblem, that famous steeplechasing mare, was saved by her shoulders. With her light middle-piece, and badly ribbed-up, she was anything but a promising beast to the eye. Yet she won the Birmingham, Derby, Liverpool, Doncaster, and Cheltenham Steeplechases in 1863 , and in 1865 the Leamington and Cheltenham Grand Annuals. 'She won her steeplechases,' wrote her owner, Lord 
Coventry, to Mr. Sidney. "at her fences: and I attribute her extraurdinary 'fuichness in jumping to her shoulders.' Ciayman, the fatvourite mount of the gimt 'Tom Edge, Assheton Smith's silent friend, was, in I ick Christian's graphic phrase, 'a (pucerlooking creature, thin neck, larese head, raw hips, and a rat tail, for all the world like a serenteen-hands doy-horse; ' jet, in a

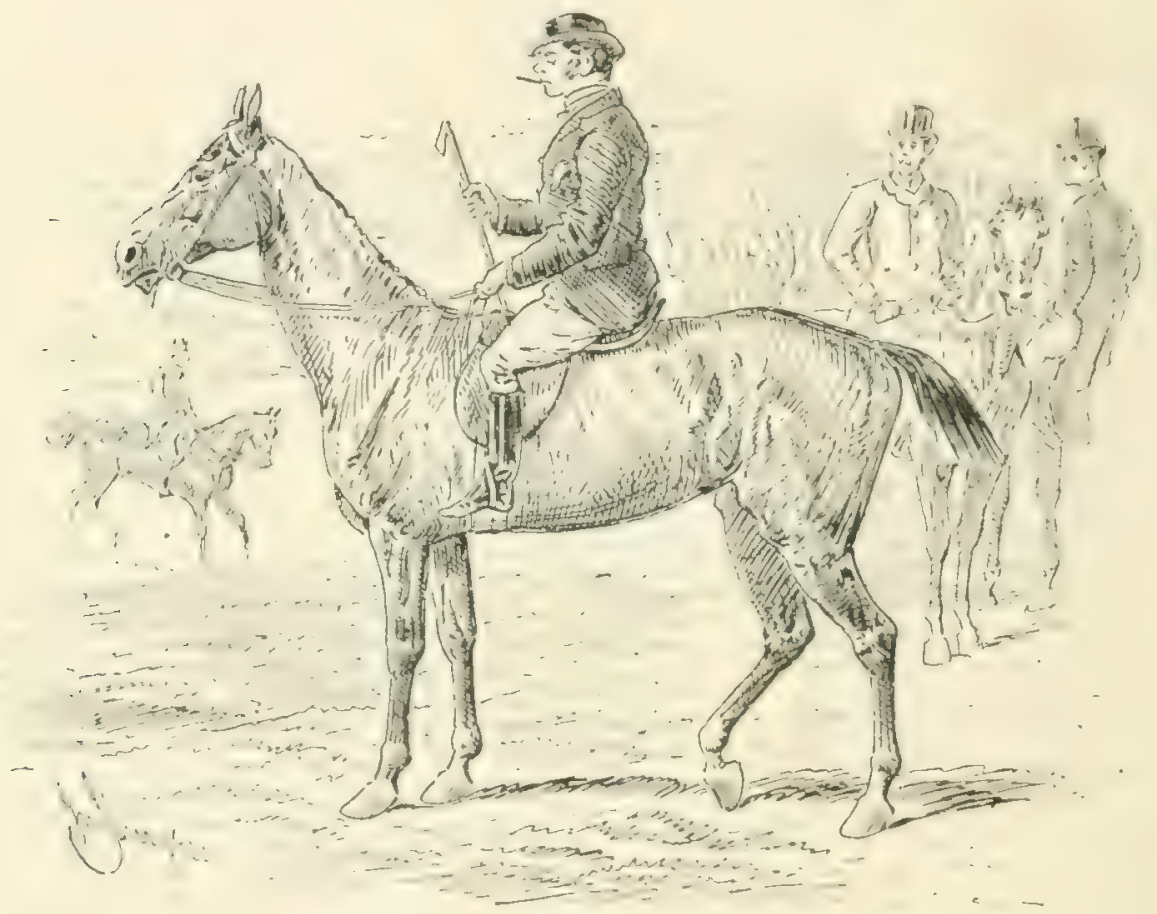

'An extensive collection of bad poinis.'

famous I, cicestershire run, thirteen miles from Botany Bay to Slawiton llindmill, only four men saw the fox killed, and Edge on Gayman was one of the four.

The northern countics have from time immemorial been the best nurseries for hunters. In the seventeentle century the fame of Malton and Richmone? fairs was great : the latter was held

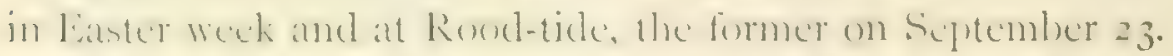

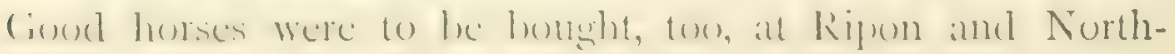

I The Book of the Horse, ch. iv. 
ampton.' Horncastle Fair, held between the roth and zoth of August, was for long the most celebrated for all kinds of norses. But the plough has rather spoilt the I incolnshire breed, once the first in the world for hunters, both in quantity and quality; the hunters bred there are sill wonderfully good, but there are not so many of them, and Howden, in the Fast Riding of Yorkshire, where the fair begins on September 25 and lasts for fourtcen days, has rather usurped the fame of IIorncastle. At Newcastle-on-Tyne, in August and October, and at Rugeley, in Staffordshire, in the first week in June, there is also much buying and selling of horseflesh. At Cahirmee, in county Cork, there is a well-known fair in July, and one at Ballinasloe, in county Galway, in October. Whyte-Melville maintains that 'handsome, clever, hunting-like animals, fit to carry thirteen stone, and capital jumpers, at reasonable prices, varying from one to two hundred pounds,' are still far more plentiful in Ireland than in England. He adds this too: "They possess also the merit of being universally well-bred. Till within a few ycars, there was literally $n$ cart-horse blood in Ireland. The "blackdrop" of the ponderous Clydesdale remained positively unknown; and although the Suffolk Punch has been recently introduced, he cannot yet have sufficiently tainted the pedigrees of the country, to render us mistrustful of a golden-coated chestnut, with a round barrel and a strong back.'

But buying a hunter first-hand at a fair is, of course, a tremendous lottery even for the kcenest and most practised eyc. Even if your eye tell you true, if the material is got ready to your hand, there is the making it up. Ready-made hunters are not bought at fairs. The farmers go there to pick up promising three- or four-year olds, giving from Sol. to I $20 l$. for them, hoping after a year's schooling or so, either at their orn or a breaker's hands, to sell again at a good profit. The dealers go there not so much to buy as to see what is bought, to mark the likely ones down, and be able to lay hands on them afterwards when the hour comes and the man. But if you go into the lottery yourself

1 The Hunter: a Discourse of Horsemanship, 1685. 
you must take your chance. How many hunting men, even if they have the skill and the patience, have the time needful to make a young horse? Hear Dick Christian on the subject:

When they're taken into the stable, give them plenty of air and walking exercise three or four hours each day; whatever you do never make them sweat. Give' $\mathrm{cm}$ an ounce of sulphur and half an ounce of nitre in their corn twice a week; for the first month I like new hay better than old, but it nust be the very best. Give them plenty of walking exercise up hill, and now and then give them a trot, but not too much of it. You may increase it by degrees; then walking over ridge and furrow is a grand thing to give them action. Action's the thing; if they haven't got it, they're like a pump without a handle, blessed if they ain't. The less you gallop hunters the better; all you want of them is to be in good condition, and fresh on their legs. It's all very well galloping racehorses if you like; but no horse should go very fast or know their best pace till they're put to the test. There's many a good horse spoiled by them tricks. I says, let me have a horse a bit above himself; he's much pleasanter to ride, and better able to do a right good day's work. Never press a horse very hard going down hill; it beats them far more than if they go fast up hill. When I wanted them to leap, I always took them to a very low bar, knee high; hold them there till you get him on to his hind legs, then let him go; likely as not he'll drop on the bar; take him to it again and again; if he turns a bit nervous, wait with him; when you've got him to go from his hind legs, then start him the same way with water, four feet wide. I was very fond of beginning them with a bit of timber like the body of a tree in a park. They can't gret a leg in ; if they force themselves agrainst it they pick over; they must spread themselves. When you get him to the fences begin with small places; first walk him to them; then trot him; you'll soon find you may take him at them any pace you like. It's only confidence he wants; then you may take liberties with him, but do it in good temper, and keep lim in the same. He'll soon get confidence for the stitchers. Whatever you do, never go fast at them ; don't go too slow or he'll ston; and many horses have becn spoilt that way; give him time to ret his hind legs under him; if you're too slow they buck, jump short, and don't spread themselves, and then down you both goes. When you takes a horse at his jumps hold him steady by the head, not puiling him hard; the longrer you hold him steady the farther 
he'll go. A horse doesn't jump the farthest by going over fast at his fences, or water; he wants to gret his stride well up to them; he can't go to last long if he's not kept collected; he'll soon be beat, particular in deep ground, and ridge and furrow. When I go to try a horse on such like ground, down hill is what I choose: if they have action to do that all right, they will make something. I don't care anything about up hill. . . . I never used thick bits. Nearly all horses ride better with a curb than a snaffle; but mind you never use too sharp a one; they only irritate the horse. I always puts the hunting curb on the first time with young horses; you must let 'em have plenty of liberty to play with the bridle, but mind as his tongue don't slip under the bit ; this is the most consequence of anything. .... When your horse refuses his fence never spur or maul him about; they doesn't know where they are and comes to no good. They want a bit of riding after all this to get them into form for a lady or gentleman. I trot them with the right leg first, head a little to the left, and quarters to the right. Then I takes them into some riding school, and rides them round and round, right-hand way; first walking, then trotting, not too much of it. Pet him and chat to him a bit, and give him a piece of carrot with your left hand; I've had a good ton or two of carrots about me one time or another. IVhen you begin to canter him round, get him on to his hind legrs, and go as slow as you possibly can. Be uncommon quiet with him ; keep him right leg first; if he changes take hold of both your reins level, pull lightly with your right, and put your left hand forward on both reins, leaning down as much as required. ${ }^{2}$

The old rough-rider, it will be seen, begins at the very beginning, whereas a horse bought out of one of these famous fairs has probably had some sort of schooling. It is pretty sure, however, to have been of a somewhat primitive, and not quite sure to have been of the right sort. In any case it will certainly not have been such as to enable the purchaser to flatter himself that he has bought a hunter, though he may possibly have bought the materials for the best a man ever threw his leg across. It Is, then, clear that to look for your hunter in these quarters, apart from its intrinsic hazard, cannot be recommended to any man who has not a great deal of time on his hands, a stock of patience beyond that enjoyed by the most part of humanity, and 
also a sufficient quantity of matured horseflesh to supply his wants till the new purchase shall be ripe for business. At the same time the pleasure of fitting yourself in this fashion is not to be gainsaid, nor the profit-when all turns out well.

But how impertinent do all warnings seem to the inexperienced man, when once he has screwed his courage up to resolve on venturing for himself into these perilous piaces. For timid as some are in these matters, when once this timidity is put aside, your 'green hand' is as 'cock-sure' as ever was Macaulay in his gayest moods. The world of horseflesh, by the way, was perhaps the only department of human knowledge in which that great man would at no time of his life have been confident of his supremacy. Only one instance is given in Mr. Trevelyan's delightful biography of his having been in the saddle, and that was on the back of a diminutive Sheltie, in one of his Scotch tours, while a huge native walked on guard at the bridle rein. Once, when he was setting off on a visit to Windsor, and it was intimated to him that a riding horse as well as a carriage would be at his disposal, as he might prefer, he made answer that, if the Queen wished him to ride, she must send an elephant with a howalah, as he could not undertake to keep his seat on any less secure conveyance. The inexperienced buyer, who scorns to put his trust in a friend's superior knowledge, is in the condition described by the poet:

Man never is, but always to be blest.

Strange stories has he heard, too good not to be true, of all manner of wiles and devices-of cheats, to put it plainlypractised on the unwary; but himself, he feels confident, is not to be thus imposed on. Yet what experience, what knowledge, what counter-cunning, shall avail to save him from such a fate as this, told in his pleasant autobiography by Mr. Yates on the authority of the late Sir Alexander Cockburn? IVe will tell it in Mr. Yates's own words, which are better than any we rould furnish :

1 Edmund Yales, his Recollections and Experiences, ii. 134-5. 
A man saw a very handsome chestnut horse at Iorncastle fair, and was astonished at the lowness of the price asked for it. After some chaffering he became the purchaser, takingr it without warranty or anything else; and having paid his money, he save a 'tip' of five shillings to the groom, and asked him what was really the matter with the animal that he should be sold so cheap. The man, after some hesitation, declared that the horse was a perfect animal with the exception of two faults. 'Two faults!' said the purchaser; 'well, tell me one of them.' 'One is,' said the man, 'that when you turn him into a field he is very difficult to catch.' 'That,' said the purchaser, 'is no harm to me, as I make a point of always keeping my horses in the stable, and never turning them into the field. Now of the other?' 'The other,' said the man, scratching his head, and looking slyly up, "the ether is that when you have caught him he is not worth a rap.'

The custom of zarranties, one may cbserve, has rather gone out of fashion now. Even when given with the best faith they opened a terribly wide door to litigation. No lapse of time puts an end to them, none, that is to say, by law defined. If a jury can be persuaded to believe that a horse who has become unsound as a three-year-old had the germs of his unsoundness latent in him when sold with a warrarity as a yearling, it is all up with the seller. And a 'British Judy' (to borrow Mrs. Crupp's time-honoured paraphrase), prone as it is to strange notions of things, is never, it may be parenthetically observed, so prone as in matters of or belonging to that noble animal, the horse. Sometimes a limited warranty will be given, valid for a month, or some period shorter or longer, as the case may be. But any such limit must inevitably, however unjustly, be touched with some sense of suspicion. An examination by a skilled veterinary surgeon, and a fair trial, are as good pledges as any warranty. They are what the best class of dealers generally offer, and what buyers will be wisest to take.

Buying at Tattersall's, or at any public auction, is of course something of a lottery too. But the chances against you here are much less, allowing of course that you do not neglect the ords nary precautions which a prudent man will observe in any trans- 
action. Indeed at Tattersall's it is mainly a question of money. The man, who does not mind opening his purse wide, will rarely fail to find himself suited, but he must open it, and wider too, it scems, every day. We are supposing of course, that he intends buying only such horses as come to the hammer with an established and trustworthy reputation : if he buys merely because he likes the look of an animal, whithout knowing more about it than the person in charge or some other equally interested and communicative individual may choose to tell him, heaven help him-we cannot. In every hunt there are always a certain number of good nags whose merits are well known, and whose price can be fairly calculated. There is no better chance, for a man who need not trouble himself cver-much about prices, for picking up a good hunter than this, nor does it at all follow that he will do better to buy privately than to wait and take his chance in the auction yard. When the stud is the property of some famous 'performer' in the grass countries, of course the competition will be brisk and the prices high. When the late Lord Stamford gave up the Quorn hounds in I863, and sent his stud to the hammer, the seventy-three horses realised nearly fourteen thousand guineas, an average of about two hundred pounds apiece, probably the highest ever known for so large a stud. In I 826 Mr. George Payne had reached an even higher average, but with a smaller stud; his twenty-seven hunters and hacks realising a sum of seven thousand five hundred guineas.

In the autumn of ISS t the stud of a young officer, who had had to give up hunting foxes in Leicestershire for hunting Arabs in the Soudan, was sold at Tattersall's at an average of two hundred and fifty pounds apiece. The pick of the famous Lord Wilton's stable brought as much as six hundred pounds !

It is probable, however, that first-rate hunters may be bought now for rather more rational prices than our grandfathers used to give. In the palmy days of the Old Club at Melton, the buying and selling of horses was quite a feature of the evening's amusement. 'Parties were often made on purpose,' say's 'The Druid,' 'and after a couple of bottles of 
claret, business became quile brisk. Each owner had oine reserve bid, and it was quite a sight the next morning to watch the different horses change stables, to the great buwilderment of the grooms.' The great time of high prices was in Lord Plymouth's day, who was never himself a particularly hard rider. Among his most costly freaks was giving 'the Squire' six hundred guineas for a horse which had already seen six seasons' work. He gave Sir Bellingham Graham one thousand guineas for a couple of nars; and Mrr. Peter Allix seven hundred for a mare he had only seen out once, and which proved a very bad bargain. A horse called Confidence, once, and more than once, the property of that rare old veteran Mr. Lackley, was sold many times over for all prices ranging from seven hundred and fifty to six hundred guineas, and once, it is said, to Lord I'lymouth for one thousand. The facetious Lord Alvanley was another who would open his purse as wide as it would go when the fancy took him. It is told of him that being asked once why he had gone out of his line in a run to get at the widest part of the Whissendine, he answered, 'What is the use of giving seven hundred guineas for a horse if he's not to do more than other horses?' Sober Robin, the famous nag on whose back the monstrous Dick Gurney used to go pounding along with a pound weight of gold and silver jingling in his waistcoat, was originally bought at Lincoln Fair for eighty pounds, and sold to Mr. Gurney for one hundred. $\mathrm{He}$ is described as 'a handsome, short-legged brown animal, perhaps a trifle under sixteen-one,' and for twelve seasons he carried his owner's nineteen stone to the front orer the. Northamptonshire pastures. The most wonderful feat the pair ever performed has been thus immortalised by our useful friend. 'The Druid' :

Sir Charles Knightley's leap of thirty-one feet over a fence and brook, just below Brixworth Hill, has ever since gone by the name 'Knightley's Leap.' It was accomplished, we believe, on his celebrated black horse Benvolio ; but he was on his nearly as famous bay, Sir Marinel, when he led MIr. Gurney, on Sober Robin, over a 
gate such as a nineteen-stone man has never yet jumped, and never will again. The Pytchley had a fast thing from a gorse of

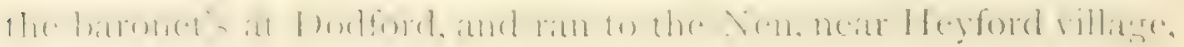
where there is a bridge across the river, and a six-barred locked rate in the midelle of it. They were just rumning into therr for,

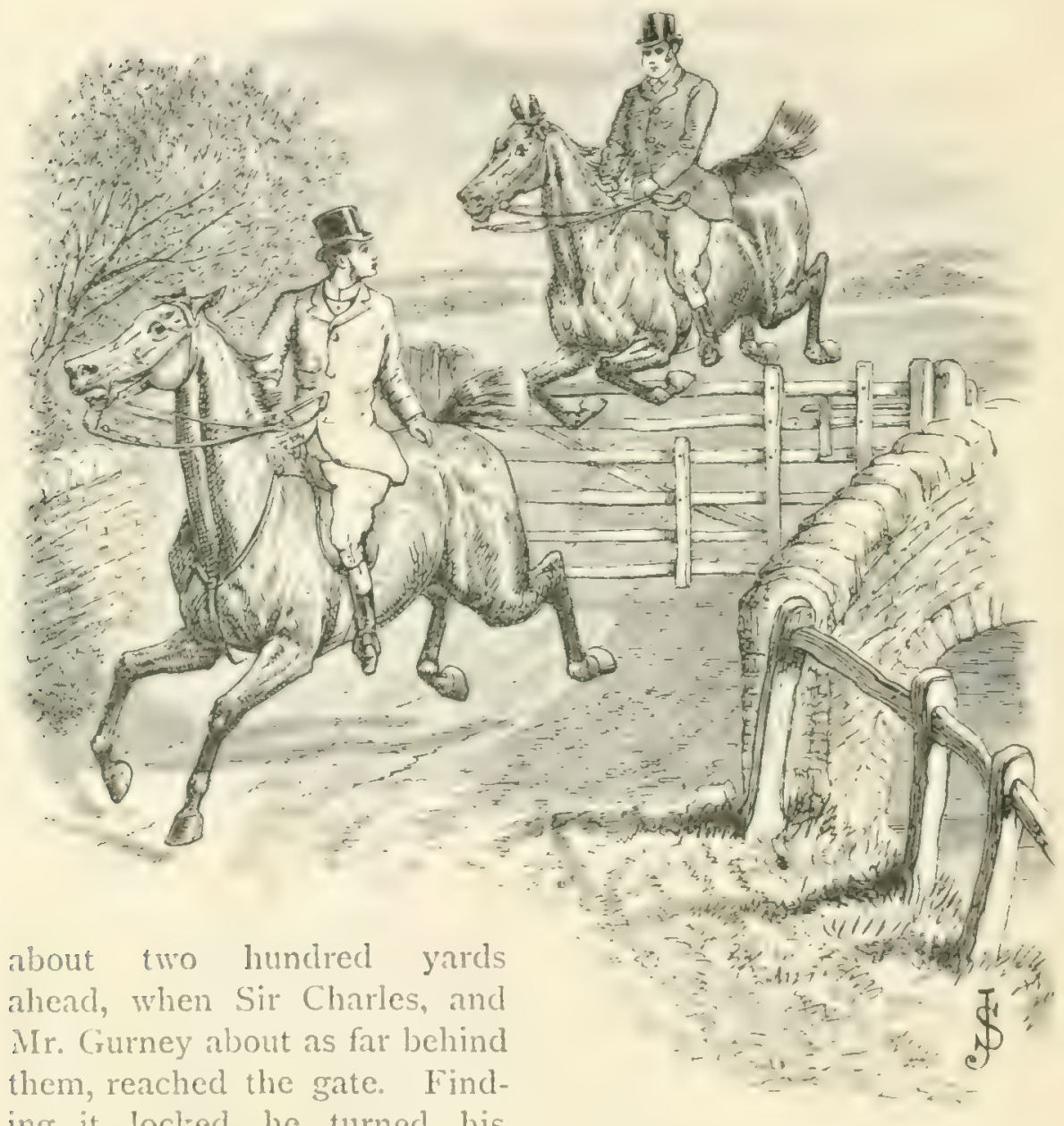
ing it locked, he turned his horse round and went over it; and to his amazement, as he

' The horse rapped it like thunder with every leg." slanced back, the Norfolk welter and his horse were in the air. Fortune favoured them, and athous kehin mplocel it like thunder with every les, they landed safe. 'What do you think of that?' was the question put to Parson Walker. who would not have charged a hurdle for a 
bishopric, at a county table that evening. 'Why, that my' friend Dick has more guts than brains,' was the prompt reply.'

Buying from a clealer is a difficult matter to treat of. Many and many a good hunter has been bought in this way, for not a penny more than he was worth, and many and many a one will so be bought hereafter, no doubt. Nevertheless, you must remember that you are buying on the responsibility of one man's word. 'The dealer has probably bought this horse in one of two ways : either at first hand, from out of one of the large fairs, or from some farmer who has done so, and then kept the nag by him to grow in wisdom and stature. In either case the dealer cannot well have much more than faith to go on, for his estimate of the animal's powers. No doubt he believes thoroughly every word he tells you : far be it from us to disparagre his honesty, and indeed, we consider a horse dealer in a large and thriving business to be as honest as any tradesman of his inches, though, no doubt, the atmosphere of the stable and 'the rattle of the hat' does exercise an untoward influence on some men's moral natures. But it is obvious that, whatever a man may think and honestly believe of the possibilities of a horse, his belief must have less practical value than the public estimate formed of a horse that has been ridden in the face of day, and several hundreds of prying eyes, by a good man to a good pack of hounds across a good country.

That experienced judge of horseflesh, who wrote under the name of 'Harry Hieover,' has observed : 'My first, best, and most strenuous advice to any man wanting horses, not being a thorough, good, practical judge, yet wishing to keep the money together, I shall write in large characters - NEVER BUY FOR YOURSELF.' 2 To get a friend who has the qualities you lack to put them at your disposal is, no doubt, much to be recommendedif you can find such a one. To be asked one's opinion is always fattering in any matter, and especially in the matter of horseflesh, wherein judgment and shrewdness, the capracity for

1 The Post and Padduck, ch. xili.

The Pocket and the Stud. 
not heing done, is by many people supposed to grive a stamp of very superior intelligence indeed. I3ut it does not follow that the man most ready to give his opinion is the man best qualified to have ar opinion worth giving. Perhaps one might, without much exaggeration, say rather the contrary, for there are not, we think, many men who have had experience in these delicate matters who would care a second time to subject themselves to the terrible ordeal contained in the seemingly simple phrase, buying a horse for a frind. For our own part we would far sooner select a wife for a friend than a horse: at any rate, we should not be expected to get rid of the former, if haply she did not suit, as would be nine times out of ten the case in the latter bargain.

If a man does not dare to rely on his own judgment, and does unt know exactly where to lay his hand on the animal he wants, and cannot find the friend wise enough and daring enough to act for him, perhaps he cannot do better than put himsulf in the hands of a respectable dealer. After all, to put the case brutally, it must be most to the latter's interest to treat his customers fairly. The buyer will of course consider the limitations above indicated in the erent of his being recommended an untried horse. He may possibly do well aiso to consider if the horse offered to him has a very shining reputation. Dealers are fallible as well as their customers, and may, themselves, have been sometimes a little too ready to listen to the voice of the charmer. One is apt to wonder 'how the devil it got there' when one finds a horse with very' splendid testimonials in a dealer's stable; it is not impossible that the testimoniais, true as grospel, as in their day they may have been, may be found on trial to refer rather to the past lime than to the future. But, when all is said and done, a man who is quite certain of the sort of animal he wants and the sort of price he intends to pay-simple pieces of knowledge in which so many buyers are so curiously deficient-will froluably not go very fas wrong to trust to a good dealer. There are a fair proportion of them to be found, and some, of course. 
not (quite so gond. It would obviously he unwise to mention names, but at least there need be no dificulty even for the veriest tyro in assuring himself where not to gro, and it has been justly said that 'to know what to avoicl. to know where at least not to go, is perhays the first stej to an arlvance in the right direction.' It would be only, we trust, an insult to our readers' common sense to impress on them that the advertisement columns of the newspapers are not the yuarters in which to look for good horses. Finally, let the buyer remember these simple facts: that he must not expect to buy a swan at the price of a goose: that a horse who is a notoriously brilliant animal in one man's hands is not necessarily the same in another's : that when he finds he has got a really good animal, even if it be not gifted with the exceptional properties of Lord Barrymore's facetious ideal, he will do well to let no offer tcmpt him, and no caprice move him, to part with it. 


\section{CHAPTER VII}

THE RIDER.

THERE is a story told of a certain highwayman, very famous and skilful in his profession, who, after a long and successful career, was at last brought to book.

The charge is prepar'd; the lawyers are met;

The judges all rang'd-a terrible show !

and, after all due preliminaries, the gallows are reached. Before the hangman advanced to play his part on the body; the chaplain was busy, according to custom, with the soul 'Do you repent of your past life?' he asked. 'I do,' was the answer, 'I repent unfeignedly. And yet-a gallop across country by moonlight! -oh, you dog, it was delicious!'

Delicious, indeed, is a gallop across country under certain conditions, among which-now that the 'Knights of the Road,' together with many another more reputable fellowship, have become

\section{Portions and parcels of the dreadful Past-}

few of us would probably care to place moonlight. 'lo be sure, such is the good nature and keenness of their master, the I) uke of Rutland's hounds have been known to kill their fox 'on a shiny night,' as the old song says, and once, indeed, if not more than once, even to find one; so that it has become a frowerh throughout his country that you are always sure of a run with the Belvoir, if you will only strip out long enough. A famous steeplechase, moreover, was once ridden under the 
rule of the 'Sweet Regent of the Sky,' and has recerved immortality from the hand of Alken. But then the riders were dashing young dragoons, and that branch of the Lnglish service has ever, as we know, been ready to go anywhere and do anything-to say nothing of the very stimulating mature of the jumping powder suprlied by a Cavalry Mess. But we may fairly assume that, on the whole, we will not say sunlight, as in this desperate climate of ours too narrowly circumscribing our possibilities, but daylight, let us say, will be found most favourable to feats of equitation.

But delicious as a gallop across country undeniably is to a good rider on the back of a good horse with, as an enthusiastic writer has expressed it, "the best fellows in the world to the right and left, but never a soul 'twixt yourself and the hounds,' it is no less capable of affording serisations the vary reverse of delightful. Everyone remembers Leech's picture of the unfortunate man going down hill at a slapping pace over ground studded with mole-hills, on a straight-shouldered ewe-necked brute ridden in a single snafle, one foot out of the stirrup, his hat off, and a dab of mud in his left eye-a combination of miseries said to have originated in the lively imagination of 'Jem' Mason. The tastes of men are notoriously various and surprising; but it is difficult to imagine any person in such a situation describing his gallop as delicious. It would be an interesting subject for discussion in one of those 'symposiums ' which at one time crept into our periodical literature, the relative amount of pity given to the good man mounted on a bad horse, and the bat man on a good horse-the man who could make everything of his chances if he had them, and the man who can make nothing of the chances he has. To be sure, one has often heard of the man who can get to the end of the hardest run on a horse which others have never been able to persuade over a single fence. but in that case we may be pretty sure that the animal was not primarily to blame : the possibilities were there, they only wanted dereloping. 'I sold you a horse, sir,' said once a 
famous rider to a rather indifferent one who was inclined to grumble at his purchase, 'but I did not sell you the gift of horscmanshiy:" ()n the other hand, a really bud num will newer

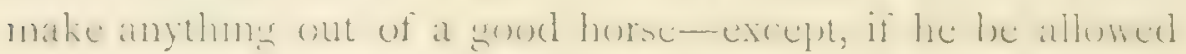

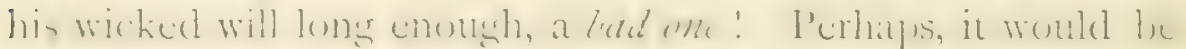
silfest to sily that, in the first calse, one fities the nuan nost, in the second, the horse.

What is a bad man? We are not about to discuss the question from a sunday-school teachers joint of ricw; undul ats

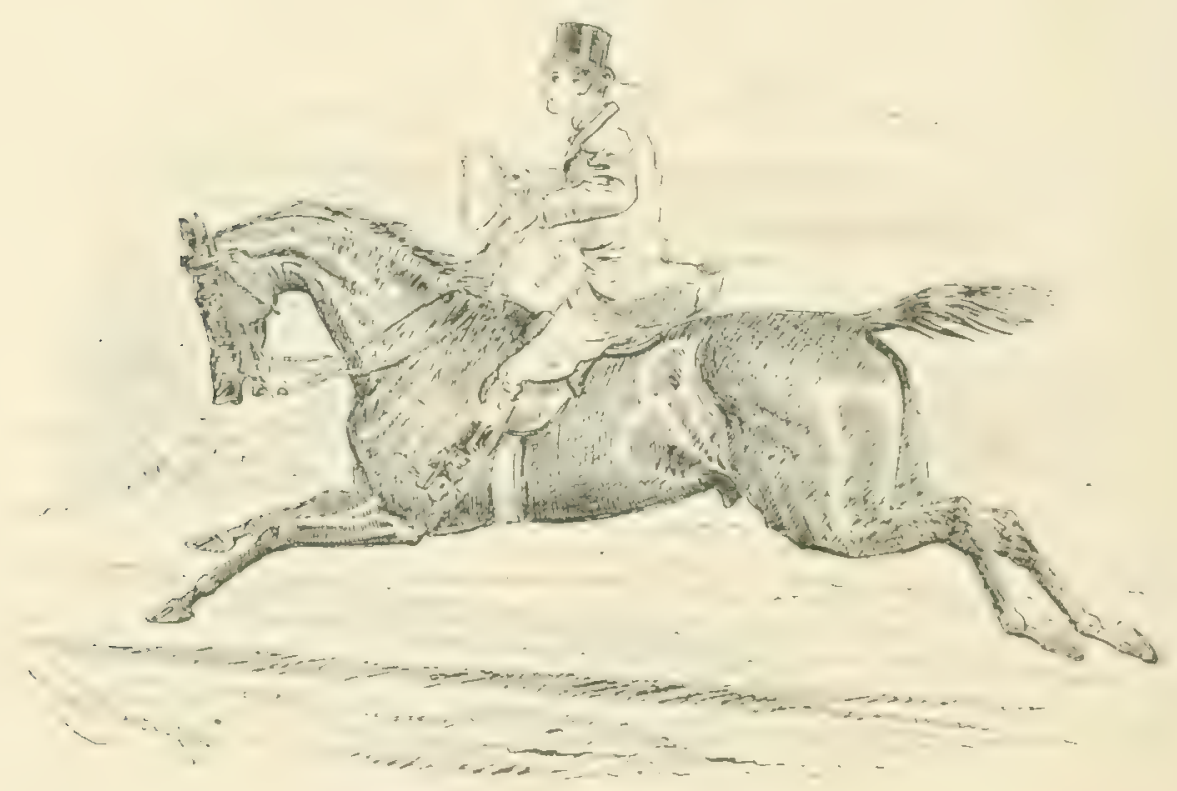

' $A$ bad man on a good horse.'

that would in its own way be; but as in our last chapter we cxposed the various points of badness in a horse, so now we propose to treat the rider to the same process. So often one

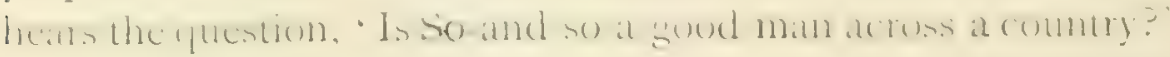
and the answer, 'Yes' or 'No' as the case may be. Now, if Soand-so be not a good man, it is clear he must be a bad man.

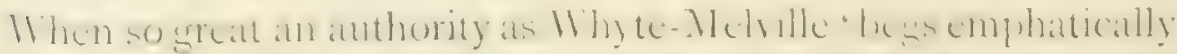
(e) dhe laim any mention of laying down the lat on such a sub- 
ject as horsemanship,' it behoves every writer to be careful. To tell a man what he ought to do, is one thing ; to teach him huid he ought to do it, is another, and a very different thin's. "livery man,' says the same master of the game, 'who) wears spurs believes himself more or less an adept in the art of riding.' For adepts it would obviously be as presumptuous as useless to write. But to briefly and gently indicate to those who are not yet adepts the chief points to be avoided, may possibly best serve to put them in the best road to become such.

There are, of course, various degrees of badness. A rider is not necessarily a bad man because he is not always in the furst flight, nor need he even merit the epithet if he be never found there. On the other hand, a 'thrusting scoundrel' is by no manner of means to be accepted unreservedly as a grood man. When the 'Spectator' paid his famous visit to Sir Roger de Coverley he was so enchanted with a day's hare hunting his host showed him (our humanitarians will be delighted to hear that the grood knight's 'stop hounds' were not permitted to kill their game) that, regardless of l'ascal's contempt for men who could 'throw away so much time and pains on a silly animal which they might buy cheaper in the market,' he registered the following resolve: 'For my own part I intend to hunt twice a wcek during my stay with Sir Roger; and shall prescribe the moderate use of this exercise to all my country friends, as the best kind of physic for mending a bad constitution and preserving a good one.' Now the 'Spectator' by his own confession was anything but a hard rider. 'My arersion,' he says, 'to leaping hedges made me withdraw to a rising ground, from whence I could have the pleasure of the whole chase without the fatigue of keeping in with the hounds.' He made no pretence of riding ; he went out for his health's sake, and for the novelty of the diversion, leaving the 'honours' of the chase to more daring spirits. Nutrue sportsman would despise such a man, any more than he would find in his heart much praise for hin who gauged his day's sport by the size of the fences he had junped and the number of his friends he had cut down. Hunting is the 
amuscment and not the business of a gentleman. The is at perfect liberty, therefore, to pursue it in the way which pleases him and suits him best, provided, of course, the gratification of his own tastes is compatible with the equal liberties of others. If he lilie best to ride the roads, or, at m st, malie his careful way through an ocrasional app, by all means let him do so; he will not, perhaps, see very much of the sport, but that, after all, is nobody's concern but his own. If, on the other hand, it is his orimion that huntirg can yicld no amusement deserving the name to anyone who is not in the same field with the hounds, arain by all means let him get there and keep there-if he can. Of the two classes into which hunting men may be broadly divided, the men who ride to hunt, and the men who liunt to ricle, it should always be remembered that the sfortsman, as distinguished from the mere hunting ma!n, will be found in the former. The latter, lowerer, may be further subdivided. There are those who hunt for the sheer sike of riding liard. In the list of their amusements fences occupy a much more prominent flace than foxes or hounds, and who would regard the fastest and strilghtest gailop in the world over the Berlshire or Sussex downs as great an infliction as a blank day in Leicestershire. There are those again who, like the good 'Spectator,' make no account of glory; who, if they successfully negotiate an accommodating sheep hurdle, are inclined with I ogrberry" to give God thanks, and make no boast of it,' and if hounds aill run away from them, follow the advice of the same sagacious philosopher and 'let them go.' Such men hunt for the sake of the exercise, the fresh air, the pleasure of meeting their friends, the diversion from the routine of every-day life. Often enough they are grood sportsmen, too, and if they scidom, perhaps, see a fox handsomely lilled, crijy as much as anyone ts, sce him hand. somely found. livery hunt knows one or more of such men; men who know the nane and fedifree of every hound in the pack, the line from erery curert, the most practicable place in every funce, the ford w every brouk, every gate and every byroad in th whole country. Uften thus, without risking then 
necks more than, if as much as, we do every time we get into a flansom cab in the London streets, they will sece far more of the day's fun, and give a far better account of it, than the most persevering and dauntless of 'bruisers.' Honest, reputable, and blameless members of the great community of fox hunters, enjoying themselves without any pretence or parade, jealous of no man's glory, interfering with no man's sport, they are entitled at least to our hearty respect if not to our admiration.

But the man who is not entitled to our respect is he who de's make parade and pretence; who at the covert-side is a thing of beauty, indeed; who from the crown of his glossy hat to the sole of his yet glossier boot is, sartorially speaking, the ideal man, whole, complete, polished to the finger nail. 1)ecked with the sweetest and choicest of flowers, soothed and supported by the largest of cigars, perched on a nag fit to carry Casar's fortunes, he is by far the most conspicuous and splendid object there, till the fox is found, and then--becomes conspicuous only by his abscnce. Not that dandyism is in. compatible with the hardest and straightest riding. "The records of the hunting field have proved that over and over again, and prove it every day, just as in that larger and bloodier field of which it is the image, the dandies have ever held their own since that famous day in the pass of Thermopyla when the Persian looked with awe on the Spartans dressing their long hair for their last battle. It is the business of every gentleman to dress himself as well as his means will permit, and in the fashion which the custom of his day prescribes. A conspicuous disregard of custom is just as contemptible a form of affectation as a too siavish adherence to it; and he who noisily affects to despise the sumptuary amenities of his time is influenced by precisely the same motive as he who carries their obserrance to a point beyond the limits of taste and reason-namely, a vulgar affectation of singularity. Brummell does not seem to have been a very wise man; but he was wise, at least, in his own affairs, when he said that the best-dressed man was the man whose dress attracted least notice In these 
soler-suited days a certain amount of splendour mest necessarily scem to belong to the hunting field, and the dandies of Melton and Market Harboro' are, no doubt, very great dandies incleed, as were their fathers before them. Liut when they can carry their splendours well to the front for forty minutes from Ranksboro' Gorse or the Coplow, nor fear to suirch them in the murky waters of the Whissendine, or the bullfinches of Ashby Pastures, no one would think of cluarrelling with those minute and various sacrifices to the graces which your true hunting dandy would as soon think of omitting as he would of turning aside from a nasty place for fear of soiling their beauty. It is only when those splendours are seen jogsing along lanes, or waiting their turn at gates and gaps, that they have the effect of making their wearer ridiculous. In the humting freld, as everywhere else, a humbug is a bad man. If your style of riding be quet, it is well that your appearance should be "in concatenation accordingly.'

No man, then, deserves to be ridiculcd or dejpised because he has not the courage and the skill necessary to enable him to ride close and straight to hounds when they are really running over a strongly fenced country, provided always that he is careful not to assume the virtue that he has not. It is clear that if it were to be regarded as a canon law of hunting that no man should make his appearance at the covert side unless he be prepared to follow the fortunes of the pack to the bitter end, like the lover in Moore's poem,

Through joy and through torment, throush glory and shame,

a sreat number of honest souls would be arbitrarily deprived of an innocent and healthful amuscment. Nay, it will often happen that a man who can ride, and does when the fit is on him, for some reason or other-disinclination, ill-health, a disappointment in the stalse, or any of those thousand and one ills to which fox-hunting tlesh is heir - will for the nonce cuntent himself with the part of spectator from the back of some safe and quiet hark, or pusibly cren an whed:. Surh a one will, 
of course, linow well how to behave himself in such circumstances, but for the benefit of the less initiated, the more uniformly unambitious, a few simple rules may not be out of place.

The first advice we should be inclined to give to a stramer in the land would be follow' a leader-advice, we may observe in passing, which holds good alike for those who intend 'groing' as for those who do not. However experienced in the art of road-riding a man may be-and an art be assured it is-however keen may be his eye for a country, it is tolerably clear that if he has never been in that country and along those roads before, there is likely to be disappointment somewhere before the day is over. So long as the disappointment is individual only it is of no particular moment-save to the individual. but he who trots along strange roads in pursuit of his own nose, knowing not where he is going, or, more important still, where the fox is likely to be going, may not at all improbably find himself sooner or later in the unenviable position of 'the man who has headed the fox' - words which may hardly even be written without a sense of unutterable misery and shame. Even when by some untoward train of circumstances beyond the best sportsman's control he finds himself in this humiliating position he must expect scant mercy or justice. But when he rides into it along a line of roads, when, in short, he has spoiled other people's sport, as he will probably be told, because he dare not share in it himself, then his case is desperate indeed. 'Hanginis,' as that eloquent nobleman Lord Scamperdale once observed, 'is too good for him.' But we have said enough : it is, indeed, a situation

To be dreamed of, not to tell.

The unaspiring adherent to Macadam will do well, then, to provide himself with a leader, and he need never be at a loss to find une. Every hunt has one or more skilful and well-trusted plots, who will be able to show him all the sport possible un such conditions, without risking his own neck, or spoiling the fun of others. Should he, however, by some mischance find 
himself left to his own gruidance, rencmulner this : always to heep well down wind, to have his eyes weil in front of him, and his cars well open, whereby he will not only aroid any too sudden intrusion on the line, but may even prove of some use at a critical moment to his more daring neightours:

He who has watched, not shared the fight, Knows how the day has gone.

And it is very possible that the judicious roadster may be able on occasions to tell the huntsman a little more about his fox than that functionary is always in a position himself to know. finally-and this for his own especial comfort and safetylut him remember that, as has been pertinently observed, the man who nerer jumps at all can by no possibility be 'pounded,' and let him never enter a field without being as certain of his egress as of his ingress. In the hunting field, as clsewhere, half measures will always prove fatal in the long run. If he mcans 'going,' let him 'go;' if he means riding the roads, let him ride them. Not to every man falls the luck that fell to Mr. Sawyer on the memorable day he rode Marathon to sell. But to turn to the riders.

Egerton Warburton has, with his usual dexterity, hit off the ideal of a 'good man to hounds :'

Give me the man to whom nought comes amiss,

One horse or another, that country or this;

Who through falls or bad starts undauntedly still

Rides up to the motto, be with them I will.

It might be broadly said that the opposite of this ideal would be a grood definition of a bad man. The man who never gets a start, who is always falling, who can only go well on a particular sort of horse, over a particular sort of cuuntry, on a particular sort of dity-one could hardly with truth speak of such a one as a 'good man to homds;' however forward he might show when all his necessary conditions were granted. But lower still in the scale, and far lower, comes the man of excuses; he who has an explanation for every contingency, a 
reason why for every mishap. Now his 'confounded fellow' has given him the wrong bridle, now the wrong sarldle; this time his stirmps are too short, that time his curb chain was too tight--the lineal descendant of Captain Guano, that clistinguished follower of the 'Mangeysterne' hounds, may he. met with to-day in every county of Fngland. Sometimes a hound crosses him at a critical moment; sometimes his good nature prevails, and he forfeits his place, if not his day's sport, to help a friend; at others, just at that precious moment when the crowd have been choked off, and the real good ones have settled to their work, he loses a shoc. Of this favourite device to conceal the failings either of horse or rider, an amusing story is told. During a very fast and straight gallop in Leicestershire a rider was observed walking his horse leisurely down a field towards a stiff fence, holding a shoe in his hand. 'What's the matter?' hailed a passing friend, 'why' don't you screw him at it?' A sorrowful shake of the head, with a demon. stration of the shoe, was the only answer. "Why, my good fellow' observed a too curious third party, 'your horse has got four shoes on!' In short, with men of these delicate susceptibilities, everybody and everything is to blame except their own want of pluck, decision, or skill.

No doubt the first essential to a good rider to hounds is courage. True, courage alone will not make one, but without courage, it may be said that all other qualities, the finest hands, the firmest seat, the surest judgment, are of no avail. Now, courage is of two sorts, moral and physical, and of these the first, in the hunting field as everywhere else, is the rarest. The man who has not the latter in sufficient quantity to enable him to make his way over a stiffly fenced country, may possibly have enough of the former to confess his wealiness. From such we withhold our contempt; though perhaps not our pity. But for one of these you will probably find twenty of those. How often, too, one hears it said of a young and inexperienced rider: 'So-and-so goes like a fool, who doesn't know his danger; wait till he has had a real bad fall, and see how he 
will go then.' 'The saying is ill-natured, no doubt, and ofter. enough contradicted by subsequent facts ; nevertheless it has a spice of truth in it. These two surts of courage, the courage of sheer innorance, rashness or foolhardiness, if you like to call it so, and the courage of judgment, which is the true couraw: are very fairly distinguished by the following story. On the morning of that famous Octuler day in Balaclava valley, after the splendid charge of our heavy cavalry had broken and scattered to the winds more than twice their number of Russian horse, while our I,ight IBrigade were waiting the fatal order which poor Nolan was to bring them, two grim war-worn veterans, as they sat on their horses in the ranks waiting for the next move, were watching a young troopur near them tickling his comrade's horse to make it kick. 'Look at Bill,' said one of them admiringly; 'ain't he a rare good plucked one?' ' T'ot a bit of it,' was the answer, 'he's only a fool ; he don't know his danger. Now you and I, mate, have been at this game before. We do know our danger, and cursedly afraid of it we are. Hut we can't run away, and we wouldn't if we could. We're the real good plucked ones.' It is probable that the young rider whose heart is really in the right place will in time acquire this better sort of courage, and that one or two rattling falls, instend of destroying his pluck, will improve it into that still more valuable and rarer quality we call nerie ; and thus will he develop into the first-rate performer who, thoroughly conscious of all the hazaris he runs, is determined to shirk none of them that are necessary, but who, by experience and judgment, has learned how far they may be minimised, and is equally determined to throw no one of his lessons away.

Nerve and pluck are two distinct qualities, though both belong to the ginus comare. Whyte-Melville very well separates them when he says, "The latter takes us into a difficulty, the former brings us out of it ;' and he groes on more minutely to define them thus: "I conceive the first to be a mural quality, the result of eclucation, sentiment, self-respect, and certain high aspirations of the intellect; the second a gift of 
nature dependent upon the health, the circulation, and the liver. Als minory to inagination in the student, so is nerie to fluck in the horseman. Not the more brilliant quality, nor the more captivating, but sound, lasting, avalable for all emergencies, and sure to conquer in the long run.' Probably no man ever role to hounds who united these two qualities in a more striking deyree than Assheton Smith, and his three favourite maxims were: Throu' your heartover and your horse is sure to followe; there is no place that you can't get ower with a fall; and no man can be callid a grood rider till he knows howe to fall.

Of the first and last of these maxims the truth is indisputable, and so, in a sense, is it with the second. No man, whatever may be the country he hunts in, can make up his mind to really see where hounds go and what they are doing, without taking falls into account. He must be prepared for them, and he will have them. Nevertheless the tyro will do well to remember that his primary business in the hunting field is to get over his fences zrithout falls; that the first and most obvious motive of the partnership between horse and rider is that it should be firm and lasting, not frail and intermittent. While, therefore, taking all possible contingencies into account, his first care should be to so manage matters that he and his compranion may encompass their fences tosether and not separatily. There was no spice of bravado in Assheton Smith's saying; neither, doing what he did, can he be held to have fallen unnecessarily. Whether he was hunting the hounds himself or not, his one fixed, unalterable resolve was always to go into the same field with them. Nor did he, as did most of his straight-going contemporaries, ride finished hunters, or as a rule give long prices. Some of his best nags were notoriously such as many men, and good riders too, could have done nothing with; some, indeed, are said to have been such as few men would even have cared to mount. 'He entertained,' it has been said, 'no fancies as to size, action, above all peculiarities in mouths and tempers. Little or big, sulky, violent, or restive, if a horse could galiop and jump, he was a hunter the moment 
he found himself letween the legs of 'Tom Smith.' Certainly no man erer put his therries into practice more zealously or more successfully than he. For nearly fifty years of his life he had ben a master of hounds. When close mpon his eightieth year, old 'lom Winufield. who had been with him when he liunted the ()uom, asticel him whether he rnuld manage 'them there big jlaces' as well as he did 'in old Jack O'Lantern's days,' and he could honestly answer, 'I hear no complaints, and I believe my nerve is as good as ever.' Only two years before he died he had no less than three falls in one day, and was none the worse for them! It has been computed that in the heyday of his fane his arerage of falls was from sixty to seventy a season, and he was never hurt but once! His light weight, his iron constitution, and temperate habits, served him well, of course; it may be admitted, too, that he was an exceptionally lucky man. But his cool head, unshaken nerve, and thorough knowledge of horses, had really enabled him, as one may say, to reduce the art of falling to a science, though it would have been difficult probably, for him or anybody, to formulate its precepts in words. One of his farourite rules was, when he fancied a fall was likely, always to put his horse at the fence asiant, so that, if his fancy was proved fact, the animal might keep at leant one leg free, and fall on its side clear of its rider. Another famous follower of this rule was Mr. Greene, the Squire of kolleston, who in his youth had sat at the feet of Mr. Smith. 'There are two other golden rules that the young rider will do well to bear also in mind: never to part company with your horse till the last mument, and nizer to leate go of the reins.

Granted, then, that the ricler has this primal gift of courage, and that he possesses both its component parts of fluck and nerre, or, as they may be now elegantly called, ralour and discretion, there remain to make him really a good man, seat, hands, judgment. The combination of all three in their proper degrees results in a perfect horseman.

of all these essentials the seat is the only one that can 


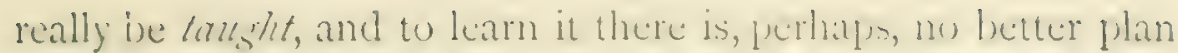
than to practse meling whthout stmreps. We are supposing, of course, that the peliminary education that most Enslish boys rercive either from their father or the family coathoman has not been newlected. In all athletic sports the child must be fither to the man. Without some experience at least in boyhood, no man is ever hkcly to attatin much proficicncy in the

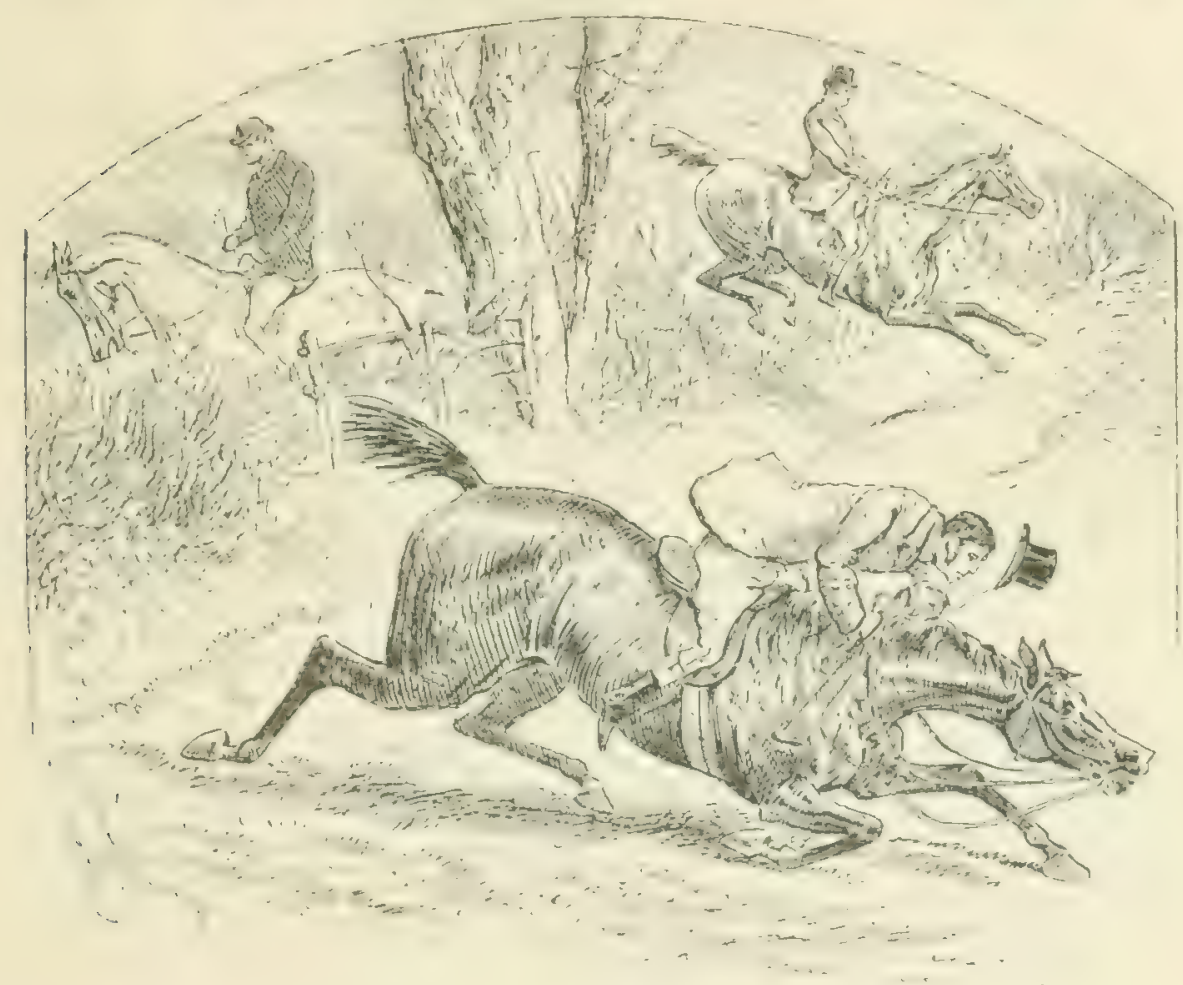

'Never part company till the last monent.'

sadelle, at any rate in the hunting saddle. But teaching, even in this matter, is only of avail up to a certain point, and after the young rider hats mastered his alphabet, so to speak, he must do the rest pretty much for himself.

To some men a good seat comes, as it were, naturally ; to others, on the contrary, it may be saict to come with great difficulty; as raciful seat perhaps nerer. Short less and round thighs are certanly terrible impediments cither to a form or a 
graceful seat; they tend to produce that most unlovely and unsafe appearance styled ly Sir Bellingham Graham a 'washball scat.' Still, even with these drawbacks, a man may leam how to sit in his sadule with comfort to himself and his horse (the one, as Mr. Jorrocks shrewdly obsurves, being 'in all humane probability' identical with the other), thoush he may not wholly saticfy a lady's eye for the picturesruue, if only he will set about it in the right way. It is probahle that the Athenians were not as eminent in horsemanship as in most other accomplishments; but no one can go into that room in the British Museum where the spoils of the Parthenon are stored without seeing at a glance that they knew well what a good seat on horseback should be. The riders in the famous Frieze bestride their steeds bare-backed and without stirrups, but they are one and all sitting precisely in the right place, that is to siy, in the iery contre of the saddle, did a sadcile form part of their equipment. 'The weight of the body is thus thrown on that part of the horse's spine, inmediately behind the withers, which is most capable of sustaining it. Starting from this point the most inexperienced rider will be surprised to find how easily his body adapts itself to the motions of the horse; starting from any other he will probably, and really not unnaturally, jump to the conclusion that he has heen cursed by fortune with an animal of annormally rough and unsympathetic fraces, the one horice in the world that 'no feilow could sit.'

Ijut a scat, to be a really good one, should be firm, as well as graceful, should be good to wear as well as to look at. Alore the waist the body should be light, supple, griving and laking with erery movement of the horse; below it should be strung as iron, and as unyielding. The distinction betwen rilling by srif and riding by lalance, on which a good deal of talk is sometimes expended, is a foolish one. 'As well,' ob-cres Ithyte-Melville, "might a man say he played the fiddle by finirer or by ear.' To insure a good seat there must be buth, and each in its proper proportion; balance above the ar?ile, srif lelow it inclecel, it is practically impessilste to 
really sccure the one without the other, as any man may prove for himself : the proper balance of the upper limbs can only be preserved by the firmness of the lower. One often hears of a resolute rider holding a shifty horse in such a grasp that, with the worst intentions in the world, refusal is quite out of the question. Now, this grasp is quite as much a matter of the legs as the hands, and a horse is quite as quick to understand and appreciate the meaning of the former as of the latter. The good Mr. Greene, whose hand and seat were so light as to have won him the nickname of 'the Fly,' always struck people as intimating his will to his horse more by knee-pressure than anything else. Most horses, it should be remembered, will gauge the quality of their riders in a much shorter time than the generality of riders will gauge the quality of animals beneath them. $\Lambda$ story is told of the wonderful sympathy Assheton Smith always contrived to establish between his horse and himself, which shows by what slight means this mutual understanding, when once established, can be maintained. He had mounted a friend upon one of the best horses then in his stable, Cicero by name. Hounds were running fast over the grass, and, as usual, Smith was at their stern, with his friend at his side. Before them stretched a most uncompromising flight of rails, which Smith saw was not much to the taste of his friend, and was likely, therefore, to prove equally distasteful to Cicero. As they neared the obstacle Smith removed the irresolution at any rate of the horse by the exclamation, 'Come up, Cicern,' and the moment that well-known voice was heard, all thought of refusal passed out of Cicero's head. The rails were cleared; but, as Cicero's rider was not quite so susceptible of sympathy, they were cleared, as one may say, in detachments, though luckily with no worse effect to the biped than a roll on the grass. A horse who has had any experience of humanity, as soon as his rider has settled himself on the saddle, will generally form a pretty shrewd opinion of that rider's intentions; and the way the human legs are placed against his flanks will help him to that opinion as much as anything else. 
The ease and security of the seat, as well as its appearance, will depend much on the lungth of the stirrups; and that will, in its turn, depend much on the conformity lioth of the rider and the horse. A m.un who his to contend against these natural olstacles to horsmanship, which we have already inclicated, will have to ride in shorter stimulys than one more suitally formed for the saddle. On a horse rather low in the withers, and rery strung in the quarters, shoner stirrujs, too, will be fomil necesary, however the man may be formed. It mity be taken as a good gencral rule for the majurity of men on the majority of horses, that that length of the stirrip) leathers will be found at once the most comfortable, and affording the firmest hold, which raises a man clear of his hurse's withers when he stands up in his stirrups with his feet home.

It will le hardly needful to expatiate on the inflections of the body necestary to preserve the eyulibrim while the horse is in the act of leaping. 'The mere instinct of self-preservation which is native in ewry breast would be suncient to teach this juinary hison, which indeed is generally leamt on the rider's fir.t nount, the nursery rocking horse; though, to be sure, one sconetimes sces it strangely forgotten in the hunting fiell. It may, however be worth while to remark that here again the mevement of the body should be mainly from the hips upwards. bown thence to the knce the legs should reain their uriginal jusition, hit from the knee, as the lurse descends, they should be inclined slightly bachwards. This, too, may seem a simple rule enough, almost an inevitable one: lout, as a matter of fact, onte wten sees it viblated, not only in the field, lut often in bouks, and nost oiten in the illustrations to books. If the feet be thrust forward, so that the whole leg be in a direct line from the hip downwards, the shock when the lorse lands, especially over a drop fence or on hard grome, will be so violent, that the ricler, if he does not actually lose it, will at least find some dificulty in keeping his seatt, besides ruming the risk, if the fence tua a high one, of stram or rupture. No man, if he leaps 
a fence on his own feet, comes to the stunnd with his legs in a stiff unyichling line-at any rate, if he does so once, he will take good care not to do so again; and the principle of 'give and take' holds equally good on horseback. We were lately' turning over the parges of the 'Life of Another'Tom Smith,' ' and came across a case in point. When this gentleman was hunting the Craven country, he came one day to the wall of Elcot Park, six feet two inches in height. The hounds made their way through the holes left at the bottom for game to pass, and the freld made for a door. Mr. Smith, however, rode at the wall. The first time his horse refused, but the second time they cleared the desperate leap. On reaching the ground on the other side, however, the horse's fore-legs gave way, and he came down on his chest, his rider's feet being dashed with such violence against the ground that when the rest of the ficld came round through the door they found him unconscious, and it was three weeks before he could get again into the saddle. 'This story is accompanied by an illustration from the pencil of the adventurous sportsman, and from his attitude in the saddle, the body thrown very far back and the legs thrust very far forward, the chicf wonder of the reader must be that Mr. Smith was not very much more seriously injured than he was.

Nor can the young rider be cautioned too much against that still so common practice of raising the whip-hand in the air while taking a fence. It not only prevents him from giving that support to his horse that may be necessiry on linding, but ii also throws the body off its balance, and, as a necessary consequence, tends to destroy the balance of the horse as well. It is really a more evil practice than that other one, which is occisionally seen, of grasping the cantle of the saddle. If any support is needed, placing one hand on the pummel of the siddle as the horse descends is far better than 'catching hold buhind.' This in the case of old and heavy riders, when 'creeping' a drop fence, may occasionally be condoned, though hardly recom-

1 Sporting Incidents in the Life of Another Tom Smith. This is the Mr. Smith to whose Diary of a Huntsman there is an allusion in ch. iv. 
mended; but the vilier, never. In rearly all the old hunting pictures, the riders will be seen not only taking their fences with their whip-hands high in air, but going at them in the same attitude, and no matter what the description of fence, always at the same headlong pace. Lilie the horsemen in Macaulay's poem who carried inland the news of the coming of the Spanish Armadia, these fiery riders are seen on the canvases of finteley' and Alken charging over the Leicestershire pastures 'with louse rein and bloody spur, as though each one har in his pocket any number of spare necks both for himself and his horse. It adds to the picturesqueness of the scene, no doubt, it maty also make the unskilful 'wonder with a foulish face of jraise ; but it will certainly make the 'judicious greve.' And if this were really the style of riding popular among those mighty men of old, the tales of their prowess must certainly lose a little of their currency. Remembering, however, Assheton Smith's saying, 'Whenever you see a man going a hundred miles an hour at his fences, depend upon it that man funks,' one may fairly suppose that the fault lay with the painters and not with their subjects.

To write of hands and judsment is indeed a difficult matter. One may write of them, of course, for ever and ever, but how little 'forwarder' will mere writing get our young friend! When Izilik Walton sat down to pen his 'Pleasant Curiosity of Fish and Fishing,' he first took care, like the wise man he was, to guard himscif about with the following precaution or "letter of advice' to his readers: "Now for the Art of catching fish; that is to say, how to nake the man that was none to be an Angler by a book, he that undertakes it shall undertatie a harder task than Mr. Hales, a must valiant and excellent fencer, who in a printed houk cilled a "Private Schoul of Defence" undertouk to teach that art or science, and was liaghed at for his labour; not but that many useful things might be learned by that book, but he was laughed at hecause that Art was nut to be taught by words, lut jractice; and so must Angling.' And so, with even more confidence maly we say, must Riding. Of all the inany and intucate sranches of the spunt wh hunting, there is 
none in which the old rule of the relative value of an ounce of practice and a ton of theory holds so grood as in that comprised under the head of Riding to Hounds, and of this particular department, again, incomparably the most dificult to treat of is that known as Ifand. One might say of it, indeed, as Mr. Matthew Arnold has said of the 'Grand Style:' it cannot be analysed or delined; it cin only be spiritully' discerned.

It is, perhaps, too much to say that the grift of hands, like 'reading and writing,' comes by nature; but it is certainly a gift that some men can never acquire, with all the experience in the world. Again, though one can hardly say that a rider blessed with a good nerve will also have good hands, it is pretty nearly certain that without the former the latter will not be found, or, at least will be found wanting when most necessary. Nerve and presence of mind are synonymous terms, and presence of mind is that quality which shows a man at a glance exactly what to do or, at any rate, what not to do, at the critical moment. Consequently an experienced rider with presence of mind and pluck (and the one can hardly exist without the other) will generally be found to have pretty good hands, a good seat being of course understood. At least, if he is not able to perform those wonderful feats with a horse's mu'th such as the late Lords Gardner and Wilton, for example, wer famous for, he will abstain from vexing, distressing, or flurrying h is horse. If he cannot always do the one thing needful at the: proper moment, he will do none of those many things that are not onily never needful at any moment, but absolutely fatal at all moments.

About as good a piece of gentral advice as could be given on this score to the young rider, if he be riding a trained hunter, whom he knows, and who knows him, would be to kinic him alone. Keep him 'in hand;' keep your hold of the bridle, and let the horse feel you have hold of it; the best and cleverest of hunters will want support at times. Moreover, as he is not gifted with the spirit of prophecy (though it is wonderful how near his instinct often approaches thereto), it is impossible for him to be quite certain what waits for him and you on the 
other side.' Your pint of vision is higher than his, and often the uncertainty becomes to you a certainty sooner than it does to him. You must be prepared therefore to stop him almost in the last stride if necessary, or at any rate to turn him, and this no man can do, however fine the mouth he has to deal with, however strong his own grasp, if he rides at his fences in that loose-reined fly-away fashion our clder painters were so fond of depicting. Dut supposing both rider and horse are willing to go, and the latter has proved his ability, then let the former leave him alone. A wise old rider was wont to say, 'People talk about size and shape, shoulders, quarters, blood, bone and muscle, but for my jart give me a hunter with brains. He has to take care of the bigsest fool of the two, and think for both!' A young rider will do well to bear this saying in mind, and believe that his horse knows more about the business than he does. Many of us have seen wonderful feats wrought in the hunting field by human hands, more of us liave read of them : horses all fire and fury made handy as poociles, sure-footed as cats, creeping up and down banks, squeczing between trees, and tripping in and out between doubles, crawling here, fying there, turned on half-a-crown, as the saying goes, managed almost like horses in a circus. Such things can be done, are done every day ; but such things, Oh young rider, you were best to believe as yet 'are not for thee.'

If your horse be well-fed, and in blooming condition, Well up to the country and up to your weight ; $\mathrm{O}$, then give the reins to your youthful ambition, Sit down in the saddle and keep his head straight.

1 A remarkable instance of this prophetic instinct is thus given by "The Druid:' 'As regards leaping, one of the cleverest things we remember was

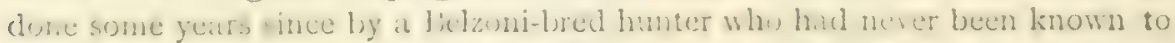
refuse a fence lufore. A lad of about fitcen was ridug him as straight as an

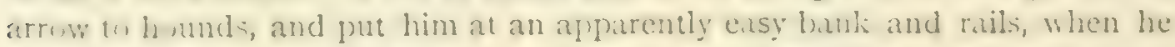
stiddenly cherl up in his stride abum twenty yards fiom it, and reiused to face it. ()n enminution there prover to he an old stone quaty on the other side;

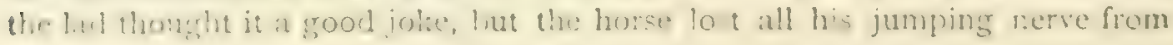
that hour. - The Post and the Padduck, ch. xii. 
While ambition is still youthful, it had hest, perhajs, be satisfied with the result of the conditions framed in these lines, remembering only not to give the reins too literally.

How often we hear a woman praised for her hands; how often hear it said that the gentler sex have naturally better hands than we men. I'artly, no doubt, this is because they are the 'gentler sex,' because they' have not the strength to pull and haul a horse about that we, alas! have. Iut mainly it comes from this, that they are content to leave their horses alone. Mounted, as they mostly are, and certainly always should be, on thoroughly trained and experienced hunters, they are satisfied to lenve everything to the horse; it is his business to carry them, theirs to he carried. Whether this happy state of confi. dence arises from their superiur tact, or from isnorance, matters nothing. The result remains, that a woman, however straight she goes, is much more rarely seen in difficulties than a man. To Diana we shall not presume to offer any advice, the more so because more than one of her own sex has already written on this score; and when a woman is competent to instruct her own kind, on this or any other subject, she will naturally know much better what to say and how to say it than a man can.

'There remains then, judgment, and of this what can be said? Whatever else may come by nature this must come by experience. Nor by experience alone. 'Rcading,' once wrote a great man to his son, 'and much reading is good; but the power of diversifying the matter infinitely in your mind, and of applying it to every occasion that arises, is far better.' Following hounds across a country through a lifetime will do you little gool if you do not keep' your eyes open, do net observe what other men and horses are doine, what the hounds are doing, ay, and what the fox, too, is duing. By what secret does that man, who you can see is not so well mounted as yourself, invariably manage to beat you? How is it that he never secms to be going half the pace that you are conscious of, that he always seems to have the weakest and smallest place in the fence before him, the soundest ground to 
gallop on? How is it that he always scems to anticipate every turn of the hounds? How is it that, no matter how deep the country, how hot the pace, how big and how frequent the fences, yet at the end of the run, which he invariably maniges to reach before you, his nag is in so much better plight than yours?--than yours which has all the blood of all the equine IIuwards in its veins, and is as well lodred and as well cared for almost as one of 'Ouida's' dandy guardsmen. It is juds'ment that does it all. The man with a head on his shoulders will always get the best of it here in the hunting field as elsewhere 'in among the throngs of men.' Some of us perhaps still remember with grateful feelings poor Mayne-Reid's enchanting romances, as we used to think them once upon a time. One of the most startling of them, 'The Headless It,rseman,' introduced the hero to us with some such words as these: 'Sumething is wanting to this solitary rider. What can it be? Good hearens! it is the head.' 'That is precisely the something wanting to so many of our horsemen, and the something that must be got by everyone who aspires to be ranlied among his fellows as a really. 'good man to hounds.'

But how to get it? asks the impatuent youth. Ciun no one teach it me? Is nothing then to be learned from books? Have all these wise men, from old Markham to Whyte-Melville, written in vain? Iar be it from us to say so. Many admirable lessons are there contained in these boolis, insjired by the fullness of knowledge and of the heart, lessons wherefrom he who is 'to the manner born' may no doubt learn much. The rider who is also a reader, and blessed with a good memory, should he ever find himself in a situation precisely similar to one he remenbers to have been treated of in his books, may then put his precepts into practice, and no doubt prosper greatly. Jiut the diticuity is that in hard fact situations are so very rarcly preciscly similar to those one reads of in books. A professor of mathenatics at Oxford once discorent a system by which the hazud of betting could be reduced to a certainty; a mathematical certainty, for he did not profen to huse prosed his 
system by practice. Like a generous man he gave his discovery to the public, and the public, of course, were very much interested in it. One by one he answered all objections, till the unknowing ones began to think that here at last was really the philosopher's stone. Ijut one fine day a knowing one stepped in and demolished his El I)orado with a word, showing that if on every race every bookmaker was prepared at any moment to grive or take on every horse precisely the odds, no more and no less, you wished to take or give, then your system would be infallible, but not till then.

Now it is pretty much the same with verbal lessons on riding. If at any particular crisis all the circumstances exactly tally with those your teacher has sclected for the purpose of his lesson, well and good. If you have read with understanding, and your memory be good, as we have already said, you may come triumphantly through the difficulty. But how rarely will that happen! Take a single instance. We all know that we should ricle fast at water and slow at timber. Theoretically the advice is excellent; no advice could be more so. But can any ricler of experience say honestly that he has not often been obliged to throw it to the wind? Some horses must be ridden quickly at all their fences; some horses must be ridden slowly. A first-rate rider used to say that he not only rode every horse differently, but he rode the same horse differently at every fence. Whyte-Melville, who records this saying, explains it thus: 'He had his system of course, like every other master of the art, but it admitted of endless variations according to circumstances and the exigrencies of the case.' Elsewhere he gives instances from his own personal observation of the various ways good riders put their horses at timber. 'Lord Wilton' (he was writing in 1878 ) 'seems to me to ride at timber a turn slower than usual, Lord Grey a turn faster. Whether father and son differ in theory I am unable to say, I can only affirm that they both are undeniable in practice. Mr. Fellowes, of Shottisham, perhaps the best of his day, and Mr. Gilmour, facile princeps, almost walk up to this kind of leap; Colonel, now General 
Pearson, known for so many seascons as the "flying Captain," charges it like a squadron of Sikh Cavalry; Captain Arthur Smith pulls back to a trot; Lord Camington scarcely shortens the stride of his rallop. Who shall decide between such professors?' Who, indeed? Auch defends on cirumstances, more perhaps on horses. That is aloout the sum-total of all that can be said, and the best man is he who can best adapt his horse to the circumstances, or, if haply he get the chance, the circum. stances to his horse.

Tuke your oun line, and kich it, is a picce of advice one often hears airily given to young riders, more often, perhaps, reads it. Like much other advice, it presupposes conditions under which the young rider, at any rate, is not often able to work. It presupposes, in the first place, an intimate knowledge of the country he is riding over. Now young riders mostly hunt from home, as the saying goes-which is, indeed, by far the most agrecable and rational form of enjoying the sport for all riders; and we may therefore suppose that he has some, if only' a vague, idea of the lie of the ground and the nature of the fences. But in the summer the country looks very different from what it does in the winter. Rambling about it leisurely, when Nature has 'hung her mantle green' on every copse and hed gerow, one gets but a rery poor idea of its characteristics and qualitics as they present themselves from the back of a galloping horse. It is under the first of these aspects that our young frend is probably most familiar with the country in which he lives, and well as he may think he knows it in such grise, he will be astonished to find how much in the dark he really is when he comes to steer a horse across it when hounds are ruming. Some nen, indeed, secm to be born with 'an eye to a rountry; as the saying goes, which, with practice, develops almost into a sort of instinct, or spirit of prophecy ; so much so that were they to be drolped, ready mounted, booted, and spurred, into almost any ficld in England through which hounds were rumning, they would incontinently find the best and quickest way out of it. Some such men are generally to be 



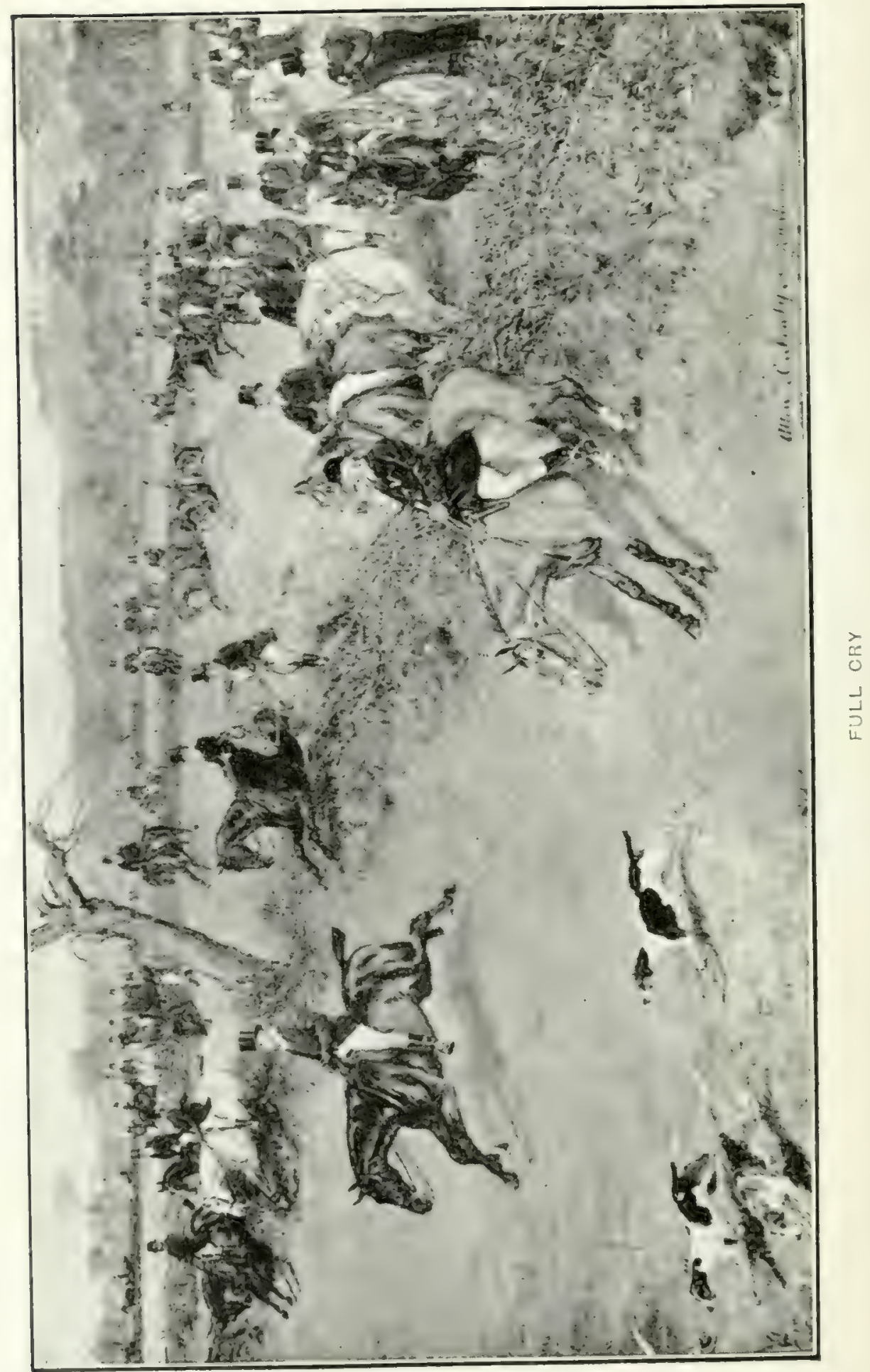


found in every hunt, and the tyro will hardly do better than take such a one for his guide. liut let him remember to sive his pilot plinty of reom. It fifty yourds distance he can see perfectly well what his leader is doing and any nearer he rums the risk of jumping on him should any mishaly ocrur on the other side of the fence, or of galloping into him shruld one oceur on this-than which, to say nothing of the daneret,

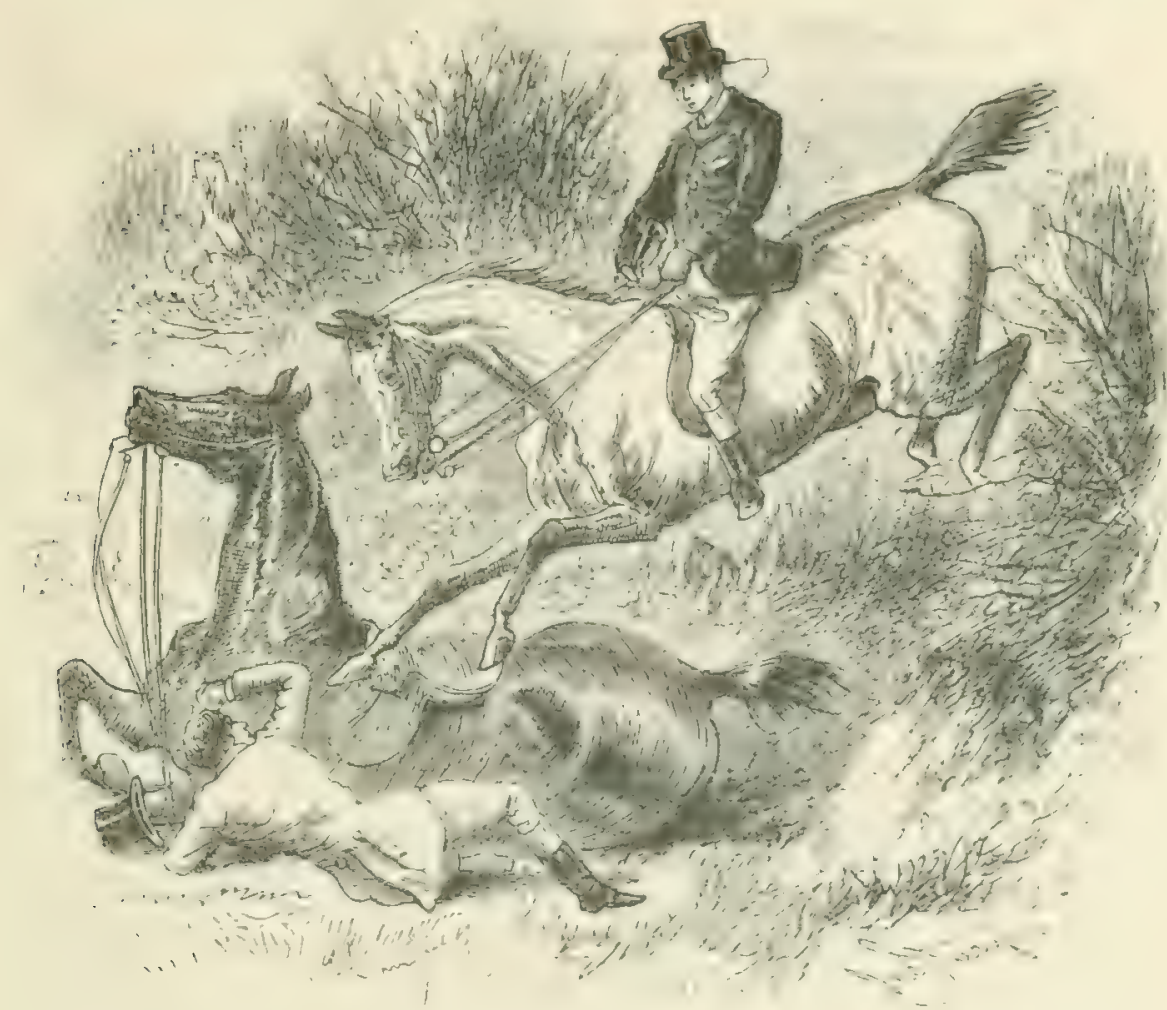

'Give your pilot plenty of room.

nothing can be more unworthy of the name and character of it sportsman. Should he determine, however, to shift for himself, wherever he may choose his own line, it must never be that of the hounds: he must nerer. that is to say, ride exactly in their wake, but a little either to the right or the left. Nothing make's hounds so wild as heine conscious of horses galloping in their track. With all his fire and dash 
the foxhound is really a timid animal, and finding a crowd of horses pressing on him, his sole idea will be to get away from them as fast and as far as he can without troubling his head much about the fox. The rider will of course choose his place, left or right, as the way of the wind may determine; for a fox will naturally as a rule run down wind, though not always. It is impossible to determine with any certainty which way a hunted animal will go; and it will often happen that without any apparent reason, a fox will set his nose straight against the stiffest breuze. He will rarely, however, keep this course for long; and in nine cases out of ten you will generally find yourself in the right place by kecping to leeward of the pack. If the day be a still and clear one, no rule can be laid down. Here only experience, and that instinct we have spoken of will arail ; and if you have not them yourself, you must trust yourself to the guidance of those who have.

When the ploughs are wet, choose always the furrow where the water lies, for there the ground will be hardest. Look out for rushes, where the grass shows indications of a swamp. Take ridge-and-furrow on the slant, where you cannot keep to the furrow. When riding at a brook, of which you know nothing, choose always the neighbourhood of a tree or bush, for there the bank will be firmest; but if there be no growth of any kind on its edges, and nothing or nobody to guide you, cross wivere the homids cross - they follow the fox, and the fox naturally crosses at the narrowest point. Remember, too, that, though hounds go away fast, and you must go fast if you want to get away with them, when once they and you have settled to your work, a run is never over till it is finished. Take every care of jour horse, then, that is compatible with keeping your place. Pull him back to a trot whenever you can safuly do so. Jump a small fence in preference to a large one, if you have the preference. Rid him of your weight whenever you can safily do so. However light you may ride, to him you can be light only by comparison. Even nine or ten stone is no juke to carry for nine or ten miles. Never holloa when you 
view a fox, till you are quite certain it is the fox, and even then it will do no harm 'to count twenty,' like Mr. Jorrocks, before you ejaculate. Even when hounds are at fault, to get their heads up is so much easier than to get them down again; and they, remember, are even more excited than you are. These are simple rules, within the compass of everyone's observance; but they are as sound as they are simple.

Whytc-Melville in his 'Riding Recollections' has deroted a chapter to the abuse of the spur, and he puotes the very high authority of George I'ordham on his side. That admirable race rider, he says, 'wholly repudiates the tormentors,' arguing that they only make a horse shorten his stride, and 'shut up,' to use an expressive term, instead of struggling gallantly home. No doubt spurs are capable of abuse like everything else, whether it be an instrument of pleasure or pain. No doubt, too, a very young rider had better be allowed to chide his steed with an unarmed hecl, especially if he propose to arm it with those monstrous lances the young Nimrods of the day delight to equip themselves with. But spurs unquestionably have their use. With. a sulky or an ill-tempered horse, sometimes even with a timid one, they ars often most effectual. They have, moreover, two advantages over the whip: firstly, they can be used without diminis!ing the strength of your grasp on the rein ; secondly, they can be used without giving the horse any warning of your intentions, while the mere act of taking up the whip will often change a dubious refusal into a certain one. Still they should always be used sparingly. The rowels of hunting spurs as now wurn are no puny weapons, and with a generous horse the slightest touch of the sharp steel should be sufficient. Horses as a rule, want control rather than coercion in the hunting field. But every rule has its exception, and even the freest and boldest horse will, like Homer, sometimes nod. When a stimulus is to be applied, or punishment inflicted, those means are the best which do their work quickest and with least display. In both these points the spur is supreme. Whyte-MIelville hints that there is danger, in the case of a fall, of the buckle of the 
spur catching in the stirrup, and says that he 'cannot remember a single instance of a man's foot remaining fixed in the iron who was riding without spurs.' As a matter of fact we do hap. pen to remember such an instance-an instance in which re ourselves unfortunately played a particular part! Yet this never suggested to us the propriety of riding without stirrups. On the whole, this problematical danger is, we submit, more than balanced by the manifest advantages to be got from what its opponent allows at any rate to give a finished look to a wellmade top-boot. But let the tyro be careful to bear this in mind : that the spur is to be applied only behind the girth. 'Du you take me for a fool ?' the tyro answers. Certainly not, my dear sir; but if, after a hard day, you will, after dismounting from your gallant steed, be careful to examine him, you may possibly be surprised to find that the particular spot, a hand's breadtin behind the girth, is one of the very few places that have remained virgin to your steel.

Finally, let the young rider bear always in mind that he owes everything to his horse, and do what he can to return the debt. After the day's work is over do not let him ret cold and stiff. Move off as soon as you decently can, and keep him gently going till you get him home. If you have far to go, and the day has been a long and hard one, get him a few mouthfuls of good gruel if you can: you have probably had some mouthfuls of something more inspiring than gruel, and he has appetites as well as you. But be careful of the place you put him in. See that there are no draughts; throw a rug over his loins while he is at his food, and lintil you too stand in imperative need of some refreshment wast upon him at his. It is not much to do for him in return for all he has done for you. Ten minutes at the outside is quite long cmough for the halt, unless the poor beast he in a very bad way indeel, and then, if the cuarters are tolerably decent, it were better for him to stay there for the night, but you must stay with him. As a gencral rule, however, it is best for your horse as well as for yourself, to get home as soon as you can. Ijy keeping up a steady even joor of some six 
miles an hour it is wonderful how quickly you set over the ground. It is not a pleasimt pace, granted; but he has heen eroing, remember, all day at the pace which suited your ente nience hest ; it is not much to ask of you to gon now at that which best suits his. (jet off and watk by his side occasionally. It will be a world of relief to him, besides stretching your own legs. Regarding the horse from a selfish point of view

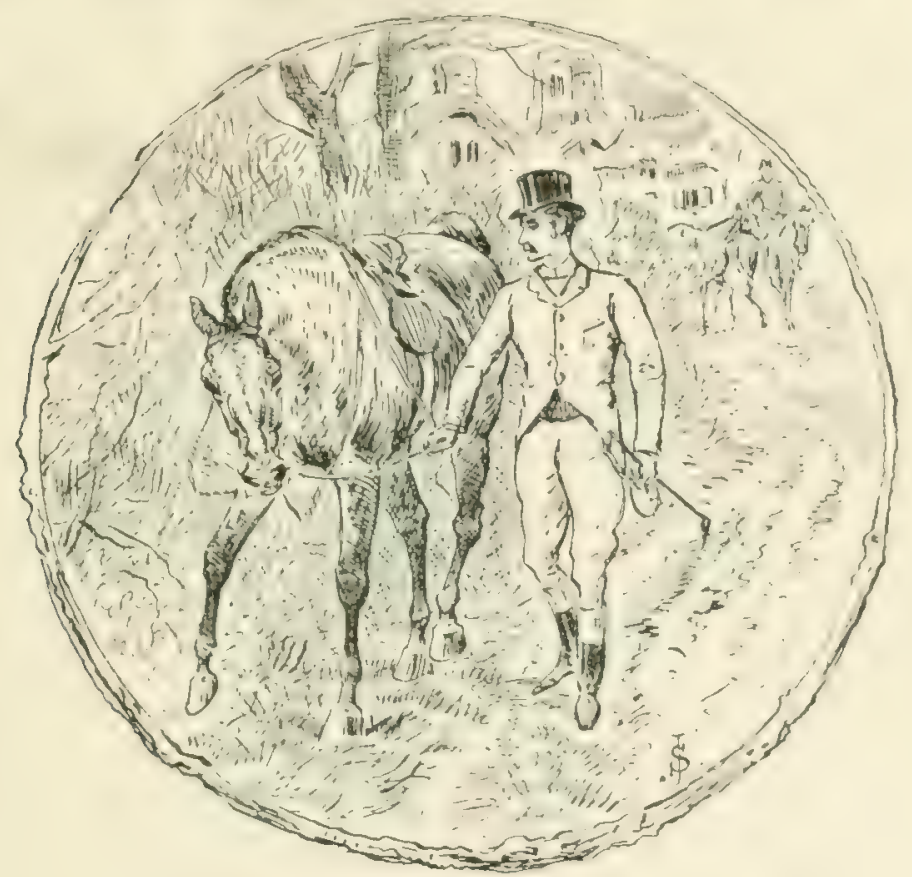

'Get off and walk by his side occasionally.'

only, you should never forget that the more care you take of him, the more care will he take of you. 'Of all our relations,' says Whyte-Melville, 'with the dumb creation, there are none in which man has so entirely the best of it as in the onesided partnership that exists between the horse and his rider.' Let it be your business to see that the profits of this partnership are not all on one side. They will be the larger and the more enduring the more the working partner gets his proper share. 


\section{CHAPTER VIIL.}

THE SHIRES.

The Shires are the eye of hunting England. There are indeed some who maintain that there is no hunting worthy of the name anywhere else : veterans who regard them as the poet's hero, who married the gardener's daughter, regarded the picture of his dead wife:

$$
\text { the idol of my youth, }
$$

The darling of my manhood, and alas!

Now the mest blessed memory of mine age.

Such a one would be that distinguished soldier who, as the story goes, when asked by a mild stranger if he had ever been out with the Crawley and Horsham, thundered in reply, 'No, sir! I have never hunted with any hounds in my life but the Quorn and the Pytchley, and I'll take d-d good care I never do !'-an expression of opinion which, it may here be observed, the narrator of this story by no means subscribes to.

Geographically defined the Shires are limited to three counties, Leicestershire, Rutlandshire, and Northamptonshire. But a geographical definition will not serve. A considerabie part of the Belvoir country is, for instance, in Lincolnshire. Now to hunt with that famous pack is most certainly to hunt in the Shires; to hunt with the Burton, the Blankney, or the Brocklesby, which also wage war with the foxes of Lincolnshire, is not. Again, Lord Ferrers' hounds, which hunt a little tract of country chipped off the north-west corner of the Quorn, are not held to be free of the guild. Neither is the Atherstone, part of whose hunting ground lies in Leicestershire; nor the two Warwickshire packs, nor the Duke of Grafton's hounds, nor the Oakley, all of which 
go often into Northamptonshire. The distinction is really one of fashion, not of geography. By the Shires is meant the country hunted wer by the followines parks of hound; - the Belvoir, the Cottesmore, the (Quorn, including Sir Barhe Cunard's, and the Pytchley. So some unwritten law, dating from what era we know not, has ordained.

Let us take the Brivorr first, a position it is well entitled to, from the excellence and varicty of its country, the excellence and uniformity of its hounds, its antipuity, and the grand style in which things have always been done within its precincts. The kennel books of the Belvoir hounds stretch back to $175^{\circ}$. Like all the historic packs the stag was their earliest chase. The foxhounds were established in the days of the third I)uke of Rutland who died in 1779 , at the patriarchal age of eightythree. The Marquis of Granby, whose jolly face and big bald head once English inns knew well, and the Frenchmen also, much to their disgust, on the day of Warburg, ${ }^{1}$ seems to have been the first master. The fourth Duke died when his son was but a lad of nine, and during his minority the hounds, which were made up by his guardian and uncle, Henry, fffth Duke of Beaufort, from the Badminton kennels, were managed by a committee under the direction of Sir Carnaby Haggerston. In I $_{3}$ I Lord Forester held the reins, and kept hold of them till the present duke came to the title in $1857 .^{2}$ There are no such beautiful hounds, men say, in England, certainly none of such pure and direct pedigree. 'Their beautiful uniformity of colouring, their high class, and their wonderful evenness in appearance are quite unapproached elsewhere. It might be thought that these qualities could not have been brought to such a pitch of excellence without sacrifice of other more practical attributes, did we not know that nearly a century and a half has been reaching this standard, and that each year as many as fifty couple of puppies (occasionally eren more) are sent out to walk. With such a choice of new material thicre can be

I See Carlyle's Frederick the Great, book xx. ch. ii.

${ }^{2}$ Cecil's Record's of the Chase, ch. ii. 
little difficulty in filling up the gaps, or even to maintain a standard so unyielding. It puzzles an outsider to imagrine how the kennel men ever learn their hounds by name-so extraordinarily similar are they in marking and contour. Every hound has the black "saddle-mark" on his back; crery" hound has his "Belvoir tan" head; while the groundwork of each skin is purest white. ${ }^{1}$ These beautiful markings, which are the peculiar type of this pack, are said to have been derived from a breed of Lord Monson's which was very famous in Lincolnshire about the close of last century. Much of the old Quorn strain of Mr. Meynell's is also in the pack, for in I 780 when Mr. Heron hunted the Cheshire country he bred largely from that blood, and when he left the field his hounds went to the Belvoir kennels. Twenty-four inches was the standard, till the year $\mathrm{I}_{42}$, when it was lowered an inch by IIill Goodall, who then took the horn from the hands of the veteran Goosey who had carried it for six-and-twenty seasons.

The most central point of the hunt is Grantham, a trim little town of some 5,000 inhabitants, 105 miles from London, two hours and a half journey by the Great Northern line from King's Cross. Six miles off stands Belvoir Castle and the kennels, and all the iest meets are within a radius of some dozen miles. 'No country', says 'Brooksby,' 'presents a greater variety in itself than the Belvoir. Within its confines you may ride over small grass meadows, broad grazing grounds, light heath, and heavy plough.' The most fashionable district lies, of course, on the Leicestershire side. On Wednesdays and on alternate Saturdays the meets lie Meltonwards. Croxton Park, the famous battle-ground of amateur jockeys, lies just midway between Grantham and Melton. Stonesby Gorse, Newman's Gorse, Freeby Wood, and Brentingby Spinneys, are the great coverts in these parts; but it is, and has been for long, a rule that the fixtures of these hounds never presuppose the drawing of any special cover. It was from Freeby Wood

1 The IIuntins Countries of England, by 'Brooksby :' a most useful work, to which we have been largely indebled for this and the folluwing chapter. 
that Dick Christian pounded a famous crowd of sume two bundred-'each determined to ride, each resolved to be first' - on Sir James Musgrave's Red Rose in a 'crasher over the Lings to Croxton Park wall in sixteen minutes.' 'I was head man all the way,' he told 'The Druid' with pardonalble pride; 'Sir James was on his old grey Baronet; Lord Gardner, Mr. Maxse, and Sir Harry (Goodricke) - he was on Limner -were the only ones near me. Sir Harry shouts to me to open a gate, and I jumps it and then turns round and laughs; "Hang you," he shouts, "that's the way you open gates, is it ?" It was a good five miles' regular coursing, severe jumping.' Stonesby and Piper Hole are also noted meets, and from the latter, if you are in luck, you will get a gallop over the best part of the famed Belvoir Vale, which the veteran Dick used to think afforded a 'partickler pretty landscape,' but whose prettiness to ride over will depend much on the quality of your horse and your heart. Then there is Melton Spinney, only four miles from Melton, and Mr. Burbage's covert, which is nearer still, lying in a loop where the boundaries of the Belvoir, the Quorn, and the Cottesmore touch. Both these are in the Duke's county, and if a good fox goes away from either towards Melton, there will probably be wigs on the Green. From Coston Covert to Woodwell Head; from Mr. Sherbrooke's Gorse to Holwell Mouth, to Dalby Wood, or over the Stygian Smite to the Curate, are the lines 'Brooksby' specifies as affording the cream of a Belvoir gallop, short and sharp, for so great is the crowd and so lawless the riding on those days, that the first burst is as often as not the last. Dick Christian describes the heroes of his early prime as 'all riding like devils against each other' across the vale. The late Mr. BromleyDavenport, in his volume called 'Sport,' reports a significant conversation which once passed within his hearing. Sir Richard Sutton, who was then hunting the Quorn country; at one of his meets called aside a gentleman who was supposed to regard his own position in the run as the capital feature in the day's sport, and, pointing at one particular hound, said, 'Please 
kindly take notire of that hound. IIe is the most valuahle animal in the pack, and I would not have him ridden over for anything.' The sentleman courteously, and very candidly, replied, 'I would do anything to oblige you, Sir Richard; but I have a shocking bad nemory for hounds, and I am afraid he will hai'e to take his chance with the rest!" Whether such shamelessness would be confessed to-day we cannot decide, but it is not impossible it might be practised.'

In the less fashionable quarters of this fine country there is quite as grood fun, and still better sport. There is plenty of grass to gallop over and plenty of fences to jump, of all sorts and sizes; the fields are more amenable to discipline; the foxes are said to be stouter; while the hounds remain the same! On the south, along the Cottesmore boundary between Grantham and Follingham is some good grass country and well fenced, with plenty of timber, but no water to speak of. Northwards from Folkingham, past Aswarhy, the ploughs are more frequent; but they carry a good scent in wet weather, anci foxes are many and stout. Tending still north, beyond Sleaford, from Ranceby on to Leadenham, the land is lighter, being of a heathy complexion, and fenced mostly with stone walls, over which the hounds get very much the better of the horses. West of I.eadenham, which is one of the boundaries between the Belvoir and the IBlankney, lies another fine stretch of grass, and then, turning south towards Belvoir, comes some very decp plough with some very stiff fences, perhaps about the hardest fart to cross of all the Duke's country when the scent is good. Iorses of all sorts, then, are wanted to ride up to the Lelvoir hounds: timber jumpers, water jumpers, fast ones, stout ones, blood ant lione; and, abore all, a good head and a good heart for the rider.

The glory of the Quon: dates from 1753 , when the immortal Meynell lezan his mastership of forty-seven years.

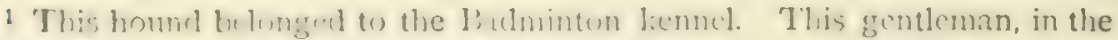
folk, win: an mith of May, went there for Bath laces. In spite of his reply, he touk somuch notice of the hound that in the kemed he picked it out of torty couple- EDPror. 
The hounds then were kept at Great Iiowden Inn, which is on the berders of Northamptonshire ; the master, or masters-for Mr. Boothby bore half the burden of the expenses-living at Langton IIall. A little later Mr. Meynell removed to Quorndon IIall, where the kennels now are, and thence the pack took its famous name. In those days there were no woodlands within the limits of the country, and so Meynell used to stoop his hounds to hare in the spring, so as to get them handy when the real business began. This did not, as may be imagined, result in universal steadiness. 'The Iruid' tells a story of a brilliant burst of twenty minutes after a hare ending with a kill in the turnpike road: 'Ah!' observed the philosophical master, 'there are days when they will hunt anything.' Lord Sefton followed Meynell, and did things in an imperial manner, with two packs and two huntsmen, and everything 'in concatenation accordingly.' His lordship was the first to introduce the custum of second horses. He was a very heavy man, and stopped for nothing, so that no horse could live under him for more than ten minutes if hounds ran hard. But he had a grand stud, nearly all thoroughbred and as large as drayhorses; and with three or even four out at a time, he managed to hold his own with the light-weights. ${ }^{1}$ Then arose the star of Melton, which still shines, if not with quite such supreme lustre. From 1805 to 1807 Lord Foley was king, and then came the great Assheton Smith, who ruled for ten years, and was succeeded by the universal Osbaldeston. In I82 I Osbaldeston went into Hampshire, changing quarters with Sir Bellingham Graham; but the change did not last long, and in 1823 ' the Squire' was back at Quorndon, Sir Bellingham going into the Albrighton country. Both Assheton Smith and Osbaldeston hunted their own hounds, and in that capacity Dick Christian, who, thanks to 'The Druid,' is our main authority for those golden days, did not think rery nobly of either of them. The former drew his coverts too quickly, and so 'drew over his fox scores of times.' Also, 'he was very uncertain : sometimes he would not lift his hounds at all,' and, adds the veteran, 'you

1 The Post and I'addock, ch. xiid. : Records of tire Chuse, ch. vi. 
must lift, and lose no time if jou want runs in Leicestershire with those big flelds.' One quality, however, he had, sure to have been appreciated by those big eager fields; 'he was alway's for being away as quick as possible.' It was his maxim that the best fox always broke first; and after the first that broke off he would go, often with only three or four couples of hounds. This, no doubt, entailed a tremendous burst, but at the first check as often as not the run was spoiled. 'The Squire' seems to have been still more 'uncertain.' 'He was the oddest man you ever saw at a covert-side. He would talk for an hour: then he would half draw, and talk again, and often blow his horn when there was no manner of occasionalways so chaffy.' But he is allowed to have been 'very keen of the sport,' and to have got away with his fox 'like a shot ;' while, for sheer riding, of his great rival Dick rowed 'no man that ever came into Leicestershire could beat MIr. Smith; I don't care what any of them says.'

Lord Southampton followed 'the Squire.' He bought the Oakley pack in 1829 , which was then in high repute, built new kennels at Leicester, and the hounds were called after his name instead of by their own title. To him succeeded Sir Harry Goodricke, and the hounds took his name, which indeed was but fair, seeing that he paid all expenses out of his owr pocket. $\mathrm{He}$ too built new kennels at 'Thrussington, midway between Melton and Leicester, and a much more convenient place than the latter. His early death in ${ }^{8} \$_{33}$ left the hounds to Mr. Francis Holyoake, who subsequently took the name of Goodricke. In his time a part of the Quorn country was handed over to the second Marquis of Hastings, who had started a pack to hunt the Donnington country, pretty much that now hunted by Lord Ferrers. Two seasons were enough for Mr. Holyoake, and three for Mr. Errington. I is next successor, Lord Suffield, who followed, spent a great deal of money, building new kennels and stabling at Billesdon, and giving Mr. Lambton 3,000 guineas for his hounds. I,ut the sport, for some cause or another, was not equal to the cost, and after one season he gate place to Mr. Iodgron of Holderness funce, who brought 
his hounds with him from Yorkshire. It was in his reign that Assheton Smith, then in his sixty-fifth year, brought his hounds from Tedworth for a fortnight into Leicestershire. The opening day was at Rollestone, when it is calculated upwards of 2,000 people were present, but there was, perhaps of course, no sport. After Mr. Hodgson came Mr. Greene, of Rollestone, a fine sportsman, who figures in the great 'Quarterly' run as skimming over the Whissendine on his bay mare, "like a swallow on a summer's evening.' In 1847 he retired in favour of Sir Richard Sutton, who had won a great name in the Burton and Cottesmore countries. In $\mathrm{I} S_{57}$ the latter took the Donnington country back, and then finding the whole rather too large to be properly hunted by one pack, he handed a part of it over to his son Mr. Richard Sutton, building him kennels at Skeffington and furnishing him with hounds. No man ever showed better sport in Leicestershire than Sir Richard, and when he died at the beginning of the season of 1855 , it was a bad day for the Quorn. Young Sir Richard and Captain Frank Sutton finished the season, and then Lord Stamford came to the front, with a pack composed largely of old hounds and a good draft from Mr. Anstruther Thomson's kennels. In this mastership Mr. Tailby took a part of the Quorn country together with a slice of the Cottesmore, and showed rare sport up to $187 \mathrm{I}$, when the latter, according to agreement, reverted to its original lords, and Mr. Tailby continued for some seasons longer to content himself with two days a week in the diminished province now governed by Sir Bache Cunard. After Lord Stamford, who kept the hounds for seven seasons, Mr. Clowes followed for three, and then the rather casual reign of the Marquis of Hastings, which lasted for two. Mr. Musters came next, with a good pack of hounds out of South Nottinghamshire. After three years he divided his country with MIr. Coupland, and after two more took his pack with him back to his own tents, and Mr. Coupland was left to his own resources. He was unlucky at first, having bought the Craven pack, which was too slow for Leicestershire. But the famous Tom Firr came to him in $\mathrm{s} 872$ from the North Warwickshire, and malters soon became more 
lively. Mr. Coupland managed matters till the season of ISS $4-5$, when Lord Manners succeeded, and so we pass from the domain of history into the living present.

Melton Mowbray is, of course, the cardinal point of this famous hunting ground, though not the central one. There hounds are comparatively close at hand every day in the week. It rarcly happens that a ride of ten miles at most will not find them, and a ride to covert in Leicestershire has been declared by an enthusiast to be better than a run anywhere else in the world. From this little paradise, isled in a sea of grass, you get the Quorn on Mondays and Fridays; on Tuesdays, the Cottesmore; on Wednesday, the Relvoir ; on Thursday comes either a by-day with the Quorn or one of Sir Bache Cunard's northern meets; on Saturday, the Belvoir and the Cottesmore are alternately' at your door. To take al! the goods thus lavishly provided a large stud is a necessity. 'True, as 'Brooksby' says, six thoroughly well-scasonerl nags, with the inevitable cast-iron hack (who must both jump and gallop more than a bit) will carry you through the season if you haveluck, and here and there a timely frost comes to help. Some men can certainly get more out of one horse than many can out of tro. But eren the cleverest and most saving rider must lose much of the fun if he makes Melton his head-quarters with only six hunters in his stable. The best sport in this country comes generally in the afternoon, when the coffec-housers have gone home, and hounds have a chance. But although you may have had no sport in the morning, there has almost certainly been enough work, what with trotting or galloping from one covert to another, a short scurry here and another there, to take the morning steel out of your horse. Then what are you to do? go home with the crowd, or stay and play second fiddle to your happier fellows on their fresh horses; or come to incvitable grief in a brare attempt to show them the way on your tired one? As to not hunting every day from Melton, that never entered into any human head. So, though undoubtedly Melton was made for man to hunt from, it is no: every man (nor horse either) was 
made to hunt from ileiton. Non calibs-but the proverts is something musty.

Plenty of sport is to be got both from Icicester and Ioughborough, and under more moderate conditions. "The latter, only three miles from the kemncls, is the most central pont in the Quorn comntry proper, while the former is just on the border line between that and Sir B. Cumard's, and is handy too for an occasional day with the Atherstone. Some five-and. twenty years ago I cicester was a famous quarter for hunting men, who used to gather in numbers at the Old Jell Inn. But then it was a cleanly quict little marlet town; now it is a great manufacturing town, not very (quiet, and not at all cleanly. Loughborough is about three hours from St. I'ancras; Leicester, about two and a quarter; Melton, about three and a half: too far all of them to be reached from London on the morning of hunting, unless you are prepared to leave your bed not much after four o'clock !

But the pick of the Quom country is certainly to be got from Miton. Shoby Scholes and Lord Aylesford's are the great coverts near by: the first a close-grown dell, the latter a covert of gorse and broom of some twenty or thirty acres; 'rare things' had Dick Christian scen from here over to Oakham in the Cottesmore country or to Belroir. Wartnaby Stone-pits is another famous place, only four miles from head-quarters. There were fearful fences hereabouts in the old days : spiked gates, mortised rails, and all manner of devilries. The owner used to say, "There never were but two men fit to come out hunting-Lord Alvanley, who walked is stone, and Quarley Wilson-they were the only men that ever rode straight across my farm.' Farther on is Cossington Gorse, from which if the fox breaks across the old Roman road between Leicester and Newark, over the Hoby and Thrussington lordships, to Shoby Scholes, you will get such a gallop over such a country as you will find nowhere else, men say, even in the Shires. When the Quorn meet at Six Hills, about six miles from Melton, you get the pick of all the best coverts : those aforesaid, 'Thrussington 
(iorse and Wolds, Walton 'Thorns (rich in the memories of historic gallops), Cossington (jorse, and Mr. Craddock's Sininney. Northwards still towards Widmerpoul you come on the plough, fairly light but with blind fences. But from the Curate's Gorse, or from the neighbouring Parson's 'Thoms you may get into the

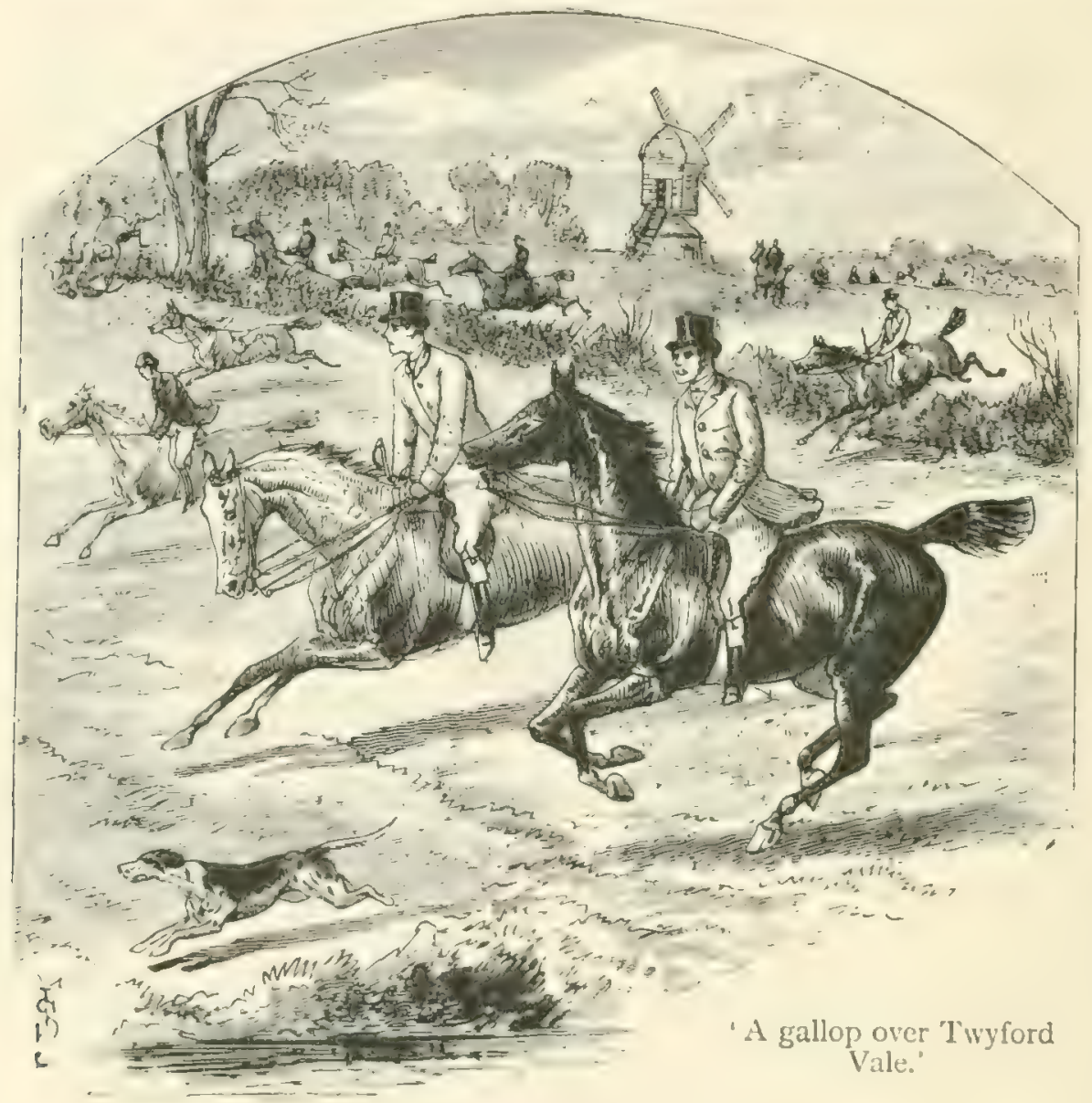

Belvoir Vale at its very finest part. It was in this neighbourhood, from Widmerpool right across the Viale to Blackberry IIill, that Assheton Smith plided the hest run he had ever had in I ceicsitershire. Whether it was the l'arson or the Curate who ome satid in lock ('hristians hearing that he used to farty tremble before a vale fence to think how he combl get over it, 
that old chronicler did not specify. Holwell Mouth, Saxellyy Spinney, and Grimston Gorse are all shared with the Belvoir, and a grand grass country lies all a: ound them.

South of Melton, arross the Wreake, historic names lie thick : Kirby (Gate and Great Dalby mean a fox at Gartree Hill, leagues of grass with 'oxers' thick as leaves in Vallambrosa, and the immemorial Whissendine. It was in this covert dwelt the legendary fox of 'the Squire's' time, that always broke at the same point and went over the same line, ten miles of it through Leesthorpe, past Cold Overton to Oakham Pastures, where he invariably disappeared in some miraculous way, undiscoverable by hounds or men. From Adam's Gorse you may get a gallop over the Melton Steeplechase Course; from Thorpe Trussels, Ashby Pastures, and Cream Gorse, you may go straight to heaven or that earthly parallel in a Quornite's eyes, found in a gallop over the Twyford Vale. Barkby Holt and Ashby Pastures are other names to conjure by. Here, in old Dick's time, grew the stoutest bullfinches, the regular 'stitchers,' at which 'we used to go slap-bang, holloaing like fun to cheer up horses and men.' Hereabouts, too, are Rearsby and Gaddesby: Lowesby Hall, made famous by poor Bromley-Davenport in one of the best parodies ever written; Baggrave and John O'Gaunt ; Scraptoft, and most traditional of all, Billesdon, with its immortal Coplow, which is really within Sir B. Cunard's border. The historical Billesdon Coplow run was in Mr. Meynell's last year of mastership, on February 24 , ISoo, on a bitter cold day with the wind blowing from the north-east. The distance is said to have been twenty-eight miles, and the estimate of the time occupied in covering it is fabulously short. After crossing the Soar, the hounds changed their fox and carried the new one on to Enderby Gorse, where they lost him. The only man who crossed the stream on horseback was Mr. Germaine. A famous picture was painted of the run at this point by Mr. Loraine Smith, and, according to him, the only men who got so far were himself, Mr. Germaine, 'Jack' Musters (Byron's rival in love and Assheton Smith's in sport), Lord Maynard, his 
groom, and Jack Raven, the huntsman. There was another great run from here in 'the Squire's' time, ten miles to Rankshoro', of which only 'the Sipuire, on his famous little Assheton, and Mr. Greene, on his even more famous bay mare, saw the end. Alomg the vestem bumblary from Kirby Nuxloe northwards to Lord Ferrers' and the Nottinghamshire districts the county changes; woods srow larger and ploughs mostly take the place of grass. Still, fores are as plentiful as ploughs; and as the hard-riding dandies do not patronise these uncivilised parts, the hunting is good enough, whatever the riding may be. If your fox slips from Chamwood Forest, as the wild hilly country from Bradgate to Gracedieu is called, over the Atherstone border, there will be plenty of riding.

The country now hunted by Sir Bache Cunard's hounds is that once known as Mrr. Tailby's. As we have said, it was first made a separate country in Sir Richard Sutton's time, and was once larger by the piece a few jears ago reclaimed by the Cottesmore. It has also been known as the Billesdon Hunt, from the fact of the hounds having been originally kept at Billesdon, a fact commemorated by the initials ' $\mathrm{B}$. H.' still worn on their coat-buttons by members of the hunt. In the old days, before Mr. 'Tailby's area became so sadly circumscribed, when Jack: Goddard, and then Frank Goodall, held the hom, there was no such sport shown anywhere in the Shires, Leicester and Market Harboro' cummand the country, but if you intend to limit yourself entirely to these hounds, and they will give you sport enough unless you insist on hunting erery day in the week, either Kibworth or Billesdon is more central. Five dajs a fortnight is the fare provided-Mondays, Thursdays, and alternate Saturdays, when the Cottesmore are away on the eastern side of their kingdom. Gumley, Mowsley, Shemsby, Bruntingthorpe, Kilby and Wistow are tine pick of the Monday meets in the sonthern district. Most of the coverts are small, and there is more plough than in the northern half; but there are several fine salloping bits, from John Ball, for instance, or Walton IIolt westward to the Aherstone country. All these 
places are on the Market Harboro' side. Iencester way, Thurnby Spinney, (ilen Gorse, Norton Gorse, Noseley, and Sheepshoms, are all famous places for grood foxes, and almost certain to grant a run over a glorious country. The Saturdays are generally spent in dusting the woodlands on the Cottesmore boundary, from which runs may come, and if they do they will probably be over a very stiff country.

'For the truest sport, the straightest foxes, for perfection of country, for long runs and fast runs, commend us,' says 'Brooksby,' 'to the wild pastures of the Corresmore.' This establishment seems to have owed its origin to Sir William Lowther, first Earl of Lonsdale, who kept a pack of harriers at Uffington in the last quarter of last century, which about I 790 he turned into foxhounds. When his hounds were sold, their pedigree went back I 30 years, which would presumably carry it into the serenteenth century. According to Dick Christian, who was born at Cottesmore, a Mr. Noel, of Exton, was the oldest accorded master of this country. He kept the hounds at Cottesmore, and his huntsman was Arthur Abbey, 'a big heavy man, with a rasping strong voice.' He was with Sir Gilbert Heathcote afterwards, and is famous, if for nothing else, for his saying to a parson who had just subsided into a muddy ditch: 'You can lie where you are, sir: you won't be wanted till next Sunday,' a happy thought subsequently appropriated, as everyone remembers, by John Leech. Lord Gainsborough took the hounds after Mr. Noel's death, and after his own they passed to Sir William Lowther. Sir Gilbert Heathcote's mastership secms to have lasted about ten years, from I 799 to I Sog, during which time Dick Christian was with him as whip and occasional huntsman, and general breaker and trainer of young horses. Then the hounds went back to Sir William, who had blossomed into the Eorl of Lonsdale, and in that family they stayed some time. Indeed the Lowthers have always been more or less connected with these hounds. When Mr. Tailby took the lower part of the Quorn country in $1856-7$, he was also given, as has been said, a slice of the 
Cottesmore, on the particular understanding that if ever a Lowther took to the latter hounds argain, it should revert to its ancient use. And this actually did hapjen in the season of I87 $1-2$. In the carly years of the century the Cottesmore country was very wild, rough, and deep; even now it is much the wildest, the most in a state of nature, of the Shires. This made the hounds particularly good hunters, and though not so quick in the open as the Quorn, they were always held to be the best on a line. The historians of the chase are less voluminous on the Cottesmore hunt than on many others. With the exception of Dick Christian's reminiscences, and the fact that Sir Richard Sutton was master for a short but brilliant reign before taking the Quorn, there are few facts to be gathered from history. Dick tells us of a tremendous run in Sir Gilbert's reign, known as 'The Prince of IVales's day,' afterwards George the Fourth. His Royal Highness was staying at Normanton; 'he was nowhere, bless you; they gave him the brush, though, just to please him.' The Prince must have had plenty to keep him company, for it was, by the veteran's account, a desperate affair. 'We found at Armley W'ood, then through Empingham, Cottesmore Wood, straight through Exton Park, across the North Road by Horn Lane toll-bar, through Ardwick Wood, where the balloon from Nottingham fell, The Lings, Fowthorpe Oaks, Stamford Field-side, Royal Belthorpe, Rasen Gretford; then we came to Langtoft and Deeping-let me see-and Tallerton, and then by Uppiniston Wood, and killed at Essendine Park - that's it. Six horses died in the field; these they laid heels up'ards. Lord Charles Manners and Sir Gilbert were up first. 'There must have been twenty-two miles or more. The run would have made sixteen or seventeen of it. The late Lord Lonsdale was out, and Lindow, and Germaine, and Vanneck. I would be about twenty-eight then, and somewhere about ten stone.' Oakham and Stamford are the head-quarters most commonly patronised, and the former the most. A quiet market town it is, about three hours' journey from London, with plenty of good accummodation for man and beast. From here you get 
not only all the pick of the native meets, but the Quorn, the Belvoir, and Sir B. Cunard's are also accessible. Westward and southward from Oakham to the Quorn boundaries is the best of the Cottesmore country : fine grass fields carrying a good scent in almost all weathers, plenty of foxes, and fences - 'tremendious,' as Dick Christian would have said, and did say, over which, on a memorable day, he pounded the late Lord Cardigan on his famous Dandy. There are some stiff hills about Tilton and Launde, which are not much admired when they present themselves in the middle of a quick burst, however much they contribute at other times to the picturesqueness of the scenery. I.cesthorpe and Langham are the favourite meets hereabouts. From the first you get the Punchbowl, from the second Ranksboro Gorse, names surely familiar to every man, woman, or child that has ever heard of a fox, a hound, or a horse. Close to Melton are W'yld's Lodge and Stapleford Park. Just outside the latter is a noted draw, Iaxton's covert, below which runs a well-known stream, commonly but wrongly assimilated with the Whissendine. If you run from Laxton's to Ranksboro, however, you are pretty sure to cross the latter, and not absolutely certain not to get into it. A great feature of the Cottesmore country is its woods; not the regular woodlands that lie on the eastern side beyond Stamford, but the smaller ones hereabouts-the Great and Little woods of Owston, the woods of Launde and Launde Park, of 'Tilton, and Wardley, and Witham, and Orton Park. A woodland draw has its drawbacks, of course (we protest against any intention of a pun); but these are such splendid nurseries of foxes that no good sportsman would wish to see them diminished by so much as a tree. Besides, when you do get well away from them, you can hardly go wrong, and no fox ever runs so staunchly and straightly as a woodland-bred one.

On the eastern side of the hunt, from Stamford northwards past Bowne to Grimsthorpe Park, which is almost on the borders of the Belvoir, runs a great range of woodlands. Full of foxes they are, but not otherwise attractive. The country 
hereabouts is mostly heavy plough, and intersected by wide and deep drains. A stout, short-legged horse is wanted here, nut fast, but a grood jumper. For the rest, a nag that will carry you well to the Quorn will not disgrace you with the Cottesmore. But he must be a strong as well as a well-bred one, for the pastures are heavier here than the Melton grass, and the country generally much wilder and less bothered by scientific agriculturists. The stiffest part of it all is the Skeffington lordship, which you will probat)ly cross (if you and your horse can) from Launde or Tilton Woods. The 'oxers' hereabouts are terrific; the hills are steep; and in most of the valleys are diabolical freaks of nature known as 'bottoms,' almost amounting to ravines, some of which no horse yet foaled could be put at with any chance of getting over, even with a fall. 'A widespread region, scarcely inhabited; ground that carries a scent in all weathers; woodlands which breed a travelling race; and mile upon mile of untracked grass, where a fox will meet nothing more terrifying than a bullock.' So 'Brooksby' summarises this glorious country, and those who have known the pleasures of a gallop from Ranksboro Gorse to Laxton's Covert, from Owston Wood to John o' Gaunt, or from Witham Common over the Vaie of Catmose, will probably agree with him that there is no sport in England like that shown by the Cottesmore bitches.

No pack of hounds in England, not even its great rival the Quorn, has so memorable a history as the PyTchley. It has cren, as one may say, a political history of its own, having, as no one will ever forget, been the cause of Homeric laughter in the House of Commons, on an occasion which no biographer of Mr. John Bright must ever pretend to pass by. The name comes from an ancient Elizabethan house, built by a certain Sir Eustace Isham about I570, and pulled down by the late Guorge Payne. The lords of the manor, 'Cecil'1 tells us, held it of the Crown on condition of their keeping dogs to destroy wolves, fores, polecats, and such like creatures. But that ex-

1 Records of the Chase, ch. vii. 
cellent sportsman and pleasant writer, the late Charles Clarke, has traced the name yet farther into 'the dark barkwarel of time.' IIe has traced it bakk to one William of l'ightestey; who, in IIemry the 'Third's reign, surceceled to the I'stah of one Alwyne the Inunter by a tenure binding hin to chase 'wolves, foxes, and other vermin.' The 'P'ytchley IIunt' of those days seems to hare been somewhat oddly composed. There were 'sixteen dogs' for hunting fallow deer, and the staff consisted of a royal huntsman, 'two horses and three men.' Their appearance could not well have been splendid, at least from a sumptuary point of view. The prince and great nobles of that day went, by all accounts, very gorgeously clad, but their retainers apparently something less so. The leader of Henry the Third's greyhounds, for instance, was allowed only fourpence for his boots and shoes; "the winter shoes of the whole establishment of Edward de Blatherwycke (a better name for a member of Parliament than for a sportsman), foxhunter to Edward the First, cost only seven shillings.' Shillings and pennies meant then a great deal more than they do now ; still, even on the most liberal computation, the expenditure could hardly have been reckless. As the Cottesmore is assuciated with the Lowther family, so the family of Spencer has long been connected with the fortunes of the Pytchley. Lord Althorp) hunted the country for many years before his death in $I 76$, though when his hounds became foxhounds purely is not known. From that year till I 794, the Spencers ruled over the Pytchley, hunting alternately what were then known as the Althorp and Pytchley countries. Nearly all the gentlemen of Northamptonshire hunted then, and when the hounds were at Nlthorp, all the squires in the neighbourhood kept open house: when the time for I'ytchley came, they shut up their houses and with their families followed the hounds to the latter place. The Pytchley Club was as famous then as the Old Club at Melton became afterwards, and among its best known menibers was Assheton Smith's father. Dick Knicht was the huntsman.

1 See Crumbs from a Sportsman's Table, vol. ii. ch. xiii. 
renowned in song and story, and the sport was glorious. In the famuls library at Althorp there are some interesting manuscript records of the history of the hunt, from which Mr. Clarke was allowed to make extracts. 'They date from the year 1773 , when John, Earl Spencer, kept the hounds, and also a most minute diary of the sport. On Octoler 23 of that year there scems to have been a red-letter day thus recorded:

Out: Lord Spencer, Lord Jersey, Lord Robert Spencer, Mr. Bouverie, Mr. Knightley, Mr. Hanbury, Mr. Percival, Colonel Durgoyne, lic. Threw off with the old hounds at Bagbrooke Hills. Found quite at the extremity of the cover. The fox took a circle round the hill and over the open ficld to the Dirt House Cover, through which he ran. He then made for the thorns on the edge of the turnpike road, back over the other sicle of the same open field, in view of the company up the hill, into the cover, where he was first found, and where, after some little check, a hound was seizing him, but was whipped off by Dick Knight, and he grot to ground. A fresh fox then jumped up, went into the inclusure, crossed the brook, through the thorns before mentioned, over the high road, bearing down the ground to the left. He then passed over the same brook to Lichborough Springs, by the edge of Grubs Copse, without daring to go into it. Keeping on in a line for Towcester, till he came within two miles of it, when he returned to the right, and within the distance of two or three grounds was killed in a turnip field. This aias a very fleasing chase, having a great deal of steady muning and excellent hunting; but the strong inclosure's at the first sturting off prevented part of the company from secing the whole of it. An old fox.

This Dick Knight, who seems grenerally to have been spoken of as 'Mr.' Knight, is not to be confounded with his namesake of a latur day, the one mentioned abuve. 'The real, the histuric 'Dick,' was a great character in hunting tradition. Ile seems to have been limous rather as a rider than a huntsman; at least his virtues must have mostly lain the former way. 'The Druid' thus describes him : ${ }^{1}$ -

He was a fine horseman, and was magnificently mounted, but he hat no practice. He thought he knew better than the hounds, 
and was ton fond of lifting them... He had neither patience nor perseverance, and was always for finding a fresh fox. Having plenty of horses, he would gallop off miles distant. Half the field thought the hounds were running, and did not discover their mistake till they got to a fresh covert with their horses half done. Such we believe to have been the mode adopted by the renowned Dick Knight.

Then, after one scason under a Mr. Buller, the hounds passed to the great Joln Warde. I Ie brought the two countries into one, and moved the kenncls to Boughton. Large hounds were his passion, 'great calves,' as the Quorn men called them; but large as they were they could chase as well as hunt, and their steadiness was a byword through the length and breadth of hunting England. When 'Glorious John' left Northamptonshire for the New Forest (a change, indeed !), the old family came to the front again in the person of Lord Althorp, who bought the hounds from his predecessor for I, oco guineas, a pretty good proof of the value of the "great calves.' Pytchley once more became the head-quarters, and the golden years returned. According to 'Cecil,' in which he differs from 'The Druid,' who, however, is vague in the matter of dates, and apt sometimes to contradict himself, Charles King was then the huntsman, a better one than Finight and quite as good a rider. $\mathrm{He}$ is said to have offered to ride, dance, play the fiddle, and hunt a pack of hounds, against any man in the midland countiss, and, like the first Lord Spencer, he was very particular in keeping a diary. The Club was then in its prime, with Frank Forester, the giant Dick Gurney, Hugo Meynell, Sir Charles Knightley, Sir David Baird, George Payne (father of the late George), the brothers Allix, Sir Thomas Salisbury, and Frederick Ponsonby among its shining lights, with an occasional flash from Melton in the shape of Lord Alvanley. This great time lasted till 1820 , and then, after a series of short reigns, including Sir Bellingham Graham's and Mr. Musters', came 'the Squire's' mastership from 1827 till I 83 , which almost rivalled the great days of Lord Althurp's. 
Mr. Ceorge I'ayne, Iord Chenterneld (whose reign was as magnificent as Iord Sefton's in Leicestershire), Mr. Tom (not Assheton) Smith followed, and then Mr. I'ayne agrain. It is in Mr. Fane's second mastership that we first find conneted with these hounds a name which has since become a household word in the l'ythley hunt-the name of Charles Payne. He came from the ( )akley, having graduated under that fine huntsman, Gicurge liecrs, and at first his duties were confined to the kennels. It wa:s in Lord Hopetoun's time, in $S_{52}$, that l'ayne was first entrusted with the horn, and never at any time, or in any country, did huntsman carry it to more effect. In his carliest days he was noted as' 'a quick, intelligent, well-behaved servant, and a marvellous fellow to get over a country;' and these fualities he preserved undiminished to the end of his active carcer. From 1852 till when he went into Wales to Sir Watkin II ym, he was at the head of aftairs, through the masterships of Lord Hupetoun, Mr. Tilliers, Lord Spencer, and Mr. Anstruther Thomson. No quicker or keener huntsman ever checred a hound; no better rider ever threw his leg over a siddlle; no more civil or intelligent servant ever wore scarlet. In 1862 , the present Lord Spencer came into office and stayed there for three seasons, and then followed Mr. Anstruther Thomson, whose reign will be for ever memorable for the great run from Watcrloo Gorse. In IS73, when Mr. Naylor was at the head of affiris, a second pack was set on foot to hunt the Rockingham woodlands. In is $S_{4}$, I ord Spencer took the hounds again and liept them for five seasons, when he retired in favour of Mr. Langham, but for a short while longer liept the woolliand country in his hands; hunting it two ditys a weck with Brigntock for his head-guarters.

'lhere are six commanding points of departure for the I'yuhley comtry - Kugby, Market Iarboro', IVeecion, 1)arentry; Intterworth, and Northampton. Of these, Northampton is the most central for the country, Marlict Ilarboro' the most fimous by nanc, and Rugby, jerhaps, the most handy

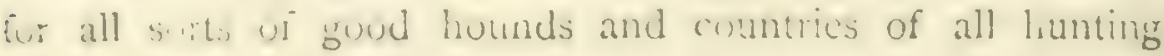


centres in Englind. All three, as well as IVeedon, are within a couple of hours' journey from London, and can be reached by a 7.30 train in time for an eleven o'clock meet.

Rugby, indeed, offers a most unlimited choice of delights. Besides the Pytchley, the Quom, Sir Bache Cunard's, the Atherstone, both the Warwickshire packs and the Oakley are all tolerably handy on various days throughout the weck. $\Lambda$ gillop with Sir Nathaniel over the Aylesbury Vale can also be encompassed with no extreme labour. There is a capital hotel and a club, any amount of stabling, and plenty of pleasant company. It would be hard to find a better place anywhere for the man obliged to make London his head-quarters, and yet able to spare a day or two together for his hunting. Almost the only objection to Rugby is its distance from all the kennels of the packs it commands. The meets consequently can often be reached only by rail; but, on the other hand, of lines of rail. way there is no lack at Rugby.

To the dwellers at Market Harboro', Sir Bache Cunard's and the Cottesmore are the only packs of convenient resort besides their native Pytchley. It has this advantage over Rugby, that the morning train leaves London half an hour later. By the souls given to festivity, Market Harboro' may probably be thought a little dull, though Mr. Sawyer did not scem to find it so. But to him who regards hunting as a serious business, not to be mingled with social frivolities, it is a nolable place. Like Rugby, it is far from any kennel, but not so far.

Northampton commands all the southern district of the Pytchley, and the best also of the Oakley, and the Duke of Grafton's. Weedon is much in the same category, with the Bicester and Warwickshire to boot. Lutterworth and Daventry are quiet little places, rather off the line of railways, but perhaps no worse for that. The former is on the extreme west of the country, in a little nook handy for the Atherstone and Sir B. Cunard's. Daventry is on the extreme south, close to the borders of the two Warwickshire packs, the Dule of Cinfion's and the northern meets of the Bicester. 
The favourite part of this fine and large country is that known as the IVednesday or Rugby district. 'The most notable meets hereabouts are Lilbourne Village, Stamford Hall, Kilworth IIall, Yelvertoft, Cold Ashby, and Crick, almost as historic a name as Billesdon. Its fame arose from a marvellous run into Oxfordshire after a fox found in a hedgerow. A covert was then made, the horses were prepared for it, says 'The Druid,' as if for the Derby. From Stamford to Misterton or the Hemplows; from Cold Ashby to the latter hills; from Lilbourne to Crick or Stamford, are tremendous lines, 'fit for a king' says 'Brooksby,' 'if that king be but well minded and well mounted.' They take you nearly all over grass, and over fences of various and most uncompromising sorts. On these Wednesdays the crowd is so huge, that a 'Pytchley Wednesday' has passed into a proverb. 'If,' says the eloquent 'Brooksby,' 'you would learn to what colossal magnitude and manifold variety a hunting field can attain, go out on a Pytchley Wednesday to a favourite fixture! If you would observe how such a field can cordially subject itself to proper discipline, stand at the covert side as one of them ! If, again, you would put your nerve and self-confidence to a thorough test, make yourself an atom in the Niagara-like rush to which the "gone away" is a signal! If you would mark in its most perfect form the first essential for a foxhound in the Shires, watch the Iytchley bitches slipping to the front through the mad torrent.'

On the Narket Harboro' side, which is visited on Fridays and Saturdays altemately with the Weedon side, the fences are terrific. Jem Mason used to say-and no one could speak with greater authority on such matters - that no one could ride the line straight from Waterloo Gorse to Dingley, without three falls, no matter what his horse was. And an authority, who quotes the saying, adds that the ox fences round about Market IIarboro' are simply impossible. 'You can't ride the country in its immediate neighbourhood straight,' he says. 'It is my belicf,' he declares, with a frankness perhaps more bold than judicious, 'that these ox fences, more than all else, bar the way 
6) Market llarboro's jrosperity as a hunting rentre. liold men, perhaps, battle with them for a year or two : fathers of families shudder as they look at them, and decline further acpuaintance at once.' Discretion is the truest intour at Hartiono'. 'To the stiffness of the Pytchley country generally another witness speaks from the mouth of one who was not wont to tum his head away from a big fence. 'I arge grass fields,' says WhyteMelville, 'from fifty to a hundred acres in extent, carrying a rare scent, are indeed tempting; but to my own taste, though perhaps in this my reader may not agree with me, they would be more inviting were they not separated by such forbidding

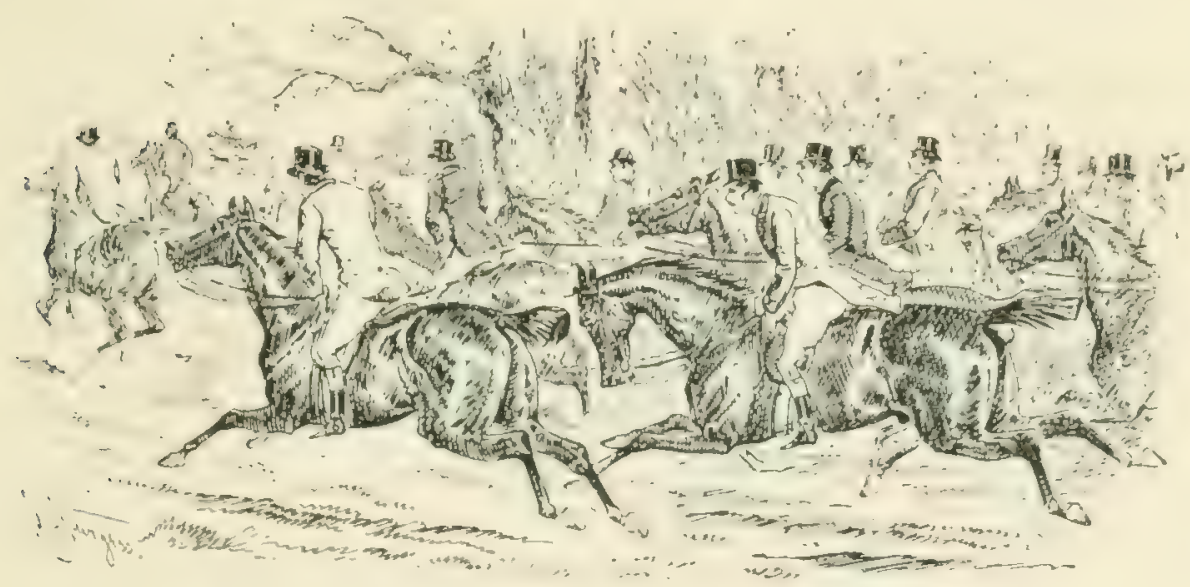

'The Niagara-like rush to which the "gone-away" is a signal.'

fences. A high black-thorn hedge, strong enough to hold an clephant, with one and sometimes two ditches, fortified, moreover, in many cases, by a rail placed half a horse's length uff to keep out cattle from the thorns, offers, indeed, scope for all the nobler qualities of man and beast, but while sufficiently jerilous for glory, seems to my mind rather too stiff for pleasure.' ' Most of the country hereabouts is grass, and in the very centre of the most formidable tract stands the far-famed Waterloo Gorse. Blue Covert (supposed to have been planted by the 'Blues' when last (quartered at Northampton), Talliho, Sulby Corse,

1 Riding Recollections, ch. xiv. 
Nasty Covert, and Marston llood, are all coverts of inark here.

From Weedon you get grass nearly all round you, and in the Sloucliburgh valley; over which a grood fox will probably take you from Braunston Gorse, some very big fences. Badby IVood is the most notalile strongtiold of foxes in these parts, and Ashipy St. Ledgers, Nobottle Wood, Iiramptom Gorse, Harberton IIeath, Whitton osier bed (with a nice little brook, though often found a nasty one, handy), Staverton Wood, and Buckby Folly; are all rich in the raw material. From Weedon, too, you may find yourself at lirixworth and try your chance at 'Knightley's leap,' a fenced brook below Brixworth Hill, over which the late Sir Charles Inishtley, on his famous Benvolio, unce corered thirty-one fect of ground. The corerts on the extreme south, Stowe Wood, Everton Stuhbs, \&c., are shared with the Duke of Grafton.

In the Northampton district there are hig woodlands, and more plough than clscwhere. From Sywell Wood to Gib Irood is almost a continuous chain of coverts, practically making one vast wood. IIerein foxes disport themselves abundantly, but they are not always to be pursuaded to go away as sood foxes should. Round Inrowden and Faxton are the best and most gra-sy parts of this district. Near Northampton the soil is lighter, and this is knuwn as the worst scenting ground of the country.

The Woodland country, now, as we have said, hunted by a separate pack, lies manly between the river llelland on the west and the Nene on the east. The kennels are at Mriesiock, a central point, and the plares from which the best of the country can be reached are Kettering, Thrapston, Ounde, and Market Harboro', but the Nimrods at the last place naturally, save in the carly autumn and late spring, prefer their own open pastures. The Int:e of Duccleuch's wouls, Bristock Forest, the liulwick lloods, the great coverts of lecene, Irampton and Oundle lloods, Carlton forest, and the l'ipwell Wor ds are the most comspictuous of these fomous strongholds. 
for these who can appmeriate the joys of this syle of huntme, and that it hats a perulial chathe of its onn none who hate crer tried it will gamsay, there ane few hetter places to enjoy it in than the I'ytchley Woullands. 'There is an unfiting supply' of foxes, even in the northermmost garts where sidme is strictly preserved ; the rides are crerywhere pasiable to a stout-limbed naw, and, as is the wont of woodlands, the deep mysterices of scent

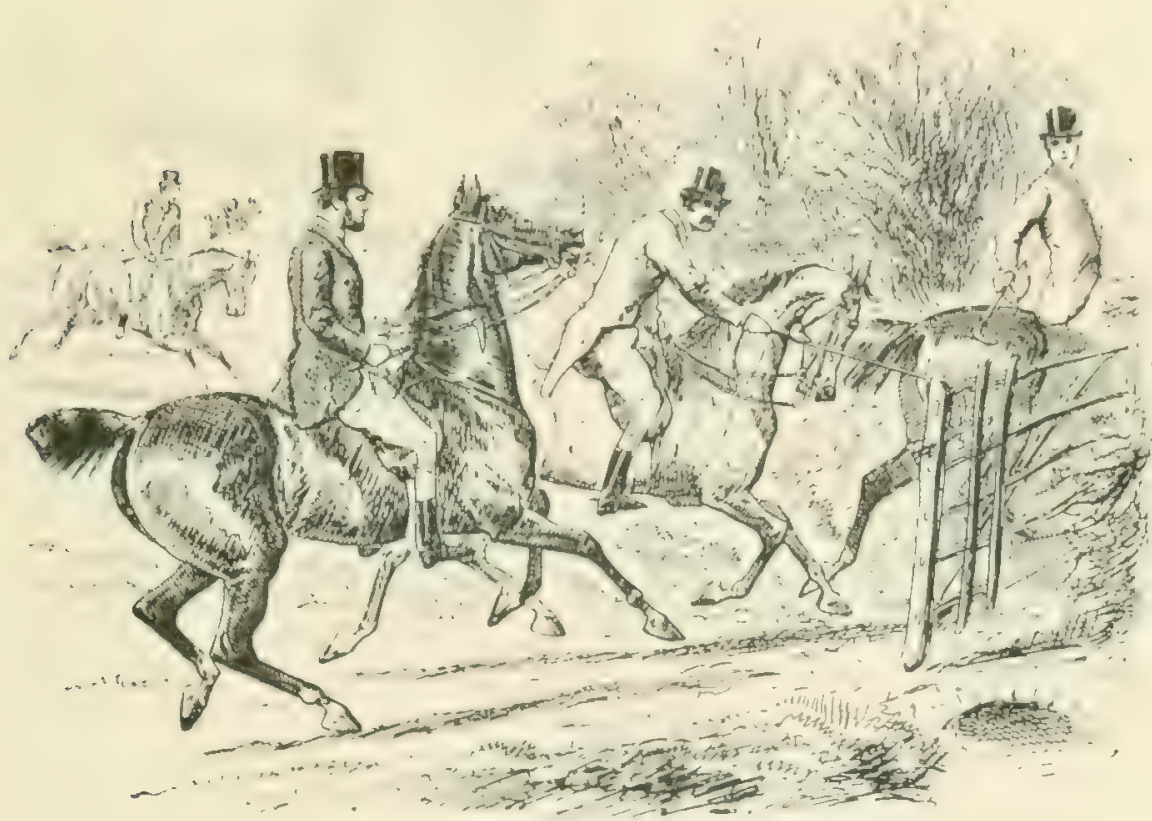

'Luckily with a liberal supply of gates.

rarely trouble much hounds' noses or men's minds. A gallop in the open, too, is no unknown thing. Between the Duke of Buccleuch's woods and Lrigstock is a fine piece of grass with some unconscionable fences, but luckily also with a liberal supply of gates. Between the roods round Rockingham and the Welland is again more grass; while from Cranford Corse and Finedon Poplars down to the Nene is an open tract of light plough and convenient fences. I man who wishes to enjoy' not too violently the senuine sport could hardly do so better than here. And he need not spend tou much moticy on 
horseflesh. 'You may,' observes the sagacious 'Brookshy,' 'if you like, keep a good horse for Dingley, Rushton, \&c., on the chance of a dive into the outer grass. But for home purposes and general occasion, something stout and short-legged-with a blood head, and heels well protected (if you can hit upon such a combination) - will carry you well cnough. An extra ten pounds on fair hack action will not be thrown away-if you would hunt far and late.'

On the whole, most people who have tried it will agree with the same much travelled authority that the Pytchley is a 'superlatively pleasant country,' to ride over. It is less hilly than High Leicestershire, except for the Hemplow Hills, which are indeed most painful cminences to confront after a quick burst; it abounds both in grass and in foxes; the fences, though everywhere big, are, save for the few exceptions indicated, not impossible for a good horse and man. Lastly, but very far from leastly, the farmers are with the fox hunters to a man; many of them riding well themselves, and ail staunch preservers, 


\section{CHAPTER IX.}

THE PROVINCES.

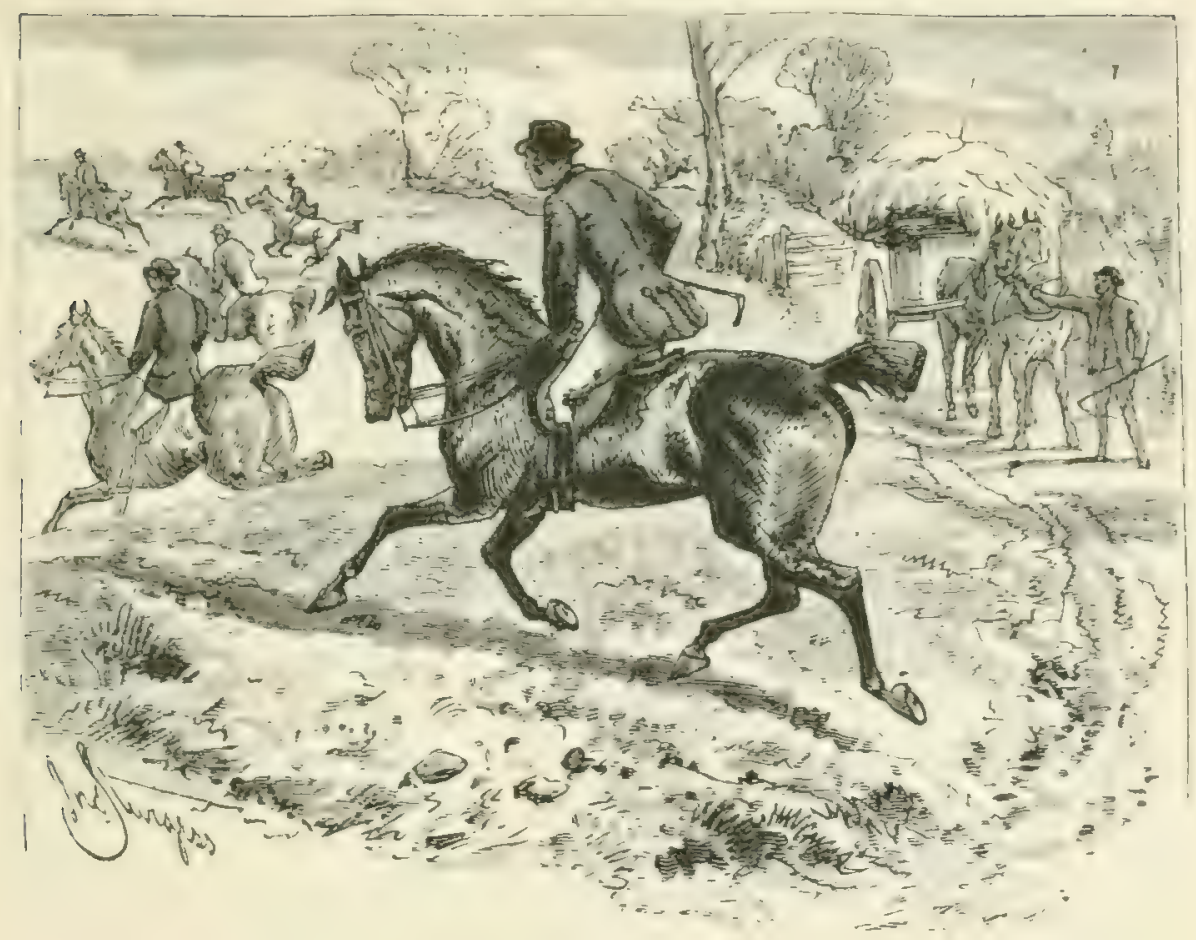

' Rough and various ground.

Round the 'Shires' lie some dozen or so of packs, with many' of which, sare for the name of the thing, it is possible to get as good sport and as good fun as in those more fashionable districts; and some few of which actually do orer the same ground. Whyte-Melville has drawn for his own jurpose a very: wide distinction between the 'Shires' and the 'Provinces,' 
and his Provinces are very Provincial indeed. He has done so, not in srom, rery far indeed from that; Whyte-Melville was too froud a sjurtiman to turm his nose up at the homeliest establishment in the runghest country in Great liritain, so long as things were done in a workmanlike rnamner. But his desim was to accentuate the dificience of ideas on the subject of sjort between 'Old Rapid' and his son. Sir he describes how the latter sees his fox min into after seven-and-twenty minutes without a check over the pick of High Leicestershire, in which run he has grone first from find to finish. And Paja Rapid possesses his soul in a real wild hunting run; in which some twelve miles of rough and various ground have been covered in an hour and three-quarters, with only one check to speak of ; sharing his delights with a 'field' consisting of Old Matthew (the huntsman), and his one whip, the Vicar, a schoolboy on his pony, and some three or four strapping yeomen.' II cnumeration of the merits of such hunting grounds as a training school for young sportsmen is worth quoting.

In large woods, amongst secluded hills, or wild tracts of monr intersected by impracticable ravines, a lover of the chase is compelled by force of circumstances to depend on his own eyes, ears, and greneral intelligence for his amusement. He finds no young kapid to pilot him over the large places, if he murns going; no rrafty band of second-horsemen to suide him in safety to the finish, if his ambition is satisided with a distant and occasional view of the stirring pageant; no convenient hand-gate in the rorner, no friendly bridge across the stream; above all, no hurry. ing cavalcade drawn out for miles, amonyst which to hile, and with whom pleatsantly to compare notes hereafter in those sclfdeceiving moments, when

Dined, o'er our claret we talk of the merit,

Of every choice spirit that rode in the run.

But here the crowd, sir, can talk just as loud, sir,

As those who were forward enjoying the fun!

in. In the P'rowinces our young sportsman must make up his mind to table his own part, to study the coverts drawn, and that

I Riding Recollections, chș, xiii. and xiv. 
out for himself the points where he can see, hear, and, so to speak, command hounds till they so away; must leam how to ri-e the hill with least labour, and descend it with greatest despatch, how to thread glen, combe, or dale, wind in and out of the rugged ravine, plunge through a morass, and make his way home at night across trackless moor, or open storm-swept down. By the time he has acquired these accomplishments, the horsemanship will have come of itself. He will know how to bore where he cannot jump, to creep where he must not fly, and so manage his horse that the animal seems to share

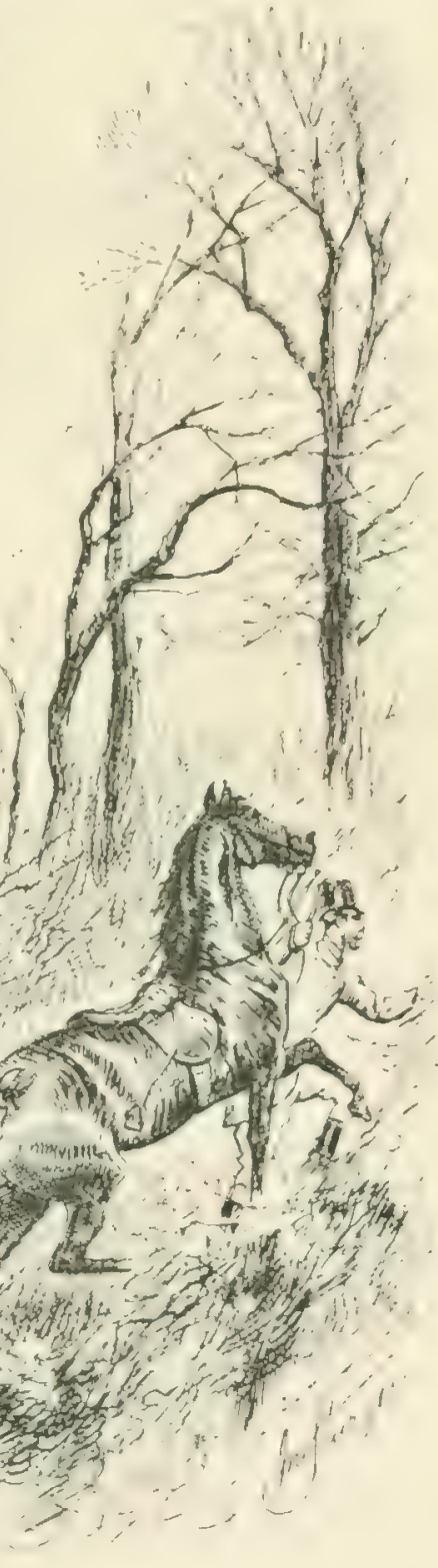

the intentions and intelligence of its rider. If he can afford it, and likes to spend a season or two in the Shires for the last superlative polish, let him gro and welcome. He will be taught to get clear of a crowd, to leap timber at short notice, to put on 
his boots and breeches, anc that is abrut a!l that there is left for him to learn!

And he arlds a shrewd fear iest he should 'offend an incalcu. lable number of good fellows and grond sportsmen, were I to describe as provincial establishments, the variety of hunts, north, south, east, and west, with which I have enjoyed so much good company and good fun. Each has its own claim to distinction, some have collars, all have sport.'

But there are Provinces and Provinces. Such countries as that in which Squire Rapid was wont to bring his foxes to hand, with the aid of those incomparable hounds Challenger and Charmer, are rare now, and grow rarer every day, what with the march of steam and of intellect. And when found, their beauties and virtues, which we for o'ur part would be the last of men to disparage, having indeed both by nature and training, a strong fancy for the more unfashionable side of fox hunting-their charms, we say, are rather local than general. Born to them, he, we are inclined to think, would be something of an ass who should leave them for the more violent and gaudier delights of the Shires-as perhaps Mr. Sawyer may have sometimes thought when things went wrong with his pretty wife; for had he stayed at home, content to triumph over the Nimrods of his native wilderness, he had never met Miss Cissy Dove. Poor BromleyDavenport has, indeed, vowed that he

Counts the swell provincial lower than the Melton MIuff;

but the poet, we have the best possible authority for knowing, is ' a maker of images and very far gone from the truth.' Still, charming as these few natural nooks and corners of Old England are, not many, we imagine, meditating on some pleasant place wherein to pitch his hunting tent and enjoy his sport with something less than Meltonian frequency and ardour, and at something considerably less than Meltonian expense, would select such a one. As a rule they are 'far from rail and turnpike road,' and that is a drawback to all hunting quarters however much of an advantage it may be to all hunting grounds. but there is plenty of choice for him nearer civilisation. IJe 
need have no difficulty in finding all he wants; good hounds and good country, good sport and good company, hunting and riding, without taking a journey to Corinth. Esjecially will he find them in those packs we have already alluded to as bordering on the Shires; of some of which it may be fairly said that if not the rose, at least they have been so long in its company that only a very nice critic could mark the difference.

Conspicuous among these is the ATHERstone, which hunts about equal parts of Leicestershire and Warwickshire, and a small corner of Staffordshire. 'The history of these hounds springs from some time in the latter half of last century. The first recorded date is the year 1793 when Lord Talbot, of Ingestre Hall, sold his hounds to Mr. Lambton. The first Lord Donegal had pre. ceded Lord Talbot, and Lord Vernon succeeded him. In the latter's day the boundaries of the hunt were considerably enlarged, and orange took the place of the orthodox scarlet as the uniform of the hunt. But for some time after there appear to have been four divisions of the country, sometimes united under one master, sometimes hunted separately on a system of mutual accommodation. ${ }^{1}$ It was in MIr. Osbaldeston's time that the pack received its present name, and the kennels moved to Witherley where they still stand. Sir Bellingham Graham, Mr. Anstruther Thomson, and MIr. SelbyLowndes have been also among the masters. The present master, Mr. Oakley, came into office in $\mathrm{I}_{77 \mathrm{r}}$. The country as at present established is bounded on the south by the North Warwickshire, on the west by the South Staffordshire, by the Quorn and the Meynell on the north, and on the east by the Quorn, Sir Bache Cunard's and the Pytchley. The pick of the country lies of course on the eastern side, which is well commanded by the universal Rugby, and farther north below Leicester is also some pretty galloping ground. When the meet is at Brownsoever, Coton House, Bitteswell, or Newnham Paddox, the 'fields' are of true Leicester dimensions, the Quornites and the Pytchley men mustering in great force. The

1 Records of the Chase, ch. vii. 
most central point is Nuneaton, near the kennels, and handy for all the four days a week on which these hounds take the field. lirom Market Pusworth, al, - and from I eicester, Lutterworth and Coventry, nearly all--the country can be rangerl. The last-named is famous among cavalry quarters, and the gallant young gunner (of late years Horse Artillery have taken the old cavalry bumacks) whom the authorities may have directed to pass his winter there will have little cause to grumble, if he be fond of fox hunting. Altogether the Atherstone is escentially a sporting country. There is much grass, and such ploughed land as there is, ever in the IBmingham district, alout the worst of all, is never very deep or sticky. There is plenty of jumping. In the greater part of this country the fences are very small, but very blind; some of it. however, is big enough for anybody; but none is of that desperate quality one meets with in some other quarters, in purts of the Belroir Vile for instance, or round Market Ifarboro'. There are plenty of coverts of all sorts and sizes, from the snug little grorre at Coton to the big woods of Coombe; and an excellest supply of foxes.

I) south of this pleasant land lie the two Warwickshire packs. The southernmost, known as the WARWCksHRE, has a famous history, in which the names of the reat John Warde, and, in county story, the yet greater Mr. Corhet, stand out with peculiar lustre. The latter reigned for twenty seasons, from I79I to I8I2. He was not a hard rider, but he had a rare arod huntsman in Will larrow, and was perhaps the most jopular master of hounds that ever hunted the country. In his time the principal kemnels were at Stratford-on-. Iron, but he harl others at Meriden, between Coventry and Colewill, handicr for the woodlands. Lord Midileton followed Mr. Corbet and manaced matters for ten seacons, and then came an era of shot ma-terships till 18.39 when Mr. Barnard, father of the present Iord Willoughty de lirule, came into ofice and stayed there for serenteen years. Lemmington is the great huntin: centre, and famous not only for hunting as it is the liveliest and most suciable of all the towns wnercin the disciples 
of Nimrod do congregate. In the year 1822 the growing importance of Lcamington had already begun to vex the souls of the good old county families who looked to Wrarwick as their capital. A year or two later Mrs. I andor wrote to her famous son at Florence that the charms of this new watering place were 'driving the gentry away from Warwick.' Between $18_{30}$ and I 4.40 I.enmington used to boast itself a rival to Melton, and if other things than riding to hounds may come into the account, it was perhaps more than a rival. The steeplechases helped it much. In the great days of that amusement, when Captain Becher on Vivian held the pride of place afterwards held hy Jem Mrason on L ottery, before the star of Liverpool had risen, Leamington divided with St. Albans the honours of the flag. Nor is it only for the Warwickshire hounds that Leamington is handy. The Quorn, the Pytchley, and the Atherstone, the I) uke of (irafton's, the Bicester, and the Heythrop may all be reached therefrom. The poorest part of the country is oddly cnough just round about Leamington; the best on the Shuckburgh side on the far east, where a deal of riding is wanted to see what hounds are doing. Banbury and lienny Compton are also convenient quarters; the latter more so for choice meets, the former, within the Oxfordshire border, as a place of residence, being by an hour or more nearer to London, and also containing more human interest. Stratford on the western side has also its advantages, besides that pre-eminent one of association with a certain William Shakespeare who knew the points of a good horse, as he knew everything else, better than most men. It is also near the kennels, which were settled at Kineton in the first year of Mr. Barnard's mastership, on land given to the hunt by Mr. George Lucy of Charlecote l'ark-another association with the name of Shakespeare. So keen was the interest taken in the work all along the countryside that the materials were drawn to the spot by the wagrgons, five hundred and fifty-three in all, of one hundred and eighty farmers.' The grass lands of Warwickshire cover about one-

\section{Records of the Chase, ch. vii.}


third of the area ; they are often deep, and the ploughs are not of the lightest. There is a good deal of timber, and the hedges are thick and strons; brooks are not very plentiful nor very large, though the land is watered by two rivers, the Avon and the Stour. I,ord Willoughby de Broke, the present master, hunts five days a week, though four only are in the bond. Both coverts and fores are well cared for, and indeed there are few countries where the old hunting spirit has been better maintained than Warwickshire, and not many quarters where a man may quietly enjoy more good sport in pleasant company than Banbury.

Though a separate pack of hounds has intermittently hunted the northern portion of the country since the beginning of the century, that now known as the NORTH WARwiclishire was not definitely settled, according to 'Brooksby,' till I $_{53}$, when Mr. Selby-Lowndes took the mastership. He only stayed in the country for two seasons, but Mr. Baker, who followed, held it till ill-health made him retire in 1862 . He showed fine sport, and so did Mr. Oswald Milne after him for seren seasons, and then his pack, a particularly good one, passed to Mr. Lamb, the present master. Birmingham on the north-west, Leanington on the south, and Rugby on the east mark the boundaries of this Hunt, which is much smaller than the older branch on the south; rougher too, with more woodland and less grass, and some say, rather fewer foxes. Still near Lirningham there is some nice galloping ground, and from Hillmorton Gorse or Bunker's Hill in the Rugby district one of the finest grass lines anywhere in England. Besides the towns mentioned, Coventry also comes into play for these hounds.

liesirles the Warwickshire packs Lanbury also commands two others of historic repute, the Bicestek and the Hextrikor. The first-named can show as fine a record as any pack in the kinglom, from the leeginning of the century when Sir Thomas Mustyn had them, with the elephantine Stephen Goodall for huntsman, and when, according to 'The I)ruid,' upwards of a hundred hunters were stabled in the little town from which the 
hunt takes its name, and 'not a chimney' corner was to be let.' As Stephen weighed twenty stone he was not of much service when hounds ran fast, which, as a matter of fact, they do not seem very often to have done in those days. Sir Thomas had curious theories of brecding, and an almost fanatic aversion to tongue, which resulted in his hounds at last running almost mute. 'I'om Wingfield was a better servant to Sir 'Thomas than either Goodall or the 'great Mr. Shawe,' and, among other accomplishments, he was famous for being the only man able to keep in order Griff Lloyd, the hunting parson, and a great character in that country and time. Mr. Dralie, the Squire of Shardeloes, succeeded to Sir Thomas, and the sport grew faster. Drake has always been a name of mark in this country, and when the present Squire hunted the country, and his brothers Edward (a parson, too, but of a different stamp) to Griff Lloyd, and as good in the cricket field as the saddle) and George were in their prime, it took an uncommon good man and horse to beat the family. Besides Banbury, the country can be hunted from Bicester, Buckingham, and Brackley. Bicester is the most central, being only three miles from the kennels at Stratton Audley. Leighton and Bletchley are also convenient spots, especially if you hunt from London, and to one so hunting there is no grood country more accessible than this. Its stiffest part is in the northern angle rumning up to Daventry, sandwched in between the Heythrop and the Warwichshire on the west and the Duke of Grafton's and a little corner of the lytchley on the east. This is ntarly all grass and fenced in true Northamptonshire style. In the centre lies the IBicester Vale, grassy too, but less formidible to cross, and separated from 'the fairest of all hunting quarters', the beilutiful vale of Aylesbury, by the Clayclon Woods on the east, while on the south lie the deep Oxford woodlands, which are mostly shared with Lord Macclesfield. Hereabouts the country is rough, deep, and wild, and bad to cross ; but eastwards towards Brill a fairer prospect opens, and in the days before Oxford became a 
dames school, when Whitecrosis (ircen or Islip Town lind was the meet, the undergraduates used to muster strong. All this part of the country, known locally as the Quarters, is commanded from Oxford, but that once great centre of learning, and other things less convenient, perhaps, but to young minds not less agrecable, is a little far off for the best of the bicester.

While in this country, we can hardly leave unnoticed the Whadnon Chase pack, better known as Mr. Selisy-Lowndes's. Save for a break of five seasons, when he was with the North Warwickshire and the Atherstone, the 'Squire' of Whaddon has hunted this country for over forty years. What the cuuntry is can be said in a very few words-it is the Vale of Aylesbury; immortalised in song by Whyte-Melville, and in specech of various degrees of eloquence by all who have ever ridrlen over its glorious pastures in dry wiather. In a decp winter its charms are more disputable, though indecd no one can deny their fuiters of attraction. It is full of brooks, but all, sive the Addington Brook only, clean fair jumps; and the doubles of the Vale are as famous as the ox fences of Market Harboro', and, in some eyes, as impracticable. No doubt, to ride straight over this country does require a very grood pair; but, griven the necessary qualifications, it is heavenly-the 'Londoner's l.eicestershire,' as 'Brookshy,' invokingr 'apt alliteration's artful aid,' has styled it; 'one great dairy farm-rich jasture from end to end,' but also, 'one weck a springboard, the next it is a treacle jot.' At its best, however, he truly describes it as 'a luvely succension of sweet-scenting meadows, from whose chistic fare a horse bounds ealsily and laclly on to sound firm banlis,

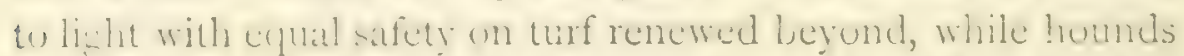
spmead out at their fences and camy a broad head from bichd to feld.' 'The iences are, as we have satid, bier, and the doubles

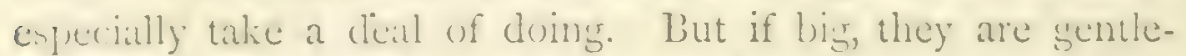
manly; they are alilie from end to end, and you may as a rule have them anywhere you please all down the line. Consefuently there is nume of the cramming and pushing for the one prace that so ofen mars the fun ten the shires; and though there 
is often a crowed in the Vale, there in senerally plenty of romm for it to disport itsclf, particularly if hound.s run fast. 'Jirookshy' describes the sort of nag for this comntry in more detail than he

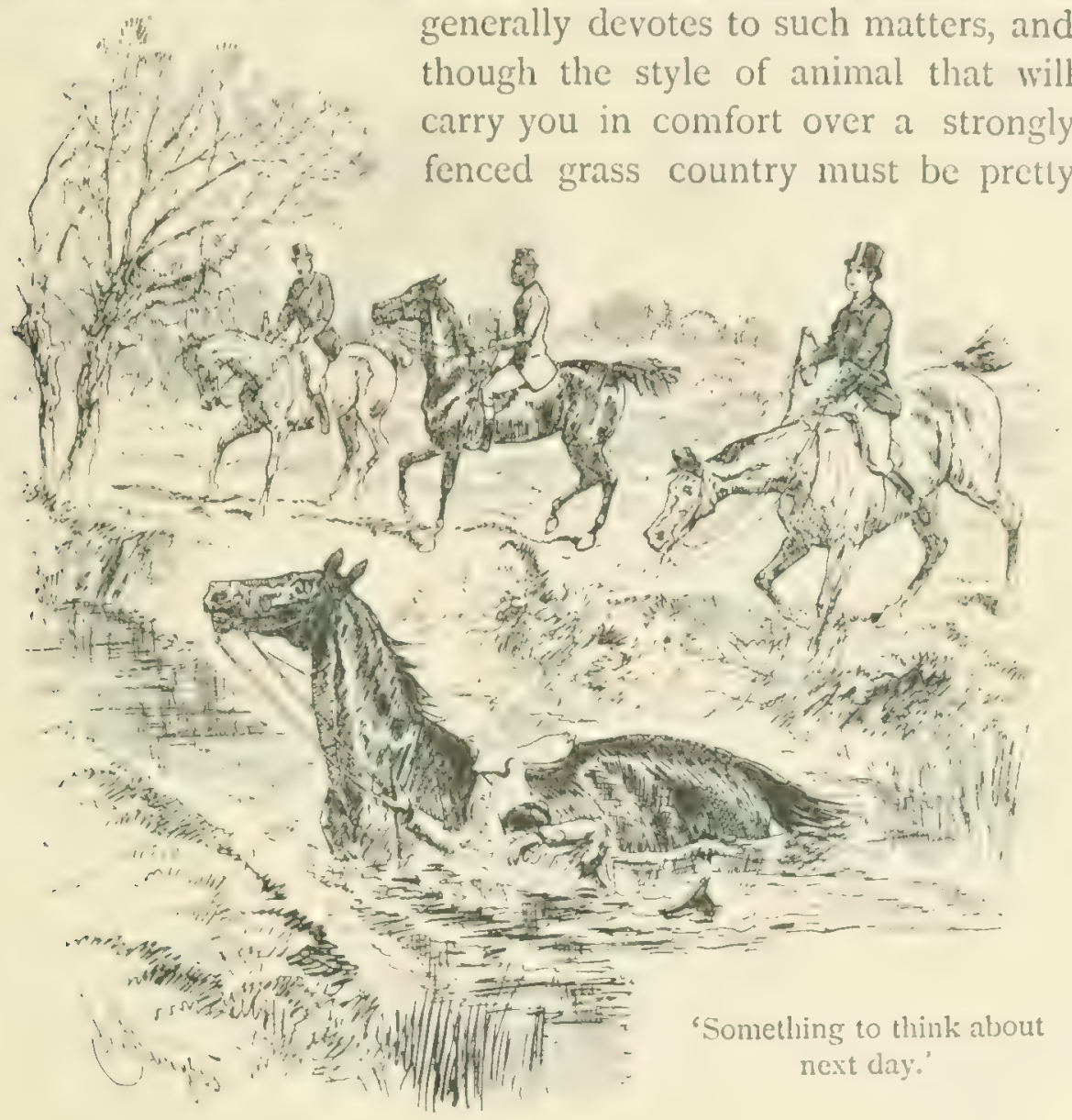

much the sime all the workd over, his descriptiun is womh quoting :

The Vale calls for all the best essentials in a hunter. He must gallop, he must jump, and he must stay. He need not be an absolute flyer, but he can't be too good; and it iș noticeable that a man tutored in the Vale is not only likely to ride well over the best of

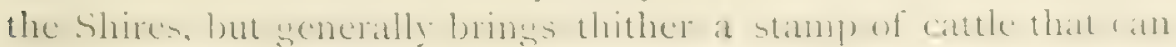

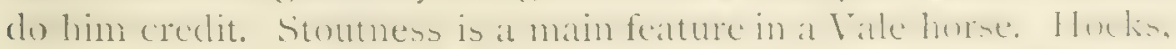
quarters, and bark are the matin proints, deptis of chest and ribs. indispensalble. The lengh of one type of Leicestershire horse is 
out of place. But there are two sorts for Lencestershire, and the thick one is the better. This is the Aylesbury horse. ${ }^{1}$

I.cighton and Bletchley are the most handy entrances to this little Garden of Kden for the Londoner; Aylesbury and Winslow are yuite as good or better for the country, but not so convenient for the railway. Christmas Gorse and High Haven are memorial names, and the line between them to be beaten nuwhe in this mortal vale of ours; from Aston Abbots, Cresluw Great Ground, or the Addington Coverts, it will be strange if you get not something to think about the next day; from the latter place it may very possibly be the temperature of the Addington Brook. Mr. Lowndes hunts twice a week, on Tuesdays and Saturdays, with an occasional by-day in the woodlands on the north-eastern side. For the last few seasons he ceased to advertise his meets, owing to the unremunerative crowds the London trains used to let loose on him; but he has latterly gone back to the newspapers. His pack, however, is maintained by subscription, and if you hunt with it, you are expected to contribute to its maintenance; should you forget to do so, you are pretty sure to be reminded of your forgetfulness. The Vale is common ground with the Rothschild staghounds, and in part with the Bicester.

The histury of the HEythrop centres round two cardinal landmarks, the figure of Icm Hills, and the fame of the Great Tar Wood run in Lord Redesdale's mastership. Up to the yeir 1835 the country had been hunted by the Dukes of Ijanfurt alternately with their home and Badminton district. In that year the sixth duke found his health was not equal to the divided duty, and, after some difficulties, a committee of mantegement was formed, consisting of Mr. Langston of Sarsion, I.urd Redesdale, and Mr. Mosty'n. The hounds were all from the Badminton kiennels, and Jem Hills ${ }^{2}$ came from Lord Ducie to hunt them. Jem was a great character, and 'The Druid' has gatlerecl a record of his sayings and doings which puts him

1 The Hunting Countries of England, vol, i. p. 362.

2 Jem I Hill hul been many years Whipper-in to the liulninton Pack and consequently knew the Heythrop country well. 
as an historic personatge quite on a par with the l)ick Knights, Stephen Goodalls, Tom Wingfields, and Tom Rances of an earlier day." His style of hunting was peculiar, and it may he said of it as was said of Charles l'ayne's with the l'ytchley, that with anyone clse it had been impossible. Iut with him it was marvellously effective. IIe was a great rider, and a very fair cricketer, playing for eight seasons in the Sussex cleven in the golden days of old Iillywhite. However, we must leave Jem's biography to 'The Druid,' and get back to the country. Lord Redesdale, who had been supreme for many seasons, had in I 855 to turn to sterner things. In 185 I he had been elected Chairman of Committees in the House of Lords, and after trying to combine the saddle and the senate for four scasons, he found the work too hard, and made his choice for the latter. Mr. Hall succeeded, and showed good sport for some years; then followed a committee again ; in $1 S 6_{5} \mathrm{Mr}$. A. WT. Hall came into office and remained there till i 873 , when Mr. Albert Brassey took the hounds, and keeps them to this day. In I 865 Tom Hills, a nephew of the great Jem, donned the green plush livery of the hunt, but he had not his uncle's gifts; and after four seasons he gave way to Stephen Goodall, who carricd the horn till Mr. Brassey promoted his first whip, John Hasleton. The Heythrop country, which is about twenty miles in extent from east to west, and fifteen from north to south, presents many varieties. The Cotswold uplands, on the west and north-west, give a light galloping country, with a very variable scent, which is best in wet weather, fenced mostly with stone walls, formidable to look at, but easy enough to surmount for a nag who knows the trick of them. They are not solid, and there is never a ditch on either side, though you may occasionally, if a stranger in the land and too adventurous, find yourself descending into an old quarry. According to 'Brooksby,' the mode of encompassing these obstacles adopted by an old hunter is not comfortable. He 'will get so near to a wall that he rises almost perpendicularly, and-mutatis 
mutundis as to head and tail-descends almost vertically on the other side. To accommodate yoursclf to this form of calisthenics, your body is at one moment lying along his neck, and at the next it must be thrown back on to the crupper, your spinal cord being called upon to perform the hinge-action recuired.' 'This form of exercise is undoubtedly laburious, especially if practised fifty-four times in a single day, as an 'old

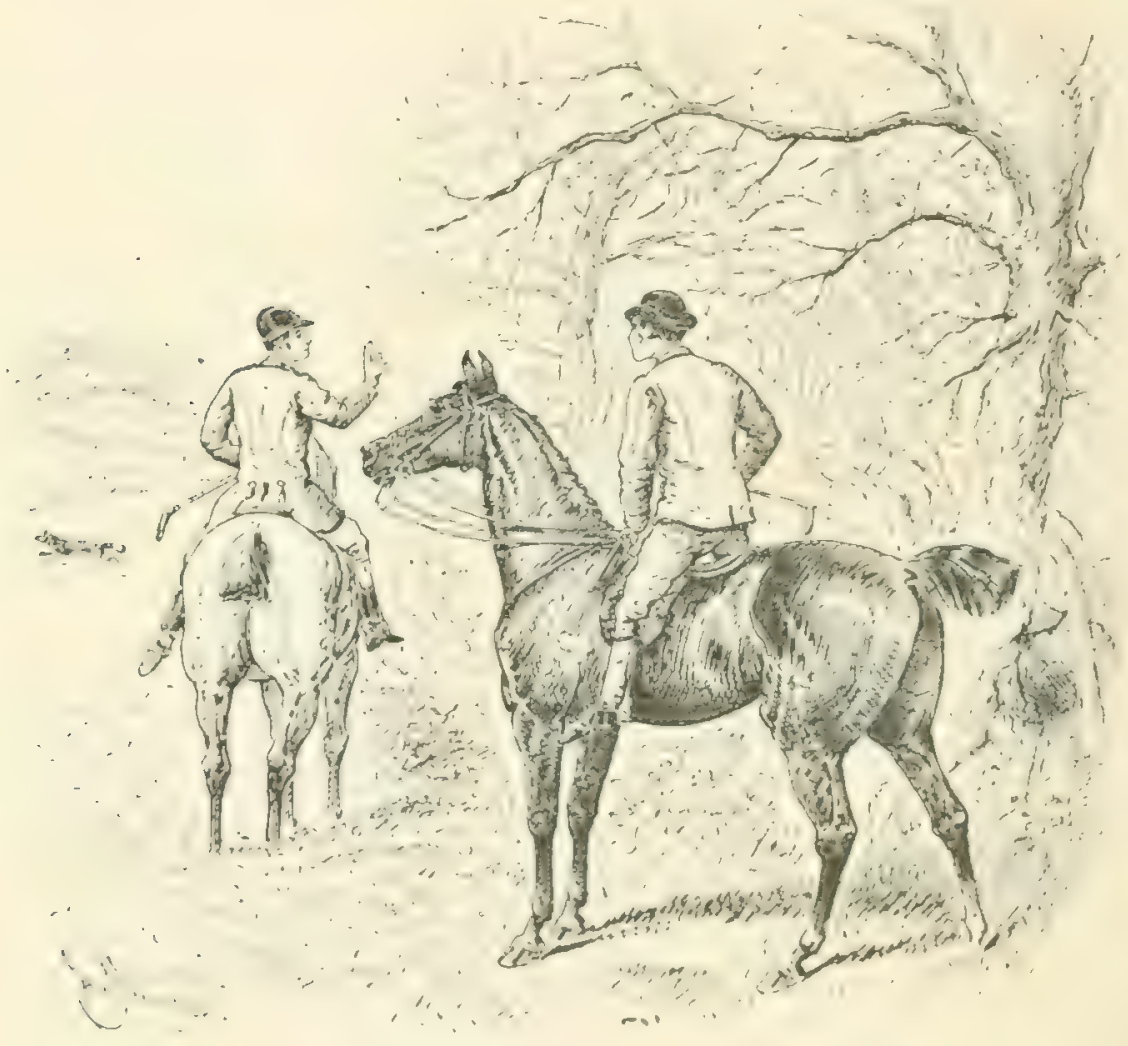

' Where Jack the whip in ambush lay.'

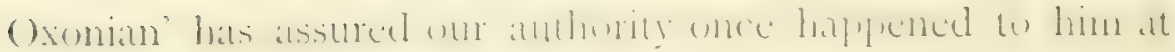
collegre. But we do not think it is necessary; at least we

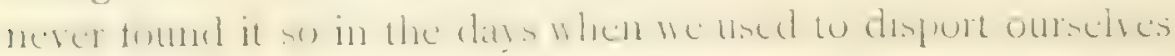
in that country, and though our tale never certainly reached

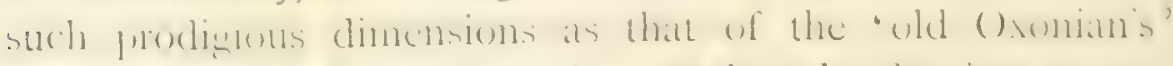
(thomeh posithy it maty have risen to them by the time we can

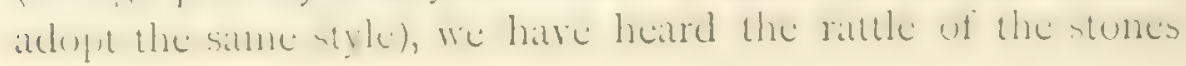


pretty often in our time. On the Gloucestershire side is the most grass land; a nice country this, the Slaughter Vale, over which a fox will probably take you from Bruern Abbey or Gawcombe, being about the cream of it all. Round Heythrop, where the master lives, Chapel House and Pomfret Castle, there is also some prety ridirg. Bradwell Grove is the great meet for the stone walls, and here the hounds come regularly' on the first II'ednesdily of each month to draw Jolley's Gorse. There were few hunting undergraduates in the old days who had not hanging on their walls the famous print recording the humours of a 'Gallop with Jem Hills from Bradwell Grove.' Tar Wood is down in the southern corner, a common property with the Old Berkshire. It is a deep heary wood, and the country round about is not very engaging. Man, according to the poet, 'grets no second day,' and we do not know that Tar Wood has ever renewed its ancient fame. 'The great run, immortalised by Egerton Warburton in one of the best of his hunting balliads, took place on December 24, i $S_{45}$.

He waited not, he was not found,

No warning note from eager hound,

But echo of the distant horn,

From outskirts of the cover borne,

Where Jack the whip in ambush lay,

Proclaim'd that he was gone away.

And go away he did. The peculiar feature of this run, according to the hero of the day, Mr. Whippy, "was the stoutness and intrepidity of the fox. With the exception of just touching one corner of Bay's Wood at Cokethorpe, he never once sought shelter in a cover of any description. 'The distance from point to point is from fifteen to sixteen miles, and I am sure the distance run over must have been at least twenty miles. Time, one luur and forty-two minutes.' Well maly the puet sing :

When younger men of lighter weight

Some tale of future sport relate,

Let Whippy show the brush he won,

And tell them of the Tar Wood run. 
In the Oxford days of the present writer, we used to look with peculiar veneration at Joe Tollit, who even then could show many a younger man the way to go, for his share in the glories of this great day.

The speed of horse, the pluck of man,

They needed both, who led the van;

This Holmes can tell, who through the day

Was ever foremost in the fray;

And Holloway with best intent,

Still shivering timber as he went;

And Williams clinging to the pack

As if the League were at his back ;

And Tollit, ready still to sell

The horse that carried him so well.

But we wander, and must hark back. 'The Heythrop have plenty of woodland hunting; Whichwood Forest and Blenheim Park on the south-east, and the woods of Stcckley, Kiddington, and Glympton. Hounds are not allowed either in Whichwood or Blenheim till late in the autumn, so the cub hunting has to be done in the smaller coverts. Four days a week is the Heythrop fare, and a frequent by-day, for foxes are plentiful everywhere. 'The Monday meets range from Chipping Norton, where the kennels are, up to the Warwickshire border, and include about the best of the country. On Wednesday hounds are alternately on the Oxfordshire and Gloucestershire side. Friday is the day for the Cotswolds, and Saturday for the Oxford woodlands. Chipping Norton (about three hours and a quarter from laddington) is the most central quarter; but both from Oxford ant Janbury the Ifeythrop can always be reached, though from the fomer place you have to go some distance to gret into their best country: Fast and strong horses and quick jumpers are an essential part of your equipment for hunting with the Heythrop hounds.

Another pack familiar to all Oxford men is the Sourn Oxlorusminl; or as they loved best to call it, Lord Macclesnield's. His lordship hunted these hounds from is57 to 
1884, when Mr. Charles Morrell took the mastership. Encircling Oxford in its welcome embrace, this country runs a few miles farther north-west to Islip, while on the south it joins Mr. Garth's borders at Marlow. From Henley to Moulsford it marches westward with the South Berkshire, from Moulsford northwards to Islip with the Old Berkshire, while on the east a pretty straight line from Wendover to Marlow divides it from the Old Berkeley. A small country, it can carry only two days a week, but it is a most unusual thing if on one at least of those two days there is not some fun going. The best of the ground is round about 'Thame, and that is certainly good enough, for it is in fact a part of the Aylesbury Vale. South of this little town, which shares with Oxford the command of the country, lies the inn of the 'Three Pigeons,' the best of all their fixtures, with its light grass, its flying fences, and-Haseley Brook, name of delight or fear to many an Oxonian, according to the hydrophobic qualities of himself and his horse. In the immediate neighbourhood of Oxford the country grows worse for riding. Here are the woodlands, those 'Quarters' already spoken of. 'Wet, grim woods are these,' says a recent writer, 'dark within and cold without ; but they make hounds, and they give a certain amount of sport, though their depths are unfathomable and their rides bid defiance to a stranger.' Yet there is many a green spot in this grim district; one of the best gallops ever enjoyed by the present writer during his sojourn at Oxford was with an afternoon fox from Stow Wood.

Directly south of the Pytchley, between the Bicester and Mr. Lowndes's countries lies that hunted by the DukE of GRAFTON's hounds. Early in the present century this pack had quite a character of its own, thus graphically described by 'The Druid :'

They were rather round than deep in their bodies, had good legs and feet, were very stout, but wild as hawks. No fox could live before them if he hung, and they did not change; but over the open, when the morning flush was on them, they could not hold it, and could never pinch him. They ran by ear more than 
by nose, and when they got to a ride half the pack would leave the cry, hop round to the next ricle, cock up their ears till they heard the others bringing it on, and then throw themselves in at his brush. In the latter days of Joe Smith, Tom Rose hunted them, and for many years afterwards had the whole control over them. He bred them in:ich larrer but never altered their character. He was a fine joyous old fellow as ever cheered a hound, and no one knew better what he was about. Ineing once asked why he bred his hounds so wild, 'Why?' says he, 'I'll tell you why. Nine days out of ten I an in a wood. Every fox I find I mear to kill, and these hounds are the sort that wil! have him. An open country and a woodland park are different things. What you call a gond pack will never catch a bad fox, and as I want to hunt him instead of his hunting me, I think my hounds best calculated for my country.' . . After the old Duke's death, the late Lord Southampton took them, and Tom Rose continued to hunt them. They were kept much in the same form, and with the same result; in short, he killed his foxes in the woodlands, and they beat him in the open. ${ }^{1}$

There is plenty of woodland still in this country, which is not now so large as it was in Lord Southampton's day and before then, but large enough to give three days a week. But besides woodland there is grass, and there is plenty of jumping. Along the northern boundary, marching with the Pytchley, lies the best of the ground, which only a Pytchley nag and a bold rider will cross in safety. The north-western part is the best and grassiest ; here you may gallop) westwarlover the Bicester borlers, or northward over the l'ytchley towards Shuckburgh. On the eastern side, round Towcester and IBlisworth, there is more plough, and the fences are mostly smaller, though in the Towcester district there are some formidable bullfinches, regular 'stitchers'! In the centre of the country run two pleasant vales, though rather interfered with now by the railway. 'The woodlands lie to the south and east, and are generally hunted on the Wednesday, Friday being devoted to the central vales, and Monday to the Northamptonslire quarter. Thittlebury and Salsey Forrests grive, according to 'Jirookshy,' 'the

\section{The Post and the Paddock, ch. xiv.}


perfection of woodland hunting, amid open rides and hollow glades; and it generally happens that hounds eventually work their way into the open,' either through Wicken Spinnies, or across the Ouse into Mr. Lowndes's country. The kennels are at Wakeficld Iawn, near Stony Stratford, and the latter town, Weedon, Wolverton, Towcester, Blixworth, and Buckingham are all convenient for head-quarters. Weedon is the best of all, for you get from there not only the Duke's, but a good part of the Pytchley, and the cream of the Bicester and the IVarwiclishire. Indeed, it shares with Coventry the pride of place as winter quarters for the soldier who, in default of sterner game, delights to employ his superfluous energies on 'the image of war without its guilt, and only five-and-twenty per cent. of its danger.'

East and norti-east of the Duke of Grafton's country lies the domain of the OAKLEY, marching with the Pytchley from Northampton to Higham Ferrers, thence to Huntingdon with the Milton; turning south and west the line runs along the Cambridgeshire and Hertfordshire borders to Leighton, whence northward it joins the boundaries of the Whaddon Chase and the Duke of Grafton's.

Fifty years ago the hounds belonged to the Duke of Bedford. Next they belonged to the country, who sold them to Mr. Arkwright. The latter added to them large drafts from the Belvoir and Brocklesby, and, by dint of a quarter of a century of skilful breeding, built up a grand pack, which, on his proffering his resignation four years ago, the present Duke of Bedford purchased from him, and generously presented to the hunt.

Such is the history of this hunt as lately set forth; but 'The Druid' carries the record back to the first decade of the century, when the Duke of that day took them in hand, with George Wells for his huntsman. Mr. Robert Arkwright had hunted the country for six-and-twenty seasons four days a week till, some six years ago, finding the work too much for him, he divided it with MIr. T. Macan, he himself hunting the woodlands in the northern half twice a week, and his colleague 
keepung to the open for the other two dass. The country is eminently a sporting one, full of fores and coverts, and of squires 'hunting from home,' as we have said before, the best of all supports to a pack of hounds. Dut it must in truth be said that as a country to ride over it has many superiors. It is flat, which is in its farour certainly; but also it is thickly wooded, and very thickly ploughed. On the western side from Newport Pagncll to Northanpton there is a fair sprinkling of meadow land, and on the Kimbolton side you may often get a gallop into the best of the Fitzwilliam country. But plough is the prevailing feature, so that a strons short-legged horse is the animal to bestride; very fast he need not be, but he must jump, both big and cleverly, for the fences as a rule are hairy and trappy. Bedford and Bletchley are the best quarters, while Shambrokk commands the woodlands, which, it may here be said, are liberally supplied with rides.

A rare pack is the Miltor, or, as it is more commonly spoken of, the Fitzwilliam. For over a hundred years it has been the property of the family of that name, and the Milton blood ranks with the Belvoir and the Brocklesby as the best in the kingdom. And a fine large sporting country it has to hunt over, stretching from Huntingdon and St. Ives on the south, almost to Crowland on the north. On the west it marches with the Pytchley and Cottesmore-good neighbours -while south and east lie the Oakley, the Cambridgeshire and the West Norfolk. Iike the Oakley, the Fitzwilliam country is a severe one for horses, wild and deep, the coverts often very far apart, much wood, and a superfuity of plough. There is also a particular kind of fence in the south and south-western districts; blackthorn, of abnormal height and density to be surmounted best, say those who know, by that discreet process linown as groing round. Yet, though as a riding ground this country cannot ranl: high, so good are the hounds, so stout the foxes, so genuine the conclition and gencral conomy of things, that the Fitzwilliam bars a name second to none in the favour of sportsmen. From l'eterborough and Huntingdon the country can best 
bereached, both under two hours' journey from London; and the former only three miles distant from the kennels at Milton Park To many of the meets the hounds have to be carried by rail, and generally it mily be said that a day's hunting with this pack involves the covering of a good deal of ground. The best of the country belongs to the Wednesday meets, Lilford, Thrapston Bridge, Bythorne Tollbar, and so forth. A good fox from Fitchmarsh Warren, Lord Lilford's park, Barnwell Wold, Stanwick Pastures, or Catworth Gorse, will nearly always take a good line southward along the Pytchley border, and possibly over it. Eastward of Elton again, in the Peterborcugh district, there is some fine grass land, and the ploughs about these parts are less tenacious than elsewhere. Farther east of Peterborough lie the Great Fens, and if foxes put their heads that way, as they often do, especially from Hoime Wood, you may as well turn yours homeward; for there is little to be done there, unless your nag be web-footed.

To go one by one through all the good packs of England and their countries is beyond our scope. 'Cecil' and 'Brooksby' have done that for us, and to them we must refer our readers who still are undecided, or thirst for yet larger knowledge. In this chapter we have specially confined ourselves to the best of those which lie within convenient reach of London; trying to indicate the quarters where a man, ambitious of some larger sport than is to be met with among the more distinctly suburban packs, and yet compelled to be in I.ondon a certain number of days in the week, is likely to gratify his ambition most reasonably and easily. Many things have necessarily been left unsaid ; many countries left unvisited. Cheshire and Shropshire, for instance, counties as rich in hunting memories and hunting realities as any in England. The 'Green Collars' of Cheshire are as historic as the "White Collars' of the Pytchley or the 'Blue and Buff' of Badminton; and their historic heroes, the famous old Nestor, Sir Harry Mainwaring, Tom Rance, with his 'single eye,' worth many another's two, Joe Maiden, and many another good sportsman 
and fellow have been enshrined for all time in the strains of Egerton Warburton. Shropshire still cherishes the memories of 'Tom Moody (whose mythic fame, however, is by all accounts very much in excess of his actual merits) and the creat 'Trojan,' Sir Bellingham Graham (the only master of hounds Shropshire has known not native to the country), and wilu Jack Mytton. Yorkshire has not yet lost the memory of its two ldols, Tom Hodsson and llill Danby, and the breed of horse, hound, and man, dues is best to keep that memory sreen. The Brocklesty, the Burton, and the Blankney, still keep up the fame that Lincolnshire won in the old days of Assheton Smitn and 'the Squire.' A special chapter were all too short fitly to commemorate the glories past and present of the Badminton country. The charms of the Blackmoor Vale in his later years drew Whyte-Melville away from the Shires of his eurlier love: indeed, he has, as it were, thrown down a challenge to the whole sporting world, by avowing that, were he 'sure of a fine morning and a safe mount,' he would 'ask for no keener pleasure than an hour's gallop with Lord Wolverton's bloodhounds over the Blackmore Vale.' A gallop from the Ilowing Stone over the Wantage Vale when Treadwell held the horn of the Old Berkshire will never die out of the memory of him who has been fortunate even once in his life to experience it-especially if he should have happened during its course to get in the way of Mr. 'Tom' Duffield. 'The Druid' has declared that the spring hunting in the New Forest is 'charming beyond description;' though his love of the picturesque, at least as much as of riding to hounds, seems to have played its part in his rapture. By the light of the 'Stars of the IVest' a man may still see to enjoy his favourite sport, when the fun of falling has began to pall, and big fences wax bigger with a waning sight. And so we might go on for ever and ever. hunting by the 'moonlight of memory,' as the Duke of Rutland's hounds will hunt so long as there is any light in the sky for

I See A lea Buk of Sforts (Bentley, I885) for a capital description of a day's fox hunting on Dartmoor. 
them to see by. But we must make an end, not fattering ourselves that we have exhausted even that side of the subject we have approached, but content if, like a finger-post, we have been of some use in pointing to some of the many roads by which the sport of fox hunting may be enjoyed.

Pastime for princes !-prime sport of our nation ! Strength in their sinew and bloom on their cheek; Health to the old, to the young recreation; All for enjoyment the hunting field seek.

Eager and emulous only, not spiteful: Grudging no friend, though ourselves he may beat ; Just enough danger to make sport delightful! Toil just sufficient to make slumber sweet. 


\section{CHAPTER $\mathrm{X}$. \\ HUNTING FROM LONDON.}

THE true pleasures of hunting are known only by those who hunt from home. Not everyone will agree with this statement. Probably a great many-now-a-days perhaps the majority-will strongly disagree with it. Given plenty of good sound grass to gallop over, good sound fences to jump over, a good sound horse for partner in these 'violent delights,' and a sufficient company of human beings to get the better of, what more can reasonable mortal man require? Foxes and hounds - well, no doubt they are a part of the fun, though sometimes rather a troublesome part; still, if foxes will always be found at home, and will always run straight, and if hounds will go fast enough to keep out of the horses' way, they are a part that may be endured. But where a man liv'es, what can that matter? He only lives to hunt (that is, to ride), so the question should be, where does he liunt, not where does he live? If he happens to live at Melton, or Market Harboro', or Grantham, of Rugby, or anywhere contiguous to those famous centres of civilisation, well and good--he must find it precious slow when hounds do not meet, though of such useless days there are, to be sure, few in those blissful neighbourhoods. But for the mere living, what fellow, who is not a fool, would live out of London? Very well; that is one way of looking at things, with which we certainly do not intend to quarrel. It is purely a matter of personal taste, and anyone who tries to set up an arhitrary standard for that is a fool indeed. But, by a parity of reasuning, we shall stick to our own colours; ray, and more, 
we shall be much surprised not to find most sportsmen (as different beings from mere riding men, different even from mere hunting men) ranged at our side beneath them. The true plecrsures of liunting, we say it again, are knouin only by those who hunt from home.

There are many reasons why this should be so, on which we fuel that we could expatiate finely, but will not. One of them, and perhaps the cardinal one, has been well put by Charles Kingsley (as genuine in his love of sport as in everything else that becomes a man) in the most charming of his shorter pieces, 'MIy Winter Garden.' He is riding through the fir woods round about liversley, when he encounters (luckily he does not head !) a hunted fox, and Mr. Garth's hounds in full cry after him.

And now appear, dim at first and distant, but brightening and nearing fast, many a right good fellow, and many a right good horse. I know three out of four of them, their private histories and the private histories of their horses, and could tell you many a good story of them, but shall not, being an English gentleman, and not an American iittirateur. They may not all be very clever, or very learned, or very anything except gallant men; but they are all gond cnough company for me, or anyone; and each has his own sficaulite, for which I like him. That huntsman I have known for tifteen years, and sat many an hour beside his father's death-bed. I am godfather to that whip's child. I have seen the servants of the hunt, as I have the hounds, grow up round me for two generations, and I feel for them as old friends, and like to look into their brave, honest, weather-beaten faces. That red-coat there, I knew him when he was a schoolboy; and now he is a captain in the Guards, and won his Victoria Cross at Inkerman; that bright green coat is the best farmer, as well as the hardest rider, for many a mile round; one who plays, as he works, with all his might, and might have been a bcau sabreur, a colonel of dragoons. So might that black-coat, who now brews good beer, and stands up for the poor at the Board of Guardians, and rides, like the green-coat, as well as he works. That other black-coat is a county banker, but he knows more of the fox than the fox knows of himself; and where the hounds are, there will he be this day. That red-coat has hunted kangaroo in Australia; that one, as clever and good as he 
is brave and simple, has stood by Napier's side in many an Indian fight: that one won his Victoria at Delhi, and was cut up at Lucknow with more than twenty wounds; that one has-but what matter to you what each man is? Enough that each can tell one a good story, welcome one cheerfully, and grive one out here, in the wild forest, the wholesome feeling of being at home among friends.

In that last sentence lies, perhaps, the root of the matter, the wholesome fecling of being at home among friends : the sense of companionship, the feeling that you are not selfishly enjoying a solitary pleasure, but are, for the time at least, united by a common bond with all sorts and conditions of your fellow-men, among whom you live, with all of whom you are more or less acquainted, and in whose pursuits and pleasures, habits and manners, you are more or less concerned or interested. Trojan and Tyrian, Whig and Tory, here is a common ground on which all can meet and disport themselves. Surely this is no light pleasure in these quarrelsome days. And there are other pleasures, too, less sentimental, if you like, and perhaps to be more generally appreciated. There is the pleasure, for instance, of knowing the country well, knowing it in all its varying moods of

Fresh spring and summer and winter hoar;

in tasting what Whyte-Melville calls the romance of hunting-

The remote scenes we should perhaps never visit for their own sake, the broken sunlight glinting through copse and gleaming on fern, the woodland sights, the woodland sounds, the balmy odours of Nature, and all the treats she provides for her votaries, tasted and enjoyed, with every faculty roused, every sense sharpened, in the excitement of our pursuit.

And this, everyone will agree, is a great profit as well as pleasure. ' When my young hounds are taken out to air,' say's Beckford, 'my huntsman takes them into that country in which they are designed to hunt. It is attended with this advantage : they acquire a knowledge of the country, and when left behind 
at any time, camnot fail to find their way home more casily.' A man has this advantage over a dos, that he can ask the way when he has lost it : though in certain counties he is by no means sure of getting a very lucid answer, or indeed, any answer at all, if the proint to which he craves direction be anywhere out of the immediate local sphere of the party interrograted. 'The writer of this chapter was once, many' years ago,

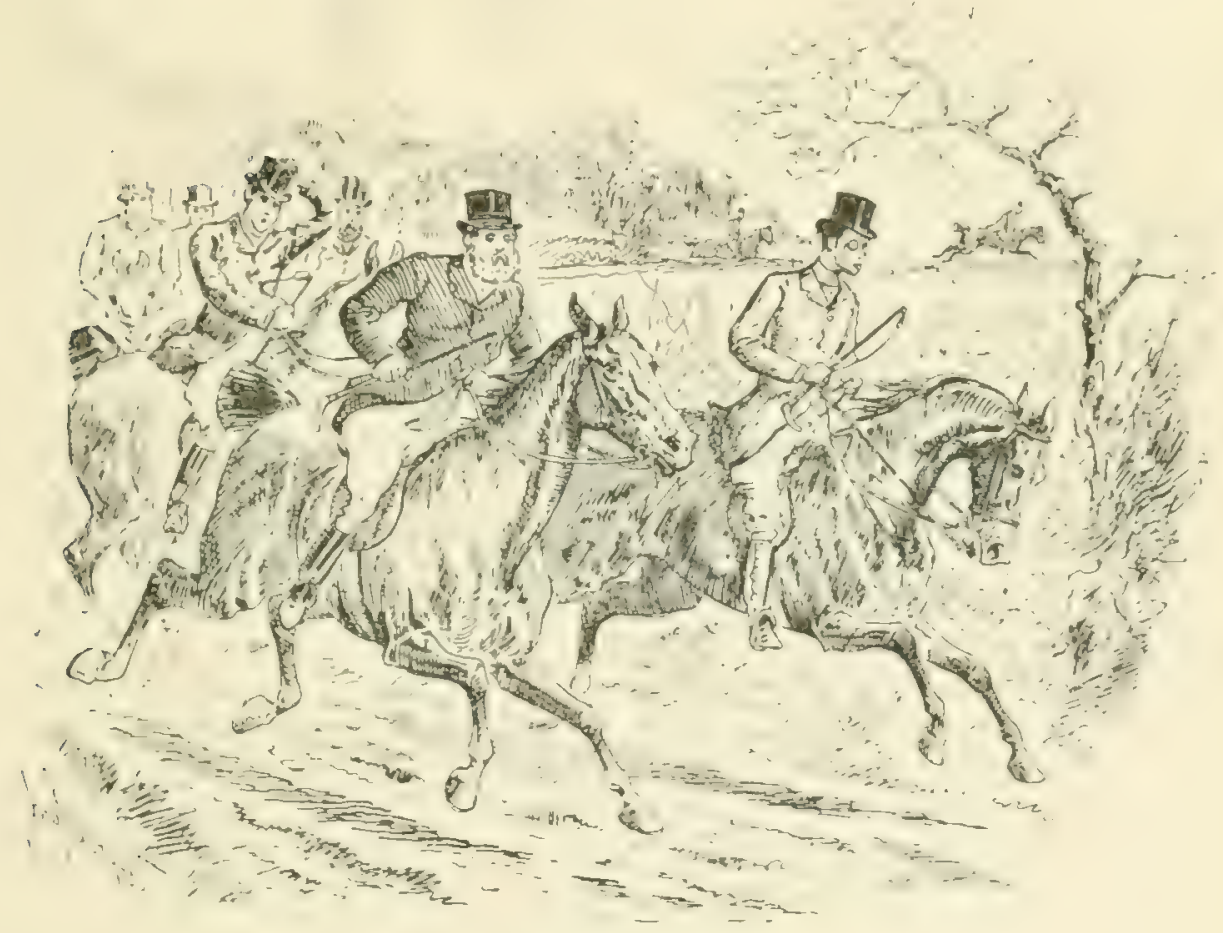

Sons of MacAdam.

on his way to meet Mr. Garth's hounds at 'The Checquers;' a public-house on Eversley (ireen. Being then a stranger in the land, and having gone about as far as the map had told him he should go, without seeing any sign of hunting man or beast. or of that place of entertainment for them to which he was bound, he asked his way of a passing countryman. A stare, a shake of the heid, and some sounds in an unknown tongue, were all the answers he couid get. So, committing himself into the 
hands of the great goddess I)iana, he pursued his way, and 10 , within less than a mile, 'The Cheçuers, and all things convenient! And yet a public-house, one might have thought, would have been within the sphere of that native's geographical knowledge. But indeed the autochthones of those parts are not of a nimble intelligence. Then, besides these considerations, a close familiarity with the country hunted over must obviously be an inestimable advantage to all concerned. From the heroes of the first flight down to the most persistent son of MacAdam such a knowledge is a thing greatly to be desired. To know the safest and easiest, and consequently the quichest, way from field to field; to know where man has smoothed and where he has increased the intricacies of nature, is not to he despised by the boldest of riders. For though falls will come and must not be shirked, it is clear that he will cross a country quickest who does so with fewest falls. And though there are nien happily gifted with an eye for a country such as no fami. liarrty will insure to some, yet this sweet and most necessary intumacy is not to be gained by the mere bird of passage.

Iet us call Whyte-Melville again to the conitnience of hunting from home, as we have called him for the romance.

We require no large stud, can choose our meets, and, abore all, are indifferent to weather. A horse comes out so many times in a season; if we don't hunt to-day we shall next week. Compare this equable frame of mind with the irritation and impatience of a man who has ten hunters standing at the sign of 'The Hand in l'ocket,' while he inhabits the front parlour without his books, deprived of his usual society and occupation, the barometer at set fair, and the atmosphere affording every indication of a six-weeks: frost !

It is true that in many of our famous hunting towns there has grown up a little huntins society, which for several reasons, perhaps, inhabits the same quarters, and some members of which have pussibly built themselves 'lordly pleasure houses,' and thus in a manner become affiliated to the soil. At Miton and at Market Harboro' this is particularly the case. At the 
former town this hats been so for gencrations, from the time of Lord Sefton's famous mastership; and 'Nimmorl,'it will be remembered, at the end of his great 'Quarterly' article, expatiates (or makes 'Snob) ' expatiate) in glowing terms on the grand style in which things were done. One is given to understind, moreover, that the society in that favoured spot is at this day a particularly sprightly and entertaining one. Certainly it must have been so a few years agro, to judge from the racy strains in which Whyte-Melville has chanted the praises of 'the Monks that live under the hill.' And, no doubt, the grolden youth of those happy hunting grounds still live as hard, and ride as hard, in as gay, if not quite in as grand, style as their fathers who bid 'Snob' to their board in the evening after they had cut down him and the 'little bay horse' over the grass in the day.

But still, this is not guite the same thing as hunting from home. Of course, these hunting centres are very gay and jovial places, and the company, both male and female, of the very best sort, both in the field and at home. Of course, too, to frequent the same place seasnn after season, though it be only for hunting, and during the hunting season, is a very different thing from wandering in search of sport, or making London your head-cluarters. But to live in a town for the sole purpose of hunting; to hunt every day, and to take flight to London the moment the hunting is over-perhaps at every temporary cessation-is clearly a very different thing from hunting from your own house, your abiding place. It is, no doubt, a very grood thing in its way, and to gay and vigorous spirits, blended with plenty of health, leisure, and money, is a most pleasant and easy way of passing time. But it is not the same thing as the other form of hunting, whose praises we uphold. Followed in that fashion, the pursuit of the fox, or whatever the animal to be hunted may be, becomes a part of the country gentleman's condition, like his flower garden, his dairy, his fat beasts, and so on. Hunting in this way, Nimrod is humanised; his manners

1 See his Songs and Verses. 
are softened, and are not permitted to become brutal-using the words, of course, in a Pickwickian sense.

Lut not to everyone does J liana srant her favolurs in this liberal fashion. Putting out of the yuestion those who are soverned by mere whims, there are many whom dire necessity forbids to take their hunting pleasures from any place but London. Men of business, to whom hunting is a relavation : who fullow it for health sake : or from a keen native lute of

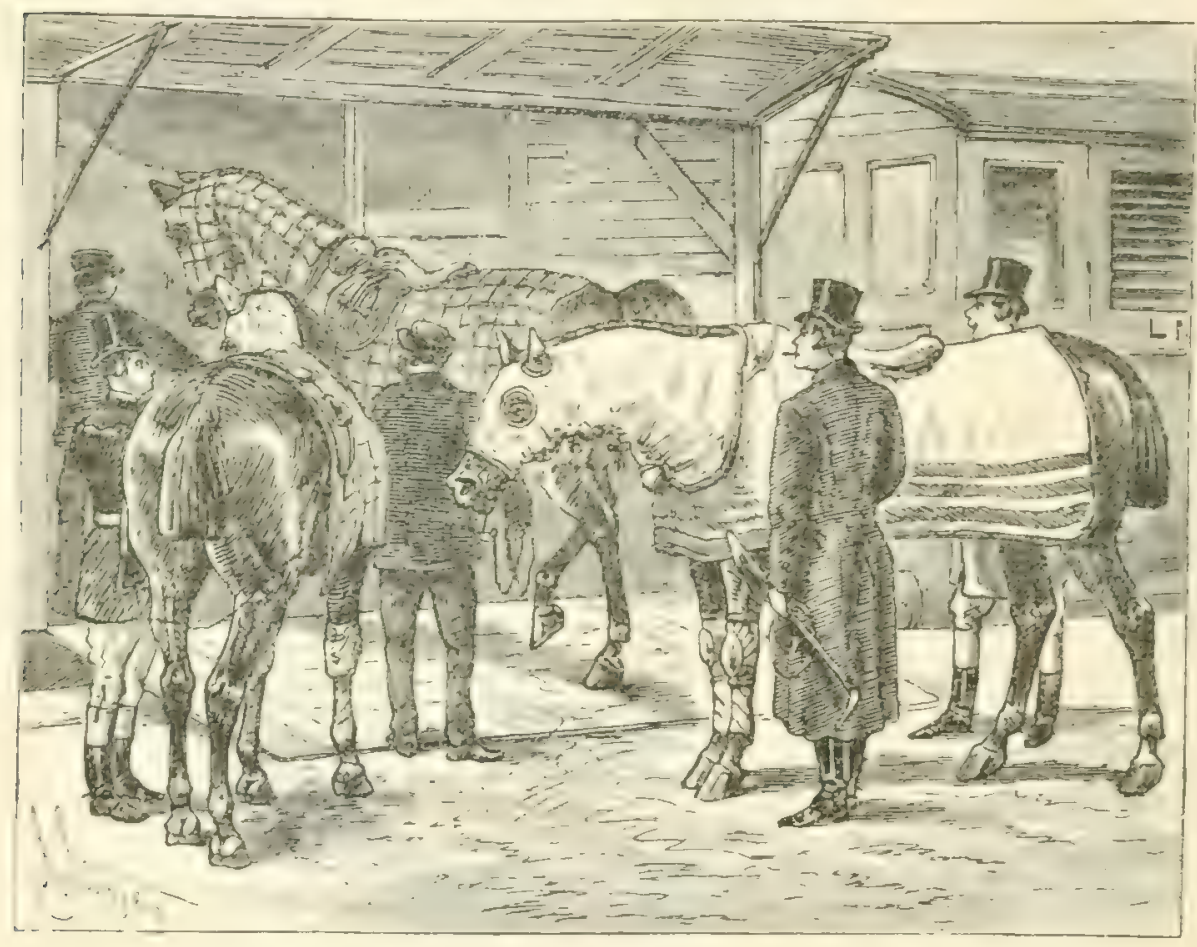

- Down with you by train on a hunting morning.'

the sport, that not all the smoke and soot, the din and hurry of great babylon can epuench : or for the sake of something to do a little more stimulating than a ride up and down Rotten kow, on a rublecr of whist at their club : or from whatever caunce yen please. Men who are jinned down to this great centre of sravity, and an leate it, except at the recognised scason of holiday, but for a few hours at a time. 
There are two ways in which hunting can be enjoyed from London : either by keeping your horses in town and taking them down with you by train on hunting mornings: or by keeping them at some hunting centre, and meeting them there or at the covertside. Of these tivo ways, one may say perhaps that the first is best for yourself, the second for your horse. Both are fuasible enough, but neither, we warn the doubtingsportsman, is child's play. In both you must be prepared to take your pleasure somewhat seriously; not to say laboriously. In his autobiography Anthony 'Trollope gives a vivid picture of the hard work this form of pleasure entails; and what Trollope found hard no one ulse will find easy, for he, indeed, like Walter Raleigh, could 'toil terribly' at work or play. He had just returned, in December $\mathrm{I} S_{72}$, from his voyage to Australia (where he harl experienced some hunting of a novel kind), and though settled in London was determined not to lose wholly his favourite exercise.

I got home in December 1872 , and in spite of any resolution made to the contrary, my mind was full of hunting as I came back. No real resolutions had in truth been made, for out of a stud of four horses I kept three, two of which were absolutely idle through the two summers and winter of my absence. Immediately on my arrival I bought another, and settled myself down to hunting fiom London three days a week. At first I went back to Essex, my old county, but finding that to be inconvenient, I took my horses to Leighton Buzzard, and became one of that numerous herd of sportsmen who rode with 'the Baron' and Mr. Selby-Lowndes. In those days Baron Meyer was alive, and the riding with his hounds was very good. I did not care so much for Mr. Lowndes. Durmg the winters of 1873,1874 , and 1875 I had my horses back in Essex, and went on with my hunting, always trying to resolve that I would give it up. But still I bought fresh horses, and, as I did not give it up, I hunted more than ever. Three times a week the cab has been at my door in London very punctually; and not unfrequently before seven in the morning. In order to secure this attendance, the man has always been invited to have his breakfast in the hall. I have gone to the Great Eastern Railway-ah! so often with the fear that frost would make all my exertions useless. and so often too with that result! And then, fiom one station of 
arrother wation, have aravelled on wherls at least a doren miles. Ifer the day sport the -ame toil has been neccs-ary to bring ne home to dinner at eight. This has been work for a young man and a rich man. but $I$ have done it as an old man and comparatively a poor man.

In siviner his preference to 'the Marnn' over Mr. Iowndes, Trollope, it is to be presumed, neant only to fignify that to one hunting after this fashion the certainty of a sallop of srme sort was the cardind pesint to be amed at. He was too - ond a spertsman to wilfully prefer riding after the unrarted deer to the real hunting of the fox. Lut the fox is an uncertain beast. You may not find him at home: and when you do you may not prevail on him to leave it, or at any rate to leave it in such a way as will conduce mont to your pleasure. I blank day, wr a dar spent in potterins about from covert to covert with a cold scent, or in splashins up and down knee-rleep in muday woodlands, are clearly things to be avoided if possible by one who has trarelled far for his fun and has not many hours to spare for it. By agrecing to satisfy yourself with such imitation of hunting, as the pursuit of the paddock-fed deer provides, you do aroid such things. lou are sure of your same at any rate and sure of a sallop of some sort. For many years the Royal Fuclihomes had a natural prominence among packs which puracd the carted deer, and their history has heon admiratsy written by I.ord Ribislestale, one of the various notalile sportanch who hare heid the oftice of Master, which inchuded the control of the

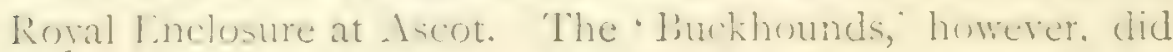
not survire into the foresent rejen, thumen the actual prek was hunted for some years by sir Robert Wiimos, and now does

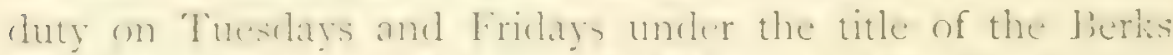

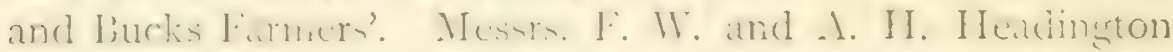

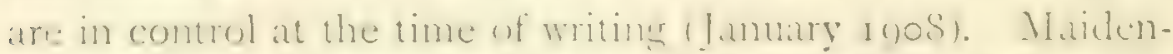

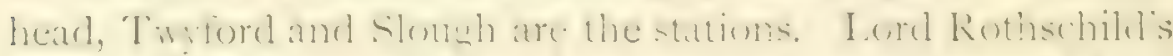

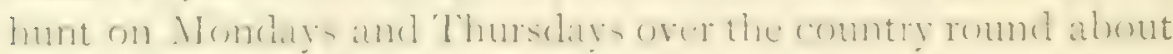

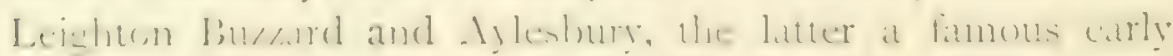

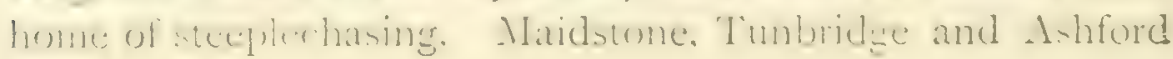


are the towns most handy for the Mid kint, whone kimmen, are at Wateringloury, near the first-named place. They hunt on llednesditys and saturdays, meeting at nom. The most persistent, then, of sluggards can conjoy the phasure of the chase as provided by these packs without doing violence: to his feelings. Convenient trains serve practically all the packs within ciasy reach of London, and of course the motor is an enormous aid to the man who wants to go hunting. ()ther available packs are the Berkhamstead, Surrey, Essex, Enfield Chise, and Warnham. These do not advertise their fixtures, and do not possibly care very much for flying visits from strangers and pilgrims - a sentiment which scems to be growing rather popular in most counties. For the surrey, Red Hill and Croydon are the best stations, to both of which there is a plentiful supply of trains from Victoria, Charing Cross, and London Bridge. The Warnham pack hunt on Mondays and Fridays over the same country as the Crawley and IFrsham Foxhounds, round Horsham, Dorking, and Guildford, which in their turn may be reached without any preternatural activity in the matter of early rising. The Berkhamstead hunt but once a week, on Wednesday, and visitors must make for (ircat licrkhamstead, St. Albans, or Tring. The Surrey are out on 'Tuesdays, Thursdays after Christmas, and Saturdays. For the Enfield Chase, out on Saturdays and alternate Iuesdays and 'Thursdays, the stations are Hatfield and St. Albans.

Of Foxhounds the Londoner has a liberal choice. Within easy reach of head-quarters are the Essex, East Lssex, and the Essex Union, the Surrey and the Surrey Union, the East and Test Kent, the Burstow, the Old Berkeley (East and Mest), the Eridge, the Whaddon Chase, the Garth, the Hertfordshirc, the Crawley and Horsham, the Puckeridge; and others are only a little farther afield, but still near enough for those who do not insist on the 'primrose path' of sport. Incleed, if you only get up early enough (though in that only, to be sure, lies the rub), and are not forced to study economy in the matter of railway tickets, there is no reason why you should not enjoy 
your gallop (at least take your chance of a gallop) with the Old licrkshire, the South Burkshire, the Bicester, the Ifeythrop, nay, no reason why you should not penetrate into the rery Shires themeclves. By leaving King's Cross at 7.45 you can reach Grantham at 10.35 , and a train from the same station starting half an hour carlicr will land you at Nelton at 10.32. Leaving Euston at 7.30 you reach Rugby at 9.34 ; leaving St. L'ancras at \$. ro you reach Narket Harboro' at 10.44. In short, if you do not mind, as we hare side, taking your pleasure somcwhat laboriously, you may get plenty of hunting, and Tlenty of good hunting, without crer passing a winter's night away from your London home. But, certainly, if not sorrow, it is labour. It is not only the early rising; though that alone, on a dark winter's morning when the water is of dubious warmth, and the fire probably will do nothing but smoke, in sullen protest against its too premature lighting, does incleed cntail something of a struggle on this poor frail human flesh. To dress at dawn is never an enlivening process, and whon the dress is such as men go a-hunting in, it is often little short of misery. To button those knce-buttons, and tie those natty little bows below them, your eyes still heary with sleep, and with blue fingers senseless with cold-ah! my friend, nate meam Consule . Wanlio-must one not be iery fond of the same, indeed, to bear these matutinal ills without repining more than once? Still, the good sportsman disdains mere sensual sorrows. The man who would grudge to give his morning slecp for a gallop orer the grass is unworthy the name of a sportsman and a Briton! But these desperate hours signify long marches into the bowels of the land; they signify long journeys by train, and they in their turn signify much disbursement of moneys, and much wear and tear of flesh, both human and cquine. Nothing sooner tires a man, body and brain, than long and frequent railway journeys. Indeed, one might say that no man, unless he be of cast-iron nerves, can stand them long when once he is past the first rigour of manhood, especially if he be one who lives by brain-work. It is burning 
the candle at both ends, and we all know how dangerous a gime that is. A youngster, some gallant guardsmin, perhaps, quartered in London, or some sprightly young stockhroker, may dash down once or twice a weck to Melton or (irantham, have his gallop, and dish back argin with impunity. But older men will be wise to take their delights less violently. And, indeed, in reason they will probably do so. For a man who can afford the drain on his purse incritable from such a form of hunting, will hardly be so much a bondsman to Necessity as to be compelled to live regularly in London.

Let us suppose, then, that our Londoner has agrecd with himself to pursue the fox soberly: he has, as we have shown, plenty of choice. If he choose to hint with the Garth, he will find as good a pack of hounds as any in England, a pleasant set of comrades, plenty of foxes, and genuine sport, if his ideas of fox hunting be not bounded by grass fields and flying fences. These hounds hunt four days a week, meeting at eleven, and can be reached best from Reading, IVokingham, and Bracknell. The two Surrey packs are good, but their country is bad, and the same must be said for the East Kent and Wickham. The West Kent have a terrible lot of woodland, but get sometimes into a nice bit of country round Penshurst. The Essex country, which is much given over to plough, and generally is not an engaging tract of land to ride over, except in the Roothings, can be commanded best from Harlow, Chelmsford, and Audley End. The Crawley and Horsham show good sport in Sussex, hunting four days a week, and meeting at eleven mostly, though sometimes a little later. Horsham and Steyning are the most convenient stations for their fixtures. The Old Berkeley are now divided into East and West, the former covering the Watford, Rickmansworth, and the Great Berkhamstead districts; the latter Wycombe, Aylesbury, and Maidenhead. Between them they hunt four days a week. To meet them, Amersham, Slough, and Hemel 
Hempstead, in addition to the other sown named, are convenient points of departure. The Hertfordshire can he reached four days a week, on Monday, Wednesday, Friday and Saturday, from Luton, St. Albans, and Hitchin; the Puckeridge, on Monday, Wednesday, and Saturday, from Bishop Stortford and Hungerford. With the Burstow one may hunt twice a week, on W'ednesday and Saturday, getting to them best from Reigate, East Grinstead, Horley, and Edenbridge. Of all the packs to which we are at present limiting ourselves, this is perhaps the most favoured in the matter of country. Indeed, the members of that hunt have a saying; that if a horse can go in their country, he can go anywhere. We have thus very slightly indicated where a Londoner, bent on a moderate participation in the pleasures of fox hunting, may turn his head with the best chance of getting what he wants. For further particulars we must refer him to 'Brooksby's' 'Hunting Counties of England,' Stanford's Hunting Maps, an excelient artıcle on 'Hunting from London' in 'Baily's Magazine' for February 1884 (to the unnamed writer of which we hereby tender our best acknowledgments), and to the experiences of his own friends.

The question remains, in what style will he elect to take his hunting? Will he keep his horses in London and carry them backwards and forwards with him by rail, or will he settle them in quarters at the town most convenient to the fixtures of the pack with which he intends to hunt? Much can be said for either plan, much against it. Let us take the former first.

The advantages of this course are clear. His horses will be under his own eye, and he will be able to vary his country at his pleasure. On the other hand, he will have to make an earlier start; unless, of course, he sends his hunter down with a groom, and himicli follows with a hack by a later train, or even sends horse and man down the day before ; both of which plans will ubviously swell the expenses not a little. If he go down with his horse he must necessarily, unless the place of meeting oe very close to the station, start in good time, to allow of that 
gente pace at which it is expedient for the hunter to travel on his own legs in the anticipation of a long day's work. 'This, however, is a matter which concerns the man only, and is con. sequently of much less moment. What does concern the horse ts the railway journey. On some horses a journey by rail has no more effect than on some human beings. On others it has a most injurious effect, both on their nerves and their temper. It is almost inevitable, too, from the confined space in which the horse is necessarily penned during the journey, that a certain stiffness will be visible when released at its end. If, however, he is a sedate and even-tempered beast, this will pass away soon enough when he breathes the fresh air and stretches his limbs; and if he is not that, he had better be got rid of quickly, for he will be of little use in this game. It must be remembered, too, that an early start signifies for the horse very much more than for the rider. 'The process of dressing and feeding means much more for the former than the latter. The rider can be trusted to look after himself in these things; the horse is dependent on his groom. Who is to insure the latter rising early enough on hunting mornings to have these indispensable preliminaries properly performed at the proper time, not huddled hastily over at the last possible moment? Of course, it may be said that if an owner of hunters cannot trust his groom, he had better give up the business of hunting altogether. And this, no doubt, is so. But this mode of hunting is an cxceptional thing, rather out of the common routine of the stable ; the possibilities of shirking are much increased, and groom's flesh is weak. You may be lucky enough to get one of those pearls who take a pride in their work, men of inexorable conscience and a high sense of duty, who need no master's eye upon them. But you may not; and at least, this objection must be taken in the balance for and against.

Then, there is the return journey. Never, if it can possibly be avoided, should you ride your horse straight from the field to the nearest station, and have him put just as he is into a box to catch the first train home. He should first be roughly dressed 
down, his legs and fect dry-rubbed and bandaced, and his inner horse mildly refreshed with a mouthful of gruel. Where there is a station there is sure to be some stable accommodation sufficient for your purpose; but it is not so sure that you will find an ostler equally sufficient. To make a tired and dirty hunter comfortable for his journey home requires no great intelligence or labour; but you will be wise to superintend matters yourself, and the judicioussuggestion of a pot of beer has sometimes a stimulating effect. The country ostlers are a pretty hardworked class, and perhaps, considering all things, can scarcely be expected to bestow much additional labour on mere pilgrims whom they may never see again. Particularly will you be wise not to trust the gruel to the tender mercics of the inn servants. See that the flour is put in boiling water and cooled with cold water, not stirred up with cold water and then qualified to the yroper temperature with hot water 'to taste.' A quart of good beer, or a wineglass of whisky, after a hard day, may be added with advantage. Of course, if you can insure returning to your starting point-and if you have self-denial enough to leave off your fun in time, there should be no difficulty in your arranging this, save in very exceptional cases - all these obstacles will vanish in the presence of your own servant, whom you will do wisely to take down with you, without whom, indeed, you will hardly do well on these journeys. However learned you may be in theory in the care and management of horses, in practice you must incritably be more or less at fault. You have never been taught to groom a horse; the groom has been. You know what things should be done, the groom knows how to do them.

Again, there is the problem of exercise. How are hunters stabled in I.ondon to be kept in proper condition? How are they to be exercised in the London streets? There is Rotten Kow to be sure, where grooms are allowed to disport themselves on their master's nags before 7 A.M. from April to October, and before 8 A.M. from October to April.

Thus, it will be seen, there are many things to be said againct lecping your hunters in I.ondon: indeed, so many 
that the despoiring sportsman may well ary to 11 in the worts of Rasselas to Imlar, "Enough, you have comvined the that no human being (an ever keep hunters in fondon.' 'That we do not say. Lut it is a diffeult business; one with many hindrances and limitations. And it is at least well that he who proposes to undertake it should do so with his eyes open. A season of practice will show him these diliculties far more clearly than we can, and probably introduce him to many other lesser ones which we have not considered. But though experience is certainly the best of all schoolmasters, the foes, as some sage has wisely said, are apt to be heavy.

No particular dificulty scems at first sight to lie in the way of the other plan. To select your head-quarters, place your hunters in a good stable, and have yourself conveyed down to them by train on hunting days, scems a simple plan cnough. And so it is, provided the stable be under the care of a groum whom you hare proved worthy of your confidence. But that is the rub.

If you place your horses at livery, where they will be among many others requiring equal care and attention, it is clear you must trust largely to the honesty and good faith of the stable keeper. Probably you will pay about thirty shillings a week ${ }^{1}$ for each horse, exclusive of 'extras,' which are apt to have limits of astounding clasticity. The prices of forage vary, of course, but at any season if the best kinds are used it is obvious that the margin of profit out of thirty shillings will not be large, and the temptation to supply something not quite so good as the best, will be. Of course a man who has to cater for a large number of horses will be able to get his forage cheaper than he who has to buy it in smaller yuantities. Wholesale, as we all know, is cheaper than retail. Dut 'margins' there must be; if they will not come by nature, they must be forced by art. Then there is the grooming. The staff of a livery-stable keeper is a hard-worked body of men. Two hunters are quite as much as one groom can do justice

1 Twerty-six shillings a weck was charsed at the Ifunt Hotel, lecighton Buzzard, cluring the season $84-85$. E E 
to. It is most prohable that in a large establishment, of the sort we are consilering, this proportion will be considerably exceeded; or, if kept, will be kept by the employment of an inferior ciass of serwant, casual helpers, men of odd jobs, who prefer beer to elbow-grease, and regard an inn rather as a place to take their case than to work in. If you place a groom of your own in charge, he will live, it is almost certain, in a perpctual feud, at any rate in a state of more or less armed neutrality, with the keeper of the stable. It must not, of course, be forgotten that we are now playing the part of the adrocatus dialioli. We are putting every possible objection in the strongest possible light. But we are very far from saying that to all livery stables, or even to the majority, these objections apply either wholly or in part. No doubt there are many to be found up and down England all that the most exacting could desire; stables where your horses will be as well fed, as well groomed, as well exercised, and gencrally as well cared for, as they would be in their own stable at home. But such perfect places are not likely to be common; perfection is common nowhere among human institutions, to say nothing of equine. You will at least be wise to stand prepared for troubles : and this perpetual watching and waiting for troubles, what a trouble is it in itself !

To have your own private establishment is, of course, the best plan. If you can trust your groom to carry on matters as well thirty or fifty miles off as though he were only round the corner and liable to visits from the master at any moment, there is really nothing to be said against this plan that cannot with equal justice be said against the keeping of a hunting stable at all. It will of course be cheaper, too, than carrying your horses about on the rails with you ; for to the ordinary cost of a hunting establishment you will have only to add your own travelling expenses. Provided stable and groom are all they should be, your horses will last much longer treated thus. The strongest constitution and most even temper ever enjoyed by a member of the equine race will not long stand the wear and tear of those frepuent rattlings over the rails, and all their inevitable discomforts and mischances. 
'There is a third way in which hunting may, after a fashion, he enjoyed by a man compelled to a life in Iondon; he may 'job.' 'There are men, of course, in all the great hunting centres, in all towns of any importance situate in a hunting country, whose business it is to provide the casual sportsman with a beast on which to take his pleasure with the hounds. It would be unfair to say that many a good day's hunting is not enjoyed in this way. The writer's own experience of hired hunters is confined to the livery stables of Oxford, and many a good run has he enjoyed - et militarit non sine gloriiwith a partner derived from those sources. But the undergraduate is a thing apart; he forms a human class by himself, and affords no instance to inductive philosophy. The beasts on which the 'men' of the present writer's time used to disport themselves so gaily' and frequently with the Heythrop, the Bicester, the Old Berkshire, or Lord Macclesfield's hounds, were often wondrous to look upon, and unlike most recognised specimens of horsellesh. To be sure, they could all of them jump, and some of them gallop ; but it is doubtful whether any but an undergraduate would have trusted himself to their conveyance. The wind, however, is always tempered to the lamb ; and elsewhere, no doubt, the horse may be hired and ridden with no, or few, misgivings. They may be hired for the season, the month, or even the day, and as the owner generally runs all risks of accidents, and relieves the hirer of all trouble, it is clear that this is at least an irresponsible way of hunting. Perhaps for a sportsman of limited means, who can allow himself but a day now and again, it is the one that presents least hindrance of any. If he be moderately young, of moderately light weight, and of moderate confidence, he might certainly do worse than trust himself to some stable keepers of good repute. The charges vary, of course, with the reputation of the stable, the country, and the hounds. For a couple of guineas, however, a decent nag may generally be secured for a day's gallop in most counties. In the Oxford days, of which we have spoken, the charge for the term was four guineas a week. For 
thes sum you Lucume pratrically possessed of a hunter of your own ; the stable kiecer ruming all reasonable risks, supplying the nag's place if clisabled (muless by some glaring fault of your own), kecjing him, and finding all necessary service. What the charies my be now we do not lnuw; but we have heard the stables at Oxford are now filled mainly with bicycles, which of course are much less expensive to keep.

It may be thought that we do not think much of 'hunting irom I.ondism, nor are keen to recommend it to our friends. This is not quite so. It is certainly a lahorous form of amusement, if fursued with ardour, and one which, we repeat, presupposes youth, health, and a strong constitution-at least, without these goud gifis we certainly should advise the I.ondoner if possible to content him.elf with some other form of excrcise. It is costly also; hut then hunting is in no form a cheap amusement, except if cnjoged after the fashions aciopted by Mr. Sponge and Mr. liacey Romford. Still, if a man sets most store on fresh air and a wholesome exercise he will no doubt find what he wants in the hunting frelds round about I.ondon, with pleasant company, and sport of a kind; and he rill find these things without any undue labour or exertion, whether he stable his horses in the country or carry them hackwards and forwards on the rail. But if his ambition soars higher, he must go farther afield. If he wish to gallop and jump, has an aversion to plough; if, in short, it is riding to loumts that he understands by the term hunting, he will not be satisfied by the suburban delinhts of his more modest and moderate ncighbuurs. Then comes the real hard worl:lic laber, lic'cefus est. It can bu done; but it is no rose-water fum. 'Broukshy;' of whose excellent little guide-books we have alrealy spotien, argues that it is just as casy to hunt in a good country as in a bad. 'A hurse', he says, 'cats no more in a f.'wh cuntry than in a bulone; hotel and stabling charges vary on quite other princifles (we know not what) than those of loralis: in sen comntry ate you likely to ride a worse horse if jou can atford a fetter; the best sabllers is everywhere 
economy; and you ought to have (why on eanth don't you?) good leathers, decent boots, coat and hat, wherezer you hunt.' All this is, no doubt, very true; but it does not really touch on what secms to us the gist of the argument. A man who could afford to keep at one of the great hunting centres a stud sufficicnt to enable him really to enjoy their advantages, would hardly, we submit, find himself bound by necessity to reside for the greater part of the week in London. Were he su bound, it would surely be an ille waste both of money, time, and 'tissue,' to incur the expense and the labour of kecping his horses at such favoured spots-for with all due respect to 'Brooksby,' it is more expensive to hunt from Melton than from Brentwood say, or Windsor - and suffering the long journeys to and fro, for the chance of a gallop once or twice a week. A man whose work keeps him mainly in London, and yet has the means to afford a few hunters in the country, is probably no longer a young man; and we repeat, the inevitable railway journeys must sooner or later tell on the human frame which has no longer the capital of youth to draw on, and in all probability sooner rather than later. There are exceptions, of course, to every rule. There are men who, for some particular cause, may find themselves obliged for a season, or part of a season, to keep touch of I.ondon. 'They, of course, will take their pleasure as best pleases them, and as they can best afford. But for the average of men who 'hunt from town' we should certainly recommend a moderate ambition. Indeed, if he elect to keep his horses in London he will find himself obliged to be so content, unless he be prepared for his stables to need renewing as fast as Russian 'arrangements.' And we shouid alio recommend him, if he keep his horses in the country, always when possible to go down to his quarters over-night. Thic additional expense of a bedroom will not be excessive; he can always, save in very exceptional circumstances (and in such it would perhaps be best to put, the hunting by for a time), get his day's work over in time for an erening train; he will find tis own comfort greatly increased; and he will last much lomerer. 


\section{CHAP'TER XI.}

THE OTTER AND HIS WAYS.

By man and all living creatures, from the worm in the ground to the eagle in the air, the advent of spring is hailed with a welcome and joy accorded in a like degree to no other period of the year.

Nature is then waking up from her winter sleep, and, laying aside her snow-white robes, is invoking the sun to expedite her toilet, that soon, like a May queen, she may step out in a mantle of cmerald hue, bespangled with goms of purple and gold-the primrose, the cowslip, and wild hyacinth-till her beauty becomes a delight to the eye no art can rival. Early and late, too, is her coming greeted by a choir of heaven-born minstrels, who pour forth their paans of joy in copse; woodland and field with sweetest melody. But, gladsome and sympatictic as all the world appears to be at this hopeful periud, it may sound strange to say that probably the sole created being who supplies an exception to the general joy is to be found in man. Yet this is truly the case; for the lan. suage of the often quoted huntsman, when his hounds threw i1) on a bank of violets and failed to carry the scent a yard bather, sill finds an echo in the breast of many such men under like circumstances.

The experience of every hunting man will remind him that oft on a ecnial April day, when the lark has been carolling welledel, and the wood anemone, the daisy, and the primrose were weaving at his fect a mosaic carpet, far more beautiful in design than cher graced a l'ontifl's hall, he has heard growls of 
discontent loudly expressed around him, the howers have heen eyed with a cold welcome, and the lark's glorious sung greeted with anything but pleasure.

It was just at this season of the year, not very long ago, that a group of well-mounted horsemen were posted at a point commanding a broad green avenue that stretched away far as the eye could see into the depths of Whittlebury Forest. 'They were listening with crident impatience to a pack of hounds which, throwing their tongues intermittently, were unable to force their fox beyond the 'quarter' in which they had found him an hour before. In fact, there was no scent; and some of the older hands, with good reason suspecting that a vixen was afoot, were anxious to whip off the hounds and draw for a fresh fox. Favoured by Nature the little mother dodged about, leaving scarcely a whiff of scent behind her; the hounds dropped their noses in vain ; and the field, now utterly disconcerted, came to a general verdict that 'those spring flowers' were the chief cause of all the misery.

'It's all up with hunting, at least for this scason,' cxclaims a young squire, somewhat impatiently; 'but what on earth is a fellow to do for the next six months of his life? I hate town, and I'm sick to death at sea; and as for the "contemplative art"-river angling-I have neither skill nor patience for that craft, of all others the most solitary and uncertain. So, without occupation, and never a hound's note to cheer me, I shall be bored to death before the first of next Nurember.'

'Nay, my boy; I don't see why we should lose you on that account,' answered an old friend, who happened to be a I)evonshire man much given to otter hunting. "Come down to us, and if Collier and Cherriton don't keep you alive, and happy too, with a feast of sport throughout the summer, I shall be surprised indeed. Otters are to be found in every Devonshire stream; and with no animal of chase is the instinct and work of hounds so well displayed as in the pursuit of the otter. Why, we have men with us who find hunting so cunducive to their health that, with stagheunds, ioxhounds, harriers and 
otter hounds, they contrive to enjoy it all the year round; and you could well do the same.'

"Thank you so much; that's quite a new lisht $10 \mathrm{mc}$, and is exactly what I should like to do; but give me a word of advice as to the best quarters for otter hunting, and I'll lose no time in paying a visit to your favoured land.'

'That I'll do with much pleasure; responded the old otter hunter, delighted to help a youngster who, from his inborn love of hounds, he felt sure would enter well at his own favourite sport. "Tiverton for otter hunting should be your first halting place; and thence $y^{\circ}$ ou could easily reach the early and best meets of two grod packs-those of Mr. Collier and Mr. Cherriton-who would not only give you a hearty welcome, but, if I mistake not, would very soon ask you to "look beluw" and lend a watchful eye to the business of the chase. But I would not recommend you to fix on any settled quarters for more than a week or so at a time; you should lead a kind of nomad life, passing on from one district to another according to the meets of the various packs hunting the Western counties, Thus, weather permitting, you might safely reckon on geting three days a week, from May I to the end of Ausust; then, to complete the cycle, you should migrate to Porlock and top up the year by enjoying a gallop with the staghounds over the wild Iixmoor. But hark ! the hounds are rumning hard ; that must be a dog fox, and we shall lose perhaps the run of the seitson if we stand gossiping here any longer.' So saying, the old otter hunter dashed off into a narrow ride, making a signal to his young friend that he'd let him know more about it at an early date.

He was as good as his word. The younger sportsman was entered to other hunting and followed many packs of famous otter hounds. At length he became so deroted to the sport that, having ample means to do so, he determined to start a pack of his own, and hunt on the south coast of I)cron a numler of maiden strcams abounding in troul and of course vivited by otters, but as yet untained by a smgle hound. 



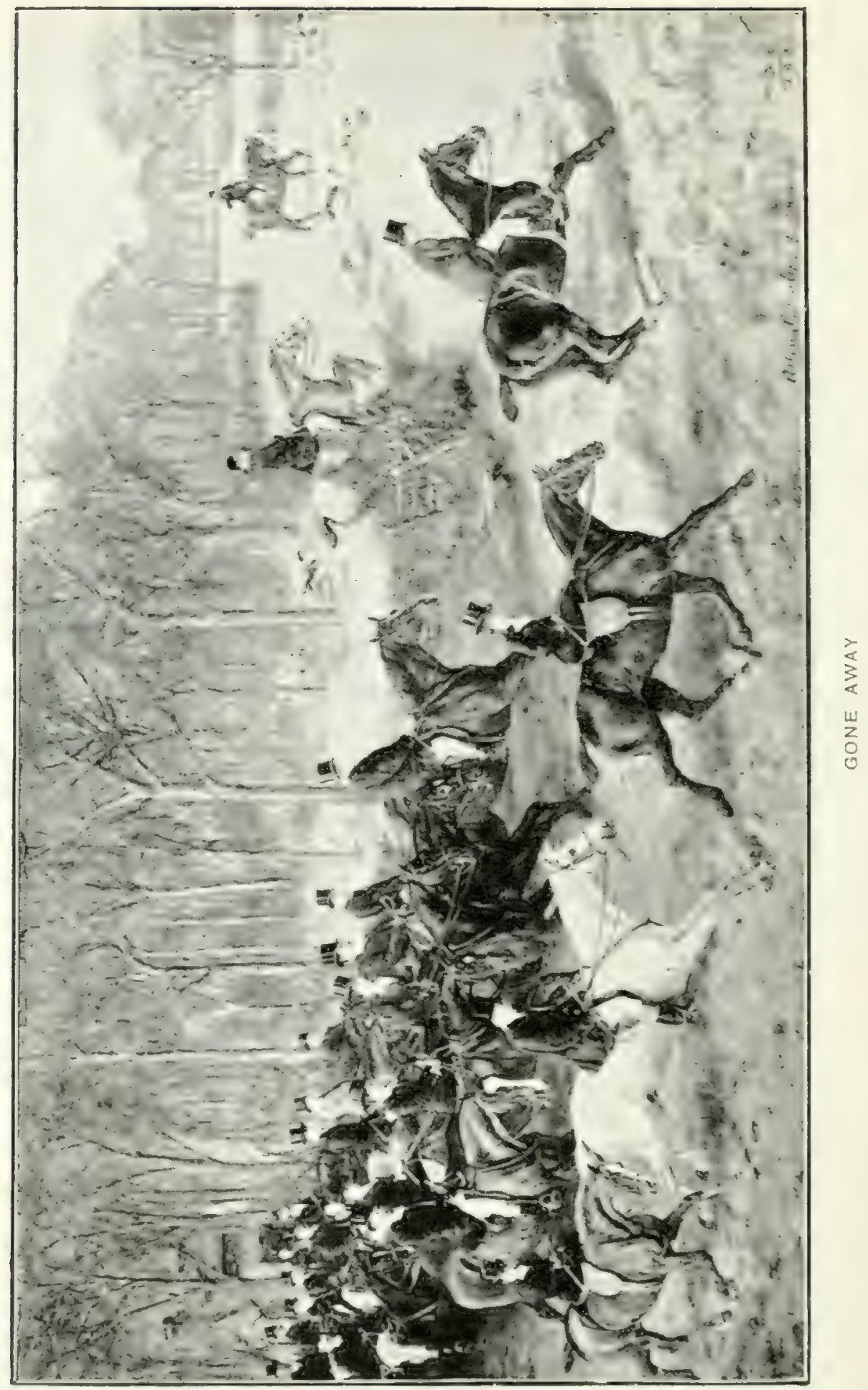


With this object in view he appealed once more to his old friend, who, from a journal he had carefully kept, noting not only his own sport but that of several well-known [klcks, now cordially' gave him the result of his long experience embodied in the following paper:

That you are going to start a pack and hunt the wild otter with your own hounds is a bit of news that interests me greatly, and you are quite welcome to the benefit, as you are pleased to term it, of any counsel I can give you on so engrossing a subject. But pray bear in mind that this paper will simply be a kind of didactic essay written to instruct rather than amuse you ; and moreover, that you are by no means bound to adopt your mentor's views when, as his julgment may often be in error, to differ from it would be the wiser course.

No man can hunt a wild animal with success if he is not fairly acquainted with that animal's habits and mode of life; he must at least know where to look for him, how to find him, and how to cope with him, when found, in the many artifices he will adopt to elude pursuit. Now, the ways of an otter I believe to be the least known and the most inscrutable of all our wild animals; so much so that its very existence is widely doubted in districts where otter hounds are never seen; and yet every rwer in the land pays tribute in turn to this nightwandering marauder. Many too, who ought to know better, think the otter to be well nigh exterminated, and that its fate will soon be that of the bearer and yellow-breasted marten, now no longer seen amongst us. But there is no ground whatcver for this belief; otters, as I will presently show by testimony of unquestionable authority, are still as plentiful on our waters in the present day as they were fifty or sixty years ago.

When I first took to keeping a pack of my own I hunted a number of streams on which the note of an otter hound had never been heard. They were a scratch lot, consisting of big old-fashioned, blue-mottled harriers and a single foxhound, called Midnight, by John Russell's famous Mercury out of his 
Rally; the only hound amongst them that would touch the scent. liut she was a jewel, and with her pleasant tongue soon won several of the others to join her on the trail. Yet not till the wild animal was actually found and killed before them would the farmers believe that it was the scent of an otter the hounds were so enjoying. 'There be scores of rats hereabouts, but us ha' never seed no sich varmint as an otter in our bottoms,' was the constant remark expressed on the veracity of dear old Midnight's tongue; a huund that never told a lie in her life. One day she carried a trail through a farmer's cabbage garden and into a drain under his very house, when a fine dos-otter, soon killed, opened his eyes and at once satisfied his doubts.

I mention these circumstances to show how little is known to men in general of the habits and even the cxistence of this wild animal, which not only lives and thrives among us, but constantly makes his bed on the dry ledges of our house drains, fellow-lodgers with ourselves and sharing the shelter the same building affords to both.

Human nature, we know, is little inclined to believe what it cannot see or realise; and doubtless the otter and his habits are mysteries to most incu, inasmuch as he is strictly a nocturnal animal, never quitting his stronghold, excejt by expulsion, till after sunset, and then only to seek his prey and disappear again with the first blush of morn. 'Then, at night, if intruded on by man, the dark colour of his hide conceals him from view, while at the same tme so oil-like and gentle are his movements in the water that it would require a fine ear indeed to note his whercabouts. Not once that I can remember do we see the otter refered to in the works of our great fabulists, from Asop and Ihacdrus down to la liontaine and Gay; and yet, from the lion to the mouse, all the beasts known to them have their characteristics described with the utmost fidelity: This surely is strong, if inclirect, evidence that they knew nothing of the ofler and his habits. l3ut I will go farther; our keenest homers, men who have pursued the animal with liound and 
horn and studied his ways from youth to old age, are prone to confess that much pertaining to the beast is beyond their ke:t and utterly inscrutable.

Still, such men by patient and watchful observation have learned enough to cnable them not only to find and hunt the animal successfully, lut to enjoy themselves and show their friends a sport the wildness and delight of which no pen or mine can describe.

The otter has no local attachment, like the badger, the fox, or the hare; but, as an experienced otter hunter once told me, he 'believed that, except in the case of a female and her young ones, an otter never occupied the same bed two days following, meaning that he is always on the tramp, seeking fresh pools and new streams from night to night. However true this inay be, it is nevertheless a fact that on ruitting one lodging for another, like old travellers, they have always a house of call in their eye-a safe well-known retreat-on which they are bent for rest and security at the far end of their night's work.

An otter, when bolted from his sleeping quarters, will make at once for the nearest stronghold, and so on frum one to another, till he has shown his observant pursuers all the drains and holts he is wont to frequent on that river. Consequently, when a fresh trail is struck on a stream well linown to the hunter, he can generally tell where his hounds should come to a mark and where, when found, the otter will go for his next retreat. This knowledge is of the utmost advantage, as it saves much time and labour both in finding and pursuing the animal ; whereas, on the other hand, if the river drawn be a new and unknown one, the uncertainty of a find and a kill is greatly increased. There may be a hot steaming drag, indicating the recent presence of the wild beast beyond a doubt, but the mouth of his haunt may be a foot or two under water, and if so, hounds and terriers will pass unwittingly over it, and the otter will sleep on undiscovered in his dry and carernous holt. Scores of utters escape detection in this way. 


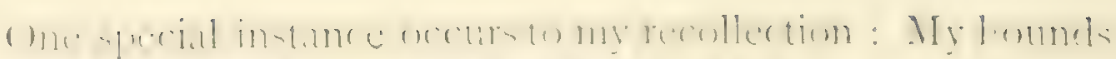

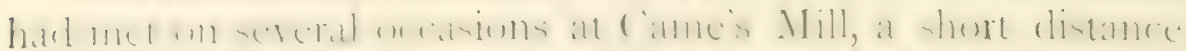

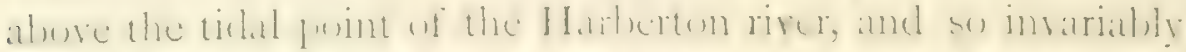

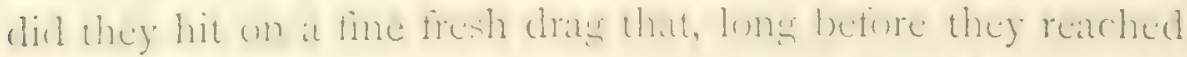
the mill, neither whip nor rate would restrain them from loreaking away in full (ry uls the hantiful meadows of the vale

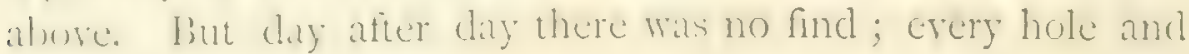
corner that would hold a rat was drawn, every open drain searched, till at length the opinion prevailed that the otter, after fishing the upper stream, had gone back to the salt-water cliffs below, an impregnable fastness at all times.

A mere accident, however, proved the contrary. The hounds one day were enjoying the drag on this

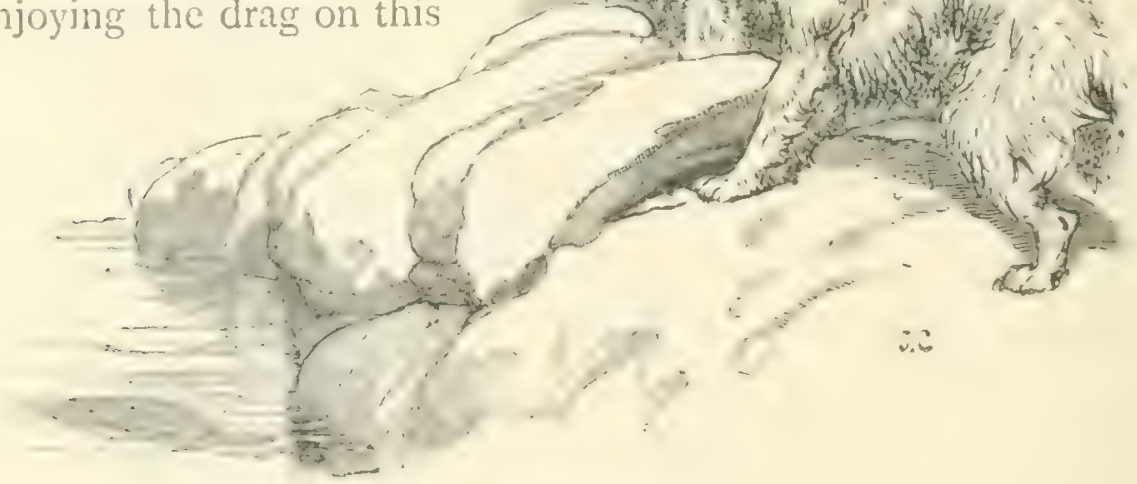

The escape of the otter.

water with the usual fruitless result, when a sharp thumderstom breaking orerheated lrowe us for shelter into an old barn crimmere with wouken lamber that had home heen stored within

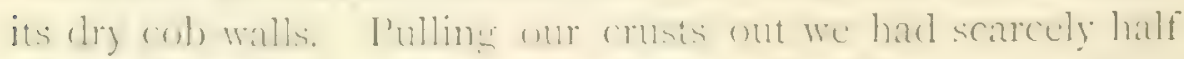

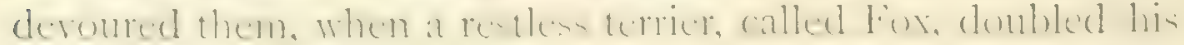

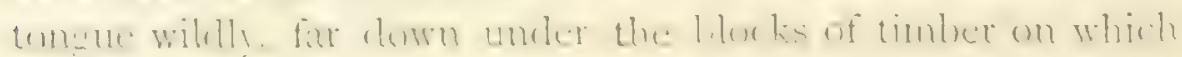
we were seated. 
'That's a cat for certain,' said my old friend, the Rev. Harry Fortescue, 'that terrier is always at riot.'

But in another instant Rattler thew his tongue like a tenor bell announcing a find, and all knew at unce the long-looked-for otter was at length found. 'T'o the river we then rushed, not fifty yards from the barn, and great was our amazement to view not one but a brace of fine otters glide rapidly from under a broad stone slab that bridged a dyke running into the stream below. But the terriers Prince and Fox, usually on the back of a bolting otter, did not appear ; they had been stoplyed by the dyke water that covered to the depth of a foot the mouth of the drain leading up to the old barn. Here then was the mystery solved; countless times had the hounds carried the drag up and down that dyke, but the submerged mouth of the drain baffled all their inquiries.

The result is soon told; the otters, male and female of course, on reaching the main stream parted at once. The dog turned downwards and made a desperate effort to gain the cliffs, but was pulled down while crossing a shallow only a short distance from his stronghold. The other, my lady, with a couple of hounds in close pursuit succeeded in gaining a longr deep mill pond in the meadows above, where, on following up, we found 'Tyrant and Wakefield hard at her and making the valley ring with their music, as they worked her to and fro from one hover to another. At length she got under a bridge which was flooded up to its very keystone, the pond being a bumper at the time; and here taking rest and recovering her wind she might ultimately have beaten us, for the swimming and marking being incessant it was beginning to tell upon the hounds and terriers, not one of which could get under the archway and so bolt her.

Happily, however, the jolly miller who had joined the chase came to the rescue; he ran home for a crowbar, lifted a floodhatch, and in half an hour so lowered the water that the terriers went in and thenceforth never gave her a moment's rest. The otter now lancied, and taking to the dense scrub on the comb 
of the herlges, just as a prolerat is wont to do, she showed us some of the prettiest sport I ever saw. The terriers of course were alone alile to follow her; but the hounds on each side of the fence were witching the fray with intense excitement, throwing their tongues frantically, as if to encourage their little mates, and expecting at every instant to grab their prey. At length down they came, tcrriers and otter all locked together, the mass rolline over and over into the midst of the hrounls; so ended this lively chase.

We always knew afterwards where to find on that river, the moment a drag was struck on the lower waters.

The otter is believed by many io be amphibious, but suffice it to. say that neither it nor any other known animal is so constituterl. With as much reason might the pearl diver be considered capable of sustaining life equally well in hoth flements-air and water-as the otter. The diver descencis into the defths of the latter to earn his livelihood, and the otter does it for the same purpoce ; yet one minute's duration in that element beyond the power of the lungs would be fatal to both. It is alio the refuge of the wild animal; but only then does he scek it when he is for ibly driven from his dry bed, and hopes by the interposition of the watery barrier between him and his enemy to save his life.

Some forty ycars agro, while hunting with Mr. Bulteel's houncle, I managed to catch a young otter alive: he was not half-gromn, and soon herame so tame that he would come to a call, junip upon my lep, and eat food out of my hands. Not far from the huse bor in which he lived there was a small fond of clear water; and to it, for he followed me like a dog, I was wont to talle him when I gave him his food. Into the fond, however, nothing would tempt him to go, if, on galloping round the bank and winding the water, he discovered by his nose there was no fish in it. Ile would then come up to me, and watching the buwl of fish I held in my hand, would look into my face, as much as to say, "Why should I wet my jacket for nothing? wy broakfont is in that bowl' While foeding he 
often sat up like a monkey, holding the fish in his fore praws and invariably eating it from head to tail. In a wild state, however, the otter eats an eel only from the anal aperture downwards to the tail ; whereas, like a true epicure, he prefers the shoulders and upper end of the lordly salmon.

From the extreme acuteness of my tame otter's nose I discovered why it was that, after a stream had been drawn and its horers tainted by hounds, it was uscless drawing that same water in less than a month or five weeks afterwards; for unless a flood had washed away all traces of the intruders, a blank on it was a dead ccrtainty. Hence, a wide range of rivers largely increases the chance of finding, as the success attending the nomad system practised by some of our most famous otter hunters amply demonstrates.

That system may be briefly described as follows: Some fifty years ago Mr. Lomax, a noted hunter, set the fashion of travelling with his otter hounds from one county to another. Hanging out at wayside inns and drawing fresh streams from day to day, he showed marvellous sport, as he crossed them in his course between Iancashire and the western counties. The late Mr. Waldron Ifill did the same, but on a somewhat grander scale; for, travelling with a van, and not content with hunting over five or six counties in Scotland, he would take ship and visit the Emerald Isle, the natives of which went almost wild with delight at the sport he was wont to show on their purling streams. Then, at the present time, we have the Hon. Geoffrey Hill adopting the same plan, and killing on an average at least eighteen brace of ottcrs in a season. Nor can I conceive a greater treat than to go a-gipsying with him throughout the summer, now sharing the wildest of all English sports in the best of company; or, if the game be not afoot, searching for it amid the most charming scenery of mountain and vale, woodland and water. But more anon of his rivers, hounds and sport.

In the west also, of late, the two famous packs of Mr. Cherriton and Mr. Collier have sought fresh streams, and 
travelled into counties far distant from ther own kemels; Wiltshire, I)orect, and Irants have been visited in turn, and many a line dny's sport has leen witnessed for the first time in those counties. Conseruently, a far greater number of otters have been annually killed by those parks, the score of each amounting to no less than tweive to fourticn brace a season.

The institution of railways throughout the land has probably done more to fromote the syort of otter hunting than any other cause; but far distant be the day when this advantage shall lead to the disalpearance of the otter from these islands. Its extinction, like that of the wolf, the boar, and the beaver, would be a national calamity; but such a result, I rejoice to think, is most improbable. The fox could be exterminated, but the otter, by man's power, never.

The following letter from Mr. Cullier, of Culmstock, conreying as it dues the opinion of an observant and thoroughly practical man, is most interesting in reference to the animal he has hunted so long and so successfully. He say's:

You ask me to name the best head-quarters for hunting with my otter hounds, and I do not think a stranger could do better than the upon latunton. That town being situated on the main line mot if not all my neets, extendingr from the Lristol to the English Channel, can be reached from it on the evening previous to the mecting day; that is, either by the main or branch lines diverging therefrom. The rivers usually hunted by ny hounds are, as you well bnow, the Exe, Iarle, Tone, Culm, Otter, Yarty, Axe, Ile, Char, and those near Dunster and Watchet on the Severn sea.

Since 1879 I have killed over Iff otters; thus averaging 12 brace per scatom. In lof I lilled 15 brace; and that was the best season I cver had. This past year (ISSt) I have brought to hand 20 frill-rown otters; but, strange to say, have neither killed a cub nor spurred one on all my rivers; nor have I lilled a bitch-otter in mill: A similar occurrence, to the best of my recollection, I never before experienced, although I have now hunted these rivers for

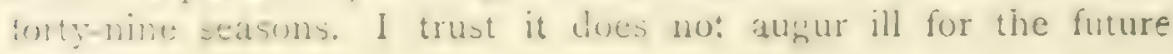
stock. 
I do not think otters are decreasing in number; neither do I consider them more plentiful than they were forty years atro. In

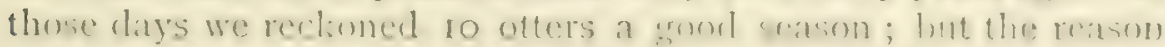
we averase: more now is due to the ratway, a help we rlich unt ene" in former years, the hounds havins been often commedled to do long, weary road-work before they reached the river side. For instance, I have left Ilillmoor at 2 o'clock in the momin'r, jogrised on to Exe Bridge, 16 miles, left my pony there, diawn up the Birle and killed my otter on the way. Then a crust of bread and cheese at Withypool and at it again, over Winsford Hill to the Exe; found and killed another otter, picked up my pony at Exe Iiridge, and back asrain with tired hounds the same night to Hillmoor; thus covering in the day at least sixty miles. Hard work, you will say, but sweetened by sport.

1 can remember on one such occasion, when Mr. Tom Carew ras Master of the Tiverton Homds and old John Beale the hunts. man, that I met their party near Tarr-Steps on the liarle; they had killed a brace of foxes, I a brace of otters, and as we approached on either side of the river we saluted each other with a couple of joyous who-whoops, blew our horns, and turned homewards. Of course my hounis could not do another day's work for a week or more. But now, with the advantage of the railway, I can hunt three or four clays a weck, so am able to make a larger score.

The time for otter hunting extends over a period of five months only; that is, from the middle of April to the middle of September; but as frost stops foxhounds, so do floods stop otter hounds, and it is no uncommon event in a wet scason to find rivers quite unhuntable for weels together; so the short measure of time allotted to the sport is thus seriously curtailed. Nevertheless such hindrances in no wise affect the working powers of the otter hound, for it matters little how lusty he may become provided care is taken to keep his feet right by regular exercise. And this at all times is an important point, for unless the balls of the feet are protected by the horny substance which only road exercise will give, the water soon sodulens and renders them painfully tender; and then, if the hound is not crippled, he becomes at least slack in his work, and does not 
do it with half the energy that otherwise might be expecterl from him.

But to return to the ofter and his ways. We have scarched the best authors on Natural Ilistory in vain with a vicw to obtain some light on the dark subject of the otter's family affairs; how long the period of gestation, when the young are brought forth, and how many they are in number. 'The first point is ignored altorether, the early spring is gucssed at for the sccond, and the number of the young is variously given as three, four and five. This last is doubtless correct, the larger or smaller number depending on the age of the parent dam. Tut as to the second point I am inclined to beliere that the period of parturition is not exactly limited to carly spring, like that of the fox, but extends also occasionally to the summer months, inasmuch as cubs of various sizes are met with at the same time of the year. Mr. Coilier, whth his half-century's experience, writes thus:

I think it is imposible to say when otters breed, as I have killed cubs of all sizes in the same month. Some thirty-live years ago, about the latter end of May, we found a bitch-otter near Inninster, and while hunting her, the poor little mother threw her cubs, one of which no bigger than a mouse I kept for years in a bottle of spirit. I regiet to say that last year, ISS3, on our own river, the Culm, I had the grcat misfortune accidentally to kill four cubs, about four or five pounds each; it was then the micidle of September. Only once in my life have I ever scen tive in one litter; this was on the Yarty, and as bad luck would have it they were lying in a dry hollow bank near some shallow water, so the hounds and terriers lilled them all instantly. I an inclined to think three to be the average number.

The IIon. Geofirey R. C. Iill, who has hunted the otter from his boyhood to the present day, not only corroborates Mr. Collier's views, hut goes so far as to say that otters, like dons, breed at all seasons of the year. Ho writes thus:

I do not think any man living can tell for certitin the exact period of he year when otters breed. My own belief is that they 
biced at all times of the year; for, during the sance otter hunting season I have myself lilled them nearly full gronn, then others about fit to take care of themselves, then cubs of a still smaller size; again, some just born, while, sad to relate, I have slain even the presnant mother with the cubs yet unborn in her. I an thus led to conclude that their season for breeding extends all round the year.

The average number of a litter is, I believe, about three or four; but I fancy they do not rear more than three. Once, and once only, have 1 seen six young ones, but that was quite an exceptional case; those I took out of a drain myself and triec? to rear them, but eventually they all died.

Still, notwithstanding the opinion of those two experienced hunters, I lean to the belief that reproduction takes place only in the spring and early summer months; that the cubs of four or five pounds each, killed by Mr. Collier in the middle of September, were born early in that year, and that those of eight or ten pounds' weight, 'fit to take care of themselves,' were dropped in the previous spring, and were, when killed, in their second year. I infer this from the very slow growth of the young otter I kejt for so many months. He was about two pounds only when I caught him in May, and although well fed daily and in perfect health weighed no more than four or fre pounds in the late autumn, that is, in Octoluer, when he was accidentally killed. Had he continued to live and thrive through the winter, I believe he would have been an eight or ten pounder in the following spring and summer.

The chase of the otter, owing to floods and cold water, is necessarily suspended for seven months in the year; and however desirable it might be in the interest of that sport to observe a close time during the infancy of the cubs, the hunting season then would be so abridged by it that few men wuld be willing to keep hounds expressly for that purpose only for so short a time. Bitch-otters vielding milk, or indicitins the very recent

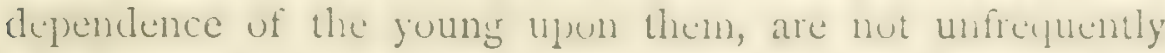
killed even in the summer months, and then of course the whole litter is destrojed; while many infant cubs, far more 
than the ye sces, are chelfed by the currices at ground before they are able to ruit their nurseries. Sis, the killing of baby cubs muat needs in on, through a grief and pain to all con cerncd in their untimely destruction.

With all paths of otter hounds the weelily continuance of the sport, as well as the number annualy killed, depends much on the state of the rivers. When they are fooded, the hounds wrold be fur beter on their benches than tainting the banks and haunts of the wild animal at a time when they have no chance of lilling him: lut when low, the hounds have then ewery advantage. Under the latter circumstances Mr. Geoffey Iill billed sinty-two otters in one scasun, the best he ever had.

IIe began hunting the otter with his own pack in $1860,{ }^{1}$ but

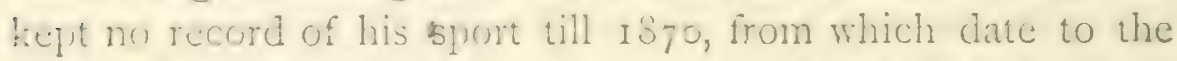
year I 884 , that is, in fiftuch scasons, he has killed the large number of $54+$ ctecri, thus ancuging thirty-six a year and four over, Yet, notwithstanding this lewey siore, he says, "Otters are not decreasing in any way on my rivers; they are better preserved than they used to be, fur gnople are berinning to find out that they kill and keep) (lown the coarse fish and cels (which live ujon the spawn and fry of the better sort). Besides, otier hunting is nore appreciated than in fomer days, and the wilel animal is now kept to siow prort. Not that an occasional cuter does not fall a virtin to the farm habourers and their dogs, when, as he is wont to do, he travels up a small hrook and is catught hofore he can rath the safe drain for which he is making. It is stmi-c but true, that when a bigriver gets low and there is no really strong holt upon it, he will yuit that river and go ul the -inallest struan, to gain if he can a more secure retreat.'

Also, he is apt to go a-frugzing even con the rills of a water maklow; but when indulging in that pasinne and luxury (for no linembnan loves a frog letter than he (loes), he is sure to have a stonghoh within e.asy leach. 'The bitch-otter, when

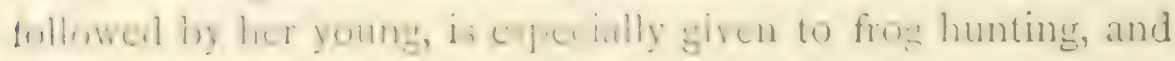

1 His elder brokluer, now Lord Hill, kept them for many years previously. EDHo: 
thus probably instructs them how partially to support themselves before they are able to stem the currents in which their slippery and more active prey can alone be found.

At the same time small brooks, often high up in mountainous districts, are almost invariably chosen by the dam as the guarters best suited for laying up her young. For there, at th. very source of perhajes our bignest rivers, Nature has provided her with an ample supply of the daintiest food-the fry of trout and salmon; and there, the currents being gentle compared with the force of those below, the young can be better trusted to learn their first lessons in the work of life, namely, selfmaintenance and self-preservation.

For the following most interesting communication on the natural history of the otter I am indebted to my friend, the late Mr. Trelawny of Coldrenick, and I have his authority for stating that Mr. Shaw, who vouches for his labourer's veracity, is a gentleman worthy of all credit. The letter written by Mr. Shaw from Trelowarren, the scat of Sir Richard $R$. Vyryan, Bart., was addressed to Mr. Trelawny; it runs thus :

Knowing you to be a great otter hunter in that dull time of the year which poets praise so much, I trust the following account which has just been related to me may not prove uninteresting to you; and I believe I can thoroughly vouch for its authenticity, having questioned the narrator very minutely about it. He (one of our labourers here), on his way to his work on Wednesday last, soon after five o'clock in the morning, saw a quantity of animals coming along the road towards him, and stood very quietly by the hedge till they came broadside of him. He then perceived they were otters, four old ones, ${ }^{1}$ and he thinls very little less, if at all, than twenty young ones. He had nothing in his hand at the time, but, as quickly as he could, he got a stick out of the hedge and struck one of the young ones and ultimately killed it. The moment the young one began to squeak, all four old oncs came back and stood grizzling, as he terms it, against him, till all the young ones had escaped through the hedge, and then went quietly off themselves, he being afraid to attack them. I have just weiched the one

1 The four old ones were doubtless four females; for the dog-otter is rarely if ever, found in company with the dam and her young ones. 
whirh he killed, and its weight is $5 \frac{1}{3} 10$.s., which will rive you some idea of its size; in fact, in appearance it is nearly as large as a common-size cat. Having hunted otters much myself in former years, I was aware of their being great travellers, but I did not know before that they journeyed in such patriarchal fashion, four families of course being here congregated together. I feel assured you will not consider the time spent in perusing this epistle thrown away, as I think it a very interesting piece of natural history about an animal whose habits are not very definitely known. Mr. Shaw in a second letter adds-I have since thourht on the probable reason for the migration of so many otters at once, and can only come to this conclusion that they were bred on one of our fresh. water rivers which are mere brooks; and as the young ones increased in strength and appetite, the supply of fish was not sufficient for them, and they were therefore making their way to the Ilelford river (the apparent point) which is an arm of the sea.

A stranger, wisling to hunt with the Hon. Geoffrey Hill's hounds on the Wye, the Irfon, the Ithon, the Llynfi, Towy, and the Eddw, could not do better than make Builth his headquarters. For the Usk, he should go to Brecon; for the Teifi and its tributaries, to Newcastle Emlyn; for the Vale of Clwyd, St. Asaph ; for Pembrokeshire, Haverfordwest ; and lastly; for North Shropshire, Market Drayton. It may be added that Mr. Hill considers the 1 ye and its tributaries, the Usk, the 'Teif, the Towy, and the Clwyd as his favourite and best rivers.

Artificial drains both on rivers and large fish ponds have proved to be a great success, when constructed with due referwre to the wild and shy habits of the otter's life. 'They arrest hum in his travelling propensities, it may be only for a night or so; but, when once such drains have been used, they are sure to lecone known to 'all the wandering train;' and conseincutly may be reckoned upun as a safe find when hounds hit upon a fresh drag in their nughbournood. Lut if made, their whereabouts should be hept secret, or be well looked

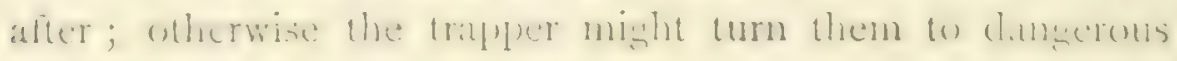
account.

A drain intended tor the lodyzaent of utlers, if constnucted 
in a river, should be made with rough stones, and have its cntrance, about eight inches square, at least a fout below the ordinary height of the water ; then it should slint upwards till it reach ground high and dry alove the highest level of a winter's flood. It that point a cruss-flue, intersecting the other, and in shape like the capital letter $T$, should be formed in the dry wil ; but it should be of larger dinensions than the entrance passage - say a foot in width - so that an olter, or a couple of otters, might find room in it to curl up and go to sleep. This chamber, covered with stone slabs and a thick layer of earth, should then be turfed over, so as thoroughly to exclude light and air from above.

When a drag in its vicinity leads to the belsef that a lodger is within, a few hearty blows with an otter pole on the turt overhead will probalbly drive him at once to quit the tenement; but failing that, a crowbar let down and rattled on the cuver stones would be sure to have the desired effect; and if so, a chain of pearl-like bubbles would at once rise to tell the tale. On no account should the ground be opened and a terrier allowed to enter the drain; an otter so bolted, if not killed, would never more trust himself in it; nay, the taint of the terrier would be so strong and lasting that I doubt much (for they tell each other) if any otters would ever lodge there again. A wonderful network of nerves permeates the otter's nose, and gives tirat organ a power possessed by few other animals - a boon Nature has bestowed upon him, not only to cnable him to hunt up his prey, but to protect his life.

If an artificial drain on a fish pond be contemplated, no man could do better than follow the plin adopted by Mr. John Bulteel of Pamflete, whose experience of otter life, derived partly therefrom, is so interesting that it may well encourage others to go and do likewise. The pond itself is an artificial one, formed by intercepting a brouk that aforetime was wont to chatter though a dark dingle, until it jomed the river Erme about a mile from the sea. The banks on either side are fringed by a dense growth of evergreens, but especially by 
rhododendrons, which flourish here in the wildest luxuriane ; while the Scotch fir and the Austrian pine orerhanging the lake rast a deep and sombre shade over it and the whole valley. To render this quiet and secluded spot a still more temptmer retreat for the otter, the pond is well storked with trout and acls; while it is only separated by a narrow sand hank from the Erme, a ticlal river famous for its truff, salmon, mullet, flomders, and other dainty fish fresh from the sea.

Here then, if anywere, are quarters suited in erery way to the shy and wild habits of otter life; and here it is that Mr. Bulteel has constructed the drain which, as might be expected, did not long remain untenanted, and has ever since proved a farourite lodying house to the come-and-go visitors frequenting that pond. The drain differs in some respects from the one described above, inasmuch as it has three distinct entrances, one below and two above the surface of the water; while three or four cross-flues, running under a dark rhododendron bed, are capacious enough to accommodate a whole family party seeking a dry and peaceful retreat. Swans, pheasants, moorhens and kingfishers are their nearest neighbours, and the only sounds that could possibly disturb their slumbers would be those of the wild sea waves breaking on the rocks so near their home.

Mr. Bulteel, who is not only a good sportsman but an enthusiastic naturalist, has been favoured in no ordinary degree with jeeps into the private life of his otter guests; and so intensely interesting were some of the scencs he witnessed that although they have already appeared in print, I will agrain venture to quote them in his own graphic words:

Yesterday (yth March) in the deluege we had, I thought it likely the otter might be moving about, so I sat down in the comer by the edge of the pond hidden by bushes, and waited. In about ten minutes I saw the otter cmorese fom the opposite bank-about filty yards from the rail on the sand - and begin to fish. For full twenty minutes she kept on diving and rising to the surface, her atitudes most graceful, when suddenly she canc up with a bright 


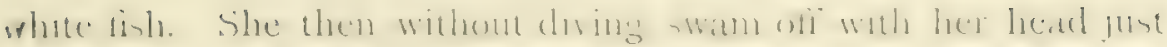
ahowe water, and with womelerful rapoldity, to the bank opponite,

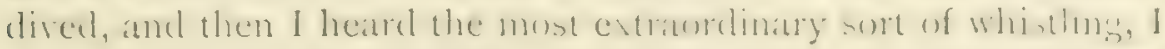
suppone the young quatreflins for their forey. In three minutes

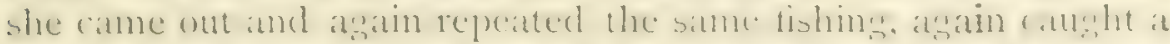
fish, agatin went to the youn:; ones. She then rane out a third time, but ats I was pretty well sorlicel I nowed on, and trom that moment all was quiet.

The swans have sot accustomed to them, for although the otter came: up several times within ten yordsof then, the old drake

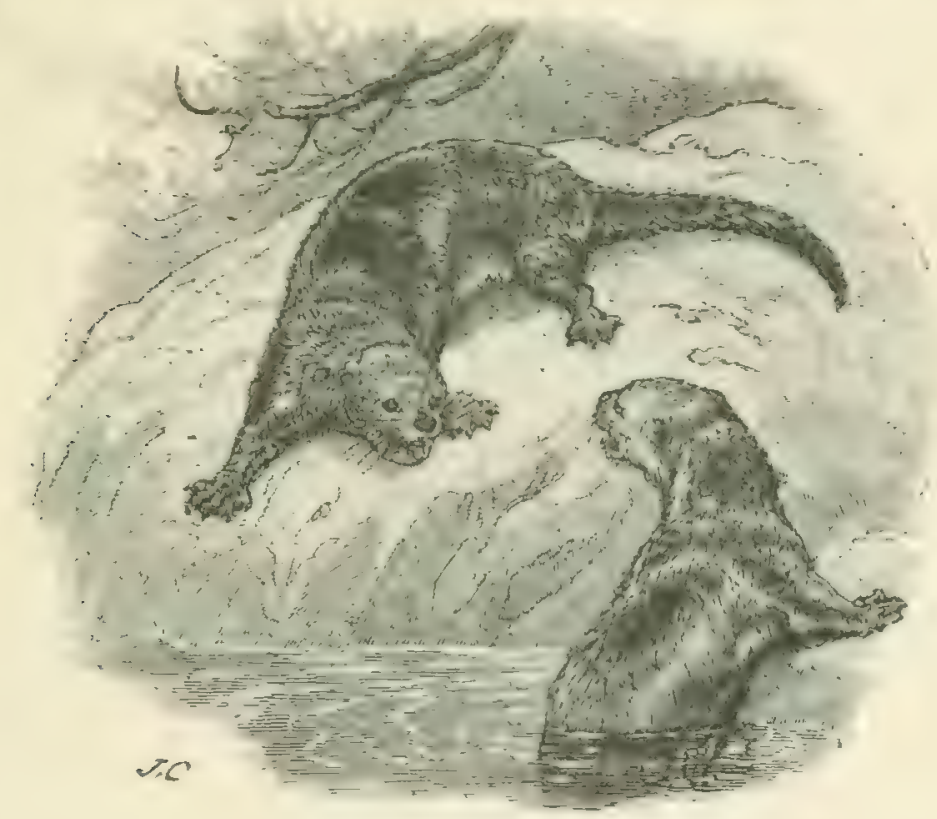

Otters at play.

only set up his hackles and did not seem to mind her much Now of course I lnow where the younts ones are latid up, and I shall see, I daresay, very many interesting episodes of otter life. I think you ought to come orer some day and enjoy the sight.

About a weets after that tempersuous day, I was again faroured with a srand sight, and I only wish you hat been present to witness it with me. I was sittins at the farthere onet of the pund from where

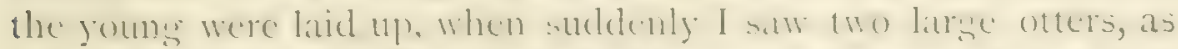
I thought, fighting. The tussle first bestun at the very place where a week before I had seen the bitch-otter feed her young. The 
utters when under water at length loosed their hold, and one rose to the surfare two or three seconds before the uther, but as soon as the head of the latter appeared they went at each other again con amore. I am inclined to think, from what I have since obsurved (more of which as I go on that it might have been a grame of play and romps; but certainly they went at it hammer and toness until the bitch had driven the intructer half acioss the pond. II then (the animal I suppose to be the stranger) landed, set the moulhens and even the cock pheasants all on the qui rive, and finally I lost sight of him in the dark.

The next exening a ncighbour of mine paid me a visit, and as he expresed a strong inclination to share this sight with me, I wayl ed lim up in a reat-coat, put him on a camp stool, and with a sood pair of opera glasses we bided our time. Suddenly, just opposite to me and within twenty yards of where I sat, out came the bitch-citter, fished for ten minutes, caught a white trout, and swam with it to her young. I looled intently but in vain at the farther end of the pond, whence she had cmerged on previous occasions; the carcful mother had, however, owing, it struck me, to the fight of the night before, shifted her young to other quarters. I can scarcely describe my friend s ciclight at witnessing this novel and genuine bit of wild sport.

A few days after this visit I let out the pond, and during that time saw nothing of the otters; I observed, however, that they still used my drain. On Wcchesday last, April 5, the waters having risen to a respectable height, I went out for a watch, and at 7.20 glided forth from the drain the finest dos-otter I ever saw. He was alone and evidently on the look-out for company, not fishing, but cruising about restlessly all over the place. Once he actually lifted himself on his hind leers until his midclle was fairly out of the water, the willest-luoting beast I ever saw; it then became dark and I saw him no more.

Astrain on food Friday evening when all was quiet around, I ionk up wy position near the pond, and at 7.20 I viewed a brace of old otters cmerge from the midklle outlet of my drain, and fish industrunsly for half an hour. During this performance they constantly setumed to the drain. I have maked the place with a cross.

On Saturday 1 hunted at Sheepstor Tor, came home late, so gave my friends, or rather myself, an evening's rest. The next night, however, hemg kaster Sunday, I saw at ten minutes before se:en a sight I wuth not have missed for gold; a israce of utters, 
widently male and female, having in broad daylight the same sot: of turn-up I had witnessed a fortniwht a:ro, when they were lomeded on the other side. 'They tumbled over atrh other, lost ingt of cach other, and then had what we call in bevon 'a real stat' at one another. Suddenly one landed and loolied out for the other, then up he came again, and both tlew into the pond loclecel together. Now I must say all this appeared to me to be a fricndly' business. I watched them till a quarter to eight, and latterly they worked independently, returning to the drain every now and then, but I saw no fish in their mouths.

I shall be able to see in a few days whether they are not, as I strongly suspect, a brace of otters that have no communication with the party opposite; but, if one happens to be the old bitchotter I first saw with her family, all I can say is we shall yet witness some pretty sights when she brings out her youngr and teaches them to fish for themselves.

On that river Erme with the first freshet in June the whitefish or truff came up in large shoals, to rest for some time in deep pools at the highest point touched by the tidal wave. One of these pools is designated far cxallence the otter pool, for as surely as the truff appear, so surcly do the strong hovers hold an otter, nay, sometimes a brace or more, in attendance on the prey so bountifully supplied to them. The arrival of the truff, a fish identical with the sewin, was in former days made the hapyy signal for the first mect at Sequer's Bridge, which meant the otter pool; and great was the sport usually shown on such occasions by Mr. Bultecl's or Mr. Trelawny's hounds; cspecially when Waterloo, Wanderer, and Whirligig were the stars of the pack. Then, as the ladies formed no small portion of the hunting field, the day was not unfrequently wound up with an impromptu feast and a dance afterwards on the old oak boards of the Flete hall. Nor should it be forgotten that on one remarkable occasion a lady deroted to the chase left a goodly portion of her white petticuat on the snags of an old willow, but nevertheless, undaunted by the loss, stepped out in her 'cutty sark' "with great effect in the bullet that followed the play; and, as a song written at the time relates: 


\section{That very e'en a liunter keen \\ Told her his tale alone; \\ And when he gave his heart to her, \\ Belinda lost her own.}

What happens on the Eme so regularly is doubtless the case on other rivers, up which shoals of fish trarel in their micration from the sea ; their enemy, the otter, follows in their wake as surely as dolphins follow the flying fish, or kites the countless host of grey squirrels secking a summer home. Thus, fishermen, whose sport is too often vexatiously marred by the nightwork of the otter, are constantly able to give useful information to masters of hounds as to the time when a find on particular streams might be almost reckoned as a certainty. At least, this was always the case on the Erme. "The truff be come, sir; and there's one if not two o' they otters along wi' em,' was the anmual report of the old lieeper, John Ford, to Mr. Bulteel, who at once adrertised an early mect with a result almost invariably successful.

I can well remember that, many years ago, a famous otter hunter, linown in Glamorganshire as Exan Llanwensant, rarely went in search of an otter sxcept about the time of a new moon; for the wild animals, he would say, preferred the dark nights for quitting the strom inold ot the cliffs, and renturing up the streams adjacent to the consts. But with due deference to Evan's theory, it is far more probable that the spring tide rousted them out and rompelled them to seek drier quarters. At all events, with only a couple of tan-coloured hounds, famous and Cinches, he managed to kill more otters and foumarts than all the packs in the country put together, the spear, however, leing frecly used when a chance occurred, his motto being 'Dum spiro spero.'

In the North of I evon, so deroted are the people to the sport of otter hunting, that not only the fishemen but the farmurs will go miles out of their way to tell a master of hounds that they have sealed an otter up such and such a stream. Mr. Cherriton, indecd, for many years had, if he has not still, 
a special correspondent at Crediton-a swecp, named John Brasg - who being a lirst-rate hand with a fly rod, harl also the cye of a lynx for an otter's seal; and when it was his groud fortune to view it freshly imprinted on a spit of sams, like a clever French pinueur he would accurately note the five pats of the foot, being one more than those of a fox or a dog, its exact size, and the direction of its course, whether up or down stream, and then bound off for the kennels, no matter how far, to convey the news so welcome to Mr. Cherriton and all the country-side.

When a fresh trail is hit on a rocky river, where a spit of sand is only occasionally met with and a mud band never seen, the sprants dropped on the boulders that crop up in mid-water indicate with tolerable certainty the course taken by the otter in his night's work. If the spraints-the odour of which is literally more like scented snuff than foul excrement-are on the lower or down-stream side of the boulder, the otter was working upwards; but if deposited on the upper side, nine times out of ten it may safely be inferred that his course was a downward one. 'The kecn hunters of the north, especially' in Cumberland, depend much on these marks; and while the hounds are busy in carrying on a drag, and no one can tell whether it is heel or not-for heel too often affords the most enjoyable scent-then every man's eye is directed to the boulders, and he who discovers the spraints shouts aloud to the field 'Oop-water' or 'Doon-water,' as the case may be.

Also, on rapid and stony rivers, if the hounds frequently land and carry the scent over the meadows and across the curves of the stream, it is a sure sign that the otter has been travelling upwards, and has taken the chord of the arc to aroid the current and shorten the distance to his next retreat. On a sluggish and meandering stream, too, he will occasionally do the same, especially if daylight be dawning, for the witches of Kirk Alloway never shumned the break of day more carefully than an old otter.

A remarkable instance of three full-grown otters avoiding 
the bends of a stream and crossing a broad meadow by daylight was witneseed at brimpts on Jartmoor by the tenamt ocruyying that farm. He was called Coker; and beine a livierman, was asked if we were likely to find an otter on the following day. 'Ouite sure, sir,' he replied, 'on the Last I art ; for it was only yesterday I saw three big otters, two black ones and a white one, crossing that meadow helow us and going up for Post Bridge.'

'A white otter, Ned?' I ail, with a smile of incredulity I could not disguise.

"Yes, sir, a white one; the colour of that white hat on the squire's head.'

Mr. Erlward A. Sanders, the owner of the property, was standing near at the time; and as he and I moved off tosether, I could not help telling him what I thought of his tenint's veracity.

However, the man's tale was true to the letter; we found and found, but owing to the hollow submerged rocks, did not ratch a single view of either a black or a white otter. At length, on the second day, Midnight came to a mark on a clitter of rocks adjoining the river; in went the terrier Prince, ancl to our utter amazement, out glided something that at first looked like a salmon belly u1 wards; but it soon proved to be a beautiful cream-coloured otter, which in the dark waters of the Dart appeared as white as an Arctic fox.

Ile was soon killer, his very colour being against him-a fine dog-otter.

Of all the beasts of vintrie, there is not one for whose scent unentered hounds scem to care so little as for that of the stter. When the Rev. Juhn Russell of 'Tordown first started a pack, during his first two scasons he had not a hound amongst them that would touch a trail. 'I walled, hesays in his memoir, 'three thousand miles without finding an otter; and although I must have gased over scores, I might as well have searched for a morse deer.' No doulit of it ; but when once he had secured a hound that thoughly kncw his work, he had no further trouble. 
The scratch lot, under the tutclage of Racer, soon learned their lesson; and Russell in a couple of seasons 'scored five-andthirty otters right off the reel.'

The scent, in truth, does not appear a natural one to hounds or terriers; and hence the difficulty in getting them to take to it. In the North of Fingland it is a common practice to enter puppies on foumart first, and after killing a few of those skunk-like vermin, they take readily to the scent of an otter. Yet, to the human nose, no two animals can differ more in their natural odour ; the slin of the one yielding an effluvium almost imperceptible and by no means disagreeable; whereas that of the other is so fuetid, so noisome, that I have seen hounds sneeze violently and turn away in disgust when killing it. But neither the rough hounds used in the north, nor the wire-haired Welsh hound evince such unreadiness to enter as their congener the foxhound, of which race it is no figure of speech to say that not one in ten ever fancies the scent. But, find one that really takes to it kindly, and that hound is priceless. His high-mettled courage carries him gallantly to the front on the longest and coldest day; and while the rough hound, good as he may be, stands shirvering on the bank, overweighted by water and chilled to the marrow, the endurance of the foxhound becomes conspicuous. He goes on marking-the most valuable quality an otter hound can possess-and when he speaks, it is a guinea to a shilling the otter is there. Not so with the rough hound; for, when at all beaten, he is very apt to throw his tongue too freely, dwelling on old scent, and so attracting the pack to hovers in which the otter is no longer to be found.

Still, as a trail hound, give me a big blue-mottled harricr, or a wire-haired hound for that purpose; he is not so prone to hit and flash ahead as the other, but is more poky in searching for his game, and consequently does not draw over it half so often as the dashing foxhound. So, to my mind, a thoroughly efficient pack of otter hounds should consist of a mixed lot, but chiefly of foxhounds, with two or three rough or big harriers 
to hely them on the trail and, if not too noisy, to keep tnern by their bell-like tongues to the water-side.

Mr. Trelawny, whose belief in a foxhound led him to undervalue every other description of hound, was nevertheless indebted to the rare drawing gualities of Romulus and Cardigan - two rough Cumberland hounds - for many a find and many a rare day's sport with his famous flying pack. Yet he cordially hated their heary sing-song tongues. Mr. Collier, too, works a rough one or two; but the otter once found, the foxhound is his main stay. Rourgh or smorth, however, an otter hound can nevur be too lusty nor too long in the leg; for often where he can tuuch-and-jo, a short-legred hound is obliged to swim, and at that game the otter is the better man.

Mr. WaIdron Hill, than whom few men ever followed the otter with greater success, adopted the plan of crossing a tame dog-wolf with his rough bitches, but down to the fourth or fifth generation the puppies were so wild and umruly that they were worse than useless - worse because at the very sight of a sheep their wolfish nature defied all discipline, and run him they would at any price. However, what with time and rating, they at length becane a serviceable pack. Nay; the Hon. Geoffrey Hill, to whom Mrs. Waldron Hill on the death of her hushand kindly presented the whole jack, describes them now as ' a steady-working lot of hounds.'

Owin's probably to thcir wolnsh incisors they were able at once to break up an old otter and tear him into

\section{A hundred tatters of brown,}

which feat, with a slout of 'Tear him and eat him, lads," Mr. Waldron Hill always encouraged them to perform.

()n a river abounding in high banks and long reaches it is doubtful if hounds cuuld ever kill an otter without the gruidance of man. In such water their best chance of success depends mainly on the help he gives them by keeping a watchful eye on the shallows above which the hounds are worling their game. And to give that help efficiently the man on whom 
the duty devolves stands, it may be, knee-deep in the stream; and there, keeping a steady and patient look-out, ejther heads him back into the pool above, or with a rattling view-holloa allows him to slip down into casier water, where the hounds can work him with more advantage.

But the sentinel must be an experienced man, not at one moment watching the stream and the next looking $u_{1}$ at the hounds, or, however clear the water may be, the wild animal

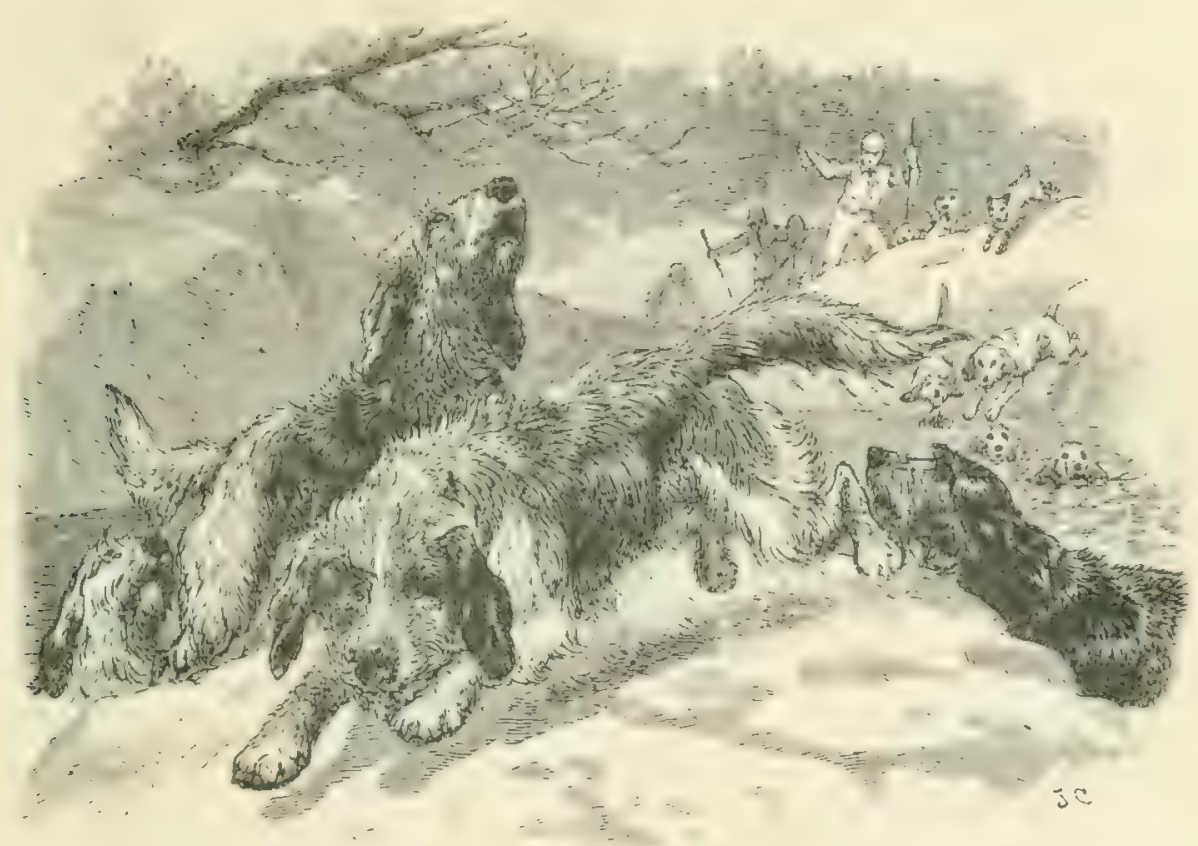

Fuil cry.

will glide by him like a ghost, and probably never be recovered again.

In drawing a river, hounds should never be allowed to stray away from its banks; riot is thus prevented, and they soon learn the practice of clinging to the stream. Nor, when the trail is hot, can a hound be too slow in searching for his game, provided his slowness be not attributable to slackness or old age. The best finder I crer saw was a stifled hound.

Hounds, when an otter is found in a deep pool, are very 
apt to flash off with the floating scent and to carry it for a long distance down stream; while the otter, scared by the men guarding the shallows, has only taken a turn or two round the pool and come back to his strong hover again. Foxhounds, especially if not old hounds at the work, are not to be stopped by whip or horn at such a time; down they go in full swing, splashing and dashing ahead in the wildest enjoyment of the surface-scent. It is a beautiful sight but does nothing towards killing the otter, for he soon recovers his wind and the terriers must again tackle him, but now with a far tougher task before them than in the first instance. He knows he is beset by a strong host without, and therefore will too often punish the lesser foe cruelly before he can be forced to quit his stronghold again. But when in a rapid river the scent is thus washed down by the current and the hounds are revelling upon it, the huntsman cannot be too steady in his action, for by standing still, instead of joining in their excitement, he will teach them a lesson of steadiness ever needful in an otter hound. Again, when an otter is loth to quit a big pool and shifts only from one strong hover to another, the water and hovers become so impregnated with scent that the most trustworthy hounds are then unable to distinguish the new from the old scent; they mark here when the otter is there, securely catching his wind to prolong the fight. The only plan then is to call off the pack till the stained water has passed down, and presently on returning, of course against stream, the hounds will fresh find him with little or no dificulty. But observe that, when all is quiet, and especially if the banks are fringed with coppice-wood, the otter. finding no rest in the hovers and now half-beaten, is rery apt to land and, if he can, slip away across country for some distant and safer refuge. This, however, is only a forlorn hope, and the enemy often overtakes him before he can 'fetch' the point he aims at.

An old otter groing for a strong holt, especially if fortified by water, is a very difficult animal to head back, and if not killed in the attempt, will make his point agamst all odds. A very 
remarkable instance of this fact occurred to Mr. Geoffrey Hill when hunting in the county of Waterford. He was standing with his hounds and a large party of friends near a rock famous for holding an otter, but equally famous for baflling the best native terriers. However he was just going to put one of his tartars in when a 'holloa' from his kennel huntsman made all the field look round, 'and we saw', he says, 'an old dog-otter coming right at us. We rushed out and did all we could to turn him towards the river, not twenty yards off, hoping to have some sport, but all in vain; he came straight into the whole pack and was of course instantly killed. This incident was witnessed by many members of my hunt and by several gentlemen who had joined me from Waterford.'

An otter was once seen to go into a clitter of rocks on Dartmoor literally between the legs of a gentleman, the Rev. Fitz Taylor, purposcly stationed there to keep him out; and the terriers, good as they were, fairly failed to bolt him afterwards.

Again, on the south coast of Devon, near Slapton, there is a small brook called Blackpool, which from the sea to its source scarcely exceeds four miles. It is well known to the local fishermen to be swarming with trout, and nightly did an otter visit it, but never failed to return to his stronghold in the cliffs before daylight. 'To cut off his retreat and head him back, several times the following plan was adopted: Leaving the kennels soon after midnight and jogging on with the hounds to a small bridge that crossed the brook within a hundred yards of the sea, the spot was reached about $2 \mathrm{~A} . \mathrm{M}$., and there the first blush of morn awaited. But all in vain; time after time the same hot trail roused up the villagers and excited warm hope, but there was no visible otter and consequently no kill. The wily beast fairly beat his enemies, managing in the dark either to slip down with the current unseen, or to land behind their backs and gain the cliffs before the hounds could catch him.

But every rule has its exception; and Mr. Collicr will never forget the triumph he once achieved in heading back an otter on the Torridge River. He certainly adopted an exceptional 
plan for his manceuvre, and moreover, it was at night-time, which rendered his success the more remarkable:

We found (he says) about 5 P.x. in a long weir-pool, some two miles above the inn at Woodford Bridge, where we were quartered for the night. Rattled hirn well for an hour; then called off, there being little chance of killing so late in the day. But, feeling sure he would go down stream to some heary water below, I decided to try a dodge with him and keep him up, if possible. So, collecting five or six lanterns, I lighted and hung them at dusk under the arches of the bridge. Then stationed two men, one on each side of the river, to thrash the water with long poles just above the bridge, and, to crown all, Mr. Frank Cockburn and I lighted a big bonfire which, while we cracked whips and blew horns, we kept going till daylight. At 4 A.M. we began to draw for him up stream, and on crossing the very first hedgre above the bonfire, away went the hounds in full cry. Then old Benedict's roar soon told us the otter was found, and the fun was on in earnest. He then landed, and crossing many acres of fern, gained a large cover, up which he went and down again through another cover; but before he could reach the river by thirty yards, they rolled him over within a short distance of our night's quarters-an old dog-otter.

The trail, when an old otter has a point to make, will not unfrequently extend to a distance of eight or ten miles, and that too across country, if his point happens to be on another river. Mr. Collier's experience of this erratic habit is very pleasantly told in the following letter :-

I have had some extraordinary sport this season (ISS4), such as I never saw, or can ever expect to see argain. The trail lunting has been something wonderful. My first mect was on the Culme, near Collompton; there took a trail, and at the end of ten miles up stream, found; had three hours and a quarter, and killed. Last June, in response to an invitation from the Hon. G. Lascelles, I took ten couple of hounds into Hampshire to draw the streams in the New Forest, making Brockenhurst my head-quarters. Nonday, IGth, we met at Beatulieu at 7 A.A. After drawing up stream about half a mile, we struck on a trail, which the hounds carried on at a rattling bace for miles through this wild country. The otter now began to twist and turn a good deal; but every inch was hunted 
out, and after nine miles we found, had one hour and twenty minutes, and killed. Wednesclay, Isth, at Irolie brir? se, soon sot on a trail; making good my lower point, tumerl and rattled up stream merrily; seven miles and a half hrought us the vamint's quarters; had some good sport, and killed a brace. Next day (Thursday) met at the kennels, Lyndhurst ; close by was a pond of several acres, which it was thought advisable to draw lofore goingr down stream. On arriving there, the hounds at once hat some very hot scent, and casting round, hit him off thrours a thick cover above. Catching sight of his seal, it put new life into my veins. 'Yoiclss forward, my lads' (but not a word to the field), away we went out of cover, across thirty acres of mowing grass to another cover above, through which the pack dashed as if running a fox, and on to another pond ahead. Leaving this in the rear and cross ing a road, they broke into a large inclosure of heather and sedge. The hunting now was simply beautiful; over the hedge they go, at the farthermost end, and out on the common, through a small piece of water, and away over the hills (many of the field, I believe, fancying I could not be hunting an otter, the country being full of deer and foxes, but my faith never wavered). Sinking the next valley, we came to the river where we killed our brace of otters the previous day, only it was a mile or two farther up stream; here was a welcome halt for a minute or two. I made my cast above, but found he had not gone up. 'Hark back;' and two hundred yards below hounds got on to him again, making the wools ring with their music. Passing the holt of the previous day, they carried it down stream for about four miles; and here he again left the river, the hounds hitting the line across a portion of the forest, and dropping into the Burley stream, up which they hunted him beautifully; now searching for him as if they meint to find. But it was hark forward again on to Burley, where several hundred head of cattle and several cottages brought the hounds to a check. However, I was soon on the spot, and lost no time in casting above the cottages as the day was growing older. 'Yoicks! at him argain!' and three hundred yards farther up Harlequin (the rough hound, which no doubt you recollect), galloping up by the stream, winded him in the hedre, made a dash, and out my friend came into the water, and was soon killed. Thus ended one of the best days from first to last I ever saw, the distance covered being about sixtcen miles. Saturday, 2Ist, met at Lymington Bridge, turned down stream, struck a trail at once, which we hunted about two miles, when the otter left this river also and went three or four miles across the 
marshes down to the Solent. When we got there, we found the hounds swimming the salt water, and I was asked what could be done. The only thing I could suggest was 'to get a steamer and cast for him on the opposite shore.' I think you will arree with me, after what I have now related, that you and I must feel how little we know what this wild animal is really capable of doing; I say it is like music, we shall never arrive at the bottom of it. Another remarkable thing has happened to me this season. On August 26 I met at Dulverton, drew up the Barle, found near Bradley Ham ; had a capital turn and killed. Slept at Withypool, and met at Winsford the following morning at six. Drew down to the junction of the Quarm and Exe; here I took a trail, and before reaching the old abbey at Barlinch, the hounds had a rattling scent on both sides of the river. I arrived at the conclusion that it must be a brace of otters, but no otter was gazed at least for an hour. While we were working him with some very pretty hunting on the weir pool, i heard a view-holloa below in the mill stream, and rushed down with only three couple of hounds at my heels. The rest of the pack remained working in the weir, and at that very moment forced their otter to land through the cover above, being close at him and of course the field with them. This I knew nothing of at the time; however, I stuck to my otter with the three couple and killed her handsomely, the other lot groing up the vale like mad, scmetimes in the river, and then agrain on land, till at length they rolled their otter over also about half a mile above. This is the first time I have ever known a pack of otter hounds dividing, each lilling their otter.

But now for the terriers, a most important and indispensable adjunct to a pack of otter hounds; for on every occasion where strong holts or underground drains are met with, on them it will depend whether a trail is to end in a find or not. The process of ejectment, generally a bloody one in close quarters, it is their duty to serve. The terrier, therefore, should be hard, wiry, and by no means too big in size; otherwise he will not only be unable to rork a narrow drain, but by scraping back the earth to gret at the otter, he will dam the water behind him, and so, if not rescued, be drowned.

Like the foxhound, not one terrier in twenty will take kindly to an otter, although the veriest cur will join a worry or 
hang to him when killed and suspended from a tree. But as to drawing the hovers and drains of their own accord and helping to find him, that is at once a rare and most valuable quality. The writer has tried to enter, first and last, scores of terricrs, most of which would readily go to ground and mark a fox or badger well ; yet four were all he ever owned that for finding and bolting an otter were worth a handful of meal. One of them, called Prince, would traverse a wet drain for a quarter of a mile, was often pounded by water, and as often rescued by the spade. Nothing would induce 'Tip to enter a drain, but he would follow its course above ground, searching for rats' holes, and so find his otter. Fox spoke freely on the trail, and would hunt an otter under a clitter of rocks like a spaniel driving a rabbit through a furze brake.

But no one perhaps has ever possessed more remarkable terriers than the present (the eighth) Duke of Beaufort, who kept otter hounds for many years. One, called Billy, was so keen and so clever that, if he caught wind of an otter through a rat's hole on the bank, he would first search for an entrance, and if he did not find one above water, would go under to a depth of eighteen inches or two feet : then shortly after-ecce signum-a chain of silver bubbles rises to the surface, and Billy, triumphant, comes up again. Two others acquired this very rare accomplishment from Billy, and like him were occasionally saved by the spade. It is highly probable that on big rivers like the Severn and the Wye, otters grow heavier and bigger than they do on smaller streams, just as trout do. In Devonshire, for instance, the top weight for an old dog-otter is twenty-six pounds; but on the Trothy, a confluent of the Wye, his Grace killed in the same week a brace of otters, the first scaling twenty-nine and the other twenty-eight pounds. 'In floods,' he writes, 'I have found otters far above the water; once, taking the drag from my own front door at Troy House, the hounds carried it for six miles up the flooded Trothy, and then found him high in a wood orerhanging a small rivulet. At first 1 feared it was a fox, but down he came bundling best pace into the brook. Hoping to head him 
from the Trothy, I ran two miles down stream and got under a bridge only two hundred yards from that river. I was scarcely in when I saw him coming, breaking the water in his hurry, and bouncing bang up against my legs. Up he went, agrain, and we then killed him -weight twenty-nine pounds.'

When an otter is found in a narrow underground drain, the best mode of bolting him is to open it at some distance from its mouth; the terrier then, with his head towards the nver, comes in behind the enemy, and will probably bolt him without bloodshed; he will thus escape the punishment he is otherwise sure to suffer. But, if there be running water in the drain and the dog is unable to get at him, the process of drowning him out, though sometimes a tedious one, is yet generally successful. By cutting a trench across the drain a few feet from its mouth the water is easily dammed by a heavy turf or two; it then soon rises, and, as it fills in the drain above, the otter is compelled to bolt. The hounds of course must be kept at a distance, or a chop would occur and mar the sport. The modern manufactured dog, commonly called a fox terrier, is so thin-skinned, and so given to fighting his own species when jammed together in a hover, that I would far prefer using the old-fashioned, wire-haired terrier, with no bull-dog blood in his voins, to all the prize terriers of the present day; but he must be a game one to the backbone.

But, let me add a few more words ere this paper be closed. The hour of meeting in the morning cannot well be too early if you have young hounds to enter and only a couple or two of old ones to act as pioneers; for then the fresh reeking scent, unimpaired by the sun, hangs invitingly upon every weed and willow touched by the otter in his night's work, and is then, of course, far more attractive in its hot condition than after it has been chilled by time. Jjut, on the other hand, if your hounds are veterans, experienced in their work, the period of meeting may well be deferred to a later and more convenient hour. 


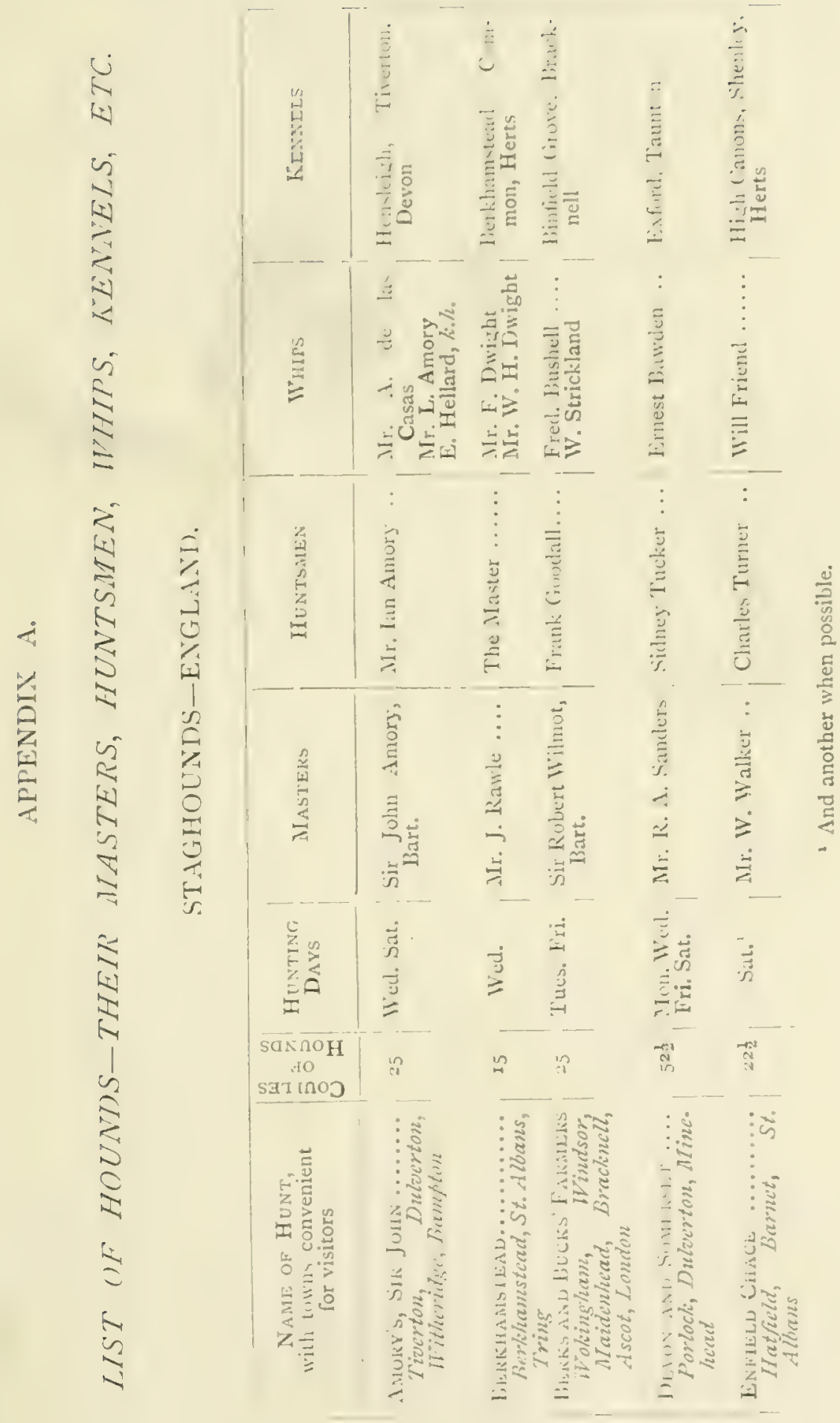




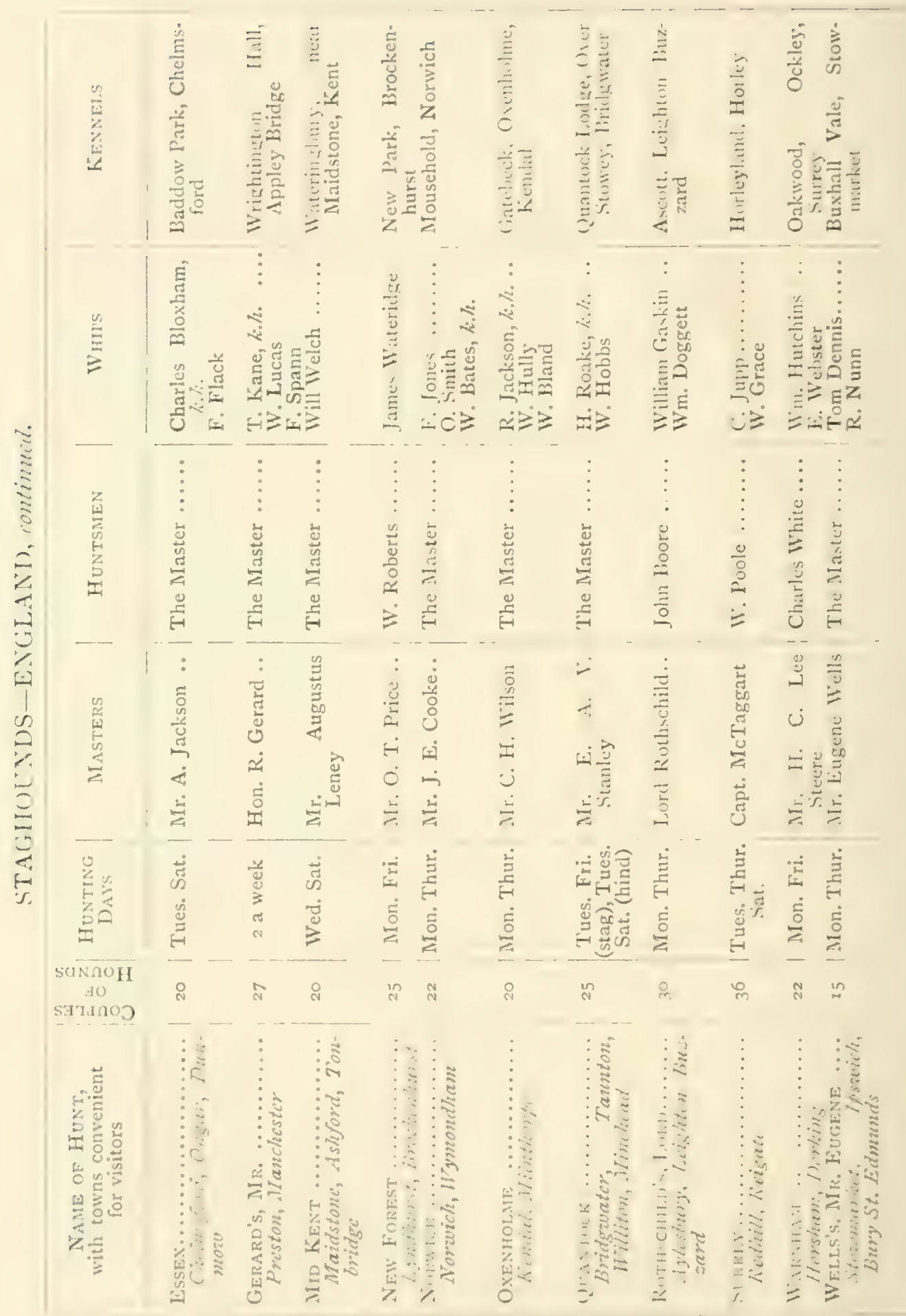




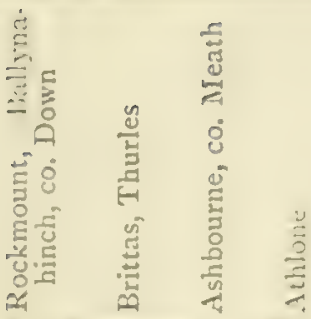

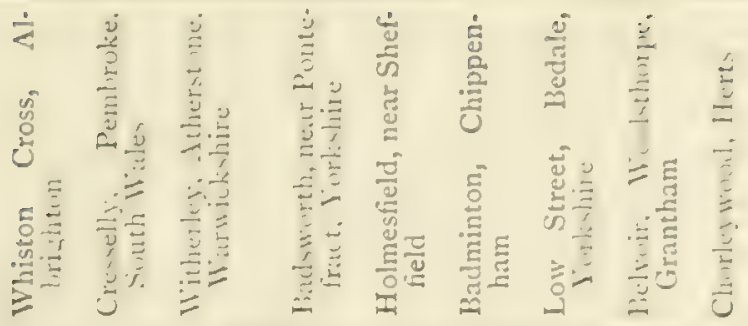

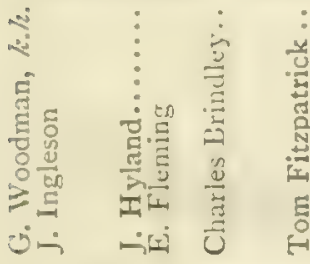

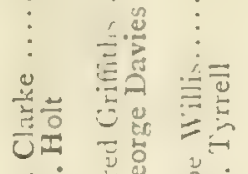

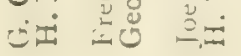

एं

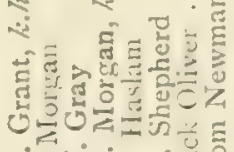

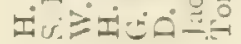

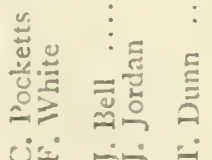

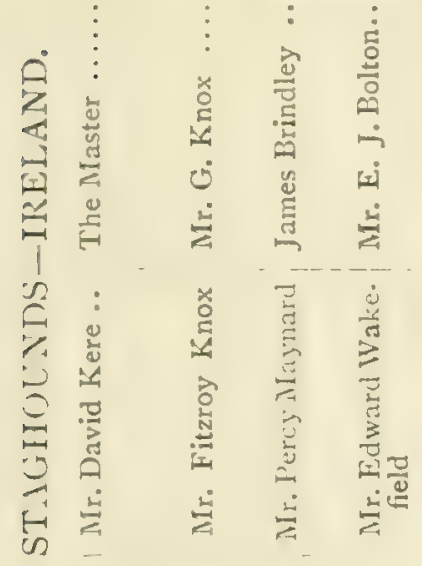

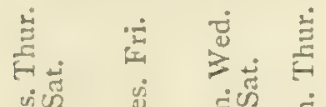

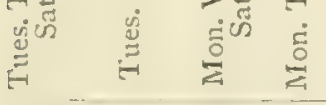

in
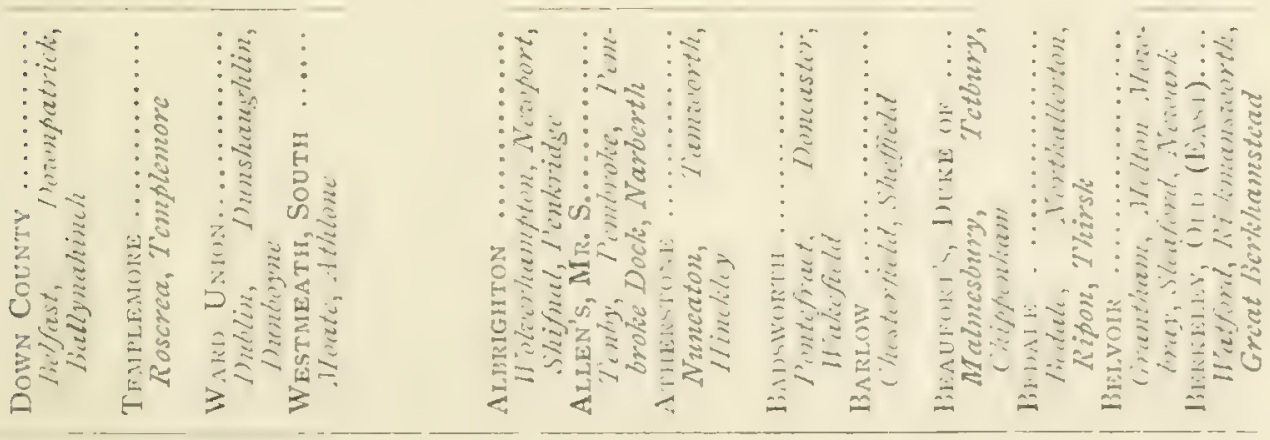

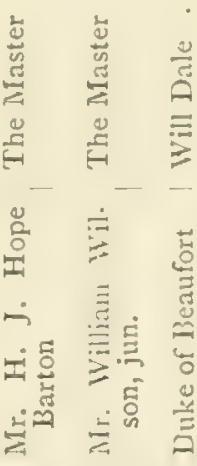

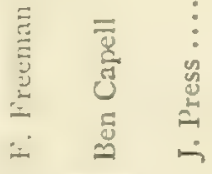

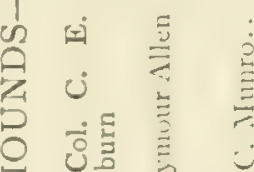

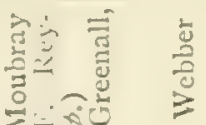

$\therefore-30$

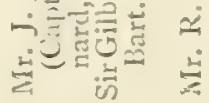

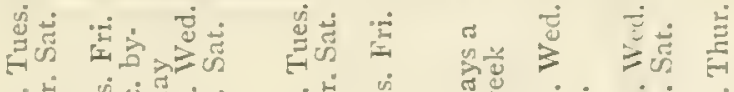

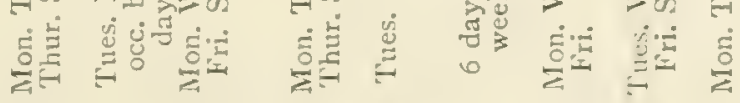

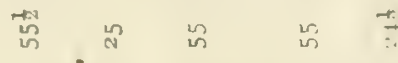

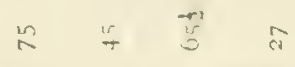




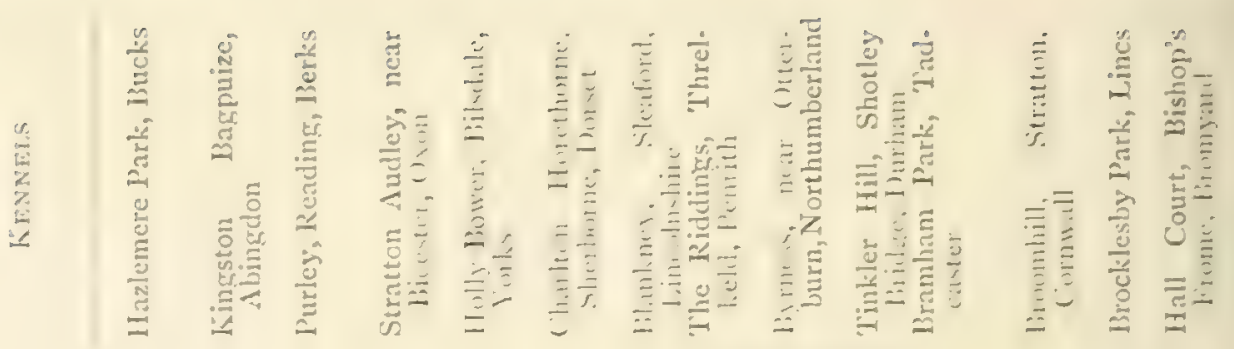

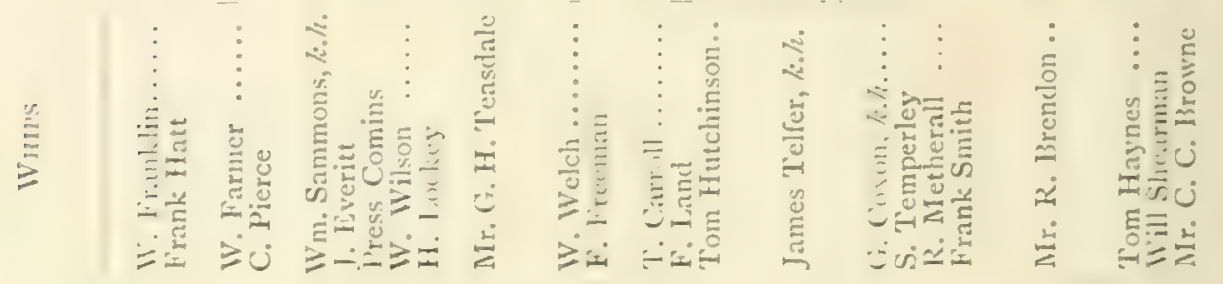

|

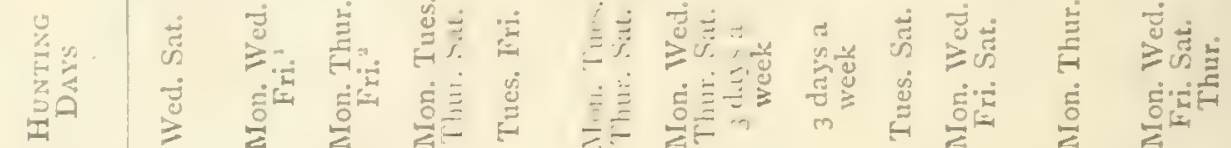
इ

satanos

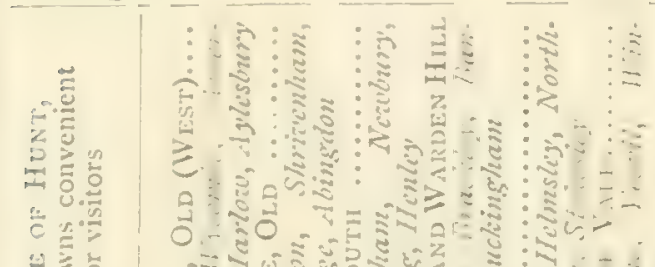

4. 万E

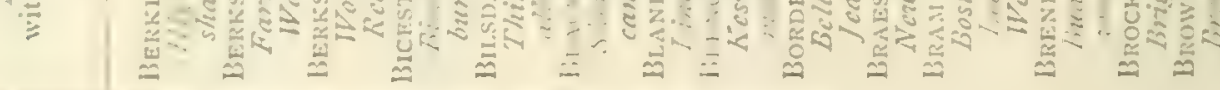




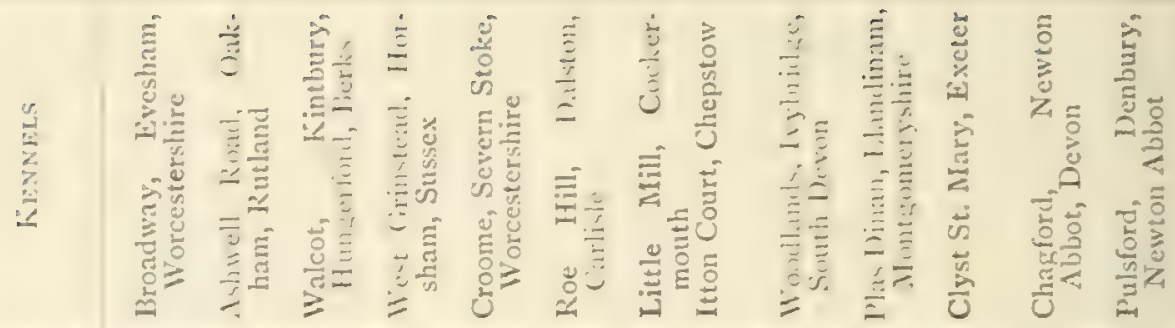

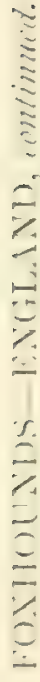

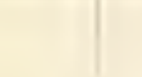

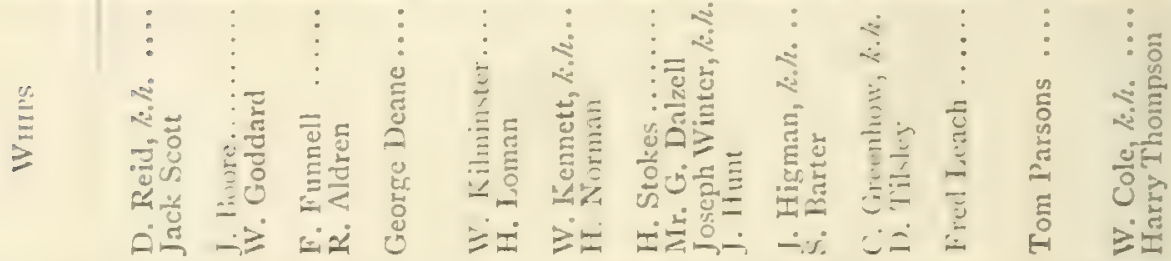

\section{:}



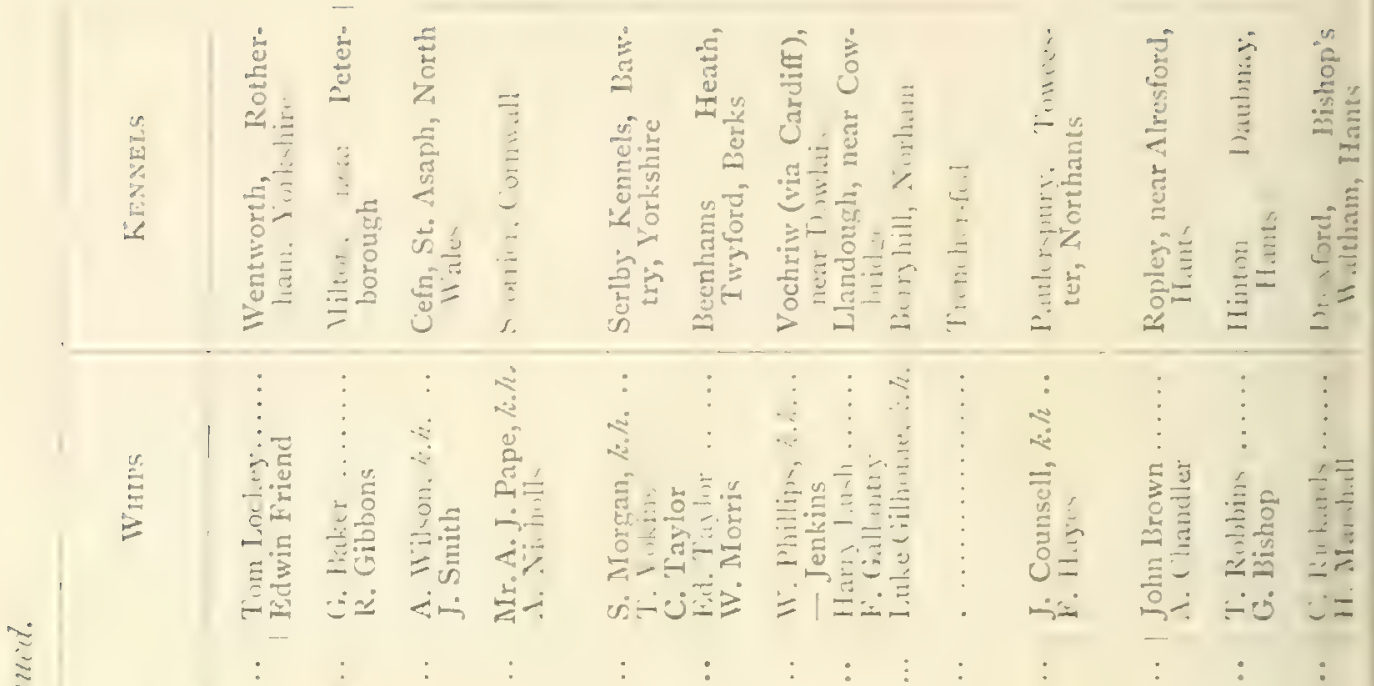

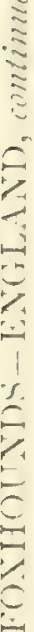

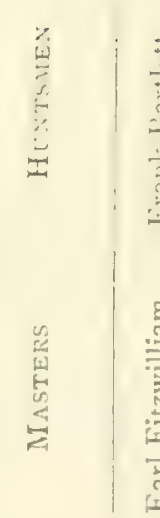

$\vdots \vdots$

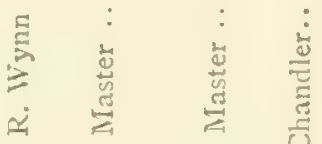

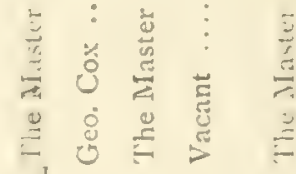

$\vdots$

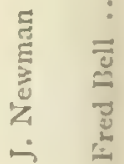

$: \quad \stackrel{\dot{N}}{*}$

$\stackrel{\dot{N}}{\check{L}}$

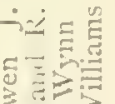

$\geqslant \quad 030$

ن.

틀

点 $\stackrel{0}{=}=2$

$\stackrel{\circ}{*}$

$\stackrel{2}{\equiv} \quad$

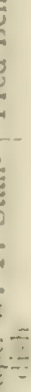

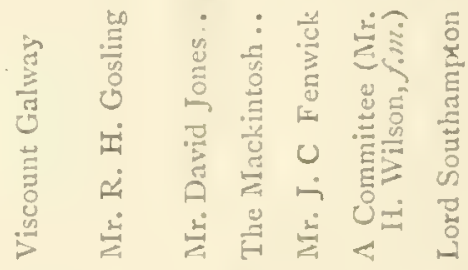

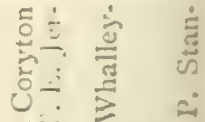

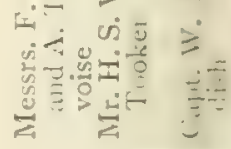

官岕

를

$\because \ddot{j}$ ¿

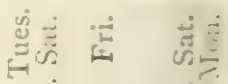

密

돈

咅离

㟔

' $\operatorname{sanOH}$ $\infty$ in

in

. है

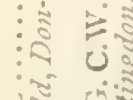

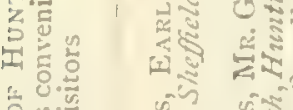

参家:

닐

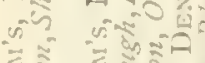

$7:$

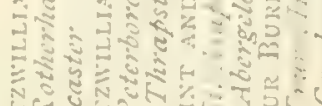

जद्य है

找

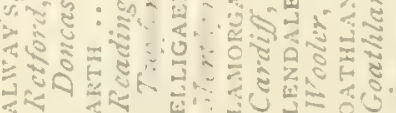

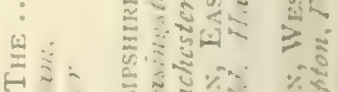

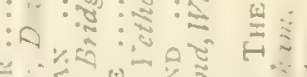

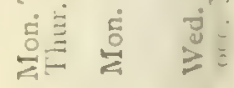
लू तू ले यदू I I2. I 네 


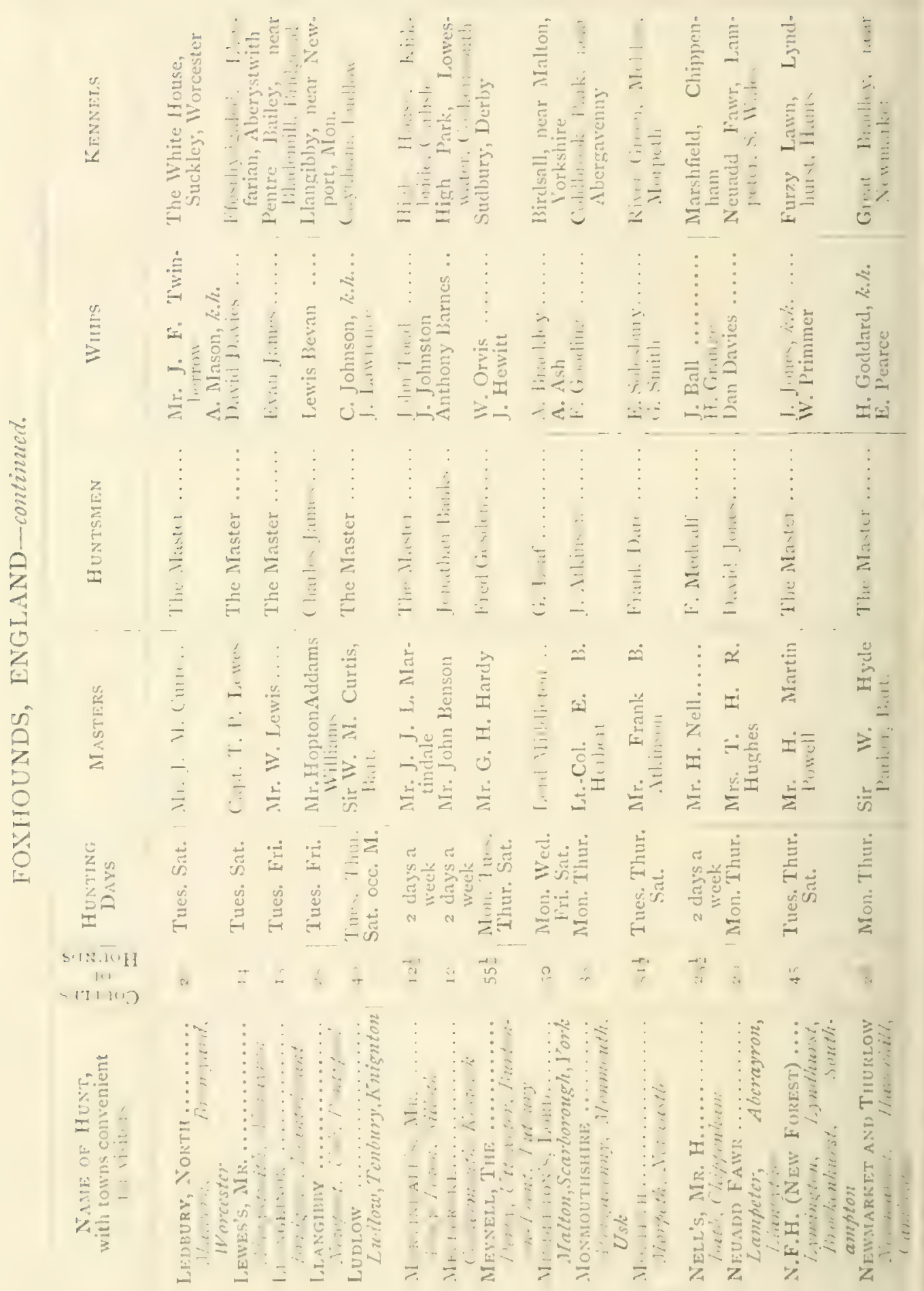



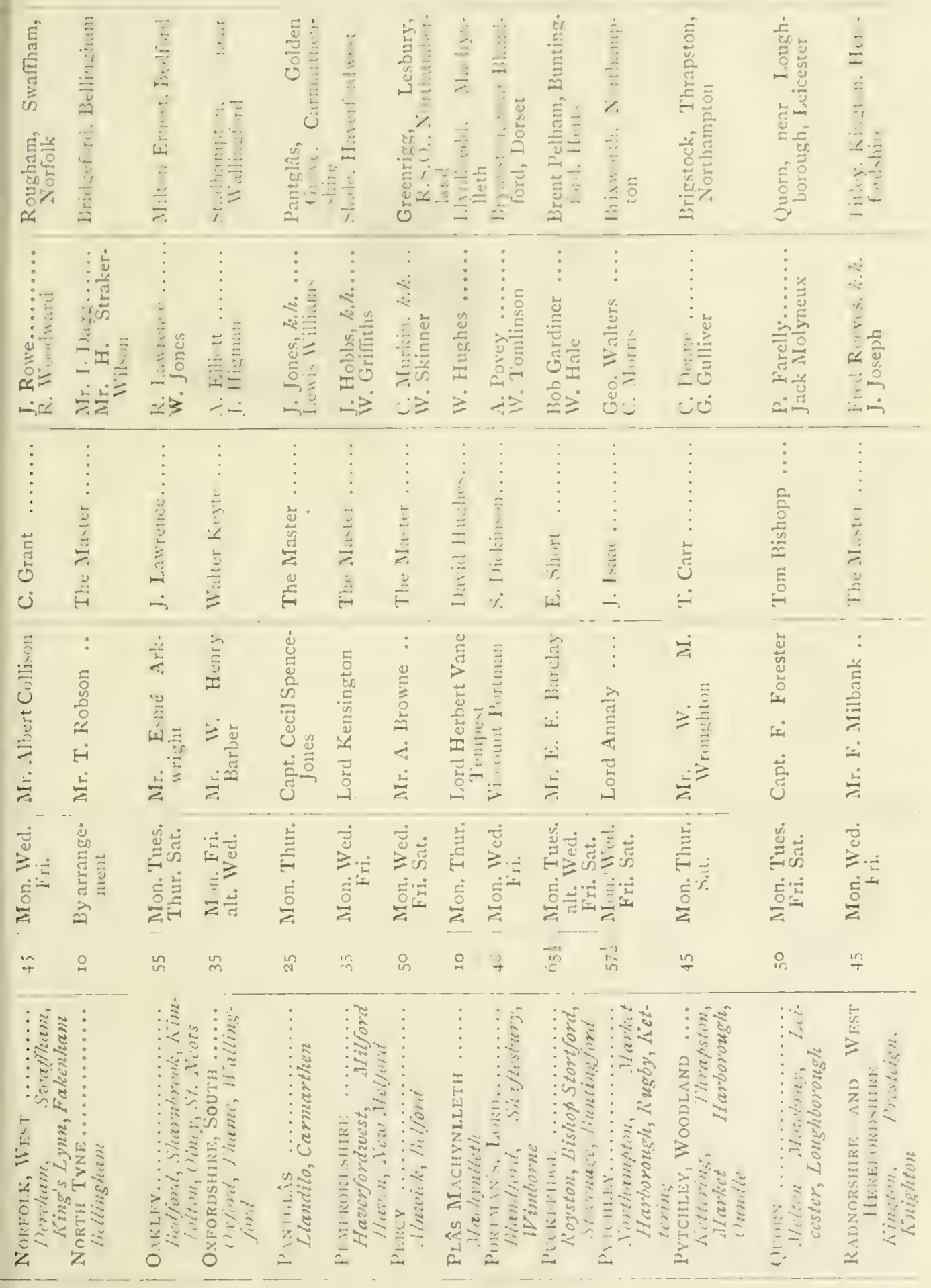


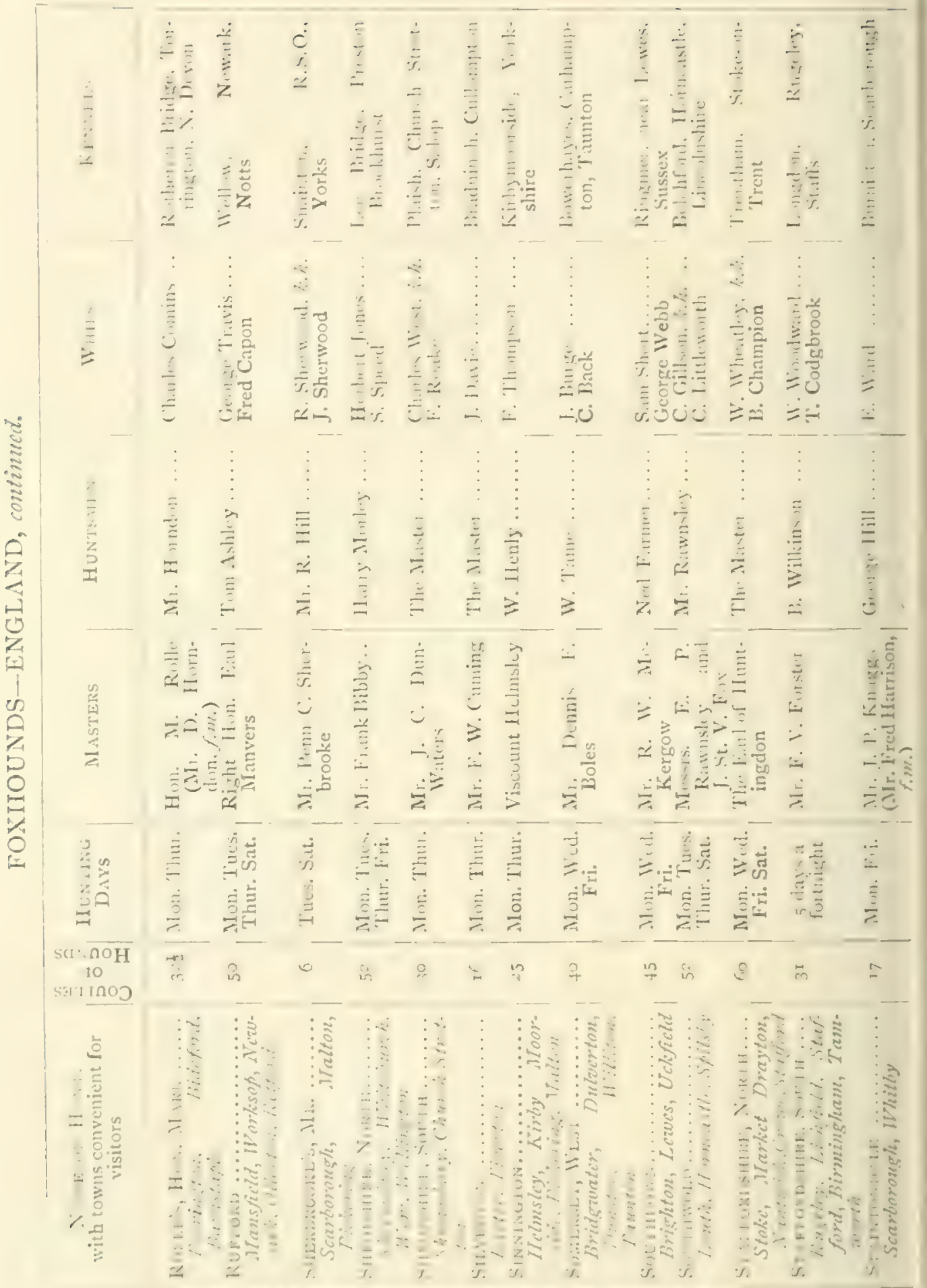


I)

Winto the

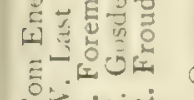
in

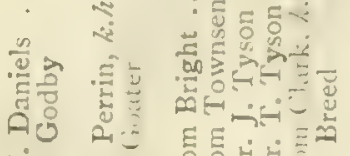

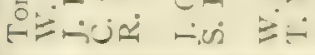

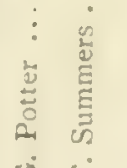

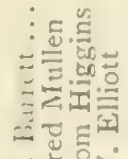

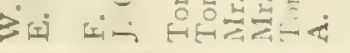
एं

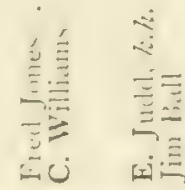

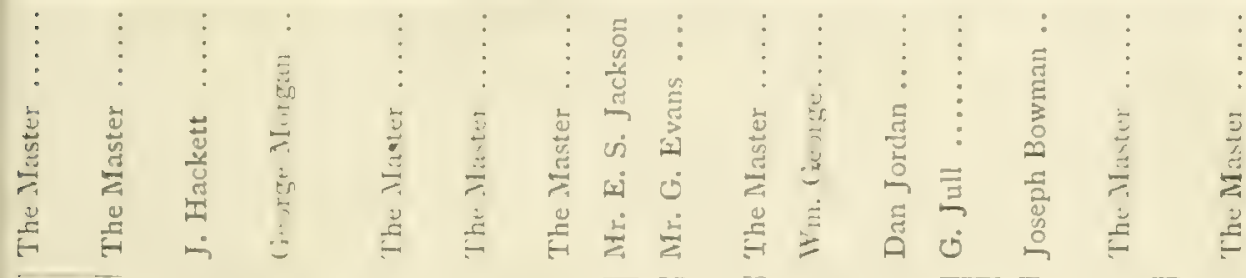

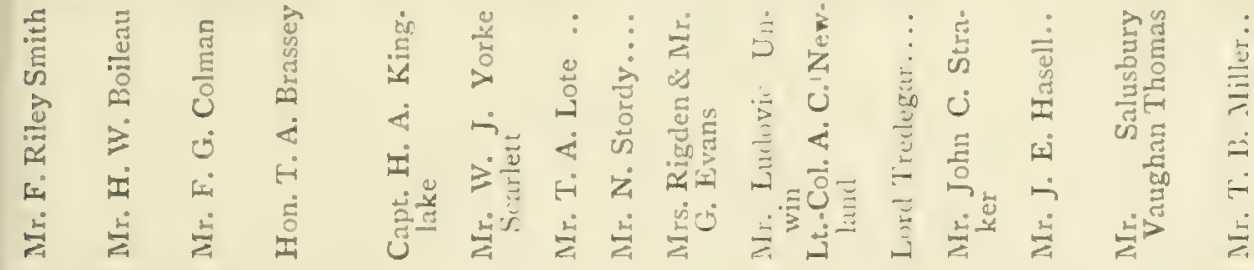

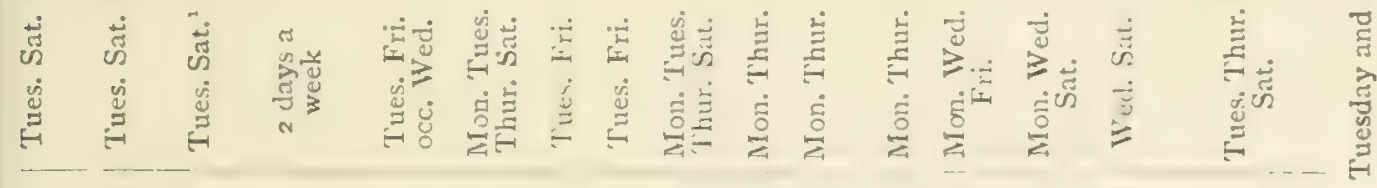

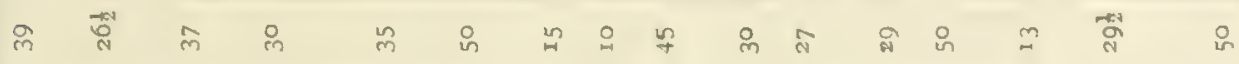

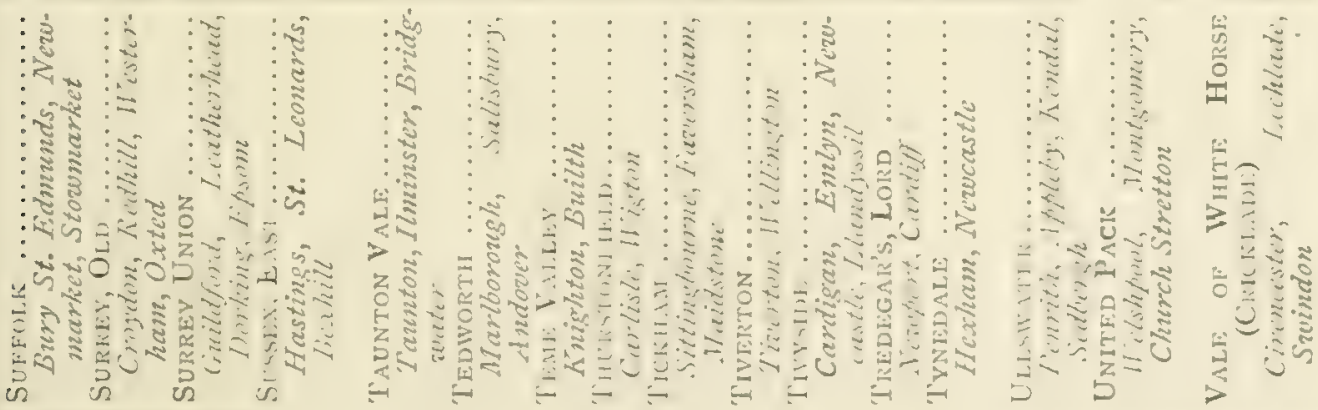

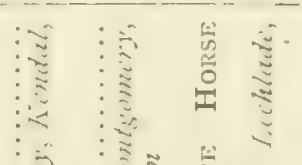

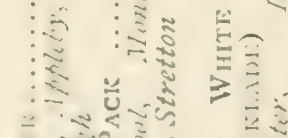




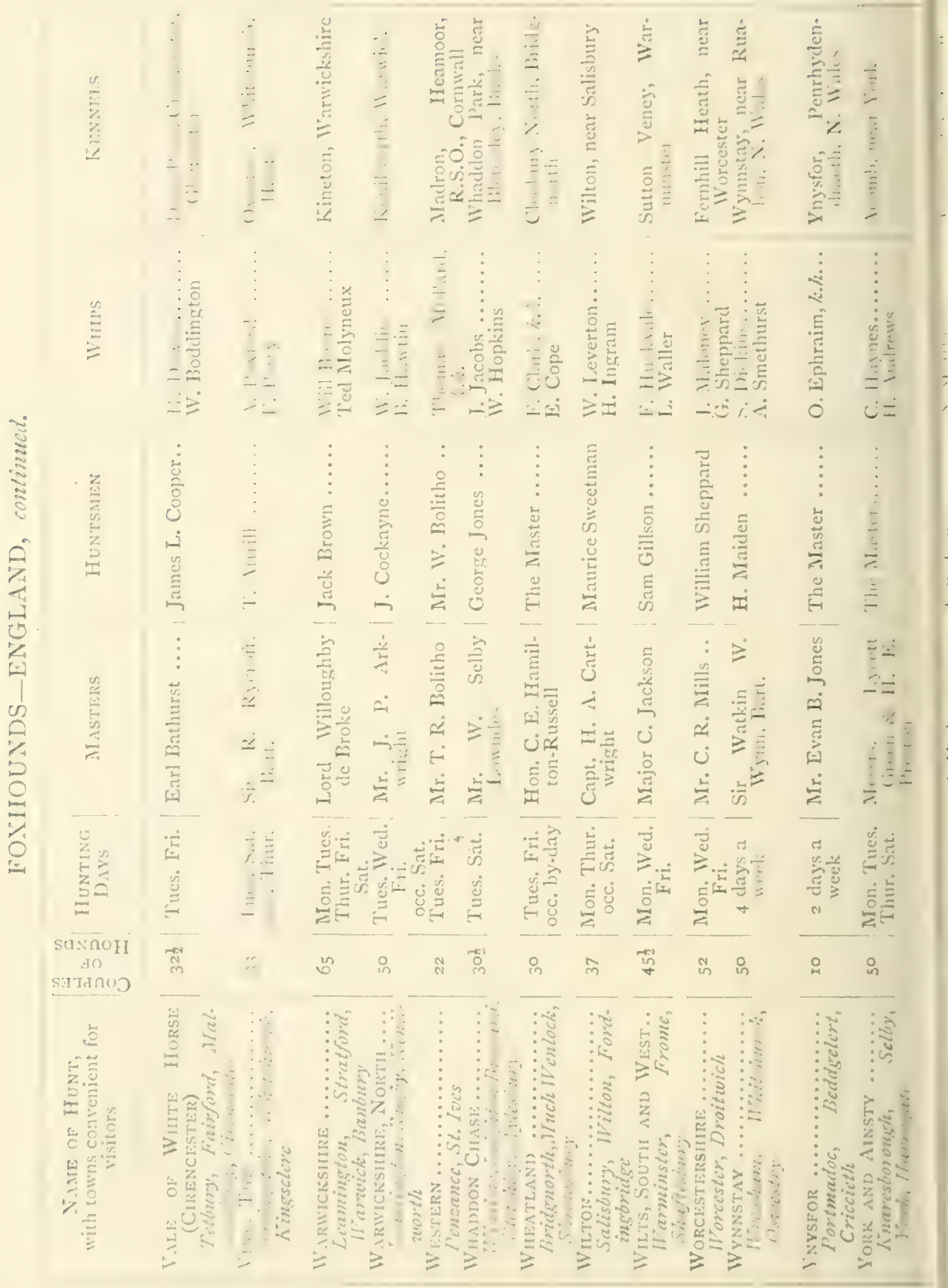




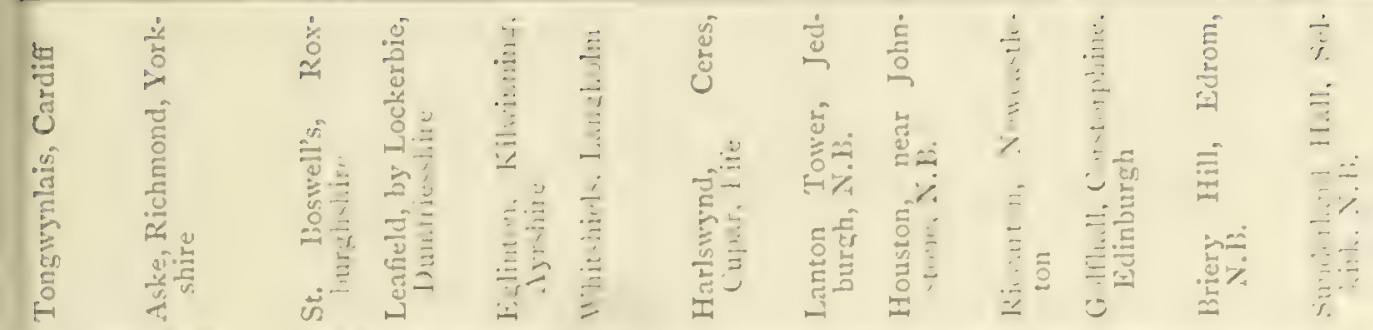

(1)

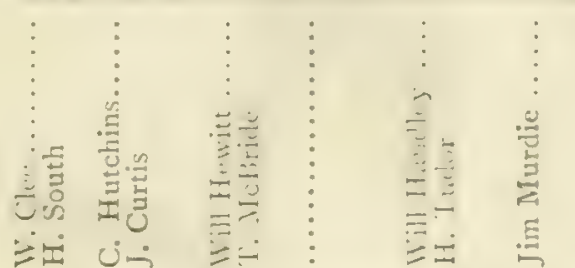

这

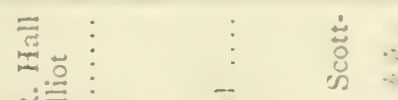

$\dot{\forall} 0 \dot{0}$

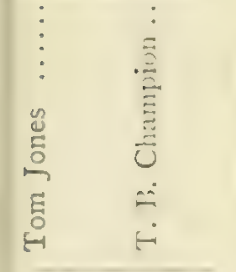

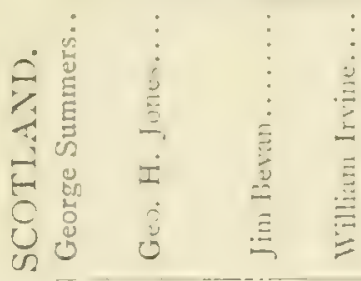

$\vdots$
$\vdots$
$\vdots$
$\vdots$

$\stackrel{\Xi}{\Xi} \equiv$

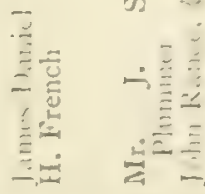

है

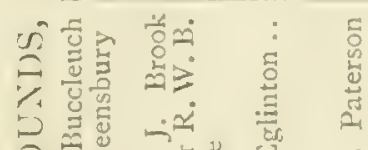

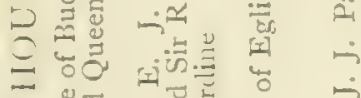

岕

is

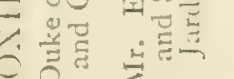

政

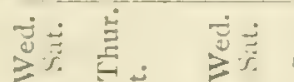

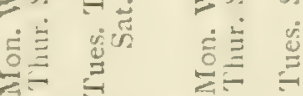

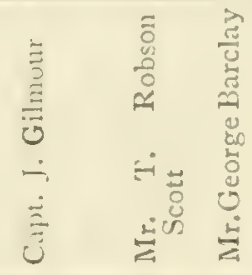

马्षे

단

:

类

o $\quad$ 绖

$\stackrel{2}{2}$

㭉 芯芯

语

a

त)

in

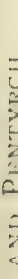

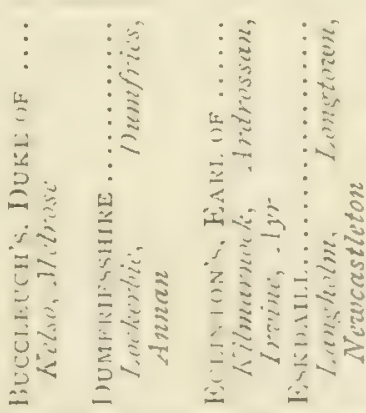

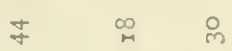

in ถี

in $\quad$ a

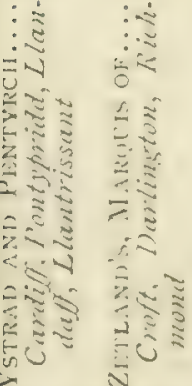

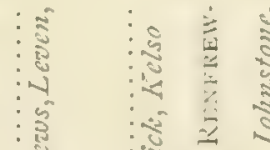

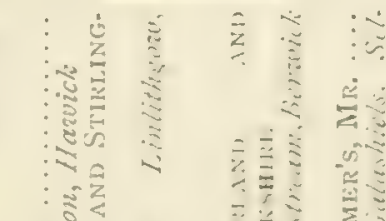




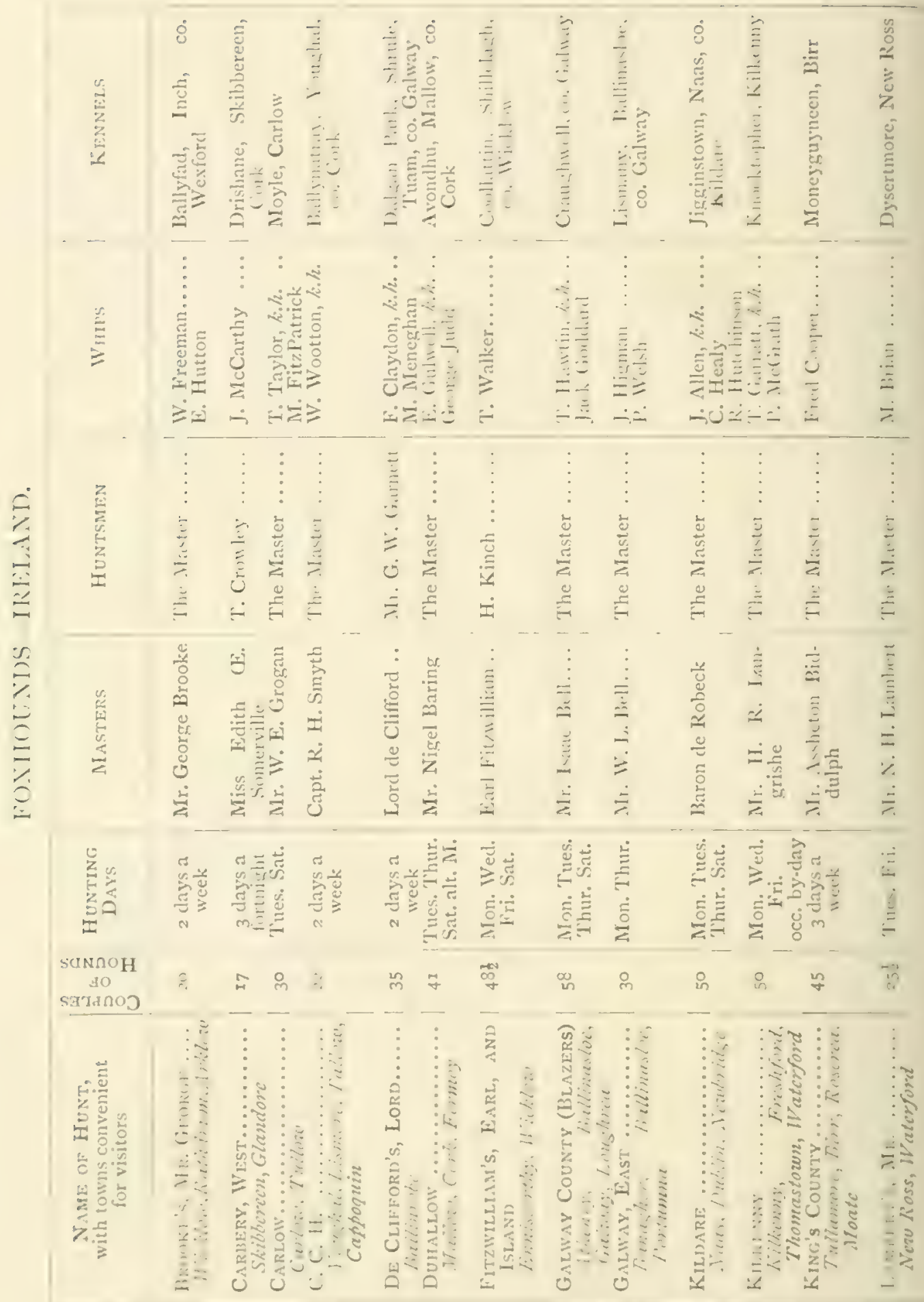




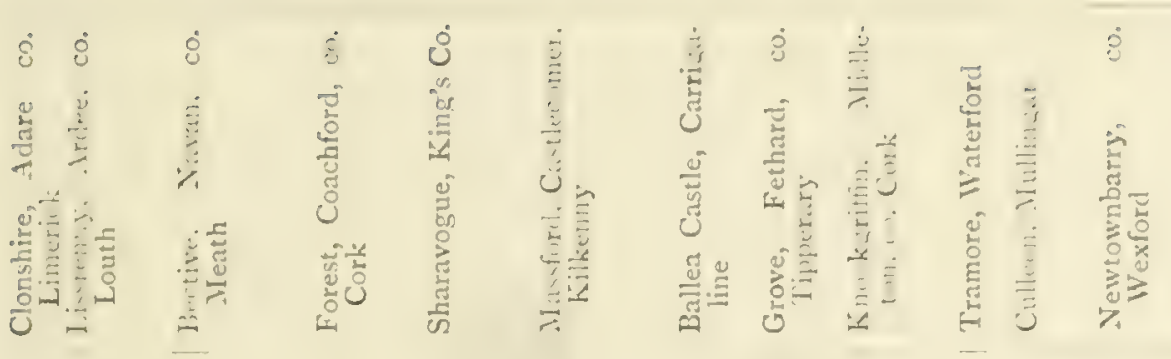

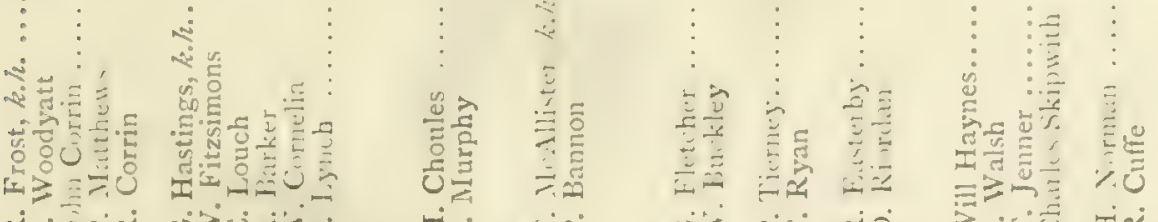

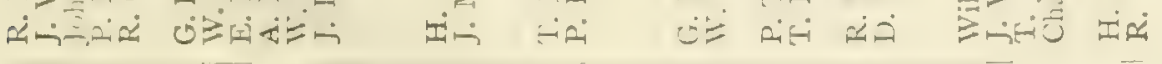

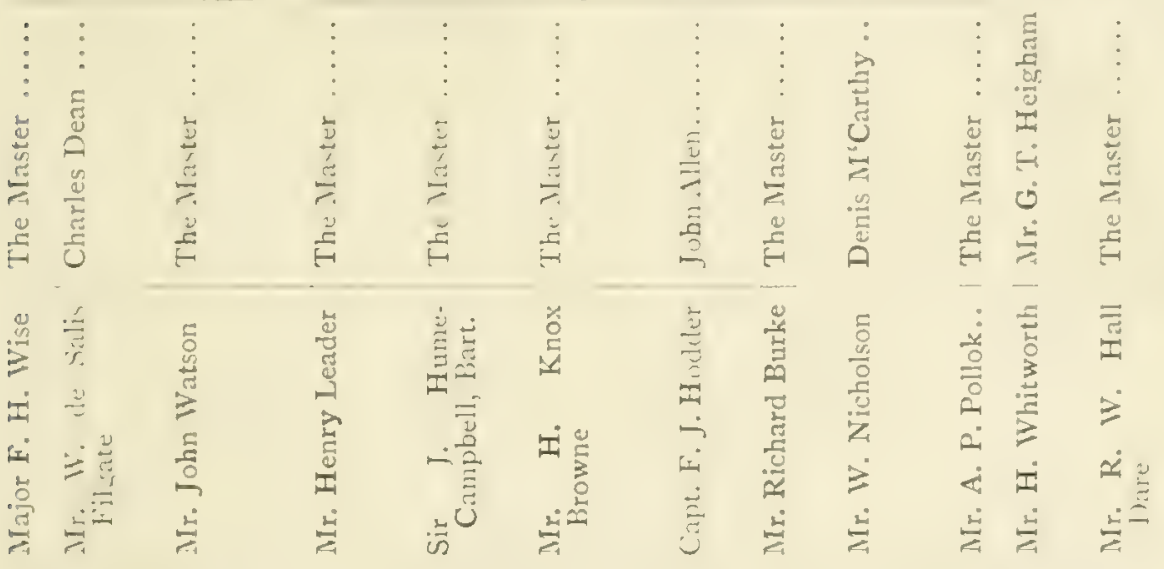

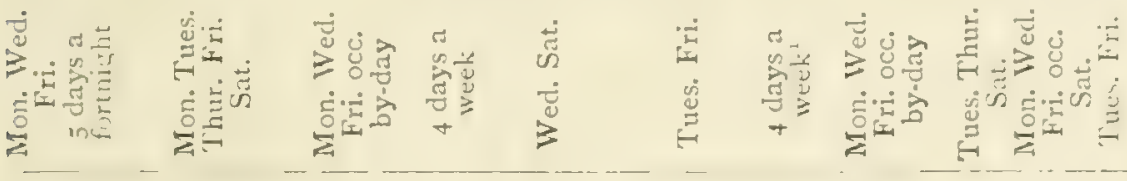
웅
$\stackrel{N}{N}$
$\div \quad 8$

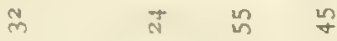
in in

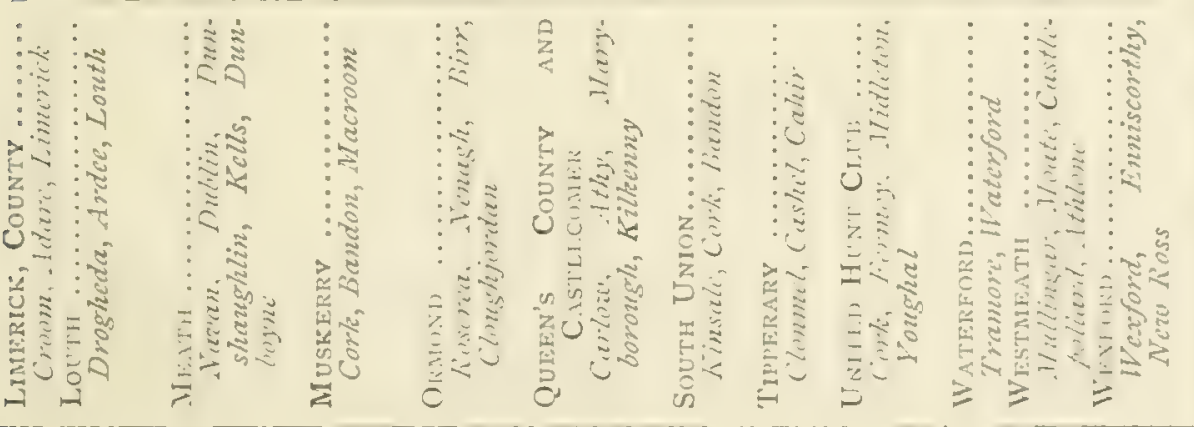




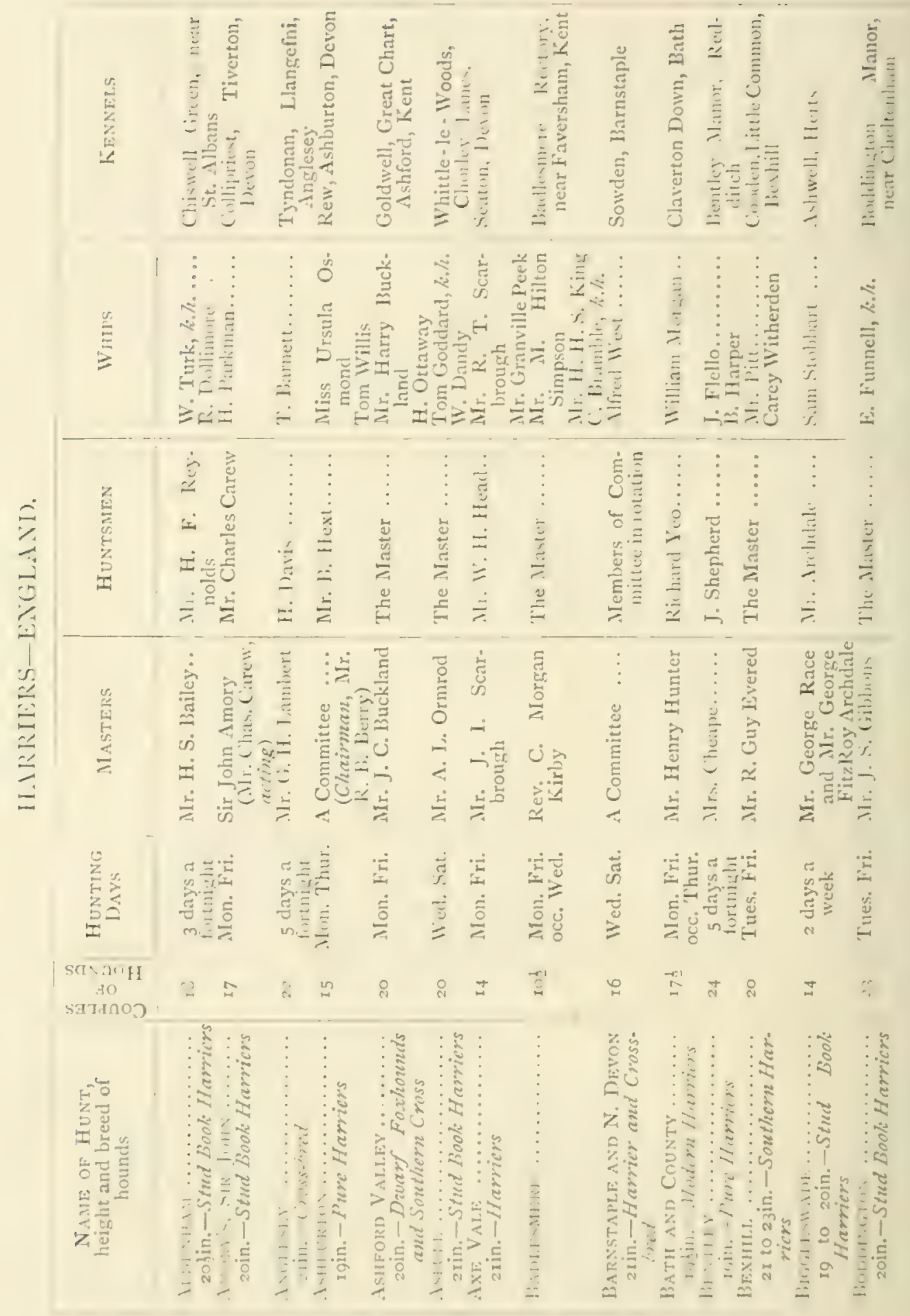




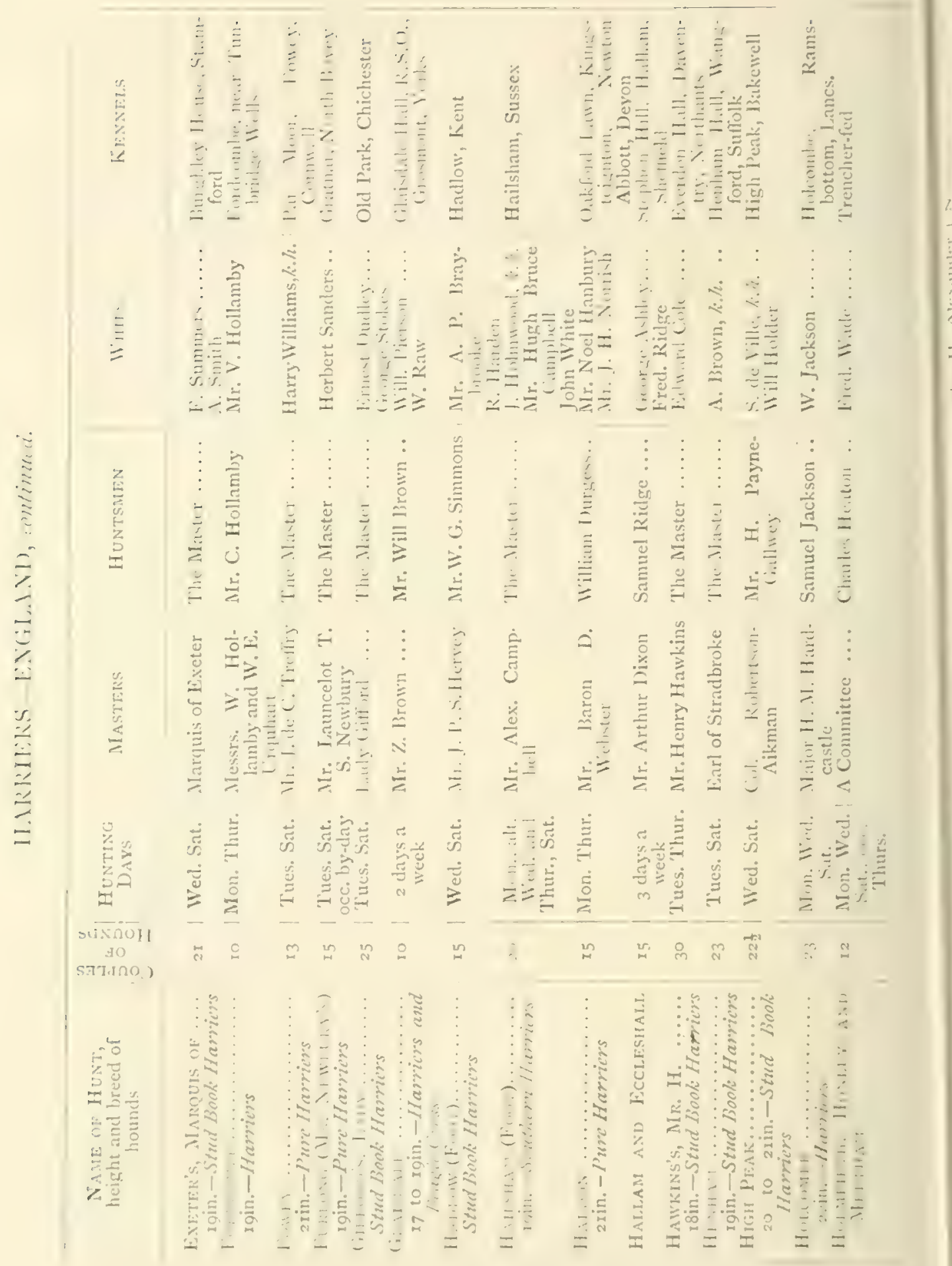




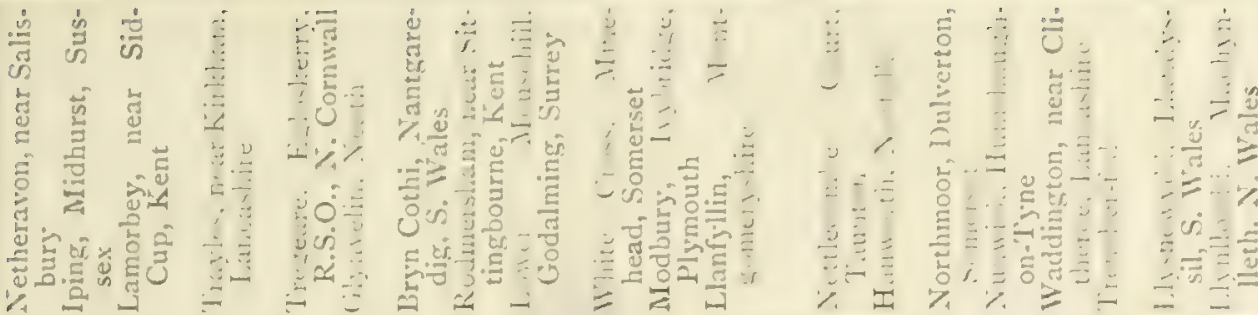

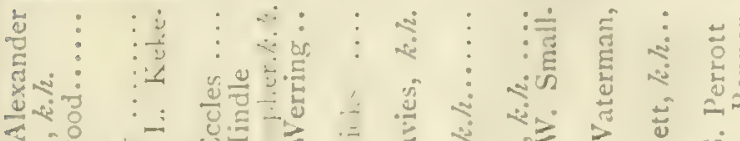

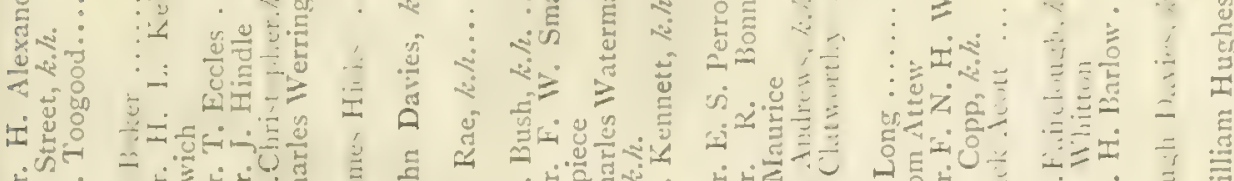

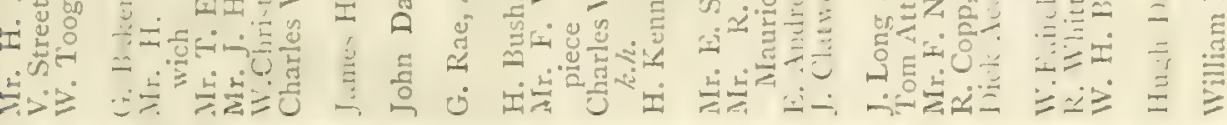

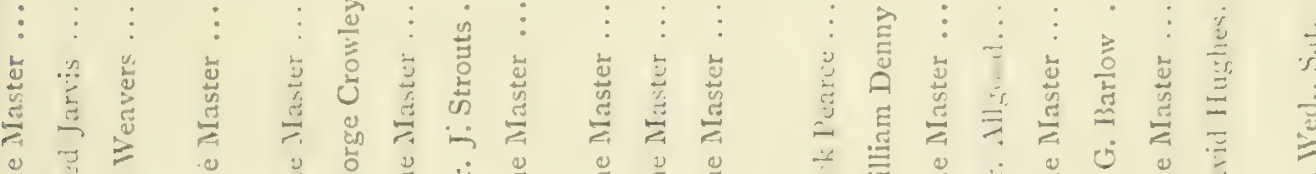

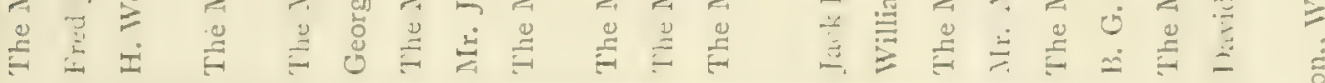

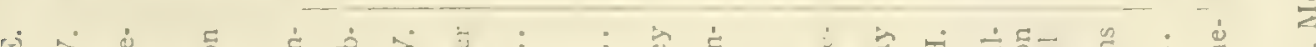

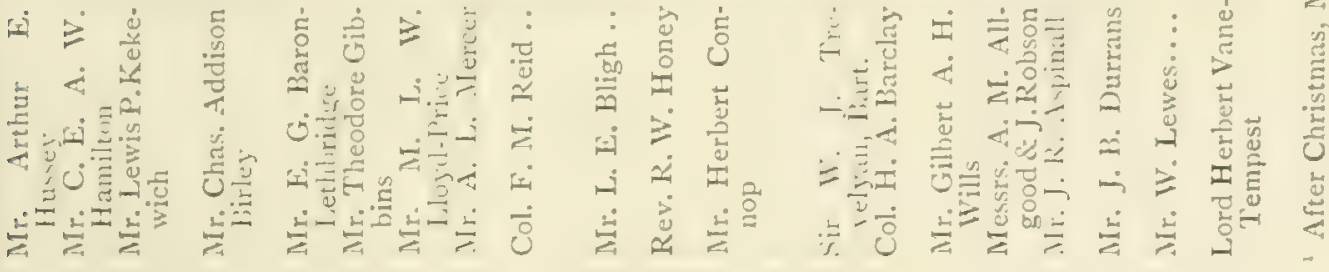

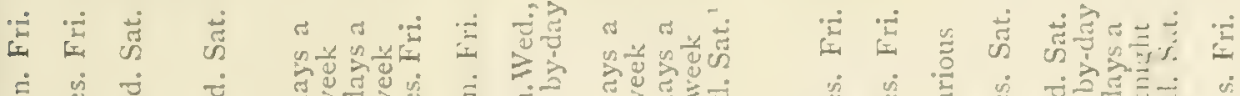

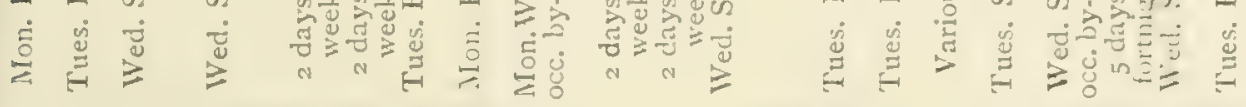

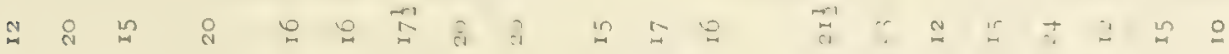

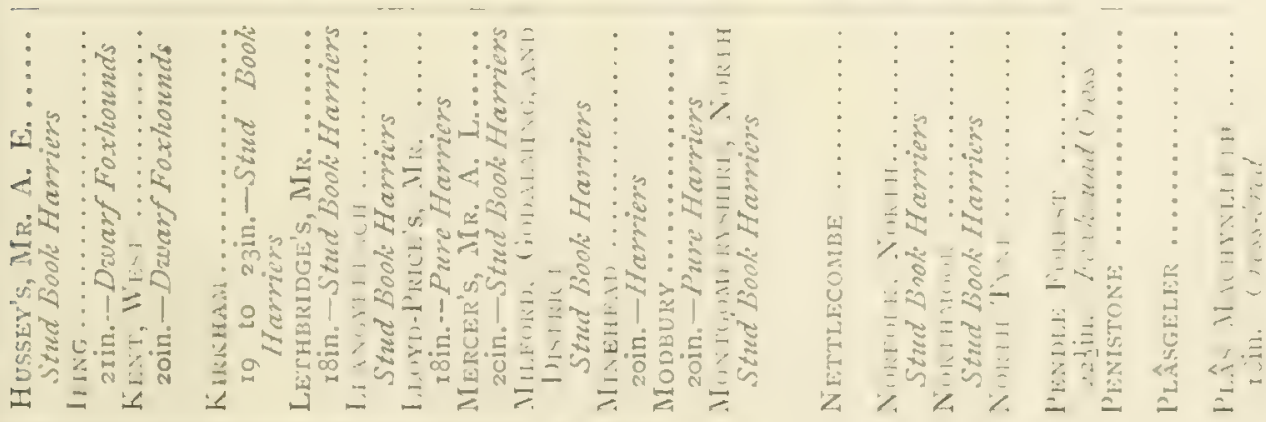




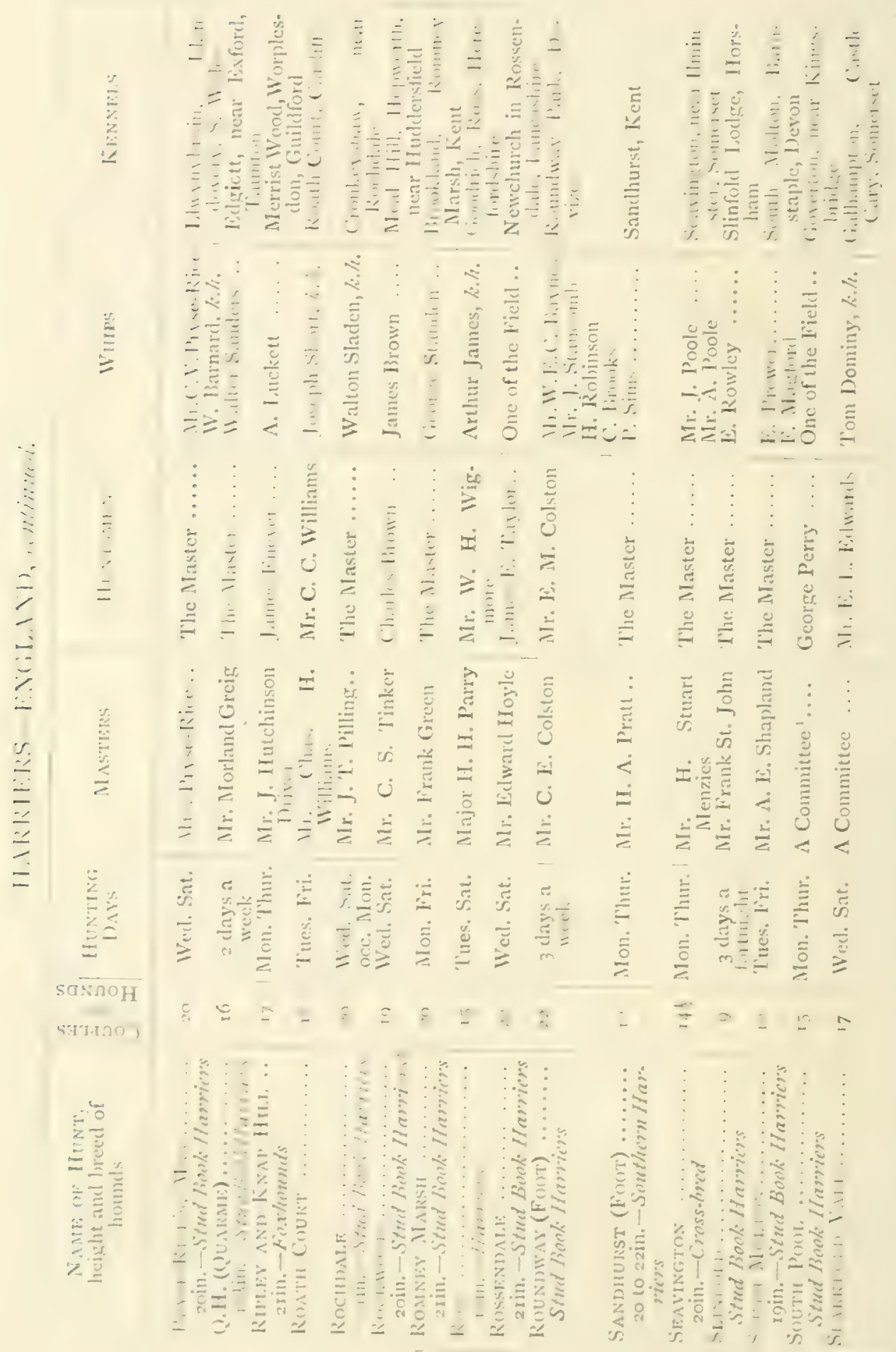




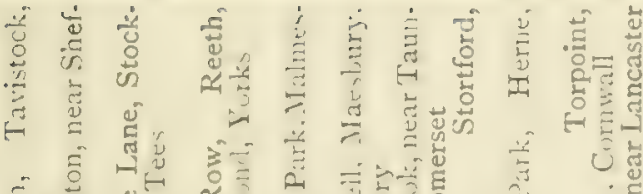

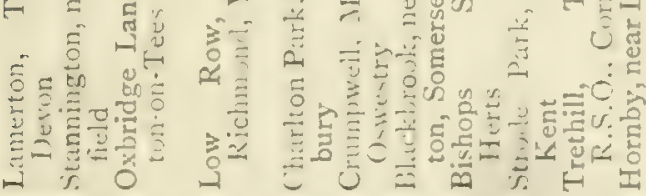

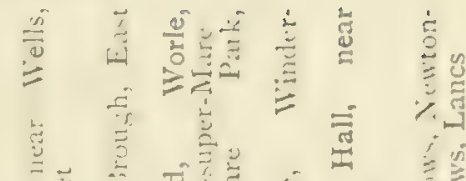

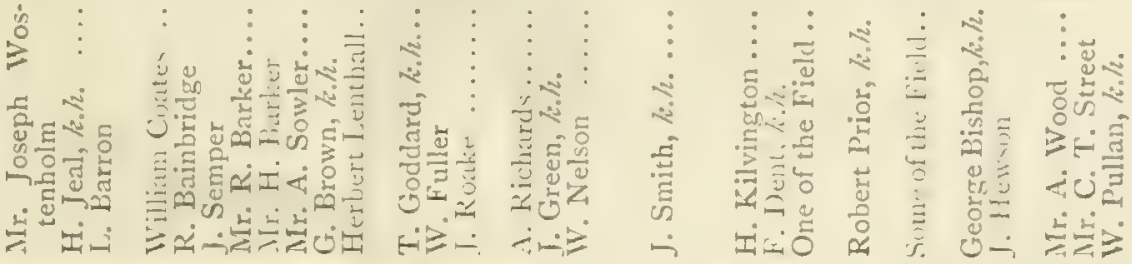

$\stackrel{3}{\Xi}$ $\Leftrightarrow$

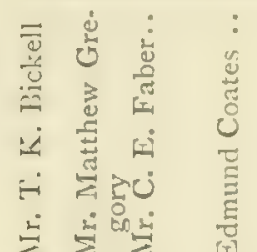

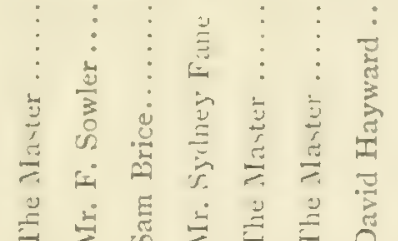

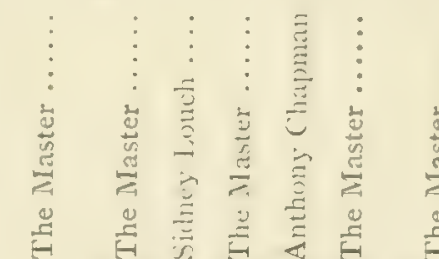

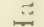

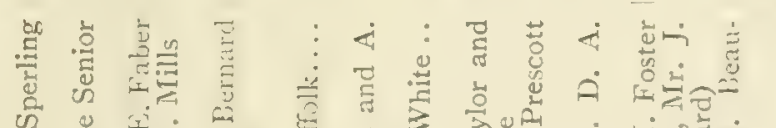

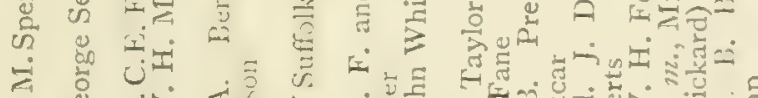

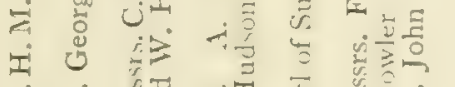

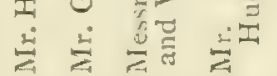

कें एं

$\stackrel{0}{=}$

芦芦

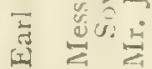

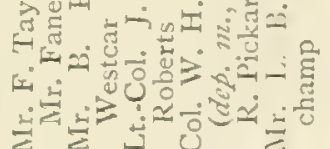

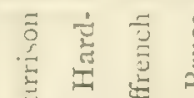

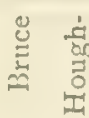

ज्ञे⿺辶⿻

-

$=\dot{\check{g}}$

$\geqslant$

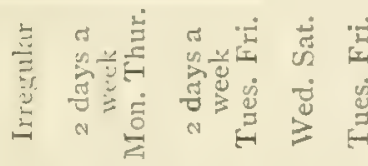

垔

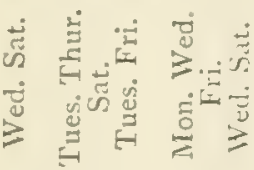

\begin{abstract}
욕요
in $\infty$ of $\rightarrow 1$

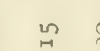

요

ม ल
\end{abstract}

¿ $\vdots \vdots \vdots 3$

है

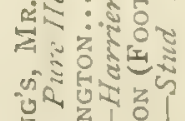

z

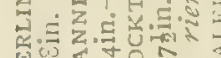

出出出 出
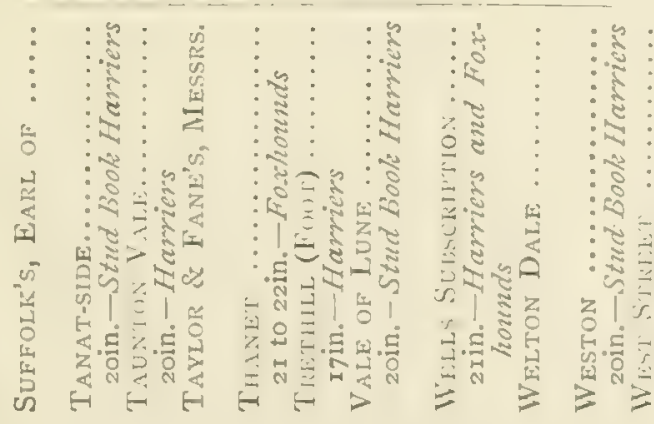

$\vdots \vdots 8$

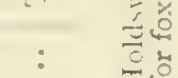



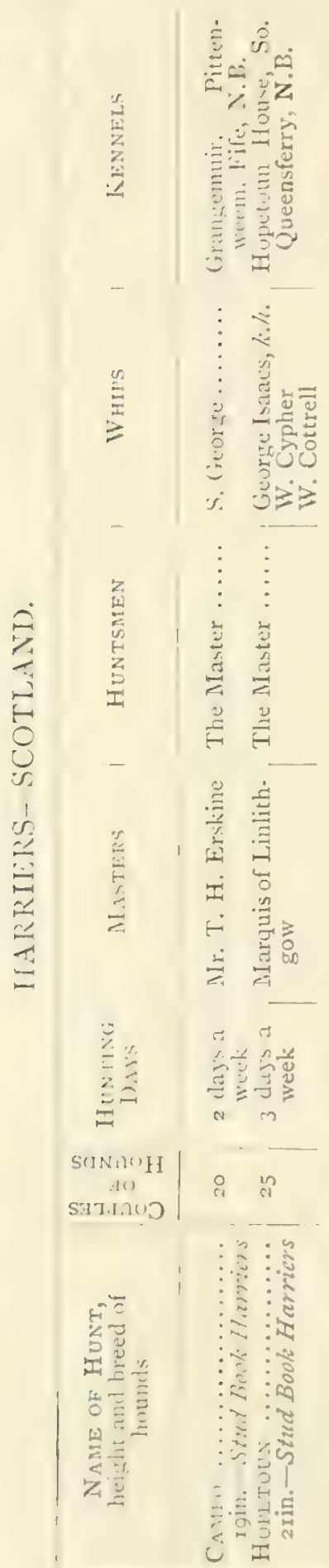
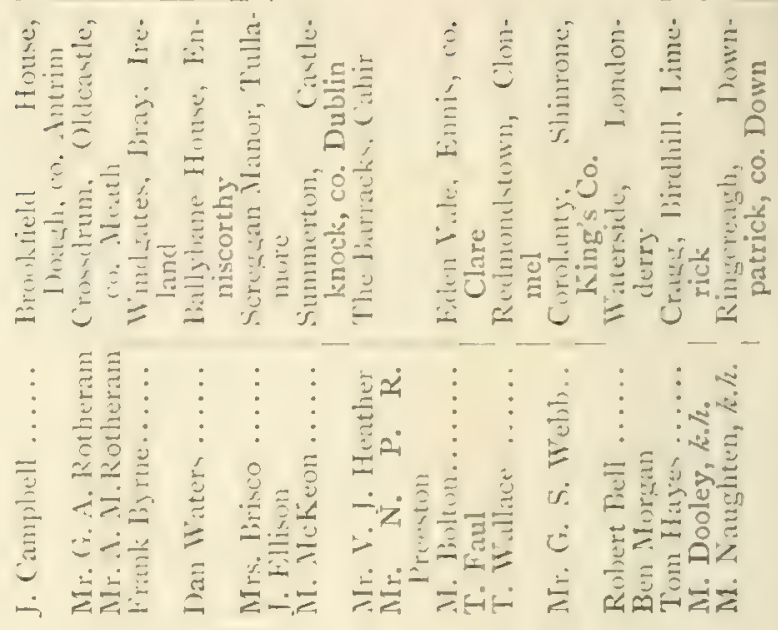

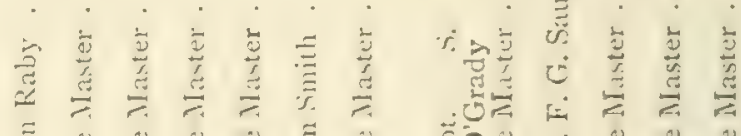

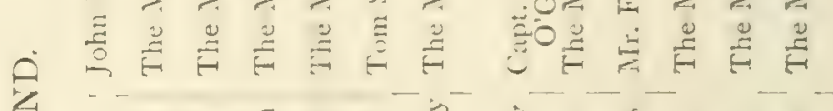

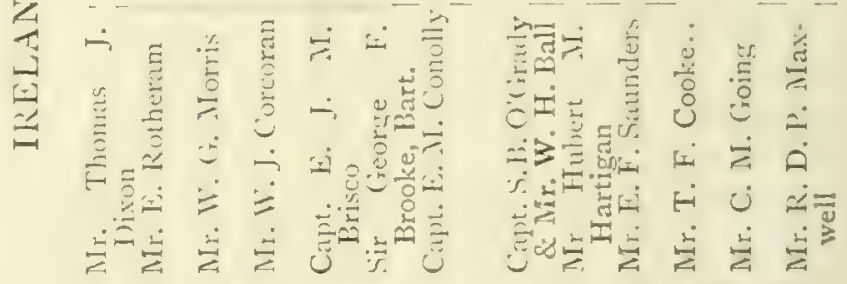

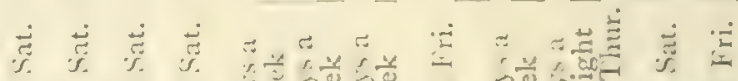

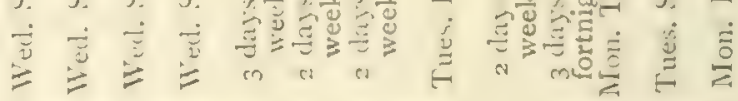

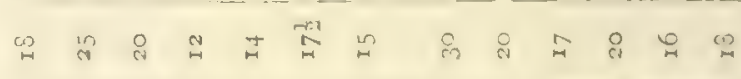

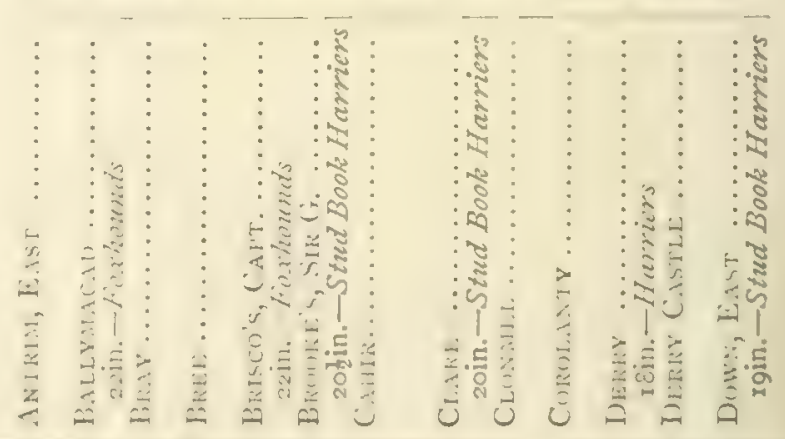




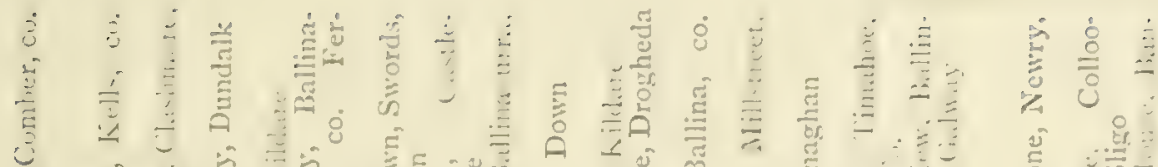

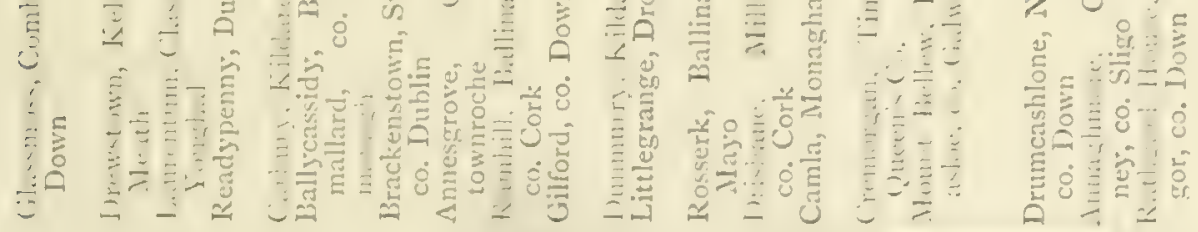

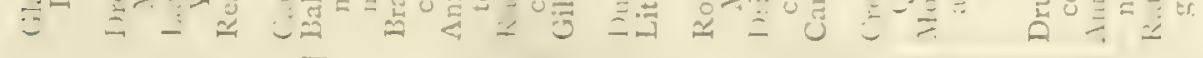

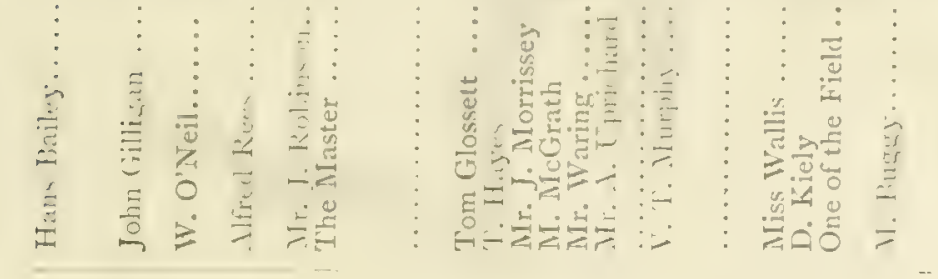

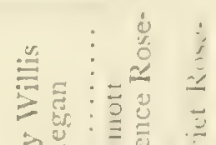

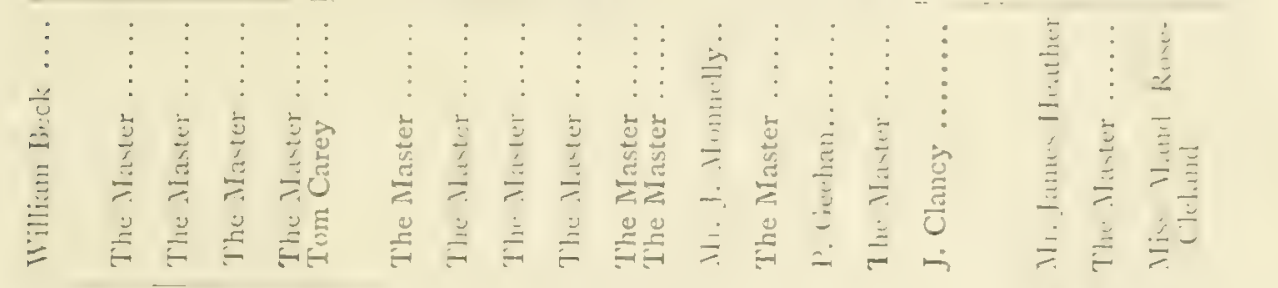

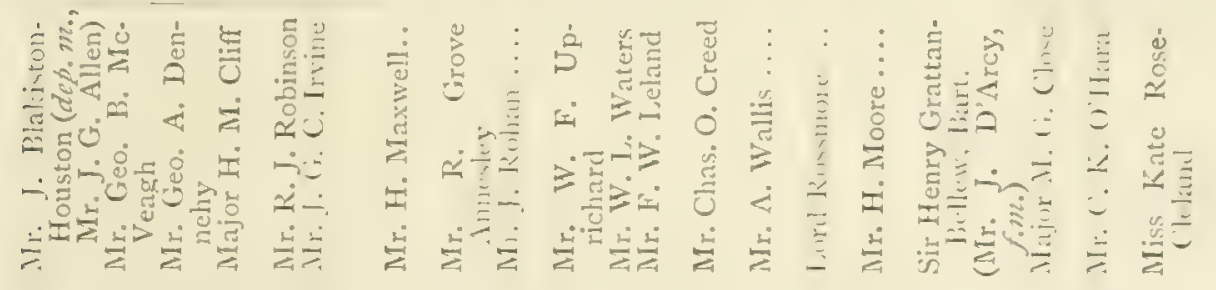

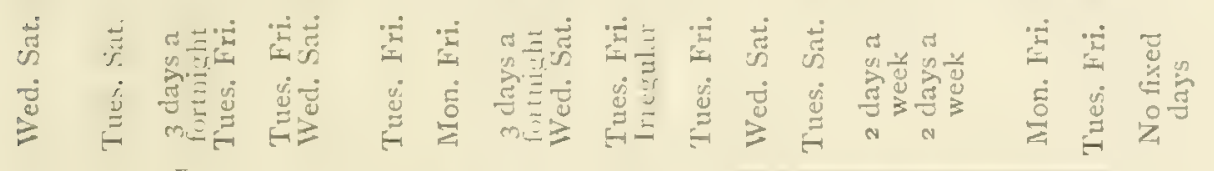

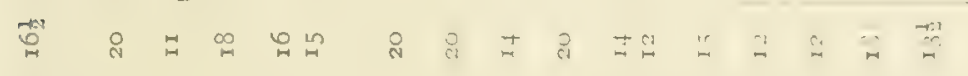

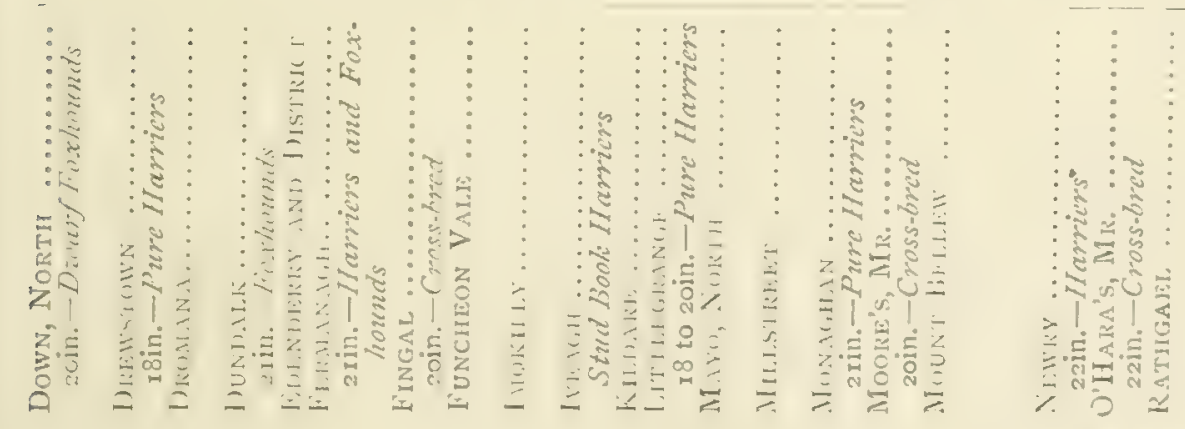




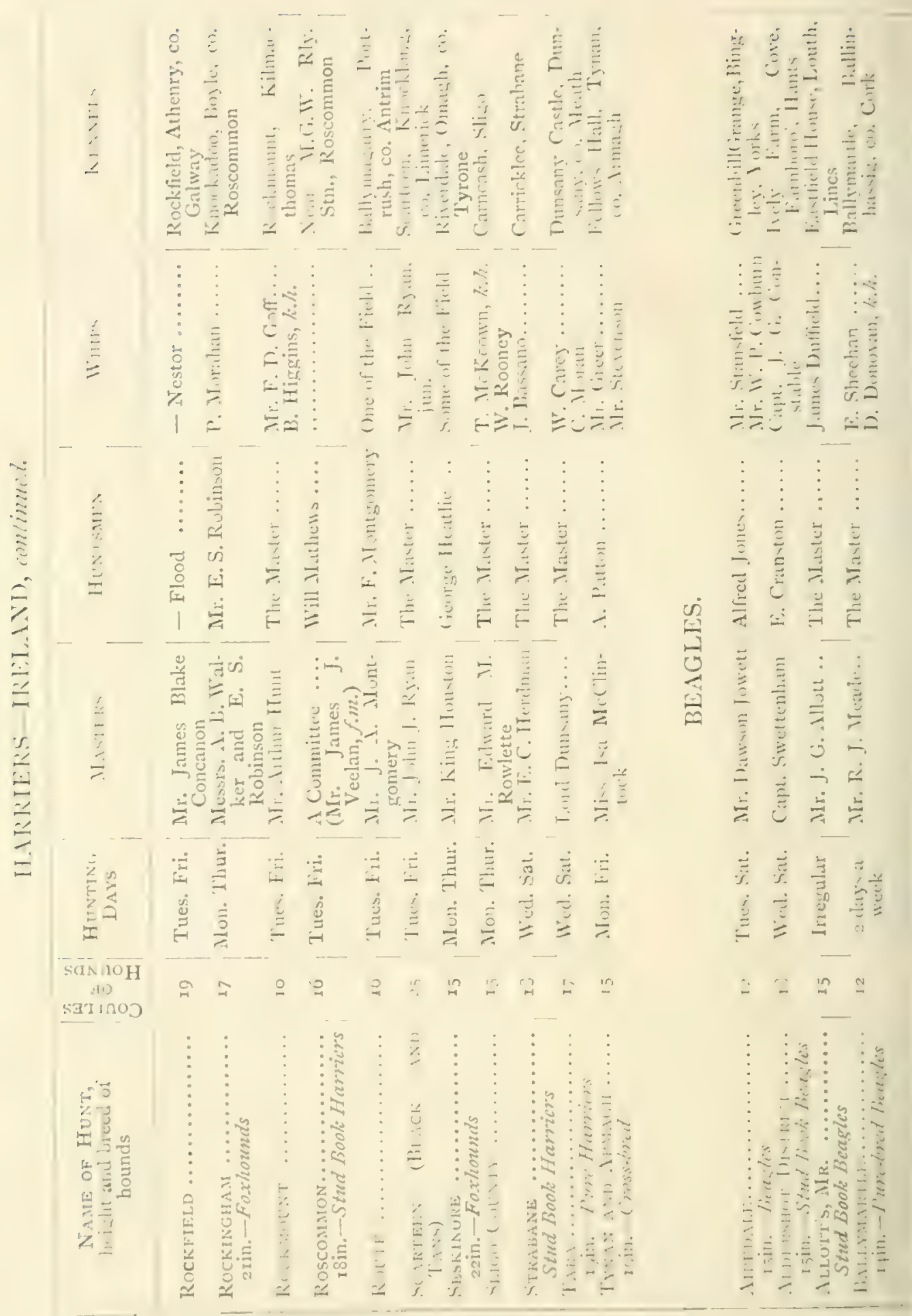




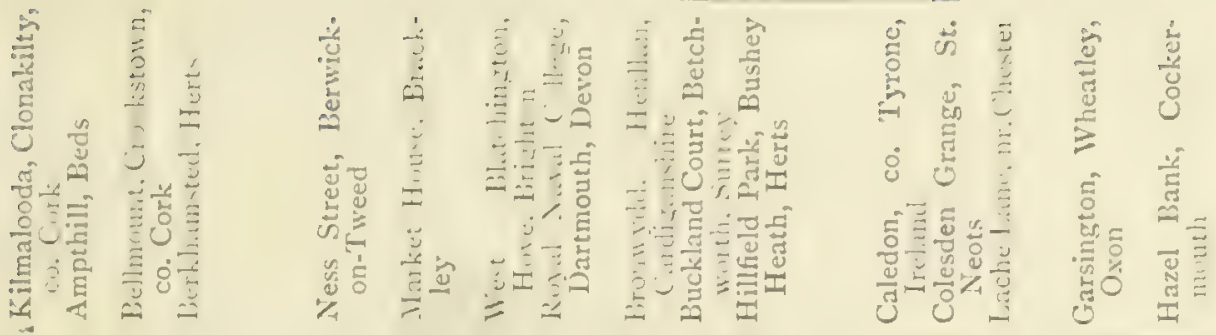

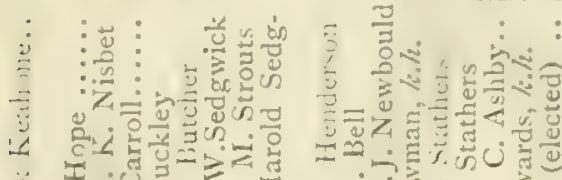

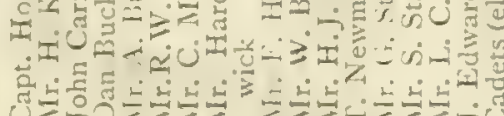

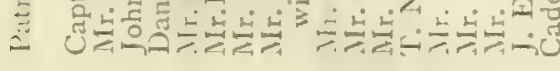

:

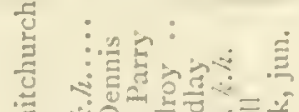

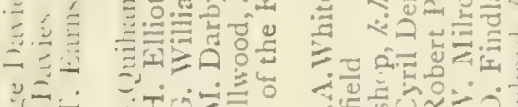

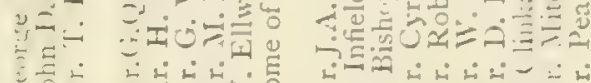

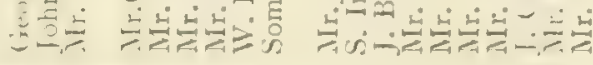

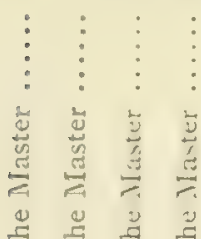

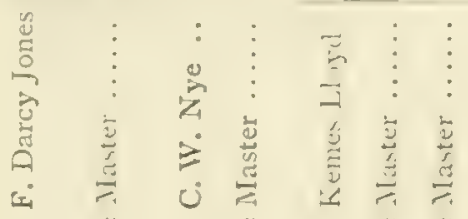

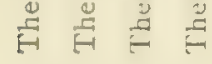

$\stackrel{2}{=}$

突

$\stackrel{D}{=}$

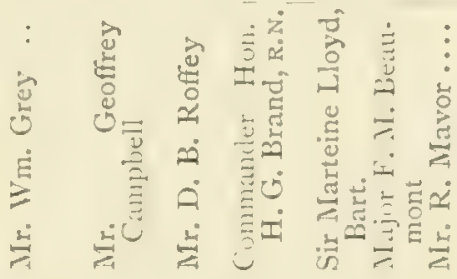

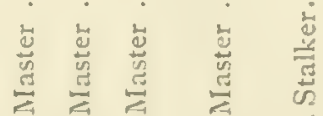

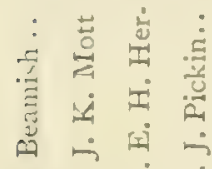

$\therefore \sim \dot{\sim} \dot{\sim}$

至

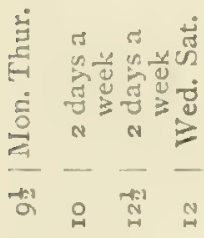

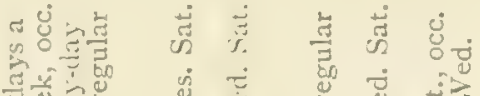

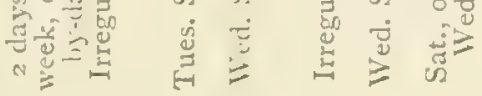

点点怘邑 站

है

स $\infty$ i

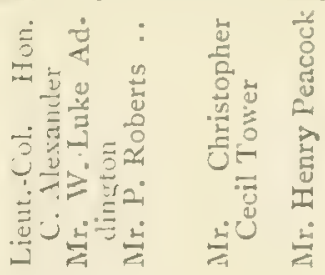
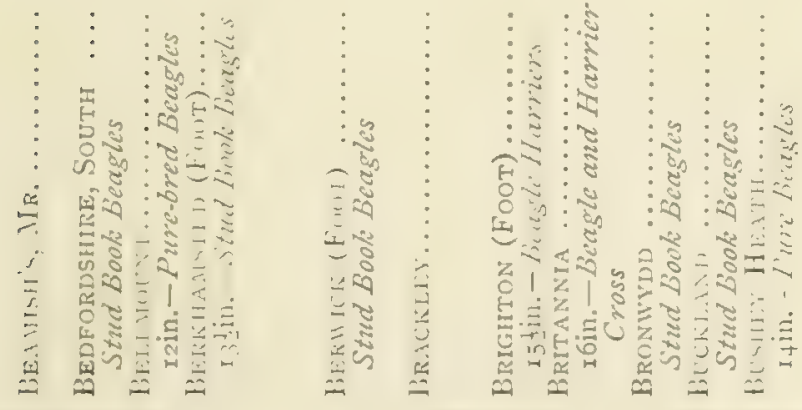

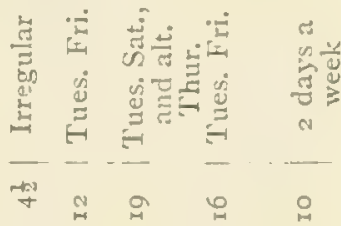

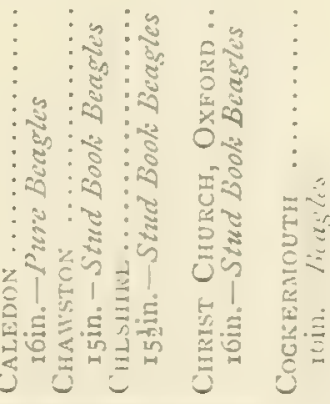



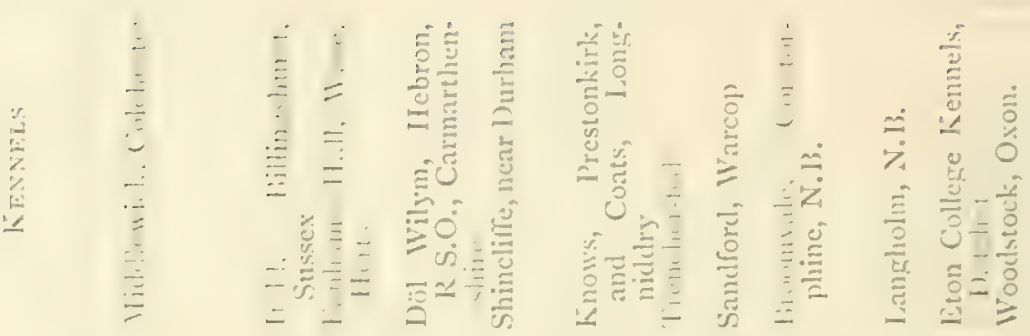

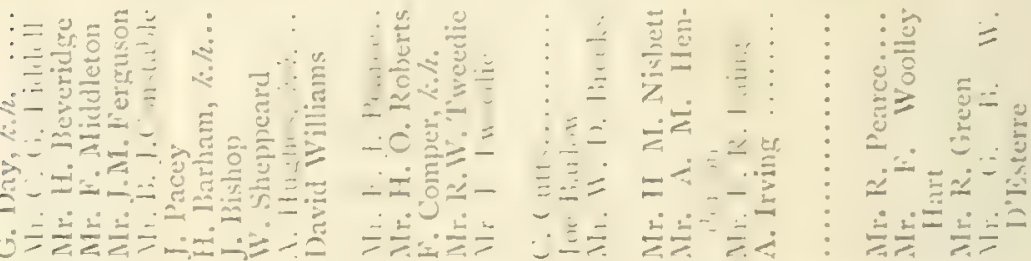
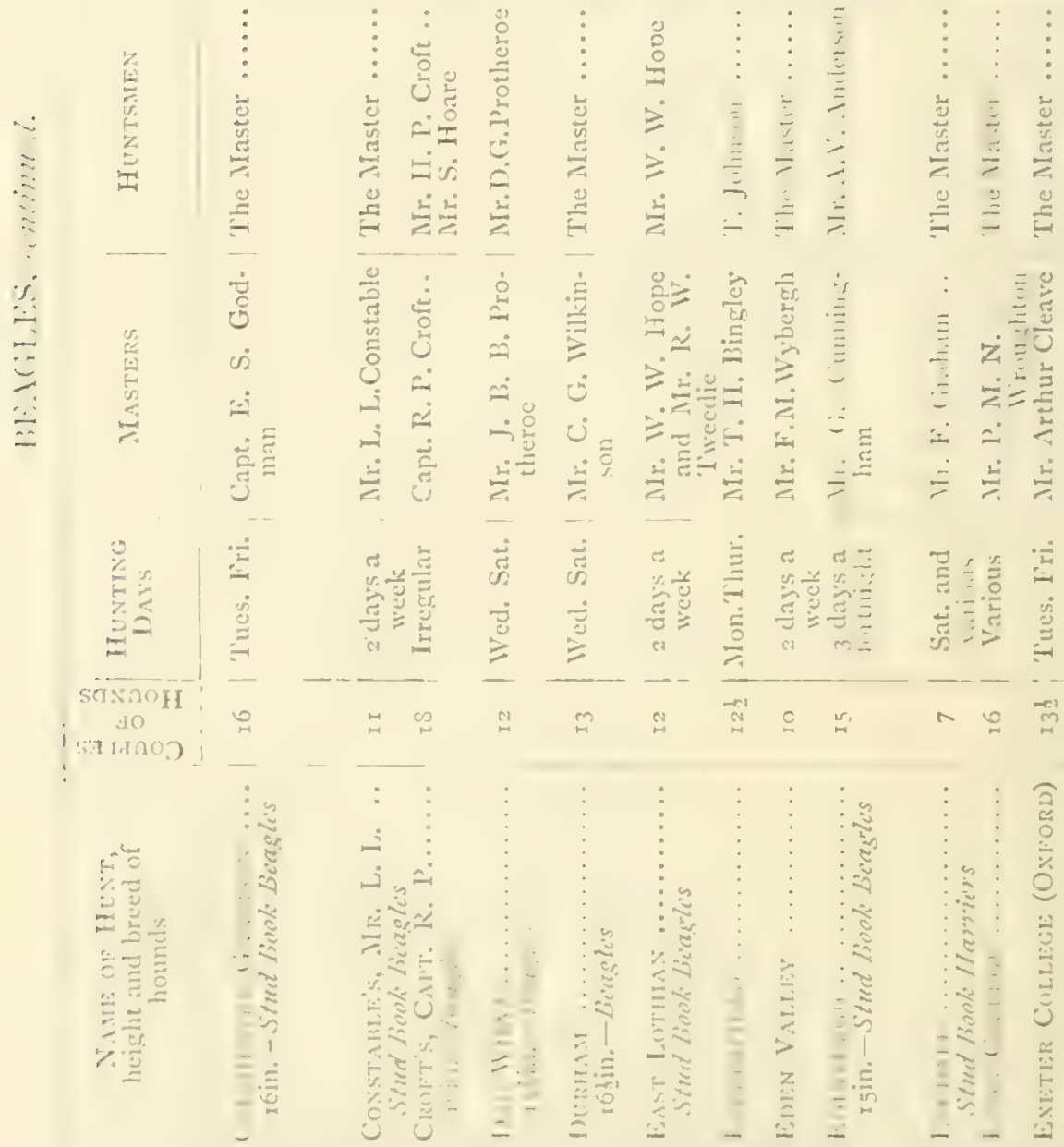


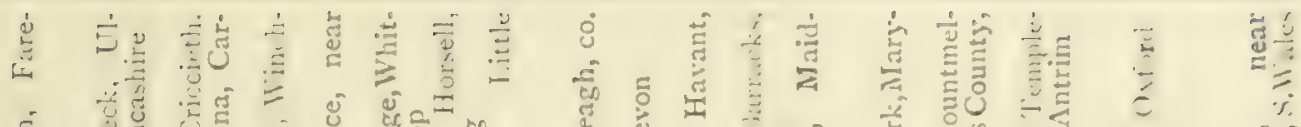
है

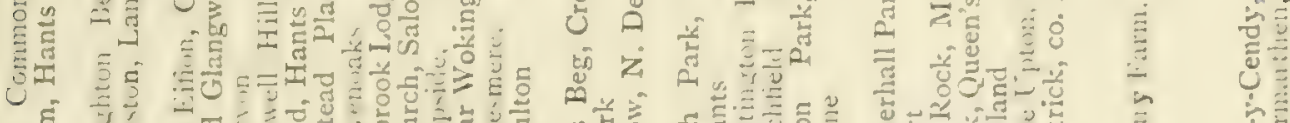

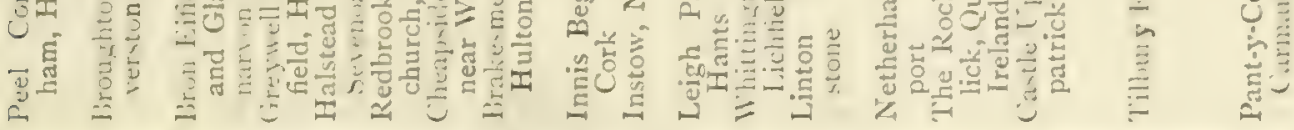

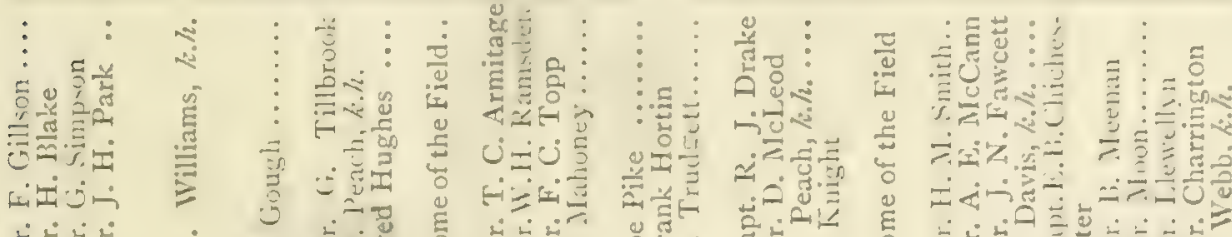

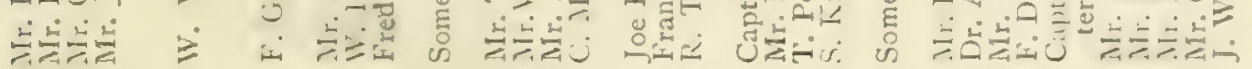

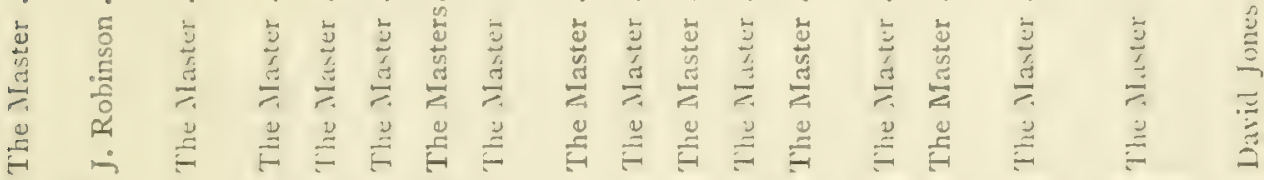

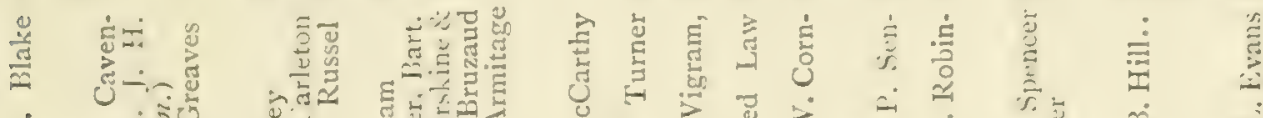

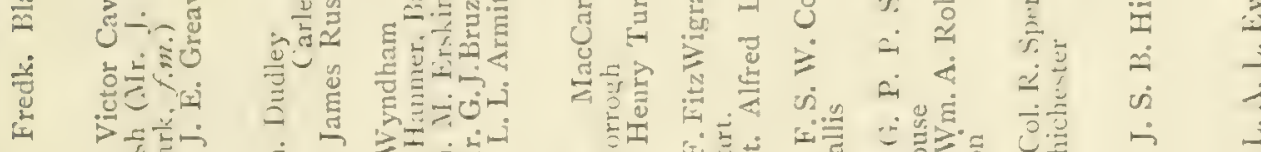

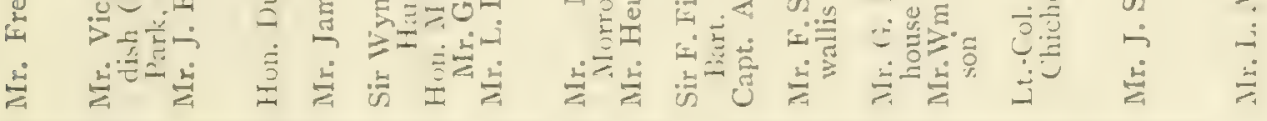

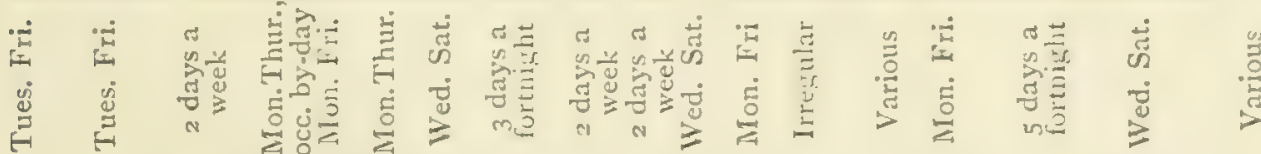

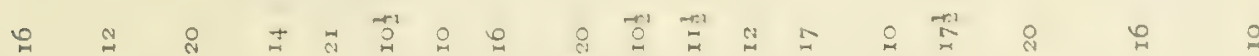

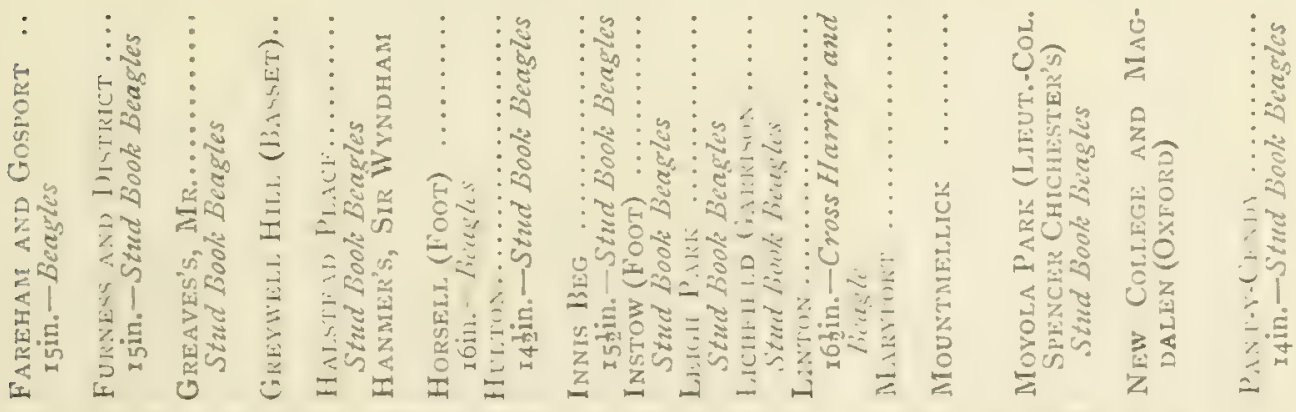




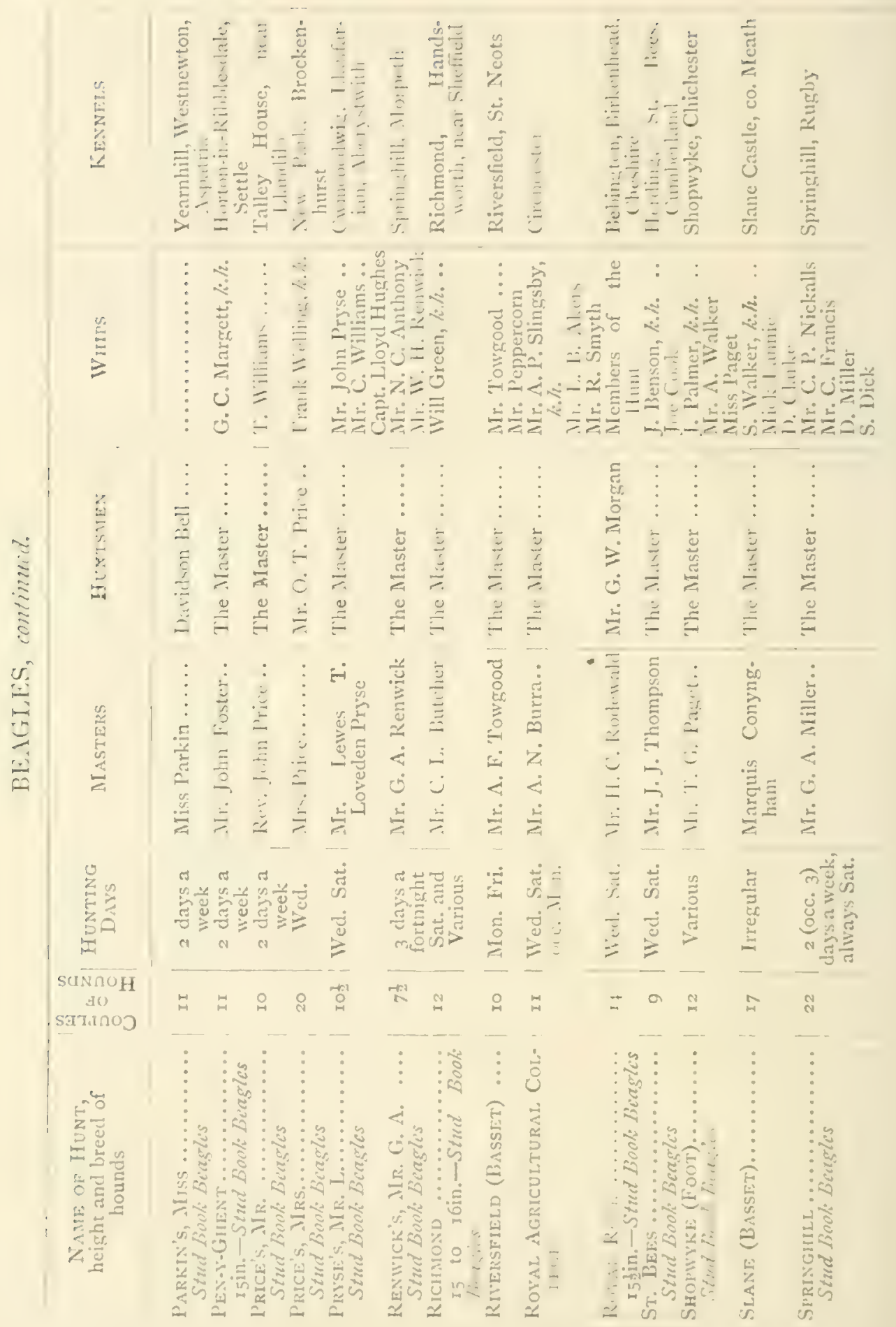




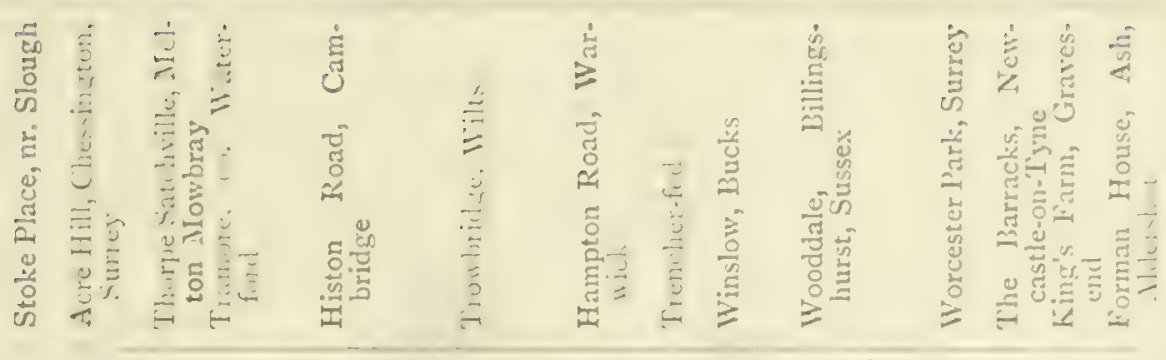

$\vdots$
$\vdots$
0
0

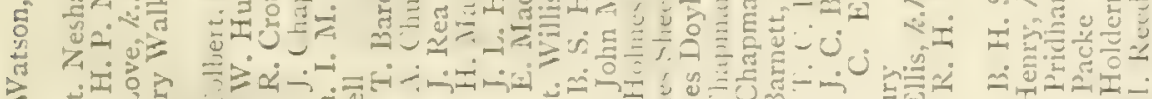
F

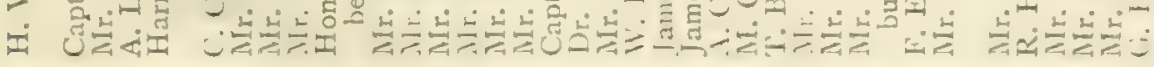

\begin{tabular}{|c|c|c|c|c|c|c|c|c|c|c|}
\hline 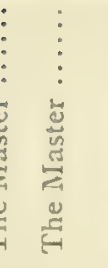 & 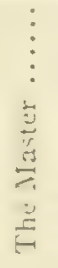 & 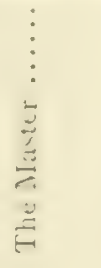 & 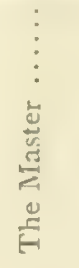 & 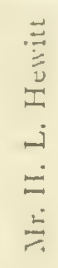 & 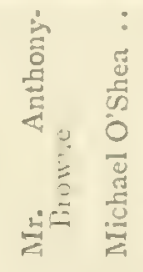 & 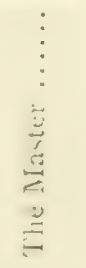 & 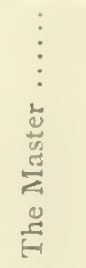 & 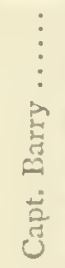 & 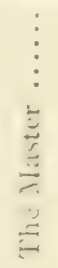 & 峞 \\
\hline 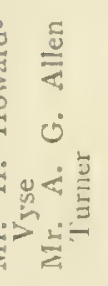 & 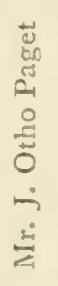 & 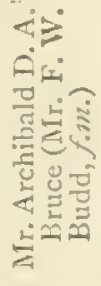 & $\begin{array}{l}\dot{1} \\
\dot{4} \\
\dot{4}=\end{array}$ & U气 & 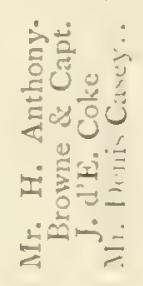 & 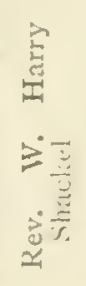 & 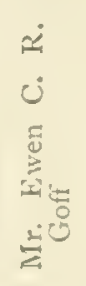 & 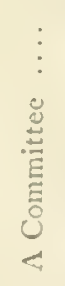 & 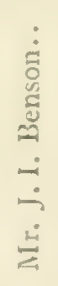 & 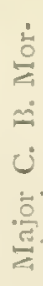 \\
\hline $\begin{array}{l}\dot{y} \\
\dot{0} \\
\dot{0} \\
=\end{array}$ & 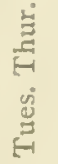 & 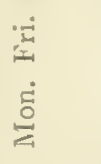 & 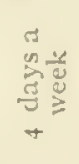 & 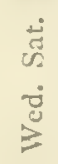 & 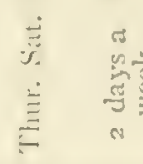 & & 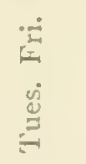 & $\begin{array}{l}\dot{\vec{H}} \\
\dot{\vdots} \\
\dot{\vdots}\end{array}$ & 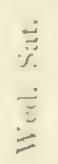 & 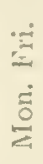 \\
\hline
\end{tabular}

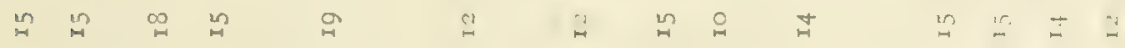

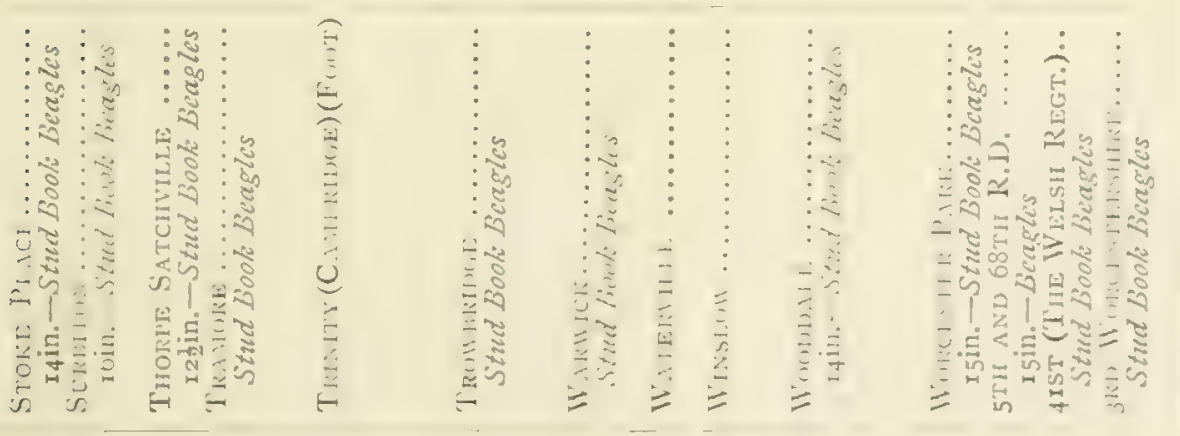




\section{APPENDIX B.}

\section{NAMES OF HOUNDS.}

DOGS.

\begin{tabular}{llll} 
Acheron & Blusterous & Cicero & Dragorı \\
Actor & Boaster & Claimant & Dreadnoughi \\
Adam & Boisterous & Clamorous & Driver \\
Adjutant & Bonniface & Clasher & Eager \\
Eolus & Boreas & Claudian & Eagle \\
Agarie & Borgia & Claudio & Earnest \\
Alaric & Bouncer & Claudius & Edgar \\
Albany & Brilliant & Claverhouse & Editor \\
Albion & Burgundy & Clinker & Elegant \\
Amelot & Bustler & Combatant & Elia \\
Amyas & Crsar & Comforter & Eminent \\
Angelo & Caliban & Conqueror & Emperor \\
Antic & Calidore & Conrad & Ennius \\
Antony & Camelot & Coroner & Enterprise \\
Aramis & Capital & Corydon & Envious \\
Arbiter & Captain & Counsellor & Escalus \\
Archer & Caradoc & Countryman & Escobar \\
Ardent & Carver & Courtier & Etheling \\
Arrogant & Castor & Crasher & Ethelred \\
Artful & Caterer & Critical & Excellent \\
Astrophel & Cato & Cruiser & Fabius \\
Athos & Caviller & Crusty & Factious \\
Atlas & Cephalus & Currier & Falliand \\
Attila & Cerberus & Cymbeline & Falstaff \\
Augur & Challenger & Dredalus & Fearnought \\
Auster & Champion & Dandy & Ferryman \\
Bachelor & Charon & Dangerous & Fiddler \\
Baffler & Chaser & Dasher & Firebrand \\
Barbarous & Chatterer & Dashwood & Fisherman \\
Bellamy & Chieftain & Desperate & Flatterer \\
Bellman & Chiron & Dexterous & Florizel \\
Bluecap & Chirper & Disputant & Flourisher \\
Blieskin & Choleric & Doncaster & Flyer \\
Blunderbore & Chorister & Doncourt & Foreman \\
\hline
\end{tabular}


DOGS-ccntinued.

\begin{tabular}{|c|c|c|c|}
\hline Forester & Harlequin & Jovial & Luria \\
\hline Frederick & Harold & Juba & Lusty \\
\hline Funnyman & Harpagon & Julian & Maccabee \\
\hline Furio & Hathaway & Julio & Madoc \\
\hline Furrier & Hatteraicl & Julius & Mahomet \\
\hline Gabriel & Havoc & Jumper & Malakoff \\
\hline Galahad & Hazlewood & Juniper & Mameluke \\
\hline Galaor & Headstrong & Junius & Manager \\
\hline Galapas & Hector & Jupiter & Manciple \\
\hline Gallant & Heedful & Juvenal & Manlius \\
\hline Galliard & Helicon & Kaled & Mannering \\
\hline Galloper & Hercules & Kennedy & Manuel \\
\hline Gameboy & Hereward & Kitely & Marcian \\
\hline Gamely & Hero & Labdacus & Marimin \\
\hline Gamester & Heron & Labourer & Marinel \\
\hline Ganem & Hesiod & Ladon & Marksman \\
\hline Ganymede & Hesperus & Lælius & Marmel \\
\hline Gareth & Hickory & Lambro & Marmion \\
\hline Gargery & Highflyer & Lammikin & Marplot \\
\hline Garrulous & Hobbema & Lance & Martial \\
\hline Gaspar & Hobinol & Lancelot & Marvellous \\
\hline Gatheral & Holiday & Lara & Matchem \\
\hline General & Honeyman & Laurence & Mazarin \\
\hline Genius. & Honeywood & Lazarus & Medler \\
\hline Genseric & Horace & Leofric & Melchior \\
\hline Gentleman & Hotspur & Leoline & Melibee \\
\hline $\begin{array}{l}\text { Geoffrey } \\
\text { Geryon }\end{array}$ & & $\begin{array}{l}\text { Leopold } \\
\text { Leveller }\end{array}$ & $\begin{array}{l}\text { Memnon } \\
\text { Menacer }\end{array}$ \\
\hline $\begin{array}{l}\text { Geryon } \\
\text { Glorious }\end{array}$ & Hypocrite & $\begin{array}{l}\text { Leveller } \\
\text { Liberal }\end{array}$ & Mentor \\
\hline Gobbo & Ibraham & Libertine & Mercury \\
\hline Goblin & Iliad & Lictor & Merlin \\
\hline Goldy & Imlac & Lightfoot & Merryboy \\
\hline Gondomar & Impetus & Lindor & Merryman \\
\hline Gorgibus & Incubus & Lion & Messmate \\
\hline Gorlois & Ingoldsby & Lionel & Methodist \\
\hline Governor & Inkle & Listener & Militant \\
\hline Gregory & Irus & Littimer & Minikin \\
\hline Gremio & Isaac & Loafer & Minion \\
\hline Grubbinol & Isenbras & Loda & Mirabel \\
\hline Grumbo & Ishmael & Lodowick & Miscreant \\
\hline Guardian & Issachar & Lohengrin & Mohican \\
\hline Guyon & Ithocles & Lorimer & Monarch \\
\hline Hadrian & Janitor & Lovibond & Monitor \\
\hline Halliday & Jason & Lounger & Mortimer \\
\hline $\begin{array}{l}\text { Hamlet } \\
\text { Hannibal }\end{array}$ & $\begin{array}{l}\text { Jericho } \\
\text { Tingle }\end{array}$ & Lucifer & Mulciber \\
\hline $\begin{array}{l}\text { Hannibal } \\
\text { Harasser }\end{array}$ & $\begin{array}{l}\text { Jingle } \\
\text { Jollyboy }\end{array}$ & Lucio & Mungo \\
\hline Harbinger & Jonathan & Lunatic & Myrmido \\
\hline
\end{tabular}




\section{DOGS-continued.}

Nadab

Nathan

Nautilus

Nibelung

Nicholas

Nickleby

Nimrod

Nobleman

Nobody

Norman

Norval

Oberon

Edipus

Ogleby

Olave

Olifant

Oliver

Ollapod

Orator

Oregon

Orleans

Orlick

Orson

Osman

Osrick

Ossian

Otho

Ouragan

Overreach

Pron

Pageant

Palamon

Palmerin

Pandarus

Paragon

Paramount

Paris

Partner

Pasquin

Patriot

Pelleas

Pellinore

Pcregrine

Perfect

Pericles

Perigot

Perilous

Perion

Pertinent
Peterson
Petulant
Phaethon
Phalaris

Pharamond

Phøbus

Phormio

Phosphorus

Pilgrim

Pillager

Pilot

Pincher

Pindar

Piper

Pitiless

Plato

Plausible

Playful

Plunder

Pluto

Politic

Potentate

Potiphar

Prattler

Premier

President

Prettyman

Priamı

Primate

Principal

Prodigal

Prodigy

Prompter

Prophet

Prospero

Prosperous

Prowler

Pyramus

Pythias

Quentin

Quixote

Rabelais

Racer

Racket

Rallywood

Rambier

Rampant
Random

Ranger

Ransack

Rantaway

Ranter

Raphael

Rasselas

Rattler

Ravager

Ravenous

Ravenshoe

Ravenswood

Ravisher

Reasoner

Rector

Regent

Regular

Remus

Resolute

Resonant

Restive

Reveller

Rifleman

Ringwood

Rioter

Risingham

Robin

Robinson

Roderick

Rodomont

Roland

Romeo

Romper

Romulus

Rouser

Rover

Ruffian

Ruffler

Rummager

Rupert

Rustic

Sampson

Sancho

Sapient

Saunterer

Scamperdale

Scamperer

Scanderbeg
Scaramouch

Scattercash

Scavenger

Schacabac

Scipio

Scrambler

Screamer

Scudamore

Scuffler

Seneca

Sentinel

Sesame

Sharper

Shifter

Silvio

Sindbad

Sintram

Sisyphus

Skirmisher

Slender

Smiler

Sociable

Socrates

Solomon

Solon

Songster

Sorcerer

Sosia

Spanker

Spartacus

Specimen

Speedwell

Splenetic

Spoiler

Spokesman

Sportsman

Statesman

Steady

Stephano

Stickler

Stormer

Strange

Striver

Stroller

Student

Subtle

Swaggerer

Sybaris 
DOGS-continued.

Sylvan
Tacitus
Taillefer
Tammany
Tantalus
Tappertit
Tarquin
Tartar
Tasso
Tatler
Teaser
Telamon
Telephone
Telephus
Terence
Terror
Teucer
Thalaba
Thamyris
Theodore
Theseus
Thrasher
Thunderer
Thurio
Thyrsis
Tickler
Timon
Timothy
Tinto
Titus

Tityrus
Tomalin
Tomboy
Tony
Torment
Torquil
Torturer
Touchstone
Tozer
Tragic
Trajan
Trampler
Transport
Traveller
Trimbush
Trimmer
Tristram
Triumph
Trojan
Trouncer
Truant
Trueboy
Truelove
Trueman
Trulliber
Trusty
Tryamour
Trywell
Tubal
Turbulent

Tyrant

Varrior

Waverley

Wayward

Wellbred

Wetheral

Whipster

Whitaker

Whiteboy

Whittington

Wildair

Wildboy

Wildman

Wilfred

Wilful

Winterton

Wisdom

Woodman

Worker

Workman

Worthy

Wrangler

Wrestler

Yarico

Yorick

Zabulon

Zachary

Zanga

Zophiel

Zosimus

BITCHES.

$\begin{array}{llll}\text { Abigal } & \text { Atropes } & \text { Bonnylass } & \text { Charity } \\ \text { Accurate } & \text { Barbara } & \text { Bountiful } & \text { Chatterbox } \\ \text { Actress } & \text { Bashful } & \text { Bradamant } & \text { Chauntress } \\ \text { Adamant } & \text { Beatrice } & \text { Busy } & \text { Cicely } \\ \text { Adelaide } & \text { Beauty } & \text { Buxom } & \text { Circe } \\ \text { Affable } & \text { Beldam } & \text { Candour } & \text { Claribel } \\ \text { Agatha } & \text { Bellicent } & \text { Capable } & \text { Clarinet } \\ \text { Airy } & \text { Bendemeer } & \text { Caramel } & \text { Clio } \\ \text { Alison } & \text { Bertha } & \text { Careless } & \text { Comely } \\ \text { Amazon } & \text { Blameless } & \text { Carnage } & \text { Comical } \\ \text { Angela } & \text { Blanche } & \text { Caroline } & \text { Concord } \\ \text { Annabel } & \text { Bluebell } & \text { Catherine } & \text { Corisande } \\ \text { Artemis } & \text { Bonnybell } & \text { Celia } & \text { Courtesy }\end{array}$




\begin{tabular}{|c|c|c|c|}
\hline Crafty & Flattery & Helinore & Lightsoms \\
\hline $\begin{array}{l}\text { Credulous } \\
\text { Cruelty }\end{array}$ & $\begin{array}{l}\text { Flighty } \\
\text { Flippant }\end{array}$ & Heloise & $\begin{array}{l}\text { Likely } \\
\text { Lilian }\end{array}$ \\
\hline $\begin{array}{l}\text { Cruelty } \\
\text { Curious }\end{array}$ & $\begin{array}{l}\text { Flippant } \\
\text { Flora }\end{array}$ & $\begin{array}{l}\text { Hemera } \\
\text { Hera }\end{array}$ & Lilian \\
\hline Cynthia & Florence & $\begin{array}{l}\text { Hera } \\
\text { Hermia }\end{array}$ & $\begin{array}{l}\text { Lilith } \\
\text { Lisa }\end{array}$ \\
\hline Dainty & Florida & Hero & Lively \\
\hline Dairymaid & Florimel & Heroine & Livia \\
\hline Daphne & Flourish & Hestia & Lorna \\
\hline Darling & Forcible & Hilda & Lotta \\
\hline Delia & Frantic & Honesty & Lovely \\
\hline Delicate & Fretful & Hoyden & Lucida \\
\hline Destiny & Friendly & Imogen & Lullaby \\
\hline Diamond & Frisky & Impudent & Lunacy \\
\hline Dian & Frolic & Industry & Lydia \\
\hline Dido & Frolicsome & Inez & Madcap \\
\hline Diligent & Funnylass & Innocent & Madeline \\
\hline Dimity & $\begin{array}{l}\text { Furious } \\
\text { Fury }\end{array}$ & Iris & Madelon \\
\hline $\begin{array}{l}\text { Doris } \\
\text { Duchess }\end{array}$ & & $\begin{array}{l}\text { Isabel } \\
\text { Isidore }\end{array}$ & $\begin{array}{l}\text { Madrigal } \\
\text { Mænad }\end{array}$ \\
\hline $\begin{array}{l}\text { Duchess } \\
\text { Dulcimer }\end{array}$ & Gaily & $\begin{array}{l}\text { 1sidore } \\
\text { Isis }\end{array}$ & Magdalen \\
\hline Dutiful & Gamesome & Isoline & Magic \\
\hline Easy & Gaylass & Joceline & Magical \\
\hline Echo & Geraldine & Jollity & Malaprop \\
\hline $\begin{array}{l}\text { Ecstacy } \\
\text { Edith }\end{array}$ & Giddy & Joyful & Marcia \\
\hline $\begin{array}{l}\text { Edith } \\
\text { Eglantine }\end{array}$ & $\begin{array}{l}\text { Glllian } \\
\text { Gluttony }\end{array}$ & $\begin{array}{l}\text { Joyous } \\
\text { Judith }\end{array}$ & Margaret \\
\hline $\begin{array}{l}\text { Eglantine } \\
\text { Eleanor }\end{array}$ & Goneril & Julia & Marjory \\
\hline Emily & Gorgon & Juliet & Nary \\
\hline Endless & Gossamer & Juno & Matchless \\
\hline Energy & Governess & Kenna & Mattie \\
\hline nid & Graceful & Kestrel & Mayflower \\
\hline Enmity & Graceless & Kisty & Meddlesome \\
\hline Equity & Gracious & Lachesis & Megra \\
\hline Etiquette & Gratitude & Lady & Melody \\
\hline Fairmaid & Gravity & Ladylike & Memory \\
\hline Fairplay & $\begin{array}{l}\text { Gretchen } \\
\text { Grethel }\end{array}$ & Lais & Merrilies \\
\hline $\begin{array}{l}\text { thful } \\
\text { cciful }\end{array}$ & $\begin{array}{l}\text { Grethel } \\
\text { Guinevere }\end{array}$ & $\begin{array}{l}\text { Lalage } \\
\text { Lamia }\end{array}$ & $\begin{array}{l}\text { Merriment } \\
\text { Merrylass }\end{array}$ \\
\hline Fantasy & Gwendoline & Languish & Mignon \\
\hline Fashion & Hæmony & Lappet & Millamant \\
\hline Fatima & Handsome & Laura & Miriam \\
\hline Favourite & Harmony & Leda & Mischief \\
\hline Fearless & Hasty & Lelia & Modish \\
\hline Festive & Hazardous & Lenity & Monody \\
\hline ickle & Hebe & Lesbia & Music \\
\hline $\begin{array}{l}\text { Fidget } \\
\text { fiery }\end{array}$ & Hecate & Levity & Musical \\
\hline firefly & Helena & $\begin{array}{l}\text { Liberty } \\
\text { Lightning }\end{array}$ & $\begin{array}{l}\text { Myra } \\
\text { Nancy }\end{array}$ \\
\hline & & & \\
\hline
\end{tabular}

BITCHES-continued 
BITCHES-continued

\begin{tabular}{|c|c|c|c|}
\hline Nelly & Racket & Stella & Venturesome \\
\hline Nicety & Radigund & Strenuous & Venus \\
\hline Nimble & Rally & Surety & Verity \\
\hline Niobe & Rantipole & Sybil & Vicious \\
\hline Nipper & Rapid & Sycorax & Victory \\
\hline Norah & Rapine & Symphony & Vigilance \\
\hline Norna & Rapture & Tannaquil & Viola \\
\hline Nourmahal & Rarity & Tattle & Violent \\
\hline Novelty & Rashness & Tamora & Violet \\
\hline Oracle & Rattle & Telltale & Violin \\
\hline Oread & Regan & Tempest & Viperus \\
\hline Oriel & Resolute & Tentative & Virulent \\
\hline Overdone & Restless & Termagant & Vivian \\
\hline Pamela & Rhapsody & Terrible & Vivid \\
\hline Partner & Rhodope & Testy & Vixen \\
\hline Passionate & Riot & Thankful & Vocal \\
\hline Patience & Rival & Thecla & Volatile \\
\hline Patty & Roguish & Thisbe & Voluble \\
\hline Pattypan & Rosa & Thoughtful & Waggery \\
\hline Peggotty & Rosabel & Tiffany & Wagtail \\
\hline Penitent & Rosalind & Topsy & Wanton \\
\hline Perdita & Rosamond & Tractable & Warlike \\
\hline Philomel & Rosemary & Tragedy & Waspish \\
\hline Phryne & Ruby & Trespass & Wasteful \\
\hline Phyllida & Ruthless & Trifle & Watchful \\
\hline Phyllis & Salamis & Trivia & Welcome \\
\hline Placid & Sanguine & Troublesome & Whimsey \\
\hline Placida & Sappho & Truelass & Whimsical \\
\hline Playful & Scylla & Truemaid & Whirligig \\
\hline Pleasant & Selima & Trulla & Wildfire \\
\hline Pliant & Semele & Tunable & Willing \\
\hline Portia & Sensitive & 'Tuneful & Winifred \\
\hline Positive & Silvia & Una & Winipeg \\
\hline Prettylass & Snowball & Ursa & Wishful \\
\hline Priestess & Songstress & Ursula & Wonderful \\
\hline Probity & Speedy & Utha & Worry \\
\hline Prophetess & Spiteful & Vanda & Wrathful \\
\hline Proserpine & Spitfire & Vehement & Zamora \\
\hline Prudence & Sportive & Vengeance & Zara \\
\hline Psyche & Sprightly & Vengeful & Zetica \\
\hline $\begin{array}{l}\text { Queenie } \\
\text { Quickly }\end{array}$ & Stately & Venomous & Zillah \\
\hline
\end{tabular}




\section{APPENDIX C.}

\section{HUNTING TERMS.}

BABBLER : a noisy hound, one given to babbling, or flinging its tongue without cause.

BAY : the second point, counting from the skull, on the main stem

of the stag's antler.

BEAM: the stem of the antler.

BILLET : the dung of the fox.

BLANCHED : a stag when turned, or headed from its line is said to have been blanched, but the term is rarely heard now-a-days. BLANK : void, empty; a blank day, to draw a cover blank.

BROCKET : the male of the red deer up to three years old.

BROW : the first point of the antler, springing from the beam close to the skull,

BRUSH : the tail of the fox.

BULLFINCH: a high and hairy hedge, impossible to get over and difficult to get through, whence perhaps the name, as of a fence impervious to a bullinch, or any other bird. It might, however, be a corruption of 'bull fence,' a fence to keep the cattle in their pastures, as it is most common in the grazing countries. It has a ditch on one side or other, sometimes on both, and altogether is a disagreeable obstacle.

BURROW : the underground home of the rabbit.

BURST: the first and, generally, the fastest part of the run, when fox, hound, horse, and man are at their freshest.

CALF : the young of the red deer whether male or female.

CARRY : to carry a good heud is said of a pack of hounds all pressing and crowding to a hot scent.

CAST : the spreading of the hounds in search of a lost scent, either a natural movement or promoted by the huntsman; also used as a verb, to cast. 
Chaldingr: the hound which first speaks to the scent in cover is said to challenge.

Circk: a stoppage in the run owing to the temporary loss of the scent; also used as a verb, to check.

CHOPPED : a fox killed before he has had time to break cover is said to have been chopped.

COCKTAIL: any horse not thorough-bred.

$\mathrm{COUCH}$ : the kennel, or lodging, of the otter.

COUNTER : hounds are running counter when they are hunting the scent the reverse way, i.e. away from the game.

CRockets : an old-fashioned phrase for the upright or top points of a stag's antler.

CROP : a hunting-whip.

CROPPER : a bad fall; the words crumpler and crowner are also used in the same significance, the latter generally with the addition of the epithet imperial.

CUB : the young of the fox.

DOE: the female of the fallow-deer, hare, or rabbit.

DOUBLE: a fox or hare doubles when it turns short back on its line.

DRAG : the scent left by the fox returning home from his midnight prowlings. Also a fictitious scent produced by trailing or dragging along the ground a rabbit-skin, wisp of straw, piece of rag, or any receptive substance soaked in aniseed. Drag hounds is the term applied to a pack (generally a very scratch one) kept particularly for this sort of chase, which is at least as good a sport as hunting the carted deer, and for the most part much better fun.

DRAW : used of the hounds ranging for their game.

EARTH : the underground home or burrow of the fox.

EARTH-STOPPER: the man whose business it is to see that all tine neighbouring earths are duly stopped on hunting-days. This must be done overnight, when the foxes are abroad after their food.

FEATHER: when a hound has a fancy that he scents his game, but is not yet quite certain enough to give tongue or speak to it, his stern will be observed to be violently agitated: this is called 'feathering on the scent.'

Feunent, or Feumishing : the dung of the deer.

FolL : an animal runs its foils when it returns on its own tracks.

ForM: the sear, or kennel, of the hare. 
FUIL-CRY : originally used of the chorus of tongues when all the pack acknowledge a burning scent; but the phrase now is generally taken to mean that period of the chase when the hounds are fairly settled on the line, and all, hunted and hunters, are doing their best - a period when hounds are as a rule going too fast to have much wind to spare for any musical performances.

HARBOURER : the man whose business it is to mark down for the huntsman the covert where a warrantable stag is lodged, or harboured.

HARK-FORWARD : the huntsman's cheer to his hounds to encourage them on the scent.

HEADED : used of the fox and hare, as blanched of the deer.

HEEL : see Counter and Foil.

HiND: the female of the red deer.

Holt : see Couch.

Hover : same as Holt.

JACK-HARE : a male hare.

JUAPING-POWDER: a facetious name for any stimulant taken to cheer a fainting heart, on the old principle of keepings spirits up by pouring spirits down.

KENNEL: the lair of the fox either above or below ground.

LATCHFORDS: a name applied to the spurs from a celebrated maker of those useful implements.

LEVERER: the young of the hare up to a year old.

LIFT : to take the hounds from the point where they have lost the scent quickly forward without waiting to cast on the chance of hitting it off again. A hazardous game to play, but sometimes very effective with a clever huntsman on bad scenting days.

MASK : the head of the fox.

MORT: the note blown on the horn at the death of the decr.

OXER : a diabolical sort of fence peculiar to the grazing countries, and named from its being designed to keep the cattle in their pastures. It consists of it tolerably high and strong hed re with a rail on one side, perthaps on both, standing out just far enough in the field to turn a horse neatly over after he has cleared the hedge, and a ditch somewhere.

PAD : the foot of the fox.

PATE: the head of the fox.

PEARLS : the rough circular bases of the stag's horns.

RIcinTs: a stag is said to have his rights when his antlers show the full number of points, 'brow, bay', and tray, and three on top.' 
RIOT: when fox-hounds hunt any scent but that of the fox they are said to be running riot.

RUNNABLE: a decr fit to be hunted; in the case of the stag, this is at five years, when the antler shows not less than two points on top, though sometimes, when stags are scarce, they are hunted at four; hinds have of late years increased so greatly on Exmoor that they are now hunted as soon as they are strong enough to run before the hounds.

SCORING: hounds are said to be scoring to cry when the scent is very hot and every hound in the pack is speaking to it.

Scur : the tail of the hare or rabbit.

SEAL : the foot-marks of the otter.

SINGLE : the tail of the deer.

SKIRTER : a hound that runs wide of the pack, "playing his own hand,' so to speak.

SLOT: the foot-mark of the deer.

So-Ho: the cry raised when a hare is viewed (probably a corruption of 'See, ho!')

SorL : a hunted deer is said to take soil when it takes to the water.

SPRAINT : the dung of the otter.

STAGGART : a male deer at four years old.

STERN : the tail of the hound.

TINE : the point, or branch, on the stag's antler.

TRAY: the third point on the antler.

TALLY-HO : the cheer announcing that the fox is viewed.

TUFTER : the hound sent into cover to find and drive the deer out; two or three couple of the oldest and wisest in the pack are used for this purpose.

VENT : to breathe, used of the otter; the bubbles of air floating on the surface of the water, which indicate his course below, are called his ventings.

VIXEN : the female of the fox.

WARRANTABLE : see Rumable.

WHELP : a hound puppy at a very tender age

WHO-HOOP: the cheer announcing the death of the fox.

WHIPPER-IN : the huntsman's subaltern, so called from one of his many offices being to impress upon the hounds the necessity of strict obedience to rules, an impression which has sometimes to be made with the whip. 


\section{Al'I'ENDIX D.}

\section{BIRLIOGRAPIIY OF GUNTING AND HUNTERS:}

Art de Venerie le quei Maistre Guillaume Twici venour le Roy d'Angleterre fist en son temps per Apmuntre autres. This is tive manuscript mentioned by Strutt in his Sports and Pastimes as the earliest known to exist on the subject. The King of England was Edward II., so the manuscript must have been written between 1307 and I327. See Chap. I.

Lo Art de Venerie, en MSS. Phillipps, no. 8336. Edited by Sir T. Phillipps. Middle Hill, 4to., 1844 . Frivately printed. Apparently another copy of the same work.

The Art of Huntins, by IV. T., huntsman to King Edward II. With preface, translation, notes, and illustrations, by H. Dryden. Daventry. Privately printed, I843, 4to.

The Haistor of the Game, a manuscript attributed to Edward de Langley, Duke of York, son of Edward III. See Chap. I. Tine boky's of Haukyng and Huntyng, and also of Cootarmuris, commonly called The Boke of S. Albans. St. Albans, 14SI, fol. See Chap. I.

The Tratises of Hawking, Inunting, Cout-armour, Fishing, and Lhasing of Arms. Edited by Joseph Ilaslewood, printed by Wynkyn de Worde. Westminster, I4S6, fol. Another edition of the above.

Treaty'ses perteynge to Hawhynge, IHuntynge, and Fishy'nge with an Angle. London, 1496. Another edition. A facsimile of The Boke was published in I $8 S \mathrm{I}$ under the supervision of Mr. William Blades.

I Merely technical books, or books which have no special reference, among other things, to hunting in any of its branches, are not included in this catalogue : c.g. getseral books on the horse, or horsemanship. The date given is always, where possible, that of the first edition. 


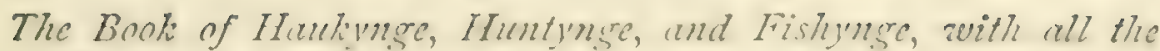
Propertics and Hedecynes that are necessary to be Repte. I'rinted by William Powell, or Powel. London, I550, 4to.

The Noble Art of lentrie or Hunting; wherein is handled and set out, the Vertues, Natures, and I'roperties of fifteene Sundrie Chaces, torether with the Order and Maner how to II unte and Kill everyone of them. Translated and collected, for pleasure of all Noblemen and Gentlemen, out of the best approved Authors, which have written anything concerning the sime, and reduced into such Order and proper Termes as are used here in the noble Realme of Engrlande. London, 1575 , 4 to. This is usually found printed with George Turberville's Bonlies of Faulconrie, to whom, therefore, it has been generally attributed. Some copies have also verses by (ieorge Gascoigne, In Comendution of the Noble Arte of Venerie.

1 Short Treatise of Hunting, compyled for the Delisht of Viblemen and Gentlemen, by Sir Thomas Cokaine. London, I 591,4 to. The Gentleman's Academy; or the Book of St. Albuns, of Hatiking, Hunting, and Armoury, from the Original of Juliuna Barnes, by Gervase Markham. London, 1595, 4to.

The Book of Hawking, Hunting, and Fishing, corrected. Printed by Edward Aldee, or Allde. London, 1506, 4to. Probably another edition of The Boke of St. Albans.

The Booke of Hawking, Hunting, Fowling and Fishing; whereunto is added the Heasures of Blowing, now newly collected by William Gryndall. London, I 596, fol.

Country Contentments; or the IHusbandmen's Recreations: consisting of the Art of Riding, Hunting, Shooting, Hawking, Coursing with Greyhounds, \&c., by Gervase Markham. London, I6II.

Canallarie; concerning Horses and Horsemanship, as much as is necessary for any man to understand, whether he be horsebreeder, horse-ryder, horse-hunter, horse-runner, horse-ambler, horse-farrier, horse-keeper, coachman, smith, or sadler. Together with the discovery of the subtil trade or mystery of horse-coursers, and an explanation of the excellency of a horse's understanding; or how to teach them to do tricks like Barlies his, Curtall: and that horses may be made to draw dry foot like a hound. Secrets before unpublished, and nowe carefully set downe, for the profit of this whole nation; by Gervase Markham. London, 1617,4 to. 
Cynoscticon, or the Art of Hunting; translated into English Verse from the Cy'nositicon of Gratius Faliscus, by Christopher Wase. London, 1654,8 vo.

The Gentlemuls Tecreation, in Hunting, Hawking, Fowling, Fishin r, by Richard Hilome, or Bloome. London, 1683,8 vo. See Chap.!.

The Sihool of Recreation; or the Gentleman's Tutor to these most ingincus Exerises of Hunting, ENc. London, 1684, $16 \mathrm{mo}$.

The Hunter, a discourse of Horsemanship, directing the right way to breed, keep, and train a Horse for ordinary Hunting; and plates. Oxford, 1685.

The Gentleman's Recreation; in four parts, viz., Hunting, Hawking, Fowling, and Fishing, whereto is prefixed a large sculpture, giving directions for Blowing the Horn, with folding plates. 1697,8 vo.

The Comfleat Sportsman; containing Hunting, Shooting, and Fishing, by Giles Jacob. 1718, $12 \mathrm{mo}$.

The School of Recreation; or $A$ Guide to the most ingenious excrcises of Hunting, Riding, Racing, Hawking, Tennis, Cock-firhting, Angling, \&c., by R. H. 1720, $18 \mathrm{mo}$.

An Essay on Hunting, by a Country Squire. London, I733.

The Chace, a poem by William Somerville, with frontispiece of Diana. London, 1735,4 to.

The Sfortman's Dictionury'; or the Country Gentleman's Companion in all Rural Recreations. London, 1735, 2 vols. 8vo.

Cynegetics; or a Poem on Hunting. The First Book of Oppian's Cynegetics, translated into English verse, with a dissertation and Oppian's Life prefixed. Dedicated to Sir Robert Walpole, by John Mawer, A.M. London, 1736, 8vo.

The Art and Pleasure of Ifure-hunting, by John Smallman Gardiner. London, 1750, 8vo.

7houghts on Hunting, by Peter Beckford. Sarum, I78r, fto.

Essay's on Hunting; containing a Philosophical Enquiry into the

Nature and Properties of Scent ; Observations on the Different kind of Hounds, with the manner of training them; also Directions for the choice of a Hunter, the Qualifications requisite for a Huntsman, and other General Rules to be observed in every contingency incident to the Chase; with an Introduc. tion, describing the method of Hare Hunting practised by the Greeks. London, 1782, 8vo. 
An Acalemy for Grozen Horsemen, containing the completed instructions for Walking, Trotting, Cantering, Galloping, Stumb. ling and Tumbling-Annals of Horsemanship, containing accounts of Experiments and Experimental Acciclents, by Geoffrey' Gambado, with plates by lumbury, 2 vols. in $1,1787,4$ to.

The British Sfortsman; or Nobleman, Gentliman, and Firmer's 1)ictionary of Recreation and Amusement, with plates. I792, 4to. The Complete Sportsmin; or Country Gentleman's Recreations, with frontispiece. $1795,12 \mathrm{mo.}$

The Complete Firnier and British Sportsman, interspersed with Sporting Anecdotes and an account of the most celebrated Horses, with plates after Stubbs, Conper, and others. No date, 4to.

Analysis of Horsemanship; teaching the whole Art of Riding in Mantye, Military, Hunting, Racing, and Travelling System, together with the Method of Breaking Horses, with numerous folding plates. I799, 8vo.

The Sportsman's Dictionary; or the Gentliman's Companion for Town and Country, containing full and particular instructions for Riding, Hunting, \&c., with plates. I80o, 4 to.

The British Sportsman, by Samuel Howitt, with plates. I79S-1800, oblong 4 to.

The Sports and P'astimes of the Pcople of England, from the carliest period to the present time, by Joseph Strutt, with woodcuts. London, I8or, 4 to.

The Meynellian Science of Fox-hunting on Sy'stem, by - Hawkes. Privately printed; probably about the early years of the present century, as Mr. Meynell gave up his hounds in 1800 .

The Sporting Dictionary and Rural Repository of General Information upon every subject appertaining to the Sports of the Field, by William Taplin, with plates, 2 vols. I803, 8 vo.

The Sportsman's Dictionary; containing Instructions for the various methods to be observed in Riding, Hunting, Fishing, Racing, Hawking, Sc., by Henry James Pye, with seventecn plates. 1807,4 to.

Songs of the Chase; containing an extensive collectron relative to the Sports of the Field, including the several subjects of Hunting, Racing, Angling, Hawking, Sic, with plates. I8I , I $2 \mathrm{mo}$.

Rural Sports, by Rev. W. B. Daniel; complete with Supplement, plates by Sroft and others. 18I2-13, royal Svo. 
The Complete Sportsman; containing view of the Ancient and Modern Chase, Breed and Training of Hounds, \&c. 1817, 8 vo.

British Ficld Sports; embracing practical Instructions in Shooting, Hunting, \&c., by William Henry Scott, with plates. I8I8, 8vo. An Essuy on Hunting, comprising its Lawfulness, Benefits, Pleasure, \&c., with plates. I820, 8vo.

The National Sports of Great Britain, fifty engravings with descriptions, by Henry Alken. 1825, royal 8vo.

The Young Sportsman's . Iiscellany, in Hunting, Shooting, Racing, Coursing, Angling, Cocking, E-c., including a reprint of Barker's Tract on Angling, frontispiece and 22 woodcuts. I S26, I2mo.

Observations on Fox-hunting, and the Management of Hounds in the Kennel and the Field, addressed to Young Sportsmen about to undertake a Hunting Establishment, by Colonel Cools, with plates. 1826 , royal 8 vo.

The Hunting Directory; containing a compendious view of the ancient and modern Systems of the Chase, the Pursuit of the Fox, the Hare, and the Stag, also Notices of the Wolf and Boar Hunting of France, by T. B. Johnson, with plates. London, I 826,8 vo.

The Sportsman's Cyclopadia; being an Elucidation of the Science and Practice of the Field, the Turf, and the Sod, accompanied with Illustrative Anecdotes, by the same, with plates. I $83 \mathrm{I}, 8 \mathrm{vo}$.

Remurts on the Condition of Hunters, the Choice of Horses, and their Managiment, by 'Nimrod' (Charles James Apperley). London, 1831, 8vo.

Wild Sports of the West, with Legendary Tales and Local Sketches. by W. H. Maxwell, with plates, 2 vols. 1832,8 vo,

The Sportsman's Cabinet, and Town and Country Magazine; a periodical devoted to the Genuine Sports of the Field, by' T. B. Johnson, with plates. I833, 8 vo.

Ficld Book of Sports and Pastime's of the Unitid Kingdom; compiled from the best authorities ancient and modern, by Maxwell, with woodcuts. London, 1833,8 vo.

A Dictionary of Sports, or Companion to the Ficld, the Forest, and the Riverside, by Harry Harewood. 1835, 8vo.

Hunting Tours, interspersed with characteristic anecdotes of Sporting Men, by 'Nimrod.' To which are added N.'s letters on Riding to Hounds. London, 1835 , 8vo. 
The Hameickshire IIunt, from 1795 to 1836 , describiner many of the most splendid Runs with these highly' celebrated Hounds, by 'Venator,' with frontispiece. 1837, 8vo.

The Chuse, the Turf, and the Road, by 'Nimrod,' with illustrations by $H$. Alken. London, 1837, 8vo. Reprinted from the Qurterly Reviea', March i832. In The Chuse is the famous description of an ideal run with the Quorn, under Mr. Osbaldiston's mastership. A separate edition of The Chuse was published in 1851 .

Memoirs of the Life of the late Fames Nytton, by 'Nimrod: with illustrations by $\mathrm{H}$. Alken and T. J. Rawlins. London, 1837,8 vo.

Extracts from the Diary of a Huntsman, by Thomas Smith, late Master of the Craven Hounds, and at present of the Pychely (sic), Northamptonshire, with illustrations by the Author. London, 1838 , 8vo.

Northern Tours, descriptive of the principal Hunts in Scotland and the North of England; with the table talk of distinguished sporting characters, and anecdotes of masters of hounds, \&c., by 'Nimrod.' London, $1838,8 \mathrm{vo}$.

The Noble Science; a Few General Ideas on Foxhunting for the Use of the Rising Generation of Sportsmen, by F.P. Delmé Radcliffe; with numerous illustrations, and coloured plates. London, i 839, 8vo.

Hints on Horsemanship to a Nephew and Niece; or Common Sense and Common Errors in Common Riding, by Colonel George Greenwood, with plates. I839, 8vo.

An Encyclopadia of Rural Sports; or A Complete Account (his. torical, practical and descriptive) of Hunting, Shooting, Fishing, Racing, Eoc., by Delabere P. Blaine, with illustrations. London, I840, 8vo. The third edition was illustrated by John Leech. The last edition was published in 1875 .

The Old English Gentleman; or, The Field and the IVoods, a novel, by John Mills, 3 vols. London, 1841, I2mo.

The Horse and the Hound; their various uses and treatment, including practical instructions in Horsemanship, and a treatise on Horse-dealing, by 'Nimrod.' Edinburgh, 18+2, I2mo.

The Life of a Sportsmam, by 'Nimrod'; with coloured illustrations by H. Alken. London, I842, 8vo.

Handley Cross, by Robert Smith Surtees, 3 vols. London, $1 \varepsilon_{+3}$, 8vo. This edition has no illustrations. 
Hunting Reminiscences, by 'Nimrod.' London, 1843, 8vo The Book of Sports, British and Foreign, 2 vols. London, I $\delta+3,4$ to. Stable Talk and Table Talk; or Speitacles for young Sportsmen, by 'Harry Hicover' (Charles Brindley), 2 vols. London $1845-6$, 8 vo.

The Sportsman's Library'; containing Hunting, Shooting, Coursing, and Fishing, by John Mills, with portraits and plates. London, 1845,8 vo.

Hunting Songs and Ballads, by R. E. Egerton-Warburton. London, I846, 4to. A sixth edition was published in 1878 .

The Life of a Fox-hound, by John Mills. London, !848, Svo.

The Pocket and the Stud; or Pracical Hints on the Manugenent of the Stable, by 'Harry Hieover.' London, I848.

Notitic Venatica; a treatise on Fox-hunting, by Robert Thomas

Vyner, with plates by Alken. London, I847, 8vo.

The Stud for Practical Purposes and Practical Men, by 'Harry Hieover,' with plates. I849, I2mo.

A Guide to the Foxhounds and Staghounds of England, to which are added the Otterhounds and Harriers of several Counties, by - Gelert. I849, 8vo.

Practical Horsemanship, by 'Harry Hieover' with plates. I 850 , $12 \mathrm{mo}$.

The Hunting Field, by the same, with plates. I850, I2mo.

A Treatise on the Proper Condition for all Horses, by the same, with plates. I852, I $2 \mathrm{mo}$.

Stable Practice; or Hints on Training for the Turf, the Chase, and the Road, by 'Cecil' (Cornelius Tongue). I852, I2mo.

Leiters on the Manugement of Hounds, by 'Scrutator' (K. W. Horlock). London, 1852, 8vo.

MIr. Sfonge's Sporting Tour, by Robert Smith Surtees; with illustrations by John Leech. London, I853, 8vo.

Sporting Facts and Sporting Fancies, by 'Harry Hieover.' London (printed at Woking), 1853, 8vo.

Records of the Chuse, and IIcmoirs of Celcbrated Sportmen; by 'Cecil,' with plates. London, 1854, $12 \mathrm{mo.}$

The P'ost and the P'addock, by 'The Druid'(H. H. Dixon), with plates. London, I856, $12 \mathrm{mo.}$

The Sportsman's Friend in a Frost, by 'Harry Hiecver,' with frontispiece. 1857,8 vo.

The Sporting World, by the same. 1858, I2mo.

T'ine Master of the Hound's, a novel, by 'Scrutator,' 3 vols. I London. 1858,8 vo. 
Horses and Founds; a practical Treatise on thir . Wanasenent, by 'Scrutator:' to which is added Taming of IVild Horses, by J. S. Rarey. Illustrated by II arrison Weir. London, I 58 , $80^{\circ}$. The Flyers of the Hunt, a story, by John Mills: illustrated by John Leech. London, 1859, 8vo.

Silk and Scarlet, by 'The Druid,' with plates. London, I 850 , I 2 mo.

A Mcumal of British Rural Sports, by 'Stonehenge' (J. H. Walsh) London, I859, 8 vo.

Reminiscences of the late Thomas Assheton Smith; or the Pursuits of an English Country Gentleman, by Sir John Eardley Wilmot, with plates. London, r86o, 8 vo.

The Horse and His Rider; by Sir Francis B. Head, with plates. London, 186r, 8vo.

Notes on the Chuse of the Will Red Deer in the Counties of Divon and Somerset; with an Appendix descriptive of remarkable Runs and Incidents connected with the Chase from the year 1780 to the year I860, by Charles Palk Collyns, with tinted plates and woodcuts. London, I86I, 8vo.

Recollections of a Fox-hunter, by 'Scrutator.' London (printed at Guildford), 186I, 8vo.

Scott and Sebright, by 'The Druid,' with plates. London, I862, $12 \mathrm{mo}$.

The County Gentleman, a novel, by 'Scrutator' 3 vols. London, I862, 8vo.

Hunting Tours, descriptive of various fashionable countries and establishments, with anecdotes of Masters of hounds and others connected with Fox-hunting by 'Cecil,' with coloured frontispiece. London, 1864, I2mo.

Mr. Facey Romford's Hounds, by Robert Smith Surtees, with illustrations by John Leech and Hablot K. Browne ('Phiz'). London, 1865, 8vo.

Practical Lessons in Hunting and Sporting, by 'Scrutator.' London, I865, 8vo.

Crumbs from a Sportsman's Table, by the Rev. Charles Clarke, 2 vols. London, I865, 8vo.

Sporting Incidents in the Life of Another Tom Smith (Thomas Smith, author of Extracts froin the Diary of a Huntsman), with illustrations. London, I867, 8 vo.

British Sports and Pastimes, by Anthony Trollope. Lnndon, IS68, 8 vo. 
Sones and lerses, by G. T. Whyte-Melville. London, 1869, 8vo. Lotes from a Hunting Lion, nut in the Shives, by G. Bowers, oblong folio, plates, 1873 .

Lay's of the Beitoir Hunt. London and Grantham, 1874, 4to.

The Stud Firm; or Hints on briciling for the Turf, the Cluse, and the lioat, addressed to Breeders of Race Horses and Huntcrs, to Landed I'roprictors, and especially to 'Tenant Farmers, by 'Cecil,' with frontispiece. I873, I2mo.

Triatata; or Cross-road Chronicles of P'assages in Irish Hunting History during the Season of $1875-76$, by MI. O'Connor MIorris, with plates. I877, 8vo.

Hilermia Venatica, by the same; with Photographs of the chief celebrities in the Hunting Field. 1878,8 vo.

Covert-Side Sketches; or Thoughts on Hunting, suggested by many days in many countries with Fox, Deer, and Hare, by J. Nevill Fitt. I878, 8vo.

Iitting Recollections, by G. T. Whyte-Nelville. London, I878, $8 \mathrm{vo}$.

Shitches in the Hunting Field, by $\mathbb{A}$. E. T. Watson. London, I $88 \mathrm{o}, 8 \mathrm{vo}$.

The Hunting Countries of Great Britain; thir Facilities, Character, and Requirements. A Guide to Hunting Nien. By 'Brooksby' (Captain Pennel-Elmhirst). London, 1882-3.

The Cream of Lcicestirstire, by the same; with illustrations, coloured and plain, by John Sturgess. London, 1883 .

Rece-course and Covert-side, by A. E. T. Watson; with illustrations by John Sturgess. London, 1883.

The Best Secrson on Recort, by 'Brooksby;' with illustrations, coloured and plain, by John Sturgess. London, 1884.

Red Deer, by Richard Jefferies. London, I884.

Fox Hlunting in Heath, by the Earl of Donoughmore. Dublin. 1885.

Sport, by W. Bromley-Davenport. London, 1885. 


\section{N D E X.}

\section{$\triangle B B$}

AnBEY, Arthur, anecdote of, 239 Acland, the second Sir Thomas, 32

Albert, Prince, the ribbon always worn by, 3I, note

Aldermaston, a run from, to Reading, $3 \mathrm{I}$

Alfred the Great a skilled hunter, 8

Alvanley, Lord, anecdnte of, 191

Anne of Bohemia, I4

Anselm, St., and the hare, 2

Armada, Spanish, deficienr muster of cavalry against the, 172

Arsenic administered to horses by grooms, IOI

Arundel, Lord, on the first regular employment of fox. hounds, 28

Ascot kennels, 122

Athelstan prohibits export of horses, I7I

Athenians as horse-riders, 210

Atherstone pack and country, 257

Aylesbury, Vale of, 262

BADMinton stables, IOI ; kennels, plan of, I2S; plan

\section{BEL}

of bitch and puppy houses, I 34

Balaclava, incident of, 206

Barrymore, Lord, anecdote of, I59

Beagles, hunting the hare on foot with, 83 ; characteristics of a good beagle hound, 84 , 85,9 I-93; things to avoid when hunting with, 86 ; best method of hunting, 87, 93, 94; casting, 88; Sir Marteine Lloyd on hunting with beagles, 89; efforts to improve the breed of, 90 ; their trentment in health, 94, 95; list of, in the United Kingdom, 356; see also Harrier and Beagle Association

Beaufort hounds, first diversion of, to fox-hunting, 28

Beaufort, Duke of, otter terriers of, 329

Beckford's ' Thoughts on Hunt. ing, 4, 20; decries hare. hunting, 25 ; on hounds and huntsmen, 84 ; on the summer treatment of the hunter, 107 ; on kennels, I20

Bell, Dr., on the renewal of horn in the stag, fo 
BEL

Belvoir hounds, antiquity of the, 28 ; history of, 227; their singular beauty, $i b$.; the country hunted by, 228

Berkeley family, fox-hunting by the, 29 ; stag-hunting, 33

Berners, Dame, and her 'Bolee of St. Albans,' $5, \mathrm{~S}$

Bibliography, 372

Bicester pack and country, 260

Billesdon Coplow run, the, 237

Billesdon kennels, plan of, 123

Bits, use of, II 6

Blades, William, his conclusion respecting Dame Berners, 6

Blaine's 'Encyclopædia of Rural Sports,' I ; records Queen Elizabeth's hunting prowess, I.3

Blome, Richard, 'Gentleman's Recreation' of, I 8 ; on harehunting, 23

Boothby, Thomas, an early keeper of fox-hounds, 28

Bradwell Grove, 267

Brian, Reginald, Bishop of IVorcester, his love of the chase, II

'Brooksby' on the Pytchley Wednesday, 248 ; on the essentials of a Vale hunter, 263 ; on ricling in the Heythrop country, 265

Bulteel, John, his plan of art:ficial clrains for otters, 313; his olservations of otter life, 3I 4

CANUTE, regulation of the chase by, 9

Carter the huntsman, 156

Casting, in hunting with beagles, 88
$\mathrm{COO}$

'Cecil,' his notice of 'The Maister of the Game,' 7

Charing Cross, old Berkeley kennel at, 29

Charles II., remarkable staghunt in the reign of, 31

Chaucer on the addiction of the clergy to the chase, II ; cited in illustration of fox-hunting, 26

Checking, I 49

Chopping of foxes, 148

Christian, Dick, on thoroughbred hunters, I78; on the method of making a hunter, I86; his reminiscences of a great run at Cottesmore, 240

Clark; Thomas, an example of a bad whipping-in system, I 52

Clergy, hunting by the, in former times, II

Clowne, Abbot Willium de, a breeder of hounds, I2

Cockaine, Sir Thomas, 7 ; on fox-hunting, 28

Cocktail breed of hunter, 177

Colic in horses, II 5

Collier, Mrr., on otter-hunting, 307 ; on the breeding habits of the otter, 308 ; successful heading back of an otter by, 325 ; his experience of trailhunting, 326

Collins, Digby, on the treatment of diseases in the horse not requiring veterinary aid, III

Collyns, Dr. Palk, instances abnormal number of points in stags' horns, 40

Compensation to farmers, 163

Cook, Colonel, on thoroughbreds compared with cocktails, 180 
COK

Corbet, Mr., 258

Curns in horses, II I

Cottesmore hunt, 239; a remarkable day's work of the, 240

'Country Gentleman's Com. panion,' 20

Crib-biting, prevention of, 103

Cross-country gallops, 196

Cunard, Sir Bache, country hunted by, 238

DANEs, game laws introduced by, 8

Daventry, 247

Deer, red, cunning and stratagems of, 38,49 ; colour of, 39 ; growth of horns as determining age, $i b$. ; designated by his points, $i b$. ; examples of abnor. mal number of points, 40 ; reproduction of horn, $i b$; time for hunting, $4 \mathrm{I}$; 'harbouring,' ib.; difficulty of procuring hounds for hunting, 47 ; scent, 49 ; taking soil, $i b$. ; running to herd, ib. ; a hunt of, at Ex. monr, 55; destructive propensity of, 6I

Derby, twelfth Earl of, staghounds of, 32

Devonshire, North, stag-hunting renown of, 32

Distemper in hounds, 137 ; effect of rounding ears in, 14 I

Dracek, Baronne de, a celebrated French huntress, 15

Drains, how to construct, for foxes, I66 ; for otters, $3^{12}$

Drake family of huntsmen, 26 I

Draper, Diana, 16
FXM

Draper, IVilliam, a Yorkshire fox-hunter, I6

Drawing for hares, 79 ; for foxes, I46; for otters, 323

'Druid' on cross-breeding for hunters, 180 ; instance of pro. phetic instinct in a horse related by, 216 note; his description of Dick Knight, 244 ; his account of the Duke of Grafton's pack, 269

EAR cropping of hunters, II 8 ; rounding of puppies, I4I

Earth, running to, 68

Earth-stopper, duties of an, I6I

Earths, artificial fox, how to construct, 166

Edward the Confessor, a patron of the chase, 9

Edward III. accornpanied by a hunting establishment in his wars, IO; endeavour of, to improve the breed of horses, I 7 I

Elizalieth, Queen, a notable huntress, 13 ; stag-hunting in the reign of, 36

'Emblem,' a famous steeple. chaser of bad shape, 183

England and Wales, list of hounds in, stag, 33I; fox, 333 ; hare, 348 ; beagle, 356 Epping hunt, origin of, 17

Erme, the, an otter river, 317

'Essay on hunting,' anonymous, 4, 19

Essex, curious hunting establishment in, 30

Essex, East, kennels, plan of, 128

Exmoor, antiquity of, as a royal hunting-ground, 32 ; charm 
FAI

of stag-hunting on the, 37 ; trying nature of, to hounds, 48 ; account of a stag-hunt with Arthur Heal at, 55

FAIRS, horse, I84; purchasing hunters at, 185

Farmers, compensation to, 164

Fences, different ways of riding at, 219

Fitzhardinge, Earl, against loud. voiced whippers-in, I56

Fitzwilliam pack and country; 272

Fordham, George, repudiation of spurs by, 223

Fortescue, Lord, 32

Founder, II 3

Fownes, Thomas, an early keeper of foxhounds, 28

Fox, George Lane, his opinion of hare-hunting, 83

Foxhounds, first regular em. ployment of, 28 ; dwarf, as harriers, 74 ; drawing, 146 ; losing scent, 149; accessible to Londoners, 285 ; lists of, in the United Kingdom, 333 Fox-hunting, literary notices of, 24; how pursued in the last century, 29; introduction of present style of, 33 ; comparison of past and present, 34 ; the practical work of, I46; by moonlight, I96; from London, 287

Fox, traditionary enmity to the, 26 ; habits of the, 62 ; his scent, 65 ; his behaviour before hounds, 66 ; going to ground, 68 ; his trick of thrusting another fox into the line, 70 ;

\section{GRO}

hand-reared cubs, 71 ; dietary, $i b$. ; mange in, caused by horseflesh, 72 ; meeting a pack of harriers, 75 ; alleged killing of lambs by, $i b ., 164$; protection of game birds from, 73 ; predilection of, for bogs, 146 ; chopping of, 148 ; coursed by a dog during a run, 150; habits of, in breaking covert, I55; feeling of farmers to. wards, 164; poultry-killing propensity of, 165 ; construction of artificial earths for, 166 Freeby Wood, a famous meet at, 228

Gardiner's 'Hare Hunting,' 20 ; reviles fox-hunting, 25

'Gayman,' a queer-looking hunter, I 84

Gelding, when first adopted in England, I7 I

George III., stag-hunting by, 3I George IV., at a run from Aldernaston to Reading, 3I ; at a famous run in the Cottes. more country, 240

Gibbons, Mr. J. S., initiates the Harrier and Beagle Association, 90

Gillard, Frank, his remedy for distemper in hounds, 137

Glossary of hunting terms, 368

Goodwood kennels, cost of, 120

Goosey, fox-hunting aphorism of, I 49

Grafton, Duke of, pack of, 269

Grantham, 228

Greene, Squire, 208, 211

Grooming, II 7

Grooms, ignorance in, 91 
GUR:

Gurney, Richard, remarkable leap of, 191

\section{IIANDS, 2 I 4}

Harbourer, work of the, 41

Hare-hunting, literary notices of, 23 ; instructions for, 79 ; season for, 82 ; the closing scene of, it.; Mr. George Lane Fox's opinion of, $S_{3}$; with beagles, ib.

Harricr and Beagle Association formerl, So, 9I, 95; its standard for beagles, $\delta_{5}$

Harriers, no distinct breed, 74 ; dwarf foxhounds used for, $i b$. ; occnsional killing of a fox by, 75 ; how to breed, ib.; ken. nel management of, $7 S$; quarrelsome disposition of, $i b$. ; how to be handled in the field, 79 ; shed book for harriers, 90 ; efforts to improve the breed of, 95-98; lists of, in the United Kingdom, 348

Heal, Arthur, Lord Ebrington's huntsman, 53

HenryI.; enclosure of Woodstock by, 9; grants hunting privileges to the citizens of London, I7

Henry II., 9

Henry III. grants hunting privi. leges to ecclesiastics, II; hunting establishment of, at Pytchley, 243

Henry VIII., efforts of, to improve the breed of horses, I7 1

Heythrop pack and country, 264

Hieover, Harry, his advice on buying horses, 193

Hill, Hon. Geoffrey, otter-hunting system of, 303 ; on the
HOK

breeding habits of the otter, 308 ; record of sport by, 310; curious otter hunting adventure of, 325

Hill, Waldron, otter-hunting system of, 303 ; cross-breeding of otter hounds by, 322

Hills, Jem, 264

Horn, use of the, 147

Horncastle fair, 185

Horse, the kind of, for Exmoor, 55 ; liability of, to illness in the stable, 99 ; importance of sanitary regulations for, 100 : a victim of ignorant grooms, IOI; how stabled at Badmin. ton, ib.; treatment of, in summer, 107 ; treatment of, after coming in from hunting, 109 ; attention to accidental injuries in, I10; diseases of, and their treatment, III; saddling, II 5 ; bitting, II 6 ; shoeing, $i$. ; grooming, 117 ; the old practice of ear crop. ping, I I8; use of, by whip. pers-in, 157 ; early history of, in England, 170; efforts of Henry VIII. to improve the breed, I7I; great change for the better recorded by Markham, 173; hunting, 174; colour, 175 ; shape according to Markham, I76; old and modern hunters, $i b$.; the thorough-bred, I78; choice of animals for crossing, ISO; judging a hunter by his head, ISI; shape often a fallacious criterion, 182 ; fairs and purchase of hunters there, IS4; 'Tattersall's auctions, I 89 ; examples of high prices for-

C C 
$\mathrm{HOU}$

merly paid for, 190; buying from dealers, I93; sympathy of, with his ricler, $2 I I$; his instinct of danger ahead, 216 ; different ways of putting at fences, 219 ; how to be treated by his rider after hunting, 224; first introduction of the custom of second horses, 231

Hounds, Beckford on, and hunts. men, $S_{4}$; term of working life of, $I_{3} \mathbf{I}$; breeding and rearing of, I 31 ; prejudices on the sub. ject of colour, 132 ; dieting, I34; distemper in, I 37 ; life of, in the liennels during the hunting season, I38; rounding the ears of, I4I ; securing obedience in, ib.; Somerville's description of a perfect animal, $i b$; the Badminton Potentate, 143 ; expenses of a pack, I44; to be allowed to eat their fox, I 50 ; how they should be dealt with by whippers-in, I52 ; singing of, in kennel, I60 ; for otter hunting, 321 ; alpha. betical lists of names of, 362 . See also Beagles; Foxhounds : Harriers; and Staghounds

Hunting vainly decried, 2 ; literature of, 3 ; restricted in favour of the upper classes by the Danes, 8 ; passion of the Norman kings for, 9 ; denounced by John of Salisbury, ib. ; caused suffering to the lower classes, I I; practice of, by the clergy, $\ddot{i b}$; early participation of ladies in, 12; privileges granted to the citizens of London, I7; list of animals formerly appropriate for, 22 ;

\section{KEN}

first regular employment of foxhounds in, 28; practised in the metropolitan suburbs, 29 ; our ancestors' early hours for beginning, $i b$; time of, for the stag, 4 I ; value of book. lore in, II9; extravagant expenditure not a necessity of, I2I ; servants, their duties, 145 ; horses for, 174 ; in rela. tion to riding, I99; rarely attended with casualties to ladies, 217 ; from home, only capable of affording its true pleasures, 276 ; from London, 281 ; glossary, 368 ; bibliography, 372. See also Foxhunting; Hare-hunting ; and Stag-hunting

Hunts, lists of, in the United Kingdom, 33 I

Huntsman, instructions for, when drawing, 146 ; use of the horn by, 147 ; what to do when the fox is afoot, 148 ; advantage of a fine voice to, I 55

Huntsman, kennel, duties of $a$, I 58

IRELAND, wild stag hunting in, 33 ; hunting breed of horses in, 175 ; lists of hounds in, stag, 333 ; fox, 346 ; harrier, $35+$; beagle, $35^{6}$

Jor hunters, 293

John, King, import of horses by, $17 \mathrm{I}$

John of Salisbury, denunciation of the chase by, 9

KexNels, conversion of out. buildings into, 120 , I2S ; must 
KEN

be dry, airy, and warm, $i b$; situation of, I2I; as near the house as possible, 122; plans of those at Billesdon, I23; at Badminton, 127; at Rivenhall, I $2 S$; use of whips in the, 158 ; singing of hounds in, 160 ; lists of, 331

kennel huntsman, duties of a, I5S

Kensington Gardens, foxhunting on the site of, 29

Kineton, establishment of the kennels at, 259

King, Charles, the Pytchley huntsman, 245

Kingsley, Charles, on the pleasure of hunting in familiar company, 277

Kinight, Dick, 244

' Knightley's Leap,' IgI

LADIES, early hunting costume of, 12 ; hands of, 217

Langley, Ednund de, work on hunting attributed to, 7

Lawrence, Mr., on the summer treatment of the hunter, 107

Leamington as a hunting centre, $25 \mathrm{~S}$

Leap, remarkable, I9I ; position of the rider in taking, 212; Leicester, 235

Lincolrs's Inr Fields, ancient meets in, IT

Llanwensant, Evan, an otter hunter, $3 I S$

Lloyd, Sir Marteine, on beagles, and the Harrier and Beagle Associarion, S9-95

Lockley, Mr., 29
MAR

Lomax, Mr., otter - hunting system of, 303

London, grants of hunting privileges 10,17 ; vicinity of, formerly hunted by the Ber. keleys, 29; hunting from, two ways of, $2 S_{3}$; its hard work as described by Anthony Trollope, $i b$. ; lists of stag and foxhounds accessible from. 284 ; effects of long and frequent railway journeys from, $2 S 6$; hunting the fox from, $2 \mathrm{~S} 7$; the plan of keeping the hunters in, $2 S S$; the alternative plan, 29I ; hunting from, on the ' $j o b$ ' sy'stem, 293

Long's Reading feeding meal, IOg

Long, William, on whipping-in, 151

Lord Mayor, hunting with the hounds of the, I7

Loughborough, 235

Lowther family, connection of, with the Cottesmore hounds, 239

Lutterworth, 247

IIACAUlay, Lord, riding experience of, ISS

Macclestield's, Lord, pack, $26 \mathrm{~S}$

' Maister of the Game," the, 7

Market Harborough, 247 ; oxers of, $24 \mathrm{~S}$

Markham, Gervase, 'Country Contentments' of, IS ; his praise of the stag, 23 ; on the chase of the fox, 27 ; records a great improvement in horsetlesh, I63; his remarks on hunters, 174 
MAY

May Fair, ancient meets in, I7

Melton Club, horse-selling soirées at the, I9o

Melton Mowbray, a point of vantage for the Quorn, 234; hunting society of, 2 So

Meynell, Mr., his mastership of the Quorn hounds, 230

Milion pack and country, 272

Mlostyn, Sir Thonıas, 260

Navicular disease, I 3

'Nimrod' on half-bred hunters past and present, 176

Northampton, 247

Northumberland, fifth Earl of, stud of, 170

Norwich, hunting grounds owned by the see of, at the Reformation, I2

OAISLY hunt, 27 I

Osbaldeston, Squire, 231

Otter, the, our defective knowledge of, 299; his habit of shifting quarters, 301 ; finding in a new neighbourhood, story of, 302 ; not capable of living in water, 304 ; necessity of changing streams in hunting, 305 ; letter from Mr. Collier on, 306; time for hunting, 307 ; breeding habits of, 308 ; hunting inlluenced by the state of the rivers, 310 ; instance of migration of, in a patriarchal fashion, 3 II; artificial drains for, 312 ; family life of, as observed by Mr. Bulteel, 3I4; arrival of, he. ralded by the truff, 317 ; po-
PYT

pular enthusiasm for hunting, in North Devon, 318 ; indications of the course of, 319 ; scent of, not readily talien by hounds, 320; choice of hounds for hunting, 321 ; difficulty of heading back, 324 ; trail of, 326 ; terriers, $32 S$; how to bolt, in a narrow underground drain, 330 ; hour for starting the hunt of, $i b$.

Oxfordshire, South, pack and country, 268

PARTRIDGE, protection of, from foxes, 73

Payne, Charles, 246

Payne, George, interlude of, with a fox while hunting hare, 75 ; sale of the stud of, Igo

Peterborough, its annual harried and beagle show, 90

Pheasants, protection of, from foxes, 73

Plymouth, Lord, horse-buying vagaries of, I9I

Pollard, Hugh, 32

Pope on the court ladies' pursuit of hunting, I4

- Potentate,' a Badminton hound of a perfect type, I 43

Poultry, compensation claims for, 165

'Prince of Wales's day' in the Cottesmore, 240

Provinces, hunting in the, 253

Pytchley hounds, history of the, 242 ; a great day's sport with the, 244; towns in the vicinity of the, 246 ; the country hunted by the, $24 \mathrm{~S}$ 
(2U1

Quittor, II3

Quorn hounds, history of, 230 ; the country hunted by, 235

RayLway facilities for hunting from London, 284, 286; effects of long and frequent journeys by, 286

Rhetumatism in hounds, from the situation of the kennel, 122

Rickards, Mr. L. E., his studbook for harriers and beagles, 90

Rider, badness in a, described, 194; course to pursue in a strange country, 203; awk. ward, subterfuges of, 205; courage in, $i b$. ; advice to, re. specting falls, 207; acquirement of a good seat by, 205 ; position of, in leaping, 212 ; his hands, 214; when to leave his horse alone, 215; judgment in, 217 ; to adapt his riding to circumstances, 220 ; to give his leader plenty of room, 22I; what to do if he choose his own line, $i b$.; how to use the spurs, 223 ; how to treat his horse after hunting, 224

Riot, breaking hounds from, 47 Robertson-Aikman, Major, his interest in harriers, 90

Rugby, 247

Saddles, 115

St. James's, ancient meets in, 17

St. John, Oliver, on the killing of the fox, 26

Salisbury, Duchess of, 14

Sandcrack, II 2
STA

Scent, decr, 49 ; fox, 65 ; otter, 320 ; mysteries of, 149, I 50

Scotland, lists of hounds in, fox, 345 ; hare, 357

Scott, Sir IValter, on the killing of the fox, 27

Sefton, Lord, 231

Selby-Lowndes, Mr., pack of, 262

Shakespeare's allusion to hare. hunting, 24

Shaw, Mr., his account of a remarkable migration of otters, 3 II

Sheep, moorland, protection of, from stag-hounds, 47

Shires, definition of the, 226 ; hunting in the, 227

Shoeing, II 6

Sidney's 'Book of the Horse,' II 6

Smith, Assheton, nerve and pluck of, 207; his mastership of the Quorn hounds, 231

Smith, Thonas, plan of, for the Billesdon kennels, I23; a bad leap by, 2I3

'Sober Robin,' a long-backed hunter, $1 S_{3}$; remarkable leap of, 19 I

Somerville's 'Chase,' 4, 20 ; on the situation for building a kennel, I2I; his description of the perfect hound, I I I

Spencer family, connection of, with the Pytchley hounds, 243

Spurs, use of, 223

Stables, excessive heat in, 99, I02; sanitary requisites of, 100 ; choice of servants for the, IOI: how arranged at Badminton, ib. 
STd

Stag, ancient laws for the protection of the, 38 . See Deer

Staghounds for the Exmoors, 47 ; breaking them from sheep, 48 ; kennel management of, ib. ; number of the pack, 49 ; choice of tufters, 50 ; how to be handled in the field, $5 \mathrm{I}$; scenting discrimination of, 52 ; treatment of, after immersion, ib. ; causes of truancy in, 54 ; accessible to Londoners, 284; lists of, 33 I

Stag-hunting in former times, 23,30 ; national love of, 36 ; peculiar charm of, on the Ex. moor, 37; season of, 4I ; choice and management of hounds for, 47 ; selection of horses for, 55; a day's experience of, with Arthur Heal, ib. ; from London, 284

Stamford, Lord, sale of the stud of, 190

Steeple-chasers, conversion of, into hunters, 179

Stirrups, length of, 212

Strutt, Joseph, his notice of an early manuscript treatise, 5 ; his antiquarian researches, $S$

Suffield, Lord, Quorn hounds removed to Billesdon by, 123 ; anecdote of, 84 ; his master. ship of the Quorn hounds, 233

TAILBY, Mr., 233 ; country of, 238

Tar IVood run, the, 267

Tattersall's, purchasing hunters at, 189

Taunton as head-quarters for otter-hunters, 306

\section{IVAR}

Terriers, suggested use of, in hare-drawing, 79; valuable adjuncts to an earth-stopper, I6I; for otter-hunting, $32 \mathrm{~S}$

Thomson's verses on fox-hunting, 24

Thomson, Col. Anstruther, on the best method of hunting, 87

Thorough-breds as hunters, $17 \mathrm{~S}$

Thrush in horses, 1 I2

Thursby, Sir John, his interest in harriers and bearles, 90

Tollit, Joseph, 268

Tout, James, Lord Fortescue's huntsman, 32

'Trencher hounds,' 29

Trollope, Anthony, his experiences of hunting from London, 283

Tufters, choice of, 50

Turberville, George, 7 ; on fox. hunting, 27

Twici, Guillaume, treatise on hunting by, 5,7 ; his division of animals of chase, 22 ; on hare-hunting, 23

'UNKNows,' a famous hunter of bat shape, IS2

Vaccination for distemper, I 37 Voice, the, and its use, 155

Vyner (MIr.), his account of the Baronne de Dracel, 15

- Walnoth, Ablot, his love of the chase, I2

Valter, Bishop of Rochester, his love of the chase, II

Walton, Izaal, on teaching by hooks, 214

Warburton, Egerton, 2: his 
IVAR

ideal of a good rider, 204 ; his description of the 'Tar Wood run, 266

Warde, John, 245

Warranties with horses, 189

Wartnalyy Stone-pits, 235

Warwickshire pack and country, 258

Warwickshire, North, pack and country, 260

Wedgenoke Park, 9

Weedon, 247

Wellington, Duke of, kept a pack of hounds in the I'enin. sula, ro

Whaddon Chase pack and country, 262

Whip-hand, not to be raised while taking a fence, 213

Whipper-in, error of second, in waiting for stray hounds, $15 \mathrm{I}$; quiet in, while hounds are drawing, I 54 ; not to occupy the angle of a covert, I55; voice an evil in, I56; necessity of a good mount for, I 57 ;
YAT

unnecessary interference of, with hounds, ib.

IVhipper-in to staghounds, duties of, 54

Whips, kennel, 158

Whissendine, 237

Whyte-Melville on thorough. breds as hunters, 178 ; on Irish hunters, I 85 ; his dis. tinction between nerve and pluck, 206; on different examples of riding at fences, 219; on the l'ytchley country, 249 ; on hunting in the Pro. vinces, 253

William the Conqueror, 9

Wilton, Lord, on the first regular employment of foxhounds, 28

Wilton stud, sale of, 190

Woburn kennels, r20

Woodstock, enclosure of, 9

Wulsig, Abbot, his love of the chase, I2

YATES, Edmund, his story of a horsefair, I 88 



\section{TIE BADMINTON LIBRARY OF SPORTS ANI) PASTIMES.}

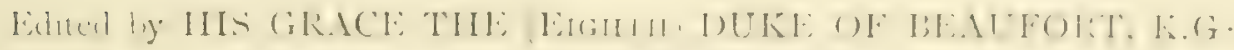
and 1. E. T. IVATSON.

ARCHERY.

By C. J. LoNGMA.X and Col. H. WALROND. With Contributions by Miss LEGH, liscount DILLoN, Sc, With 2 Maps, 23 I'lates, and 172 Illustrations in the lext. Crown 8 vo. cloth, 65 . net; half-bound, gs. net.

A'I'HLE'I'ICS.

By Montague Simarman. IVith Chapters on Athletics at School by

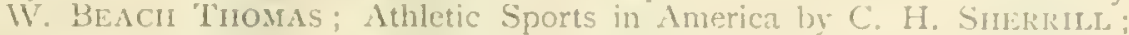

a Contribution on Paper-chasing by IV. RYE, and an Introduction by Sir RiCHARD WEBSTER (LORD ALVERstonk). With 12 Plates and 37 Illustrations in the Text. Crown $8 v 0$. cloth, 6 s, net; half-bound, 9s. net.

BIG GAME SHOOTING.

By Clive P'Hillipps-WOLley.

Vol. I. AFRICA AVD AMERICA. With Contributions by Sir SAMUEL W. BAKER, W. C. Oswell, F. C. SElous, dic. With 20 I'lates and 57 Illustrations in the 'lext. Crown $8 v^{\circ}$. cloth, $6 s$. net; half-bound, 9s. net.

Vol. II. EUROPE, ASIA, AND THE ARCTIC REGIONS. With Contributions by Lieut. -Colonel R. HEBER PERCY, MIajor ALrEkNoN, C. HEBER PkRCY, dic. With 77 I'lates and 56 Illustrations in the Text. Crown 8vo. cloth, 6s. net; half-bound, 9s. net.

BILLIARDS.

By Major IV. BRoldfoot, R.E. A. H. Bord, Sydeviam Dixon, dec. With II l'ates, $x_{7}$ Illustrations in the Text, and numerous Diagrams. Crown 8vo. cloth, 6s. net; half-bound, 9s. net.

COURSING AND FALCONRY.

Coursing. By HARDIAG COX, thoroughly Revised by CHARJES RICHARDso.N. - Falconry. By the Hon. GERALD LASCELLES. With 20 Plates and 55 Illustrations in the Text. Crown $8 \mathrm{vo}$. cloth, 65 , net; half-bound, 9s. net.

CRICKE'I'

By A. G. STEEI, the Hon. R. H. LytTELTON, ANDREw LANG, IV. G. GKACE, \&c. With 13 Plates and 5 I Illustrations in the Text. Crown 8vo. cloth, 6s. net; half-bound, gs. net.

CICIII I I.

By the EARL OF ALBEMARLF: and G. LACr HIllier. With Io Plates and +4 Illustrations in the 'Text. Crown 8vo.cloth, 6 s. net; half-bound, 95. net.

DANCING.

By Mrs. Lilly Grove, F.R.G.S. Miss Mintuletox, the Hon. Mrs. ARMYTAGE, Sc. With Musical Examples, and $3^{8}$ Full-page Plates and 93 Illustrations in the 'lext. Crown 8vo. cloth, 6s. net; half-bound, 9s. net.

\section{DRIVING.}

By His Grace the (Eighth) DUKE of BEAtforT, K. G., A. E. T. IVATSON, the EARL OF ONsLow, de. With I2 Plates and 54 Illustrations in the Text. Crown $8 r^{\circ}$. cloth, $6 s$. net; half-bound, gs. net.

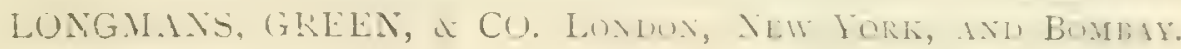




\section{THE BADMINTON LIBRARY OF SPORTS AND PASTIMES.}

Edited by HIS GRACE 'THE (EIGHTH) DUKE OF BEAUFORT, K.G. and A. E. T. WATSON.

FENCING, HOXING, NNI) WRESTLING.

By IVAlter H. Poliock, F. C. Grove, C. PREVost, E. B. Mitchell,

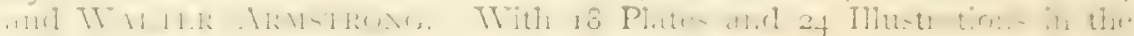
Text. Crown 8vo. cloth, 6s. net; half-bound, 9s. net.

FISHING.

By H. CHOLMONDELEY-PENNELL。

Vol. I. SALMON AND TROU'T. With Contributions by H. R. FRANCIS, Major JOHN P. TRAHER.NE, Sc. With g Plates and numerous Illustrations of Tackle, \&c. Crown 8vo. cloth, 6s. net; half-bound, $9 s$. net.

Vol. II. PIKE AND OTHER COARSE FISH. With Contributions by the (Fourth) MARQuIS OF EXETER, WILIIAM SExIOR, G. Christopher DAvis, \&c. With 7 Plates and numerous Illustrations of Tackle, \&c. Crown 8 vo. cloth, 6s, net; half-bound, 9 s. net.

FOOTBALL.

History. By Montague Shearmax.-The Association Game. By IV. J. OAKLEY and G. O. SMITH. - The Rugby Union Game. By FRANK MitChell. With other Contributions by R. E. MaCNaGHTEN, M. C. KEMP, J. E. VINCENT, WALTER CAMP, and A. SUTHERLAND. With I9 Plates and 3.5 Illustrations in the Text. Crown 8 vo. cloth, $6 s$. net; halfbound, 9 s. net.

GOLF

By Horace G. Hutchinson. With Contributions by the Right Hon. A. I. BALFOUR, M.P. Sir WALTER SIMPSON, Bart. ANDREW LANG, Sc. With 32 Plates and 57 Illustrations in the Text. Crown 8vo. cloth, 6s. net; halfbound, 95. net.

HUNTING.

By His Grace the (Eighth) DUke of BeAUfort, K. G. Mowbral Morkis,

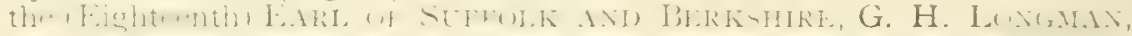
\&c. With 5 Plates and $5+$ Illustrations in the "Text. Crown 8vo. cloth, 6s. net; half-bound, os. net.

MOTORS AND MO'TOR-DRIVING.

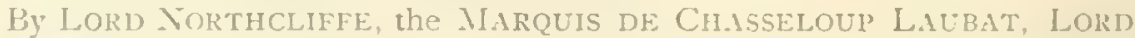
Montagu of Beaulieu, R. J. Mecredy, the Hon. C. S. Rolls, Sir DAvin SALomoxs, Bart, \&c. With 23 Plates and If7 Illustrations in the Text. Crown 8ro. cloth, 9s, net; half-bound, $12 s$, net.

1 Cloth Box for use when Motoring, price 2s, net.

MOUNTAINEERING.

By C. T. DENT, Sir WV. M. CoNWAY, D. W. FresheIELD, Sc. With 13 Plates and 95 Illustrations in the Text. Crown 8vo. cloth 6s. net; halfbound, 9s, net.

POETRY OF SPORT (THE).

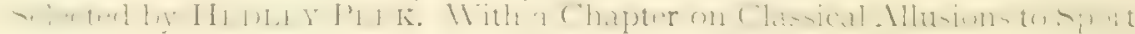
by ANDRE W LANG, and a Specia 1 Preface to the B.ADAIN'TON LIBR.ARY by $A$. E. "I. W W Tsos. With 32 Plates and 74 Illustrations in the 'Text. Crown 8vo. cloth, 6s, net; half-bound, $9 s$, net.

RACING AND STEEPLE-CHASING.

Iyy the (Eighteenth) EARL OF SUFFOLK AND BERKSHIRE, IV. G. CRAVFN, the Hon. I. LAWI.EY, ARTHUR COVENTRY, and A. E. T. WATSON. With Frontispiece and 56 Illustrations in the 'Text. Crown 8vo. cloth, 6s, net; balf-isound, 9s. net.

IONGMANS, GRELN, ¿ CO. LONDON, NEW VORK, AND BOMHA. 


\section{THE BADMINTON LIBRARY OF SPORTS AND PASTIMES.}

Edited by HIS GRACE 'IHE (EIGHTII) DUKE OF HEAUFORT, K.G. and A. E. T. WATSON,

RIDING AND POLO.

By Captain ROBERT WEIR, the (Eighth) DURF OF BlaturoRT, the EARI. OF ONSLOW, J. MOR.M I3ROWN, T. F. DALE, \&C. With 26 l'lates and 35 Illustrations in the 'lext. Crown 8 vo. cloth, 6s. net; half-bound, 9s. net.

ROWING.

By R. P. P. Rowr and C. M. PITMAN. With Chapters on Steering by C. P. SERocolo and F. C. BEGG; Metropolitan Rowing by S. LE BLANC SMITH; and on PUN'ING by P. WT. SQUIRE. With 75 Illustrations. Crown $8 \% 0$. cloth, 65 . net; half-bound, 9s. net.

\section{SEA FISHING.}

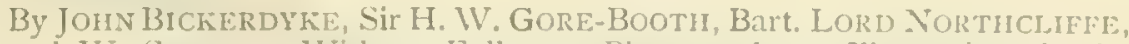
and W. SEvior. With 22 Full-page Plates and 175 Illustrations in the Text. Crown 8vo. cloth, 6s. net; half-boumd, 9s. net.

\section{SHOO'TING.}

Vol. I. FIELD AND COVERT. By LORD WVALSINGAM, Sir RALPg PAYNE-GAllWEy, Bart. the Hon. GERALD LASCELles, and A. J. STUART-IVoRTLEY. With II Plates and 95 Illustrations in the Text. Crown 8\%o. cloth, 6s. net; half-bound, 9 s. net.

Vol. II. MOOR AND MARSH. By LORD WALSINGHAM, Sir RALIII PAYNE-GALLWEY, Bart. LORD LOVAT, and LORD CHARLES LENXOX KERR. With 8 Plates and 57 Illustrations in the 'Iext. Crown 8 vo. cloth, 6s. net; half-bound, gs. net.

Sh.IIING, ('LRLINi, TOBOCiCi.JINi.

By J. M. Heatricote, C. G. TEbbut, T. Maxwell Withas, \&c. With 12 Plates and 272 Illustrations in the 'Text. Crown 8 vo. cloth, 6 s. net; half-bound, $9 s$. net.

\section{SIVIMMIING.}

By ARCinbald Sinclair and IVILLIAM HENRY. With I3 Plates and I06 Illustrations in the Text. Crown 8vo, cloth, 6s, net; half-bound, 9s. net.

TENNIS, LIMN 'TENNIS, R.CLETS INI) IITES.

By J. M. and C. G. HeAtricote, E. O. Pleydell-Bouterie, and A. C. Ainger. With Contributions by the Hon. A. LytTeltov, W. C. Marsiall, Miss L. Dod, Sc. With I Plates and 67 Illustrations in the Text. Crown 8vo. cloth, 6s. net; half-bound, 9s. net.

\section{YACHTING.}

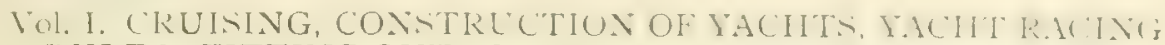
RULES, FITTING-OUT, \&C, By Sir EDWARD SULlIY Bart, the (Thirteenth) EARL OF PEMBROKE, LORD BRASSEr, K.C.B. R. T. PRITCHETT, E. F. KNIGHT, \&c. With 2 I Plates and 93 Iliustrations in the Text. Crown 8vo, cloth, 6s. net; half-bound, 9s, net.

Vol. I1. YACHT CLUBS, YACHTING IN AMERICA AND THE COLONIES, YACH'T RACING, \&C. By R. 'T. PRITCHETT, the MARquis of DUfFerin A.ND AVA, K.P. the EARL OF ONSLOW, dec. With 35 Plates and 160 Illustrations in the Text. Crown 8vo. cloth, 6s, net: half-bound, 95. net.

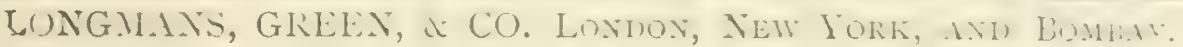




\section{FUR, FEATHER, AND FIN SERIES.}

Edited by A. E. T. Watson.

Crown Sro, cloth, price 5s, each Volume.

** The Volumes are also issued half-bound in Leather, with gilt. top. P'rice 7 s. 6d. net each.

'THI: I'ARTRIDCiE. Vintrmal History. liy the Ker. H. A.

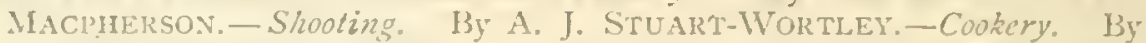
George Santsbury. WVith II Illustrations and various Diagrams in the Text.

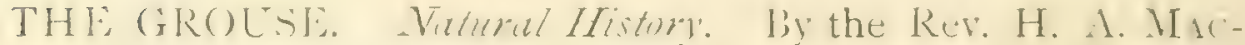
pierson.-Shooting. By A. J.STUART-WORTLEY - Cookery. By GEORGE SAINTSRURY. With I Illustrations and various Diagrams in the "Text.

THE: PHIDAsNT. Gramal History. By the Rer. H. I. Maclierson. - Shooting. By A. J. Stuart-Wortley.-Cookery. By AlExander INNes Shand. With ro Mllustrations and various Diagrams.

THE HARE. Natural History. By the Rer. H. A. MACPHERSON. - Shooting. By the Hon. GERALD LASCELLES.-Coursing. By Charles Richardson. - Hunting. By J. S. Gibbons and G. H. Longman. Cookery. By Col. KENNEY HERBERT. With g Illustrations.

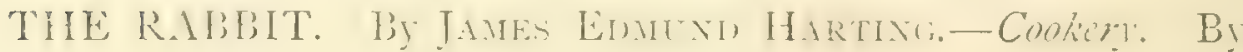
AlexAnder Innes Sirand. With ro Illustrations.

THE S.ILMON. By the Hon. A. E. Gaturene-Harme. With Chapters on the Law of Salmon Fishing by Claud Douglas PEnNant. Cookery. By Alexander INNES SHand. With 8 Illustrations.

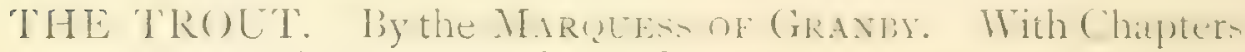
on the Breeding of 'Trout by Col. H. CustaNCE. - Cookery. By ALENANDER IN.NES SHANI). With I2 Illastrations.

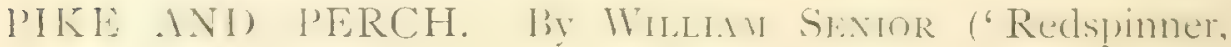
Editor of the Field). With Chapters by 'JoHn BiCkernyke' and W. H. Pol'e,-Cookery. By Alexander InNes Shand, With iz Illustrations.

RED DELR. Natural History. By the Rev. H. A. MACpHerson.-Deer Stalning. By CAMERON OF LOCHEL. -Stas Hunting. By Viscount EmRington.-Cookery. By Alexander Innes SHand. With Io Illustrations.

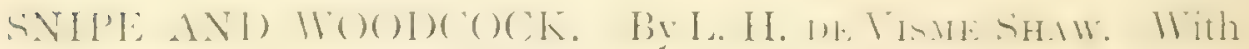
Chapters on snipe and Woodcock in Ireland by RICHARI) J. UsSIER. Cookery. By Alexander InNes Shand. With 8 Illustrations.

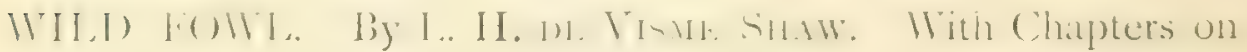
Shooting the Duck and the Goose by IV. H. ['Ol'E.-Cookery. By ALEXANIDER INAES SHAND, With 8 Illustrations.

THE FOX. By THOMAS F. DALE. With 8 Illustrations.

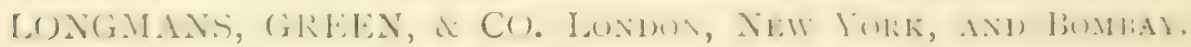





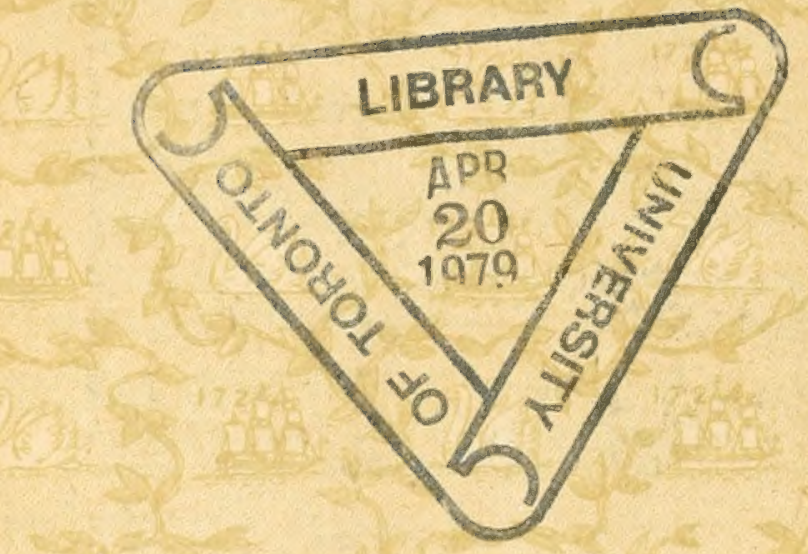

20n 5 -
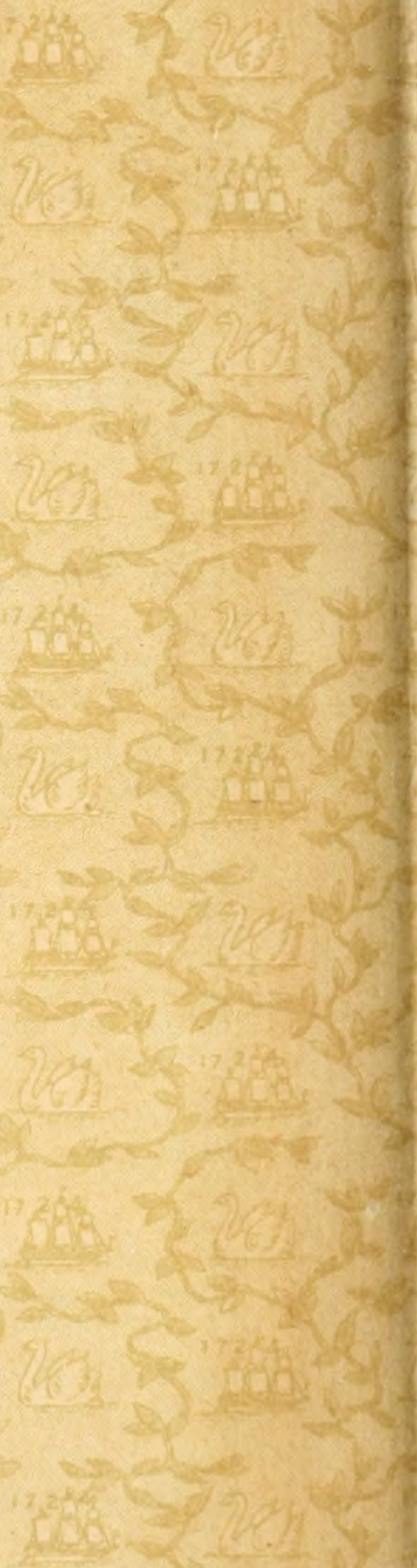


\section{PLEASE DO NOT REMOVE CARDS OR SLIPS FROM THIS POCKET}

\section{UNIVERSITY OF TORONTO LIBRARY}

SK Beaufort, Henry Charles Fitz

31 Roy Somerset

B3 Hunting

1906

BioMed. 
